This work is licensed under a Creative Commons Attribution 3.0 License.

\author{
Monograph \\ urn:1sid:zoobank.org:pub:9600FFB8-3FB9-4522-B030-D5A6B145EDEB
}

\title{
Atlas of European millipedes 2: Order Julida (Class Diplopoda)
}

\author{
Richard Desmond $\mathrm{KIME}^{1}$ \& Henrik ENGHOFF 2 ,* \\ ${ }^{1}$ La Fontaine, La-Chapelle-Montmoreau, F-24300 Nontron, France. \\ ${ }^{2}$ Natural History Museum of Denmark, University of Copenhagen, \\ Universitetsparken 15, DK-2100 Copenhagen Ø, Denmark. \\ *Corresponding author: henghoff@snm.ku.dk \\ ${ }^{1}$ Email: deskime2@aol.com \\ ${ }^{1}$ urn:Isid:zoobank.org:author:847CC68F-00BF-4DAB-8E53-B7A3384D66C1 \\ ${ }^{2}$ urn:Isid:zoobank.org:author:FB09A817-000D-43C3-BCC4-2BC1E5373635
}

\begin{abstract}
For each of the 593 species of the millipede order Julida known from Europe, available information on taxonomy, distribution and habitat is summarized, and the distribution in $50 \times 50 \mathrm{~km}$ UTM squares is shown on a map.
\end{abstract}

Keywords. Distribution, map, UTM, faunistics, taxonomy.

Kime R.D. \& Enghoff H. 2017. Atlas of European millipedes 2: Order Julida (Class Diplopoda). European Journal of Taxonomy 346: 1-299. https://doi.org/10.5852/ejt.2017.346

\section{Contents}

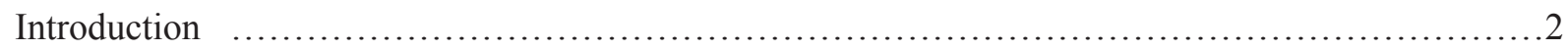

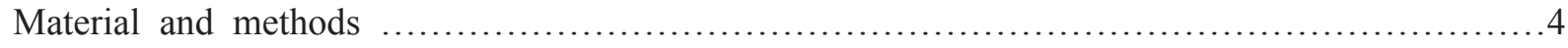

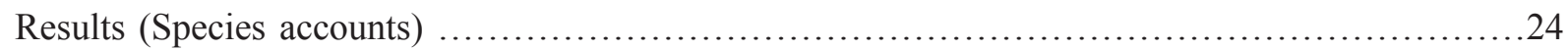

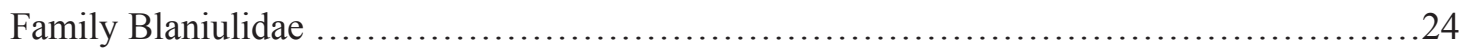

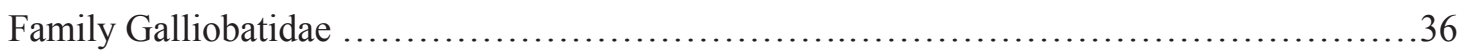

Family Nemasomatidae ..................................................................

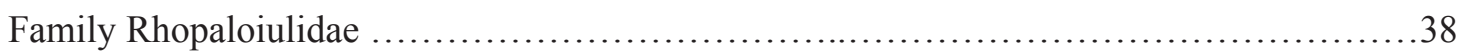

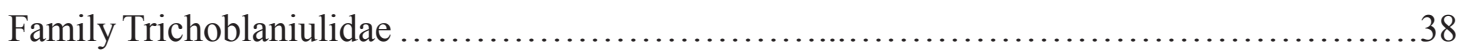

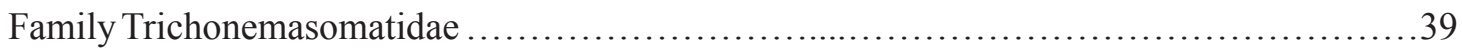

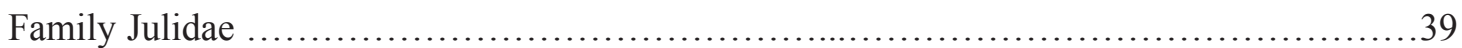

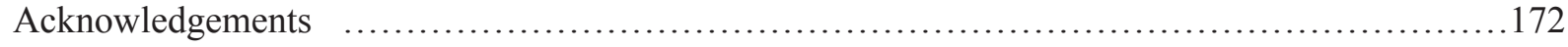

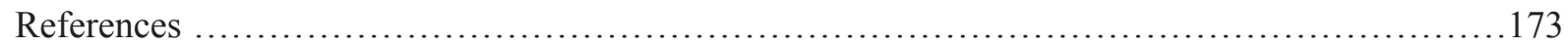

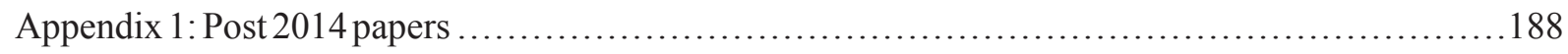

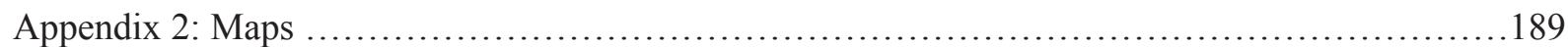




\section{Introduction}

The primary purpose of this atlas is to provide maps showing the known distribution of all European millipedes. The present volume (the second of three) deals with the 593 species belonging to the order Julida (sometimes called "snake millipedes") which are currently known from Europe. The order Julida is the largest order of millipedes in Europe, where it also is the order with the largest geographic range. It has many species adapted to withstand harsher conditions than most species belonging to other orders, occurring throughout the Holarctic except in parts with permafrost and the warmer deserts (Shelley \& Golovatch 2011: fig. 26). A list of the included species is given in Table 4 (p. 12), and images of a selection of species are shown on Fig. 1. The coverage map, Fig. 2, summarizes the known distribution of Julida in Europe.

The first part of the Atlas of European Millipedes was published several years ago (Kime \& Enghoff 2011) and covered the orders Polyxenida, Glomerida, Platydesmida, Siphonocryptida, Polyzoniida, Callipodida and Polydesmida. The present part, covering the order Julida, is the second. The third and last part, covering the order Chordeumatida, is in preparation.

Millipedes are terrestrial arthropods belonging to the class Diplopoda. They comprise the largest class of the Myriapoda, the other classes being the Chilopoda (centipedes), Symphyla and Pauropoda. Globally, about 12,000 species of millipedes have now been described (Brewer et al. 2012). Very many species, especially tropical ones, remain to be described, and the best estimate of the actual number of existing millipede species may be that of Hoffman (1980) who, based on his unique knowledge of millipedes, estimated 80,000 existing millipede species. A recent attempt to make an estimate with advanced statistical methods resulted in much lower estimates (14-21,000 species), but the authors of this analysis (Brewer et al. 2012) realized that the numbers are too low.

Well over 1500 species of millipedes are currently known from Europe, according to the 'Fauna Europaea' database (Enghoff \& Kime 2009). We have largely applied the same species concepts as 'Fauna Europaea', although in some cases there are differing opinions about species limits. It is likely that some of the "species" recognized here will in the future prove to be synonymous with other species, just as some subspecies may be regarded as species in the future. Very many subspecies of European millipedes have been named. In general, we have not considered subspecies, although they are mentioned in some cases. Some new species have been described since the Fauna Europaea database was composed and some others have been synonymised. We have taken account of all changes up to and including the end of 2014.

Problems with subspecies and synonyms aside, more new species will certainly be added to the European list; the fauna is not yet fully known. Since we stopped collecting data for the present atlas (end of 2014) several papers describing and recording European julidan millipedes have been published. These are listed and commented in Appendix 1. We are furthermore aware of scores of new species in various museum collections, waiting to be described, and we can say with confidence that further scores have still not been collected.

Several species of Julidae and Blaniulidae which occur in the open in the south are confined to hothouses in the north. Whereas we have tried to exclude hothouse records from the maps, we cannot be sure that we have been entirely successful with this. In several European hothouses the species Paraspirobolus lucifugus (Gervais, 1836) occurs (Jeekel 2001; Read 2008; Decker et al. 2014). It belongs to the juliformian order Spirobolida, which has no free-living European species. Three other species of Spirobolida have been found in a few hothouses, viz. Pseudospirobolellus avernus (Butler, 1876) in the British Eden project (see Stoev et al. 2010), as well as Anadenobolus monilicornis (Porat, 1876) and Leptogoniulus sorornus (Butler, 1876) in a few German hothouses (Decker et al. 2014), the latter also in 

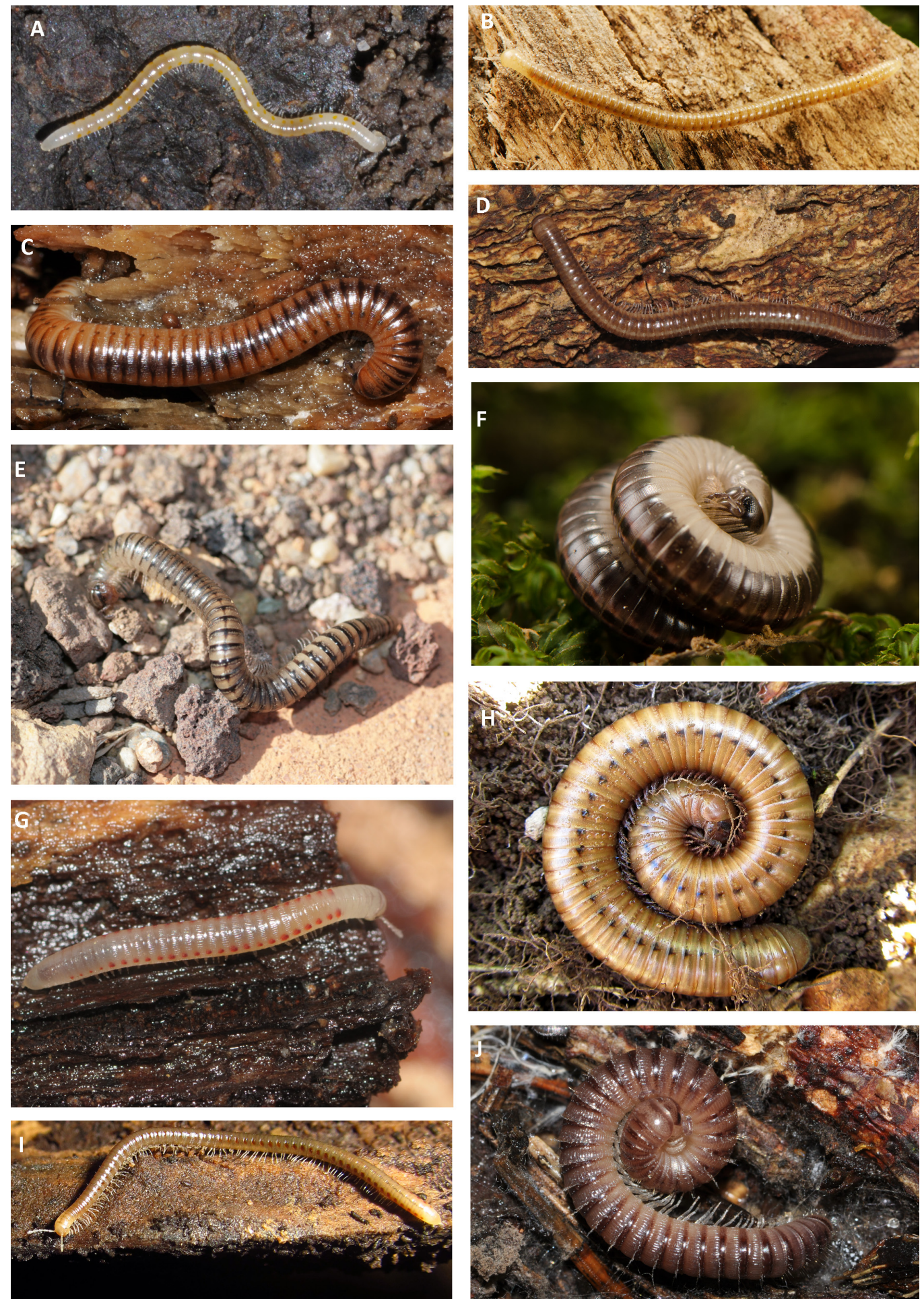

Fig. 1. A selection of European species of Julida. A. Boreoiulus tenuis (Bigler, 1913) (Blaniulidae) (J. Spelda phot.). B. Trichoblaniulus hirsutus (Brölemann, 1899) (Trichoblaniulidae) (D. Cheung phot.). C-J. Julidae. C. Cylindroiulus boleti (C.L. Koch, 1847) (J. Spelda phot.). D. Leptoiulus belgicus (Latzel, 1884) (J. Spelda phot.). E. Ommatoiulus hoffmani Akkari \& Enghoff, 2012 (K. Mohr phot.). F. Ommatoiulus sabulosus (Linnaeus, 1758), colour variety from the Italian Riviera (D. Cheung phot.). G. Pteridoiulus aspidiorum Verhoeff, 1913 (J. Spelda phot.). H. Pachyiulus cattarensis (Latzel, 1884) (D. Antić phot.). I. Serboiulus deelemanni Strasser, 1971 (D. Antić phot.). J. Unciger foetidus (C.L. Koch, 1838) (J. Spelda phot.). Not to scale. 
a Danish one (unpublished, H.E. det.). A few species of a further juliformian order, Spirostreptida, which likewise has no free-living species in Europe, have also established themselves indoors in Europe. Thus, Aulonopygus aculeatus Attems, 1914, has a population in a heated building in a zoological garden in the Netherlands (Soesbergen \& Jeekel 2007) and two species of the genus Epinannolene have been found in German hothouses (Decker et al. 2014).

\section{Material and methods}

Taxonomy above the species level follows Hoffman (1980), with updates by Shelley (2002) except where otherwise stated. Newer papers of importance for classification at the generic level include Read (1990) on Allajulus, Cylindroiulus, Enantiulus and related genera, as well as Tabacaru (1978), Mauriès (1982) and Enghoff (1992) on the tribe Pachyiulini. Other important review papers are mentioned under the respective genera. Table 1 shows the ordinal-level classification of millipedes according to Shelley (2002), and Table 2 shows the families covered by the present volume.

The sequence of species is as follows: Families are treated in alphabetical sequence except for the very large family Julidae, which is placed last (cf. Table 2 where the families are shown in systematic order). Within each family, genera are treated in alphabetical order, as are the species within each genus.

For each species, the text is organised as follows:

The valid name of the species, in accordance with Fauna Europaea (Enghoff \& Kime 2009), except where noted.

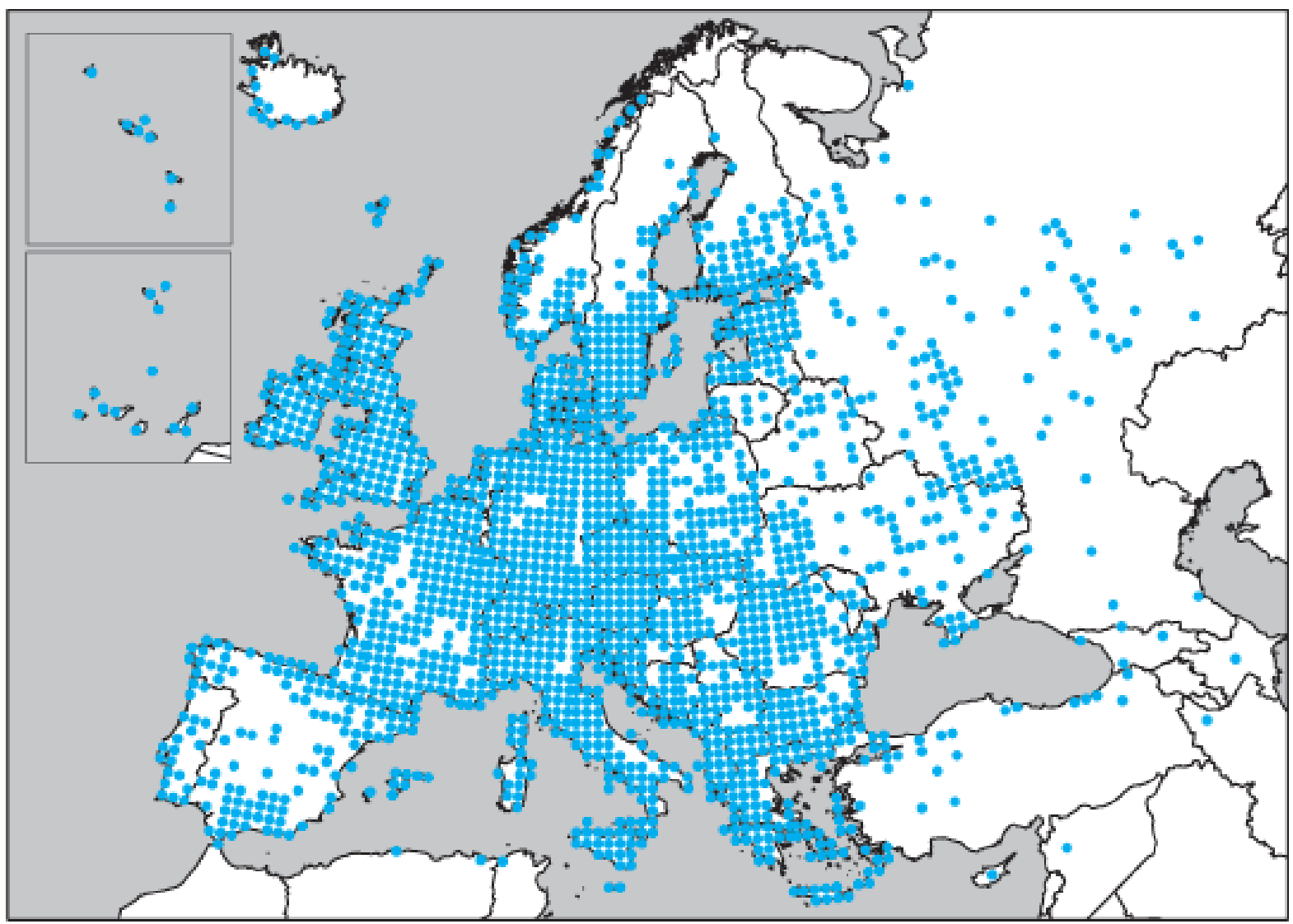

Fig. 2. Map showing all the $50 \mathrm{~km}$ squares which provided records included in this volume. 
Table 1. Classification of millipedes according to Shelley (2002). Orders in brackets have no European species. The orders Spirobolida and Spirostreptida, marked with asterisks (*), are represented in Europe only by hothouse species. The order Julida, covered by the present volume, is shown in bold.

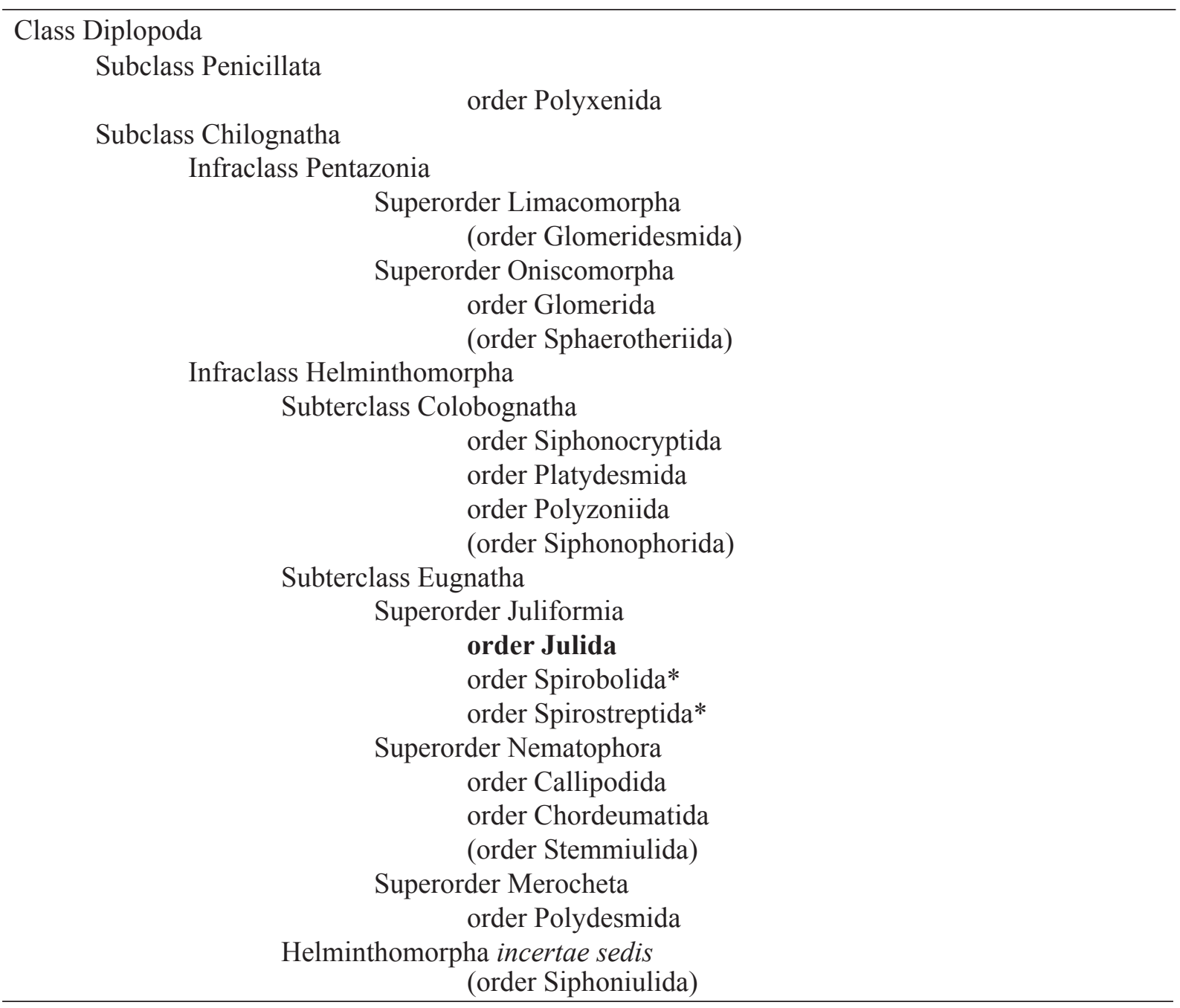

Synonyms, again largely in accordance with Fauna Europaea. Whereas the synonymy does not pretend to be complete, we have tried to include all synonyms which may cause confusion, and we have always included the original combination, e.g., in the case of Blaniulus guttulatus (Fabricius, 1798), the first synonym given is Julus guttulatus Fabricius, 1798. The synonyms include in many cases subspecific names, cf. Introduction.

Where a synonym is given as, e.g., Brachyiulus littoralis Verhoeff, 1898, in the list of synonyms of Brachyiulus pusillus (Leach, 1814) it means that Verhoeff in 1898 described B. littoralis as a new species, but that littoralis is now regarded as a synonym of pusillus. Where a name is followed by "auct." rather than an author name, it means that some authors used this name, which is not regarded as valid.

Distribution. The European distribution is given as a list of the geopolitical units from where the species has been reliably documented. The units and the abbreviations are, with one exception, the same as those used in Fauna Europaea, see Table 3 and Fig. 3. The exception concerns Serbia (SB) and Montenegro (MN) which in Fauna Europaea are treated as one unit ("Yugoslavia", YU). Despite recent political changes, records from Kosovo are ascribed to Serbia (SB) and records from the Crimea are ascribed 
Table 2. Families of Julida. Classification and sequence according to Shelley (2002). Families covered by the present volume are shown in bold. Notice that in the main text, the Julidae are placed last, and the other families are placed in alphabetical order.

\author{
ORDER JULIDA \\ Superfamily Blaniuloidea \\ Blaniulidae C.L. Koch, 1847 \\ Galliobatidae Brolemann, 1921 \\ Okeanobatidae Verhoeff, 1942 \\ Zosteractinidae Loomis, 1943 \\ Superfamily Juloidea \\ Julidae Leach, 1814 \\ Rhopaloiulidae Attems, 1926 \\ Trichoblaniulidae Verhoeff, 1911 \\ Trichonemasomatidae Enghoff, 1991 \\ Superfamily Nemasomatoidea \\ Chelojulidae Enghoff, 1991 \\ Nemasomatidae Bollman, 1893 \\ Pseudonemasomatidae Enghoff, 1991 \\ Telsonemasomatidae Enghoff, 1992 \\ Superfamily Paeromopodoidea \\ Aprosphylosomatidae Hoffman, 1961 \\ Paeromopodidae Cook, 1895 \\ Superfamily Parajuloidea \\ Mongoliulidae Pocock, 1903 \\ Parajulidae Bollman, 1893
}

\begin{abstract}
to Ukraine (UA). We have found several publications in which distributional data are erroneous with regard to present-day geopolitical units, including some which have been reiterated even as recently as 2012 in national inventories of species made after boundary changes. The Balkan countries have been particularly affected in this respect, especially Albania, in view of the numerous descriptions of endemics attributed there before the First World War which have for a long time related to other neighbouring countries. Specification of the distribution within one geopolitical unit is given in brackets, e.g., ES-SPA (Jaén Province). Distribution outside Europe is given in more general terms in the form (example) " Also North Africa". In many cases a general characterisation of the distribution type is given as well, e.g., "Central, N \& E Europe". A map (Fig. 4) shows the major biogeographical zones within Europe which are referred to. Terms such as "extended Atlantic" - meaning in this case western species which occur further east than the limit on the map - are also used. For species with restricted distributions, of which there are very many, the types of distribution denoted are largely based on secondary glacial refugia found in De Lattin (1967), which are centres of endemism in millipedes, with more precise examples from, e.g., Verhoeff (1938), Tabacaru (1970) and Spelda (1996).
\end{abstract}

Habitat. Ecological information is given if known. It has, however, not been possible to examine every paper that has been published throughout Europe to find whether such details are given. When an author has made an important contribution to the knowledge of the ecology of a species, we have quoted the paper; otherwise the information is an amalgam of that found in several publications, together with our own experience in the field.

Clearly the ecological requirements of the majority of millipedes are to some extent similar, the bulk of them being detritivores and inhabitants of the forest floor. However, many millipedes are strictly limited 
Table 3 (continued on next page). Geopolitical units in Europe as used in the present atlas and in Fauna Europaea. (A few of the geopolitical units in the table still have no millipede records.)

\begin{tabular}{|c|c|}
\hline$\overline{\mathrm{AD}}$ & Andorra \\
\hline $\mathrm{AL}$ & Albania \\
\hline AT & Austria \\
\hline $\mathrm{BA}$ & Bosnia-Herzegovina \\
\hline $\mathrm{BE}$ & Belgium \\
\hline BG & Bulgaria \\
\hline BY & Belarus \\
\hline $\mathrm{CH}$ & Switzerland \\
\hline $\mathrm{CZ}$ & Czech Republic \\
\hline $\mathrm{DE}$ & Germany \\
\hline DK-DEN & Danish mainland \\
\hline DK-FOR & Faroe Is \\
\hline $\mathrm{EE}$ & Estonia \\
\hline ES-BAL & Balearic Islands \\
\hline ES-CNY & Canary Islands \\
\hline ES-SPA & Spanish mainland \\
\hline FI & Finland \\
\hline FR-COR & Corsica \\
\hline FR-FRA & French mainland \\
\hline GB-CI & Channel Islands \\
\hline GB-GI & Gibraltar \\
\hline GB-GRB & Great Britain, including Shetlands, Orkneys, Hebrides \& Isle of Man \\
\hline GB-NI & Northern Ireland \\
\hline GR-CYC & Cyclades Islands \\
\hline GR-DOD & Dodecanese Islands \\
\hline GR-GRC & Greek mainland, including Ionian Is, Evia, Sporades \& North Aegean Is. \\
\hline GR-KRI & Crete, including small adjacent islands \\
\hline HR & Croatia \\
\hline HU & Hungary \\
\hline IE & Republic of Ireland \\
\hline IS & Iceland \\
\hline IT-ITA & Italian mainland \\
\hline IT-SAR & Sardinia \\
\hline IT-SI & Sicily, including all neighbouring Italian islands \\
\hline LI & Liechtenstein \\
\hline LT & Lithuania \\
\hline LU & Luxembourg \\
\hline LV & Latvia \\
\hline $\mathrm{MC}$ & Monaco \\
\hline MD & Republic of Moldova \\
\hline MN & Montenegro \\
\hline MT & Malta \\
\hline NL & The Netherlands \\
\hline NO-NOR & Norwegian mainland and inshore islands \\
\hline NO-SVA & Svalbard, Jan Mayen \& Bear Island. \\
\hline PL & Poland \\
\hline
\end{tabular}




\begin{tabular}{ll} 
PT-AZO & Azores Islands \\
PT-MDR & Madeira Islands \\
PT-POR & Portuguese mainland \\
PT-SEL & Selvagens Islands \\
RO & Romania \\
RU-FJL & Franz Josef Land \\
RU-KGD & Kaliningrad Region \\
RU-NOZ & Novaya Zemlya \\
RU-RUC & Central European Russia \\
RU-RUE & East Central Russia \\
RU-RUN & North European Russia \\
RU-RUS & South European Russia \\
RU-RUW & Northwest Russia \\
SB & Serbia \\
SE & Sweden \\
SI & Slovenia \\
SK & Slovakia \\
SM & San Marino \\
TR-TUE & European Turkey, including Imroz I.-Gökceada, but not islands in the Sea of Marmara \\
UA & Ukraine \\
VA & Vatican City \\
\hline
\end{tabular}

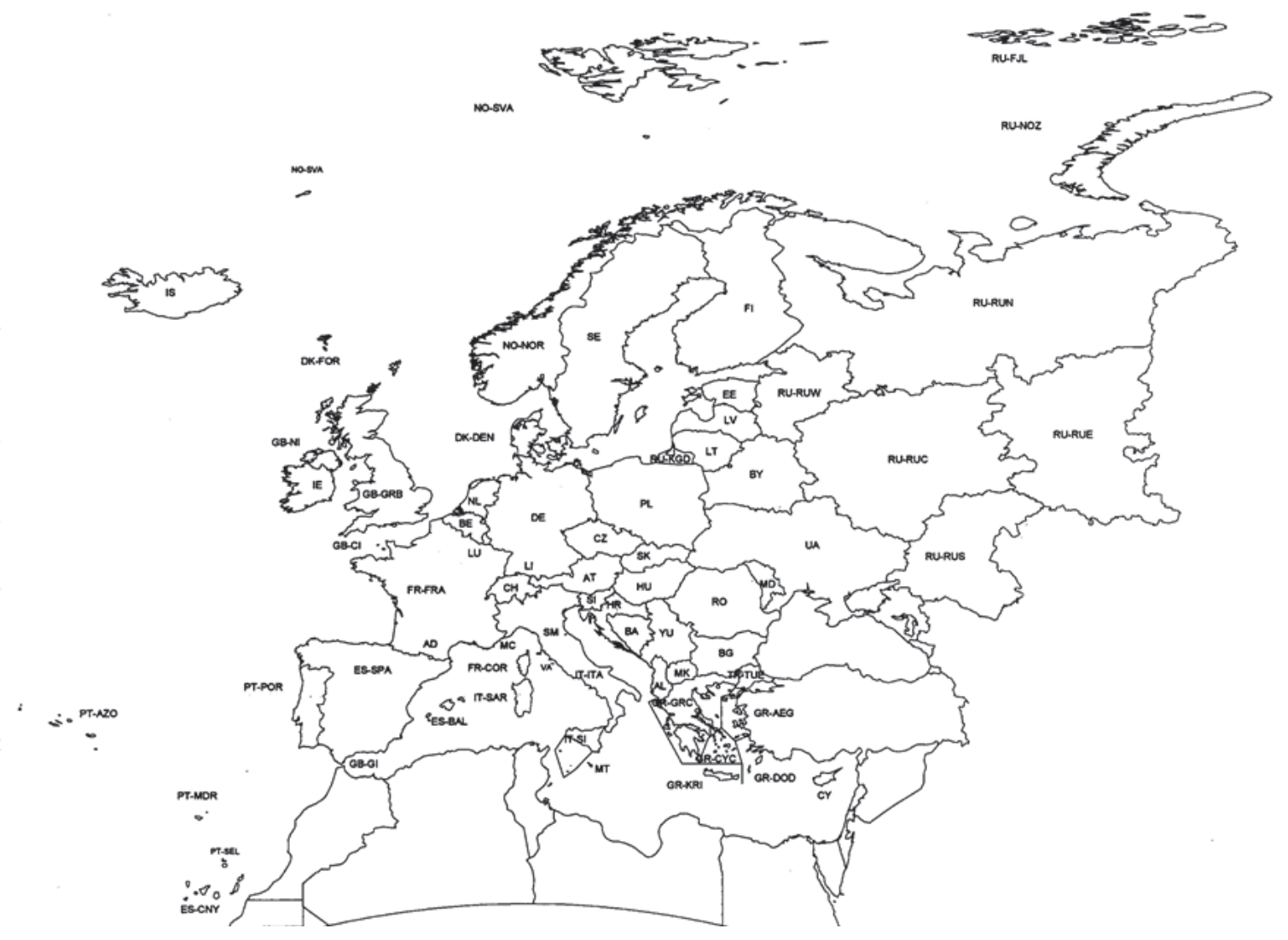

Fig. 3. Area codes as used in the atlas, from Fauna Europaea guidelines (Jong et al. 2014, supplementary material 1). Reproduced with permission. Note that MN (Montenegro) and SB (Serbia) in the above list and throughout this paper are shown as YU (Yugoslavia) on this map. 


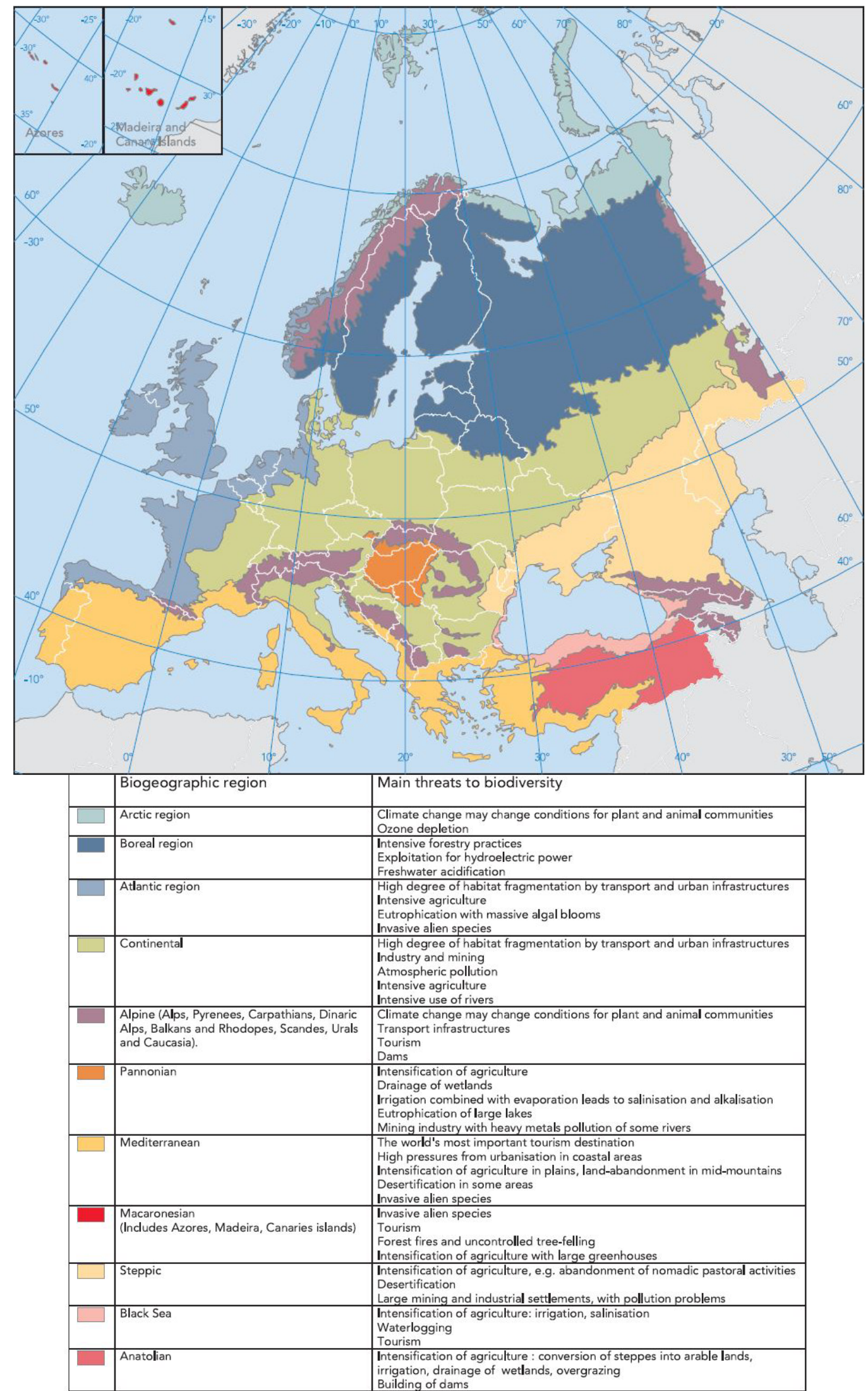

Fig. 4. Biogeographic regions in Europe, from European Environment Agency (2003); reproduced with permission. 
by ecological factors such as temperature, soil texture, mineral composition (e.g., calcium content), humidity and humus type, which of course link with the type of vegetation. Therefore, where possible, we have tried to draw attention to specific biotopes and altitudinal ranges that have been noted by collectors. There is still a long way to go in this direction. For many species we have no information.

For the forest types (or other vegetation types) we have in general used the Latin names of the trees, etc. involved (e.g., Quercus-Carpinus forest) rather than, e.g., "oak-hornbeam forest" or "quercetocarpinetum". The latter types of descriptive terms have, however, been included in some cases where this information is in the form of a citation of particular papers.

The term cavernicole is used "sensu lato"; true troglobionts are indicated as such.

Remarks. May include notes on taxonomy and distribution, and/or may refer to particular studies on, e.g., reproduction, economic importance, etc. Again, we do not claim completeness of coverage. It is beyond the scope of this atlas to analyse the reasons for the distribution of the genera and species. These lie in the history of Europe and such phenomena as plate tectonics, the Late Tertiary aridity crisis, the Quaternary glaciations, changes in sea level and climate change with associated shifts in vegetation belts. In addition, several species have become widespread due to the activities of Man.

In connection with the maps the reader's attention is sometimes drawn to uneven coverage, the paucity of records and/or predicted distributional limits of species. To give an example, Stojałowska \& Staręga (1974) noted the presence of Unciger foetidus C.L. Koch, 1838, in all 21 clearly demarcated regions of Poland. Yet this left over fifty $50 \mathrm{~km}$ squares devoid of precise records of this widespread species in the first Polish UTM maps later received from our colleague Wojciech Jędryczkowski, few of which we have subsequently been able to fill. This represents over a third of Poland. In view of its size, Russia is inevitably much less covered altogether. The same applies to some other larger countries. Accordingly, we have felt able to add imprecise records for the two Polish regions lacking precise records but have not done so for Russia, where the species' limits are uncertain. Another difficulty is that in view of the very many boundary changes resulting from conflict in Europe and consequent changes of official language, we have been unable to locate some published sites when it is no longer clear to which place the author was referring. Moreover, there are often several places with the same name even in one region, those of saints for example; also, in some countries the names of towns have simply been altered without a change of language. Unfortunately, such records may be missing, owing to our uncertainty, again affecting mainly eastern areas of the continent.

The maps. The presence of each species is recorded in $50 \mathrm{~km}$ squares of the UTM grid. Six different base maps are used:

All of Europe, for species occurring north of ca $48^{\circ} \mathrm{N}$.

Southern Europe, for relatively widespread species not occurring north of ca $48^{\circ} \mathrm{N}$.

Southwestern Europe, for species confined to the Iberian Peninsula and southern-central France.

South-central Europe, for species confined to Italy and neighbouring areas.

Southeastern Europe, for species confined to the Balkans and neighbouring areas.

Madeira and Canary Islands, for species confined to these archipelagos.

A map is presented for each species except in the case of the Macaronesian species swarms in the genera Acipes, Cylindroiulus and Dolichoiulus, which each may have several species on the same small 
island. Squares in which precisely located records occur are shown by blue dots in the centre of the 50 $\mathrm{km}$ square concerned. Because a record may refer to a corner of a $50 \mathrm{~km}$ square the centre of which is in another country/region some species seem to occur in countries/regions from where they have not been recorded. A few records referable only to, e.g., a province, occasionally a country, are shown using a blue circle located at the centre of the province in question. No distinction is made between old and new records; this is mainly because the number of specialist recorders has been relatively small and because they have operated over different time periods in many of the countries concerned. There are few recent records from some countries and few old records from others. Under these circumstances, using different symbols for different time periods would give a false impression of movement of species. Moreover, there is little evidence that millipede distributions have changed much over the past century, with the possible exception of a few introduced or pioneer species. A coverage map (Fig. 2) showing all the $50 \mathrm{~km}$ squares from which records included in this volume have been reported is given. Thus, while interpreting the distribution of the species indicated on the maps it should be borne in mind that the coverage has been far from uniform at the European scale and, indeed, within individual countries. While there are exceptions, there has been a marked tendency for collectors to concentrate on the more interesting mountainous areas, especially in areas of known endemism, and to pay scant attention to the less biodiverse lowland plains. Even on the basis of units of $50 \mathrm{~km} \times 50 \mathrm{~km}$ squares, many squares have no records at all, especially in the larger countries.

In most calcareous regions, speleologists have been very active; in some of these there are far more records of cavernicolous species than of species living in the vegetation, litter and soil. There are many true troglobionts, but, at the same time, many of the species that were first found in caves are strongly pigmented and are either known to occur, or most probably occur, on the surface.

In this atlas "Europe" extends from the Azores to the Ural Mountains in Russia: the European part of Russia is delimited as in Fauna Europaea, which does not include the Caucasus area. In the Aegean area, this atlas covers all the islands belonging to Greece, while Cyprus and Asia Minor are not included. Only the European part of Turkey is covered. In the Atlantic, species from Iceland, the Azores, Madeira and the Canary Islands are listed. Some North African and Asiatic Turkish records of species occurring in Europe are shown on the maps, but exclusively African or Asiatic species are not considered. Dots in Asia Minor and North Africa refer only to species found in the Fauna Europaea database that occur there as well as in Europe. These data are not always complete. The vast majority of European millipedes do not occur elsewhere, except for those which have been introduced to other regions by way of human activities.

We have clearly not been able to find every published record and we have not been able to place some localities. Ambiguous or doubtful records have either been omitted or commented upon.

Our knowledge of the distribution of many species is very good, though for others it is extremely sketchy or inadequate. The maps represent a total of 13,217 $50 \mathrm{~km}$ square records; with 593 species this means that on average each species has been recorded from 22 squares. There are many regional and probably even more point endemics, i.e., species recorded from only one $50 \mathrm{~km}$ square. The species with the most records is Ommatoiulus sabulosus (Linnaeus, 1758) which has been recorded from 796 squares. The maps are published in the knowledge that some of them do not show the full distribution of the species concerned, as mentioned above. In some cases it is possible to imagine the full picture and comments are sometimes made to this effect in the text. It is left to present and future myriapodologists to fill in those gaps that remain and to complete the ecological information and other data that are missing. The rich southern faunas are most in need of investigation, especially in Iberia. 
Table 4 (continued on next pages). Species covered by the present atlas.

\section{Family BLANIULIDAE}

1. Acipes andalusius Enghoff \& Mauriès, 1999

2. Acipes atlanticus Attems, 1937

3. Acipes bifilum Enghoff \& Reboleira, 2013

4. Acipes continentalis Enghoff, 1986.

5. Acipes decolor Enghoff, 1983

6. Acipes franzi (Loksa, 1967)

7. Acipes lateralis Enghoff, 1983

8. Acipes machadoi Enghoff \& Reboleira, 2013

9. Acipes portosantoensis Enghoff, 1983

10. Acipes serratus Enghoff, 1983

11. Acipes waldeni Enghoff, 1983

12. Alpiobates peyerimhoff (Brölemann, 1900)

13. Archiboreoiulus pallidus (Brade-Birks, 1920)

14. Archiboreoiulus sollaudi Brolemann, 1921

15. Blaniulus dollfusi Brölemann, 1894

16. Blaniulus eulophus Silvestri, 1903

17. Blaniulus guttulatus (Fabricius, 1798)

18. Blaniulus lichtensteini Brolemann, 1921

19. Blaniulus lorifer (Brolemann, 1921)

20. Blaniulus mayeti (Brölemann, 1902)

21. Blaniulus orientalis Brolemann, 1921

22. Blaniulus troglobius Latzel, 1886

23. Blaniulus troglodites Brölemann, 1898

24. Blaniulus velatus Ribaut, 1954

25. Blaniulus virei Brölemann, 1900

26. Boreoiulus simplex Brolemann, 1921

27. Boreoiulus tenuis (Bigler, 1913)

28. Choneiulus faunaeuropaeae Enghoff, 2002

29. Choneiulus lacinifer Strasser, 1980

30. Choneiulus palmatus (Nĕmec, 1895)

31. Choneiulus subterraneus (Silvestri, 1903)

32. Cibiniulus phlepsii (Verhoeff, 1897)

33. Euzdakiulus sarensis Mauriès, 1970.

34. Iberoiulus breuili Ceuca, 1967

35. Iberoiulus cavernicola Ceuca, 1967

36. Mesoblaniulus serrula (Brölemann, 1905)

37. Monacobates monoecensis (Brölemann, 1905)

38. Nopoiulus kochii (Gervais, 1847)

39. Occitaniulus rouchi Mauriès, 1965

40. Orphanoiulus dinapolii Strasser, 1960

41. Orphanoiulus religiosus Silvestri, 1903

42. Proteroiulus broelemanni Lohmander, 1925

43. Proteroiulus fuscus (Am Stein, 1857)

44. Proteroiulus hispanus Schubart, 1959

45. Sardoblaniulus annae Manfredi, 1956

46. Tarracoblaniulus lagari Mauriès \& Vicente, 1977

47. Tarracoblaniulus phantasmanus Enghoff, Serra \& Martínez, 2009 
48. Thassoblaniulus simplarius Mauriès, 1985

49. Vascoblaniulus cabidochei Mauriès, 1967

Family GALLIOBATIDAE

50. Galliobates gracilis (Ribaut, 1909)

Family NEMASOMATIDAE

51. Nemasoma varicorne C.L. Koch, 1847

52. Thalassisobates almeriensis Enghoff, 2013

53. Thalassisobates emesesensis Enghoff, 2013

54. Thalassisobates littoralis (Silvestri, 1903)

Family RHOPALOIULIDAE

55. Rhopaloiulus cameratanus Attems, 1927

Family TRICHOBLANIULIDAE

56. Trichoblaniulus cavernicola Brölemann, 1905

57. Trichoblaniulus hirsutus (Brölemann, 1889)

58. Trichoblaniulus lanuginosus Ribaut, 1947

59. Trichoblaniulus tarraconensis Mauriès \& Vicente, 1977

Family TRICHONEMASOMATIDAE

60. Trichonemasoma peloponesius (Mauriès, 1966)

Family JULIDAE

61. Acanthoiulus cassinensis (Verhoeff, 1910)

62. Acanthoiulus fuscipes (C.L. Koch, 1847)

63. Afropachyiulus maritimus Strasser, 1970

64. Allajulus dicentrus (Latzel, 1884)

65. Allajulus groedensis (Attems, 1899)

66. Allajulus infossus (Verhoeff, 1930)

67. Allajulus marguareisi (Strasser, 1970)

68. Allajulus molybdinus C.L. Koch, 1847

69. Allajulus nitidus (Verhoeff, 1891)

70. Allajulus spinosus (Ribaut, 1904)

71. Allopodoiulus schiodtei (Verhoeff, 1898)

72. Allopodoiulus verhoeffi (Jawłowski, 1931)

73. Alpityphlus seewaldi Strasser, 1967

74. Amblyiulus aphroditae (Attems, 1902)

75. Amblyiulus creticus (Verhoeff, 1901)

76. Amblyiulus kovali Golovatch, 2008

77. Amblyiulus sporadensis (Verhoeff, 1901)

78. Apfelbeckiella bulgarica Verhoeff, 1926

79. Apfelbeckiella byzantina Verhoeff, 1901

80. Apfelbeckiella dobrogica Tabacaru, 1966

81. Apfelbeckiella golemanskyi Ceuca, 1973

82. Apfelbeckiella trnowensis (Verhoeff, 1928)

83. Balkanophoenix borisi Verhoeff, 1937

84. Banatoiulus troglobius Tabacaru, 1985

85. Brachyiulus apfelbecki Verhoeff, 1898

86. Brachyiulus bagnalli (Brolemann, 1924)

87. Brachyiulus jawlowskii Lohmander, 1928

88. Brachyiulus klisurensis Verhoeff, 1903

89. Brachyiulus lusitanus Verhoeff, 1898 
90. Brachyiulus pusillus (Leach, 1814)

91. Brachyiulus stuxbergi (Fanzago, 1875)

92. Brachyiulus varibolinus Attems, 1904

93. Buchneria cornuta Verhoeff, 1941

94. Buchneria sicula Strasser, 1959

95. Chaetoleptophyllum montanum (Verhoeff, 1898)

96. Chaitoiulus spinifer (Verhoeff, 1895)

97. Chersoiulus ciliatus Strasser, 1938

98. Chersoiulus sphinx Strasser, 1940

99. Chromatoiulus hamuligerus (Verhoeff, 1932)

100. Chromatoiulus podabrus (Latzel, 1884)

101. Cylindroiulus abaligetanus Verhoeff, 1901

102. Cylindroiulus aetnensis Verhoeff, 1910

103. Cylindroiulus anglilectus Read, 2007

104. Cylindroiulus aostanus Verhoeff, 1932

105. Cylindroiulus apenninorum (Brölemann, 1897)

106. Cylindroiulus arborum Verhoeff, 1928

107. Cylindroiulus aternanus Verhoeff, 1930

108. Cylindroiulus attenuatus Enghoff, 1982

109. Cylindroiulus bellus (Lignau, 1903)

110. Cylindroiulus boleti (C.L. Koch, 1847)

111. Cylindroiulus boreoibericus Read, 2007

112. Cylindroiulus brachyiuloides Enghoff, 1982

113. Cylindroiulus britannicus (Verhoeff, 1891)

114. Cylindroiulus broti (Humbert, 1893)

115. Cylindroiulus burzenlandicus Verhoeff, 1907

116. Cylindroiulus caeruleocinctus (Wood, 1864)

117. Cylindroiulus cambio Korsós \& Read, 1994

118. Cylindroiulus cantonii (Brölemann, 1892)

119. Cylindroiulus caramujensis Lohmander, 1955

120. Cylindroiulus chalandei (Ribaut, 1904)

121. Cylindroiulus cristagalli Enghoff, 1982

122. Cylindroiulus dahli Demange, 1970

123. Cylindroiulus decipiens (Berlese, 1885)

124. Cylindroiulus digitus Enghoff, 1982

125. Cylindroiulus disjunctus Read, 1989

126. Cylindroiulus dubius Verhoeff, 1930

127. Cylindroiulus exiguus Enghoff, 1982

128. Cylindroiulus fenestratus Read, 1989

129. Cylindroiulus festai Manfredi, 1939

130. Cylindroiulus fimbriatus Enghoff, 1982

131. Cylindroiulus finitimus (Ribaut, 1905)

132. Cylindroiulus franzi Attems, 1952

133. Cylindroiulus fulviceps (Latzel, 1884)

134. Cylindroiulus gemellus Enghoff, 1982

135. Cylindroiulus generosensis Verhoeff, 1900

136. Cylindroiulus gestri (Silvestri, 1898)

137. Cylindroiulus gigas Verhoeff, 1932

138. Cylindroiulus gregoryi Read, 2007

139. Cylindroiulus hirticauda Enghoff, 1982 
140. Cylindroiulus horvathi (Verhoeff, 1897)

141. Cylindroiulus ibericus Brölemann, 1913

142. Cylindroiulus iluronensis Brölemann, 1912

143. Cylindroiulus infernalis Lohmander, 1955

144. Cylindroiulus insolidus Lohmander, 1955

145. Cylindroiulus italicus (Latzel, 1884)

146. Cylindroiulus julesvernei Reboleira \& Enghoff, 2014

147. Cylindroiulus julipes Enghoff, 1982

148. Cylindroiulus kappa Enghoff, 1982

149. Cylindroiulus lagrecai Manfredi, 1957

150. Cylindroiulus latestriatus (Curtis, 1845)

151. Cylindroiulus latro Attems, 1927

152. Cylindroiulus latzeli (Berlese, 1884)

153. Cylindroiulus laurisilvae Enghoff, 1982

154. Cylindroiulus limitaneus (Brölemann, 1905)

155. Cylindroiulus londinensis (Leach, 1814)

156. Cylindroiulus lundbladi Lohmander, 1955

157. Cylindroiulus luridus (C.L. Koch, 1847)

158. Cylindroiulus madeirae Attems, 1937

159. Cylindroiulus meinerti (Verhoeff, 1891)

160. Cylindroiulus molisius Verhoeff, 1932

161. Cylindroiulus numerosus Enghoff, 1982

162. Cylindroiulus obscurior Enghoff, 1982

163. Cylindroiulus oromii Reboleira \& Enghoff, 2014

164. Cylindroiulus pallidior Enghoff, 1982

165. Cylindroiulus parisiorum (Brölemann \& Verhoeff, 1896)

166. Cylindroiulus pelatensis Verhoeff, 1930

167. Cylindroiulus perforatus Verhoeff, 1905

168. Cylindroiulus propinquus (Porat, 1870)

169. Cylindroiulus punctatus (Leach, 1815)

170. Cylindroiulus pyrenaicus (Brölemann, 1897)

171. Cylindroiulus quadratistipes Enghoff, 1982

172. Cylindroiulus rabacalensis Lohmander, 1955

173. Cylindroiulus rubidicollis Verhoeff, 1930

174. Cylindroiulus rufifrons (C.L. Koch, 1847)

175. Cylindroiulus sagittarius (Brölemann, 1897)

176. Cylindroiulus salicivorus Verhoeff, 1908

177. Cylindroiulus sanctimichaelis Attems, 1927

178. Cylindroiulus sangranus (Verhoeff, 1932)

179. Cylindroiulus sardous (Silvestri, 1898)

180. Cylindroiulus schubarti Verhoeff, 1943

181. Cylindroiulus segregatus Brölemann, 1903

182. Cylindroiulus siculus (Silvestri, 1897)

183. Cylindroiulus solarius Verhoeff, 1942

184. Cylindroiulus solis Verhoeff, 1908

185. Cylindroiulus sorrentinus Verhoeff, 1912

186. Cylindroiulus speluncaris Lohmander, 1955

187. Cylindroiulus strasseri Verhoeff, 1930

188. Cylindroiulus tirolensis Verhoeff, 1901

189. Cylindroiulus transmarinus Enghoff, 1982

190. Cylindroiulus tricuspis Verhoeff, 1932 
191. Cylindroiulus truncorum (Silvestri, 1896)

192. Cylindroiulus turinensis (Brölemann, 1897)

193. Cylindroiulus unciger Attems, 1952

194. Cylindroiulus uncinatus Strasser, 1969

195. Cylindroiulus uroxiphos Enghoff, 1982

196. Cylindroiulus velatus Enghoff, 1982

197. Cylindroiulus ventanaea Read, 2007

198. Cylindroiulus verhoeffi (Brölemann, 1896)

199. Cylindroiulus vulnerarius (Berlese, 1888)

200. Cylindroiulus waldeni Read, 1989

201. Cylindroiulus xynon Read, 1989

202. Cylindroiulus ynnox Read, 1989

203. Cylindroiulus zarcoi Read, 1989

204. Cylindroiulus zinalensis (Faës, 1902)

205. Dolichoiulus alluaudi (Brölemann, 1901)

206. Dolichoiulus altitenerife Enghoff, 1992

207. Dolichoiulus aquasilvae Enghoff, 1992

208. Dolichoiulus architheca Enghoff, 1992

209. Dolichoiulus axeli Enghoff, 1992

210. Dolichoiulus baezi Enghoff, 1992

211. Dolichoiulus blancatypa (Enghoff, 1992)

212. Dolichoiulus canariensis (Pocock, 1893)

213. Dolichoiulus carolineae Enghoff, 1992

214. Dolichoiulus chioensis Enghoff, 1992

215. Dolichoiulus dendromystax Enghoff, 1992

216. Dolichoiulus dubiosus Enghoff, 1992

217. Dolichoiulus eumadeirae Enghoff, 1992

218. Dolichoiulus fjellbergi Enghoff, 1992

219. Dolichoiulus fuerteventurae Enghoff, 1992

220. Dolichoiulus gara Enghoff, 1992

221. Dolichoiulus heliophilus Enghoff, 1992

222. Dolichoiulus hercules (Schubart, 1960)

223. Dolichoiulus hyaena Enghoff, 1992

224. Dolichoiulus ibericus Ceuca, 1973

225. Dolichoiulus ingeae Enghoff, 1992

226. Dolichoiulus insularis (Brölemann, 1901)

227. Dolichoiulus jandiensis Enghoff, 1992

228. Dolichoiulus jonay Enghoff, 1992

229. Dolichoiulus kraepelinorum (Latzel, 1895)

230. Dolichoiulus labradae Enghoff, 1992

231. Dolichoiulus lasiurus Enghoff, 1992

232. Dolichoiulus longunguis Enghoff, 2012

233. Dolichoiulus madeiranus (Mauriès, 1970)

234. Dolichoiulus martini Enghoff, 1992

235. Dolichoiulus mystax (Brölemann, 1901)

236. Dolichoiulus nemasoma Enghoff, 1992

237. Dolichoiulus oromii Enghoff, 2012

238. Dolichoiulus oskari Enghoff, 1992

239. Dolichoiulus parcestriatus (Brölemann, 1901)

240. Dolichoiulus praesenilis Enghoff, 1992

241. Dolichoiulus quasimystax Enghoff, 1992 
242. Dolichoiulus rectangulus Enghoff, 1992

243. Dolichoiulus salvagicus (Latzel, 1895)

244. Dolichoiulus sansebastianus (Attems, 1911)

245. Dolichoiulus senilis (Attems, 1911)

246. Dolichoiulus silvahierro Enghoff, 1992

247. Dolichoiulus silvapalma Enghoff, 1992

248. Dolichoiulus tiendarius (Attems, 1911)

249. Dolichoiulus tongiorgii (Strasser, 1973)

250. Dolichoiulus troglohierro Enghoff, 1992

251. Dolichoiulus typhlocanaria Enghoff, 2012

252. Dolichoiulus typhlops Ceuca, 1973

253. Dolichoiulus ultimus Enghoff, 1992

254. Dolichoiulus variabilis Enghoff, 1992

255. Dolichoiulus vosseleri (Verhoeff, 1900)

256. Dolichoiulus wunderlichi Enghoff, 1992

257. Dolichoiulus xerohierro Enghoff, 1992

258. Dolichoiulus xeropalma Enghoff, 1992

259. Dolichoiulus xylomystax Enghoff, 1992

260. Dolichoiulus ypsilon Enghoff, 1992

261. Dolichoiulus zygodon Enghoff, 1992

262. Elbaiulus carpinorum Verhoeff, 1930

263. Elbaiulus chrysopygus (Berlese, 1888)

264. Enantiulus armatus (Ribaut, 1909)

265. Enantiulus austriacus (Verhoeff, 1896)

266. Enantiulus dentigerus (Verhoeff, 1900)

267. Enantiulus karawankianus (Verhoeff, 1908)

268. Enantiulus nanus (Latzel, 1884)

269. Enantiulus simplex (Verhoeff, 1926)

270. Enantiulus tatranus (Verhoeff, 1907)

271. Enantiulus transsilvanicus (Verhoeff, 1899)

272. Enghophyllum naxium (Verhoeff, 1901)

273. Enghophyllum sifnium Lazányi \& Vagalinski, 2013

274. Geopachyiulus negreai Tabacaru, 1978

275. Geopachyiulus nematodes (Latzel, 1884)

276. Haplophyllum mehelyi (Verhoeff, 1897)

277. Haplopodoiulus spathifer (Brölemann, 1897)

278. Heteroiulus intermedius (Brölemann, 1892)

279. Hylopachyiulus pygmaeus (Attems, 1904)

280. Hypsoiulus alpivagus (Verhoeff, 1897)

281. Interleptoiulus cernagoranus Mršić, 1988

282. Julus curvicornis Verhoeff, 1899

283. Julus scandinavius Latzel, 1884

284. Julus scanicus Lohmander, 1925

285. Julus terrestris Linnaeus, 1758

286. Kryphioiulus occultus (C.L. Koch, 1847)

287. Lamellotyphlus belevodae Makarov, 2008

288. Lamellotyphlus mehedintzensis (Tabacaru, 1976)

289. Lamellotyphlus sotirovi Makarov, Mitić \& Ćurčić, 2002

290. Leptoiulus abietum Verhoeff, 1914

291. Leptoiulus alemannicus (Verhoeff, 1894)

292. Leptoiulus arelatus Bigler, 1919 
293. Leptoiulus atticus Strasser, 1970

294. Leptoiulus baconyensis (Verhoeff, 1899)

295. Leptoiulus belgicus (Latzel, 1884)

296. Leptoiulus bertkaui (Verhoeff, 1896)

297. Leptoiulus borisi Verhoeff, 1926

298. Leptoiulus brentanus Verhoeff, 1926

299. Leptoiulus brevivelatus Bigler, 1919

300. Leptoiulus broelemanni (Verhoeff, 1895)

301. Leptoiulus bruyanti Ribaut, 1951

302. Leptoiulus carpinorum Verhoeff, 1929

303. Leptoiulus cernagoranus (Attems, 1927)

304. Leptoiulus chiesensis Verhoeff, 1934

305. Leptoiulus cibdellus (Chamberlin, 1921)

306. Leptoiulus czarnohoricus Jawłowski, 1928

307. Leptoiulus demangei Schubart, 1962

308. Leptoiulus deubeli (Verhoeff, 1897)

309. Leptoiulus discophorus (Attems, 1927)

310. Leptoiulus dolinensis Verhoeff, 1928

311. Leptoiulus durmitorius (Attems, 1927)

312. Leptoiulus faesi Bigler, 1919

313. Leptoiulus frigidarius Verhoeff, 1913

314. Leptoiulus garumnicus (Ribaut, 1904)

315. Leptoiulus gilvicollis Verhoeff, 1932

316. Leptoiulus hauseri Strasser, 1976

317. Leptoiulus helveticus (Verhoeff, 1894)

318. Leptoiulus hospitelli Brölemann, 1901

319. Leptoiulus ivanjicae Ćurčić \& Makarov, 1997

320. Leptoiulus juvenilis (Ribaut, 1908)

321. Leptoiulus kervillei (Brölemann, 1896)

322. Leptoiulus korongsius (Attems, 1904)

323. Leptoiulus krueperi (Verhoeff, 1900)

324. Leptoiulus laetedorsalis (Verhoeff, 1898)

325. Leptoiulus legeri (Brölemann, 1897)

326. Leptoiulus liptauensis (Verhoeff, 1899)

327. Leptoiulus macedonicus (Attems, 1927)

328. Leptoiulus magnus Bigler, 1919

329. Leptoiulus mariae Gulička, 1952

330. Leptoiulus matulicii (Verhoeff, 1901)

331. Leptoiulus meridionalis (Brölemann, 1897)

332. Leptoiulus montivagus (Latzel, 1884)

333. Leptoiulus noricus Verhoeff, 1913

334. Leptoiulus oribates (Latzel, 1884)

335. Leptoiulus pentheri (Attems, 1927)

336. Leptoiulus piceus (Risso, 1826)

337. Leptoiulus polonicus Jawłowski, 1930

338. Leptoiulus pretneri Strasser, 1940

339. Leptoiulus proximus (Nĕmec, 1896)

340. Leptoiulus remyi Schubart, 1962

341. Leptoiulus riparius (Verhoeff, 1894)

342. Leptoiulus roszkowskii Jawłowski, 1930

343. Leptoiulus saltuvagus (Verhoeff, 1898) 
344. Leptoiulus sarajevensis (Verhoeff, 1898)

345. Leptoiulus sarasini Bigler, 1929

346. Leptoiulus semenkevitshi Lohmander, 1928

347. Leptoiulus simplex (Verhoeff, 1894)

348. Leptoiulus storkani Verhoeff, 1932

349. Leptoiulus tatricus Gulička, 1956

350. Leptoiulus tendanus Verhoeff, 1930

351. Leptoiulus transsylvanicus (Daday, 1889)

352. Leptoiulus trilineatus (C.L. Koch, 1847)

353. Leptoiulus trilobatus (Verhoeff, 1894)

354. Leptoiulus tussilaginis (Verhoeff, 1907)

355. Leptoiulus umbratilis (Ribaut, 1905)

356. Leptoiulus uncinatus Ribaut, 1951

357. Leptoiulus vagabundus (Latzel, 1884)

358. Leptoiulus vieirae (Verhoeff, 1900)

359. Leptoiulus zagrebensis Verhoeff, 1929

360. Leptotyphloiulus coeruleoalbus (Verhoeff, 1899)

361. Leptotyphloiulus dolinensis (Verhoeff, 1901)

362. Macheiroiulus compressicauda Verhoeff, 1901

363. Mammamia profuga Akkari, Stoev \& Enghoff, 2011

364. Megaphyllum anatolicum (Attems, 1926)

365. Megaphyllum argolicum (Verhoeff, 1900)

366. Megaphyllum austriacum (Latzel, 1884)

367. Megaphyllum beroni (Strasser, 1973)

368. Megaphyllum bicolor (Loksa, 1970)

369. Megaphyllum bosniense (Verhoeff, 1897)

370. Megaphyllum brachyurum (Attems, 1899)

371. Megaphyllum byzantinum (Verhoeff, 1901)

372. Megaphyllum carniolense (Verhoeff, 1897)

373. Megaphyllum cephalonicum (Strasser, 1974)

374. Megaphyllum chiosense Lazányi \& Korsós, 2012

375. Megaphyllum crassum (Attems, 1929)

376. Megaphyllum creticum (Strasser, 1976)

377. Megaphyllum cygniforme Lazányi \& Korsós, 2012

378. Megaphyllum danyi Lazányi \& Korsós, 2012

379. Megaphyllum dentatum (Verhoeff, 1898)

380. Megaphyllum digitatum Lazányi \& Korsós, 2012

381. Megaphyllum erythronotum (Latzel, 1884)

382. Megaphyllum euphorbiarum (Verhoeff, 1900)

383. Megaphyllum glossuliferum (Schubart, 1934)

384. Megaphyllum hercules (Verhoeff, 1900)

385. Megaphyllum imbecillum (Attems, 1935)

386. Megaphyllum karschi (Verhoeff, 1901)

387. Megaphyllum kievense (Lohmander, 1928)

388. Megaphyllum lamelliferum (Strasser, 1974)

389. Megaphyllum leucadium (Attems, 1929)

390. Megaphyllum lictor (Attems, 1904)

391. Megaphyllum loebli (Strasser, 1974)

392. Megaphyllum margaritatum (Fanzago, 1875)

393. Megaphyllum metsovoni (Strasser, 1976)

394. Megaphyllum montivagum (Verhoeff, 1901) 
395. Megaphyllum mueggenburgi (Verhoeff, 1901)

396. Megaphyllum platyurum (Latzel, 1884)

397. Megaphyllum projectum Verhoeff, 1894

398. Megaphyllum recticauda (Attems, 1903)

399. Megaphyllum rhodopinum (Verhoeff, 1928)

400. Megaphyllum rosenauense (Verhoeff, 1897)

401. Megaphyllum rossicum (Timotheew, 1897)

402. Megaphyllum rubidicolle (Verhoeff, 1901)

403. Megaphyllum sapphicum (Strasser, 1976)

404. Megaphyllum silvaticum (Verhoeff, 1898)

405. Megaphyllum sjaelandicum (Meinert, 1868)

406. Megaphyllum syrense (Verhoeff, 1903)

407. Megaphyllum tauricum (Attems, 1907)

408. Megaphyllum taygetanum (Attems, 1903)

409. Megaphyllum taygeti (Strasser, 1976)

410. Megaphyllum transsylvanicum (Verhoeff, 1897)

411. Megaphyllum unilineatum (C.L. Koch, 1838)

412. Megaphyllum vicinum (Verhoeff, 1903)

413. Mesoiulus berlesei Silvestri, 1898

414. Mesoiulus cavernarum (Verhoeff, 1938)

415. Mesoiulus derouteae Mauriès, 1971

416. Mesoiulus drescoi Mauriès, 1971

417. Mesoiulus gridellii Strasser, 1934

418. Mesoiulus henroti Mauriès, 1971

419. Mesoiulus kosswigi Verhoeff, 1936

420. Mesoiulus mauriesi Strasser, 1974

421. Mesoiulus paradoxus Berlese, 1886

422. Mesoiulus rusticanus Mauriès \& Vicente, 1977

423. Mesoiulus siculus Silvestri, 1902

424. Mesoiulus stammeri (Verhoeff, 1936)

425. Metaiulus pratensis Blower \& Rolfe, 1956

426. Micropachyiulus paucioculatus (Verhoeff, 1899)

427. Ommatoiulus albolineatus (Lucas, 1845)

428. Ommatoiulus andalusius (Attems, 1927)

429. Ommatoiulus armatus (Verhoeff, 1910)

430. Ommatoiulus aurozonatus (Berlese, 1886)

431. Ommatoiulus baenai Akkari \& Enghoff, 2012

432. Ommatoiulus baileyi Akkari \& Enghoff, 2012

433. Ommatoiulus bavayi (Brölemann, 1897)

434. Ommatoiulus bipartitus (Verhoeff, 1910)

435. Ommatoiulus buchneri (Verhoeff, 1940)

436. Ommatoiulus cervinus (Verhoeff, 1910)

437. Ommatoiulus cingulatus (Attems, 1927)

438. Ommatoiulus clavigerus (Verhoeff, 1921)

439. Ommatoiulus corsicus (Brölemann, 1903)

440. Ommatoiulus corunnensis (Verhoeff, 1910)

441. Ommatoiulus demangei Vicente \& Rodriguez, 1992

442. Ommatoiulus diplurus (Attems, 1903)

443. Ommatoiulus dorsovittatus (Verhoeff, 1893)

444. Ommatoiulus fuentei (Brolemann, 1920)

445. Ommatoiulus haackeri Mauriès, 1969 
446. Ommatoiulus hoffmani Akkari \& Enghoff, 2012

447. Ommatoiulus ibericus Ceuca, 1974

448. Ommatoiulus ilicis (Brölemann, 1897)

449. Ommatoiulus imminutus (Brolemann, 1926)

450. Ommatoiulus inconspicuus (L.Koch, 1881)

451. Ommatoiulus jaenensis Akkari \& Enghoff, 2012

452. Ommatoiulus kimei Akkari \& Enghoff, 2012

453. Ommatoiulus lienharti (Brolemann, 1921)

454. Ommatoiulus lusitanus (Verhoeff, 1895)

455. Ommatoiulus martensi Mauriès, 1969

456. Ommatoiulus moreleti (Lucas, 1860)

457. Ommatoiulus navasi (Brölemann, 1918)

458. Ommatoiulus niger (Attems, 1952)

459. Ommatoiulus oliveirae (Verhoeff, 1893)

460. Ommatoiulus oxypygus (Brandt, 1841)

461. Ommatoiulus parallelus (C.L. Koch, 1847)

462. Ommatoiulus porathi (Verhoeff, 1893)

463. Ommatoiulus pseudoflagellatus Akkari \& Enghoff, 2012

464. Ommatoiulus recueroi Akkari \& Enghoff, 2012

465. Ommatoiulus reipi Akkari \& Enghoff, 2012

466. Ommatoiulus robustus Ceuca, 1972

467. Ommatoiulus rutilans (C.L. Koch, 1847)

468. Ommatoiulus sabinarensis Akkari, Mauriès \& Enghoff, 2012

469. Ommatoiulus sabulosus (Linnaeus, 1758)

470. Ommatoiulus schubarti Akkari \& Enghoff, 2012

471. Ommatoiulus teruelensis Ceuca, 1974

472. Ommatoiulus tridentifer Ceuca, 1974

473. Ommatoiulus variolosus (Silvestri, 1898)

474. Ophyiulus aspidiorum (Verhoeff, 1913)

475. Ophyiulus bastiensis Verhoeff, 1943

476. Ophyiulus castanearum Verhoeff, 1930

477. Ophyiulus cerii Verhoeff, 1942

478. Ophyiulus chilopogon (Latzel, 1884)

479. Ophyiulus collaris Verhoeff, 1930

480. Ophyiulus corsicus Verhoeff, 1943

481. Ophyiulus curvipes (Verhoeff, 1898)

482. Ophyiulus germanicus (Verhoeff, 1896)

483. Ophyiulus italianus Attems, 1927

484. Ophyiulus jeekeli Strasser, 1974

485. Ophyiulus lostiae Silvestri, 1898

486. Ophyiulus macchiae Verhoeff, 1930

487. Ophyiulus minimus Strasser, 1958

488. Ophyiulus muelleri Strasser, 1937

489. Ophyiulus napolitanus (Attems, 1903)

490. Ophyiulus nigrofuscus (Verhoeff, 1894)

491. Ophyiulus osellai Strasser, 1970

492. Ophyiulus pilosus (Newport, 1842)

493. Ophyiulus renosensis Mauriès, 1969

494. Ophyiulus rubrodorsalis (Verhoeff, 1900)

495. Ophyiulus sardus Attems, 1927

496. Ophyiulus solitarius Bigler, 1929 
497. Ophyiulus spezianus Verhoeff, 1936

498. Ophyiulus targionii Silvestri, 1898

499. Ophyiulus velebiticus Attems, 1927

500. Pachyiulus apfelbecki Verhoeff, 1901

501. Pachyiulus asiaeminoris Verhoeff, 1898

502. Pachyiulus cattarensis (Latzel, 1884)

503. Pachyiulus dentiger Verhoeff, 1901

504. Pachyiulus flavipes (C.L. Koch, 1847)

505. Pachyiulus humicola Verhoeff, 1910

506. Pachyiulus hungaricus (Karsch, 1881)

507. Pachyiulus marmoratus Verhoeff, 1901

508. Pachyiulus oenologus (Berlese, 1885)

509. Pachyiulus silvestrii Verhoeff, 1923

510. Pachyiulus speciosus Verhoeff, 1900

511. Pachyiulus valonensis Verhoeff, 1901

512. Pachyiulus varius (Fabricius, 1781)

513. Pachypodoiulus eurypus (Attems, 1895)

514. Parastenophyllum frondicola (Verhoeff, 1899)

515. Pteridoiulus aspidiorum Verhoeff, 1913

516. Rhamphidoiulus bujukderensis Attems, 1905

517. Rhodopiella beroni (Strasser, 1966)

518. Rossiulus kessleri (Lohmander, 1927)

519. Rossiulus vilnensis (Jawłowski, 1925)

520. Rumaniulus mammosus Attems, 1927

521. Serboiulus deelemanni Strasser, 1971

522. Serboiulus kresnik Makarov, 2013

523. Serboiulus lucifugus Strasser, 1962

524. Serboiulus spelaeophilus Gulička, 1967

525. Stenophyllum hermannimuelleri Verhoeff, 1897

526. Stenophyllum primitivum Verhoeff, 1897

527. Stenophyllum semenicense Ceuca, 1989

528. Stenophyllum tabacarui Vanoaica, 2003

529. Styrioiulus pelidnus (Latzel, 1884)

530. Styrioiulus styricus (Verhoeff, 1896)

531. Symphyoiulus impartitus (Karsch, 1888)

532. Syniulus bolivari (Ceuca, 1971)

533. Syniulus lagari (Ceuca, 1971)

534. Syniulus puddui Strasser, 1974

535. Syrioiulus andreevi Mauriès, 1984

536. Tachypodoiulus niger (Leach, 1814)

537. Telsonius nycteridonis Strasser, 1976

538. Titanophyllum spiliarum Akkari, Stoev \& Enghoff, 2011

539. Trogloiulus binii Enghoff, 1985

540. Trogloiulus boldorii Manfredi, 1940

541. Trogloiulus comensis Strasser, 1977

542. Trogloiulus concii Manfredi, 1948

543. Trogloiulus minimus Manfredi, 1935

544. Trogloiulus mirus Manfredi, 1931

545. Trogloiulus osellai Strasser, 1977

546. Trogloiulus vailatii Strasser, 1978

547. Typhloiulus acutunguis Ceuca, 1979 
548. Typhloiulus albanicus Attems, 1929

549. Typhloiulus ausugi Manfredi, 1953

550. Typhloiulus beroni Mauriès, Golovatch \& Stoev, 1997

551. Typhloiulus bosniensis Strasser, 1966

552. Typhloiulus bureschi Verhoeff, 1926

553. Typhloiulus carniolensis Strasser, 1940

554. Typhloiulus edentulus Attems, 1951

555. Typhloiulus ganglbaueri (Verhoeff, 1898)

556. Typhloiulus gellianae Makarov \& Rađa, 2006

557. Typhloiulus georgievi Strasser, 1962

558. Typhloiulus giganteus Ćurčić \& Makarov, 2002

559. Typhloiulus hauseri Strasser, 1974

560. Typhloiulus illyricus Verhoeff, 1929

561. Typhloiulus incurvatus Verhoeff, 1899

562. Typhloiulus insularis Strasser, 1938

563. Typhloiulus kotelensis Jawłowski, 1938

564. Typhloiulus lobifer Attems, 1951

565. Typhloiulus longinquus Strasser, 1966

566. Typhloiulus longipes Strasser, 1973

567. Typhloiulus maximus Verhoeff, 1929

568. Typhloiulus montellensis Verhoeff, 1930

569. Typhloiulus motasi Tabacaru \& Gava, 1992

570. Typhloiulus nevoi Makarov, Mitić \& Ćurčić, 2002

571. Typhloiulus polypodus (Loksa, 1960)

572. Typhloiulus psilonotus (Latzel, 1884)

573. Typhloiulus sculterorum Brölemann, 1905

574. Typhloiulus serbani (Ceuca, 1956)

575. Typhloiulus serborum Ćurčić \& Makarov, 2005

576. Typhloiulus staregai Strasser, 1973

577. Typhloiulus strictus (Latzel, 1882)

578. Typhloiulus tobias (Berlese, 1886)

579. Typhloiulus uncinifer Strasser, 1974

580. Unciger foetidus (C.L. Koch, 1838)

581. Unciger transsilvanicus (Verhoeff, 1899)

582. Xestoiulus bjelasnicensis (Verhoeff, 1898)

583. Xestoiulus carpathicus (Verhoeff, 1907)

584. Xestoiulus dalmaticus Mršić, 1987

585. Xestoiulus fimbriatus (Attems, 1904)

586. Xestoiulus fontisherculis (Verhoeff, 1899)

587. Xestoiulus graciliventris (Verhoeff, 1898)

588. Xestoiulus imbecillus (Latzel, 1884)

589. Xestoiulus laeticollis (Porat, 1889)

590. Xestoiulus luteus (Attems, 1951)

591. Xestoiulus pirinicus (Gulička, 1967)

592. Xestoiulus rebeli (Attems, 1904)

593. Xestoiulus rucneri (Ceuca, 1990) 


\section{Results}

\section{Species accounts}

Class Diplopoda Blainville-Gervais, 1844

Order Julida Brandt, 1833

Family Blaniulidae C.L. Koch, 1847

Genus Acipes Attems, 1937

1. Acipes andalusius Enghoff \& Mauriès, 1999

\section{Distribution}

ES-SPA (Jaen and Alicante Provinces).

\section{Habitat}

Caves and the Mesovoid Shallow Stratum (MSS).

\section{Remarks}

Described from a cave in Jaen Province. Recently collected in the Mesovoid Shallow Stratum (MSS) in Alicante Province (Confrides, Sierra de Aitana) (Enghoff \& Reboleira 2013).

\section{Acipes atlanticus Attems, 1937}

\section{Distribution}

PT-MDR.

\section{Habitat}

Forest, mainly laurel forest; under bark and in wood of logs, under moss cushions on boulders, often together with $A$. serratus.

3. Acipes bifilum Enghoff \& Reboleira, 2013

\section{Distribution}

PT-POR (Algarve).

\section{Habitat}

Cavernicolous.

\section{Acipes continentalis Enghoff, 1986}

\section{Distribution}

ES-SPA (Avila \& Madrid Provinces, Sierra de Gredos \& Sierra de Gaudarrama).

\section{Acipes decolor Enghoff, 1983}

\section{Distribution}

PT-MDR (Porto Santo).

\section{Habitat}

Only found once, on a stony, strongly grazed gentle slope facing W, with short grass. 
6. Acipes franzi (Loksa, 1967)

Choneiulus franzi Loksa, 1967.

\section{Distribution}

ES-CNY (E1 Hierro, Gran Canaria, La Gomera, La Palma, Tenerife).

\section{Habitat}

Most common in laurel forest and fayal-brezal, also occurring in lower, dry areas (e.g., with Kleinia and Rumex vegetation).

\section{Acipes lateralis Enghoff, 1983}

\section{Distribution}

PT-MDR (Porto Santo).

\section{Habitat}

Cupressus-Pinus forest, Erica scrub, also in more open, treeless places.

8. Acipes machadoi Enghoff \& Reboleira, 2013

\section{Distribution}

PT-POR (Algarve).

\section{Habitat}

Cavernicolous.

9. Acipes portosantoensis Enghoff, 1983

\section{Distribution}

PT-MDR (Porto Santo).

\section{Habitat}

Cupressus-Pinus forest, Erica scrub, also in more open, treeless places.

\section{Acipes serratus Enghoff, 1983}

\section{Distribution}

PT-MDR.

\section{Habitat}

Forest, mainly laurel forest; almost exclusively in logs, often together with A. atlanticus.

\section{Acipes waldeni Enghoff, 1983}

\section{Distribution}

PT-MDR.

\section{Habitat}

Laurel forest; in the soil/litter interface. 
Genus Alpiobates Verhoeff, 1911

12. Alpiobates peyerimhoffi (Brölemann, 1900)

Blaniulus peyerimhoffi Brölemann, 1900.

\section{Distribution}

FR-FRA, IT-ITA. Alps along Franco-Italian border. Hautes Alpes; Piedmont.

\section{Habitat}

Verhoeff (1932a) found it in an old, hollow chestnut (Castanea) tree.

Genus Archiboreoiulus Brolemann, 1921

13. Archiboreoiulus pallidus (Brade-Birks, 1920)

Proteroiulus pallidus Brade-Birks, 1920.

Boreoiulus pallidus auct.

\section{Distribution}

BE, CH, DE, DK-DEN, ES-SPA, FI, FR-FRA, GB-CI, GB-GRB, GB-NI, HU, IE, LU, NL, NO-NOR, PL, RO, RU-KDG, RU-RUC, RU-RUW, SE, SK, UA. Central, N \& E Europe. - Also found in Stavropol, northern Caucasus, Russia (Zuev 2014) and introduced into Canada and USA.

\section{Habitat}

Endogean and troglophile, it has been found mainly in the soil, especially in loamy calcareous and other base-rich types. It is also synanthropic, especially in northern and eastern regions, found in forests, cultivated fields, grassland, gardens, garden waste, spoil heaps, etc.

\section{Remarks}

It is often associated with Blaniulus guttulatus and is similarly regarded as an agricultural pest in several root crops (Pierrard \& Biernaux 1974). Its vertical migrations in the soil were described by Biernaux \& Baurant (1964). Some parthenogenetic populations exist in the northern part of its European range, as well as in Canada. Prisnyi (2001) stated that all Russian populations appear to be male-free and largely anthropochoric. Regarded as highly endangered in Germany (Voigtländer et al. 2011).

\section{Archiboreoiulus sollaudi Brolemann, 1921}

\section{Distribution}

FR-FRA (Doubs Department, Jura Mountains).

\section{Habitat}

Cavernicolous.

\section{Genus Blaniulus Gervais, 1836}

Typhloblaniulus Verhoeff, 1897.

Plusioiulus Silvestri, 1903.

The genus Blaniulus is essentially Atlanto-Mediterranean. Most species are troglophiles or troglobionts. 
15. Blaniulus dollfusi Brölemann, 1894

\section{Distribution}

BE, ES-SPA, FR-FRA, PT-POR. Southern part of Atlantic zone.

\section{Habitat}

Frequently found in forest litter (especially Quercus) and soil, also in stony pastures and dune systems with bushes, sometimes in fungi, e.g., twenty adult specimens were found in October, vertically arranged in the stipe of an edible Boletus in the Dordogne Department of France (R.D. Kime). Many records from N Portugal to Aquitaine. Introduced into Belgium (Enghoff 2010). Troglophile in Spain at least (Mauriès 1971).

\section{Blaniulus eulophus Silvestri, 1903}

Typhloblaniulus eulophus auct.

\section{Distribution}

IT-SAR (Oristano \& Càgliari Provinces).

\section{Habitat}

Found under a log at Oristano and in two caves, the Grotta Pirosu at Su Benatzu and the Grotta delle Cava d'Onice at Is Cattas, both near San Antonio di Santadi in the province of Càgliari.

\section{Remarks}

Listed as a synonym of $B$. troglodites by Enghoff \& Kime (2009) but the two species are clearly different by, e.g., eulophus having eyes and troglodites being blind.

\section{Blaniulus guttulatus (Fabricius, 1798)}

Julus guttulatus Fabricius, 1798.

Blaniulus guttulatus (Bosc, 1792) auct.

Iulus pulchellus Leach, 1814.

\section{Distribution}

AT, BE, BG, CH, CZ, DE, DK-DEN, EE, ES-CNY, ES-SPA, FI, FR-FRA, GB-CI, GB-GRB, GB-NI, HU, IE, IS, IT-ITA, IT-SI, LT, LU, LV, NL, NO-NOR, PL, PT-POR, PT-AZO, PT-MDR, RO, RU-KGD, RU-RUC, RU-RUW, SE, SK, UA. Most of Europe north of the Mediterranean zone, synanthropic and widely introduced. - Also introduced into Canada, USA, St. Helena, Tristan da Cunha and Norfolk Island.

\section{Habitat}

Sometimes found "wild" in forest litter and topsoil, e.g., deciduous forest on limestone. Research in Belgium (Kime et al. 1992) showed that all the specimens at such sites were found in soils with mull humus, about half of them being calcic mulls.

Generally on heavy loam soils, as in Britain, where Blower (1985) associated it with good arable loams and found it infrequently in base-deficient soils. The only Bulgarian record was from Pinus sylvestris and Quercus petraea forest (Vagalinski \& Stoev 2007). Blaniulus guttulatus is strongly associated with cultivation, especially on ground with compost and surface refuse (Breny \& Biernaux 1966). It occurs 
in farmland, gardens, parks, orchards, colliery spoil heaps and waste ground, associated with organic matter and it often occurs in very large populations, also in caves.

\section{Remarks}

The genus Blaniulus being Atlanto-Mediterranean, it is possible that B. guttulatus is native to woodland on base-rich soils in western Europe. It has received much attention as an agricultural pest. A detailed study with respect to its behaviour and invasion of crops was made by Biernaux (1968); see also Pierrard \& Biernaux (1974). Brookes \& Willoughby (1978) studied the general ecology and life history of the species.

18. Blaniulus lichtensteini Brolemann, 1921

\section{Distribution}

FR-FRA (Southern, west of the Rhône: Gard, Hérault \& Aveyron).

\section{Habitat}

Cavernicolous, confined to limestone areas.

19. Blaniulus lorifer (Brolemann, 1921)

Typhloblaniulus lorifer Brolemann, 1921.

\section{Distribution}

ES-SPA, FR-FRA. Pyrenean endemic.

\section{Habitat}

Cavernicolous.

\section{Remarks}

Brolemann $(1921,1923)$ distinguished four subspecies. At the moment there is no record within 100 $\mathrm{km}$ of either the Atlantic or the Mediterranean coasts. Mauriès (1969a) described the mating and periodomorphosis of $B$. lorifer.

\section{Blaniulus mayeti (Brölemann, 1902)}

Typhloblaniulus mayeti Brölemann, 1902.

\section{Distribution}

FR-FRA (Eastern Pyrenees near the Mediterranean Sea).

\section{Habitat}

Surface living.

21. Blaniulus orientalis Brolemann, 1921

\section{Distribution}

ES-SPA, FR-FRA. Mediterranean Pyrenees and south to Barcelona.

\section{Habitat}

Surface living. 
Typhloblaniulus troglobius auct.

\section{Distribution}

FR-FRA (Western and Central Pyrenees).

\section{Habitat}

Cavernicolous.

23. Blaniulus troglodites Brölemann, 1898

Blaniulus guttulatus troglodites Brölemann, 1898.

Typhloblaniulus troglodites auct.

Typhloblaniulus troglodytes auct.

\section{Distribution}

ES-SPA, FR-FRA. Pyrenean Region.

\section{Habitat}

Cavernicolous.

\section{Blaniulus velatus Ribaut, 1954}

\section{Distribution}

FR-FRA (Aude \& Hérault Depts.).

\section{Habitat}

Cavernicolous.

\section{Remarks}

Known from two caves at Rieussec and Citou.

\section{Blaniulus virei Brölemann, 1900}

Typhloblaniulus virei auct.

\section{Distribution}

FR-FRA (Hérault Dept.).

\section{Habitat}

Cavernicolous.

\section{Remark}

Known only from the Grotte des Démoiselles near Ganges. 
Genus Boreoiulus Brolemann, 1921

26. Boreoiulus simplex Brolemann, 1921

\section{Distribution}

CH, FR-FRA. Jura Mountains.

\section{Habitat}

Cavernicolous.

\section{Boreoiulus tenuis (Bigler, 1913)}

Monacobates tenuis Bigler, 1913.

Monacobates marcomannius Verhoeff, 1915.

\section{Distribution}

BE, DE, DK-DEN, FI, FR-FRA, GB-GRB, GB-NI, IE, LT, NL, NO-NOR, PL, RU-RUW, SE. Northern Europe (N Atlantic, N Central and Baltic).

\section{Habitat}

In base-rich soils; woodland and arable land. Highly synanthropic and occurs in crops. May be a pest of sugar beet (Breny 1964; Breny \& Biernaux 1966). Has also been found on banks of clay deep in caves. Reported from Reykjavik, Iceland (Ólafsson 2010), but the images shown are clearly Blaniulus guttulatus.

Genus Choneiulus Brolemann, 1921

28. Choneiulus faunaeuropaeae Enghoff, 2002

\section{Distribution}

IT-SI (Grotta di Santa Ninfa in the Province of Trapani).

\section{Habitat}

Cavernicolous.

29. Choneiulus lacinifer Strasser, 1980

\section{Distribution}

IT-SAR (Grotta del Cane near Gortoe in the Province of Nuoro).

\section{Habitat}

Cavernicolous.

30. Choneiulus palmatus (Němec, 1895)

Blaniulus palmatus Nĕmec, 1895.

\section{Distribution}

BE, CH, CZ, DE, DK-DEN, GB-CI, GB-GRB, FI, FR-FRA, HU, IT-ITA, IE, LT, LU, NL, NO-NOR, PL, PT-AZO, PT-MDR, RO, RU-RUC, SE. - Also introduced into Canada, USA and Australia. 


\section{Habitat}

Soil and litter of woodland on mainly sedimentary basic and calcareous rocks. Tajovský (1998) recorded it from Tilio cordatae-Fagetum in the Czech Republic. May be found under bark. Widespread in gardens, parks, orchards, vineyards, cemeteries, quarries, mine galleries, disused railway areas, spoil heaps and frequently in greenhouses (predominantly in the latter in the $\mathrm{N} \& \mathrm{E}$ of its range). Recorded from catacombs in France and from caves. Found in the nests of ants and moles. Regarded as a stenotopic xerobiont woodland species with preference for xeric/mesoxeric meadows, fields and fallows in Saxony-Anhalt, Germany (Voigtländer 2011). It reaches an altitude of $1230 \mathrm{~m}$ in the Swiss Alps (Pedroli-Christen 1993).

\section{Remarks}

Its natural habitat may be woodland on base-rich soils. Sometimes an agricultural pest (Pierrard \& Biernaux 1974).

\section{Choneiulus subterraneus (Silvestri, 1903)}

Nopoiulus subterraneus Silvestri, 1903.

Choneiulus gallicus Brolemann, 1921.

Nopoiulus minimus Verhoeff, 1941.

Choneiulus minimus auct.

\section{Distribution}

ES-CNY, FR-COR, FR-FRA, IT-ITA, MC. Western Mediterranean.

\section{Habitat}

Woodland, e.g., litter in small copse of Castanea sativa, surrounded by coniferous forest and maquis; in gardens, under stones; in rotting wood; in ants' nests; in caves (Enghoff 1984).

Genus Cibiniulus Verhoeff, 1927

Bilselibates Verhoeff, 1940.

32. Cibiniulus phlepsii (Verhoeff, 1897)

Blaniulus phlepsii Verhoeff, 1897.

Bilselibates bosporanus Verhoeff, 1940.

Bilselibates phlepsii auct.

\section{Distribution}

BG, HU, PL, RO, RU-RUS, SB, TR-TUE, UA. E Central \& E Balkan. - Also Anatolia, Georgia.

\section{Habitat}

Often in dead wood and under bark; ants' nests.

Genus Euzdakiulus Mauriès, 1970

33. Euzdakiulus sarensis Mauriès, 1970

\section{Distribution}

FR-FRA (Basque Region at Sare, Pyrénées Atlantiques).

\section{Habitat}

Cavernicolous. 
Genus Iberoiulus Mauriès, 1985

Iberoiulus Ceuca, 1967, proposed without a type species and therefore not available.

34. Iberoiulus breuili Ceuca, 1967

Euzdakiulus breuili auct.

\section{Distribution}

GB-GI.

\section{Habitat}

Cavernicolous.

\section{Iberoiulus cavernicola Ceuca, 1967}

Euzdakiulus cavernicola auct.

\section{Distribution}

ES-SPA (Cadiz Province at Grazalema).

\section{Habitat}

Cavernicolous. Known only from two caves $3 \mathrm{~km}$ from each other (Enghoff \& Reboleira 2014).

Genus Mesoblaniulus Brolemann, 1921

36. Mesoblaniulus serrula (Brölemann, 1905)

Blaniulus serrula Brölemann, 1905.

\section{Distribution}

FR-FRA (Maritime Alps).

Genus Monacobates Verhoeff, 1911

37. Monacobates monoecensis (Brölemann, 1905)

Typhloblaniulus monoecensis Brölemann, 1905.

Monacobates ormeanus Verhoeff, 1930.

\section{Distribution}

IT-ITA, MC. Riviera of Provence and Liguria.

\section{Habitat}

First recorded from underground in the basement of the Oceanographical Museum of Monaco; later, by Verhoeff, in the litter and humus of Castanea woodland at $950 \mathrm{~m}$ near Ormea.

Genus Nopoiulus Menge, 1851

38. Nopoiulus kochii (Gervais, 1847)

Iulus Kochii Gervais, 1847.

Nopoiulus pulchellus auct., not C.L. Koch (1838).

Nopoiulus minutus auct., not Brandt (1841). 
Blaniulus venustus Meinert, 1868.

Nopoiulus breuili Brolemann, 1921.

Blaniulus atticus Verhoeff, 1925.

\section{Distribution}

AL, AT, BA, BE, BG, BY, CH, CZ, DE, DK-DEN, EE, ES-BAL, ES-CNY, FI, FR-FRA, GB-GRB, GBNI, GR-GRC, HR, HU, IE, IT-ITA, IT-SI, LT, LV, LU, MK, NL, NO-NOR, PL, PT-AZO, PT-MDR, RO, RU-KGD, RU-RUC, RU-RUE, RU-RUS, RU-RUW, SB, SE, SI, SK, TR-TUE, UA. Euro-Caucasian, though few records from the $\mathrm{W}$ Mediterranean region. - A cosmopolitan species, introduced into North Africa (Egypt), Asia, North and South America and New Zealand.

\section{Habitat}

In Eastern Europe it is characteristically found in swamp woodland but in other forests as well. Found in light soils rich in humus, often in alluvial valleys or sandy areas. Also open grassland, horticultural ground, suburban areas, parks and gardens. Rotting tree stumps, under bark, in manure heaps, under plant pots, in litter and in the soil, once in a mole's nest. Reported from catacombs, caves and gypsum quarries/chalk pits. Largely synanthropic away from Eastern Europe. There is a report on this species infesting the human intestine (Ertek et al. 2004).

\section{Remarks}

As in the case of Blaniulus guttulatus, records of Iulus / Blaniulus / Nopoiulus pulchellus had to be treated with caution in making the maps. Errors are possible.

Genus Occitaniulus Mauriès, 1965

39. Occitaniulus rouchi Mauriès, 1965

\section{Distribution}

FR-FRA (Languedoc and Toulouse).

\section{Habitat}

Deep $(50 \mathrm{~cm})$ in soil; under a rock.

Genus Orphanoiulus Silvestri, 1903

40. Orphanoiulus dinapolii Strasser, 1960

\section{Distribution}

IT-SI (Palermo Province).

\section{Habitat}

Found in the Molara Cave at Cozzo Santa Croce.

\section{Remarks}

Although it was recorded from three caves near Palermo by Strasser (1970), Strasser (1960) pointed out in his description that this pigmented animal is in no way adapted to a cavernicolous existence.

\section{Orphanoiulus religiosus (Silvestri, 1903)}

Nopoiulus religiosus Silvestri, 1903. 


\section{Distribution}

ES-BAL, IT-ITA. West Mediterranean.

\section{Habitat}

One record from a cemetery, two from caves.

\section{Remarks}

Originally associated with Christian catacombs. Specimens from Mallorca were described as ssp. majoricensis Mauriès \& Vicente, 1977.

Genus Proteroiulus Silvestri, 1897

42. Proteroiulus broelemanni Lohmander, 1925

\section{Distribution}

ES-SPA, FR-FRA. Pyrenean / N Iberian.

\section{Habitat}

Sub-corticolous, may be found in leaf litter.

43. Proteroiulus fuscus (Am Stein, 1857)

Blaniulus fuscus Am Stein, 1857.

Nopoiulus pulchellus auct., not C.L. Koch, 1838.

Nopoiulus palmatus coelebs Verhoeff, 1907.

\section{Distribution}

AT, BE, BG, BY, CH, CZ, DE, DK-DEN, DK-FOR, EE, ES-CAN, FI, FR-FRA, GB-CI, GB-GRB, GBNI, HU, IE, IS, IT-ITA, IT-SI, LT, LU, LV, NL, NO-NOR, PL, PT-AZO, PT-MDR, RU-KGD, RU-RUC, RU-RUE, RU-RUN, RU-RUW, RU-RUS, SE, SK, UA. Northern, Eastern and Central Europe. - Also introduced into Canada, USA, South Africa and St. Helena.

\section{Habitat}

Subcorticolous on many kinds of trees, both deciduous and coniferous, for most of its life cycle and found in a wide variety of wooded biotopes (forest tundra, taiga, mixed and deciduous forests and forest-steppe). It is to be found in leaf litter and in the soil, seasonally. Trapping on trees and on the ground indicates that it tends to disperse in autumn and winter, at least in the more temperate areas. It is associated with non-calcareous soils and peaty soils in particular (Tajovský 1998; Lee 2006).

It is sometimes the only millipede found in very dry pinewoods on sand.

South of about $48^{\circ} \mathrm{N}$ it is generally only found in mountainous terrain, for instance, in Switzerland at altitudes of between $400 \mathrm{~m}$ and $1525 \mathrm{~m}$ (Pedroli-Christen 1993).

\section{Remarks}

A hardy species, very common in northern Europe, declining southwards, absent from much of France, Iberia, Italy and the Balkans. Found further north than any other species of millipede, in the foresttundra of the Yamal Peninsula. Males are very rare, and P. fuscus is regarded as a purely parthenogenetic species (Enghoff 1978). The record from the Faeroe Islands is based on a juvenile and hence doubtful (Meidell \& Solhøy 1990). 
44. Proteroiulus hispanus Schubart, 1959

\section{Distribution}

ES-SPA (Sierra Nevada). - Also Morocco.

\section{Habitat}

At 2400-3450 m in Sierra Nevada. Found in rotten wood at 1400-2000 m in Morocco.

Genus Sardoblaniulus Manfredi, 1956

45. Sardoblaniulus annae Manfredi, 1956

\section{Distribution}

IT-SAR (Grotta Conca 'e Crapas in the Province of Nuoro).

\section{Habitat}

Cavernicolous.

Genus Tarracoblaniulus Mauriès \& Vicente, 1977

46. Tarracoblaniulus lagari Mauriès \& Vicente, 1977

\section{Distribution}

ES-SPA (Tarragona, Llaveria, Cova Janet).

\section{Habitat}

Cavernicolous.

47. Tarracoblaniulus phantasmanus Enghoff, Serra \& Martínez, 2009

\section{Distribution}

ES-SPA (Tarragona Province).

\section{Habitat}

Mountain oak wood (Quercetum mediterraneomontanum), sclerophyllous forest consisting mainly of Quercus ilex. A soil species.

\section{Remarks}

Postembryonic development and life cycle were studied by Enghoff et al. (2009).

Genus Thassoblaniulus Mauriès, 1985

\section{Thassoblaniulus simplarius Mauriès, 1985}

\section{Distribution}

GR-GRC (Thessaly, Thassos Island).

\section{Habitat}

Cavernicolous. 
Genus Vascoblaniulus Mauriès, 1967

49. Vascoblaniulus cabidochei Mauriès, 1967

\title{
Distribution
}

FR-FRA (Gouffre de la Pierre-Saint-Martin in the Pyrenees, Basque Region).

\section{Habitat}

Cavernicolous. Cabidoche (1968: 670) described the unusual habitat of the species in detail: "Among the species living in this cavity, Vascoblaniuilus cabidochei should be especially emphasized; it is localised very differently from the remaining fauna ... and is never found together with ... species which come to baits. (This is in contrast to what one can usually see in numerous caves at low altitude in the same region, where diplopods of the genus Typhloblaniulus $=[$ Blaniulus $]$ litterally swarm on baits. The new genus described by Mauriès is thus quite distinct: in addition to morphological criteria its ecology is quite different because it is the only species which frequents the banks of subterranean watercourses" (translated from French). In the latter respect, V. cabidochei is reminiscent of certain Trogloiulus and Typhloiulus species (Enghoff 1985b).

\section{Remarks}

Its mouthparts are very different from those of other blaniulids, probably an adaptation to living in very wet places (Enghoff 1985b).

\author{
Family Galliobatidae Brolemann, 1921 \\ Genus Galliobates Verhoeff, 1911
}

50. Galliobates gracilis (Ribaut, 1909)

Trichoblaniulus gracilis Ribaut, 1909.

\section{Distribution}

FR-FRA (West and South, from Britanny to just west of the Rhône).

\section{Habitat}

In the soil; found embedded under large stones and logs in woodland. Has been found in a cave in the Hérault Department (J.-F. David, pers.comm.)

Family Nemasomatidae Bollman, 1893

Genus Nemasoma C.L. Koch, 1847

Isobates Menge, 1851.

51. Nemasoma varicorne C.L. Koch, 1847

\section{Distribution}

AT, BA, BE, BG, BY, CH, CZ, DE, DK-DEN, FI, FR-FRA, GB-GRB, GB-NI, HR, HU, IE, IT-ITA, ITSI, LT, LU, LV, MK, NL, NO-NOR, PL, RO, RU-KGD, RU-RUC, SB, SE, SI, SK, UA. North, Central and Eastern Europe. Missing from most of the Mediterranean region and the whole of SW Europe.

\section{Habitat}

Obligate subcorticole found on a wide variety of trees, although some species seem to be favoured, especially Fagus sylvatica. In Sweden, however, the most frequent 'host' is Populus tremula; in 
the Rhein-Main region of Germany, it is Alnus glutinosa. Common on Populus tremula in Belarus (Tarasevich 1992). It may occasionally be found on the ground and has been taken in pitfall traps, even in grassland, perhaps during dispersal. It occurs in the southern taiga, broad-leaved and mixed forests as well as the northern forest-steppe.

\section{Remarks}

Parthenogenetic in the western, northern, eastern and southern parts of its large range, bisexual in the centre; areas of overlap where both forms occur are so far located in Denmark, the Netherlands, western Germany and Lithuania (Enghoff 1976, 1994; Hoy Jensen et al. 2002).

Genus Thalassisobates Verhoeff, 1908

52. Thalassisobates almeriensis Enghoff, 2013

\section{Distribution}

ES-SPA (Almeria).

\section{Habitat}

Cavernicolous.

53. Thalassisobates emesesensis Enghoff, 2013

\section{Distribution}

ES-CNY (La Gomera).

\section{Habitat}

Inhabits the Mesovoid Shallow Stratum (MSS).

54. Thalassisobates littoralis (Silvestri, 1903)

Isobates littoralis Silvestri, 1903.

Isobates adriaticus Verhoeff, 1908.

Isobates coiffaiti Demange, 1961.

\section{Distribution}

ES-BAL, ES-SPA, FR-COR, FR-FRA, GB-GRB, GR-GRC, GR-DOD, HR, IE, IT-ITA, IT-SAR, IT-SI, MC, NO-NOR, SE. Mediterranean + Atlantic. - Also North Africa and eastern USA.

\section{Habitat}

Marine, occurring in the intertidal zone of rocky coasts and banks of shingle. Not in sand or mud.

\section{Remarks}

The very large distribution, with large gaps, between Mediterranean records and those in Galicia, Britain, Ireland, Norway and Sweden, and the USA, is remarkable. The gaps must be largely due to long stretches of unsuitable coastline and lead to speculation about the method of dispersal through the ocean. 
Family Rhopaloiulidae Attems, 1926

Genus Rhopaloiulus Attems, 1926

\section{Rhopaloiulus cameratanus Attems, 1927}

Cyphopoditius ciminensis Verhoeff, 1930.

Rhopaloiulus delattini Vehoeff, 1951.

\section{Distribution}

IT-ITA (Central Italy).

\section{Habitat}

In dark loam in a gorge with large rocks in Castanea forest on trachyte, under bushes, $450 \mathrm{~m}$.

\section{Remarks}

Enghoff (1981) stated: "Of the four species/subspecies described in Rhopaloiulus, $R$. cameratanus Attems, 1927, C. ciminensis Verhoeff, 1930 and $R$. cameratanus anenianus Verhoeff, 1932 are without doubt synonyms, and $R$. delattini Verhoeff, 1951 should probably be relegated to synonymy as well". We do this with some reservation.

Family Trichoblaniulidae Verhoeff, 1911

Genus Trichoblaniulus Verhoeff, 1898

56. Trichoblaniulus cavernicola Brölemann, 1905

Trichoblaniulus hirsutus cavernicola Brölemann, 1905.

\section{Distribution}

FR-FRA (Alpes de Haute Provence, Alpes Maritimes and Var Departments).

\section{Habitat}

Cavernicolous.

57. Trichoblaniulus hirsutus (Brölemann, 1889)

Blaniulus hirsutus Brölemann, 1889.

\section{Distribution}

FR-FRA, IT-ITA, IT-SAR, MC. West Mediterranean.

\section{Habitat}

Found in many superficial habitats, e.g., under stones in olive groves, in gardens, along the French and Italian Rivieras, Monaco and Sardinia.

58. Trichoblaniulus lanuginosus Ribaut, 1947

\section{Distribution}

FR-FRA (known only from the Cova Bastera at Villefranche de Conflent, E Pyrenees).

\section{Habitat}

Cavernicolous. 
59. Trichoblaniulus tarraconensis Mauriès \& Vicente, 1977

\section{Distribution}

ES-SPA (known only from the Cova Janet at Llaveria, Tarragona).

\section{Habitat}

Cavernicolous.

Family Trichonemasomatidae Enghoff, 1991

Genus Trichonemasoma Mauriès \& Vicente, 1975

60. Trichonemasoma peloponesius (Mauriès, 1966)

Trichoblaniulus peloponesius Mauriès, 1966.

\section{Distribution}

GR-GRC (Taygetos Mts \& Mani Peninsula).

\section{Habitat}

Described from Glyphada Cave at Anogia, but also found epigeically at Pirgos-Dirou and in Abies-Pinus forest at Anoiga.

Family Julidae Leach, 1814

Genus Acanthoiulus Verhoeff, 1894

61. Acanthoiulus cassinensis (Verhoeff, 1910)

Pachyiulus cassinensis Verhoeff, 1910.

\section{Distribution}

IT-ITA (Central and southern Italy).

\section{Habitat}

A broad spectrum of habitats up to $1650 \mathrm{~m}$ in the Apennines. Limestone slope with Olea, dry Quercus scrub etc. (Verhoeff 1931, 1932b), deciduous forest at Amalfi on the coast near Naples. Caves.

\section{Acanthoiulus fuscipes (C.L. Koch, 1847)}

Julus fuscipes C.L. Koch, 1847.

Julus idriensis C.L. Koch, 1847.

Julus dalmaticus C.L. Koch, 1847.

Pachyiulus bosniensis Verhoeff, 1895.

Pachyiulus fuscipes auct.

\section{Distribution}

AL, BA, GR-GRC, HR, IT-ITA, MK, MN, SB, SI. Balkan-Adriatic.

\section{Habitat}

Coastal Pinus forest, scrub, among ruins, under stones. Troglophile: found in a cave and in artificial galleries in Albania (Mauriès et al. 1997). 


\section{Remark}

Several subspecies and varieties of this species have been named. The isolated record from Southern Greece was attributed to a new variety arcadicus by Verhoeff (1900), whose the taxonomic status remains uncertain.

Genus Afropachyiulus Schubart, 1960

63. Afropachyiulus maritimus Strasser, 1970

\section{Distribution}

IT-SI (Island of Marettimo in the Egadi archipelago).

Genus Allajulus C.L. Koch, 1847

Ypsiloniulus Verhoeff, 1899.

Hoffman (1980) synonymised the large genus Cylindroiulus under Allajulus, but Read (1990) revalidated Cylindroiulus as a separate genus, leaving Allajulus with just seven species.

64. Allajulus dicentrus (Latzel, 1884)

Iulus dicentrus Latzel, 1884.

Cylindroiulus dicentrus auct.

Diploiulus dicentrus auct.

\section{Distribution}

AT, BA, HR, HU, IT-ITA, SI. Eastern \& Dinaric Alpine area.

\section{Habitat}

Woodland, in Slovenia frequently Fagus forest from 650 to $1350 \mathrm{~m}$. In Austria woodland trees included Fagus sylvaticus, Carpinus betulus, Quercus petraea, Castanea sativa, Tilia cordata, Acer pseudoplatanus, Crataegus monogyna and Picea abies, while the ground flora included Salvia glutinosa, Gentiana asclepiadea, Vaccinium myrtillus, Campanula persicifolia, Sanicula europaea and Pteridium aquilinum (Voigtländer et al. 1997). Also found in a cave.

\section{Allajulus groedensis (Attems, 1899)}

Iulus groedensis Attems, 1899.

Cylindroiulus groedensis auct.

Ypsiloniulus grödensis auct.

\section{Distribution}

AT, DE, HR, HU, IT-ITA, SI. Mainly Austrian \& Italian Alps.

\section{Habitat}

Beechwoods up to $1200 \mathrm{~m}$ in Slovenia. Mixed woods. In litter, humus and screes.

66. Allajulus infossus (Verhoeff, 1930)

Cylindroiulus (Ormeoiulus) infossus Verhoeff, 1930. 


\section{Distribution}

IT-ITA (Piedmont).

\section{Habitat}

Woodland in the mountains - Castanea, 1100-1200 m; Corylus, 1450 m; Fagus, 1250-1300 m. In litter and humus.

\section{Allajulus marguareisi (Strasser, 1970)}

Cylindroiulus marguereisi Strasser, 1970.

\section{Distribution}

IT-ITA (Piedmont).

\section{Habitat}

Described from a cave, Arma delle Fascetti, at Viozene in the Province of Ormea (1250 m); also found epigeically at Frabosa Soprana ca $15 \mathrm{~km} \mathrm{~N}$ of the type locality (G. Delmastro leg., HE det., specimens in ZMUC).

\section{Remarks}

Read (1990) suggested that this could be $A$. groedensis with a broken preanal spine. The two species are indeed very similar, and Strasser (1970) mentioned the straight preanal spine as one of the distinguishing characters. The specimens from Frabosa Soprana, however, have a pointed, upturned preanal spine, just like $A$. groedensis.

68. Allajulus molybdinus C.L. Koch, 1847

Cylindroiulus molybdinus auct.

Ypsiloniulus molybdinus auct.

\section{Distribution}

AT, BA, HR, SI. East Alpine and NW Balkan.

69. Allajulus nitidus (Verhoeff, 1891)

Iulus nitidus Verhoeff, 1891.

Cylindroiulus nitidus auct.

Ypsiloniulus nitidus auct.

Cylindroiulus nitidus rhenanus Verhoeff, 1910.

\section{Distribution}

AT, BE, CH, CZ, DE, DK-DEN, FR-FRA, GB-GRB, IS, LU, NL, NO-NOR, PL, SE. Central European, extending north to Scandinavia and Britain.

\section{Habitat}

A species particularly found in closed woodland on brown earth soils, strongly associated with clay, mull humus and active calcium, although it does occur on lighter neutral to moderately acidic soils and is scarce or absent from heavy waterlogged soils. Rare in sandy areas and in acidic woodlands on higher ground, yet it has been found on both Muschelkalk and Vosges Sandstone in Alsace, in montane Fagus 
woods up to $1600 \mathrm{~m}$ in the French Alps (Geoffroy 1981b) and up to $2175 \mathrm{~m}$ in Switzerland (PedroliChristen 1993).

Associated with deciduous forest, especially Quercus/Carpinus, and while frequent in beech hangers, less so with Fagus. Other trees and shrubs frequently present are Fraxinus excelsior, Acer campestre A. pseudoplatanus, Prunus avium, Cornus alba and Corylus avellana. In many of these woods ivy (Hedera helix) is omnipresent and in many of those on heavy calcareous soils it is by far the dominant species of millipede. Occasionally it is found in mixed forest with Pinus and other conifers.

Allajulus nitidus is most abundant in the lowlands and in the montane zone, increasingly synanthropic in the north of its range.

\section{Remarks}

It burrows readily and may be found throughout the year in the soil. It migrates vertically (Geoffroy 1981a) and is generally nearer the surface during the spring and again in the autumn, being hygrophile. It is very common in suitable soils throughout west-central Europe A very variable species; males may go through several successive morphologically mature stadia; hence, there is a wide range of sizes and body ring numbers (Sahli 1969, 1986; Voigtländer 1987; Enghoff et al. 1993; Akkari \& Enghoff 2011).

\section{Allajulus spinosus (Ribaut, 1904)}

Julus spinosus Ribaut, 1904

Leucoiulus spinosus auct.

Cylindroiulus spinosus auct.

\section{Distribution}

ES-SPA, FR-FRA. Atlanto-Mediterranean.

\section{Habitat}

Deciduous, mixed and coniferous woodland. Recorded dominant trees include Fagus sylvatica, Fraxinus excelsior, Quercus petraea, Q. ilex, Abies alba and Pinus sylvestris, with a mention of Tilia in oakwood. Most records are montane, up to $1600 \mathrm{~m}$, from leaf litter, under bark on the ground and in the soil. Under large stones beside tracks. The soil is often very light and sandy. Troglophile.

\section{Remarks}

A rather unusual known distribution centred on the Pyrenees with northward extensions to the Dordogne, Montagne Noire and the Massif Central, but, while most records are montane, it has been found in pinewoods near sea level in Aquitaine, in lowland caves and around Toulouse. The limits of its range are uncertain, both in France and in Spain.

Genus Allopodoiulus Verhoeff, 1898.

\section{Allopodoiulus schiodtei (Verhoeff, 1898)}

Julus Schiödtei Verhoeff, 1898.

\section{Distribution}

BA.

\section{Habitat}

Deciduous forest. 
72. Allopodoiulus verhoeffi (Jawłowski, 1931)

Leptoiulus verhoeffi Jawłowski, 1931.

\section{Distribution}

RO, UA. NW Romanian and NE Carpathian Mountains.

Genus Alpityphlus Strasser, 1967

73. Alpityphlus seewaldi Strasser, 1967

Typhloiulus seewaldi auct.

\section{Distribution}

AT, DE.

\section{Habitat}

Troglobiont, found at $1620 \mathrm{~m}$. a.s.l.

\section{Remarks}

Originally described as Austrian, but the type locality was later shown to lie just on the German side of the border. However, A. seewaldi has subsequently been found on Austrian territory as well (Christian \& Spötl 2010). Regarded as threatened with extinction in Germany (Voigtländer et al. 2011).

Genus Amblyiulus Silvestri, 1896

\section{Amblyiulus aphroditae (Attems, 1902)}

Pachyiulus aphroditae Attems, 1902.

\section{Distribution}

GR-DOD (Rhodos). - Also Cyprus and Asiatic Turkey.

75. Amblyiulus creticus (Verhoeff, 1901)

Pachyiulus creticus Verhoeff, 1901.

Pachyiulus obscurus Attems, 1902.

\section{Distribution}

GR-KRI.

\section{Habitat}

Forests. One record from a cave. Found from sea level to $640 \mathrm{~m}$ (Felesaki et al. 2010).

76. Amblyiulus kovali Golovatch, 2008

\section{Distribution}

UA (SW Crimea).

\section{Habitat}

Cavernicolous. 


\section{Remarks}

Regarded as a neoendemic troglobiont in the Crimea by Golovatch (2008).

\section{Amblyiulus sporadensis (Verhoeff, 1901)}

Pachyiulus sporadensis Verhoeff, 1901.

\section{Distribution}

GR-GRC (Nikaria).

\section{Habitat}

The side of the road between Oxea and Monokampion (Strasser 1976).

Genus Apfelbeckiella Verhoeff, 1901

78. Apfelbeckiella bulgarica Verhoeff, 1926

\section{Distribution}

BG, TR-TUE. Strandzha Mountains.

\section{Habitat}

Broad-leaved forest, particularly Quercus. Caves. Under stones in cornfield on karst (Vagalinski \& Stoev 2007).

\section{Apfelbeckiella byzantina Verhoeff, 1901}

\section{Distribution}

TR-TUE. - Also Asiatic Turkey.

\section{Habitat}

Forest.

80. Apfelbeckiella dobrogica Tabacaru, 1966

\section{Distribution}

RO (Dobrogea, Movile and Casian Caves).

\section{Habitat}

Cavernicolous.

\section{Apfelbeckiella golemanskyi Ceuca, 1973}

\section{Distribution}

BG (Western Rhodope Mountains).

\section{Remarks}

Recorded from only three sites by Ceuca (1973).

\section{Apfelbeckiella trnowensis (Verhoeff, 1928)}

Typhloiulus trnowensis Verhoeff, 1928. 


\section{Distribution}

BG.

\section{Habitat}

Cavernicolous.

\section{Remarks}

Three subspecies have been described from different parts of Bulgaria.

Vagalinski \& Stoev (2007) stated that, since the taxonomic status of some of the subspecies and species of the trnowensis group is uncertain, the records from the Pirin and Rhodope Mountains in the South may belong to closely related but different taxa.

Genus Balkanophoenix Verhoeff, 1937

83. Balkanophoenix borisi Verhoeff, 1937

\section{Distribution}

BG (Stara Planina \& Rhodope Mountains).

\section{Habitat}

Cavernicolous.

Genus Banatoiulus Tabacaru, 1985

84. Banatoiulus troglobius Tabacaru, 1985

\section{Distribution}

RO (Zamonita Cave in the Banat Mountains).

\section{Habitat}

Cavernicolous.

Genus Brachyiulus Berlese, 1884

Brachiulus Berlese, 1886.

Anoploiulus Verhoeff, 1894.

Microbrachyiulus Verhoeff, 1897.

85. Brachyiulus apfelbecki Verhoeff, 1898

\section{Distribution}

AL, BA, BG, GR-GRC, HR, IT-ITA, MN. West Balkan, Transadriatic.

\section{Habitat}

Open habitats: meadows. Found in large numbers in a meadow at Marango (Venezia) and also in Padova. Olea europaea forest, under stones. Botanical garden in Tirana.

\section{Brachyiulus bagnalli (Brolemann, 1924)}

Microbrachyiulus bagnalli Brolemann, 1924.

Brachyiulus latzeli Attems, 1949. 


\section{Distribution}

AT, BG, CZ, HU, MK, PL, RO, SB, SI, SK.

\section{Habitat}

Mainly lowland pastures and on marshy ground in floodplains near watercourses; also natural forest, including Quercus in protected areas. Yet it has been found on a chalk hill at $550 \mathrm{~m}$. It is often associated with human habitation, e.g., city parks and planted forests in Budapest, a service station, a hotel, an agricultural institute, a restaurant, a house yard. It may be located under wood.

\section{Brachyiulus jawlowskii Lohmander, 1928}

\section{Distribution}

MD, RO, PL, RU-RUC, RU-RUE, RU-RUS, UA. The forest-steppe belt of Kazakhstan, Russia, including SW Siberia, the Ukraine, reaching Moldova, Eastern Romania and just into Poland to the west.

\section{Habitat}

It occurs in broad-leaved and mixed forest in the Eastern European Plain, including the more southerly meadow-steppes of the Volga and Don Basins, usually in the litter. Several sites are on limestone. Among habitats cited by Prisnyi (2001) in the Middle-Russian upland are primary Quercus forest, limestone denudations and calciphilous steppe with Hyssopus and Artemisia. Jastrzębski (2012) found it on Poa pratensis-Festuca rubra meadows in Poland. Records from SW Siberia and Kazakhstan are from anthropogenous and semi-anthropogenus habitats (Nefediev et al. 2014).

\section{Remarks}

The species is a subendemic of the forest-steppe (Chornyi \& Golovatch 1993) and according to the map in Prisnyi (2001) has a discontinuous distribution. There seems to be a substantial gap between the records from the eastern area including parts of the Districts of Kirov, Tatarstan, Bashkortostan, Chuvashia and Ulyanovsk and the main western body of records going west from the interfluvial area between the Don and the lower Volga through the basins of the Dnieper and the Dniester to those of the Siret in Romania and the Bug in Poland (Jastrzebski 2012). Jastrzebski added that it ranges from the Taiga (boreal coniferous forest) in the north to the semi-desert belt in the south. The optimal area appears to be within the steppe belt east of the Dnieper (Wytwer et al. 2009); the Middle-Russian Upland is an area which harbours relict species.

\section{Brachyiulus klisurensis Verhoeff, 1903}

\section{Distribution}

GR-GRC (Klisura Sikia N of Aitoliko).

\section{Habitat}

The type locality is a wooded gorge.

\section{Remarks}

There is only the original record.

\section{Brachyiulus lusitanus Verhoeff, 1898}

Brachyiulus pusillus lusitanus Verhoeff, 1898.

Brachyiulus corcyraeus Verhoeff, 1900. 
Brachyiulus corcyraeus arcadius Verhoeff, 1900.

Microbrachyiulus calcivagus Verhoeff, 1910.

\section{Distribution}

AT, BG, CH, CZ, DE, ES-BAL, ES-CNY, ES-SPA, FR-COR, GB-GRB, GR-GRC, HR, HU?, IT-ITA, IT-SAR, MC, MK, PT-AZO, PT-MDR, PT-POR. - Also Algeria, Egypt, Iran; introduced into Australia and North America.

\section{Habitat}

Found in forests, also open land (sandy area on Adriatic coast, on the roof of a police station situated in a field, grassy slopes on Gran Canaria as well as in laurel forest, under bark and moss. Dominant in meadows, corn fields and vineyards in NE Italy (Paoletti et al. 1988). In Bulgaria in mixed forests, in meadows, under stone debris in quarry, in city park, 224-900 m (Vagalinski \& Stoev 2007). The British record is from the Eden Park Project in Cornwall, which has created some warmer foreign environments in very large heated greenhouses. We leave it in as an introduction as it has been found outside.

\section{Remarks}

There is a record, from Iran, of this species infesting a child's alimentary canal (Mowlavi et al. 2009).

90. Brachyiulus pusillus (Leach, 1814)

Iulus pusillus Leach, 1814.

Brachyiulus littoralis Verhoeff, 1898.

\section{Distribution}

AL, AT, BA, BE, CH, DE, DK-DEN, EE, ES-CNY, ES-SPA, FR-FRA, GB-CI, GB-GRB, GB-NI, GRGRC, HR, IE, IT-ITA, LT, LU, MC, MN, NL, PL, PT-AZO, PT-MDR, RU-KGD, SE. - Introduced into Tunisia, South Africa, Australia and North America,

\section{Habitat}

Often in damp areas near watercourses, meadows, marshes, marshy woodland and farmland. On afforested colliery spoil heaps with garden refuse (Decker \& Hannig 2010). In Western Europe it is not usually common in woodland, much more associated with arable land and pastures. It is reputed to favour heavy soils and is probably able to withstand inundation (Jeekel \& Brugge 2001). Numbers may be found in damp buildings. In the north of its range it is synanthropic.

\section{Remarks}

Brachyiulus pusillus adults are visible throughout the year, by far most frequently in the spring when they breed. The species has been widely dispersed by human activity, occurring in Australasia, South Africa, North and South America and on many of the Atlantic Islands (Blower 1985; Lee 2006).

The Greek specimens from the Ionian area were named as the variety ionica by Strasser (1974).

\section{Brachyiulus stuxbergi (Fanzago, 1875)}

Iulus stuxbergi Fanzago, 1875.

Microbrachyiulus olearum Verhoeff, 1910.

Microbrachyiulus gilvicollis Verhoeff, 1941.

?Julus (Microiulus) merontis Attems, 1902? 


\section{Distribution}

GR-GRC, GR-KRI, IT-ITA, IT-SI, MT. Mediterranean. - Also Algeria and Tunisia.

\section{Habitat}

Seems to tolerate relatively arid conditions, found on clayey slopes and in garrigue, as well as woodland, maquis and gardens in Malta (Enghoff \& Schembri 1989). On Crete it has been found up to an altitude of $860 \mathrm{~m}$, in Epirus up to $990 \mathrm{~m}$ and in Sicily up to $1950 \mathrm{~m}$ on Mt.Etna.

\section{Remark}

Attems (1902) described Julus (Microiulus) merontis from several localities in Crete. This species remains uncertain (Felesaki et al. 2010); it is definitely not a species of Xestoiulus (=Microiulus) but rather seems to belong in Brachyiulus. Since B. stuxbergi is the only Brachyiulus known from Crete, we tentatively suggest that $J$. merontis may be a synonym of $B$. stuxbergi.

\section{Brachyiulus varibolinus Attems, 1904}

Brachyiulus beratinus Manfredi, 1945.

\section{Distribution}

AL, GR-GRC.

\section{Habitat}

In the Epirus Mountains at $530 \mathrm{~m}$ and $1620 \mathrm{~m}$ without habitat details (Strasser 1976).

Genus Buchneria Verhoeff, 1941

93. Buchneria cornuta Verhoeff, 1941

\section{Distribution}

IT-ITA (Ischia).

\section{Habitat}

In rotten vineyard poles.

94. Buchneria sicula Strasser, 1959

\section{Distribution}

IT-SI.

\section{Habitat}

Found on three occasions, once on the underside of a large lava rock in an abandoned vineyard.

Genus Chaetoleptophyllum Verhoeff, 1898

95. Chaetoleptophyllum montanum (Verhoeff, 1898)

Leptophyllum montanum Verhoeff, 1898.

\section{Distribution}

BA (Trebević). 


\title{
Habitat
}

Under litter in woodland.

\author{
Genus Chaitoiulus Verhoeff, 1895
}

96. Chaitoiulus spinifer (Verhoeff, 1895)

Iulus spinifer Verhoeff, 1895.

\section{Distribution}

AT, HR, SI.

\section{Habitat}

Forest, under litter.

Genus Chersoiulus Strasser, 1938

97. Chersoiulus ciliatus Strasser, 1938

\section{Distribution}

HR (Cres Island).

\section{Habitat}

Cave entrance in dim light under straw by trickling water and on rotten wood on clay.

\section{Remark}

Čampari Cave near Petrićevi is on Cres, not on Krk Island as stated by Mrsic (1994).

\section{Chersoiulus sphinx Strasser, 1940}

\section{Distribution}

HR, IT-ITA, SI.

\section{Habitat}

Cavernicolous. Found under rotting wood.

Genus Chromatoiulus Verhoeff, 1894

Pachybrachyiulus Verhoeff, 1897.

99. Chromatoiulus hamuligerus (Verhoeff, 1932)

Pachybrachyiulus hamuligerus Verhoeff, 1932.

Leptomastigoiulus hamuligerus Mršić (1993).

\section{Distribution}

MK.

\section{Habitat}

Mountains. 


\section{Remarks}

Listed as occurring in AL by Attems (1959), Ceuca (1992) and Mauriès et al. (1997), but all verified sites are on the Macedonian side of the border. There are similar mistakes for other species described in the first decade of the $20^{\text {th }}$ Century when Albania was larger, some sites are now in Serbia / Kosovo.

100. Chromatoiulus podabrus (Latzel, 1884)

Iulus podabrus Latzel, 1884.

Pachybrachyiulus podabrus auct.

\section{Distribution}

AL, BA, GR-GRC, HR, IT-ITA, MK, MN, SB. Transadriatic.

\section{Habitat}

Forests, e.g., Pinus, Abies, Quercus, Fagus, under litter, stones and moss, in soil. Also Olea groves and bushy places.

\section{Genus Cylindroiulus Verhoeff, 1894}

Micromastigoiulus Verhoeff, 1899.

Dendroiulus Verhoeff, 1930.

Allajulus auct.

Diploiulus auct.

This is a very large genus consisting of over 100 species in Europe ranging from Central Asia to Macaronesia, the majority being in Southern Europe, especially Italy, and on the island of Madeira, which hosts an endemic species swarm (Enghoff 1982, 1983; Reboleira \& Enghoff 2014). Several species have spread northwards into much of the rest of Europe while some pioneering and anthropochorous members are becoming widespread globally.

\section{Cylindroiulus abaligetanus Verhoeff, 1901}

Cylindroiulus hyperophorus Attems, 1903.

\section{Distribution}

AT, BG, HR, HU. - Also Asiatic Turkey.

\section{Habitat}

Broad-leaved forest (Gruber 2007), e.g., Quercus cerris, Q. frainetto, Fagus orientalis with Rhododendron ponticum. Trogloxene.

\section{Remarks}

This species seems to be genuinely rare (Korsós \& Read 1994).

102. Cylindroiulus aetnensis Verhoeff, 1910

\section{Distribution}

IT-ITA (Liguria), IT-SI.

\section{Habitat}

Sicilian mountains, recorded from 500-1900 m, at Randazzo in earth, humus and Castanea stumps. 


\section{Remarks}

There is some doubt about the validity of records from the Italian mainland. On the one hand the record from Liguria (Strasser \& Minelli 1984) seems improbable, but, on the other hand the suggestion by Strasser (1970) that the records of Cylindroiulus rufifrons from Calabria (see below) must refer to another species, probably $C$. aetnensis, is reasonable. On our map we have not placed a dot on the Italian mainland.

103. Cylindroiulus anglilectus Read, 2007

\section{Distribution}

ES-SPA, PT-POR. NW Iberia.

\section{Habitat}

Woodland in the Atlantic zone: deciduous, e.g., Alnus, Quercus, mixed or coniferous, e.g., Pinus. Found under large stones and pieces of wood.

104. Cylindroiulus aostanus Verhoeff, 1932

\section{Distribution}

IT-ITA (Piedmont).

\section{Habitat}

South of Aosta in Pinus-Castanea woodland in a ravine at $750 \mathrm{~m}$. In deep litter decomposing into humus-rich soil.

105. Cylindroiulus apenninorum (Brölemann, 1897)

Iuluus apenninorum Brölemann, 1897.

Cylindroiulus apenninorum albanensis Verhoeff, 1905.

Cylindroiulus albanensis auct.

\section{Distribution}

IT-ITA (Liguria to Calabria), NL, SM.

\section{Habitat}

Many biotopes from sea level to the alpine grasslands (at least to $2350 \mathrm{~m}$ ). Castanea forest, maquis with Carpinus, under Quercus laurifolia, in Laurus-Quercus suber forest. In the leaf litter of mixed deciduous woodland in the Netherlands, presumably introduced from Italy to The Hague, where it is well established. Known from caves.

\section{Remarks}

There are some possible errors in the determination of the C. apenninorum group. See, e.g., Strasser (1970).

106. Cylindroiulus arborum Verhoeff, 1928

\section{Distribution}

AT, BE, BG, CZ, DE, GR-GRC, HU, LT, MK, PL, RO, SK, UA. Central and Eastern European. Also found in Stavropol, northern Caucasus, Russia (Zuev 2014). 


\section{Habitat}

Forests, e.g., Fagus sylvatica, Pinus nigra, mostly in dead wood, but also found in litter. Oak-Hornbeam forest (Quercus/Carpinus). A mainly lowland species, recorded up to $550 \mathrm{~m}$. The Belgian records are from a greenhouse and its immediate vicinity and it must have been an introduction (Biernaux 1972). Jawłowski (1933a) found the species exclusively in hothouses and similar artificial habitats in Poland. The Belgian and Polish records are, therefore, not shown on the map.

\section{Remarks}

Reports from France probably relate to C. parisiorum or perhaps C. truncorum; C. arborum is not included in the French checklist (Geoffroy 1996). The record from Lithuania (Schubart 1934) does not include a specific locality and is not shown on the map. The species has a patchy distribution in central continental Europe, extending south into the Balkans and rarely west of the River Elbe.

\section{Cylindroiulus aternanus Verhoeff, 1930}

\section{Distribution}

IT-ITA (Abruzzo Region, l’Aquila Province).

\section{Habitat}

Near the Aterno River in a gorge with scattered old oaks, upstream from l'Aquila above $600 \mathrm{~m}$ a.s.l. on calcareous rocks with litter, rich humus and screes.

108. Cylindroiulus attenuatus Enghoff, 1982

\section{Distribution}

PT-MDR.

\section{Habitat}

Laurisilva, both dense/undisturbed and open or secondary, 400-1000 m.

109. Cylindroiulus bellus (Lignau, 1903)

Iulus bellus Lignau, 1903.

Cylindroiulus costatus Verhoeff, 1941.

\section{Distribution}

BG, TR-TUE. Pontian. - Also W Caucasus.

\section{Habitat}

Forest.

110. Cylindroiulus boleti (C.L. Koch, 1847)

Iulus boleti C.L. Koch, 1847.

Diploiulus boleti auct.

\section{Distribution}

AL, AT, BA, BG, CZ, DE, HR, HU, IT-ITA, MD, MK, MN, RO, SB, SI, SK, UA. Southeast Central Europe. 


\section{Habitat}

A common lowland forest species, regularly in many types of oakwoods (Quercus petraea, Q. pubescens, Q. frainetto, Q. dalechampii) and often with hornbeam (Carpinus betulus, C. orientalis) and Fagus sylvatica, Robinia pseudo-acacia, Picea abies, Pinus sp. (Stašiov 2005; Vagalinski \& Stoev 2007). Also Fraxinus excelsior, Tilia cordata, Castanea sativa, Acer pseudoplatanus, Crataegus monogyna, Cornus mas, Ligustrum vulgaris (Voigtländer et al. 1997). Sometimes found in caves. Also anthills.

111. Cylindroiulus boreoibericus Read, 2007

\section{Distribution}

ES-SPA, PT-POR. NW Iberia.

\section{Habitat}

In a coastal dune area with Pinus and in temperate woodlands at low altitude, mainly deciduous, e.g., Quercus, Fraxinus. So far found near the sea or in lowland river valleys. Mostly under stones but also below wood and in leaf litter.

112. Cylindroiulus brachyiuloides Enghoff, 1982

\section{Distribution}

PT-MDR.

\section{Habitat}

Slopes on or near the north coast with mosses, ferns, grass, herbs, Rubus; occasionally partly forested (Lauraceae, Pinus). 100-350 m.

113. Cylindroiulus britannicus (Verhoeff, 1891)

Iulus britannicus Verhoeff, 1891.

Cylindroiulus pollicaris Attems, 1904.

Cylindroiulus pollinaris Attems, 1933 (misspelling of pollicaris).

\section{Distribution}

AT, CZ, DE, DK-DEN, ES-CNY, ES-SPA, FI, FR-FRA, GB-GRB, GB-NI, IE, LT, NL, NO-NOR, PL, PT-AZO, PT-MDR, PT-POR, RO, RU-RUC, RU-RUW, SE, UA. - Also widely introduced into Siberia and the Afrotropical, Australian, Nearctic, Neotropical and Oriental regions.

\section{Habitat}

In Britain and Ireland it is found beneath the bark of dead deciduous tree trunks and stumps and in their decomposing wood. Sometimes in the soil but, if so, usually close to wood or leaf litter (Blower 1985). These remarks apply to rural and semi-natural woodland habitats. There are several records from alder (Alnus) woods near rivers in NW Spain and England; a very large population occurred in an Alnus/Salix swamp with Carex at Stodmarsh Nature Reserve in Kent. Yet, it also has a strong relationship with urban sites in Britain and Ireland (Lee 2006). In the majority of other countries it appears to be mostly or exclusively synanthropic, occurring particularly in cities and cultivated areas. The close link with parks, gardens and market gardens with greenhouses suggests that specimens found out of doors may be reliant on artificially warm habitats for much of the year in the North. In Sweden the records from the northern provinces of Västerbotten and Norrbotten are associated with greenhouses, as are records from Finland and elsewhere. Such records are not shown on the map. Cylindroiulus britannicus was found on an afforested colliery spoil heap with garden refuse in Germany 
(Decker \& Hannig 2010). It was discovered in a cave on a beach at Funchal, Madeira, and in logs of the laurisilva.

\section{Remarks}

The recorded distribution of $C$. britannicus in Europe is quite strange. Until recently, with the exception of Portugal, there were no records from the western part of the mainland. Recently, it has been found in seminatural habitats in NW Spain and again in Portugal (Read 2007). As it is necessary to dissect adult males to identify the species it may have been overlooked in France, Belgium, Luxemburg and Switzerland; however, much field work has been undertaken in these countries by expert myriapodologists who have not found it. It may be that $C$. britannicus is essentially a Lusitanian or strictly Atlantic species - the west of France is very poorly known - which has become anthropochorous and a successful pioneer elsewhere, as witnessed by its fairly cosmopolitan distribution.

\section{Cylindroiulus broti (Humbert, 1893)}

Iulus broti Humbert, 1893.

Julus allobrogicus Brölemann, 1896.

Cylindroiulus castanearum Verhoeff, 1930.

\section{Distribution}

CH (Valais, Ticino), FR-FRA (Alps), IT-ITA (Alps and Apennines).

\section{Habitat}

Montane, subalpine and alpine from 400 to $2200 \mathrm{~m}$ in Switzerland (Pedroli-Christen 1993), up to 2400 $\mathrm{m}$ in the Oisans area of the French Alps (Schubart 1954) and up to $2500 \mathrm{~m}$ in the Ecrins National Park (Geoffroy 1981b) where it was observed principally in forests including Larix decidua, Fagus sylvatica, Populus tremula Alnus viridis, Betula, Pinus sylvestris, Pinus uncinata, Abies and Picea, but also in meadows with these trees, high level grasslands, rocky places and heaths or moors.

In the Vanoise National Park it was similarly distributed and particularly abundant in subalpine grassy Larix forests (Geoffroy 1983). In the Alpes Maritimes C. broti is assocated with Rhododendron, Vaccinium moors and the more open Larix stands containing many alpine flowers. In the Ticino and in Italy, from $500 \mathrm{~m}$ up to $1450 \mathrm{~m}$. Also in Italy in Castanea woodland, in Corylus litter from 1100 to 1200 $\mathrm{m}$ and in Fagus litter at $1250 \mathrm{~m}$.

\section{Remarks}

A common species within its range. There is some possible confusion between records of this species and those of C. decipiens from the Apennines in Central Italy (see Strasser 1970).

\section{Cylindroiulus burzenlandicus Verhoeff, 1907}

\section{Distribution}

PL, RO, SK, UA. East Carpathian

\section{Habitat}

Broad-leaved forest; Carpathian beech (Fagus) forest (Jędryczkowski 1992); in Maramures (Romania), where the species is common, it was collected along streams in deciduous forest, mainly Fagus, but in Quercus, mixed and in Pinus woods as well (Korsós \& Lazányi 2008). By the streams it was found in alder (Alnus) carr, peat bogs and pastures. Found in forest steppe in the Ukraine (Golovatch 1992). Quoted altitudes range from $400 \mathrm{~m}$ to $1000 \mathrm{~m}$. 


\section{Remarks}

Very similar to C. luridus of which it has been regarded as a subspecies (Korsós \& Lazányi 2008). Gromysz-Kałkowska et al. (2000) studied the influence of environmental stress on the physiology of C. burzenlandicus.

\section{Cylindroiulus caeruleocinctus (Wood, 1864)}

Iulus caeruleocinctus Wood, 1864.

Julus teutonicus Pocock, 1900.

Cylindroiulus londinensis caeruleocinctus Brade-Birks, 1922.

Cylindroulus teutonicus auct.

Cylindroiulus londinensis auct.

\section{Distribution}

AT, BE, CH, CZ, DE, DK-DEN, EE, ES-SPA, FI, FR-FRA, GB-GRB, GB-NI, HU, IE, IT-ITA, LT, LU, LV, NL, NO-NOR, PL, PT-POR, RU-KGD, RU-RUW, SE, UA. Widely distributed from Iberia to Russia but not south of the Alps and the Carpathians. Mainly Central Continental. - Also widely introduced into Canada and the USA.

\section{Habitat}

An abundant species in much of Central Europe, often dominant in open habitats, especially grassland, and characteristic of dry grassland on chalk and limestone in many regions. But it also occurs in hedges and small woods, though very rarely in forests. Common in parks, gardens, cemeteries, waste places and arable land, and over much of its range it is strongly synanthropic. Many large populations have been found in urban areas; Davis $(1979,1982)$ found it the commonest species to fall into pitfall traps in London, while Fairhurst (1984) found the optimum habitat in the United Kingdom to be loamy agricultural soils. It may be found under wet leaves in parks and beside rivers in towns. While considered calcicole by many authors (e.g., Haacker 1968 found a strong preference for alkaline soils), there are records from other types of soil. The same author indicated that its preferred foods were broadleaves, followed by grass and moss.

It both hibernates and aestivates at some depth in the soil and shows a marked activity peak in the spring and a lesser one in the autumn. Principally a lowland species, found up to $1240 \mathrm{~m}$ in Switzerland (Pedroli-Christen 1993) and on a xerorendzina with evergreen oaks (Quercus) at $940 \mathrm{~m}$ and a pasture on brown earth at $1130 \mathrm{~m}$ in the Spanish Pyrenees (Serra et al. 1996). There are many records of this species attacking crops.

\section{Remarks}

As can be seen from the synonyms there has been much confusion in the past as to the identity of this species (see, e.g., Mauriès 1964; David 1995). As a general rule all records of C. teutonicus and records of $C$. londinensis from countries other than Spain, France, Ireland and Great Britain relate to $C$. caeruleocinctus.

117. Cylindroiulus cambio Korsós \& Read, 1994

\section{Distribution}

RU-RUS.

\section{Habitat}

Steppe. 


\section{Remarks}

Described from the Botanical Garden in Rostov-on-Don, subsequently found in natural steppe habitats near Rostov-on-Don (Evsyukov \& Golovatch 2013).

118. Cylindroiulus cantonii (Brölemann, 1892)

Iulus cantonii Brölemann, 1892.

\section{Distribution}

IT-ITA.

\section{Habitat}

Known only from the Botanical Garden of Pavia, where a male was collected by Professor Cantoni in the spring of 1873. Maybe an introduction?

119. Cylindroiulus caramujensis Lohmander, 1955

\section{Distribution}

PT-MDR.

\section{Habitat}

Laurisilva with Erica arborea; dry grassland with bracken (Pteridium).

Located under fallen leaves, under moss covering large boulders and under dry bark flakes of Erica arborea 1-2 $\mathrm{m}$ above the ground. Habitats from 900 to $1350 \mathrm{~m}$.

\section{Cylindroiulus chalandei (Ribaut, 1904)}

Iulus chalandei Ribaut, 1904.

Cylindroiulus simplex Ceuca, 1974.

\section{Distribution}

AD, ES-SPA, FR-FRA. Central and Eastern Pyrenees.

\section{Habitat}

Montane/subalpine/alpine. Over its restricted range common in the leaf litter of woodland and under stones in meadows. In Spain associated with Fagus sylvestris, Quercus ilex, Q. faginea, Pinus mugo, Buxus sempervirens and Populus sp. (Vicente 1985) and found at altitudes from 250 to $2070 \mathrm{~m}$. It occurs in alpine meadows. In France, there are precise records from pasture with dead wood at the edge of old coniferous forest, $1730 \mathrm{~m}$, and from under pine cones in Rhododendron/Cytisus scrub with scattered Pinus, 2150 m, on Mont Canigou.

\section{Cylindroiulus cristagalli Enghoff, 1982}

\section{Distribution}

PT-MDR.

\section{Habitat}

Under stones in an area with almost no vegetation on Pico Areeiro, $1800 \mathrm{~m}$. 
122. Cylindroiulus dahli Demange, 1970

\section{Distribution}

ES-SPA (La Coruña, Orense, Pontevedra Provinces), PT-AZO (São Miguel). Lusitanian.

\section{Habitat}

Woodland (Quercus, Fraxinus, Pinus), rocky shoreline with grassland, garden, city park. Often under stones or wood.

\section{Remarks}

This species was described from São Miguel and originally supposed to be endemic in the Azores but has been found more recently in nine locations in Galicia, most of which are given in Read (2007). It will most probably occur in Portugal.

123. Cylindroiulus decipiens (Berlese, 1885)

Iulus decipiens Berlese, 1885.

\section{Distribution}

IT-ITA. Calabria and perhaps mountains further north.

\section{Habitat}

Found above the tree line.

\section{Remarks}

Maybe some records of $C$. decipiens are due to confusion with $C$. broti (q.v.). It may be endemic in Calabria. Records are all from higher than $1200 \mathrm{~m}$, on Montalto as high as $1950 \mathrm{~m}$.

124. Cylindroiulus digitus Enghoff, 1982

\section{Distribution}

PT-MDR.

\section{Habitat}

Laurisilva, mainly under moss on stones, $900 \mathrm{~m}$.

125. Cylindroiulus disjunctus Read, 1989

\section{Distribution}

ES-CNY (El Hierro, La Palma).

\section{Habitat}

Laurisilva, under bark, stones and litter, in stump of Erica tree.

126. Cylindroiulus dubius Verhoeff, 1930

\section{Distribution}

IT-ITA (Piedmont). 


\section{Habitat}

At the foot of an old Castanea tree on the side of Monte Mottarone near Stresa at an altitude of $500 \mathrm{~m}$.

\section{Remarks}

Verhoeff (1930) stated that this blind species is very similar to Cylindroiulus vulnerarius. He found just one female.

127. Cylindroiulus exiguus Enghoff, 1982

\section{Distribution}

PT-MDR.

\section{Habitat}

Laurisilva, both relatively undisturbed and pronouncedly secondary, 700-900 m.

\section{Cylindroiulus fenestratus Read, 1989}

\section{Distribution}

ES-SPA, PT-POR.

\section{Habitat}

The type material was found in Quercus litter in Portugal. Also found in Eucalyptus woods, woodland margins, road verges, ditches, a fishing harbour.

129. Cylindroiulus festai Manfredi, 1939

\section{Distribution}

IT-ITA (Piedmont).

\section{Habitat}

At 1100 m on the Gran Piano de Noasca in the Gran Paradiso National Park.

\section{Cylindroiulus fimbriatus Enghoff, 1982}

\section{Distribution}

PT-MDR.

\section{Habitat}

Under stones and leaf litter in relatively undisturbed laurisilva, 600-1000 m.

\section{Cylindroiulus finitimus (Ribaut, 1905)}

Iulus finitimus Ribaut, 1905.

\section{Distribution}

ES-SPA, FR-FRA. Pyrenees and neighbouring mountains.

\section{Habitat}

Forest and some open habitats generally between $500 \mathrm{~m}$ and $2000 \mathrm{~m}$ in altitude. Alpine meadows from 1600 to $2200 \mathrm{~m}$. 


\section{Remarks}

It is possible that the two southernmost records on the map (Sierra de Aguila, Sierra del Moncayo) relate to Cylindroiulus caeruleocinctus (see remarks below under Cylindroiulus londinensis).

132. Cylindroiulus franzi Attems, 1952

\section{Distribution}

ES-SPA (W Andalusia).

\section{Habitat}

Mountains around Ronda. Collected from pine litter. Found up to $1500 \mathrm{~m}$.

133. Cylindroiulus fulviceps (Latzel, 1884)

Iulus luridus var. fulviceps Latzel, 1884.

Cylindroiulus partenkirchianus Verhoeff, 1901.

\section{Distribution}

AT, DE, IT-ITA. E Alpine.

\section{Habitat}

Usually on calcareous terrain. Fagus forest; bushy woods; chalk scree; caves. One record from the Altiplano del Consiglio at $1200 \mathrm{~m}$.

\section{Cylindroiulus gemellus Enghoff, 1982}

\section{Distribution}

PT-MDR.

\section{Habitat}

In and under logs and branches, under leaf litter, under moss covers on boulders from laurisilva. 700 $1000 \mathrm{~m}$.

\section{Cylindroiulus generosensis Verhoeff, 1900}

Diploiulus generosensis auct.

\section{Distribution}

CH, IT-ITA. Largely cisalpine.

\section{Habitat}

Montane and subalpine, mainly in coniferous or marshy forests but also alpine heaths and meadows from 1000 to 2100 m, found from April until November with a peak in May (Pedroli-Christen 1993).

\section{Remarks}

Most records come from Switzerland (the Ticino with a few from the Valais) with a few from the Centovalli in Italy. It is common around Monte Generoso, after which it is named. 
Allaiulus gestri Silvestri, 1898.

Cylindroiulus gestroi auct.

\section{Distribution}

IT-SAR.

137. Cylindroiulus gigas Verhoeff, 1932

\section{Distribution}

IT-ITA (Piedmont).

\section{Habitat}

In a deep gorge with Betula, Corylus and Castanea, under forest litter. Mountain slopes south of Susa and of Torre Pellice, 700-800 m.

\section{Cylindroiulus gregoryi Read, 2007}

\section{Distribution}

ES-SPA (Galicia, Pontrevedra Province).

\section{Habitat}

On the grounds of a finca with a garden and tourist accommodation.

139. Cylindroiulus hirticauda Enghoff, 1982

\section{Distribution}

PT-MDR.

\section{Habitat}

Laurisilva, both relatively undisturbed and secondary with Castanea, 725-1000 m.

140. Cylindroiulus horvathi (Verhoeff, 1897)

Iulus horvathi Verhoeff, 1898.

Julus dietli Verhoeff, 1898.

Cylindroiulus vitosae Strasser, 1962.

Cylindroiulus ponticus Golovatch, 1978.

\section{Distribution}

BG, HU, PL, RO, UA. East Central European.

\section{Habitat}

Apparently a xerophilous species inhabiting dry grasslands and steppe vegetation (Korsós \& Read 1994). Also Quercus petraea and Carpinus orientalis woodland, and caves (Golovatch 1990; Vagalinsky \& Stoev 2007). Occurs in ant nests in Bulgaria (Stoev \& Lapeva-Gjonova 2005). Lowland and up to $1500 \mathrm{~m}$ in Bulgaria. 


\section{Remarks}

Records suggest a very patchy distribution ranging from the Pannonian biogeographic region in Hungary as far east as the Crimea.

141. Cylindroiulus ibericus Brölemann, 1913

\section{Distribution}

ES-SPA. Central Pyrenees.

\section{Habitat}

Forest in the Provinces of Huesca and Lerida. One precise record of altitude at $1500 \mathrm{~m}$.

142. Cylindroiulus iluronensis Brölemann, 1912

\section{Distribution}

ES-SPA, FR-FRA. West-central Pyrenees.

\section{Habitat}

Open grassy Fagus/Picea woodland, in logs, $1360 \mathrm{~m}$; Fagus forest with Buxus, in leaf litter on limestone, 1400-1500 m; Fagus forest, 1700-1800 m. At upper tree limit in Pinus, Abies, Rhododendron vegetation.

143. Cylindroiulus infernalis Lohmander, 1955

\section{Distribution}

PT-MDR.

\section{Habitat}

Laurisilva. Associated with dead wood - under bark, under and in decaying logs, 800-1150 m.

144. Cylindroiulus insolidus Lohmander, 1955

\section{Distribution}

PT-MDR.

\section{Habitat}

Near springs in laurisilva, $1080-1150 \mathrm{~m}$.

145. Cylindroiulus italicus (Latzel, 1884)

Iulus italicus Latzel, 1884.

Iulus dalmaticus C.L. Koch, 1847, sensu Berlese (1883).

non Julus italicus Verhoeff, 1894.

\section{Distribution}

AT, IT-ITA. Cisalpine.

\section{Habitat}

Subalpine; forest and open habitats. Several records give altitudes which range from $520 \mathrm{~m}$ to $1700 \mathrm{~m}$. 


\section{Remarks}

This species has been confused with $C$. tirolensis, and some records are probably wrongly referred to italicus.

\section{Cylindroiulus julesvernei Reboleira \& Enghoff, 2014}

\section{Distribution}

PT-MDR.

\section{Habitat}

Cavernicolous, found in a lava tube.

147. Cylindroiulus julipes Enghoff, 1982

\section{Distribution}

PT-MDR.

\section{Habitat}

Slopes and precipices on the north coast with a vegetation of mosses, grasses, herbs, Rubus and Aeonium, $100-150 \mathrm{~m}$.

148. Cylindroiulus kappa Enghoff, 1982

\section{Distribution}

PT-MDR.

\section{Habitat}

In logs in laurisilva, $900 \mathrm{~m}$.

\section{Remark}

Recorded only from Faja de Nogueira.

149. Cylindroiulus lagrecai Manfredi, 1957

\section{Distribution}

IT-ITA (Calabria).

\section{Habitat}

Mountains (Monte Pollino and La Sila), one site was at $1700 \mathrm{~m}$. Not found below $1200 \mathrm{~m}$ (Strasser 1970).

\section{Cylindroiulus latestriatus (Curtis, 1845)}

Julus latestriatus Curtis, 1845.

Julus luscus Meinert, 1868.

Cylindroiulus frisius Verhoeff, 1891.

Cylindroiulus owenii Bollman, 1887.

Iulus parisiorum miraculus Brölemann \& Verhoeff, 1896. 


\section{Distribution}

BE, BY, CH, CZ, DE, DK-DEN, DK-FOR, EE, ES-CNY, ES-SPA, FI, FR-FRA, GB-CI, GB-GRB, GB-NI, HU, IE, LT, LV, NL, NO-NOR, PL, PT-AZO, PT-POR, RO, RU-KGD, RU-RUC, RU-RUW, SE, SK, UA. Extended Atlantic. - Also widely introduced in the Afrotropical, Australian, Palaearctic, Nearctic and Oriental regions. Found on several remote islands including Tristan da Cunha, Saint Paul and Easter Island.

\section{Habitat}

Among the roots of halophytes on fixed coastal dunes and in grassland on a sandy substrate; inland strongly associated with sandy areas, common on some heaths, has been found in the deciduous litter of woodland on light soils, but more usually synanthropic. Abundant in some horticultural areas and found often in urban gardens.

\section{Remarks}

This remarkable species is distributed along the Atlantic and North Sea coasts from Macaronesia and Portugal to Norway and in the Baltic reaches Finland and Russia. It becomes increasingly synanthropic into the Gulf of Bothnia and the Gulf of Finland, similarly inland on the Continent where there are numerous scattered records eastwards to Russia and the Ukraine. From Europe C. latestriatus has spread as far as South Africa, North, Central and South America, even to remote places such as St. Paul Island in the Antarctic and Easter Island in the Pacific Ocean, showing unusual pioneering abilities. It is perhaps the most widely distributed millipede on Earth. This may be correlated with its unusually short life cycle: reproduction may take place already in the second year of life (Voigtländer 1996).

151. Cylindroiulus latro Attems, 1927

\section{Distribution}

IT-ITA (Abruzzo).

152. Cylindroiulus latzeli (Berlese, 1884)

Iulus latzeli Berlese, 1884.

Dendroiulus latzeli auct.

Diploiulus latzeli auct.

\section{Distribution}

CH, IT-ITA (N Italy and in mountains further south, only above $1200 \mathrm{~m}$ in Calabria).

\section{Habitat}

It has a large altitudinal range. Woodland up to about $1100 \mathrm{~m}$; strongly associated with dead wood and regularly found in large numbers under loose bark. It does occur in leaf litter, including on screes, and has been recorded with Robinia and Corylus. Also, it has been found in tree stumps in meadows and under stones in a park. Found in a number of caves. Attems (1927) cited agricultural land in Lombardy.

153. Cylindroiulus laurisilvae Enghoff, 1982

\section{Distribution}

PT-MDR. 


\section{Habitat}

Laurisilva, semi-natural or secondary with Castanea. Mostly found under and in fallen leaves but also under stones and logs, once in a log. 600-1000 m.

\section{Cylindroiulus limitaneus (Brölemann, 1905)}

Iulus limitaneus Brölemann, 1905.

\section{Distribution}

FR-FRA, MC. Maritime Alps.

\section{Habitat}

Only known from a few sites, mostly in Pinus woodland.

\section{Cylindroiulus londinensis (Leach, 1814)}

Iulus londinensis Leach, 1814.

\section{Distribution}

ES-SPA, FR-FRA, GB-GRB, IE. Atlantic.

\section{Habitat}

Woodland and open habitats, until above the tree line up to $2000 \mathrm{~m}$, common on calcareous soils, but also present on brown earths and on well-drained acidic sandy soils. In Britain and Ireland not yet found on heaths, moorland, wetland or in synanthropic habitats (Lee 2006). In deciduous, mixed or coniferous (Pinus) forest; frequently in Fagus forests and also in Quercus woodland, sometimes with Carpinus and/ or Buxus, often with Castanea, Fraxinus, Tilia, Betula, Corylus, in scrubby land with Prunus, Cornus, Ligustrum, Juniperus, Ruscus. At least in the south of its range in Spain it is found in evergreen Quercus stands. It is associated with a wide range of ground floras, occurring principally in litter and logs, descending into the topsoil during unfavourable weather. Common in Atlantic woods in France, on many types of parent rock, e.g., limestone, sandstone, schist, granite, volcanic, at the same time notably unrecorded from the eastern departments.

\section{Remarks}

There are correct records only from the countries listed above. All the references to this species in the literature from other countries relate to $C$. caeruleocinctus, with which it was formerly confused. In Spain, north of $42^{\circ} \mathrm{N}$ we are absolutely sure that our records do relate to $C$. londinensis, but, because of its strongly Atlantic distribution we are not certain if the three records in the literature shown south of $42^{\circ} \mathrm{N}$ relate to it or not, especially because when Ceuca (1972) made them, at two of the same sites he also identified Cylindroiulus finitimus, which he equated with $C$. londinensis var. finitimus and $C$. teutonicus, although the latter is now known to be a different species (C. caeruleocinctus). The previous nomenclatural confusion was rectified by Mauriès (1964), who demonstrated the specific differences between $C$. caeruleocinctus, $C$. finitimus and $C$. londinensis, making it clear that they were not all varieties of $C$. londinensis as many authors then believed. Blower (1985) gave an explanation of the confusion.

156. Cylindroiulus lundbladi Lohmander, 1955

\section{Distribution}

PT-MDR. 


\section{Habitat}

Laurisilva, mostly with Erica arborea as an important element. Under the bark of standing trees, 1-2 m above ground, under moss cover on boulders, under leaves. 800-1150 m. Observed crawling on tree trunks during the night.

157. Cylindroiulus luridus (C.L. Koch, 1847)

Julus luridus C.L. Koch, 1847.

\section{Distribution}

AT, BA, BG, CZ, DE, HR, HU, IT-ITA, MK, RO, SB, SI, SK. Southeast Central Europe.

\section{Habitat}

Deciduous, mixed and coniferous forest. Fagus, Quercus, Carpinus, Castanea, Tilia, Alnus, Fraxinus, Ulmus, Populus, Acer, Pinus, Picea, etc. In leaf litter, under wood, etc. Occasionally in caves. May be found at altitudes as high as $1500 \mathrm{~m}$. Particularly frequent in Fagus forests in the mountains, as high as $1630 \mathrm{~m}$ in Bulgaria (Golovatch \& Kondeva 1992).

\section{Cylindroiulus madeirae Attems, 1937}

\section{Distribution}

PT-AZO (São Miguel), PT-MDR.

\section{Habitat}

Laurisilva, more open herb/bush vegetation and treeless terrain with more or less xerophilous herbs and grasses at the eastern end of Madeira. Found under stones and leaf litter up to an altitude of $900 \mathrm{~m}$.

\section{Remark}

In all probability the record from São Miguel is the result of introduction by human agency.

159. Cylindroiulus meinerti (Verhoeff, 1891)

Iulus luridus var. meinerti Verhoeff, 1891.

Iulus meinerti auct.

\section{Distribution}

AT, CH, DE, HR, HU, IT-ITA, SI. Central and Eastern Alps from the Rhine to Croatia.

\section{Habitat}

Occurs up to $2000 \mathrm{~m}$, above the tree line but mainly in montane deciduous, e.g., Fagus, mixed or coniferous, e.g., Larix forest between about $650 \mathrm{~m}$ and $1750 \mathrm{~m}$. Often in dead wood and under loose bark. Also found under cowpats in meadows. Associated particularly with calcareous mountains. See notes under $C$. tirolensis.

160. Cylindroiulus molisius Verhoeff, 1932

\section{Distribution}

IT-ITA (Molise \& Puglia). 
Habitat

Broad-leaved forest, $800 \mathrm{~m}$.

161. Cylindroiulus numerosus Enghoff, 1982

\section{Distribution}

PT-MDR.

\section{Habitat}

Open vegetation with grasses, herbs, Rubus, sometimes Euphorbia, Opuntia or Erica scoparia, or under stone on almost barren areas of lava. Found not only on the main island, but also on the tiny Desertas islands to the SE (Read 1989). Only one specimen was taken from secondary laurisilva; 50-700 m, mostly below $500 \mathrm{~m}$.

162. Cylindroiulus obscurior Enghoff, 1982

\section{Distribution}

PT-MDR.

\section{Habitat}

Laurisilva, in one case open with bushes and only scattered laurels (Laurus), in another with Pinus and open, moist, moss-covered slopes. Under stones, leaf litter, and under dry moss on boulders, $250-900 \mathrm{~m}$.

163. Cylindroiulus oromii Reboleira \& Enghoff, 2014

\section{Distribution}

PT-MDR.

\section{Habitat}

Cavernicolous, found in a lava tube.

\section{Distribution}

164. Cylindroiulus pallidior Enghoff, 1982

PT-MDR.

\section{Habitat}

Laurisilva, both relatively undisturbed and secondary. Under a fallen branch and under leaf litter in rather moist situations, $800-1000 \mathrm{~m}$.

165. Cylindroiulus parisiorum (Brölemann \& Verhoeff, 1896)

Iulus parisiorum Brölemann \& Verhoeff, 1896.

Iulus luscus auct.

Cylindroiulus ignoratus Attems, 1927.

\section{Distribution}

AT, BE, CH, CZ, DE, DK-DEN, FR-FRA, GB-GRB, GB-NI, HR, HU, IT-ITA, MC, NL, PL, SI, UA. 


\section{Habitat}

In at least Britain, Belgium, Denmark and Switzerland it occurs as a subcorticole in rural sites and is found in hollow decaying trees, soft wood and sawdust. Elsewhere the records are usually synanthropic, usually in gardens, parks, spoil heaps, greenhouses or graveyards. Recorded from the catacombs in Paris, quarries, a wood yard and rural localities in France, including a wheatfield.

\section{Remarks}

While the map shows records scattered from France to the Ukraine, the vast majority of these come from south and east England, with fewer than 10 from France and three from Belgium; the others are isolated captures. It occurrs in association with human activity in all the countries shown, except Belgium (forest) and Switzerland (Caricaie wetlands). It is a fairly rare species, and some records are likely to be erroneous owing to possible confusion with other tail-less Cylindroiulus species. This includes the extra-European record from St. Helena Island by Hoffman (1977). We have left out some of the more doubtful records on the map. Regarded as threatened with extinction in Germany (Voigtländer et al. 2011).

166. Cylindroiulus pelatensis Verhoeff, 1930

\section{Distribution}

IT-ITA (Mt. Pelato near Castillioncello in Tuscany).

\section{Habitat}

Under a stone on cool SW slope, $150-250 \mathrm{~m}$.

167. Cylindroiulus perforatus Verhoeff, 1905

Julus occultus Verhoeff, 1893, preoccupied.

\section{Distribution}

ES-SPA, PT-POR. Southwest Spain and Portugal.

\section{Habitat}

Woodland, most frequently captured in Pinus and Quercus suber litter.

168. Cylindroiulus propinquus (Porat, 1870)

Iulus propinquus Porat, 1870.

Micromastigoiulus propinquus auct.

\section{Distribution}

PT-AZO, PT-MDR, PT-POR.

\section{Habitat}

Quercus and Pinus woodland on granite in Portugal. On the islands in laurisilva, under stones and leaf litter.

\section{Cylindroiulus punctatus (Leach, 1815)}

Julus punctatus Leach, 1815.

Iulus silvarum Meinert, 1868.

Cylindroiulus silvarum auct. 


\section{Distribution}

AT, BE, CH, CZ, DE, DK-DEN, ES-BAL, ES-SPA, FI, FR-FRA, GB-CI, GB-GRB, GB-NI, IE, LU, NL, NO-NOR, PL, SE. Extended Atlantic. - Also introduced into the Nearctic region (Newfoundland).

\section{Habitat}

Woodland of all sorts, most frequently in dead and decaying wood and under the bark of dead trees and branches. However, it migrates vertically and is found in leaf litter especially from autumn to spring and in the soil when it is cold. It is hygrophile and accumulates in rather deep decomposing litter and the underlying humus on silty soils in particular (Kime \& Wauthy 1984) and extends into sandy heathlands (Blower 1985). It is found in hedges, arable land, parks, gardens and other places, generally associated with wood, yet is more rural than synanthropic.

It is a thermophile lowland species, although it occurs up to over $1000 \mathrm{~m}$ at its southern limit in the Mediterranean woodlands of Catalonia. Schubart (1934) associated it with various ants' nests.

\section{Remarks}

Many studies of this species have been made, e.g., Barlow (1957), Breny \& Biernaux (1966), Banerjee (1967a, 1967b), Haacker (1968) and Geoffroy (1981a). It migrates vertically from the leaf litter or the soil in cold winters up into trees in the spring; in summer it may be found metres above the ground, descending again during the autumn. Its lowland Atlantic distribution is probably governed by the avoidance of cold winter temperatures. Wood and leaf litter are both important foods. It is a very common species, the most frequently recorded in Britain (Lee 2006) and Belgium (Kime 2004).

170. Cylindroiulus pyrenaicus (Brölemann, 1897)

Iulus pyrenaicus Brölemann, 1897.

\section{Distribution}

ES-SPA, FR-FRA. Pyrenees and Montagne Noire.

\section{Habitat}

Regularly in Fagetum. Apart from Fagus forest recorded in mixed woodland with Fagus / Quercus / Tilia / Corylus / conifers; recorded in a Pinus plantation in the Basque Country. In often deep litter, moss, under bark and in dead wood. Also in stony pastures with marginal bushes or some trees.

\section{Cylindroiulus quadratistipes Enghoff, 1982}

\section{Distribution}

PT-MDR.

\section{Habitat}

Relatively undisturbed and secondary laurisilva, under leaf litter, 800-850 m.

172. Cylindroiulus rabacalensis Lohmander, 1955

\section{Distribution}

PT-MDR. 


\section{Habitat}

Laurisilva, semi-natural or secondary; most specimens found under leaf litter, a few under dry moss on a boulder. From 600 to $1000 \mathrm{~m}$.

173. Cylindroiulus rubidicollis Verhoeff, 1930

Julus (Cylindroiulus) Verhoeffii Brölemann - Verhoeff (1896).

\section{Distribution}

IT-ITA (Northern Piemonte: Aosta, Susa, Lake Maggiore).

\section{Habitat}

Castanea thicket, $650 \mathrm{~m}$ a.s.1.; under cushions of Sedum on a sunny hill; under large stones and aspen (Populus tremula) litter on sand on a river bank.

\section{Cylindroiulus rufifrons (C.L. Koch, 1847)}

Julus rufifrons C.L. Koch, 1847.

\section{Distribution}

IT-ITA (Lombardia, Venezia, Calabria).

\section{Habitat}

No information apart from a cave at Scilla in Calabria (see below).

\section{Remarks}

There are only old records from the $19^{\text {th }}$ century concerning this species. Berlese $(1882-1903)$ listed sites from Calabria, and Brölemann (1895) listed sites from Lombardy. Minelli (1985) stated that the above-mentioned cave record might be attributed to another species, and Strasser (1970) thought that the Calabrian records possibly referred to $C$. aetnensis and that the Venetian record probably referred to C. boleti. Strasser \& Minelli (1984) regarded C. rufifrons as a doubtful species in need of revision.

\section{Cylindroiulus sagittarius (Brölemann, 1897)}

Iulus sagittarius Brölemann, 1897.

Cylindroiulus hispanicus Ceuca, 1974.

\section{Distribution}

ES-SPA, FR-FRA. Western Pyrenees and Northern Spanish Cordillera.

\section{Habitat}

Montane forest, especially Fagus, Quercus, often with Fraxinus, Crataegus, Ilex, Corylus; Alnus woods along streams; Castanea grove with Daphne, Helleborus, Salvia, Lathraea and Rubus. Found in litter, moss, under bark and in rotting trunks and logs. 550-2000 m. Frequently on limestone.

\section{Remarks}

It occupies a similar niche to Cylindroiulus punctatus, which it replaces higher up in the mountains. 


\section{Cylindroiulus salicivorus Verhoeff, 1908}

\section{Distribution}

DE, GB-GRB, IT-ITA. Cisalpine.

\section{Habitat}

Wet grassland with Salix; in the humus of an old chestnut (Castanea) wood, $530 \mathrm{~m}$.

\section{Remarks}

It has been found in Scotland at the Royal Botanic Gardens, Edinburgh, and the St Andrews Botanic Garden (Lee 2006) and also in Germany at Karlsruhe Palace (Spelda 2005). This clearly suggests introduction by human agency.

177. Cylindroiulus sanctimichaelis Attems, 1927

\section{Distribution}

ES-SPA (Basque Country, Navarre, Catalonia, Castilla la Mancha, Andalusia).

\section{Habitat}

Woodland, bushy areas, meadows, pastures, alpine habitats, rocky scrub (garrigue) and stony ground as on karst. Woodlands include Pinus, Ulmus, Populus, Fraxinus, Castanea, Fagus and many kinds of Quercus, both deciduous and evergreen species, especially Q. ilex and Q. cozza in Catalonia (Vicente 1985). Associated shrubs include Buxus, Crataegus, Corylus, Sambucus and Viburnum; some woodlands were heavily grazed. Commonly found in leaf litter. Records are from low down up to $2500 \mathrm{~m}$ altitude (Mauriès 1974).

\section{Remarks}

Most of our data are from the provinces of Alava, Navarra and Barcelona, where it is common. Records from further south indicate that it may have a wide range in Spain and may occupy a wide range of habitats.

\section{Cylindroiulus sangranus (Verhoeff, 1932)}

Dendroiulus sangranus Verhoeff, 1932.

Dendroiulus foveolatus Schubart, 1932.

\section{Distribution}

IT-ITA (Marche, Abruzzi e Molise, Lazio, Campania).

\section{Habitat}

Broad-leaved forest, 800-850 m, in hollow Castanea trunk at Nemi, 620 m, Quercus ilex and Castanea near Ariccia. $1200 \mathrm{~m}$ on Monte Vettore.

\section{Cylindroiulus sardous (Silvestri, 1898)}

Diploiulus sardous Silvestri, 1898.

\section{Distribution}

IT-SAR. 


\section{Habitat}

Little information; one record is from a cave.

180. Cylindroiulus schubarti Verhoeff, 1943

\section{Distribution}

FR-COR.

\section{Habitat}

Corsican mountains.

181. Cylindroiulus segregatus Brölemann, 1903

\section{Distribution}

FR-COR.

\section{Habitat}

Deciduous forests, evergreen Quercus woods, Pinus and Ilex wood; grassy areas; maquis; screes; below stones and wood. From sea level up to at least $1000 \mathrm{~m}$.

\section{Cylindroiulus siculus (Silvestri, 1897)}

Diploiulus siculus Silvestri, 1897.

\section{Distribution}

IT-SI (Trapani, Palermo \& Messina Provinces).

\section{Remarks}

Perhaps an uncommon species, so far as we know only reported once (from between Cesaro and the Femmina Morta Pass by Minelli in litt.) since it was recorded from Ficuzza and S. Ninfa by Silvestri.

\section{Cylindroiulus solarius Verhoeff, 1942}

\section{Distribution}

IT-ITA (Campania, Isle of Capri).

\section{Habitat}

In needle litter of Pinus halepensis, in Quercus-Castanea grove, dense maquis under stones and in litter.

\section{Remarks}

According to Verhoeff (1942) the most frequent julid of the Isle of Capri.

184. Cylindroiulus solis Verhoeff, 1908

\section{Distribution}

IT-ITA (Liguria).

\section{Habitat}

In the woodland litter and humus-rich earth of Castanea, Quercus and Fagus stands, up to about 1000 $\mathrm{m}$ in Castanea and at 1250-1300 $\mathrm{m}$ on limestone in the case of Fagus. 
185. Cylindroiulus sorrentinus Verhoeff, 1912

\section{Distribution}

IT-ITA (Campania, Calabria).

186. Cylindroiulus speluncaris Lohmander, 1955

\section{Distribution}

PT-MDR.

\section{Habitat}

Laurisilva at $1150 \mathrm{~m}$.

187. Cylindroiulus strasseri Verhoeff, 1930

\section{Distribution}

IT-ITA (Elba).

\section{Habitat}

Castanea forest, under litter and humus.

188. Cylindroiulus tirolensis Verhoeff, 1901

Cylindroiulus broelemanni Attems, 1904.

Julus italicus - Verhoeff (1894).

non Iulus italicus Latzel, 1884.

\section{Distribution}

CH, IT-ITA. Cisalpine.

\section{Habitat}

Mainly subalpine, in both open grassland and closed forest communities, from 1100 to $2200 \mathrm{~m}$.

\section{Remarks}

Species close to C. meinerti and C. italicus, see Pedroli-Christen (1993). It is possible that some of the data on the map relate to another species.

\section{Cylindroiulus transmarinus Enghoff, 1982}

\section{Distribution}

PT-MDR (Porto Santo).

\section{Habitat}

Woodland with Quercus coccifera, Erica, Cupressus, Pinus, Taxus, Laurus, Mimosa; treeless areas often with sparse rock vegetation, screes, gravel and lichens; grassland, mossy places and in ferns; associated with Mesembryanthemum, Carduus, Euphorbia, Trifolium, Oxalis etc. Altitudinal range 150-400 m (the highest point on the island is $517 \mathrm{~m}$ ). 
190. Cylindroiulus tricuspis Verhoeff, 1932

\section{Distribution}

IT-ITA (Piedmont).

\section{Habitat}

In Corylus litter and humus, $1400 \mathrm{~m}$, also on humus below Corylus, Acer and Berberis, litter on crystalline scree at $1280 \mathrm{~m}$.

191. Cylindroiulus truncorum (Silvestri, 1896)

Diploiulus truncorum Silvestri, 1896.

Cylindroiulus luscus salicis Verhoeff, 1926.

\section{Distribution}

AT, BE, CH, DE, DK-DEN, ES-CNY, FI, FR-FRA, GB-GRB, GB-CI, GB-NI, HU, LU, NL, NO-NOR, PL, PT-MDR, PT-POR, SE, UA. Extended Atlantic. - Also North Africa (Algeria, Tunisia), introduced into Siberia and the Australian, Neotropical and Nearctic regions.

\section{Habitat}

Strongly synanthropic over most of its known range, found in botanical and other gardens, parks, cemeteries, horticultural nurseries, greenhouses, farms, in hay, on spoil heaps, quarries, scrub, in refuse on waste ground. There was an infestation of house walls in Belgium (Kime, 2004). Haacker (1968) found that it spread into surrounding woodland in West Germany, that it preferred high humidity and ate mainly leaves. Found in woodland litter in Portugal as well as Germany. In laurisilva with tree heather at $800-900 \mathrm{~m}$ on Tenerife (Monte de las Mercedes).

\section{Remarks}

Schubart (1934) thought that the species was probably introduced into northern Europe from the Mediterranean, and its occurrences on the Canary Islands and Madeira are certainly also due to introduction. However, while it occurs in North Africa, there are no records from Italy or continental Spain and only two or three from France, in western and central parts - Finistère (Blower 1987), Nièvre (Jawłowski 1933b), and possibly Vienne departments (a female). It may have been overlooked in the past because of known confusion with similar species, especially $C$. parisiorum and C. arborum. We have not shown on our map records from Göteborg and Piteå in Sweden, Buskerud in Norway, southern Finland, and Kiev in the Ukraine because these are from greenhouses.

\section{Cylindroiulus turinensis (Brölemann, 1897)}

Iulus turinensis Brölemann, 1897.

\section{Distribution}

IT-ITA (Piedmont).

\section{Habitat}

In the litter of woodlands and shaded rocky slopes with bushes; Castanea, Corylus, Fagus, Acer, Berberis; 1000-1500 m. 
193. Cylindroiulus unciger Attems, 1952

\section{Distribution}

ES-SPA (Madrid and Zaragoza Provinces).

\section{Habitat}

A specimen from Peñaflor (Zaragoza) was collected on dry gypsum ground with planted Pinus halepensis trees.

194. Cylindroiulus uncinatus Strasser, 1969

\section{Distribution}

IT-SI.

\section{Habitat}

Islands off the west coast of Sicily.

195. Cylindroiulus uroxiphos Enghoff, 1982

\section{Distribution}

PT-MDR.

\section{Habitat}

Laurisilva with Castanea, $725 \mathrm{~m}$.

196. Cylindroiulus velatus Enghoff, 1982

\section{Distribution}

PT-MDR.

\section{Habitat}

Open woodland, 525-1000 m.

197. Cylindroiulus ventanaea Read, 2007

\section{Distribution}

ES-SPA (Galicia: La Coruña and Lugo Provinces).

\section{Habitat}

Quercus wood.

198. Cylindroiulus verhoeffi (Brölemann, 1896)

Iulus verhoeffi Brölemann, 1896.

Cylindroiulus henningsi Verhoeff, 1912.

\section{Distribution}

AT, CH (Ticino), FR-FRA (Savoy Alps), IT-ITA (Alpine Piedmont \& Lombardy). Cisalpine \& western Alps. 


\section{Habitat}

Eurytope up to subalpine level, 1500 m (Pedroli-Christen 1993).

199. Cylindroiulus vulnerarius (Berlese, 1888)

Mesoiulus vulnerarius Berlese, 1888.

Typhloiulus vulnerarius auct.

Cylindroiulus ellingseni Verhoeff, 1912.

\section{Distribution}

BE, CZ, DE, FR-FRA, GB-GRB, GB-NI, IE, IT-ITA (from Liguria and Veneto south to Campania), NL, SE. - Also introduced into the Nearctic region.

\section{Habitat}

In association with wood and rich, decaying organic matter in contact with the soil. In Tuscany, Verhoeff (1908) found it beside a river in Alnus litter and under dead wood. Most records in other regions are urban or suburban, from gardens, parks, glasshouses, under manure heaps, compost or debris. Found in buried dead wood and in a mole's nest. It occurs in caves and catacombs.

\section{Remarks}

Schubart (1934) presumed an Italian origin and introduction into all the other countries. Its occurrence in a rural Belgian cave and its numerous captures in the Low Countries and in the United Kingdom and Ireland lead one to wonder if it survived recent glaciations in caves in the Mosan district of Belgium and perhaps elsewhere (Kime 2004; Kime \& Dethier 2010). We have not shown on our map a record from Göteborg in Sweden because this is from a greenhouse.

200. Cylindroiulus waldeni Read, 1989

\section{Distribution}

PT-MDR.

\section{Habitat}

Laurisilva with giant Ocotea trees, under leaves and in soil between stones. 700-1000 m.

201. Cylindroiulus xynon Read, 1989

\section{Distribution}

PT-MDR.

\section{Habitat}

Laurisilva dominated by Erica, in soil under leaf litter.

202. Cylindroiulus ynnox Read, 1989

\section{Distribution}

PT-MDR.

\section{Habitat}

Laurisilva dominated by Erica, in soil under leaf litter. 
203. Cylindroiulus zarcoi Read, 1989

\section{Distribution}

PT-MDR.

\section{Habitat}

Laurisilva with giant Ocotea trees, under moss and lichens on Ocotea.

204. Cylindroiulus zinalensis (Faës, 1902)

Iulus zinalensis Faës, 1902.

\section{Distribution}

AT, CH, DE, IT-ITA. Swiss Alps and eastwards to the Rivers Inn and Adige.

\section{Habitat}

Montane and subalpine forests of several types (e.g., Quercus, Fagus, Castanea, mixed forest and often in conifers), bushy areas, heaths, moors and open marshy ground. Some forest sites are clearly calcareous. It has a wide altitudinal range up to over $2500 \mathrm{~m}$.

\section{Remarks}

Pedroli-Christen (1993) noted that it is parapatric with, and morphologically similar to Allajulus nitidus.

\section{Genus Dolichoiulus Verhoeff, 1900}

Nesopachyiulus Attems, 1902.

Trichopachyiulus Verhoeff, 1910.

Anagaiulus Enghoff, 1992.

A large genus of over 50 species, the vast majority of which are found on the Canary Islands, with a few on the Madeiran Islands, the Cape Verde Islands and on the mainland of SW Europe + Morocco. Detailed descriptions of the species and information on their habitats and distribution may be found in Enghoff $(1992,2012)$ and Enghoff \& Báez (1993).

\section{Dolichoiulus alluaudi (Brölemann, 1901)}

Pachyiulus alluaudi Brölemann, 1901.

Pachyiulus canariensis Brölemann, 1901.

Geopachyiulus alluaudi auct.

Geopachyiulus canariensis auct.

Nesopachyiulus alluaudi auct.

Nesopachyiulus canariensis auct.

\section{Distribution}

ES-CNY (Gran Canaria).

\section{Habitat}

Pinus forest under the needle litter and stones; also in bushes and grassland. Associated with species of Euphorbia, Lavandula, Cistus, Castanea, Opuntia, Agave, Rubus, Prunus, Teline. Occurs in the more humid central and northern parts of Gran Canaria, 150-1900 m. 


\section{Distribution}

ES-CNY (Tenerife).

\section{Habitat}

High altitude sites from forest, especially Pinus canariensis forest at an elevation of $1300 \mathrm{~m}$ to about $2000 \mathrm{~m}$ and Spartocytisus bushland above the forest, up to $2200 \mathrm{~m}$. Under stones and in litter.

\section{Remarks}

Records so far confined to the Cordillera Dorsal to the north-east of Teide.

207. Dolichoiulus aquasilvae Enghoff, 1992

\section{Distribution}

ES-CNY (Monte del Agua, NW Tenerife).

\section{Habitat}

In a $\log$ in laurisilva.

208. Dolichoiulus architheca Enghoff, 1992

\section{Distribution}

ES-CNY (Gran Canaria).

\section{Habitat}

Open vegetation, known locally as "Tabaibas and Cardones", typically dominated by large xerophytic species of Euphorbia. Also associated with Launaea, Cistus, Echium, Eucalyptus, Lavandula, Micromeria, Kickxia, Beta, Opuntia, Plocama and occasionally scattered Pinus canariensis. Often under stones and mainly in barrancos, gullies which only occasionally contain water, $50-950 \mathrm{~m}$.

209. Dolichoiulus axeli Enghoff, 1992

\section{Distribution}

ES-CNY (Tenerife).

\section{Habitat}

Barren rocky sites, dry slopes with Euphorbia species (Taibabas \& Cardones) and in lush bushy situations in the west coastal areas of Tenerife, $0-970 \mathrm{~m}$.

\section{Dolichoiulus baezi Enghoff, 1992}

\section{Distribution}

ES-CNY (Tenerife).

\section{Habitat}

Collected from under stones in the Tabaibas and Cardones with Euphorbia and other xerophytes (Lavandula, Kleinia, Zygophyllum, Neochamaelia, Plocama) along the north coast of Tenerife, up to $150 \mathrm{~m}$. 
211. Dolichoiulus blancatypa (Enghoff, 1992)

Anagaiulus blancatypa Enghoff, 1992.

\section{Distribution}

ES-CNY (Tenerife).

\section{Habitat}

Laurisilva, found in the soil in the eastern part of the Anaga Mountains. It may also be in litter or under logs and stones.

212. Dolichoiulus canariensis (Pocock, 1893)

Iulus canariensis Pocock, 1893.

\section{Distribution}

ES-CNY (Tenerife).

\section{Habitat}

A wide variety of habitats from near the sea to an altitude of $3050 \mathrm{~m}$ on Mount Teide, where it occurs in the "retamar" (specialised mountain broom vegetation with endemic species which is usually above the cloud layer created by the north-east trade winds). Plentiful in the Pinus canariensis forest below the retamar, it is less frequently found on the dry slopes of the Euphorbia zone (Taibabas and Cardones) below the forest (and usually below the cloud layer), reaching the desert along the south coast. It has not been found in the laurisilva of the humid north-east.

\section{Remarks}

Widespread, though recorded mainly from the central part of the island in and around the National Park and on the south coast, often associated with D. kraepelinorum (Latzel, 1895). Replaced by D. axeli in the west and not yet recorded from the east coast (partly replaced by D. insularis (Brölemann, 1901)). Occurs higher than any other species of Dolichoiulus, at $3050 \mathrm{~m}$ (Enghoff 1992).

213. Dolichoiulus carolineae Enghoff, 1992

\section{Distribution}

ES-CNY (southern Gran Canaria).

\section{Habitat}

Very dry open areas with Euphorbia, under stones, 50-120 m.

\section{Dolichoiulus chioensis Enghoff, 1992}

\section{Distribution}

ES-CNY (Cueva Grande de Chio, W Tenerife).

\section{Habitat}

Cavernicolous. 
215. Dolichoiulus dendromystax Enghoff, 1992

\section{Distribution}

ES-CNY (Anaga Mts, Tenerife).

\section{Habitat}

Laurisilva, 600-900 m. Mostly found in epiphytic mosses and lichens on trees, under the flakes of bark of Erica scoparia and sometimes in logs on the ground.

216. Dolichoiulus dubiosus Enghoff, 1992

\section{Distribution}

ES-CNY (La Gomera).

\section{Habitat}

A forest species, known only from El Cedro and Los Aceviños.

\section{Remarks}

The species was described from a female specimen which may correspond to a male described by Loksa (1967) from laurisilva and assigned by him to D. tiendarius (Attems, 1911). Subsequent, unpublished finds (material in ZMUC) including a male have confirmed this. D. tiendarius is similar to but smaller than D. dubiosus and is not a forest species.

217. Dolichoiulus eumadeirae Enghoff, 1992

\section{Distribution}

PT-MDR ( $\mathrm{S}$ coast).

\section{Habitat}

Open scrub with Euphorbia, Aeonium, Opuntia, Rubus, thistles, grasses, herbs. Stony slopes and screes on basalt.

\section{Dolichoiulus fjellbergi Enghoff, 1992}

\section{Distribution}

ES-CNY (Santa Lucia, Gran Canaria).

\section{Habitat}

Upper dry zone, under plants on a cliff, $990 \mathrm{~m}$.

\section{Dolichoiulus fuerteventurae Enghoff, 1992}

\section{Distribution}

ES-CNY (Fuerteventura).

\section{Habitat}

More or less open vegetation in central and southern Fuerteventura with Euphorbia, Argyranthemum, Sideritis, Asteriscus, Kleinia, Launaea and grasses. On rocks in litter under bushes; under stones, moss and other vegetation, $370-760 \mathrm{~m}$. 
220. Dolichoiulus gara Enghoff, 1992

\section{Distribution}

ES-CNY (La Gomera).

\section{Habitat}

Laurisilva, associated with logs and trees, under bark and moss pads, often several metres above the ground. Found well inside rotting wood. Has been observed in the soil, 900-1200 m.

\section{Remarks}

Seems to prefer slightly more moist/less superficial microsites than its syntopic congener, $D$. senilis (Attems, 1911).

\section{Dolichoiulus heliophilus Enghoff, 1992}

\section{Distribution}

ES-CNY (S Gran Canaria).

\section{Habitat}

Under stones on dry rocky slopes with Euphorbia. A dry barranco. At low altitude near the sea.

\section{Dolichoiulus hercules (Schubart, 1960)}

Nesopachyiulus hercules Schubart, 1960.

\section{Distribution}

ES-SPA (Málaga, Antequera, Mollina, Cueva de los Organos). - Also Morocco.

\section{Habitat}

Cavernicolous.

\section{Remarks}

Possibly a senior synonym of $D$. ibericus Ceuca, 1973 (Mauriès \& Vicente 1977).

\section{Dolichoiulus hyaena Enghoff, 1992}

\section{Distribution}

ES-CNY (Monte de las Mercedes, Anaga Mts, Tenerife).

\section{Habitat}

Laurisilva. In the soil and litter, rarely in logs, 860-900 m.

224. Dolichoiulus ibericus Ceuca, 1973

\section{Distribution}

GB-GI (Glenrocky Cave).

\section{Habitat}

Cavernicolous. 


\section{Remarks}

Possibly a junior synonym of $D$. hercules.

225. Dolichoiulus ingeae Enghoff, 1992

\section{Distribution}

ES-CNY (Tenerife).

\section{Habitat}

Coastal sites of the eastern Anaga Peninsula, where it occurs under stones on slopes from sea level to 320 m. In the dry zone with Euphorbia, Opuntia, Argyranthemum, Astydamia and grasses.

\section{Dolichoiulus insularis (Brölemann, 1901)}

Pachyiulus insularis Brölemann, 1901.

Pachyiulus insularis penicillata Attems, 1903.

Pachyiuluis penicillatus auct.

Geopachyiulus insularis auct.

Geopachyiulus penicillatus auct.

Nesopachyiulus insularis auct.

Nesopachyiulus penicillatus auct.

\section{Distribution}

ES-CNY (S coast of Anaga Peninsula, Tenerife).

\section{Habitat}

Euphorbia scrubland and bushes. Under stones. Once in a cave.

\section{Dolichoiulus jandiensis Enghoff, 1992}

\section{Distribution}

ES-CNY (Jandia, S Fuerteventura).

\section{Habitat}

Grassy area with Asteriscus, under stones and under moss and higher plants on rocks. 720-750 m.

\section{Dolichoiulus jonay Enghoff, 1992}

\section{Distribution}

ES-CNY (Bosque del Cedro, La Gomera).

\section{Habitat}

In a relatively dry log in laurisilva-brezal. $1100 \mathrm{~m}$.

\section{Dolichoiulus kraepelinorum (Latzel, 1895)}

Julus Kraepelinorum Latzel, 1895.

Pachyiulus kraepelinorum auct.

Trichopachyiulus kraepelinorum auct.

Nesopachyiulus kraepelinorum auct. 


\section{Distribution}

ES-CNY (Tenerife).

\section{Habitat}

Found in many different habitats from sea level to about $2200 \mathrm{~m}$. Abundant in Pinus canariensis forest where it is found in the litter, under stones and in the topsoil, sometimes in close association with the root mycorrhiza of the pines. It occurs above the forest in the sparse mountain vegetation of the Teide National Park, associated with Spartocytisus nubigenus and Pterocephalus. Below the forests it occurs in bushy areas, the extensive Euphorbia zone, in dry fields, coastal sites and a barranco with Artemisia, under stones.

\section{Remarks}

Widespread and common on Tenerife but apparently replaced by $D$. insularis on the south coast of the Anaga Peninsula and by $D$. axeli in the west.

\section{Dolichoiulus labradae Enghoff, 1992}

Dolichoiulus tiendarius - Izquierdo et al. 1986.

\section{Distribution}

ES-CNY (NE Tenerife).

\section{Habitat}

Cavernicolous.

231. Dolichoiulus lasiurus Enghoff, 1992

\section{Distribution}

ES-CNY (Tenerife).

\section{Habitat}

Laurisilva of the eastern part of the Anaga Mountains and from degraded laurisilva (fayal) above Güimar on the eastern slope of the Teide massif. Under stones, in the litter and in the soil, rarely in logs, 600 $900 \mathrm{~m}$

\section{Dolichoiulus longunguis Enghoff, 2012}

\section{Distribution}

ES-CNY (Gran Canaria).

\section{Habitat}

Found in an artificial gallery.

233. Dolichoiulus madeiranus (Mauriès, 1970)

Nesopachyiulus madeiranus Mauriès, 1970.

\section{Distribution}

PT-MDR (Porto Santo). 


\section{Habitat}

Sparsely vegetated habitat types on dry stony slopes, from sea level to about $200 \mathrm{~m}$. Cushion plants, grass, lichens, herbs, thistles, Euphorbia, scattered Tamarix.

\section{Dolichoiulus martini Enghoff, 1992}

\section{Distribution}

ES-CNY (Roque Bentayga near Artenara, Gran Canaria).

\section{Habitat}

Sparse soil and litter on small ledges of rocks with bushes, $1125 \mathrm{~m}$.

235. Dolichoiulus mystax (Brölemann, 1901)

Pachyiulus mystax Brölemann, 1901.

Geopachyiulus mystax auct.

Nesopachyiulus mystax auct.

\section{Distribution}

ES-CNY (Anaga Mts, NE Tenerife).

\section{Habitat}

Laurisilva, records being above $600 \mathrm{~m}$ and most about 800-900 m. Typically in Laurus, Erica arborea and Erica scoparia forest with mosses and ferns, often in ravines. Under stones, in the soil and under or in litter, moss and decaying logs.

\section{Dolichoiulus nemasoma Enghoff, 1992}

\section{Distribution}

ES-CNY (Tenerife).

\section{Habitat}

Under stones in very dry lava-fields and open types of vegetation (Launaea, Plocama and frequently Euphorbia) including abandoned fields. A coastal species from sea level up to only $100 \mathrm{~m}$ for all sites where the altitude is known.

\section{Dolichoiulus oromii Enghoff, 2012}

\section{Distribution}

ES-CNY (Gran Canaria)

\section{Habitat}

The mesovoid shallow stratum (MSS, "milieu souterrain superficiel"), a system of narrow crevices in the ground.

\section{Distribution}

ES-CNY (Gran Canaria). 


\section{Habitat}

Open vegetation often dominated by species of Euphorbia, with Kleinia, Aeonium, Opuntia, and Plocama cited. On barranco slopes, terraces, cultivated fields. Found under stones from 50 to $900 \mathrm{~m}$.

\section{Dolichoiulus parcestriatus (Brölemann, 1901)}

Pachyiulus parcestriatus Brölemann, 1901.

Geopachyiulus parcestriatus auct.

Nesopachyiulus parcestriatus auct.

\section{Distribution}

ES-CNY (N Gran Canaria).

\section{Habitat}

Open vegetation dominated by a few different species of Euphorbia, under the litter and under stones, $150-375 \mathrm{~m}$.

\section{Dolichoiulus praesenilis Enghoff, 1992}

\section{Distribution}

ES-CNY (Parque Nacional de Garajonay, La Gomera).

\section{Habitat}

Laurisilva/fayal-brezal or plantations of Pinus canariensis with indigenous undergrowth (Erica and Adenocarpus). Under stones and in logs, $1150-1400 \mathrm{~m}$, the summit region.

\section{Dolichoiulus quasimystax Enghoff, 1992}

\section{Distribution}

ES-CNY (Anaga Mountains, Tenerife).

\section{Habitat}

Litter in laurisilva.

\section{Remark}

The only specimen known was found in a deep ravine with a brook, together with D. mystax.

\section{Dolichoiulus rectangulus Enghoff, 1992}

\section{Distribution}

ES-CNY (La Gomera).

\section{Habitat}

Laurisilva/fayal-brezal. Under and in logs and in litter. 1150-1200 m.

\section{Remarks}

Records confined to the southwestern edge of the laurisilva zone, apparently vicariant with D. gara. 
Julus salvagicus Latzel, 1895.

Pachyiulus salvagicus auct.

Geopachyiulus salvagicus auct.

Nesopachyiulus salvagicus auct.

\section{Distribution}

PT-SEL (Selvagem Grande and Grand Piton Island).

\section{Habitat}

Once collected under a succulent cushion plant.

244. Dolichoiulus sansebastianus (Attems, 1911)

Pachyiulus sansebastianus Attems, 1911.

Nesopachyiulus sansebastianus auct.

\section{Distribution}

ES-CNY (La Gomera).

\section{Habitat}

Unforested parts of La Gomera, especially in the drier southern part of the island. In xerophilous vegetation, lower to upper Euphorbia zone, associated also with Cistus, Aeonium, Sonchus, Carlina, Plocama and Argyranthemum, and littoral communities with Salsola longifolia. Under stones, in litter and the soil, 20-1200 m.

\section{Dolichoiulus senilis (Attems, 1911)}

Pachyiulus senilis Attems, 1911.

Nesopachyiulus senilis auct.

\section{Distribution}

ES-CNY (La Gomera).

\section{Habitat}

Laurisilva, found in logs and under their bark or under bark flakes or moss pads on living trees. May be several metres above the ground but sometimes in leaf litter and found at altitudes of 950-1200 m.

246. Dolichoiulus silvahierro Enghoff, 1992

\section{Distribution}

ES-CNY (El Hierro).

\section{Habitat}

Laurisilva, under bark, $1010-1030 \mathrm{~m}$.

247. Dolichoiulus silvapalma Enghoff, 1992

\section{Distribution}

ES-CNY (La Palma). 


\section{Habitat}

Laurisilva and brezal. Found in logs and under bark; under stones on the ground, 590-750 m.

\section{Dolichoiulus tiendarius (Attems, 1911)}

Pachyiulus tiendarius Attems, 1911.

Nesopachyiulus tiendarius auct.

\section{Distribution}

ES-CNY (La Gomera).

\section{Habitat}

Unforested parts of La Gomera. Open vegetation types in grassy zones, abandoned fields and barrancos, associated with Euphorbia, Launaea, Plocama, Argyranthemum, Rumex, Schizogyne, Adenocarpus. Found under stones, in plant litter and in dead Euphorbia stems, 10-1200 m. One record from Pinus forest at $1200 \mathrm{~m}$.

\section{Dolichoiulus tongiorgii (Strasser, 1973)}

Amblyiulus tongiorgii Strasser, 1973.

\section{Distribution}

FR-FRA (Alpes-Maritimes and Gard departments), IT-ITA (San Rossore near Pisa, Porto Caleri S of Chioggia).

\section{Habitat}

Sandy beaches of the Mediterranean. Found with halophile isopods and amphipods. Also collected under the bark of a tree stump (Mauriès 1982).

\section{Dolichoiulus troglohierro Enghoff, 1992}

\section{Distribution}

ES-CNY (El Hierro, Cuaclo las Moleras cave).

\section{Habitat}

Cavernicolous.

251. Dolichoiulus typhlocanaria Enghoff, 2012

\section{Distribution}

ES-CNY (Gran Canaria).

\section{Habitat}

The mesovoid shallow stratum (MSS, "milieu souterrain superficiel"), a system of narrow crevices in the ground.

\section{Dolichoiulus typhlops Ceuca, 1973}

\section{Distribution}

ES-CNY (E1 Hierro, La Palma), ES-SPA (Cadiz, Málaga, Sevilla). 


\section{Habitat}

In litter, soil and caves.

\section{Remarks}

Regarded as introduced on the Canary Islands (Enghoff 2002).

253. Dolichoiulus ultimus Enghoff, 1992

\section{Distribution \\ ES-CNY (Gran Canaria).}

\section{Habitat}

Stony field with xerophytic bushes (Euphorbia, Kleinia, Launaea), $475 \mathrm{~m}$.

\section{Dolichoiulus variabilis Enghoff, 1992}

\section{Distribution}

ES-CNY (La Gomera, Tenerife).

\section{Habitat}

Found under stones and litter in open vegetation near the coast, associated with Euphorbia, Plocama, launaea and grass on La Gomera at La Crucita, $250 \mathrm{~m}$. On Tenerife it is associated with Solanum vespertilio and Aeonium lindleyi litter at Punta del Hidalgo, $350 \mathrm{~m}$.

\section{Remarks}

This is the only endemic Canarian Dolichoiulus species occurring on more than one island. There is but one record from each of the two islands.

\section{Dolichoiulus vosseleri (Verhoeff, 1900)}

Pachyiulus vosseleri Verhoeff, 1900.

Trichopachyiulus vosseleri auct.

Nesopachyiulus vosseleri auct.

\section{Distribution}

ES-CNY (Tenerife).

\section{Habitat}

Occurs in the more humid parts of Tenerife; from the relatively open areas near sea level the species occurs up into the frequently cloudy Pinus canariensis forests at $850 \mathrm{~m}$. In the lower zones it may be found in association with stands of Euphorbia canariensis, Euphorbia regis-jubae, Opuntia, Agave, Solanum vespertilio - zones known locally as Tabaibes and Cardones. Found on sea slopes. Often under stones, sometimes in dead succulent plants.

\section{Dolichoiulus wunderlichi Enghoff, 1992}

\section{Distribution}

ES-CNY (Lanzarote). 


\section{Habitat}

Xerophilous vegetation. Litter under Sideritis on rocks; under Euphorbia, grass, etc. Lower dry zone, $350 \mathrm{~m}$.

\section{Dolichoiulus xerohierro Enghoff, 1992}

\section{Distribution}

ES-CNY (El Hierro).

\section{Habitat}

Open coastal habitats from sea level to about $400 \mathrm{~m}$. In dry, sandy, stony and beach fields, under stones and in rotten roots. Associated with Schizogyne, Lotus, Plantago, Kleinia, Rumex.

258. Dolichoiulus xeropalma Enghoff, 1992

\section{Distribution}

ES-CNY (La Palma).

\section{Habitat}

Fairly lush open vegetation, under rotten bark of Echium and in plant litter, 410-740 m.

259. Dolichoiulus xylomystax Enghoff, 1992

\section{Distribution}

ES-CNY (Tenerife).

\section{Habitat}

Laurisilva in the Anaga Mountains in north-eastern Tenerife. Mostly in logs.

260. Dolichoiulus ypsilon Enghoff, 1992

\section{Distribution}

ES-CNY (Tenerife).

\section{Habitat}

Cavernicolous, among plant roots on mud.

\section{Dolichoiulus zygodon Enghoff, 1992}

\section{Distribution}

ES-CNY (near Cuevas de Corcho, N Gran Canaria).

\section{Habitat}

Small moss pads in wet rock crevices on west-facing rockface outside the forest, $1300 \mathrm{~m}$. 
262. Elbaiulus carpinorum Verhoeff, 1930

\section{Distribution}

IT-ITA (Elba Island).

\section{Habitat}

Dense woodland with Castanea, Carpinus, Quercus laurifolia, Rubus, Clematis mixed with maquis bushes, under a deeply embedded stone.

\section{Elbaiulus chrysopygus (Berlese, 1888)}

Iulus chrysopygus Berlese, 1888.

Mesoiulus scossirolli Manfredi, 1948.

\section{Distribution}

IT-ITA (Tuscany).

\section{Habitat}

Cavernicolous.

Genus Enantiulus Attems, 1894

Leptophyllum Verhoeff, 1895.

Metaleptophyllum Schubart, 1957.

\section{Enantiulus armatus (Ribaut, 1909)}

Leptophyllum armatum Ribaut, 1909.

\section{Distribution}

FR-FRA, GB-GRB. Atlantic.

\section{Habitat}

Forest and woodland - Fagus, Fraxinus, Quercus, Carpinus, Tilia, Acer, Populus, Castanea, Corylus. Under bark, in logs and in leaf litter. On several types of soil from clayey inundation forest to rendzinas on limestone, sandy areas and brown earths on metamorphic rocks. Mainly at low altitude but on high limestone plateaus ("causses") and in volcanic areas up to at least $900 \mathrm{~m}$ in the Massif Central of France. In England found in mainly coastal and synanthropic sites including a golf course.

\section{Remarks}

As things stand at present, all the records of Enantiulus armatus from France are from a zone south and west of the River Loire. All the British records are from Devon and Cornwall in SW England. Unless it has been introduced into England it ought to be found in NW France. In so far as it is eurytopic it resembles its congener to the east, Enantiulus nanus (Latzel, 1884) (see below).

\section{Enantiulus austriacus (Verhoeff, 1896)}

Leptophyllum austriacum Verhoeff, 1896. 


\section{Distribution}

IT-ITA. Cisalpine.

\section{Habitat}

Between litter and stones in a shadowy place.

\section{Remarks}

Pedroli-Christen (1993) referred the records of E. austriacus given by Attems (1949) to E. dentigerus, but it is not clear that she regarded the two species as synonymous. For the time being, we regard both as valid.

\section{Enantiulus dentigerus (Verhoeff, 1900)}

Leptophyllum dentigerum Verhoeff, 1900.

\section{Distribution}

CH, IT-ITA. Cisalpine.

\section{Habitat}

Deciduous forests from 285 to $1000 \mathrm{~m}$ in Switzerland (Pedroli-Christen 1993). In Italy from 270 to 1100 $\mathrm{m}$ in litter and under stones in mainly Castanea, Quercus and Robinia woodland and bushy thickets, often on steep slopes (Reip, pers. comm.).

267. Enantiulus karawankianus (Verhoeff, 1908)

Leptophyllum karawankianum Verhoeff, 1908.

\section{Distribution}

AT, IT-ITA, SI.

\section{Habitat}

On calcareous ground under Corylus litter and in humus; under Salix litter.

268. Enantiulus nanus (Latzel, 1884)

Iulus nanus Latzel, 1884.

Leptophyllum nanum auct.

\section{Distribution}

AT, BA, BE, BG, CH, CZ, DE, DK-DEN, FR-FRA, HR, HU, IT-ITA, LT, LU, MK, MN, NL, PL, RO, SB, SE, SI, SK, UA. Central European.

\section{Habitat}

Eurytopic to a large degree though showing a preference for relatively warm and especially damp forests, including inundation forests with Alnus and/or Populus, marshes and bogs. Yet it occurs in Fagus forests on limestone and in deciduous, mixed or coniferous forests on many other types of rock, e.g., basalt, granite, gneiss and sandstone. It also occurs in bushy areas, heaths, pastures, moorland and even dry calcareous grassland over a large altitudinal range. In Switzerland, for instance, it has been found from $270 \mathrm{~m}$ to $2060 \mathrm{~m}$ (Pedroli-Christen 1993) and in Bulgaria up to $2400 \mathrm{~m}$ (Vagalinski \& Stoev 
2007). There are records from caves. It shuns urban sites and cultivated land and is most abundant in montane forests.

\section{Remarks}

Population densities of E. nanus are very high in many localities. It has been the subject of some detailed studies, e.g., Voigtländer (1987) and Kofler \& Meyer (1992).

269. Enantiulus simplex (Verhoeff, 1926)

Leptophyllum simplex Verhoeff, 1926.

\section{Distribution}

AT.

\section{Habitat}

Under Fagus litter.

270. Enantiulus tatranus (Verhoeff, 1907)

Leptophyllum tatranum Verhoeff, 1907.

\section{Distribution}

HU, PL, SK.

\section{Habitat}

Cave entrance.

271. Enantiulus transsilvanicus (Verhoeff, 1899)

Leptophyllum transsilvanicum Verhoeff, 1899.

\section{Distribution}

AT, PL, RO, SI, UA.

\section{Habitat}

Found in pine-beech forest in Maramures (Romania) (Korsós \& Lazányi 2008). Attems (1951) described ssp. verrucosus from a cave.

Genus Enghophyllum Lazányi \& Vagalinski, 2013

272. Enghophyllum naxium (Verhoeff, 1901)

Brachyiulus naxius Verhoeff, 1901.

Chromatoiulus naxius auct.

Megaphyllum naxium auct.

\section{Distribution}

GR-CYC (Naxos, Antiparos), GR-DOD (Mavri Islet).

\section{Habitat}

Litter. 
273. Enghophyllum sifnium Lazányi \& Vagalinski, 2013

\section{Distribution}

GR-CYC (Sifnos).

Genus Geopachyiulus Verhoeff, 1899

274. Geopachyiulus negreai Tabacaru, 1978

\section{Distribution}

RO (Caras-Severin Province, River Caras valley).

\section{Habitat}

Leaf litter of deciduous forests.

275. Geopachyiulus nematodes (Latzel, 1884)

Iulus nematodes Latzel, 1884.

\section{Distribution}

RO (Braşov, Timiş, Hunedoara and Salaj Provinces).

\section{Habitat}

Humus-rich earth in woodland and gardens, several centimetres below the surface.

Genus Haplophyllum Verhoeff, 1897

276. Haplophyllum mehelyi (Verhoeff, 1897)

Micropodoiulus mehelyi Verhoeff, 1897.

\section{Distribution}

RO, UA (East Carpathian).

\section{Habitat}

Mountains up to alpine levels.

Genus Haplopodoiulus Verhoeff, 1898

277. Haplopodoiulus spathifer (Brölemann, 1897)

Micropodoiulus spathifer Brölemann, 1897.

\section{Distribution}

ES-SPA, FR-FRA, GB-GRB. Western half of the Pyrenees and at least the eastern half of the Northern Spanish Cordillera, extending north into the Landes in France. Probably introduced into Britain.

\section{Habitat}

Deciduous, mixed and coniferous woods: common in forests of Fagus and Quercus (mainly deciduous but some evergreen) and sometimes found with Acer, Alnus, Pinus, Platanus, Robinia and Salix. Associated shrubs or small trees are Buxus, Ilex, Corylus, Ligustrum, Crataegus, Juniperus, Sambucus, Viburnum, Genista, Ruscus, Cornus and Daphne. Lonicera, Clematis and Rubus are frequently present 
in the woods. It has occasionally been collected in stony pastures but usually in the presence of some thorny bushes, e.g., Prunus and/or a few trees. Most of the reported sites were on limestone, up to $1400 \mathrm{~m}$ in the mountains. It shows a preference for deep deciduous leaf litter which retains moisture (Corbet \& Jones 1996).

\section{Remarks}

In all probability introduced into the south of England because all four known sites are connected with botanical gardens in which it survives.

Haplopodoiulus spathifer may largely dominate the diplopod population in suitable sites, occurring in very large numbers. The eastern limit of this species in the Pyrenees is fairly clear but the other limits of its distributional range are not yet known. It may well be confined to the Atlantic biogeographic zone.

Genus Heteroiulus Verhoeff, 1897

Heteroporoiulus Silvestri, 1897.

278. Heteroiulus intermedius (Brölemann, 1892)

Julus intermedius Brölemann, 1892.

Allajulus salvadorii Silvestri, 1896.

\section{Distribution}

IT-ITA (Piedmont, Liguria, Lombardy, Venetia).

\section{Habitat}

Castanea, Carpinus, Quercus woodland, in deep litter layers, especially in the lower, more decomposed part.

Genus Hylopachyiulus Attems, 1904

279. Hylopachyiulus pygmaeus (Attems, 1904)

Pachyiulus pygmaeus Attems, 1904.

Micropachyiulus corylorum Verhoeff, 1908.

Hylopachyiulus likanus Attems, 1927.

\section{Distribution}

AT, BA, HR, IT-ITA, SI.

\section{Habitat}

Under deeply embedded stones in Fagus woodland, 1100 m (Strasser 1966). Under Corylus (Verhoeff 1908). One record from a cave.

Genus Hypsoiulus Verhoeff, 1913

280. Hypsoiulus alpivagus (Verhoeff, 1897)

Iulus (Leptoiulus) alpivagus Verhoeff, 1897.

\section{Distribution}

AT, CH, DE, FR-FRA, IT-ITA. Alpine. 


\section{Habitat}

Mainly alpine; when lower down it is generally in deep, cool gorges or in caves. Petrophile on sedimentary rocks - rocky outcrops, screes, bases of cliffs, old river beds, limestone pavements and alpine meadows in mosaics with stony and rocky places. Found between $600 \mathrm{~m}$ and $2800 \mathrm{~m}$ in Switzerland (PedroliChristen 1993), as low as $500 \mathrm{~m}$ in Vorarlberg, Austria (Mathis 1951).

\section{Remarks}

Two varieties have been described, the small typical form and the taxon alpivagus suevicus Verhoeff, 1908 , the latter being larger and rare, confined to a few sites in Germany and Switzerland.

Genus Interleptoiulus Mršić, 1988

281. Interleptoiulus cernagoranus Mršić, 1988

\section{Distribution}

MN.

\section{Habitat}

The only information is "near the source of the Ribnica, in the vicinity of Titograd [= Podgorica]".

Genus Julus Linnaeus, 1758

Iulus auct.

Micropodoiulus Verhoeff, 1893.

The type genus of the family Julidae, consisting of four species in Europe. The vast majority of the numerous European species originally described in Julus/Iulus have been transferred to other genera.

282. Julus curvicornis Verhoeff, 1899

\section{Distribution}

SK.

\section{Habitat}

Principally Quercus-Carpinus and Fagus forests in central and western parts of Slovakia. According to Stašiov $(2002,2005)$, suitable sites were Quercus-Carpinus forest litter with low humus and carbon content, high nitrogen content and maximum degree of saturation capacity of the soil and litter layers; some of the forests were relatively young, with smaller trees (40-60 yrs), but at least one well-populated stand was 80-100 years old. In Fagus stands there was more activity in litter of relatively low $\mathrm{pH}$. Trees listed from the sampling sites were Quercus petraea, $Q$. cerris, $Q$. dalechampii, $Q$. virgiliana, Carpinus betulus, Fagus sylvatica, Fraxinus excelsior, Tilia cordata, Acer campestre, Picea abies, Abies sp. Site records indicate a vertical distribution between 200 and $930 \mathrm{~m}$ in the area studied, with Quercus forest lower down, increasingly mixed with Fagus going higher up and then replaced by mainly montane Fagus forests, some (Fagetum dealpinum) on dry, steep calcareous slopes. True Central European xerothermic mixed Quercus woodland on sunny, base-rich soils too dry for Fagus includes LithospermoQuercetum, another quoted habitat. Julus curvicornis was also recorded from mixed Fagus, Abies and Picea (Fagetum Abietino-piceosum) which is situated above $850 \mathrm{~m}$.

\section{Remarks}

A record from Déj, NW Romania (Verhoeff 1899) is based on a female and is not shown on the map. 
Iulus scandinavius Latzel, 1884.

Iulus ligulifer Latzel \& Verhoeff, 1892.

Micropodoiulus ligulifer auct.

Iulus terrestris auct.

\section{Distribution}

AT, BE, CH, CZ, DE, DK-DEN, FR-FRA, GB-GRB, GB-NI, HU, IE, LU, NL, NO-NOR, PL, SE, SK. Central European, extending north to Britain, Ireland and S Scandinavia. - Also introduced into the Nearctic Region.

\section{Habitat}

A very common animal, eurytopic to some degree, it is chiefly a species of woodland, although it occurs frequently on heaths, wetlands, humid open grassland and sand dunes. While it has been found in moderately dry calcareous grassland it appears to be generally absent from forests on limestone. It prefers woods characteristic of lighter acidic soils on a sandy or loamy substrate, for instance on the Lüneburger Heide in Germany where it is found in Pinus/Betula with Calluna, Molinia and ferns and in Alnus and Populus stands in wetter areas (Lindner et al. 2010). Similarly, in Belgium it is strongly associated with Erica/Calluna heaths, ranging into Pinus/Betula/Quercus woodland and Alnus by streams. Another strongpoint is the coastal dune area. Higher up in the Ardennes it is abundant in Fagus and coniferous forest. Many authors associate it with a thick litter/humus layer; Barlow (1957) related this to its preference for high humidity and its avoidance of extreme conditions. Kime \& Wauthy (1984) listed it as intermediate in specialisation on habitat, neither a generalist nor a specialist. According to Lee (2006) it shows a strong negative association with cultivated land and waste ground.

Common microsites are below stones or rock, in leaf litter and in grass tussocks.

\section{Remarks}

One of the most frequently recorded European species within its quite large range. The map therefore gives a good indication of the recording effort across Central Europe. Rather isolated to the east are the records of Ložek \& Gulička (1962) who give Humenné and Michalovce in E Slovakia.

Golovatch (pers. comm.) states that the published records by Lang (1954) from the Carpathian area in the Ukraine (and East Slovakia?) are erroneous and we have omitted them. Ložek \& Gulička (1962) give Humenné and Michalovce in E Slovakia which we include.

Haacker (1969) described the mating behaviour of J. scandinavius.

284. Julus scanicus Lohmander, 1925

Julus terrestris scanicus Lohmander, 1925.

\section{Distribution}

AT, CZ, DE, DK-DEN, HU, LV, SE, SK. Discontinuous in Central Europe.

\section{Habitat}

Deciduous woodland, mostly damp, even very damp biotopes like Alnus swamps, also (wet?) heathland. Regarded as a eurytopic hygrobiont woodland species with preference for floodplains and swamp forests in Saxony-Anhalt, Germany (Voigtländer 2011). 


\section{Remarks}

The known distribution is very patchy. There is a group of populations in the Danube basin in Austria, Hungary, SW Slovakia and SE Czech Republic, another in E Germany (Brandenburg), a patch near Oldesloe in Schleswig-Holstein, more on the Danish islands of Sjaelland and Bornholm, in SW Sweden, and finally an isolated record from Skangalia in Latvia.

\section{Julus terrestris Linnaeus, 1758}

Micropodoiulus terrestris auct.

Julus rugifrons Meinert, 1868.

\section{Distribution}

BY, CZ, DE, DK-DEN, EE, FI, HR, HU, LT, LV, PL, RO, RU-KGD, SB, SE, SK, UA.

\section{Habitat}

Forests, Fagus woodland, mixed forest, bushes, "Erlenbruch" (Erle = Alnus), humid Alnus swamps, wet heaths with Myrica gale, sandbanks with Hippophaë, lowland meadows with or without shrubs, grass tussocks.

\section{Remarks}

Tajovský (2001) stated that there are no recent records from the Czech Republic and that the validity of historical data is questionable. In view of this we omit Czech records from our map.

Genus Kryphioiulus Read, 1990

286. Kryphioiulus occultus (C.L. Koch, 1847)

Allajulus occultus C.L. Koch, 1847.

Cylindroiulus occultus auct.

Ypsiloniulus occultus auct.

\section{Distribution}

AT, CZ, DE, HU, LT, NO-NOR, PL, RO, RU-KGD, RU-RUC, SE, SK, UA. East Central European.

\section{Habitat}

In SE Germany it is common in damp deciduous woodland on basic rocks and in former vineyards. Spelda (1999) quoted the edge of a wood on Muschelkalk in Baden-Württemberg at the western limit of its range. Numerous recorders have cited woodland including Quercus, Fagus and Pinus, as well as Alnus swamps. Under stones and bark.

In an important paper involving this species Voigtländer (1987) stated that it is hygrophilic and prefers warm calcareous sites, becoming increasingly synanthropic towards the northern part of its range, where it may occur on other soils and is found in gardens, parks, cemeteries, greenhouses and town ramparts. This applies to other peripheral records. Regarded as an stenotopic xerobiont woodland species with preference for xeric/mesoxeric meadows, fields and fallows in Saxony-Anhalt, Germany (Voigtländer 2011). 
KIME R.D. \& ENGHOFF H., Atlas of European millipedes 2: Order Julida

Genus Lamellotyphlus Tabacaru, 1976

287. Lamellotyphlus belevodae Makarov, 2008

\section{Distribution}

SB (Bele Vode Cave, Mt Miroč in eastern Serbia).

\section{Habitat}

Cavernicolous.

288. Lamellotyphlus mehedintzensis (Tabacaru, 1976)

Typhloiulus mehedintzensis Tabacaru, 1976.

\section{Distribution}

RO (several caves at the western end of the southern Carpathians).

\section{Habitat}

Cavernicolous.

289. Lamellotyphlus sotirovi Makarov, Mitić \& Ćurčić 2002

\section{Distribution}

SB (Buronov Ponor Cave, Mt Miroč in eastern Serbia).

\section{Habitat}

Cavernicolous.

Genus Leptoiulus Verhoeff, 1894

A large genus of over seventy described species which is almost exclusively European. Several subgenera have been denoted, and very many subspecific and infrasubspecific names have been suggested which are not listed here. Our interpretation of the species and names should, despite the valuable help of J.-P. Mauriès, be regarded as a preliminary one, to be tested by future revisionary work.

\section{Leptoiulus abietum Verhoeff, 1914}

\section{Distribution}

AT (Northeast Alps).

\section{Habitat}

Coniferous and mixed woodland, 600-1400 m (Schubart 1934).

\section{Leptoiulus alemannicus (Verhoeff, 1894)}

Iulus allemannicus Verhoeff, 1894.

\section{Distribution}

AT, CH, CZ, DE, HR, IT-ITA, SI. Subalpine-Alpine. 


\section{Habitat}

Occurs from about $800 \mathrm{~m}$ up to $2800 \mathrm{~m}$ without any very evident habitat preference between river banks, screes, rocky areas, moraines, subalpine meadows (1960-1980 m) and alpine meadows including Rhododendro-vaccinietum-cembretosum (2070 m); Rhododendro-Vaccinion (2100-2190 m); communities of Empetro-Vaccienetum uliginosi with extended lichen-heaths (2250-2340 m); a stony Loiseleurieto-Cetrarietum (2500-2550); Hygrocurvuletum (2650 m) (Meyer 1985; Pedroli-Christen 1993;). It also occurs in some forests, especlally shady slopes with Alnus viridis, Fagus (Schubart 1934; Strasser,1940) and conifers (Verhoeff 1913). Microsites under decaying wood, heaps of rubble and stones. Active from June to November, with a pronounced peak in July (Pedroli-Christen 1993).

\section{Remarks}

Records from the Czech Republic are discounted, following Tajovský (2001). Verhoeff created a few subspecies of L. alemannicus. The most southerly records which are from a relatively low altitude on the Island of Cres and the South of Slovenia belong to the subspecies L. alemannicus austriacus Verhoeff, 1910 (Mršić 1994).

\section{Leptoiulus arelatus Bigler, 1919}

\section{Distribution}

FR-FRA, IT-ITA. Piedmontese Alps.

\section{Habitat}

Alpine. Up to over $2600 \mathrm{~m}$.

\section{Remarks}

Apparently more or less restricted to NW Piedmont. In France it has been found only close to the frontier.

293. Leptoiulus atticus Strasser, 1970

\section{Distribution}

GR-GRC.

294. Leptoiulus baconyensis (Verhoeff, 1899)

Julus alemannicus baconyensis Verhoeff, 1899.

Leptoiulus bakonyensis auct.

Leptoiulus alemannicus auct.

Leptoiulus vagabundus auct.

Leptoiulus vagabundus baconyensis auct.

\section{Distribution}

HR, HU, PL, RO, SI, SK, UA.

\section{Habitat}

Forest. By stream in Fagus forest (Korsós \& Lazányi 2008). Fagus-Acer forest with Alnus (Jawłowski 1931).

Iulus belgicus Latzel, 1884. 
Julus gracilis Rothenbühler, 1899.

Leptoiulus albolineatus auct.

\section{Distribution}

AT, BE, CH, DE, ES-SPA, FR-FRA, GB-CI, GB-GRB, GB-NI, IE, IT-ITA, LU, NL. Extended Atlantic from northern Spain to Germany.

\section{Habitat}

Eurytopic but showing a tendency to occur along river courses and in coastal areas, whether in forests, bushy areas, hedges, grasslands, or on sandbanks and dunes. Found in large numbers under stones in the intertidal zone on a sandy beach on the south coast of Wales (Kime 2004). It climbs readily, occurring in vegetation and moss on old roofs in Southwest France. Apparently thermophile, while it shows no clear preference for one type of soil, it favours warm sites in well-drained positions on limestone, light loams or sand. It was found in xeric scrub societies in Saxony-Anhalt, Germany (Voigtländer 2011), and has been regarded as a eurytopic xerobiont woodland species with preference for thermophilous oak woods. Known, too, from a well-drained Fagus silvatica forest with Pinus and Cytisus at an altitude of just below $1000 \mathrm{~m}$ in the Haute Loire Department of France, it has been recorded at $1100 \mathrm{~m}$ in Spain (Kime 1990) and $1800 \mathrm{~m}$ on a south-facing slope in Switzerland (Pedroli-Christen 1993). Sometimes on spoil heaps of old coal mines. L. belgicus is most active in late summer and autumn (Morgan 1989; Pedroli-Christen 1993; Kime 1997).

\section{Remarks}

According to the literature it has a highly patchy distribution, more than might be deduced from its supposed preferences. Of the many regions investigated, some have yielded many records and others scarcely any. In Italy, reported only near Aosta (Manfredi 1937) and doubted by Strasser (1978a). It is found nearby in the Upper Rhône Basin.

The white dorsal stripe mentioned in its description is not always present; moreover, marbled specimens possessing absolutely typical gonopods have been found in France. Its regional variability and abundance not only, but particularly in SW France, Benelux and SW England, together with S Wales, suggest that it is a relict species indicative of survival during glacial times.

\section{Leptoiulus bertkaui (Verhoeff, 1896)}

Iulus bertkaui Verhoeff, 1896.

\section{Distribution}

CH, DE, FR-FRA, LU. Meuse, Rhine and Weser river basins.

\section{Habitat}

Humid areas, usually in close proximity to rivers; these may be open (meadows and marshes) or more frequently closed (wooded river margins, inundation forest). It prefers natural or semi-natural biotopes. In the Meuse Basin associated with woodland (Salix, Alnus, Betula, Quercus, Fagus) on greensand or in valleys in Jurassic limestone. Most active in springtime. Found as high as $1000 \mathrm{~m}$ above sea level in the south of its range.

\section{Remarks}

For almost a century it was known only from the Rhine Basin. Then it was reported from the Rhône Basin, but only near Geneva in Switzerland, not very far from the headwaters of the Rhine (Pedroli- 
Christen 1993). More recent finds in Alnus and Quercus woods in the Meuse Basin in France and the upper Weser Basin near Kassel in Germany (Voigtländer \& Hauser 1998) add extensively to its range.

\section{Leptoiulus borisi Verhoeff, 1926}

Leptoiulus rylaicus Verhoeff, 1928.

Leptoiulus macrovelatus Schubart, 1934.

\section{Distribution}

BG.

\section{Habitat}

Mainly montane and alpine, on both limestone and granite, and as high as $2750 \mathrm{~m}$ in the Pirin Mountains (Beron 2008). Lower down it occurs in Quercus petraea, Fagus sylvatica and coniferous forests (Vagalinski \& Stoev 2007).

\section{Remarks}

While this species occurs mainly in the mountains of SW Bulgaria, there are isolated records from the centre and the Black Sea coast.

298. Leptoiulus brentanus Verhoeff, 1926

\section{Distribution}

IT-ITA (Southern Alps).

\section{Habitat}

Found in the Brenta Valley and in the Trentino (Monte te Pari, 1600-1800 m).

\section{Leptoiulus brevivelatus Bigler, 1919}

\section{Distribution}

FR-FRA, IT-ITA. Western Alps.

\section{Habitat}

Alpine, on the frontier in Piedmont and Rhône-Alps.

\section{Leptoiulus broelemanni (Verhoeff, 1895)}

Iulus broelemanni Verhoeff, 1895.

\section{Distribution}

AT, CH, IT-ITA. Southern Alpine.

\section{Habitat}

Thermophile and eurytopic; found in warm situations from $193 \mathrm{~m}$ to $1700 \mathrm{~m}$, mostly in the lower part of the range (Pedroli-Christen 1993). Castanea forest. Once in a cave. 
301. Leptoiulus bruyanti Ribaut, 1951

\section{Distribution}

FR-FRA (Morvan, Massif Central).

\section{Habitat}

Apparently montane. Recorded from sites between $500 \mathrm{~m}$ and $900 \mathrm{~m}$ in altitude in the beech forests of the Morvan Massif in Burgundy, in pure Fagus forest with no ground vegetation, or with Pinus, with Ilex or with Quercus, Ilex, Sorbus aucuparia and Rubus. Alternatively high up in mixed Fagus, Abies and Picea forest. In the south of the Massif Central it was found on the open Causse de Sauveterre (a limestone plateau at $900 \mathrm{~m}$ in the Department of Lozère) under a small group of trees. Occurs on sedimentary, metamorphic and volcanic rocks.

\section{Remarks}

All the recorded sites for this endemic French species are cited in Kime \& Iorio (2010).

302. Leptoiulus carpinorum Verhoeff, 1929

\section{Distribution}

HR (North-west).

\section{Habitat}

Under Carpinus, Fagus and Acer litter at Plitvice.

303. Leptoiulus cernagoranus (Attems, 1927)

Microiulus cernagoranus Attems, 1927.

\section{Distribution}

MN.

\section{Remarks}

Described from a single male from an unknown site in the country.

304. Leptoiulus chiesensis Verhoeff, 1934

\section{Distribution}

IT-ITA (Lombardy).

\section{Habitat}

River gorges around the northern end of Lake Garda and in the Giudicarie Valley to the west.

305. Leptoiulus cibdellus (Chamberlin, 1921)

Iulus minutus Porat, 1889, preoccupied.

Iulus cibdellus Chamberlin, 1921.

Leptoiulus minutus auct.

\section{Distribution}

AT, BY, CZ, DE, DK-DEN, EE, FI, HU, LT, PL, RO, RU-KGD, RU-RUW, SE, SK. Central Europe. 


\section{Habitat}

Moist localities with decaying leaves. Wet areas with Alnus and Salix, swampy meadows (Schubart 1934), it has been associated with Iris and puddles of water. Grassy woodland, e.g., Quercus, Fraxinus.

\section{Remarks}

Precise localities for this species are lacking from LV, and largely lacking from BY and LT, where the species is probably more widespread than shown on the map.

306. Leptoiulus czarnohoricus Jawłowski, 1928

\section{Distribution}

UA (East Carpathian).

\section{Habitat}

Forested mountains.

307. Leptoiulus demangei Schubart, 1962

\section{Distribution}

ES-SPA, FR-FRA. Catalan Pyrenees.

\section{Habitat}

Woodland, with mention of Fagus silvatica, Quercus petraea and Castanea sativa. Meadow with trees. In leaf litter. Records from $550 \mathrm{~m}$ to $1150 \mathrm{~m}$. Believed to be hygrophile (Vicente 1985).

\section{Leptoiulus deubeli (Verhoeff, 1897)}

Iulus deubeli Verhoeff, 1897.

\section{Distribution}

RO, UA (East Carpathian).

\section{Habitat}

Alpine. Above forests under stones.

309. Leptoiulus discophorus (Attems, 1927)

Microiulus discophorus Attems, 1927.

\section{Distribution}

AL (northern mountains).

\section{Habitat}

Unknown.

\section{Distribution}

HR, SI. Dinaric Alps. 


\section{Habitat}

Fagus forest, valleys; under boards.

311. Leptoiulus durmitorius (Attems, 1927)

Microiulus durmitoricus Attems, 1927.

\section{Distribution}

MN (Durmitor Mt).

\section{Leptoiulus faesi Bigler, 1919}

\section{Distribution}

$\mathrm{CH}$ (Alps).

\section{Habitat}

Calcicole, collected under stones in alpine meadows, 2170-2500 m.

\section{Remarks}

A doubtful species similar to L. helveticus according to Pedroli-Christen (1993), who found only L. helveticus at one of Bigler's sites that she reinvestigated.

\section{Leptoiulus frigidarius Verhoeff, 1913}

\section{Distribution}

IT-ITA (Alps).

\section{Habitat}

Found at $2500 \mathrm{~m}$ altitude.

\section{Leptoiulus garumnicus (Ribaut, 1904)}

Iulus garumnicus Ribaut, 1904.

\section{Distribution}

FR-FRA (north side of Central Pyrenees: Haute Garonne, Ariège).

\section{Habitat}

Rural sites between $500 \mathrm{~m}$ and $800 \mathrm{~m}$ in altitude are quoted, but the vegetation is generally not specified. In garden refuse and under stones. Known to be active in autumn with L. belgicus.

\section{Leptoiulus gilvicollis Verhoeff, 1932}

\section{Distribution}

FR-FRA, IT-ITA.

\section{Habitat}

Broad-leaved forest. 


\section{Remarks}

There is an unpublished note by Ribaut in his papers located in the Muséum national d'Histoire naturelle (Paris) that this species was found at Fontan in the Alpes Maritimes in France.

\section{Leptoiulus hauseri Strasser, 1976}

\section{Distribution}

GR-GRC (Epirus).

\section{Habitat}

Found in two places, Kato Kalentini at $230 \mathrm{~m}$ and Anemoraki at $410 \mathrm{~m}$.

317. Leptoiulus helveticus (Verhoeff, 1894)

Iulus helveticus Verhoeff, 1894.

Iulus odieri Brölemann, 1896.

Leptoiulus odieri auct.

Leptoiulus vagabundus auct.

\section{Distribution}

AT, CH, IT-ITA. Alps and Jura Mountains.

\section{Habitat}

Predominantly in alpine meadows, rocky outcrops and screes on sedimentary strata. Castanea and coniferous forest. Found at an altitude as low as $500 \mathrm{~m}$ in the Jura but up to $2800 \mathrm{~m}$ in the Alps.

\section{Remarks}

Several subspecies have been described. Pedroli-Christen (1993) suggested that it may be a polytypic species including $L$. faesi and $L$. sarasini.

\section{Leptoiulus hospitelli Brölemann, 1901}

Julus laurorum Verhoeff, 1908.

\section{Distribution}

FR-FRA (Alpes Maritimes), IT-ITA (Piedmont and Liguria), MC.

\section{Habitat}

Under Corylus leaves close to snowfields (in April) near the Tende/Tenda Pass from Italy into the Maritime Alps in France, at an altitude of 1400-1500 m. In a damp meadow, under stones, $200 \mathrm{~m}$. One record from a cave.

\section{Remarks}

Very similar to L. piceus and regarded as a synonym of the latter by Brolemann (1924).

\section{Leptoiulus ivanjicae Ćurčić \& Makarov, 1997}

\section{Distribution}

SB (West). 


\section{Habitat}

Quercus and Fagus litter.

320. Leptoiulus juvenilis (Ribaut, 1908)

Julus juvenilis Ribaut, 1908.

\section{Distribution}

FR-FRA (north side of Central Pyrenees: Haute Garonne, Hautes Pyrénées).

\section{Habitat}

Montane, usually at about $1000 \mathrm{~m}$. Several sites are mentioned without ecological details; some are known to be forests.

321. Leptoiulus kervillei (Brölemann, 1896)

Iulus kervillei Brölemann, 1896.

Leptoiulus vanoyei De Queker, 1957.

\section{Distribution}

BE, DE, FR-FRA, GB-CI, GB-GRB, LU, NL. Mild Atlantic.

\section{Habitat}

Very strictly linked with woodland, almost always deciduous (Fagus, Quercus, Carpinus, Robinia) with rich organic layers on the woodland floor (mull or mull-moder humus) and on loamy soils; scarce on very sandy or heavy clay substrates. There are records from old spoil heaps re-colonized by forest. In Britain, at the northern end of its range, it has a largely coastal distribution with a preference for noncalcareous loams (Lee 2006). Its distribution in the west and north of France, Belgium, Luxemburg, NW Germany, the southern tip of the Netherlands and the south of England and Wales links it with a mild, oceanic climate. It is principally a lowland species, occurring up to about $600 \mathrm{~m}$ in the Massif Central. Adults are mainly found in the spring when they breed.

\section{Remarks}

The apparent preference for non-calcareous soils in Britain may be connected with the scarcity of calcareous soils in the southwest where it is most abundant. It does occur on chalk formations in the southeast as it does in France, especially in Fagus forest. Analyses made in Belgium, where it is closely associated with silty soil ("limon") on which it is very common, suggested that L. kervillei is very specialized with regard to habitat. Climatic requirements aside, soil texture is the predominating factor, more important than $\mathrm{pH}$ (Kime \& Wauthy 1984; Kime et al. 1992).

\section{Leptoiulus korongsius (Attems, 1904)}

Julus korongsius Attems, 1904.

\section{Distribution}

PL, RO, UA. East Carpathians.

\section{Habitat}

Mainly alpine, up to $1700 \mathrm{~m}$ on Mt Howerla, under stones or in grass tussocks, sometimes in high-level conifers. 
323. Leptoiulus krueperi (Verhoeff, 1900)

Julus krüperi Verhoeff, 1900.

\section{Distribution}

GR-GRC (central mountains).

\section{Habitat}

Discovered in the alpine zone of Mt Koras.

324. Leptoiulus laetedorsalis (Verhoeff, 1898)

Iulus laetedorsalis Verhoeff, 1898.

Microiulus laetedorsalis auct.

\section{Distribution}

BA (south), MN.

\section{Habitat}

Forest, e.g., Fagus. Under moss; in a large, rotting log.

\section{Leptoiulus legeri (Brölemann, 1897)}

Julus legeri Brölemann, 1897.

\section{Distribution}

FR-FRA (Mediterranean, extending north and west).

\section{Habitat}

Little information. Under moss and debris.

326. Leptoiulus liptauensis (Verhoeff, 1899)

Julus ciliatus liptauensis Verhoeff, 1899.

\section{Distribution}

PL, SK. Carpathian.

\section{Habitat}

Higher mountain forests: spruce and pine (Oxalido-Picetum, Vaccinio-myrtilli-Pinetum) 1240-1755 m on Nizké Tatry Mts; mainly calcicole and in small numbers in the Zapadné Tatra on subalpine Vaccinium myrtillus heath and alpine grassland (1660-1750 mm) - details in Tajovský (1997). Lower down in eastern Slovakia found in deciduous forests (Alnus, Fagus, Carpinus) at 440-500 m (Mock 1999).

\section{Leptoiulus macedonicus (Attems, 1927)}

Microiulus macedonicus Attems, 1927.

Xestoiulus macedonicus auct.

\section{Distribution}

AL, GR-GRC, MK, SB (Kosovo). 


\section{Habitat}

Upper Fagus forests and alpine; in litter, under stones. Up to $2550 \mathrm{~m}$ on Alpet, Albania (Beron 2008).

328. Leptoiulus magnus Bigler, 1919

\section{Distribution}

IT-ITA (Piedmont).

\section{Habitat}

High alpine, very close to the French frontier. Up to at least $2650 \mathrm{~m}$.

329. Leptoiulus mariae Gulička, 1952

\section{Distribution}

SK (Muranska Plateau).

\section{Habitat}

Trogloxene. Cave entrance.

330. Leptoiulus matulicii (Verhoeff, 1901)

Julus matulicii Verhoeff, 1901.

Microiulus matulicii auct.

\section{Distribution}

BA (far south) MN (near Adriatic).

\section{Habitat}

Fagus forest.

\section{Leptoiulus meridionalis (Brölemann, 1897)}

Iulus meridionalis Brölemann, 1897.

\section{Distribution}

ES-SPA, FR-FRA. Basque Country and Western Pyrenees.

\section{Habitat}

Forest, especially Fagus woods; in litter up to around 1000 m. On one occasion in evergreen Quercus with Rubus and moss. Also in stony meadows, on dry slopes but often near streams, sometimes with Prunus scrub and scattered Fagus trees, recorded on lower slopes from $300 \mathrm{~m}$. In a town park with Platanus and Castanea.

\section{Leptoiulus montivagus (Latzel, 1884)}

Iulus montivagus Latzel, 1884.

Iulus braueri Verhoeff, 1895.

Iulus tosanus Verhoeff, 1916.

Leptoiulus braueri auct.

Leptoiulus weberi Verhoeff, 1927.

Leptoiulus tosanus zurstrasseni Verhoeff, 1929. 
Leptoiulus catascaphicus Verhoeff, 1931.

Leptoiulus triglavensis Strasser, 1940.

\section{Distribution}

AT, CH, CZ, DE, FR-FRA, IT-ITA, SI. Alpine.

\section{Habitat}

Alpine meadows, under stones. In Switzerland it is found in pastures and dry grassland from as low as $280 \mathrm{~m}$ in the north. In the south it occurs from 920 to $2860 \mathrm{~m}$ (Pedroli-Christen 1993). It reaches $2400 \mathrm{~m}$ in Slovenia, where it was found under stones and in cushions of turf (Strasser 1940). In Bavarian woods it may be found under decaying bark and below moss on blocks of granite (Schubart 1934). KobelLamparski (1987) found it to be the most abundant millipede in vineyards in Kaiserstuhl, southern Germany, and gave detailed information on its population structure.

\section{Remarks}

Among all the species of Leptoiulus with complicated taxonomic histories, L. montivagus probably takes the prize. It seems to be a relict species surviving at high altitudes, formerly widespread during the ice age, and since then the now isolated populations on the summits of mountain chains have diversified to some degree. Regarded as highly endangered in Germany (Voigtländer et al. 2011).

\section{Leptoiulus noricus Verhoeff, 1913}

Leptoiulus alemannicus auct.

Leptoiulus simplex auct.

Leptoiulus marcomannius Verhoeff, 1913.

Leptoiulus simplex obenbergeri Gulička, 1965.

\section{Distribution}

AT, CZ, DE, SK. Sudetico-Carpathian.

\section{Habitat}

In forest litter, both deciduous and coniferous, from 500 to $1900 \mathrm{~m}$.

\section{Remarks}

The noricus records are predominantly Austrian and come from a compact area mainly in the Salzburg sector of the Alps (including part of SE Bavaria) while the marcomannius records come from E Bavaria, the Czech Republic and Slovakia. Also dubiously recorded from PL, see under L. simplex.

\section{Leptoiulus oribates (Latzel, 1884)}

Julus oribates Latzel, 1884.

Leptoiulus simplex oribates auct.

\section{Distribution}

AT, IT-ITA. Corinthian and Gailtaler Alps.

\section{Habitat}

High Alpine. Trogkofel, Rosskofel and Gartnerkofel (Strasser 1959). 
Microiulus pentheri Attems, 1927.

\section{Distribution}

MN.

\section{Remarks}

The type and so far only locality, Koštica, is a location on Prokletije Mt, on the border between Montenegro and Albania but in the territory of MN.

336. Leptoiulus piceus (Risso, 1826)

Iulus piceus Risso, 1826.

\section{Distribution}

FR-FRA, IT-ITA, MC, PT-MDR.

\section{Habitat}

Mediterranean coastal vegetation, gardens.

\section{Remarks}

Regarded as introduced on Madeira (Enghoff 2008).

\section{Leptoiulus polonicus Jawłowski, 1930}

Leptoiulus trilobatus polonicus Jawłowski, 1930.

\section{Distribution}

PL, UA. North-east Carpathian (Bieszczady, Pieniny and Gorgany Mountains).

338. Leptoiulus pretneri Strasser, 1940

\section{Distribution}

SI (Sanntal Alps).

339. Leptoiulus proximus (Nĕmec, 1896)

Julus proximus Němec, 1896.

Julus ciliatus bükkensis Verhoeff, 1899.

Leptoiulus trilobatus buekkensis auct.

Leptoiulus vagabundus auct.

Leptoiulus ciliatus auct.

Leptoiulus trilobatus auct.

\section{Distribution}

AT, BY, CZ, DE, DK-DEN, FI, HR, HU, LT, LV, MD, NL, NO-NOR, PL, RO, RU-KGD, RU-RUC, RU-RUE, RU-RUN, RU-RUW, SE, SI, SK, UA. 


\section{Habitat}

Deciduous woodland, Quercus, Carpinus, Alnus, Betula, and also some coniferous woods, e.g., Picea, and especially Pinus; generally shady and humid to wet low-lying woods with thick moder litter; bushy areas by streams, Alnus swamps; cemeteries.

\section{Remarks}

The effects of flooding on a L. proximus population were studied by Tufová (2003).

\section{Leptoiulus remyi Schubart, 1962}

\section{Distribution}

ES-SPA, FR-FRA. Catalan Pyrenees.

\section{Habitat}

Wooded areas, e.g., Pinus halepensis, Quercus suber, Olea groves, maquis with Rosmarinus and Lavandula. In litter and under stones. At low altitude and up to at least $800 \mathrm{~m}$. Xerophile in Mediterranean habitats (Vicente 1985).

\section{Remarks}

All the records were from the Mediterranean end of the Pyrenees until recently, when it was reported from an evergreen oakwood in Navarre (H. Reip in litt.).

\section{Leptoiulus riparius (Verhoeff, 1894)}

Iulus riparius Verhoeff, 1893.

Iulus baldensis Verhoeff, 1896.

Iulus nivicomes Verhoeff, 1901.

Leptoiulus nivicomes auct.

\section{Distribution}

AT, CH, IT-ITA. South Central Alpine.

\section{Habitat}

Mostly stony alpine meadows, $1050-2630 \mathrm{~m}$, in sunny localities but in subalpine and montane zones as well (Pedroli-Christen 1993).

\section{Remarks}

The distribution of L. riparius was discussed in detail by Thaler \& Meyer (1974).

342. Leptoiulus roszkowskii Jawłowski, 1930

\section{Distribution}

RO, UA. NE Carpathian.

\section{Habitat}

Found at $809 \mathrm{~m}$ in Prut valley. 


\section{Remarks}

A possibly rare species of the NE Carpathians described from the Prut valley above Vorokhta in the south of Ivano-Frankovsk Province in the Ukraine and reported by Ceuca (1967) from Durau in Ceahlau National Park in the province of Neamt in NE Romania.

\section{Leptoiulus saltuvagus (Verhoeff, 1898)}

Iulus marmoratus Attems, 1895.

Julus saltuvagus Verhoeff, 1898.

Leptoiulus vagabundus auct.

\section{Distribution}

AT, CH, DE, HR, HU, IT-ITA, SI. Central and Eastern Alps.

\section{Habitat}

Woodland in the montane zone, e.g., Quercus, Carpinus, Tilia, Castanea, Fraxinus, Acer, Fagus, Pinus and occasionally Picea, and with Cornus, Ligustrum and Crataegus in the shrub layer. These habitats range up to about $1500 \mathrm{~m}$. It is also found at some open sites. Higher up it occurs in sub-alpine meadows, the Rhododendron/Vaccinium shrub layer and at Alnus viridis sites at about $2000 \mathrm{~m}$ in Tyrol. It occurs above $2000 \mathrm{~m}$ in Empetrum-Vaccinietum-uliginosi heaths with lichens (Pedroli-Christen 1993, Meyer 1985, Voigtländer et al. 1997). Beron (2008) gives an altitudinal range from $700 \mathrm{~m}$ to $2500 \mathrm{~m}$.

\section{Remarks}

The synonymy saltuvagus = marmoratus follows Attems (1927). Pending revisionary work on this species complex, we use the better known, albeit younger name, saltuvagus. The species seems to be quite tolerant with regard to water loss (Meyer \& Eisenbeis 1985).

\section{Leptoiulus sarajevensis Verhoeff, 1898}

Julus sarajevensis Verhoeff, 1898.

Macedoiulus storkani Verhoeff, 1932.

\section{Distribution}

BA, BG, HR, MK, MN, SB (Serbia, Kosovo).

\section{Habitat}

Mountains.

\section{Remarks}

See under L. storkani Verhoeff, 1932.

345. Leptoiulus sarasini Bigler, 1929

\section{Distribution}

CH (Engadine).

\section{Habitat}

Under blocks of limestone on an alpine meadow (2320-2550 m). 


\section{Remarks}

Bigler (1929) described the species from two males found with L. helveticus in the Swiss National Park. It is very similar to L. helveticus (see Pedroli-Christen 1993) and has not been found again.

\section{Leptoiulus semenkevitshi Lohmander, 1928}

\section{Distribution}

UA.

\section{Habitat}

Forest-steppe endemic.

\section{Remarks}

A relict species in the Red Data Book of the Ukraine, known from Goloseyevo near Kiev and Zolotonosha in the Cherkassy Region (S. Golovatch, pers. comm.).

\section{Leptoiulus simplex (Verhoeff, 1894)}

Julus alemannicus simplex Verhoeff, 1894.

Julus alemannicus glacialis Verhoeff, 1908.

Leptoiulus simplex glacialis auct.

Leptoiulus marcomannius traunianus Verhoeff, 1913.

\section{Distribution}

AT, BE, CH, DE, FR-FRA, HR, HU, IT-ITA, LU, SB, SI. Alpine and parts of Central Europe.

\section{Habitat}

Mainly alpine. In the Central High Alps it occurs mainly in grassland and lichen-heath with Empetrum at about 2200-2300 m (Meyer 1985), reaching as high as $3300 \mathrm{~m}$. In Switzerland it is the most frequently encountered species in open alpine and open or closed subalpine habitats. It is often found in boggy areas at about $1500 \mathrm{~m}$. At lower altitudes it is confined to cool and humid forests, often coniferous areas in the Black Forest, or Fagus woods, as in the Jura and Italy and again in some boggy areas (Meyer 1985; Pedroli-Christen 1993; Spelda 1999). Found in Erica cinerea cushions scattered with Fagus leaves in the montane zone (500-750 m) near Laveno in Italy (Verhoeff 1930). Discovered in several coniferous and Fagus forests and in a raised bog in the Belgian Ardennes, all at about $550 \mathrm{~m}$, but even lower down in the Viroinval and in the Moselle Valley in the Grand Duchy of Luxemburg (Kime 2004). It has an unusually large altitudinal range of over $3000 \mathrm{~m}$. Found under stones in pastures, in tree stumps, under rotten wood, moss and ferns in woodland.

\section{Remarks}

A glacial relict (Schubart, 1934). The distribution is unusual; beyond the Alps it reaches Belgium to the northwest and Serbia to the southeast. Also recorded from Poland in the east by Enghoff \& Kime (2009), but as Leptoiulus simplex marcommanius, which is presumably Leptoiulus noricus Verhoeff, 1913. Its distribution in Poland is logical for L. noricus and not for L. simplex. These records are not shown on either map. Taxonomically close to L. alemannicus, its complicated taxonomic history was explained by Spelda (1999).

\section{Leptoiulus storkani Verhoeff, 1932}

Microiulus (Oroiulus) storkani auct. 
Xestoiulus (Oroiulus) storkani auct.

Leptoiulus (Oroiulus) jaroslavi Mauriès, Golovatch \& Stoev, 1997.

\section{Distribution}

AL?, GR-GRC?, HR?, MK.

\section{Habitat}

The type locality is "Korab, Duboka Recka" which refers to a stream (Duboka Recka) on Mt Korab on the border between Albania and Macedonia. No ecological details.

\section{Remarks}

This species has the same locus typicus as L. sarajevensis to which it is similar. Makarov et al. (2004) claim that it is a Macedonian endemic. Mauriès et al. (1997) proposed the replacement name Leptoiulus jaroslavi to avoid secondary homonymy with Macedoiulus storkani Verhoeff, 1932. Inasmuch as the latter species is regarded as a junior synonym of Leptoiulus sarajevensis Verhoeff, 1898, the replacement is unnecessary.

Attems' data cite presence in Epirus in Greece and Albania; however, many of these were collected in the first decade of the $20^{\text {th }}$ century and do not apply to present day national boundaries - several species quoted by Attems for Albania are often in other bordering countries, or even Bulgaria.

349. Leptoiulus tatricus Gulička, 1956

\section{Distribution}

SK.

\section{Habitat}

Alpine region of Tatra Mts.

350. Leptoiulus tendanus Verhoeff, 1930

\section{Distribution}

FR-FRA, IT-ITA.

\section{Habitat}

Leaf litter of Fagus and Corylus in two woods near the mountain pass of Tenda (Tende) close to the French-Italian border, at an altitude of 1200-1500 m.

\section{Leptoiulus transsylvanicus (Daday, 1889)}

Julus transsylvanicus Daday, 1889.

\section{Distribution}

RO (Southern Carpathian).

\section{Habitat}

Alpine; under stones and grass tussocks.

\section{Remarks}

Known only from the Retezat and Bucegi Mountains (Transylvanian Alps). 
Julus trilineatus C.L. Koch, 1847.

Julus silvivagus Verhoeff, 1898.

\section{Distribution}

AL, AT, BA, BG, CH?, GR-GRC, HR, IT-ITA, MK, MN, RO, SB, SI, TR-TUE. Southern Alps, largely Balkan, and Transadriatic.

\section{Habitat}

A widely distributed Balkan species found from sea level up to well above $2000 \mathrm{~m}$ in the Balkan Mountains $-2150 \mathrm{~m}$ on Durmitor (Beron 2008), 2200-2300 m in the Rila Mountains (Vagalinski \& Stoev 2007). Reported from woodland dominated by Fagus sylvatica, several species of Quercus, Carpinus betulus, C. orientalis, Abies and Pinus spp. Also in open habitats (meadows and alpine grasslands). Collected from leaf litter, under stones and bark, on a limestone slope, between Corylus, Rubus and Ruscus.

Troglophile, for instance caves in the Italian province of Puglia - Strasser (1965) argues that it was one of the Balkan species which was able to cross the Adriatic when the sea level was much lower than today, before the breaching of the Straits of Gibraltar.

\section{Remarks}

Widespread and common from the southern Alps to Greece and Turkey. There are also records from Piedmont and Liguria (NW Italy), e.g., by Verhoeff (1932a), but we are in doubt about these (the quite similar L. hospitelli occurs in the same area) and have omitted them from the map. We have also omitted some records from Apulia and Calabria (S Italy) referred by Strasser (1970), as these probably concern other species. There have been no records of this species from Switzerland since Verhoeff (1913) collected it near Lugano, although the site was revisited (Pedroli-Christen 1993).

\section{Leptoiulus trilobatus (Verhoeff, 1894)}

Iulus trilobatus Verhoeff, 1894.

Iulus ciliatus Verhoeff, 1897.

Iulus Adensameri Verhoeff, 1897.

\section{Distribution}

AT, CZ, DE, HU, PL, RO, SK, UA.

\section{Habitat}

Submontane and montane closed forests, including Picea forest. Has been found in peat bogs.

354. Leptoiulus tussilaginis (Verhoeff, 1907)

Iulus tussilaginis Verhoeff, 1907.

\section{Distribution}

HU (North-west), PL (Tatra Mts), SK (Nizke Tatra Mts; Muranska Plateau). (Western) Carpathians.

\section{Habitat}

Mountains. Subalpine coniferous woodland. Cave entrance. The isolated record from Hungary was from hills adjoining the Austrian Burgenland. Most records are over $850 \mathrm{~m}$. 
Iulus umbratilis Ribaut, 1905.

\section{Distribution}

ES-SPA, FR-FRA (Pyrenees, Landes).

\section{Habitat}

Montane woodland, e.g., Quercus, Castanea, in litter, on tree trunks, below moss. Pinus forest associated with Sorbus aucuparia, Vaccinium, Rhododendron, Lonicera, Rubus fruticosus, R. idaeus, Aconitum, Gentiana, Campanula, Epilobium. Pasture being invaded by woody plants, $1130 \mathrm{~m}$. Echinospartum shrubland, $1272 \mathrm{~m}$ (Serra et al. 1996). Under logs in pasture near old Pinus forest, $1600 \mathrm{~m}$. Thus, so far found from a height of $95 \mathrm{~m}$ in the Landes up to at least $1600 \mathrm{~m}$ in the Pyrenees.

\section{Remarks}

The recent discovery of this species in the lowland pine forests in the Department of the Landes, on the west coast of France, about $175 \mathrm{~km}$ north-west of the nearest previously known locality, is noteworthy.

356. Leptoiulus uncinatus Ribaut, 1951

\section{Distribution}

FR-FRA (Pyrenees near the Mediterranean Sea).

357. Leptoiulus vagabundus (Latzel, 1884)

Iulus vagabundus Latzel, 1884.

Leptoiulus hermagorensis Verhoeff, 1928.

Leptoiulus lignivagus Verhoeff, 1928.

\section{Distribution}

AT, SI.

\section{Habitat}

Forest. Under wood, litter and moss; under Blechnum ferns.

358. Leptoiulus vieirae (Verhoeff, 1900)

Julus vieirae Verhoeff, 1900.

\section{Distribution}

PT-POR.

\section{Habitat}

Captured in Robinia/Quercus/Pinus litter at Sintra, west of Lisbon by P.T. Bailey in November, 1986, in a pitfall trap (pers comm.).

\section{Remarks}

The only other record is from the vicinity of Coimbra - Verhoeff's locus typicus. 


\section{Leptoiulus zagrebensis Verhoeff, 1929}

\section{Distribution}

HR, SI.

Habitat

Forest, under litter. Cave in Slovenia (Strasser 1940).

Genus Leptotyphloiulus Verhoeff, 1899

360. Leptotyphloiulus coeruleoalbus (Verhoeff, 1899)

Typhloiulus coeruleoalbus Verhoeff, 1899.

\section{Distribution}

AL, BA.

\section{Habitat}

Fagus forest, in litter.

\section{Remarks}

Recorded from Albania by Ceuca (1992) who did, however, not give an exact locality.

\section{Leptotyphloiulus dolinensis (Verhoeff, 1901)}

Typhloiulus dolinensis Verhoeff, 1901.

\section{Distribution}

BA (South Hercegovina).

\section{Habitat}

In deep humus of a valley.

\section{Remarks}

Supposed endemic found at Suma near Trebinje.

Genus Macheiroiulus Verhoeff, 1901

362. Macheiroiulus compressicauda Verhoeff, 1901

\section{Distribution}

GR-GRC (Epirus and Thessalia).

\section{Habitat}

Subalpine wood. 


\section{Distribution}

IT-ITA (Prov. Taranto).

\section{Habitat}

Cavernicolous.

\section{Remarks}

Only known from Grotta della Cava; the cave is now destroyed.

Genus Megaphyllum Verhoeff, 1894

Brachyiulus auct., non Berlese, 1884.

Chromatoiulus auct., non Verhoeff, 1894.

Cerabrachyiulus Verhoeff, 1901.

This large genus is distributed from Central Europe to the Middle East and the Caucasus and is currently under study by Eszter Lazányi and Boyan Vagalinsky. The vast majority of the European species occur in the Balkan Peninsula (Lazányi et al. 2012).

\section{Megaphyllum anatolicum (Attems, 1926)}

Chromatoiulus anatolicus Attems, 1926.

Chromatoiulus anatolicus denticulatus Strasser, 1969.

Megaphyllum anatolicum denticulatum - Lazányi et al. 2012.

\section{Distribution}

BG, GR-GRC.

\section{Habitat}

Open areas; grassland with Pinus trees; under stones in disused quarry. Up to $1350 \mathrm{~m}$ in Turkey; 50-244 $m$ in Bulgaria (Vagalinski \& Stoev 2007).

\section{Remarks}

Bulgarian specimens were described as ssp. denticulatus Strasser, 1969. The nominate subspecies inhabits Asia Minor. Specimens from Greece seem to be intermediate (Strasser 1974).

\section{Megaphyllum argolicum (Verhoeff, 1900)}

Brachyiulus argolicus Verhoeff, 1900.

Chromatoiulus argolicus auct.

\section{Distribution}

GR-GRC (Peloponnese).

\section{Habitat}

Under Malva-like bushes between soil and plant litter; under Laurus litter. 


\section{Remarks}

The species has not been found again since 1900 .

366. Megaphyllum austriacum (Latzel, 1884)

Iulus austriacus Latzel, 1884.

Brachyiulus austriacus auct.

Chromatoiulus austriacus auct.

Brachyiulus dahli Verhoeff, 1901.

Chromatoiulus austriacus dahli auct.

Chromatoiulus dahli auct.

\section{Distribution}

BA, HR, IT-ITA, MK, MN, SI, SB. Balkan from Venezia to Macedonia.

\section{Habitat}

Woodland and bushy areas. Reported from woods with Ruscus in Croatia (Verhoeff, 1929).

\section{Remarks}

Lazányi et al. (2012) discussed the status of the taxon dahli and concluded that it is at most a subspecies of austriacum.

\section{Megaphyllum beroni (Strasser, 1973)}

Chromatoiulus beroni Strasser, 1973.

\section{Distribution}

BG (Rhodope Mountains).

\section{Habitat}

A cave near Triglad at $1150 \mathrm{~m}$.

\section{Remarks}

Known only from the type locality. It does not look like a troglobiont and is probably a rare surface living form (Laźanyi et al. 2012).

\section{Megaphyllum bicolor (Loksa, 1970)}

Chromatoiulus bicolor Loksa, 1970.

Megaphyllum bicolor crassiflagellum Mauriès \& Karamaouna, 1984.

\section{Distribution}

GR-CYC, GR-DOD.

\section{Habitat}

The subspecies crassiflagellum is the dominant millipede in the Juniperus maquis ecosystem on the island of Naxos (Karamaouna \& Geoffroy 1985).

\section{Megaphyllum bosniense (Verhoeff, 1897)}

Brachyiulus bosniensis Verhoeff, 1897. 
Chromatoiulus bosniensis auct.

Chromatoiulus cotinophilus Loksa, 1962.

\section{Distribution}

AL, AT, BA, BG, GR-GRC, HR, HU, IT-ITA, MK, MN, RO, SB, SI.

\section{Habitat}

Woodland, e.g., Fagus, Acer, Quercus, Carpinus, Fraxinus, Tilia, Castanea, Picea, Pinus. Also pastures and a city park. Up to at least $1400 \mathrm{~m}$. Collected in litter, under stones and bark.

370. Megaphyllum brachyurum (Attems, 1899)

Brachyiulus brachyurus Attems, 1899.

Megaphyllum brachyurus thassensis Mauriès, 1985.

\section{Distribution}

GR-GRC. - Also Asiatic Turkey, Iran, Russia, from the Caucasus north to Stavropol District, Georgia, Azerbaijan.

\section{Habitat}

Forests in the mountains of Eastern Turkey where it has been found on a few occasions between $1700 \mathrm{~m}$ and $2500 \mathrm{~m}$ above sea level; also in forests in southern parts of Russia east of the Black Sea where the nominal subspecies occurs at lower altitudes. In Greece ssp. thassensis was found in a cave.

\section{Remarks}

The nominal subspecies lives in the Caucasus (Russia, Georgia, Azerbaijan). On present evidence there is a very large gap between the populations in Eastern Turkey, Iran, Azerbaijan, Georgia and from the Caucasus as far north as Stavropol District, just south of the Fauna Europaea mapping area, on the one hand and the subspecies thassensis Mauriès, 1985, in Greece on the other.

\section{Megaphyllum byzantinum (Verhoeff, 1901)}

Brachyiulus byzantinus Verhoeff, 1901.

Chromatoiulus byzantinus auct.

\section{Distribution}

TR-TUE. - Also Asiatic Turkey.

\section{Habitat}

Forest.

372. Megaphyllum carniolense (Verhoeff, 1897)

Brachyiulus carniolensis Verhoeff, 1897.

Brachyiulus austriacus carniolensis auct.

Chromatoiulus carniolensis auct.

Brachyiulus monticola Verhoeff, 1898.

Chromatoiulus monticola auct.

Megaphyllum monticola auct. 


\section{Distribution}

AL, BA, HR, MN, SB, SI.

\section{Habitat}

Forests, under litter but especially under moss cushions on old or dead trees (Verhoeff 1929). Fagus forest, under wood. Under Saxifraga cushions. Up to $2000 \mathrm{~m}$ on Bjelasnica Mountain.

\section{Megaphyllum cephalonicum (Strasser, 1974)}

Chromatoiulus cephalonicus Strasser, 1974.

\section{Distribution}

GR-GRC.

\section{Habitat}

Quercus coccifera woodland.

374. Megaphyllum chiosense Lazányi \& Korsós, 2012

\section{Distribution}

GR-GRC (Chios Island).

375. Megaphyllum crassum (Attems, 1929)

Chromatoiulus crassus Attems, 1929.

\section{Distribution}

MK, SB. Šar Planina mountain range.

\section{Habitat}

Fagus forest.

376. Megaphyllum creticum (Strasser, 1976)

Chromatoiulus margaritatus var. cretica Strasser, 1976.

Megaphyllum cretica auct.

\section{Distribution}

GR-KRI.

\section{Habitat}

Found at heights of 1500-2200 m.

\section{Remarks}

Described as a variety, elevated to full species status by Ćurčić et al. (2001).

377. Megaphyllum cygniforme Lazányi \& Korsós, 2012

\section{Distribution}

GR-GRC (Greek Macedonia). 


\section{Habitat}

At brook in secondary forest and on rocky pasture, 370-442 m.

378. Megaphyllum danyi Lazányi \& Korsós, 2012

\section{Distribution}

GR-GRC (Arcadia County, Peloponnese).

\section{Habitat}

Platanus galley along Lousios River.

379. Megaphyllum dentatum (Verhoeff, 1898)

Brachyiulus dentatus Verhoeff, 1898.

Chromatoiulus dentatus auct.

\section{Distribution}

AL, BA, BG, MK, MN, SB.

\section{Habitat}

Forest, under litter.

\section{Remarks}

The imprecise record from Bulgaria stems from the mention by Attems (1929) of "East Rumelia", an old province of the Ottoman Empire comprising much of Southern Bulgaria, the capital of which was Philippopolis (now Plovdiv). The species was listed from Albania by Ceuca (1992) who gave no precise locality.

\section{Megaphyllum digitatum Lazányi \& Korsós, 2012}

\section{Distribution}

GR-GRC (Arcadia County, Peloponnese).

\section{Habitat}

Picea forest and grassland, $1310 \mathrm{~m}$.

381. Megaphyllum erythronotum (Latzel, 1884)

Julus austriacus var. erythronotus Latzel, 1884: 299.

Brachyiulus banaticus Verhoeff, 1899.

Chromatoiulus banaticus auct.

Megaphyllum banaticum auct.

\section{Distribution}

RO.

\section{Habitat}

Forests, under litter. 


\section{Remarks}

This species has mostly been referred to under Verhoeff's species epithet banaticum.

\section{Megaphyllum euphorbiarum (Verhoeff, 1900)}

Brachyiulus euphorbiarum Verhoeff, 1900.

Chromatoiulus euphorbiarum auct.

\section{Distribution}

GR-GRC (Peloponnese).

\section{Habitat}

Alpine grassland and rocky areas. Under dead Euphorbia stems in stony desert. Also found in AbiesPinus forest in Aroania Mts near Kalavrita. Known sites well over 1000 m in altitude.

\section{Megaphyllum glossuliferum (Schubart, 1934)}

Chromatoiulus glossulifer Schubart, 1934.

Megaphyllum glossulifer auct.

\section{Distribution}

BG (Stara Planina and Rila Mountains).

\section{Habitat}

Subalpine and alpine, 2200-2400 m. In coniferous forest, beneath bark and stones, and in alpine grassland. Found in grass litter in granite scree near snowfield.

\section{Megaphyllum hercules (Verhoeff, 1900)}

Brachyiulus unilineatus hercules Verhoeff, 1900.

Chromatoiulus hercules auct.

\section{Distribution}

AL, BG, GR-GRC, MK, UA. South Balkan.

\section{Habitat}

In diverse habitats from anthropogenic habitats to montane forests, 180-2100 m (Lazányi et al. 2012). Scrub, gravel, under stones and bark. Leaf litter.

\section{Remarks}

There are records from Ljuboten, a peak on Šar Planina Mt on the frontier of Macedonia with Kosovo (SB).

\section{Megaphyllum imbecillum (Attems, 1935)}

Chromatoiulus imbecillus Attems, 1935.

\section{Distribution}

AL, GR-GRC, MK. Epirus region. 


\section{Habitat}

Fallen leaves in a virgin Platanus forest. Near springs. 410-704 m.

\section{Remarks}

Strasser (1976) described two varieties of M. imbecillum which were listed as subspecies by Ceuca (1992). He suggested that this might be the most common Megaphyllum species in the Epirus.

\section{Megaphyllum karschi (Verhoeff, 1901)}

Brachyiulus karschi Verhoeff, 1901.

Chromatoiulus karschi auct.

\section{Distribution}

AL.

\section{Habitat}

Leaf litter.

387. Megaphyllum kievense (Lohmander, 1928)

Chromatoiulus kievensis Lohmander, 1928.

\section{Distribution}

MD, RO, RU-RUC, UA.

\section{Habitat}

Steppe and forest-steppe zones: calciphilous steppe with Hyssopus and Artemisia, meadows and limestone denudations (Prisnyi 2001).

\section{Megaphyllum lamelliferum (Strasser, 1974)}

Chromatoiulus lamellifer Strasser, 1974.

Megaphyllum lamellifer auct.

\section{Distribution}

GR-GRC (Epirus).

\section{Habitat}

Young coniferous plantation, $550 \mathrm{~m}$. Oakwood (Quercus), $360 \mathrm{~m}$.

\section{Megaphyllum leucadium (Attems, 1929)}

Chromatoiulus leucadius Attems, 1929.

\section{Distribution}

GR-GRC (island of Lefkada).

\section{Remarks}

Supposed endemic, similar to species on other Ionian islands. 
390. Megaphyllum lictor (Attems, 1904)

Brachyiulus lictor Attems, 1904.

Chromatoiulus lictor auct.

\section{Distribution}

BG, RO, TR-TUE. East Balkan.

\section{Habitat}

Broad-leaved forests, especially Quercus. Also Fagus. Up to $1500 \mathrm{~m}$.

391. Megaphyllum loebli (Strasser, 1974)

Chromatoiulus loebli Strasser, 1974.

\section{Distribution}

GR-GRC (Peloponnese).

\section{Habitat}

Gorges with forest; conifers and Platanus, in leaf litter. One site at $885 \mathrm{~m}$.

\section{Remarks}

Only two known sites, a ravine at Kalavrita and a gorge at Korfes in Arkadia County.

\section{Megaphyllum margaritatum (Fanzago, 1875)}

Julus margaritatus Fanzago, 1875.

Chromatoiulus margariatus auct.

Brachyiulus aetnensis Verhoeff, 1910.

Brachyiulus garganensis Verhoeff, 1932.

\section{Distribution}

GR-GRC, IT-ITA, IT-SI.

\section{Habitat}

Pastures. Fagus forest. One record at $990 \mathrm{~m}$ in the Epirus and only above $1200 \mathrm{~m}$ in Calabria.

\section{Remarks}

Strasser $(1974,1976)$ described three varieties of M. margaritatum, one of which is now regarded as a separate species, $M$. creticum.

\section{Megaphyllum metsovoni (Strasser, 1976)}

Chromatoiulus metsovoni Strasser, 1976.

\section{Distribution}

GR-GRC (Epirus and Parnassos Mountains)

\section{Habitat}

Found at $1630 \mathrm{~m}$ in the Metsovon Pass and in Picea forest at $1115 \mathrm{~m}$ on Parnassos Mts. 
394. Megaphyllum montivagum (Verhoeff, 1901)

Brachyiulus montivagus Verhoeff, 1901.

Brachyiulus latesquamosus Attems, 1903.

Chromatoiulus montivagus auct.

Chromatoiulus latesquamosus auct.

Chromatoiulus macedonicus Strasser, 1976.

Megaphyllum latesquamosum auct.

Megaphyllum macedonicum auct.

\section{Distribution}

GR-GRC, MK, SB.

\section{Habitat}

Found in woodland in Athens, in the suburbs of Skopje, Macedonia, on the shore of Lake Prespa, in dry grassland and gallery forest; near water. $700-1650 \mathrm{~m}$.

\section{Remarks}

Lazányi et al. (2012) discussed the synonymy and variability of this apparently quite versatile species.

\section{Megaphyllum mueggenburgi (Verhoeff, 1901)}

Brachyiulus mueggenburgi Verhoeff, 1901.

Chromatoiulus mueggenburgi auct.

Cerabrachyiulus mueggenburgi auct.

\section{Distribution}

GR-DOD (Kasos, Karpathos).

\section{Habitat}

Found between 800 and 1400 m (Lazányi et al. 2012).

396. Megaphyllum platyurum (Latzel, 1884)

Iulus platyurus Latzel, 1884.

Chromatoiulus platyurus auct.

\section{Distribution}

RO, SB.

\section{Habitat}

Under moist, rotting fallen giant fir trees (Verhoeff 1897); trogloxene.

\section{Remarks}

Recorded in northern Serbia without a precise locality.

\section{Megaphyllum projectum Verhoeff, 1894}

Brachyiulus projectus deubeli Verhoeff, 1899.

Brachyiulus dioranus Verhoeff, 1907.

Brachyiulus projectus kochi Verhoeff, 1907. 
Brachyiulus projectus dioritanus Verhoeff, 1907.

Brachyiulus austriacus auct.

Chromatoiulus projectus dioranus auct.

Chromatoiulus projectus dioritanus auct.

Chromatoiulus projectus kochi auct.

Megaphyllum projectum kochii auct.

\section{Distribution}

AT, BY, CZ, DE, HR, HU, LT, MD, NL, PL, RO, RU-KGD, SI, SK, UA. Central European.

\section{Habitat}

Forest, e.g., Quercus, Carpinus, Fagus, Acer, Fraxinus, Pinus. Slope woodland. Under stones in thick litter and in areas with dead wood on the ground. Alnus swamp woodland, "responsible for the mass transformation of decaying litter with its large abundance” (Korsós \& Lazányi 2008).

\section{Megaphyllum recticauda (Attems, 1903)}

Brachyiulus recticauda Attems, 1903.

Chromatoiulus recticauda auct.

Chromatoiulus recticauda discrepans Strasser, 1976.

\section{Distribution}

GR-GRC (Corfu).

\section{Remarks}

The only species of Megaphyllum on Corfu, found in various places.

399. Megaphyllum rhodopinum (Verhoeff, 1928)

Brachyiulus rhodopinus Verhoeff, 1928.

Chromatoiulus rhodopinus auct.

\section{Distribution}

BG, GR-GRC. East Balkan.

\section{Habitat}

Deciduous and coniferous forests, meadows, pastures and caves. Decaying wood. From 550 to $2100 \mathrm{~m}$ altitude (Golovatch \& Kondeva 1992; Vagalinski \& Stoev 2007).

\section{Megaphyllum rosenauense (Verhoeff, 1897)}

Brachyiulus rosenauensis Verhoeff, 1897.

Chromatoiulus rosenauensis auct.

\section{Distribution}

MD, RO, UA.

\section{Habitat}

Woodland; edge in sandstone gorge, under leaves and in sand; under pine needles; arable land; limestone quarry. 
Iulus rossicus Timotheew, 1897.

Brachyiulus strandschanus Verhoeff, 1937.

Chromatoiulus rossicus auct.

Chromatoiulus rossicus strandschanus auct.

\section{Distribution}

BG, GR-GRC, RU-RUC, RU-RUE, RU-RUS, UA.

\section{Habitat}

Forest-steppe and steppe. Frequently in Quercus forest; calciphytic steppe, limestone denudations; meadows, orchards, $0-300 \mathrm{~m}$.

\section{Remarks}

Two subspecies are recognized. According to Golovatch (1990) the nominal subspecies is a Pleistocene relict with a disjunct distribution east of the Dniepr River. The subspecies Megaphyllum rossicum strandschanum (Verhoeff, 1937) occurs in southeast Bulgaria and Greece (Thrace).

\section{Megaphyllum rubidicolle (Verhoeff, 1901)}

Brachyiulus rubidicollis Verhoeff, 1901.

Chromatoiulus rubidicollis auct.

\section{Distribution}

GR-GRC.

\section{Habitat}

Found on Velouchi, the highest peak of Mount Timfristos. In subalpine forest and in the alpine zone near a snowfield in the month of May.

\section{Remarks}

Known only from the type series, which consists of a female and some juveniles. Strasser (1976) and Laźanyi et al. (2012) gave the altitude as $2315 \mathrm{~m}$, but there is no altitude information in the original description; $2315 \mathrm{~m}$ is the height of the Velouchi peak.

\section{Megaphyllum sapphicum (Strasser, 1976)}

Chromatoiulus sapphicus Strasser, 1976.

\section{Distribution}

GR-GRC (Lesbos). - Also Asiatic Turkey (W coast).

\section{Habitat}

Found at altitudes of $600-930 \mathrm{~m}$.

\section{Remarks}

Recently identified from the Turkish mainland (B. Vagalinski, unpubl.). 
404. Megaphyllum silvaticum (Verhoeff, 1898)

Brachyiulus silvaticus Verhoeff, 1898.

Chromatoiulus silvaticus auct.

\section{Distribution}

AT, HR, HU, IT-ITA, MD, PL, RO, SI, SK, UA. East Central Europe.

\section{Habitat}

Tends to be found in mountainous country, sometimes at high elevations, e.g., $1900 \mathrm{~m}$ under alpine grass (Verhoeff 1900), 1520 m in the Rodna Mountains (Laźanyi \& Korsós 2009). Beech (Fagus) forest; limestone rocks on pasture.

\section{Remarks}

Verhoeff (1900) stated that the species favours high places but is not confined to mountains. Golovatch (1992) finds it a typical Carpathian species. It also occurs in the SE and Dinaric Alps as well as some lowland areas.

Laźanyi \& Korsós (2010) found three different types of male gonopod in this variable species but only one type of female vulva, explaining why the subspecies discolor Verhoeff, 1907, is not valid.

405. Megaphyllum sjaelandicum (Meinert, 1868)

Julus sjaelandicus Meinert, 1868.

Brachyiulus wolterstorffi Verhoeff, 1904.

Brachyiulus seelandicus Verhoeff, 1907.

Brachyiulus sjaelandicus auct.

Chromatoiulus sjaelandicus auct.

\section{Distribution}

BY, DE, DK-DEN, EE, FI, LT, LV, PL, RU-KGD, RU-RUC, RU-RUE, RU-RUN, RU-RUW, SE, UA. Northern Central and East Europe. - Also Siberia.

\section{Habitat}

Boreo-nemoral habitats in the east from taiga in the north, through mixed coniferous and broad-leaved woods to forest-steppe in the south. Some particular assemblages mentioned are swamp and marshy woodland with Carex, Filipendula, Iris, Oxalis; Alder (Alnus) carr (Ribeso-nigri Alnetum, GlutinosoAlnetum aegopodiosum; Betula, Fagus, Carpinus (Carpinetum-aegopodosium); Pinus forest in Russia (Prisnyi 2001). Cemeteries.

\section{Remarks}

A forest-dwelling species found from the taiga in the north down to the forest-steppe belt of Russia and the Ukraine. This European species also occurs in the Altai Region of Siberia and possibly Kazakhstan (Mikhaljova et al. 2013). It is very unusual to find a species that occurs in Europe further east than the Ural Mountains.

\section{Megaphyllum syrense (Verhoeff, 1903)}

Brachyiulus syrensis Verhoeff, 1903.

Chromatoiulus syrensis auct. 


\section{Distribution}

GR-CYC (Syros).

407. Megaphyllum tauricum (Attems, 1907)

Brachyiulus tauricus Attems, 1907.

\section{Distribution}

UA (Crimea).

\section{Habitat}

Forests in the hilly southern areas of the Crimea.

\section{Remarks}

In retaining this species Golovatch (1990) comments on the similarities between this species and several congeners, but suggests regarding it a separate species, a point of view supported by Lazányi \& Vagalinsky (2013) in their revision of the genus.

408. Megaphyllum taygetanum (Attems, 1903)

Brachyiulus taygetanum Attems, 1903.

Chromatoiulus taygetanus auct.

\section{Distribution}

GR-GRC (Peloponnese).

\section{Habitat}

Open wood, rocky Acer forest; 490-680 m (Lazányi et al. 2012).

409. Megaphyllum taygeti (Strasser, 1976)

Chromatoiulus taygeti Strasser, 1976.

\section{Distribution}

GR-GRC (Peloponnese), GR-KRI.

\section{Habitat}

Mountains from 1000 to $2000 \mathrm{~m}$.

410. Megaphyllum transsylvanicum (Verhoeff, 1897)

Brachyiulus transsylvanicus Verhoeff, 1897.

Chromatoiulus transsylvanicus auct.

\section{Distribution}

BA, BG, GR-GRC?, HR, HU, MD, MK, RO, RU-RUS, SB, TR-TUE, UA. Eastern Central Europe.

\section{Habitat}

Forests, more broad-leaved than coniferous: Quercus, Carpinus, Fagus, Pinus. Coastal rocks, grassland and bush. Pastures. Steppe. In litter; under stones on grass, under dung. Sometimes found in caves. From sea level to at least $1300 \mathrm{~m}$. 
411. Megaphyllum unilineatum (C.L. Koch, 1838)

Julus unilineatus C.L. Koch, 1838.

Chromatoiulus unilineatus auct.

Julus gilvolineatus L. Koch, 1881.

Julus balearicus L. Koch, 1881.

Brachyiulus genuinus Verhoeff, 1907.

\section{Distribution}

AL, AT, BA, BG, CZ, DE, ES-BAL, GR-GRC, HR, HU, IT-ITA, MK, MN, PL, RO, SB, SI, SK. Balkan, extending into Central Europe.

\section{Habitat}

Generally in dry habitats such as grasslands on karst, the Pannonian Plain, and disturbed areas. Under stones, along roadsides, in ruins, quarries, urban habitats, caves. Coniferous forests, e.g., Pinus, Picea; Robinia and Quercus woodland. Under Salix leaves by a stream. Regarded as a stenotopic xerobiont open land species with preference for xeric/mesoxeric meadows, fields and fallows in Saxony-Anhalt, Germany (Voigtländer 2011). Mass swarmings have been reported by, e.g., Paszlawsky (1878), Ćurčić \& Makarov (1995, lasting nearly four weeks) and Korsós (1998).

\section{Remarks}

The species has not been recorded from the Balearic Islands since Koch (1881), possibly based on a now extinct population (see Enghoff \& Vicente 2000). In his fauna of Moldavia, Jawłowski (1935) quoted three sites for this species, as Chromatoiulus projectus genuinus (Verhoeff, 1907); these are Braseu (=Braşov), Socola and Barnova, all of which are in Romania.

\section{Megaphyllum vicinum (Verhoeff, 1903)}

Brachyiulus vicinus Verhoeff, 1903.

Chromatoiulus vicinus auct.

\section{Distribution}

GR-GRC.

\section{Remarks}

The description was based on a single male found at Etoliko (Stolico, Aitoliko) in Dytiki Province; to this day the species has not been rediscovered.

Genus Mesoiulus Berlese, 1886

Baskoiulus Mauriès, 1982.

\section{Mesoiulus berlesei Silvestri, 1898}

\section{Distribution}

IT-ITA (Piedmont).

\section{Habitat}

Under stones. 
414. Mesoiulus cavernarum (Verhoeff, 1938)

Baskoiulus cavernarum Verhoeff, 1938.

Mesoiulus chappuisi Mauriès, 1964.

\section{Distribution}

ES-SPA (Guipuzcoa and Santander Provinces).

\section{Habitat}

Cavernicolous.

415. Mesoiulus derouteae Mauriès, 1971

\section{Distribution}

ES-SPA (Santander Province).

\section{Habitat}

Cavernicolous. Known only from the Cueva del Agua at Matienzo.

416. Mesoiulus drescoi Mauriès, 1971

\section{Distribution}

ES-SPA (Oviedo and Santander Provinces).

\section{Habitat}

Cavernicolous.

\section{Remarks}

Found in three caves; it is very similar to Mesoiulus stammeri. Mauriès \& Vicente (1977) suggested that it might be a variety of the latter.

\section{Mesoiulus gridellii Strasser, 1934}

Mesoiulus franzi Attems, 1944.

\section{Distribution}

AT, IT-ITA (Venezia).

\section{Habitat}

Found in garden litter beach debris in Venice (Strasser 1934). Thaler \& Christian (2003) reported the species from the catacombs below St. Stephen's cathedral in central Vienna. Also found in a palm house in Frankfurt, Germany; this record is not shown on the map.

\section{Remarks}

When Attems (1944) described Mesoiulus franzi he drew attention to its similarity with M. gridellii and remarked on its northerly situation with respect to all the other pachyiulines which are found in the Mediterranean zone. He considered it to be a relict in the warmest part of Austria. 
418. Mesoiulus henroti Mauriès, 1971

\section{Distribution}

ES-SPA (Navarra Province).

\section{Habitat}

Cavernicolous. Known only from Akelar Cave at Lecumberri.

419. Mesoiulus kosswigi Verhoeff, 1936

\section{Distribution}

TR-TUE.

\section{Habitat}

Cavernicolous.

420. Mesoiulus mauriesi Strasser, 1974

\section{Distribution}

GR-GRC (Attica).

\section{Habitat}

Found on the east side of Hymittos Mountain up to $600 \mathrm{~m}$, apparently not cavernicolous.

421. Mesoiulus paradoxus Berlese, 1886

\section{Distribution}

HU, IT-ITA (Venezia).

\section{Habitat}

Gardens, fields, e.g., dominant in alfalfa fields in NE Italy (Paoletti et al. 1988). Korsós (1992) recorded it from anthropogenic sites in Hungary.

422. Mesoiulus rusticanus Mauriès \& Vicente, 1977

\section{Distribution}

ES-SPA (Tarragona Province).

\section{Habitat}

Soil.

423. Mesoiulus siculus Silvestri, 1902

\section{Distribution}

IT-SI.

\section{Habitat}

Under a stone. 
424. Mesoiulus stammeri (Verhoeff, 1936)

Baskoiulus stammeri Verhoeff, 1936.

\section{Distribution}

ES-SPA (Santander, Viscaya, Guipuzcoa and Burgos Provinces).

\section{Habitat}

Cavernicolous.

Genus Metaiulus Blower \& Rolfe, 1956

425. Metaiulus pratensis Blower \& Rolfe, 1956

\section{Distribution}

FR-FRA, GB-GRB. Atlantic.

\section{Habitat}

Heavy soils of farmland, woodland and wetland; in caves in the south of its range in Aquitaine.

\section{Remarks}

Four subspecies have been described from French caves by Demange $(1958,1965)$, Mauriès $(1965)$ and Ceuca (1968). This little-recorded species was reviewed by Lee (2006).

Genus Micropachyiulus Verhoeff, 1899

\section{Micropachyiulus paucioculatus (Verhoeff, 1899)}

Pachyiulus paucioculatus Verhoeff, 1899.

\section{Distribution}

RO (Caras-Severin and Hunedoara Provinces).

\section{Habitat}

Cavernicolous. However, Verhoeff (1899) found it under leaves and in humus below a beech tree (Fagus) and it has also been found in a Betula wood.

\section{Remarks}

There are only four records.

Genus Ommatoiulus Latzel, 1884

Archiulus Berlese, 1886, preoccupied.

Mesoiulus Verhoeff, 1893, preoccupied.

Palaioiulus Verhoeff, 1894.

Schizophyllum Verhoeff, 1895.

This is a large genus; 47 European species are included here, mostly from the Iberian Peninsula, where many new species are currently being found. On the other hand, many species have quite variable gonopods, and some of the species recognized here may turn out to be synonyms of others. 
427. Ommatoiulus albolineatus (Lucas, 1845)

Iulus albolineatus Lucas, 1845.

Schizophyllum albolineatum parvum Brolemann, 1920.

Schizophyllum olivarum Verhoeff, 1921.

Schizophyllum albolineatum tenebrosum Schubart, 1961.

\section{Distribution}

ES-SPA, FR-FRA, IT-ITA, MC. - Also Morocco.

\section{Habitat}

In Mediterranean vegetation.

\section{Remarks}

Most records come from the French and Italian Rivieras, from Toulon to Menton in France, Monaco and from San Remo in Italy. There is one record from Mont Ventoux in the Vaucluse, ca $1900 \mathrm{~m}$ altitude (Schubart 1961). The very distant isolated Spanish records are both from the interior, and Brolemann named them Schizophyllum albolineatum parvum. The two sites where it was found in Spain and which were recorded by Brolemann are Pozuelo de Calatrava, which is on an extensive plateau at an altitude of about $630 \mathrm{~m}$, and La Granja, Peñalara, which is at least $1180 \mathrm{~m}$ above sea level. This evidence suggests that Ommatoiulus parvus might be a separate species. On the other hand, Schizophyllum olivarum, described by Verhoeff from San Remo and listed as a separate species in Fauna Europaea (Enghoff \& Kime 2009), seems to be a synonym of O. albolineatus (N. Akkari, pers. comm.).

\section{Ommatoiulus andalusius (Attems, 1927)}

Archiulus andalusius Attems, 1927.

Schizophyllum andalusium auct.

\section{Distribution}

ES-SPA.

\section{Remarks}

Attems described the species from an unknown locality in Andalusia. The species has not been found subsequently.

\section{Ommatoiulus armatus (Verhoeff, 1910)}

Schizophyllum armatum Verhoeff, 1910.

Schizophyllum cornigerum Verhoeff, 1921.

Schizophyllum ceratophorus Attems, 1952.

\section{Distribution}

ES-SPA.

\section{Habitat}

Found under stones up to an altitude of about $2000 \mathrm{~m}$ in the Sierra de Guadarrama, and on a motorway station in Cantabria. 


\section{Remarks}

Hoffman (1975) regarded the synonymy of ceratophorus under armatus as "very likely", and it has been confirmed by N. Akkari (pers. comm.)

430. Ommatoiulus aurozonatus (Berlese, 1886)

Julus aurozonatus Berlese, 1886.

Archiulus latinus Attems, 1927.

Schizophyllum aprutianum Verhoeff, 1932.

Schizophyllum aurozonatus auct.

\section{Distribution}

IT-ITA.

431. Ommatoiulus baenai Akkari \& Enghoff, 2012

\section{Distribution}

ES-SPA (Andalusia, Granada, Casas de Carrasco).

432. Ommatoiulus baileyi Akkari \& Enghoff, 2012

Ommatoiulus sp. 1 - Bailey \& De Mendonça 1990.

\section{Distribution}

ES-SPA (Andalusia, Doñana National Park S of Sevilla).

\section{Habitat}

Found in leaf litter of Halimium sp. on sand dunes (Bailey \& De Mendonça, 1990).

\section{Ommatoiulus bavayi (Brölemann, 1897)}

Schizophyllum bavayi Brölemann, 1897.

\section{Distribution}

ES-SPA (Murcia and Cadiz Provinces).

\section{Ommatoiulus bipartitus (Verhoeff, 1910)}

Schizophyllum bipartitum Verhoeff, 1910.

Schizophyllum fissum Verhoeff, 1921.

Schizophyllum involutum Verhoeff, 1925.

\section{Distribution}

ES-SPA, FR-FRA, PT-POR.

\section{Habitat}

Common in various largely rural habitats in Galicia and Asturias.

\section{Remarks}

Located in the provinces of Braga in Portugal (as Schizophyllum involutum) and Pontevedra, La Coruña, Lugo, Oviedo, Segovia (as Schizophyllum fissum) and Madrid (as Schizophyllum fissum) in Spain. 
Mauriès \& Vicente (1977) synonymised these species. O. lienharti is very similar and may be another synonym (N. Akkari in litt.).

435. Ommatoiulus buchneri (Verhoeff, 1940)

Schizophyllum buchneri Verhoeff, 1940.

\section{Distribution}

IT-ITA, IT-SI.

\section{Habitat}

Offshore islands in the south (Ischia, Capri, Lipari Islands) and the south of the Calabrian Peninsula.

436. Ommatoiulus cervinus (Verhoeff, 1910)

Schizophyllum cervinum Verhoeff, 1910.

\section{Distribution}

PT-POR.

\section{Remarks}

Almost certainly a synonym of $O$. moreleti (N. Akkari in litt.).

437. Ommatoiulus cingulatus (Attems, 1927)

Archiulus cingulatus Attems, 1927.

Schizophyllum cingulatum auct.

\section{Distribution}

PT-POR (South).

\section{Habitat}

One site was a heath with Calluna, Erica, Ulex, Rosmarinus, Cistus and grasses. Bailey \& De Mendonça (1990) mostly found it in grassland, but also in Cistus litter.

\section{Remarks}

Attems gave "Peisha" as the locus typicus of this species. This presumably should be the town of Beja in the old province of Baixo Alentejo. It has subsequently been found in Setubal and Faro Provinces on either side of Beja.

\section{Ommatoiulus clavigerus (Verhoeff, 1921)}

Schizophyllum clavigerum Verhoeff, 1921.

\section{Distribution}

ES-SPA (Madrid Province).

\section{Habitat}

Alpine. Found at an altitude of about $2000 \mathrm{~m}$ in the Sierra de Guadarrama. 
439. Ommatoiulus corsicus (Brölemann, 1903)

Schizophyllum corsicum Brölemann, 1903.

Archiulus corsicus schulzei Schubart, 1931.

\section{Distribution}

FR-COR.

\section{Habitat}

Large altitudinal range. Skeletal soils. Under Genista. Under stones at above $2000 \mathrm{~m}$ on Monte Rotondo.

440. Ommatoiulus corunnensis (Verhoeff, 1910)

Schizophyllum corunnense Verhoeff, 1910.

\section{Distribution}

ES-SPA (Galicia).

441. Ommatoiulus demangei Vicente \& Rodriguez, 1992

\section{Distribution}

ES-SPA (Lugo Province).

\section{Habitat}

In woodland (Bosque de Penedal) of Quercus robur, Quercus pyrenaica and Salix fragilis at about $1000 \mathrm{~m}$ in the Sierra de los Ancares.

442. Ommatoiulus diplurus (Attems, 1903)

Schizophyllum diplurum Attems, 1903.

Schizophyllum hoplites Verhoeff, 1910.

Ommatoiulus diplurus mauriesi Hoffman, 1975.

\section{Distribution}

ES-SPA (Andalucia). - Also (doubtfully) Algeria.

\section{Habitat}

Common in grasslands (Bailey \& De Mendonça 1990) but also in leaf litter under Quercus and under small rocks on clay-loam soil.

\section{Remarks}

Hoffman (1975) and Akkari \& Enghoff (2012) reviewed the different taxa which are now referred to O. diplurus. The nominal subspecies appendiculatus Brolemann, 1926, from Algeria is based only on females; the occurrence of $O$. diplurus in North Africa is therefore doubtful.

\section{Ommatoiulus dorsovittatus (Verhoeff, 1893)}

Julus dorsovittatus Verhoeff, 1893.

Schizophyllum dorsovittatum estrellanum Verhoeff, 1910.

Schizophyllum calatravanum Brolemann, 1920.

Palaioiulus dorsovittatus auct.

Schizophyllum dorsovittatum auct. 


\section{Distribution}

ES-SPA (Albacete, Ciudad Real, Badajoz and Jaén Provinces), PT-POR (Coimbra Province).

\section{Habitat}

Open sites; under stones on road verge beside arable land, waste ground below Medellin Castle.

444. Ommatoiulus fuentei (Brolemann, 1920)

Schizophyllum fuentei Brolemann, 1920.

\section{Distribution}

ES-SPA (Ciudad Real, Badajoz and Córdoba Provinces).

\section{Habitat}

Litter of shrub with Halimium spp. (Baiely \& De Mendonça 1990).

445. Ommatoiulus haackeri Mauriès, 1969

\section{Distribution}

ES-SPA, FR-FRA. Basque Region, Pyrenees.

446. Ommatoiulus hoffmani Akkari \& Enghoff, 2012

\section{Distribution}

ES-SPA (Almería Province).

\section{Habitat}

Dry rocky hill, under stones.

\section{Ommatoiulus ibericus Ceuca, 1974}

\section{Distribution}

ES-SPA (East).

\section{Habitat}

From $300 \mathrm{~m}$ in Buxus sempervirens and Ulex parviflorus on Monte Caro in Tarragona Province up to $1900 \mathrm{~m}$ on Monte Peñarroya in Teruel Province (Vicente 1985).

448. Ommatoiulus ilicis (Brölemann, 1897)

Schizophyllum ilicis Brölemann, 1897.

Schizophyllum nivale Schubart, 1959.

Ommatoiulus nivalis - Mauriès 1969b.

\section{Distribution}

ES-SPA (Sierra Nevada, Granada Province), FR-FRA (Central and Eastern Pyrenees).

\section{Habitat}

At foot of elm tree. In fallen trunk. In old trunks of evergreen Quercus sp. In a small valley, moist, dense shrub, in leaf litter. From near sea level in France up to $2900 \mathrm{~m}$ in Spanish Sierra Nevada. 


\section{Remarks}

Akkari \& Enghoff (2012) synonymised nivalis under ilicis. This species has a remarkably disjunct distribution: the Pyrenees in the north and Sierra Nevada and Sierra de Grazalema in the south.

449. Ommatoiulus imminutus (Brolemann, 1926)

Schizophyllum imminutum Brolemann, 1926.

\section{Distribution}

FR-FRA (Pyrénées Orientales).

450. Ommatoiulus inconspicuus (L. Koch, 1881)

Julus inconspicuus L. Koch, 1881.

Julus nigritarsus L. Koch, 1881.

Schizophyllum ibizanum Verhoeff, 1924

\section{Distribution}

ES-BAL, ES-SPA (Alicante and Almería Provinces).

\section{Habitat}

Pinewoods (Pinus halepensis) under bark, Mediterranean shrubs (macquis), under stones in open rocky areas and in leaf litter in a dried, yet moist, riverbed with a lush herb layer.

\section{Remarks}

Known from the Balearic Islands Cabrera, Ibiza, Menorca and Mallorca (Enghoff \& Vicente 2000), as well as from the coastal provinces of Alicante and Almería on the Spanish mainland (Akkari \& Enghoff 2012).

451. Ommatoiulus jaenensis Akkari \& Enghoff, 2012

\section{Distribution}

ES-SPA (Jaén Province).

452. Ommatoiulus kimei Akkari \& Enghoff, 2012

Ommatoiulus sp. 3 - Bailey \& De Mendonça, 1990.

\section{Distribution}

ES-SPA (Córdoba Province).

\section{Habitat}

Litter of Quercus suber forest and shrub with Cistus spp. (Bailey \& De Mendonça 1990).

453. Ommatoiulus lienharti (Brolemann, 1921)

Schizophyllum moreleti Lienharti Brolemann, 1921.

\section{Distribution}

ES-SPA (Alava and Guipuzcoa Provinces), FR-FRA. (Gironde Department). Atlantic. 


\section{Habitat}

Alava: Fagus forest with some Quercus; in leaf litter, 830 m. Guipuzcoa: Pinus woodland. Gironde: in woods around Arcachon.

\section{Remarks}

Very similar to, and possibly a synonym of $O$. bipartitus (N. Akkari in litt.).

454. Ommatoiulus lusitanus (Verhoeff, 1895)

Schizophyllum lusitanum Verhoeff, 1895.

\section{Distribution}

PT-POR.

\section{Remarks}

Almost certainly a senior synonym of $O$. cingulatus (N. Akkari in litt.).

455. Ommatoiulus martensi Mauriès, 1969

\section{Distribution}

ES-SPA (Western Pyrenees, Picos de Europa), PT-POR (Serra da Estrela). Atlantic.

\section{Habitat}

Alpine. Often below stones. Records from 1600 m to 2200 m altitude.

\section{Ommatoiulus moreleti (Lucas, 1860)}

Iulus moreleti Lucas, 1860.

Julus lusitanicus Karsch, 1881.

Julus karschi Verhoeff, 1892.

Scizophyllum moreletii auct.

Palaioiulus karschi auct.

\section{Distribution}

ES-CNY, ES-SPA, PT-AZO, PT-MDR, PT-POR. - Also introduced into the Afrotropical and Australian regions, and to Bermuda.

\section{Habitat}

Abundant in several habitats in Macaronesia, Portugal and Western Spain, with a large altitudinal range. On a site where it coexists with $O$. cingulatus and $O$. oliveirae, Bailey \& de Mendonça (1990) found it in Quercus and Cistus litter but not in grassland where O. oliveirae predominated. In Australia it is regarded as a pest due to its sometimes extreme abundance see, e.g., http://www.polydesmida.info/ tasmanianmultipedes/milli-jul-exo.html.

\section{Remarks}

Quite a variable species (see, e.g., Baker 1984). O.cervinus is most likely a synonym of $O$. moreleti (N. Akkari in litt.). 
457. Ommatoiulus navasi (Brölemann, 1918)

Schizophyllum navasi Brölemann, 1918.

\section{Distribution}

ES-SPA (Sierra de Moncayo, Zaragoza Province; Sierra de la Demanda, Rioja Province).

\section{Habitat}

Alpine, above $2000 \mathrm{~m}$.

\section{Ommatoiulus niger (Attems, 1952)}

Schizophyllum nigrum Attems, 1952.

\section{Dsitribution}

ES-SPA (Cádiz, Sevilla, Almería, Granada, Jaén, Málaga and Madrid Provinces).

\section{Habitat}

Mountains. Litter of Olea europaea crops (Bailey \& De Mendonça 1990). Litter of low bush; in soil, under grass between limestone stones and pebbles (Akkari \& Enghoff 2012).

\section{Ommatoiulus oliveirae (Verhoeff, 1893)}

Julus oliveirae Verhoeff, 1893.

Palaioiulus oliveirae auct.

Schizophyllum oliveirae auct.

\section{Distribution}

PT-POR.

\section{Habitat}

Under stones in grassland, in cork litter, in litter under Quercus suber and Cistus, and in grassland (Bailey \& De Mendonça 1990).

\section{Ommatoiulus oxypygus (Brandt, 1841)}

Iulus oxypygus Brandt, 1841.

Iulus brandti Berlese, 1886.

Schizophyllum oxypygum auct.

\section{Distribution}

IT-ITA, IT-SI, MT.

\section{Habitat}

A wide variety of biotopes below $600 \mathrm{~m}$.

461. Ommatoiulus parallelus (C.L. Koch, 1847)

Julus parallelus C.L. Koch, 1847.

Julus cavannae Berlese, 1886.

Schizophyllum parallelum auct. 


\section{Distribution}

IT-ITA (Lombardy, Emilia-Romagna, Tuscany, Umbria).

\section{Habitat}

Found on dry, gravelly slopes with Erica, Cistus, Genista, Castanea, Ilex and Pinus on the island of Capri by H.W. Waldén (HE det., unpublished material in the Natural History Museum of Gothenburg).

462. Ommatoiulus porathi (Verhoeff, 1893)

Julus porathi Verhoeff, 1893.

Palaioiulus porati auct.

Schizophyllum porathi auct.

\section{Distribution}

PT-POR.

\section{Remarks}

Known only from the type locality near Coimbra.

463. Ommatoiulus pseudoflagellatus Akkari \& Enghoff, 2012

\section{Distribution}

ES-SPA (Sevilla and Málaga Provinces).

\section{Habitat}

Under bark of Eucalyptus tree, Pinus forest (Akkari \& Enghoff 2012).

464. Ommatoiulus recueroi Akkari \& Enghoff, 2012

\section{Distribution}

ES-SPA (Jaén Province).

465. Ommatoiulus reipi Akkari \& Enghoff, 2012

Ommatoiulus sp. 5 - Bailey \& De Mendonça 1990.

\section{Distribution}

ES-SPA (Córdoba and Sevilla Provinces).

\section{Habitat}

Leaf litter of oak forests with Quercus suber and Quercus ilex (Bailey \& Mendonça 1990).

\section{Ommatoiulus robustus Ceuca, 1972}

\section{Distribution}

ES-SPA (Huesca Province).

\section{Habitat}

Pyrenean mountain grassland, 1250-2000 m. Alpine pasture, brushwood with Echinospartum horridum on skeletal soil (Serra et al. 1996). 
Julus rutilans C.L. Koch, 1847.

Julus mediterraneus Latzel, 1884.

Schizophyllum hispanicum Verhoeff, 1910.

Schizophyllum rutilans auct.

Palaioiulus rutilans auct.

\section{Distribution}

BE, CH, DE, ES-SPA, FR-FRA, IT-ITA, LU, NL, SM. Atlanto-Mediterranean. - Also Morocco.

\section{Habitat}

Warm, dry calcareous grassland, submediterranean in the north of its range. Found up to $1400 \mathrm{~m}$ in Switzerland (Pedroli-Christen 1993). Frequently under stones. Juniperus forest in Spain.

\section{Remarks}

This species is often found wandering on the ground after rain. Regarded as highly endangered in Germany (Voigtländer et al. 2011).

\section{Ommatoiulus sabinarensis Akkari, Mauriès \& Enghoff, 2012}

\section{Distribution}

ES-SPA (Almería Province).

469. Ommatoiulus sabulosus (Linnaeus, 1758)

Julus sabulosus Linnaeus, 1758.

Iulus aimatopodus Risso, 1826.

Archiulus sabulosus auct.

Palaioiulus sabulosus auct.

Schizophyllum sabulosum auct.

Archiulus irregularis Attems, 1927.

Ommatoiulus irregularis auct.

\section{Distribution}

AL, AT, BA, BE, BG, BY, CH, CZ, DE, DK-DEN, ES-SPA, FI, FR-FRA, GB-CI, GB-GRB, GB-NI, HR, HU, IE, IT-ITA, LT, LU, LV, MC, MK, NL, NO-NOR, PL, RO, RU-KGD, RU-RUC, RU-RUE, RU-RUN, SB, SE, SI, SK, UA. Most of Europe, from the Mediterranean to the Boreal Zones and east to the Ural Mts.

\section{Habitat}

Eurytopic, with an altitudinal range of nearly $3000 \mathrm{~m}$, though it is particularly associated with warm habitats and sandy areas. It is often abundant in sand dune systems and is closely associated with heaths but may be found on limestone as well as sandstone. It is common in more or less open woods on lighter soils but, in Belgium at least, it is almost never observed in large closed forests. Yet, in Eastern Europe it is dominant in some Quercus and Picea stands in the Byelovezskaya Puzcha (Tarasevich 1992) and it occurs in the taiga. Adults wander into a very wide variety of habitats from lowland woodlands and grasslands to alpine meadows, usually during the summer. In winter it appears to be more restricted to damper places occurring in the leaf litter and superficial layers of well drained soil. There are several references to its occurrence in wetlands and on moors, including peat bogs. 


\section{Remarks}

One of the most widely dispersed millipedes in Europe, from $38^{\circ} \mathrm{N}$ in Calabria to $64^{\circ} \mathrm{N}$ in the taiga of Finland. It has not yet been recorded from Greece, some major Mediterranean islands and much of Iberia, where many other species of Ommatoiulus occur. Records from Portugal are not reliable (N. Akkari, pers. comm.) It is active in summer when many other species are dormant, spatially very patchy and it undergoes large population fluctuations. Mass swarming has been observed on many occasions (e.g., Ehrnsberger 2002; Helb 1975; Kania \& Tracz 2005; Voigtländer 2005). An entirely black form without the two characteristic orange dorsal stripes, O.s.aimatopodus (Risso, 1826), is known from some southern departments of France. We treat $O$. irregularis as a synonym of $O$. sabulosus on the advice of Nesrine Akkari, who has seen Attems' type specimen. O. irregularis was included in the Italian checklist (Strasser \& Minelli 1984) with a question mark, but excluded from the later list of Foddai et al. (1995). Numerous other forms have been named but are not listed here.

470. Ommatoiulus schubarti Akkari \& Enghoff, 2012

\section{Distribution}

ES-SPA (Granada Province).

\section{Remarks}

Only known from the type specimens collected in 1863.

\section{Ommatoiulus teruelensis Ceuca, 1974}

Ommatoiulus terulensis auct. (lapsus calami).

\section{Distribution}

ES-SPA (Teruel Province).

\section{Habitat}

Two records from mountains at 1600-1900 m.

472. Ommatoiulus tridentifer Ceuca, 1974

\section{Distribution}

ES-SPA (Teruel Province).

473. Ommatoiulus variolosus (Silvestri, 1898)

Iulus variolosus Silvestri, 1898.

Schizophyllum variolosum auct.

\section{Distribution}

IT-SAR (Cagliari Province).

Genus Ophyiulus Berlese, 1884

Taueriulus Verhoeff, 1913.

474. Ophyiulus aspidiorum (Verhoeff, 1913)

Taueriulus aspidiorum Verhoeff, 1913.

Ophyiulus alpinus Attems, 1927. 


\section{Distribution}

AT.

\section{Habitat}

Coniferous forest under Aspidium ferns; under Alnus incana and Aspidium at a snowfield (Schubart 1934).

475. Ophyiulus bastiensis Verhoeff, 1943

\section{Distribution}

FR-COR (found on one occasion at Fango, near Bastia).

476. Ophyiulus castanearum Verhoeff, 1930

\section{Distribution}

IT-ITA (Tuscany and Piedmont).

\section{Habitat}

Castanea and Robinia forests, gorge with Quercus laurifolia, bushland.

477. Ophyiulus cerii Verhoeff, 1942

\section{Distribution}

IT-ITA (Island of Capri).

\section{Ophyiulus chilopogon (Latzel, 1884)}

Iulus chilopogon Latzel, 1884.

Iulus barbatus Verhoeff, 1908.

Iulus holdhausi Attems, 1908.

Ophyiulus barbatus auct.

\section{Distribution}

FR-COR, IT-ITA (Tuscany, Emilia-Romagna).

\section{Habitat}

A wide range of open and closed habitats, including grassland, sward by the sea, limestone cliffs, maquis; deciduous, evergreen and coniferous forests: Castanea, Quercus, Pinus, Eucalyptus, with Ilex, Ruscus, Helleborus, Rubus, ferns and xerophytic vegetation. In litter, soil, under wood and stones. Up to well above $1000 \mathrm{~m}$.

\section{Remarks}

Mauriès (1969b) clarified the synonymy of barbatus with chilopogon.

479. Ophyiulus collaris Verhoeff, 1930

Ophiiulus collaris Verhoeff, 1930.

\section{Distribution}

IT-ITA (Veneto). 


\section{Habitat}

Scree hill, under litter.

480. Ophyiulus corsicus Verhoeff, 1943

\section{Distribution}

FR-COR (found once, at Pietracorbara).

481. Ophyiulus curvipes (Verhoeff, 1898)

Julus (Leptoiulus) fallax curvipes Verhoeff, 1898.

\section{Distribution}

AT, BA, HR, IT-ITA, SB, SI.

\section{Habitat}

Karst.

482. Ophyiulus germanicus (Verhoeff, 1896)

Julus germanicus Verhoeff, 1896.

Ophyiulus strandi Attems, 1927.

\section{Distribution}

DE, ES-SPA, IT-ITA (mainly apennine from Campania to Liguria).

\section{Habitat}

Woodland with Castanea, Quercus, Carpinus, Corylus, Fraxinus, Hedera, Clematis, Rubus. Collected at 14-1600 m at Mt Turbon, Huesca, Spain (M. and G. Osella leg., H. Enghoff det.).

\section{Remarks}

Despite its name, this species has only very recently been recorded from Germany, where it is obvioiusly introduced (Decker \& Hannig 2011).

483. Ophyiulus italianus Attems, 1927

\section{Distribution}

IT-ITA (Gargano Peninsula, Apulia).

\section{Ophyiulus jeekeli Strasser, 1974}

\section{Distribution}

IT-SAR

\section{Remark}

Possibly a synonym of $O$. lostiae Silvestri, 1898.

485. Ophyiulus lostiae Silvestri, 1898

Ophiiulus lostiae Silvestri, 1898. 


\section{Distribution}

IT-SAR.

Remark

Might include $O$. jeekeli.

486. Ophyiulus macchiae Verhoeff, 1930

\section{Distribution}

IT-ITA (Tuscany).

\section{Habitat}

Maquis, apparently coastal.

\section{Remark}

Verhoeff (1935) stated that it is endemic on Mt Argentario; there appear, however, to be other references to the Tuscan coast.

487. Ophyiulus minimus Strasser, 1958

Ophiiulus minimus Strasser, 1958.

\section{Distribution}

IT-ITA (Lazio, Alban Hills south of Rome).

\section{Habitat}

In Castanea woodland, under leaf litter, 370-900 m.

488. Ophyiulus muelleri Strasser, 1937

Ophiiulus mülleri Strasser, 1937.

\section{Distribution}

IT-ITA (Veneto).

\section{Habitat}

In leaf litter, mostly Fagus. 430-550 m.

489. Ophyiulus napolitanus (Attems, 1903)

Julus napolitanus Attems, 1903.

Ophyiulus glandulosus Verhoeff, 1910.

\section{Distribution}

FR-COR, IT-ITA (Campania).

490. Ophyiulus nigrofuscus (Verhoeff, 1894)

Julus nigrofuscus Verhoeff, 1894. 


\section{Distribution}

AT, CH, DE, IT-ITA. East-central Alps (Vorarlberg-Nordtirol, Engadine, Allgäu, Tre Venezie).

\section{Habitat}

Eurytopic in forest, pastures and alpine meadows but almost entirely between $1000 \mathrm{~m}$ and $2900 \mathrm{~m}$, chiefly alpine and subalpine. Regarded as highly endangered in Germany (Voigtländer et al. 2011).

\section{Ophyiulus osellai Strasser, 1970}

\section{Distribution}

IT-ITA.

\section{Habitat}

Alpine; from $2000 \mathrm{~m}$, reaching $2458 \mathrm{~m}$ on Monte Gorzano in the Apennines.

\section{Ophyiulus pilosus (Newport, 1842)}

Iulus pilosus Newport, 1842.

Julus longabo C.L. Koch, 1847.

Iulus fallax Meinert, 1868.

Ophyiulus major Bigler, 1920.

Ophyiulus fallax auct.

Ophyiulus fallax major auct.

Leptoiulus fallax minor Verhoeff, 1908.

Ophyiulus fallax lobatus Attems, 1927.

\section{Distribution}

AT, BA, CH, CZ, DE, DK-DEN, FR-FRA, GB-CI, GB-GRB, GB-NI, IT-ITA, HR, HU, IE, NL, NONOR, PL, RO, RU-KGD, SE, SI, SK. An unusual distribution in mainly Central Europe, Britain, Ireland and southern Scandinavia. - Also introduced into New Zealand and North America.

\section{Habitat}

It has been found in a wide variety of habitats but shows a preference for humid deciduous woodland (Blower 1985) often beside lakes and rivers (Pedroli-Christen 1993): Alnus woods, boggy ground. In dune-slacks, wetland behind coastal dunes, often wooded. Found under stones in meadows and parks. Sometimes in caves (Blower \& Gabutt 1964; Blower \& Miller 1974).

\section{Remarks}

Ophyiulus major Bigler, 1920 has been regarded as a subspecies or synonym of pilosus by several authors, e.g., Attems (1927, as O. fallax lobatus) and Pedroli-Christen (1993). Due to difficulties in distinguishing major from 'true' pilosus the map combines records of both nominal taxa. Specific records of major are available from Switzerland (Bigler's original locus typicus), Germany (southern Bavaria), Austria and Slovenia as well as the northern half of Italy and Croatia. It would be useful if genetic studies were performed on this group in order to settle the synonymy. The proposed separate taxa are sympatric in Central Europe. While O. pilosus s.s. is very common in Britain and Ireland, in northern France it has been found only in damp woodland immediately behind the dunes in the Pas de Calais and Somme departments. There are similar records from the Netherlands but it has not yet been recorded from inland France or anywhere in Belgium. The very unusual distribution of Ophyiulus pilosus may partly relate to its pioneering abilities, as revealed in the New World. 
493. Ophyiulus renosensis Mauriès, 1969

\section{Distribution}

FR-COR.

\section{Habitat}

High mountain species found from beechwoods (Fagus) at $1200 \mathrm{~m}$ up to $2200 \mathrm{~m}$ on Monte Renoso.

494. Ophyiulus rubrodorsalis (Verhoeff, 1900)

Julus (Leptoiulus) rubrodorsalis Verhoeff, 1900.

\section{Distribution}

CH, IT-ITA. Southern Central Alps of Ticino and Lombardy.

\section{Habitat}

Thermophile forests, abandoned fields and coppices at low altitude around 200-400 m, but it does reach $1080 \mathrm{~m}$ on warm slopes (Pedroli-Christen 1993). Frequent in the litter of Castanea woods in Lombardy.

495. Ophyiulus sardus Attems, 1927

Ophiulus sardus Attems, 1927.

\section{Distribution}

IT-SAR.

\section{Habitat}

One record from a cave at Arizzo.

496. Ophyiulus solitarius Bigler, 1929

\section{Distribution}

$\mathrm{CH}$ (Engadine).

\section{Habitat}

Alpine.

\section{Remarks}

The description of this species was based on a single male from the Engadine. Pedroli-Christen (1993) suggested that it may relate to a gonopod variation of the extremely similar $O$. nigrofuscus which occurs in the area.

497. Ophyiulus spezianus Verhoeff, 1936

\section{Distribution}

IT-ITA (Liguria).

\section{Habitat}

Forested gorge under Castanea litter; quarry; Olea plantation, Quercus shrubbery. 


\section{Ophyiulus targionii Silvestri, 1898}

Ophiiulus targionii Silvestri, 1898.

Ophyiulus targionii verruculiger Verhoeff, 1910.

Ophyiulus verruculiger auct.

Ophyiulus fretarius Attems, 1927.

\section{Distribution}

ES-BAL, IT-ITA, IT-SI, MT. Southern and Central Italy, with islands. - Also introduced into the Australian region.

\section{Habitat}

Quercus laurifolia forest, quarry, limestone mountains, open, sunny slope. Up to $2300 \mathrm{~m}$ in Sicily. In Malta, it occurs in leaf-litter in woodland and macquis (Enghoff \& Schembri 1989). Has been found in caves (Minelli 1985).

\section{Remarks}

Quite a variable species; several subspecies have been described.

499. Ophyiulus velebiticus Attems, 1927

\section{Distribution}

HR (Velebit Mountains).

Genus Pachyiulus Berlese, 1883

Diploiulus Berlese, 1883.

Megaiulus Verhoeff, 1894.

Oxyiulus Verhoeff, 1896.

A thermophile genus found mainly in the E Mediterranean zone. Taxonomically very complicated.

500. Pachyiulus apfelbecki Verhoeff, 1901

\section{Distribution}

GR-GRC (Epirus, Central Greece and Ionian Islands).

\section{Habitat}

From sea level up to $1600 \mathrm{~m}$ on Kefallonia (Mt. Ainos).

\section{Remarks}

Pachyiulus apfelbecki was synonymised under P. varius (Fabricius, 1781) by Mauriès et al. (1997). In light of the study by Frederiksen et al. (2012) we treat $P$. apfelbecki as a separate species. See also P. flavipes (C.L. Koch, 1847), P. oenologus (Berlese, 1885) and P. varius.

\section{Pachyiulus asiaeminoris Verhoeff, 1898}

Pachyiulus oenologus auct.

Pachyiulus flavipes auct.

\section{Distribution}

GR-DOD, GR-KRI. - Also the Near East. 
Iulus cattarensis Latzel, 1884.

Pachyiulus longelobatus Attems, 1906.

Pachyiulus venetus Verhoeff, 1926.

Pachyiulus flavipes catterensis auct.

\section{Distribution}

AL, BA, BG, GR-GRC, HR, IT-ITA, MK, MN, SB, TR-TUE. - Also Asiatic Turkey.

\section{Habitat}

Forests and open areas from sea level up to $2400 \mathrm{~m}$ in the Epirus Mountains. Fagus, Quercus, Carpinus woods; pastures, meadows; limestone areas; caves, ruins, scrub, grave, under stones, litter and bark. Sometimes synanthropic.

\section{Remarks}

A common Balkan species. Recorded by Attems (1929) from "Prinkipo" which is the old name of the Island of Büyükada on the Asiatic side of the Sea of Marmara. So far this is the only record from Turkey (overlooked by Enghoff 2006).

\section{Pachyiulus dentiger Verhoeff, 1901}

\section{Distribution}

AL, GR-GRC.

\section{Habitat}

Beside Kanalakion Lake at Prevesa, $100 \mathrm{~m}$.

504. Pachyiulus flavipes (C.L. Koch, 1847)

Julus flavipes C.L. Koch, 1847.

\section{Distribution}

AL, BG, ES-BAL, FR-FRA, GR-CYC, GR-DOD, GR-GRC, GR-KRI, HR, IT-ITA, IT-SAR, IT-SI, MT, TR-TUE, UA. - Also Asiatic Turkey, Cyprus, Middle-East, Caucasus.

\section{Habitat}

Synanthropic, frequently found in towns and villages where it is often observed in large numbers climbing walls.

\section{Remarks}

A very common, expansive Ponto-Mediterranean species. Synonymised under $P$. varius by Mauriès et al. (1997). In light of the study by Frederiksen et al. (2012) we treat $P$. flavipes as a separate species. See also $P$. apfelbecki, P. oenologus (Berlese, 1885) and P. varius (Fabricius, 1781).

\section{Pachyiulus humicola Verhoeff, 1910}

\section{Distribution}

IT-SIC. 
Julus hungaricus Karsch, 1881.

\section{Distribution}

AL, BA, BG, GR-GRC, HR, MK, MN, RO, SB. Carpathian-Balkan.

\section{Habitat}

Chiefly deciduous (Fagus, Quercus, Carpinus) but also mixed and coniferous (Pinus, Picea and Abies) forests up to an altitude of at least $1500 \mathrm{~m}$. It was found at the top of the tree zone on Mt Ljubeten. Collected under stones and in rotting wood. Also climbing trees at Avala Mt in Serbia, up to $3 \mathrm{~m}$. It frequents open scrub and grassland habitats and has been found in caves.

\section{Remarks}

A common Balkan species. Kondeva (1998) studied its feeding biology.

\section{Pachyiulus marmoratus Verhoeff, 1901}

\section{Distribution}

GR-GRC.

\section{Habitat}

Koras Mt, below Quercus trees.

508. Pachyiulus oenologus (Berlese, 1885)

Iulus oenologus Berlese, 1885.

\section{Distribution}

FR-COR, IT-ITA, IT-SI.

\section{Habitat}

Deciduous forest.

\section{Remarks}

Pachyiulus oenologus was synonymised under P. varius by Mauriès et al. (1997). In light of the study by Frederiksen et al. (2012) we treat P. oenologus as a separate species. See also P. apfelbecki, P. flavipes and $P$. varius.

509. Pachyiulus silvestrii Verhoeff, 1923

\section{Distribution}

IT-ITA (Campania).

\section{Distribution}

GR-GRC. 
511. Pachyiulus valonensis Verhoeff, 1901

\section{Distribution}

AL, GR-GRC.

512. Pachyiulus varius (Fabricius, 1781)

Iulus varius Fabricius, 1781.

Julus nigripes C.L. Koch, 1847.

Julus unicolor C.L. Koch, 1847.

\section{Distribution}

AL, BA, BG, FR-FRA, GR-GRC, HR, IT-ITA, MK, MN, RO, SB, SI, TR-TUE. - Also Georgia.

\section{Habitat}

Common on karst. Collected from forest litter and rotting wood. Several records from caves.

\section{Remarks}

Pachyiulus varius is the oldest available name for a group of species which are notoriously difficult to distinguish. Mauriès et al. (1997) provided a good discussion of the problem and synonymised several other nominal species under P. varius. Recent studies by Frederiksen et al. (2012) suggest, however, that there are several species hiding under $P$. varius sensu Mauriès et al. (1997). We therefore treat P. apfelbecki, P. flavipes and $P$. oenologus as separate species, although we realize that additional studies may yet change the picture. Numerous infraspecific forms have been named within the complex - their status is largely unresolved.

Genus Pachypodoiulus Verhoeff, 1901

513. Pachypodoiulus eurypus (Attems, 1895)

Iulus eurypus Attems, 1895.

\section{Distribution}

AT, CZ, DE, HU. Eastern Alps and Bohemian hills.

\section{Habitat}

Largely subalpine in damp or wet woods, bogs and swampy ground. Often found in decaying wood, also in litter among rocks (Richter 1967).

Genus Parastenophyllum Verhoeff, 1899

514. Parastenophyllum frondicola (Verhoeff, 1899)

Julus frondicola Verhoeff, 1899.

\section{Distribution}

RO (Caras-Severin, Mehedinti, Braşov \& Suceava Provinces).

\section{Habitat}

Deciduous forests. 
Genus Pteridoiulus Verhoeff, 1913

515. Pteridoiulus aspidiorum Verhoeff, 1913

\section{Distribution}

AT, DE, SI. East Alpine.

\section{Habitat}

Upper montane and subalpine woods; also alpine (far above the tree line in Slovenia). The type series was taken in a conifer forest under moss and Aspidium ferns. Most data are from the "Kalkalpen", limestone mountains.

\section{Remarks}

The several records from Germany are limited to the Alps near the Königsee in Bavaria.

Genus Rhamphidoiulus Attems, 1905

516. Rhamphidoiulus bujukderensis Attems, 1905

\section{Distribution}

TR-TUE (Büyükdere on the west side of the Bosporus).

Genus Rhodopiella Strasser, 1966

\section{Rhodopiella beroni (Strasser, 1966)}

Apfelbeckiella beroni Strasser, 1966.

Mesoiulus bulgaricus Gulička, 1967.

\section{Distribution}

BG, GR-GRC, MK. East Balkan.

\section{Habitat}

Caves in Greece, Macedonia, the Danubian Plain and the Rhodope Mountains of Bulgaria (ssp. beroni), and in the Strandzha Mountains (ssp. saetigera).

Genus Rossiulus Attems, 1926

Sarmatiulus Lohmander, 1927.

518. Rossiulus kessleri (Lohmander, 1927)

Schizophyllum kessleri Lohmander, 1927.

Rossiulus strandi Attems, 1927.

Sarmatiulus kessleri auct.

\section{Distribution}

BY, RU-RUC, RU-RUE, RU-RUN, RU-RUS, UA. East European.

\section{Habitat}

Forest, forest-steppe and northern steppe zones of Russia and Belarus in a wide variety of habitats, e.g., primary oak forest, mixed forest, pine forest, flood-plain forest, meadows, agricultural land, limestone 
denudations, calciphytic Stipa steppe with Thymus, Hyssopus and Artemisia. Abundant and often predominating in diplopod communities of both natural and anthropogenic habitats (Striganova 1996).

\section{Remarks}

This calciphilous subendemic of the Russian plain ranges from Central Belarus in the west to the regions of Bashkir and Orenburg in the east and from the Archangelsk region in the north (northernmost record: Severnaya Dvina River delta N of Archangelsk) southwards to Dagestan, beyond our European frontier.

Prisnyi (2001) gave ecological details and showed a map suggesting a disjunct distribution based on the large river valley systems in the nemoral belt (Dnieper, Don, Volga). He described new varieties of the species and stated that these show increasing body miniaturisation and tegument sclerotisation towards the hotter and dryer south-east. The variety stepposa approaches Rossiulus vilnensis (Jawłowski, 1925) in the form of the opisthomerite and, as the two species occur together in Belarus, Prisnyi suggests that the status of the latter remains to be confirmed. Striganova (1996) studied the life cycle and reproductive strategy of R. kessleri.

\section{Rossiulus vilnensis (Jawłowski, 1925)}

Schizophyllum vilnense Jawłowski, 1925.

\section{Distribution}

BY, CZ, DE, EE, LT, LV, PL, RU-KGD. (North) Central European.

\section{Habitat}

Moist and wet habitats, river valleys; lush meadows, hayfields, heaths, swamps, bogs, inundation forests - Alnus woods, e.g., Medio-European stream ash-alder wood (Fraxino-Alnetum), Glutinosaabietum, Populus woodland.

Genus Rumaniulus Attems, 1926

520. Rumaniulus mammosus Attems, 1927

\section{Distribution}

RO (Cluj Province).

\section{Habitat}

Garden in Cluj City, otherwise in forest.

Genus Serboiulus Strasser, 1962

Balkaniulus Gulička, 1967.

\section{Serboiulus deelemanni Strasser, 1971}

Serboiulus lucifugus deelemanni Strasser, 1971.

\section{Distribution}

SB (Vlaška Planina).

\section{Habitat}

Cavernicolous. 


\section{Remarks}

Upgraded to full species by Makarov et al. (2005).

522. Serboiulus kresnik Makarov, 2013

\section{Distribution}

SB (Mt. Tupižnica).

\section{Habitat}

Cavernicolous.

523. Serboiulus lucifugus Strasser, 1962

\section{Distribution}

SB (Svrljiške Planine Mts).

\section{Habitat}

Cavernicolous.

524. Serboiulus spelaeophilus Gulička, 1967

Serboiulus popovi Strasser, 1969.

\section{Distribution}

BG, SB (Western Stara Planina and Danubian plain).

\section{Habitat}

Cavernicolous.

Genus Stenophyllum Verhoeff, 1897

525. Stenophyllum hermannimuelleri Verhoeff, 1897

\section{Distribution}

RO (Eastern Carpathians).

\section{Habitat}

Litter of deciduous forests.

526. Stenophyllum primitivum Verhoeff, 1897

\section{Distribution}

RO.

\section{Habitat}

Under decomposing, moist leaf litter in a bush grove. 
527. Stenophyllum semenicense Ceuca, 1989

\section{Distribution}

RO (Western Carpathians, Semenic Mountains).

\section{Habitat}

Mixed forest.

528. Stenophyllum tabacarui Vanoaica, 2003

\section{Distribution}

RO (Eastern Carpathians, Braşov Province).

\section{Habitat}

Trogloxene, known only from a small cave near Vârghişului.

Genus Styrioiulus Verhoeff, 1928

529. Styrioiulus pelidnus (Latzel, 1884)

Iulus pelidnus Latzel, 1884.

Enantiulus pelidnus auct.

\section{Distribution}

AT, BA, HR, HU, IT-ITA, SI. Mainly East Alpine.

\section{Habitat}

Fagus and Larix woods, records in Slovenia from 1200 to 1700 m (Strasser 1940).

\section{Remarks}

Records from N Tirol (AT) shown on the map were disputed by Thaler et al. (1993).

\section{Styrioiulus styricus (Verhoeff, 1896)}

Iulus styricus Verhoeff, 1896.

Leptophyllum styricum auct.

Metaleptophyllum styricum auct.

\section{Distribution}

AT (Steiermark County), HU (Zala County).

\section{Habitat}

Fagus woodland in Hungary.

\section{Remarks}

A rare species occasionally found in the mountainous country around Graz in Austria and found only once in Hungary at Balatongyörök on Meleg Hill in the Keszthely Mountains. 
Genus Symphyoiulus Verhoeff, 1898

531. Symphyoiulus impartitus (Karsch, 1888)

Iulus impartitus Karsch, 1888.

Iulus postsquamatus Verhoeff, 1898.

Symphyoiulus densestriatus Verhoeff, 1941.

\section{Distribution}

GR-GRC. - Also Asiatic Turkey (Anatolia).

\section{Habitat}

Pinus halepensis forest with a shrub layer of Quercus coccifera, Phillyrea media and Arbutus unedo (Karamaouna 1992). Found on an open field under rosettes of Verbascum in western Anatolia.

Genus Syniulus Strasser, 1974

Paratyphloiulus Mauriès, 1983, validation of Paratyphloiulus Ceuca, 1971, proposed without a type species.

\section{Syniulus bolivari (Ceuca, 1971)}

Paratyphloiulus bolivari Ceuca, 1971.

\section{Distribution}

ES-SPA (Tarragona Province, Cambra Cave near the summit of Mola de Cati Mt).

\section{Habitat}

Cavernicolous.

533. Syniulus lagari (Ceuca, 1971)

Paratyphloiulus lagari Ceuca, 1971

\section{Distribution}

ES-SPA (Barcelona Province, caves at Sant Pau de Ordal and Esparraguera).

\section{Habitat}

Cavernicolous.

534. Syniulus puddui Strasser, 1974

\section{Distribution}

IT-SAR

\section{Habitat}

Cavernicolous. 
Genus Syrioiulus Verhoeff, 1914

535. Syrioiulus andreevi Mauriès, 1984

\section{Distribution}

GR-CYC (Paros Isl.).

\section{Habitat}

Marble quarry and cave at Marathi.

Genus Tachypodoiulus Verhoeff, 1893

Ischiolobus Attems, 1951.

536. Tachypodoiulus niger (Leach, 1814)

Julus niger Leach, 1814.

Julus albipes C.L. Koch, 1838.

Ischiolobus niger Attems, 1951.

Ommatoiulus (Phylommatoiulus) montanus Ceuca, 1974.

Tachypodoiulus albipes auct.

\section{Distribution}

AT, BE, CH, CZ, DK-DEN, DE, ES-SPA, FR-FRA, GB-CI, GB-GRB, GB-NI, IE, LU, NL. Extended Atlantic.

\section{Habitat}

Eurytopic and generally very common throughout its range, with large population densities in woodland, especially on limestone, while it is found on most other types of soil as well. It is very scarce on peaty soils, rare or absent from polders in Holland and Belgium. In some areas it is markedly associated with forest and hedges. In Britain, however, the very large bank of records does not particularly confirm this (Lee 2006); perhaps owing to its abundance, it is found in many different habitats. It readily climbs trees and often shelters under dead bark. It has been trapped high above the ground and has even been found in Malaise traps.

\section{Remarks}

North of the Mediterranean zone it is one of the most abundant millipedes in Western Europe. While it occurs in the north of Spain and the French Pyrenees, it appears to be uncommon or missing from low ground in the warmer parts of southern France (Mauriès, pers. comm.). Its southern limits are all in the mountains. A very active species, easily observed and thus one of the most recorded species in Western Europe.

Genus Telsonius Strasser, 1976

537. Telsonius nycteridonis Strasser, 1976

\section{Distribution}

GR-GRC (Chalkidiki).

\section{Habitat}

Cavernicolous. In a bat cave near Petralona. 
Genus Titanophyllum Akkari, Stoev \& Enghoff, 2011

538. Titanophyllum spiliarum Akkari, Stoev \& Enghoff, 2011

\section{Distribution}

GR-GRC (Magnesia, Othri Mts).

\section{Habitat}

Cavernicolous, collected at the bottom of a vertical shaft.

\section{Genus Trogloiulus Manfredi, 1931}

A genus of Italian endemic cavernicolous species. Most sites are listed in Minelli (1985).

539. Trogloiulus binii Enghoff, 1985

\section{Distribution}

IT-ITA (Lombardia).

\section{Habitat}

Cavernicolous, found in very muddy places (Enghoff 1985a).

\section{Remarks}

Its mouthparts are modified (reduced biting parts, hypertrophied pectinate lamellae), like those of T. vailatii Strasser, 1978 and some species of Typhoiulus, probably an adaptation to living in very wet places (Enghoff 1985b).

\section{Trogloiulus boldorii Manfredi, 1940}

Trogloiulus tamaninii Verhoeff, 1941.

\section{Distribution}

IT-ITA (Lombardia, Veneto).

\section{Habitat}

Mainly caves, including artificial galleries (Enghoff 1985a), but also found in deep soil outside caves (Strasser 1977).

\section{Trogloiulus comensis Strasser, 1977}

\section{Distribution}

IT-ITA (Lombardia).

\section{Habitat}

Cavernicolous.

\section{Distribution}

IT-ITA (Trento). 


\section{Habitat}

Cavernicolous.

543. Trogloiulus minimus Manfredi, 1935

\section{Distribution}

IT-ITA (Lombardia).

\section{Habitat}

Cavernicolous, also found under rotten wood in an artificial gallery (Enghoff 1985a).

544. Trogloiulus mirus Manfredi, 1931

\section{Distribution}

IT-ITA (Lombardia).

\section{Habitat}

Cavernicolous.

545. Trogloiulus osellai Strasser, 1977

\section{Distribution}

IT-ITA (Lombardia).

\section{Habitat}

Under deeply imbedded stones.

546. Trogloiulus vailatii Strasser, 1978

\section{Distribution}

IT-ITA (Lombardia, cave at Serle, Cariadeghe).

\section{Habitat}

Cavernicolous. Strasser (1978b) cited the notes of the collector, D. Vailati: "the millipedes were collected in an active meander in the abovementioned cave, called 'branch of the waterfalls' because of the presence of many waterfalls. The waterfalls change, in periods of little flow, into a film of water running over the vertical parts of the canal excavated in the rock. When collected, the adult diplopods were heading upstream, covered by at least a couple of millimetres of water, whereas the juvenile stadia could be found at the sides, where only the spray was reaching" (translated from Italian).

\section{Remarks}

Its mouthparts are modified like those of T. binii (q.v.).

Genus Typhloiulus Latzel, 1884

Haploprotopus Verhoeff, 1899.

Spelaeoblaniulus Ceuca, 1956.

Spelaeoiulus Strasser, 1962. 
A large genus of cavernicolous species from Italy, Hungary and especially the Balkans; while most are troglobionts a few may be found above the ground as well.

\section{Typhloiulus acutunguis Ceuca, 1979}

Typhloiulus actunguis auct. (lapsus calami).

\section{Distribution}

RO (Vladeasa Mountain Range, Cluj Province).

\section{Habitat}

Coniferous woodland.

Remark

A dubious species, known only from one female specimen.

548. Typhloiulus albanicus Attems, 1929

\section{Distribution}

MK, SB.

\section{Habitat}

Cavernicolous and above ground (Fagus forest.)

\section{Remarks}

Attems (1929) gave Kačanik, Ljubeten and Cviljen as localities in Albania. Kačanik is in southern Kosovo, the Ljubeten is a mountain south-west of Kačanik whose summit is on the border with Macedonia and Cviljen is a mountain south of Prizren in Kosovo further west. While Cviljen is only about $10 \mathrm{~km}$ from the border, no Albanian record has come to light. The only certain records are from Serbia and Macedonia. Makarov et al. (2004) gave details and a map of distribution.

549. Typhloiulus ausugi Manfredi, 1953

\section{Distribution}

IT-ITA (Veneto, Venezia Tridentina, Friuli-Venezia Giulia).

\section{Habitat}

Cavernicolous. There are indications that it prefers very wet caves. Its mouthparts are modified like those of Trogloiulus binii (q.v.), Typhloiulus edentulus and T. serbani, probably an adaptation to living in very wet places (Enghoff 1985b).

\section{Remarks}

Strasser (1971) described two subspecies of T. ausugi.

550. Typhloiulus beroni Mauriès, Golovatch \& Stoev, 1997

\section{Distribution}

AL (Korcë District, Pustec). 


\section{Habitat}

Found in an artificial gallery.

\section{Typhloiulus bosniensis Strasser, 1966}

\section{Distribution}

BA (Bosnia, Govednica Cave at Banja Stijena).

\section{Habitat}

Cavernicolous.

552. Typhloiulus bureschi Verhoeff, 1926

\section{Distribution}

BG (Stara Planina and Predbalkan).

\section{Habitat}

Cavernicolous.

\section{Remarks}

Found in a large number of caves situated between $250 \mathrm{~m}$ and $830 \mathrm{~m}$ above sea level (Vagalinski \& Stoev 2007).

\section{Typhloiulus carniolensis Strasser, 1940}

\section{Distribution}

SI.

\section{Habitat}

Discovered in Fagus forest under deeply embedded stones, $750 \mathrm{~m}$.

554. Typhloiulus edentulus Attems, 1951

\section{Distribution}

BA (Hercegovina, Vjetrenica Cave on the Popovo Polje, and Dolnja Pećina Cave in Kijev Do).

\section{Habitat}

Cavernicolous.

\section{Remarks}

The mouthparts of this species are modified like those of Trogloiulus binii (q.v.).

555. Typhloiulus ganglbaueri (Verhoeff, 1898)

Julus ganglbaueri Verhoeff, 1898.

Haploprotopus gangbaueri auct.

\section{Distribution}

IT-ITA, HR, MN. 


\section{Habitat}

Under stones.

\section{Remark}

The inclusion of this species in the Italian checklist by Foddai et al. (1995) is based on an otherwise unpublished find at a riverbank near Veggiano, Padova (M.G. Paoletti leg., H. Enghoff det.).

556. Typhloiulus gellianae Makarov \& Rađa, 2006

\section{Distribution}

HR.

\section{Habitat}

Cavernicolous.

\section{Typhloiulus georgievi Strasser, 1962}

\section{Distribution}

BG (Predbalkan).

\section{Habitat}

Cavernicolous.

\section{Remarks}

Known from four caves.

558. Typhloiulus giganteus Ćurčić \& Makarov, 2002

\section{Distribution}

MK (Momiček Cave in Dautica Mountain north-east of Makedonski Brod).

\section{Habitat}

Cavernicolous.

\section{Typhloiulus hauseri Strasser, 1974}

\section{Distribution}

GR-GRC (Kephalonia, Peloponnese).

\section{Habitat}

Not in caves, found near a beach and in a gorge.

\section{Typhloiulus illyricus Verhoeff, 1929}

Typhloiulus illyricus stygis Verhoeff, 1933.

\section{Distribution}

HR, SI. 


\section{Habitat}

Troglobiont. The subspecies stygis was found in a very wet cave.

561. Typhloiulus incurvatus Verhoeff, 1899

\section{Distribution}

BA (Hercegovina), SB.

\section{Habitat}

Fagus forest, in litter. A cave in Serbia (Antić et al. 2013).

562. Typhloiulus insularis Strasser, 1938

\section{Distribution}

HR (Cres Island, cave at Petrićevi).

\section{Habitat}

Cavernicolous.

563. Typhloiulus kotelensis Jawłowski, 1938

\section{Distribution}

BG (Eastern Stara Planina and Sredna Gora Mts).

\section{Habitat}

Forest: quoted from Fagus sylvatica, Quercus petraea, Q. cerris, Q. dalechampii, Carpinus orientalis. There is one cave listed (Vagalinski \& Stoev 2007).

\section{Typhloiulus lobifer Attems, 1951}

\section{Distribution}

HR (Brač Island, Jama Žejava).

\section{Habitat}

Cavernicolous.

\section{Typhloiulus longinquus Strasser, 1966}

\section{Distribution}

IT-ITA (Lazio, Abruzzi-Molise).

\section{Habitat}

Quoted from caves in the provinces of Pescara and Roma (Minelli 1985).

566. Typhloiulus longipes Strasser, 1973

\section{Distribution}

BG (Stara Planina). 


\section{Habitat}

Cavernicolous.

\section{Remarks}

Known from Belyar Cave situated at $860 \mathrm{~m}$ in the Vrachanska Planina, and possibly from a second location (Vagalinski \& Stoev 2007).

\section{Typhloiulus maximus Verhoeff, 1929}

\section{Distribution}

IT-ITA (Tre Venezie).

\section{Habitat}

Cavernicolous, but also found outside caves on a few occasions (Strasser 1962).

\section{Typhloiulus montellensis Verhoeff, 1930}

\section{Distribution}

IT-ITA (Treviso Province in Veneto).

\section{Habitat}

Cavernicolous.

\section{Typhloiulus motasi Tabacaru \& Gava, 1992}

\section{Distribution}

RO.

\section{Habitat}

In soil in Quercus forest.

570. Typhloiulus nevoi Makarov, Mitić \& Ćurčić, 2002

\section{Distribution}

SB (known from few caves in Odorovci Karst Field, between Vidlič and Stara Planina).

\section{Habitat}

Cavernicolous.

571. Typhloiulus polypodus (Loksa, 1960)

Allotyphloiulus polypodus Loksa, 1960.

Allotyphloiulus bükkensis Loksa, 1962.

Cylindroiulus polypodus auct.

\section{Distribution}

HU (Bükk Mts).

\section{Habitat}

Cavernicolous. 


\section{Remarks}

See Korsós (1994) for a discussion of this poorly known species.

572. Typhloiulus psilonotus (Latzel, 1884)

Iulus psilonotus Latzel, 1884.

\section{Distribution}

BA, HR, MN (S Dalmatia, S Hercegovina, W Montenegro).

\section{Habitat}

Coastal regions under stones, in Quercus woods and Olea groves.

\section{Typhloiulus sculterorum Brölemann, 1905}

\section{Distribution}

FR-FRA (Alpes Martimes).

\section{Habitat}

Deep in the soil under stones and logs in humid ravines.

\section{Typhloiulus serbani (Ceuca, 1956)}

Spelaeoblaniulus serbani Ceuca, 1956.

Spelaeoblaniulus serbani unilineatus Ceuca, 1961.

Typhloiulus (Spelaeoiulus) serbani auct.

\section{Distribution}

RO (Apuseni Mts).

\section{Habitat}

Cavernicolous.

\section{Typhloiulus serborum Ćurčić \& Makarov, 2005}

\section{Distribution}

SB

\section{Habitat}

Known from several caves in eastern Serbia, as well as one site outside cave, under a huge stone on Svrljiske Planine (Antić et al. 2013).

576. Typhloiulus staregai Strasser, 1973

\section{Distribution}

BG (W Stara Planina).

\section{Habitat}

Only known from the Prelaz Cave near Salas, at $1050 \mathrm{~m}$. 
Iulus strictus Latzel, 1882.

\section{Distribution}

BG, RO, SB. Carpathian-Balkan.

\section{Habitat}

Often in deep leaf litter or in the humus of forests, particularly noted from Quercus woodland. Endogeic and troglophile, widespread in caves in the region indicated on the map.

\section{Typhloiulus tobias (Berlese, 1886)}

Iulus tobias Berlese, 1886.

\section{Distribution}

IT-ITA (Tre Venezie).

\section{Habitat}

Cavernicolous, but also found outside caves on a few occasions (Strasser 1962).

\section{Typhloiulus uncinifer Strasser, 1974}

\section{Distribution}

GR-GRC (Cephalonia Island).

\section{Habitat}

Not in a cave.

\section{Remarks}

A dubious species, known only from a juvenile. Akkari et al. (2011) suggested that the species may be related to Titanophyllum spiliarum.

Genus Unciger Brandt, 1841

Oncoiulus Verhoeff, 1899.

580. Unciger foetidus (C.L. Koch, 1838)

Julus foetidus C.L. Koch, 1838.

Oncoiulus foetidus auct.

\section{Distribution}

AT, BA, CH, CZ, DE, DK-DEN, EE, FI, GB-GRB, HR, HU, IT-ITA, LT, LV, NL, NO-NOR, PL, RO, RU-KGD, SB, SE, SI, SK, UA. Central European, extending northwards.

\section{Habitat}

Hygrophile. Closed, undisturbed deciduous forests (Laźanyi \& Korsós, 2009). Recorded in old Quercus woodland and also in Fagus, Fraxinus, Carpinus, Castanea, Tilia, Alnus, Acer. Also recorded from Pinus forest. In beechwood (Fagus) up to $1100 \mathrm{~m}$ in Slovenia (Strasser 1940). Found on afforested 
colliery spoil heaps with garden rubbish (Decker \& Hannig 2010). Common in gardens (Schubart 1934). Synanthropic, particularly in the north. Common in gardens (Schubart 1934).

\section{Remarks}

Thaler (1989) reported on a mass occurrence in Innsbruck, Austria. In the introduction to this volume we have indicated the ubiquity of $U$. foetidus in Central Europe and here we draw attention to the range shown on the map. The two imprecise records are from districts for which we have no precise record.

\section{Unciger transsilvanicus (Verhoeff, 1899)}

Oncoiulus foetidus transsilvanicus Verhoeff, 1899.

\section{Distribution}

AT, BG, CZ, HU, MD, PL, RO, RU-RUS, SB, SK, UA. Central European. Also found in Stavropol, northern Caucasus, Russia (Zuev 2014).

\section{Habitat}

Broad-leaved forest: Fagus sylvatica, Quercus sp. Open meadowland and alpine grassland up to $1900 \mathrm{~m}$. Genus Xestoiulus Verhoeff, 1893

Microiulus Verhoeff, 1895.

\section{Xestoiulus bjelasnicensis (Verhoeff, 1898)}

Iulus bjelasnicensis Verhoeff, 1898.

Microiulus bjelasnicensis auct.

\section{Distribution}

BA, HR. West Balkan.

\section{Xestoiulus carpathicus (Verhoeff, 1907)}

Iulus carpathicus Verhoeff, 1907.

Microiulus carpathicus auct.

\section{Distribution}

PL, SK. Northern Carpathians.

\section{Habitat}

Cave entrance.

\section{Distribution}

HR (Biokovo).

\section{Habitat}

Valleys and a cave. 
585. Xestoiulus fimbriatus (Attems, 1904)

Julus (Femoriferus) fimbriatus Attems, 1904.

Microiulus fimbriatus auct.

\section{Distribution}

HR (Dalmatia: Dubrovnik).

586. Xestoiulus fontisherculis (Verhoeff, 1899)

Iulus fontisherculis Verhoeff, 1899.

Microiulus fontisherculis auct.

Microiulus urbanskii Strasser, 1969.

\section{Distribution}

BG, RO, SB. Carpathian-Balkan.

\section{Habitat}

Leaf-litter in Fagus and Quercus forests. Meadows. From sea level to $1300 \mathrm{~m}$.

587. Xestoiulus graciliventris (Verhoeff, 1898)

Iulus graciliventris Verhoeff, 1898.

Microiulus graciliventris auct.

\section{Distribution}

BA (mountains around Sarajevo).

\section{Habitat}

Leaf litter of bushy woodland.

\section{Xestoiulus imbecillus (Latzel, 1884)}

Iulus imbecillus Latzel, 1884.

Microiulus imbecillus auct.

Leptoiulus imbecillus auct.

Iulus blanuloides Verhoeff, 1893.

Iulus Moebiusi Verhoeff, 1897.

Microiulus imbecillus obscuratus Attems, 1927.

Leptoiulus muscivagus Verhoeff, 1930.

Microiulus bezkidensis Loksa, 1967.

\section{Distribution}

AT, BA, HR, HU, IT-ITA, RO, SB, SI, UA.

\section{Habitat}

Quercus forest, Alnus and Tilia woodland. Alnus gallery along stream in Fagus forest (Korsós \& Lazányi 2008); shrub on sunny slope; between calcareous rocks.

\section{Remark}

The occurrence of this species in SK is doubtful (Mock 2001). 
Iulus laeticollis Porat, 1889.

Microiulus laeticollis auct.

Microiulus laeticollis mierzeyewskii Jawłowski, 1925.

Microiulus dudichi Verhoeff, 1927.

\section{Distribution}

BY, DE, DK-DEN, EE, HU, LT, LV, NL, PL, RO, RU-KGD, RU-RUC, RU-RUW, SE, UA.

\section{Habitat}

This millipede is particularly associated with damp habitats: Swamps and marshes, wet woodland: Fraxinus and Alnus forests and Alnus swamps (Fraxino-Alnetum, Ribeso-nigri Alnetum, AlnetumQuercetum fluvialis). Pinus woods. Meadows. Regarded as a stenotopic hygrobiont woodland species with preference for floodplains and swamp forests in Saxony-Anhalt, Germany (Voigtländer 2011). The subspecies mirzeyewskyii found in Quercus and Pinus forest in Russia (Prisnyi 2001).

\section{Remarks}

Several subspecies have been described in addition to the frequently cited ssp. mirzeyewskii.

590. Xestoiulus luteus (Attems, 1951)

Microiulus luteus Attems, 1951.

\section{Distribution}

BA (Brataljevića Cave, Kladanj), SB.

591. Xestoiulus pirinicus (Gulička, 1967)

Microiulus pirinicus Gulička, 1967.

\section{Distribution}

BG (Pirin Mountains, Demyanitsa Valley).

592. Xestoiulus rebeli (Attems, 1904)

Iulus rebeli Attems, 1904.

Microiulus rebeli auct.

\section{Distribution}

BG (E Stara Planina, near Sliven).

\section{Xestoiulus rucneri (Ceuca, 1990)}

Microiulus rucneri Ceuca, 1990.

\section{Distribution}

HR (Hvar Isl.). 


\section{Acknowledgements}

The production of this atlas has been a team effort. As stated in 'A Provisional Atlas of European Myriapods' (Kime 1990) the decision to prepare it was taken at the Fourth International Congress of Myriapodology as long ago as 1978, and later it received the full backing of the European Invertebrate Survey.

The network of myriapodologists who have contributed to this atlas has been organised from Paris by the Centre International de Myriapodologie, run over the years by Dr J.-M. Demange, Dr J.-P. Mauriès, Dr M. Nguyen Duy-Jacquemin and Dr J.-J. Geoffroy. They produced an annual bulletin in Paris and world congresses have been held in different countries every three years since the second one in 1972. The first was in Paris in 1968. Furthermore, they have welcomed visits to Paris on many occasions, giving access to their extensive library and providing a wealth of data. Dr Mauriès has taken time to identify specimens, to confirm identifications and to search the French collections for unpublished occurrences of species. There has been a most fruitful collaboration with Dr Geoffroy concerning the French and European databases for myriapods.

In the early days of the survey much support and encouragement was given by the late Dr C.P. Fairhurst of Salford University, who proposed the scheme, by the late Mr J.G. Blower of the University of Manchester and by Mr P.T. Harding MBE, in charge of the very advanced British database at the Biological Records Centre near Cambridge and successor to the late John Heath, who was a pioneer of European mapping.

In Belgium, where one of us (R.D.K.) worked from 1974 until 2004, much help was received from Professor Ph. Lebrun and Dr G. Wauthy at the Catholic University of Louvain-la-Neuve. Dr Wauthy was later at the Royal Belgian Institute of Natural Sciences, where more help was given by Dr L. Baert, Dr P. Grootaert and Dr D. Drugmand. The maps for this atlas are provided by Vincent Kalkman of the European Invertebrate Survey, Naturalis, Leiden, The Netherlands, and we cannot thank him enough for this essential contribution.

Thanks are also due to the late Mr Marc Meyer, Curator at the Natural History Museum of Luxemburg, who organised field work and provided millipedes from ecological surveys over several years and who edited Volume 1 of the Provisional Atlas (Kime 1990).

We are deeply indebted to several colleagues for detailed revisions or partial revisions of certain genera of Julidae, including Dr N. Akkari, Natural History Museum Vienna (Ommatoiulus), Dr Eszter Lazányi, Hungarian Natural History Museum, and Dr Boyan Vagalinsky, Sofia University (Megaphyllum and related genera), and Dr Helen Read, London (Cylindroiulus). Some genera, however, are still problematic, Leptoiulus in particular.

Dr Hans Reip has been an extremely valuable source of literature and provided his database. Many myriapodologists have unstintingly given their time to this project, sending a vast number of publications, unpublished data and collections of animals from the field. Many of the same persons, as well as some others, have contributed through their support to the Fauna Europaea database (Enghoff \& Kime 2009).

Dragan Antić, Dave Cheung, Katrine Mohr and Jörg Spelda provided colour photos of julidan species.

We are grateful to Dragan Antić and Sergei Golovatch for their meticulous reviews of the manuscript.

In addition to those mentioned above, contributors who have gone out of their way to provide records are listed below under their respective countries; we are greatly indebted to them all. 
Austria: J. Gruber, M. Malicky, E. Meyer, V. Stagl, the late K. Thaler

Belgium: M. Alderweireldt, M. André, E. Branquart, D. De Bakker, F. Delecour, M. Dethier, M. Dufrêne, K. Lock, L. Van Den Haute

Bulgaria: Y. Khristov, P. Stoev

Belarus: the late Y. Tarasevitch

Czech Republic: P. Kocourek, K. Tajovský, J. Tufová

Finland: the late M. Peitsalmi, M. Rantala

France: L. Chabrol, J.-F. David

Germany: the late J. Adis, W. Dunger, H.-C. Fründ, H. Hauser, P. Ploch, H. Reip - a huge amount of data, J. Spelda - also a huge amount of data, K. Voigtländer

Greece: M. Karamouna

Hungary: Z. Korsós

Iceland: E. Ólafsson

Ireland: D. Doogue

Italy: A. Minelli

Netherlands: M. Berg, the late C.A.W. Jeekel

Norway: P. Djursvoll, B. Meidell

Poland: W. Jędryczkowski, H. Tracz, J. Wytwer

Portugal: N. Akkari

Romania: the late T. Ceuca

Russia: S.I. Golovatch

Serbia: D.Ž. Antić, S.E. Makarov

Slovakia: A. Mock, S. Stašiov

Slovenia: the late N. Mršić

Spain: N. Akkari, J.L. Carballo, J.D. Gilgado, H. Reip, A. Serra, the late M.C. Vicente

Sweden: G. Andersson, U. Gärdenfors

Switzerland: A. Pedroli-Christen

Ukraine: S.I. Golovatch

United Kingdom: British Myriapod \& Isopod group, particularly A.D. Barber, A. Fowles, S. Gregory, R.E. Jones, P. Lee, J.G.E. Lewis, H.J. Read, J.P. Richards

\section{References}

Akkari N. \& Enghoff H. 2011. Copulatory-copulatory male succession and male slenderness in Ommatoiulus sempervirilis n. sp., a new insular millipede from Tunisia (Diplopoda: Julida: Julidae). Journal of Zoological Systematics and Evolutionary Research 49: 285-291. https://doi.org/10.1111/ j.1439-0469.2011.00625.x

Akkari N. \& Enghoff H. 2012. Review of the genus Ommatoiulus in Andalusia, Spain (Diplopoda: Julida) with description of ten new species and notes on a remarkable gonopod structure, the fovea. Zootaxa 3538: 1-53.

Akkari N., Stoev P. \& Enghoff H. 2011. Two new cavernicolous genera of Julidae (Diplopoda, Julida), with notes on the tribe Brachyiulini and on julid subanal hooks and anchors. Zookeys 114: 13-34. https:// doi.org/10.3897/zookeys.114.1490 
Antić D.Ž., Ćurčić B.P.M., Tomić V.T., Ćurčić S.B., Stojanović D.Z., Dudić B.D. \&. Makarov S.E. 2013. One hundred millipede species in Serbia (Arthropoda: Myriapoda: Diplopoda). Archives of Biological Sciences, Belgrade 65 (4): 1559-1578.

Attems K. 1902. Myriopoden von Kreta, nebst Beiträgen zur allgemeinen Kenntnis einiger Gattungen. Sitzungsberichte der kaiserlichen Akademie der Wissenschaften in Wien, Mathematischnaturwissenschaftliche Classe 106 (1): 1-88.

Attems C. 1927. Über palaearktische Diplopoden. Archiv für Naturgeschichte 92A: 1-256.

Attems C. 1929. Die Myriopodenfauna von Albanien und Jugoslavien. Zoologische Jahrbücher, Abteilung für Systematik 56: 269-356.

Attems C. 1944. Zwei zoogeographisch bemerkenswerte Vorkommen von Myriopoden. Zoologischer Anzeiger 144: 162-165.

Attems C. 1949. Die Myriopodenfauna der Ostalpen. Österreichische Akademie der Wissenschaften, Sitzungsberichte, Abteilung 1, Biologie, Mineralogie, Erdkunde und verwandte Wissenschaften 158 (1-2): 79-153.

Attems C. 1951. Neue Höhlen-Myriopoden, gesammelt von Professor Absolon. Anzeiger der mathematisch-naturwissenschaftlichen Klasse der Österreichischien Akademie der Wissenschaften 10: $1-6$.

Attems C. 1959. Die Myriopoden der Höhlen der Balkanhalbinsel nach dem Material des "Biospeologica balcanica". Annalen des Naturhistorischen Museums in Wien 63: 281-406.

Bailey P.T. \& De Mendonça T.R. 1990. The distribution of the millipede Ommatoiulus moreletii (Diplopoda: Julida: Julidae) in relation to other Ommatoiulus species on the south-western Iberian Peninsula. Journal of Zoology 221: 99-111. https://doi.org/10.1111/j.1469-7998.1990.tb03779.x

Baker G.H. 1984. Distribution, morphology and life history of the millipede Ommatoiulus moreletii (Diplopoda. Iulidae) in Portugal and comparisons with Australian populations. Australian Journal of Zoology 32: 811-822.

Banerjee B. 1967a. Seasonal changes of the distribution of the millipede Cylindroiulus punctatus (Leach) in decaying logs and soil. Journal of Animal Ecology 36: 171-177. https://doi.org/10.2307/3020

Banerjee B. 1967b. Diurnal and seasonal variations in the activity of the millipedes Cylindroiulus punctatus (Leach), Tachypodoiulus niger (Leach) and Polydesmus angustus Latzel. Oikos 18: 141-144. https://doi.org/10.2307/3564643

Barlow C.A. 1957. A factorial analysis of distribution in three species of diplopods. Tijdschrift voor Entomologie 100: 349-426.

Berlese A. 1882-1903. Acari, Myriopoda et Scorpiones hucusque in Italia reperta. Patavii, [Padova; Italy], Sumptibus Auctoris.

Beron P. 2008. High-altitude Isopoda, Arachnida and Myriapoda in the Old World. Bureschiana Series of Monographs. Pensoft, Sofia.

Biernaux J. 1968. Influence du taux d'humidité du sol sur la localisation en profondeur des "Iules de betterave" au cours de la bonne saison. Bulletin de la Recherche agronomique de Gembloux, N.S. 3: $234-240$.

Biernaux J. 1972. Chorologie et Étude biologique comparée de deux Families de MyriapodesDiplopodes belges: les Blaniulidae et les Iulidae. Dissertation, Faculté des Sciences Agronomiques de l'Etat, Gembloux. 
Biernaux J. \& Baurant R. 1964. Observations sur l'hibernation de Archiboreoiulus pallidus Br.-Bk. Bulletin de l'Institut Agronomique et des Stations de Recherche Gembloux 32 (3): 290-298.

Bigler W. 1929. Die Diplopodenfauna des schweizerischen Nationalparks. Ergebnisse der wissenschaftlichen Untersuchung im schweizerischen Nationalpark 5: 1-87.

Blower J.G. 1985. Millipedes. Synopses of the British Fauna (New Series) 35: 1-242.

Blower J.G. 1987. More myriapods from Brittany. Bulletin of the British Myriapod and Isopod Group 4: $37-40$.

Blower J.G. \& Gabutt P.D. 1964. Studies on the millipedes of a Devon oak wood. Proceedings of the Zoological Society of London 143: 143-176.

Blower J.G. \& Miller P.F. 1974. The life-history and ecology of Ophyiulus pilosus (Newport) in Britain. Symposia of the Zoological Society of London 32: 502-525.

Breny R. 1964. Considérations actuelles sur le problème des Iulus mouchetés en culture betteravière. Bulletin de l'Institut Agronomique et des Stations de Recherches Gembloux 32 (1): 12-25.

Breny R. \& Biernaux J. 1966. Diplopodes belges: Position systématique et biotopes. Bulletin et Annales de la Société royale d'Entomologie de Belgique 102. 269-326.

Brewer M.S. Sierwald P. \& Bond J.S. 2012. Millipede taxonomy after 250 years: Classification and taxonomic practices in a mega-diverse yet understudied arthropod group. PLoS ONE 7(5): e37240. https://doi.org/10.1371/journal.pone.0037240

Brölemann H.W. 1895. Elenco di Miriapodi raccolti in Lombardia. Bollettino della Società Entomologica Italiana 27: 79-112.

Brolemann H.W. 1921. Clef dichotomique des divisions et des espèces de la famille des Blaniulidae (Myriap.). Archives de Zoologie Expérimentale et Générale 60: 1-10.

Brolemann H.W. 1923. Biospeologica XLVIII. Blaniulidae, Myriapodes (première série). Archives de Zoologie Expérimentale et Générale 61: 99-453.

Brolemann H.W. 1924. Notes synonymiques (Myriapodes). Bulletin de la Société d'Histoire naturelle de Toulouse 52: 101-111.

Brookes C.H. \& Willoughby J. 1978. An investigation of the ecology and life history of the millipede Blaniulus guttulatus (Bosc) in a British woodland. Abhandlungen und Verhandlungen des naturwissenschaftlichen Vereins in Hamburg (NF) 21/22: 105-114.

Cabidoche M. 1968. Biocénose cavernicole de la Salle de la Verna (Gouffre de la Pierra-Saint-Martin), méthode d'étude en milieu naturel. Annales de Spéléologie 23: 667-688.

Ceuca T. 1967. Semnalări de noi Diplopode în fauna României. Studii si Cercetari de Biologie, Serie Zoologie 19 (1): 3-5.

Ceuca T. 1968. Une nouvelle forme cavernicole du genre Metaiulus (Dilopoda-Julidae). Annales de Spéléologie 23: 191-193.

Ceuca T. 1972. Alcuni diplopodi epigei delle fauna di Spagna raccolti dal Dr. Giuseppe Osella. Memorie del Museo civico di Storia naturale di Verona 20: 507-527.

Ceuca T. 1973. Contribution à la connaissance des diplopodes (Myriapoda, Diplopoda) de Bulgarie. Bulletin de l'Institut de Zoologie et Musée 38: 241-247.

Ceuca T. 1992. Quelques aspects sur la faunistique, l'écologie et la zoogeographie des diplopodes de la région Balkanique. Berichte des naturwissenschaftlich-medizinischen Vereins in Innsbruck, Supplementum 10: 411-429. 
Chornyi N.G. \& Golovatch S.I. 1993. Millipedes (Diplopoda) of the plain territories of the Ukraine. Kiev University, Kiev. [In Russian]

Christian E. \& Spötl C. 2010. Karst geology and cave fauna of Austria: a concise review. International Journal of Speleology 39: 71-90.

Corbet G.B. \& Jones R.E. 1996. Haplopodoiulus spathifer (Brölemann, 1897) in Southeast England: a millipede new to the British Isles. Bulletin of the British Myriapod Group 12: 13-15.

Ćurčić B.P.M. \& Makarov S.E. 1995. The occurrence of swarming in Megaphyllum unilineatum (C.L. Koch, 1838) (Diplopoda: Julidae), with observations on a case of pedal anomaly. Archives of Biological Sciences, Belgrade 47: 67-70.

Ćurčić B.P.M., Makarov S.E. \& Lymberakis P.S. 2001. Diplopoda of Crete. Archives of Biological Sciences, Belgrade 53: 99-108.

David J.-F. 1995. Size criteria for the distinction between Cylindroiulus londinensis (Leach) and Cylindroiulus caeruleocinctus (Wood) (Diplopoda: Julidae). Journal of Natural History 29: 983-991. https://doi.org/10.1080/00222939500770361

Davis B.N.K. 1979. The ground arthropods of London gardens. London Naturalist 58: 15-24.

Davis B.N.K. 1982. Studies on the arthropod faunas of green urban ecosystems. In: Bornkamm R., Lee J.A. \& Seaward M.R.D. (eds) Urban Ecology. Blackwell, Oxford.

Decker P. \& Hannig K. 2010. Nanogona polydesmoides (Leach, 1815) - new for the German fauna (Diplopoda, Chordeumatida, Craspedosomatidae). Bulletin of the British Myriapod and Isopod Group 24: 33-34.

Decker P. \& Hannig K. 2011. Checkliste der Hundert- und Tausendfüßer (Myriapoda: Chilopoda, Diplopoda) Nordrhein-Westfalens. Abhandlungen aus dem Westfälischen Museum für Naturkunde 73 (1): 3-48.

Decker P., Reip H.S. \& Voigtländer K. 2014. Millipedes and centipedes in German greenhouses (Myriapoda: Diplopoda, Chilopoda). Biodiversity Data Journal 2: e1066. https://doi.org/10.3897/ BDJ.2.e1066

De Lattin G. 1967. Grundriss der Zoogeographie. Gustav Fischer Verlag, Jena.

Demange J.-M. 1958. Trois nouveaux myriapodes cavernicoles de France. Notes Biospéologiques 13: $51-56$.

Demange J.-M. 1965. Remarques sur quelques myriapodes cavernicoles de France. Description d'une forme nouvelle du genre Metaiulus. Bulletin de la Société d'Histoire naturelle de Toulouse 100: 446-450.

Ehrnsberger R. 2002. Massenauftreten und Wanderung des Diplopoden Ommatoiulus sabulosus in Westniedersachsen. Osnabrücker Naturwissenschaftliche Mitteilungen 28: 199-203.

Enghoff H. 1976. Parthenogenesis and bisexuality in the millipede, Nemasoma varicorne C.L. Koch, 1847 (Diplopoda: Blaniulidae). Morphological, ecological and biogeographical aspects. Videnskabelige Meddelelser fra dansk naturhistorisk Forening 139: 21-59.

Enghoff H. 1978. Parthenogenesis and spanandry in millipedes. Abhandlungen und Verhandlungen des naturwissenschaftlichen Vereins Hamburg (NF) 21/22: 73-85.

Enghoff H. 1981. A cladistic analysis and classification of the millipede order Julida. Zeitschrift für zoologische Systematik und Evolutionsforschung 19: 285-319.

Enghoff H. 1982. The millipede genus Cylindroiulus on Madeira - an insular species swarm (Diplopoda, Julida: Julidae). Entomologica Scandinavica, Supplement 18: 1-142. 
Enghoff H. 1983. Adaptive radiation of the millipede genus Cylindroiulus on Madeira: habitat, body size, and morphology (Diplopoda, Julida: Julidae). Revue d'Écologie et de Biologie du Sol 20: 403-415.

Enghoff H. 1984. Revision of the millipede genus Choneiulus (Diplopoda, Julida, Blaniulidae). Steenstrupia 10: 193-203.

Enghoff H. 1985a. A new species of Trogloiulus with modified mouthparts. With a revised key to the species and new records of the genus (Diplopoda, Julida: Julidae). Lavori Società Veneziana Scienze Naturali 10: 69-77.

Enghoff H. 1985b. Modified mouthparts in hydrophilous cave millipedes (Diplopoda). Bijdragen tot de Dierkunde 55: 67-77.

Enghoff H. 1992. Dolichoiulus - a mostly Macaronesian multitude of millipedes. With the description of a related new genus from Tenerife, Canary Islands (Diplopoda, Julida, Julidae). Entomologica Scandinavica, Supplement 40: 1-158.

Enghoff H. 1994. Geographical parthenogenesis in millipedes. Biogeographica 70: 25-31.

Enghoff H. 2002. Dolichoiulus typhlops Ceuca, 1973, in Canarian caves (Diplopoda, Julida, Julidae). Vieraea 30: 147-152.

Enghoff H. 2006. The millipedes of Turkey (Diplopoda). Steenstrupia 29: 175-198.

Enghoff H. 2008. Diplopoda, Chilopoda. In: Borges P.A.V., Abreu C., Aguiar A.M.F., Carvalho P., Jardim R., Melo I., Oliveira P., Sérgio C., Serrano A.R.M. \& Vieira P. (eds.) A List of the Terrestrial Fungi, Flora and Fauna of Madeira and Selvagens Archipelagos: 279-291. Direcção Regional do Ambiente da Madeira and Universidade dos Açores, Funchal and Angra do Heroísmo.

Enghoff H. 2010. A $700 \mathrm{~km}$ disjunct population of the millipede Blaniulus dollfusi (Brölemann, 1894) in Belgium (Diplopoda: Julida: Blaniulidae). Phegea 38: 153-155.

Enghoff H. 2012. Three new species of Dolichoiulus millipedes from the underground of Gran Canaria, with notes on the circumscription of the genus (Diplopoda, Julida, Julidae). European Journal of Taxonomy 15: 1-12. https://doi.org/10.5852/ejt.2012.15

Enghoff H. \& Báez M. 1993. Evolution and habitat patterns in endemic millipedes of the genus Dolichoiulus (Diplopoda: Julidae) on the Canary Islands, with notes on distribution patterns of other Canarian species swarms. Biological Journal of the Linnean Society 49: 277-301. https://doi. org/10.1006/bijl.1993.1037

Enghoff H. \& Kime R.D. 2009. Fauna Europaea: Diplopoda. Fauna Europaea version 2.0. Available from http://www.faunaeur.org [accessed 13 Jun. 2017].

Enghoff H. \& Reboleira A.S.P.S. 2013. Subterranean species of Acipes Attems, 1937 (Diplopoda, Julida, Blaniulidae). Zootaxa 3652: 485-491. https://doi.org/10.11646/zootaxa.3652.4.6

Enghoff H. \& Reboleira A.S.P.S. 2014. Redescription of Iberoiulus cavernicola Ceuca, 1967, and the relationships of the genus Iberoiulus Mauriès, 1985 (Diplopoda, Julida, Blaniulidae). Zootaxa 3869 (2): 153-158. https://doi.org/10.11646/zootaxa.3869.2.4

Enghoff H. \& Schembri P.J. 1989. The millipedes of the Maltese Islands (Central Mediterranean) (Diplopoda). Bollettino della Società Entomologica Italiana 120: 164-173.

Enghoff H. \& Vicente M.C. 2000. Millipedes of the Balearic Islands, and the identity of the species described by L. Koch in 1881 (Diplopoda). Steenstrupia 25: 195-200. 
Enghoff H., Dohle W. \& Blower J.G. 1993. Anamorphosis in millipedes (Diplopoda), the present state of knowledge with some developmental and phylogenetic considerations. Zoological Journal of the Linnean Society 109: 103-234. https://doi.org/10.1111/j.1096-3642.1993.tb00305.x

Enghoff H., Serra A. \& Martínez H. 2009. A new species of Tarracoblaniulus: description, postembryonic development, life cycle, and spatial distribution (Diplopoda, Julida: Blaniulidae). Graellsia 65: 3-17. https://doi.org/10.3989/graellsia.2009.v65.i1.132

Ertek M., Aslan I., Yazgi H., Torun H.C., Ayyildiz A. \& Tasyaran M.A. 2004. Infestation of the human intestine by the millipede, Nopoiulus kochii. Medical and Veterinary Entomology 18 (3): 306-307. https://doi.org/10.1111/j.0269-283X.2004.00507.x

European Environment Agency. 2003. Europe's environment: the third assessment. European Environment Agency, Copenhagen. ISBN ISBN 92-9167-574-1. Available from http://www.eea.europa. eu/publications/environmental_assessment_report_2003_10 [accessed 6 Jun. 2016].

Evsyukov A.P. \& Golovatch S.I. 2013. Millipedes (Diplopoda) from the Rostov-on-Don region, southern Russia. Arthropoda Selecta 22 (3): 207-215.

Fairhurst C.P. 1984. British Millipede Survey; 10,000 Records for Great Britain. 50 Kilometre Square Maps and Habitat Information. University of Salford, Manchester.

Felesaki I., Stoev P., Simaiakis S. \& Mylonas M. 2010. A catalogue of the millipedes of Crete (Myriapoda: Diplopoda). Natura Montenegrina, Podgorica 9 (3): 357-368.

Foddai D., Minelli A., Scheller U. \& Zapparoli M. 1995. Chilopoda, Diplopoda, Pauropoda, Symphyla. In: Minelli A., Ruffo S. \& La Posta S. (eds) Checklist delle Specie della Fauna italiana 32. Calderini, Bologna.

Frederiksen S., Petersen G. \& Enghoff H. 2012. How many species are there of Pachyiulus? A contribution to the taxonomy of Europe's largest millipedes (Diplopoda, Julida, Julidae). Journal of Natural History 46: 599-611. https://doi.org/10.1080/00222933.2011.651636

Geoffroy J.-J. 1981a. Étude d'un écosystème forestier mixte. V. Traits généraux du peuplement de Diplopodes édaphiques. Revue d'Écologie et de Biologie du Sol 18: 357-373.

Geoffroy J.-J. 1981b. Les Myriapodes du parc national des Ecrins I. Stations de récolte (1976-1979) et présentation générale des peuplements de chilopodes et de diplopodes. Travaux scientifiques du Parc National d'Ecrins 1: 97-123.

Geoffroy J.-J. 1983. Myriapodes du Parc National de la Vanoise II: Haute Marienne: 1-27. Contrat de Recherche No. 11. Paris, École Normale Superieur.

Geoffroy J.-J. 1996. The French Millipede Survey: Towards a comprehensive inventory and cartography of the Diplopoda in France. Mémoires du Muséum national d'Histoire naturelle 169: 269-280.

Golovatch S.I. 1990. On the distribution and faunogenesis of Crimean millipedes (Diplopoda). In: Minelli A. (ed.) Proceedings of the $7^{\text {th }}$ International Congress of Myriapodology: 361-366. E.J. Brill, Leiden.

Golovatch S.I. 1992. Some patterns in the distribution and origin of the millipede fauna of the Russian Plain. Berichte des Naturhistorisch-Medizinischen Vereins in Innsbruck, Supplementum 10: 373-383.

Golovatch S.I. 2008. On three remarkable millipedes (Diplopoda) from the Crimea (Ukraine). International Journal of Myriapodology 1: 97-110.

Golovatch S.I. \& Kondeva E.A. 1992. Contribution to the millipede fauna of Bulgaria (Diplopoda). Acta Zoologica Bulgarica 44: 19-26. 
Gromysz-Kałkowska K., Unkiewicz-Winiarczyk A. \& Szubartowska E. 2000. The influence of environmental contamination on respiratory metabolism and humoral immunity in Cylindroiulus burzenlandicus Verh. (Diplopoda, Julidae). Fragmenta Faunistica Warszawa 43, Supplement: 207-221.

Gruber J. 2007. Neue Fundnachweise für drei Juliden-Arten in Österreich (Diplopoda: Julida: Julidae). Schubartiana 2: 21-28.

Haacker U. 1968. Deskriptive, experimentelle und vergleichende Untersuchungen zur Autökologie rhein-mainischer Diplopoden. Oecologia 1: 87-129. https://doi.org/10.1007/BF00377255

Haacker U. 1969. An attractive secretion in the mating behaviour of a millipede. Zeitschrift für Tierpsychologie 26: 988-990.

Helb H.W. 1975. Zum Massenauftreten von Schizophyllum sabulosum im Saarland. Entomologica Germanica 1: 376-381.

Hoffman R.L. 1975. A consideration of the subgenus Megaschizophyllum of the diplopod genus Ommatoiulus (Julidae). Revue Suisse de Zoologie 82: 459-464. https://doi.org/10.5962/bhl.part.78269

Hoffman R.L. 1977. Diplopoda. In: La Faune terrestre de 1'Ile de Sainte-Hélène. Annales du Musée royal de l'Afrique centrale 220: 360-377.

Hoffman R.L. 1980. Classification of the Diplopoda. Muséum d'Histoire naturelle, Genève.

Hoy Jensen L., Enghoff H., Frydenberg J. \& Parker Jr. E.D. 2002. Genetic diversity and the phylogeography of parthenogenesis: comparing bisexual and thelytokous populations of Nemasoma varicorne (Diplopoda: Nemasomatidae) in Denmark. Hereditas 136: 184-194. https://doi.org/10.1034/ j.1601-5223.2002.1360302.x

Izquierdo I., Medina A.L. \& Diaz M. 1986. La fauna invertebrada en las cuevas La Labrada y Las Mechas (Tenerife, Islas Canarias). Vieraea 16: 309-320.

Jastrzębski P. 2012. Brachyiulus jawlowskii Lohmander, 1928, a millipede species new to the fauna of Poland (Myriapoda: Diplopoda). Fragmenta Faunistica Warszawa 55: 1-3.

Jawłowski H. 1931. Neue Arten paläarktischer Diplopoden aus den Ost-Karpathen und aus Palästina. Annales Musei Zoologici Polonici 9: 161-166.

Jawłowski H. 1933a. Zur Kenntnis der Diplopodenfauna Osteuropas. Annales Musei Zoologici Polonici 9: 359-362.

Jawłowski H. 1933b. Contribution à la faune des diplopodes de la France. Annales Musei Zoologici Polonici 9: 369-374.

Jawłowski H. 1935. Przyczynek do znajomości fauny krocionogów Moldawji. Fragmenta Faunistica Musei Zoologici Polonici 2 (24): 249-251.

Jeekel C.A.W. 2001. Julus lucifugus Gervais, 1836, a long overlooked name for a wide-spread synanthrope millipede (Diplopoda, Spirobolida, Spirobolellidae). Myriapod Memoranda 3: 39-43.

Jeekel C.A.W. \& Brugge B.J.H. 2001 Millipedes and centipedes of the Kleimeer Polder, province N. Holland, The Netherlands. Myriapod Memoranda 3: 72-93.

Jędryczkowski W.B. 1992. The distribution and ecology of the millipedes in Poland. Berichte des Naturhistorisch-Medizinischen Vereins in Innsbruck, Supplementum 10: 385-391.

Jong Y. de, Verbeek M., Michelsen V., Bjørn P. de P., Los W., Steeman F., Bailly N., Basire C., Chylarecki P., Stloukal E., Hagedorn G., Wetzel F.T., Glöckler F., Kroupa A., Korb G., Hoffmann A., Häuser C., Kohlbecker A., Müller A., Güntsch A., Stoev P. \& Penev L. 2014. Fauna Europaea - all European animal species on the web. Biodiversity Data Journal 2: e4034 https://doi.org/10.3897/ BDJ.2.e4034 
Kania G. \& Tracz H. 2005. Mass occurrence and migration of Ommatoiulus sabulosus (Linnaeus, 1758) (Diplopoda: Julida: Julidae) in Poland. Peckiana 4: 57-66.

Karamaouna M. 1992. On the ecology of the iulid millipede Symphyoiulus impartitus (Karsch) in a Mediterranean pine forest of Greece. Berichte des naturwissenschaftlich-medizinischen Vereins in Innsbruck, Supplementum 10: 191-196.

Karamaouna M. \& Geoffroy J.-J. 1985. Millipedes of a maquis ecosystem (Naxos Island, Greece): preliminary description of the population (Diplopoda). Bijdragen tot de Dierkunde 55: 113-115.

Kime R.D. 1990. A Provisional Atlas of European Myriapods. Vol. 1. Fauna Europaea Evertebrata. European Invertebrate Survey, Luxembourg.

Kime R.D. 1997. Year-round pitfall trapping of millipedes in mainly open grassland in Belgium (Diplopoda). Entomologica Scandinavica, Supplementum 51: 263-268.

Kime R.D. 2004. The Belgian millipede fauna. Bulletin de l'Institut Royal des Sciences naturelles de Belgique, Entomologie 74: 35-68.

Kime R.D. \& Dethier M. 2010. Les Myriapodes des milieux souterrains de Belgique. Bulletin des Chercheurs de la Wallonie, hors-série 3: 67-78.

Kime R.D. \& Enghoff H. 2011. Atlas of European millipedes (Class Diplopoda), volume 1, orders Polyxenida, Glomerida, Platydesmida, Siphonocryptidae, Polyzoniida, Callipodida, Polydesmida. Fauna Europaea Evertebrata 3: 1-282. Pensoft, Sofia-Moscow.

Kime R.D. \& Iorio E. 2010. Centipedes and millipedes of Burgundy. Bulletin of the British Myriapod \& Isopod Group 24: 16-31.

Kime R.D. \& Wauthy G. 1984. Aspects of relationships between millipedes, soil texture and temperature in deciduous forests. Pedobiologia 26: 387-402.

Kime R.D., Wauthy G., Delecour F., Dufrêne M. \& Drugmand D. 1992. Distribution spatiale et préférences écologiques chez les diplopodes du sol. Memoires de la Société Royale Belge d'Entomologie 35: 661-670.

Kobel-Lamparsky A. 1987. Die Neubesiedlung von flurgereinigtem Berglände im Kaiserstuhl und die weitere frühe Sukzession am Beispiel ausgewählter Tiergruppen aus verschiedenen Trophieebenen. Inaugural-Dissertation, Fakultät für Biologie, Albert-Ludwigs-Universität, Freiburg.

Koch L. 1881. Zoologische Ergebnisse von Excursionen auf den Balearen II. Arachniden und Myriopoden. Verhandlungen der kaiserlich-königlichen zoologisch-botanischen Gesellschaft in Wien 31: $625-678$.

Kofler E.M. \& Meyer E. 1992. Lebenszyklus, Abundanz und Produktion von Enantiulus nanus (Latzel) in einem inneralpinen Eichenmischwald (Tirol, Österreich). Berichte des naturwissenschaftlichmedizinischen Vereins in Innsbruck, Supplementum 10: 153-166.

Kondeva E.A. 1998. Consumption and assimilation of beech leaves Fagus sylvatica L. by millipedes Pachyiulus hungaricus (Karsch, 1881) (Diplopoda: Julidae). Acta Zoologica Bulgarica 50: 89-92.

Korsós Z. 1992. Millipedes from anthropogenic habitats in Hungary. Berichte des naturhistorischmedizinischen Vereins Innsbruck, Supplementum 10: 237-241.

Korsós Z. 1994. Checklist, preliminary distribution maps, and bibliography of millipedes in Hungary (Diplopoda). Miscellanea Zoologica Hungarica 9: 29-82.

Korsós Z. 1998. Ikerszelvényes-invázió Magyarországon [Mass occurrence of millipedes (Diplopoda) in Hungary]. Állattani Közlemények 83: 53-65. 
Korsós Z. \& Lazányi E. 2008. Millipedes (Diplopoda) of Maramures (Romania). Studia Universitatis "Vasile Goldis", Seria Stiintele Vietii (Life Sciences Series), 18 (supplement): 199-209.

Korsós Z. \& Read H.J. 1994. Revision of the horvathi group and description of a new species of Cylindroiulus (Diplopoda: Julidae). Journal of Natural History 28: 841-852. https://doi. org/10.1080/00222939400770441

Lang J. 1954. Mnohonožky Diplopoda. Fauna ČSR 2: 1-188.

Lazányi E. \& Korsós Z. 2009. Millipedes (Diplopoda) of the Aggtelek National Park, Northeast Hungary. Opuscula Zoologica Budapest 40: 35-46.

Lazányi E. \& Korsós Z. 2010. Megaphyllum silvaticum (Verhoeff, 1898) (Diplopoda: Julida), a new species to the Hungarian millipede fauna, with notes on the status of M. s. discolor (Verhoeff, 1907) and on their relationship to M. projectum Verhoeff, 1894. Opuscula Zoologica Budapest 41: 39-46.

Lazányi E. \& Vagalinski B. 2013. Redefinition of the millipede subgenus Megaphyllum sensu stricto Verhoeff, 1894 and neotype designation for Megaphyllum austriacum (Latzel, 1884) (Myriapoda: Diplopoda: Julida: Julidae). Zootaxa 3741: 55-100. https://doi.org/10.11646/zootaxa.3741.1.2

Lazányi E., Vagalinski B. \& Korsós Z. 2012. The millipede genus Megaphyllum Verhoeff, 1894 in the Balkan Peninsula, with description of new species (Myriapoda: Diplopoda: Julida: Julidae). Zootaxa 3228: $1-47$.

Lee P. 2006. Atlas of the Millipedes (Diplopoda) of Britain and Ireland. Pensoft, Sofia.

Lindner E.N., Voigtländer K. \& Reip H.S. 2010. Hundert- und Tausendfüsser (Myriapoda: Chilopoda, Diplopoda) aus der Lüneburger Heide (Niedersachsen). Ergebnisse der Herbstexkursion 2008 der AG Deutschsprachiger Myriapodologen. Schubartiana 4: 35-38.

Loksa I. 1967. Diplopoden aus den Sammlungen von Prof. H. Franz auf den Kanarischen Inseln. Opuscula Zoologica Budapest 7: 133-145.

Ložek V. \& Gulička J. 1962. Gastropoda, Diplopoda a Chilopoda slovenskej časti Východných Karpát. Acta Facultatis Rerum Naturalium Universitatis Comenianae 7: 61-93.

Makarov S.E., Ćurčić B.P.M., Tomic V.T. \& Legakis A. 2004. The Diplopods of Serbia, Montenegro, and the Republic of Macedonia. Institute of Zoology, University of Belgrade.

Makarov S.E., Tomić V.T., Mitić B.M. \& Dudić B. 2005 Revision of the genus Serboiulus Strasser, 1962 (Diplopoda, Julidae). Archives of Biological Sciences, Belgrade 57: 47-52.

Manfredi P. 1937. I miriapodi italiani (III contributo), miriapodi del Parco Nazionale del Gran Paradiso. Bollettino dei Musei di Zoologia ed Anatomia Comparata della Reale Università di Torino 46, Ser. III, 73: 51-71.

Mathis J.A. 1951. Zur Kenntnis der Diplopoden des nördlichen Vorarlberg. Dissertation, University of Innsbruck.

Mauriès J.-P. 1964. Notes sur les diplopodes pyrénéens. I. Les Cylindroiulus du sous-genre Bracheoiulus Verhoeff. Bulletin de la Société d'Histoire naturelle de Toulouse 99: 444-449.

Mauriès J.-P. 1965. Une nouvelle sous-espèce cavernicole de Metaiulus pratensis Blower \& Rolfe, 1956 (Diplopoda Iuloidea). Annales de Spéléologie 20: 519-522.

Mauriès J.-P. 1969a. Observations sur la biologie (sexualité, périodomorphose) de Typhloblaniulus lorifer consoransis Brölemann (Diplopoda, Blaniulidae). Annales de Spéléologie 23: 495-504.

Mauriès J.-P. 1969b. Contribution à la faune épigée et cavernicole de Corse: Diplopodes récoltés par P. Beron. Annales de Spéléologie 23: 505-527. 
Mauriès J.-P. 1971. Diplopodes épigés et cavernicoles des pyrénées espagnoles et des monts cantabriques. IV-V. Blaniulides et iulides. Bulletin de la Société d'histoire naturelle de Toulouse 107: 103-116.

Mauriès J.-P. 1974. Myriapodes. In: Dendaletche C. (ed.) Guide du Naturaliste dans les Pyrénées occidentales. Hautes montagnes: 352-380. Delachaux \& Niestle, Neuchâtel.

Mauriès J.-P. 1982. Dolichoiulus tongiorgii (Strasser), diplopode halophile nouveau pour la faune de France. Remarques sur la classification des Pachyiulini (Myriapoda, Diplopoda, Iulida). Bulletin du Muséum national d'Histoire naturelle, $4^{e}$ Série, Section A 3-4: 433-444.

Mauriès J.-P. \& Vicente M.C. 1977. Diplópodos cavernicolas nuevos y poco concidos de España, recoletados por A. Lagar. Descripción de tre géneros nuevos. Miscellania Zoologica 4: 109-134.

Mauriès J-P., Golovatch S.I. \& Stoev P. 1997. The millipedes of Albania: recent data, new taxa: systematical, nomenclatural and faunistical review (Myriapoda, Diplopoda). Zoosystema 19: 255-292.

Meidell B.A. \& Solhøy T. 1990. Terrestrial invertebrates of the Faeroe Islands: VI. Centipedes (Chilopoda) and millipedes (Diplopoda). Check-list, distribution and habitats. In: Minelli A. (ed.) Proceedings of the $7^{\text {th }}$ International Congress of Myriapodology: 413-427. E.J. Brill, Leiden.

Meyer E. 1985. Distribution, activity, life-history and standing crop of Julidae (Diplopoda, Myriapoda) in the Central High Alps (Tyrol, Austria). Holarctic Ecology 8: 141-150.

Meyer E. \& Eisenbeis G. 1985. Water relations in millipedes from some alpine habitat types (Central Alps, Tyrol) (Diplopoda). Bijdragen tot de Dierkunde 55: 131-142.

Mikhaljova E.V., Nefediev P.S. \& Nefedieva J.S. 2007. New data on millipedes of the family Julidae (Diplopoda, Julida) from Altai, Siberia. Zootaxa 1541: 57-63.

Mikhaljova E.V., Ulykpan K. \& Burkitbaeva U.D. 2013. New data on the millipedes (Diplopoda) from East Kazakhstan (Altai). Far Eastern Entomologist 260: 1-11.

Minelli A. 1985. Catalogo dei diplopodi e dei chilopodi cavernicoli italiani. Memorie Museo civico di Storia Naturale di Verona (II Serie), Sezzione Biologica 4: 1-50.

Mock A. 1999. Mnohonôžky (Myriapoda, Diplopoda) vybraných lokalít východného Slovenska I. Natura Carpatica 40: 217-224.

Mock A. 2001. Millipedes of the Slovak Republic. Myriapodologica Czecho-Slovaca 1: 25-38.

Morgan I.K. 1989. Millipedes and centipedes in Dyfed, 1988. Dyfed Invertebrate Group Newsletter 12: $2-3$.

Mowlavi G.H., Naddaf S.R., Rezaeian M., Najafi N., Lucio-Forster A. \& Bowman D.D. 2009. Apparent pseudoparasitism of the alimentary canal of a 5-year-old child by the millipede Brachyiulus lusitanus (Diplopoda: Julidae). Parasite 16: 161-163.

Mršić N. 1994. The Diplopoda (Myriapoda) of Croatia. Razprave IV, Razreda SAZU 35: 219-296.

Nefediev P.S., Nefedieva J.S. \& Dyachkov Yu.V. 2014. A review of the anthropochore millipede fauna of Asian Russia, with new records from the Altai Province, Siberia (Diplopoda). Arthropoda Selecta 23 (4): 337-345.

Ólafsson E. 2010. Nátvífætla (Boreoiulus tenuis). Available from http://www.ni.is/biota/animalia/ arthropoda/myriapoda/diplopoda/julida/blaniulidae/natvifaetla-boreoiulus-tenuis [accessed 1 Aug. 2017].

Paoletti M.G., Iovane E. \& Cortese M. 1988. Pedofauna bioindicators and heavy metals in five agroecosystems in north-east Italy. Revue d'Écologie et de Biologie du Sol 25: 33-58. 
Paszlavsky J. 1878. Massenhaftes Erscheinen von Tausendfüsslern. Verhandlungen der königlichkaiserlichen zoologisch-botanischen Gesellschaft Wien 37: 545-552.

Pedroli-Christen A. 1993. Faunistique des mille-pattes de Suisse (Diplopoda). Documenta Faunistica Helvetiae 14: 1-245.

Pierrard G. \& Biernaux J. 1974. Note à propos des diplopodes nuisible aux cultures tempérées et tropicales. Symposia of the Zoological Society of London 32: 629-643.

Prisnyi A. V. 2001. A review of the millipede fauna of the south of the Middle-Russian Upland, Russia (Diplopoda). Arthropoda Selecta 10: 297-305.

Read H.J. 1989. New species and records of the Cylindroiulus madeirae-group, with notes on phylogenetic relationships (Diplopoda, Julida: Julidae). Entomologica Scandinavica 19: 333-347.

Read H.J. 1990. The generic composition and relationships of Cylindroiulini - a cladistic analysis (Diplopoda, Julida: Julida). Entomologica Scandinavica 21: 97-112.

Read H.J. 2007. The millipede genus Cylindroiulus Verhoeff, 1894 in north-west Spain and northern Portugal: recent records and descriptions of four new species (Diplopoda, Julida, Julidae). Graellsia 63: 279-294. https://doi.org/10.3989/graellsia.2007.v63.i2.95

Read H.J. 2008. Records of millipedes from Kew Gardens and the Eden Project, including descriptions of three species. Bulletin of the British Myriapod \& Isopod Group 23: 27-35.

Reboleira A.S.P.S. \& Enghoff H. 2014. Insular species swarm goes underground: two new troglobiont Cylindroiulus millipedes from Madeira (Diplopoda: Julidae). Zootaxa 3785 (3): 481-489. https://doi. org/10.11646/zootaxa.3785.3.9

Richter H. 1967. Zur Diplopodenfauna des Osterzgebirges. Faunistisch-ökologische und morphologische Untersuchungen in Blockhaldenbiotopen. Abhandlungen und Berichte des Naturkundemuseum Görlitz 42: $1-62$.

Sahli F. 1969. Existence d'une succession adulte-adulte chez les mâles du diplopode Cylindroiulus nitidus (Verh.) - la question de mâles rhenanus. Comptes Rendus hebdomadaires de l'Académie des Sciences 269: 2254-2257.

Sahli F. 1986. Mues periodomorphiques et mues post-imaginales mâles adulte-mâle adulte chez Cylindroiulus nitidus (Verh.) (Myriapoda, Diplopoda, Julidae): passage d'un type de mues à l'autre. Bulletin Scientifique de Bourgogne 39: 83-87.

Schubart O. 1934. Tausendfüssler oder Myriapoda I: Diplopoda. Die Tierwelt Deutschlands 28. Fischer, Jena.

Schubart O. 1954. Über einige von Professor H. Janetschek in der hochalpin-nivalen Region der Dauphiné gesammelte Diplopoden. Österreichische zoologische Zeitschrift 5: 350-365.

Schubart O. 1961. Einige neue Diplopoden aus Frankreich. Vie et milieu 12: 615-625.

Serra A., Vicente M. \& Mateo E. 1996. Études des communautés des myriapodes (Diplopoda et Chilopoda) des forêts prépyrénéennes (Huesca, Espagne). Mémoires du Muséum national d'Histoire naturelle 169: 187-204.

Shelley R.M. 2002. A revised, annotated, family-level classification of the Diplopoda. Arthropoda Selecta 11: 187-207.

Shelley R.M. \& Golovatch S.I. 2011. Atlas of Myriapod Biogeography. I. Indigenous ordinal and supraordinal distributions in the Diplopoda: Perspectives on taxon origins and ages, and a hypothesis on the origin and early evolution of the class. Insecta Mundi 0158: 1-134. 
Soesbergen M. \& Jeekel C.A.W. 2007. Aulonopygus aculeatus, een kasmiljoenpoot nieuw voor de nederlandse fauna (Diplopoda: Spirostreptida: Spirostreptidae). Nederlandse faunistische Mededelingen 27: 91-92.

Spelda J. 1996. Millipedes as aids for the reconstruction of glacial refugia (Myriapoda, Diplopoda). Mémoires du Muséum national d'Histoire naturelle 169: 151-161.

Spelda J. 1999. Verbreitungsmuster und Taxonomie der Chilopoda und Diplopoda Südwestdeutschlands. Diskriminanzanalytische Verfahren zur Trennung von Arten und Unterarten am Beispiel der Gattung Rhymogona Cook, 1896 (Diplopoda: Chordeumatida: Craspedosomatidae). Dissertation, Universität Ulm.

Spelda J. 2005. Improvements in the knowledge of the myriapod fauna of southern Germany between 1988 and 2005 (Myriapoda: Chilopoda, Diplopoda, Pauropoda, Symphyla). Peckiana 4: 101-129.

Stašiov S. 2002: Selected Groups of Epigeic Macrofauna (Opilionida, Diplopoda and Chilopoda) as Indicators of the Upper Soil Horizon Stage in Submountainous Beech Stand. Scientific studies. Technical university in Zvolen, Zvolen. [In Slovakian, English abstract.]

Stašiov S. 2005. Millipede communities (Diplopoda) of oak-hornbeam ecosystems (the Malé Karpaty Mts, Trnavská Pahorkatina Hills, SW Slovakia). Ekológia 24, Supplement 2: 143-151.

Stoev P. \& Lapeva-Gjonova A. 2005. Myriapods from ant nests in Bulgaria (Chilopoda, Diplopoda). Peckiana 4: 131-142.

Stoev P., Zapparoli M., Golovatch S., Enghoff H., Akkari N. \& Barber A. 2010. Myriapods (Myriapoda). Chapter 7.2. In: Roques A., Kenis M., Lees D., Lopes-Vaamonde C., Rabitsch W., Rasplus J.-Y. \& Roy D.D.B. (eds) Alien Terrestrial Arthropods of Europe: 97-130. BioRisk 4 Special Issue. https://doi. org/10.3897/biorisk.4.51

Stojałowska W. \& Staręga W. 1974. Krocionogi Diplopoda. Katalog Fauny Polski 14 (2): 1-71.

Strasser C. 1934. Diplopodi della laguna di Venezia. Atti del Museo Civico di Storia Naturale Verona 19: $1-21$.

Strasser C. 1965. Diplopodi raccolti in alcune grotte dell'Abruzzo. Bollettino della Società adriatica di Scienze naturali 53: 173-182.

Strasser C. 1970. Diplopodi della Sicilia e della Calabria. Memorie del Museo civico di Storia naturale, Verona 17: 151-200.

Strasser C. 1978a. Diplopodi del Piemonte. Bollettino del Museo civico di Storia naturale di Verona 5: $141-173$.

Strasser C. 1978b. Un Trogloiulus eterogeneo del Bresciano. Natura Bresciana 15: 120-128.

Strasser C. \& Minelli A. 1984. Elenco dei diplopodi d'Italia. Lavori Società veneziana Scienze naturali 9: 193-212.

Strasser K. 1940. Diplopoden des jugoslavischen Draubanats. Prirodoslovne Razprave 4: 13-85.

Strasser K. 1959. Die Diplopoden (Tausendfüssler) von Kärnten. Carinthia II 69: 58-84.

Strasser K. 1960. Diplopoden aus Alpen-, Apenninen- und Balkanländern. Fragmenta Entomologica 3(6): 95-140.

Strasser K. 1962. Die Typhloiulini (Diplopoda Symphyognatha). Atii del Museo civico di Storia naturale di Trieste 23: 1-77.

Strasser K. 1966. Die Diplopoden Sloweniens. Acta Carsologica 4: 159-220. 
Strasser K. 1971. Ueber italienische, besonders kavernikole Diplopoden. Memorie del Museo civico di Storia naturale, Verona 19: 1-21.

Strasser K. 1974. Über Diplopoda-Chilognatha Griechenlands. Revue suisse de Zoologie 81: 219-300. https://doi.org/10.5962/bhl.part.76003

Strasser K. 1976. Über Diplopoda-Chilognatha Griechenlands II. Revue suisse de Zoologie 83: 579645. https://doi.org/10.5962/bhl.part.91453

Strasser K. 1977. Über Trogloiulus Manfredi (Diplopoda Iulida). Bollettino del Museo civico di Storia naturale, Verona 4: 21-33.

Striganova B. 1996. Life cycles and reproductive strategies in local populations of Rossiulus kessleri (Lohmander) (Julidae, Diplopoda) from isolated habitats. Mémoires du Muséum national d'Histoire naturelle 169: 515-522.

Tabacaru I. 1970. Sur l'origine de la faune des Diplopodes des Carpates. Bulletin du Muséum national d'Histoire naturelle, $2^{e}$ Série 41, Supplément 2: 139-143.

Tabacaru I. 1978. Sur la systématique des Pachyiulinae. Description d'une nouvelle espèce du genre Geopachyiulus. Travaux du l'Institut spéléologique "Emile Racovitza” 17: 67-80.

Tajovský K. 1997. Distribution of millipedes along an altitudinal gradient in three mountain regions in the Czech and Slovak Republics. Entomologica Scandinavica, Supplement 51: 225-233.

Tajovský K. 1998. Mnohonozky (Diplopoda) a Suchozemsti Stejnonozci (Oniscidea) Narodniho Parku Podyji. Thayensia (Zmojmo) 1: 137-152.

Tajovský K. 2001. Millipedes (Diplopoda) of the Czech Republic. Myriapodologica Czecho-Slovaca 1: $11-24$.

Tarasevich Y.L. 1992. Diplopoda in the associations of mixed forests in Byelorussia. Berichte des naturhistorisch-medizinischen Vereins Innsbruck, Supplementum 10: 213-218.

Thaler K. 1989. Kleintiere im Kulturland der Innsbrucker Mittelgebirge. In: Köck L. \& Holaus K. (eds) 50 Jahre Landesanstalt für Pflanzenschutz und Samenprüfung in Rinn: 159-177. Landesanstalt für Pflanzenzucht und Samenprüfung, Rinn (Germany).

Thaler K. \& Christian E. 2003. Meosiulus gridellii Strasser (=M. franzi Attems, nov. syn.) in Wien (Diplopoda, Julida, Julidae). Entomologische Nachrichten und Berichte 47: 187-189.

Thaler K. \& Meyer E. 1974. Fragmenta faunistica tirolensia, II (Diplopoda, Chilognatha: Julidae, Craspedosomatidae). Berichte des naturhistorisch-medizinischen Vereins in Innsbruck 61: 93-99.

Thaler K., Knoflach B. \& Meyer E. 1993. Fragementa faunistica tirolensia, X (Arachnida, Acari: Caeculidae; Myriapoda: Diplopoda; Insecta, Nematocera; Limoniidae, Sciaridae). Berichte des naturhistorisch-medizinischen Vereins in Innsbruck 80: 311-325.

Tufová J. 2003. The population structure of Leptoiulus proximus (Němec, 1896) (Diplopoda, Julidae) in floodplain forests after summer flooding. African Invetebrates 44: 277-282.

Vagalinsky B. \& Stoev P. 2007. An annotated catalogue of the millipede order Julida (Diplopoda) in Bulgaria. Historia Naturalis Bulgarica 18: 35-63.

Verhoeff C. 1897. Beiträge zur vergleichenden Morphologie, Gattungs- und Artsystematik der Diplopoden, mit besonderer Berücksichtigung derjenigen Siebenbürgens. Zoologischer Anzeiger 20: 97-125.

Verhoeff C. 1898. Ueber Diplopoden aus Bosnien, Herzogowina und Dalmatien. IV. Theil: Julidae. Enthaltend: Schlüssel und Stammbaum von Leptoiulus, sowie einige anderen europäische Juliden. 
Archiv für Naturgeschichte 64: 119-160. Available from http://biodiversitylibrary.org/page/14202410 [accessed 15 Jun. 2017].

Verhoeff C. 1899. Beiträge zur Kennnis paläarktischer Myriopoden. IX. Aufsatz: Zur Systematik, Phylogenie und vergleichenden Morphologie der Juliden und über einige andere Diplopoden. Archiv für Naturgeschichte 65 (I): 183-230. Available from http://biodiversitylibrary.org/page/15115004 [accessed 15 Jun. 2017].

Verhoeff C. 1900. Beiträge zur Kenntnis paläarktischer Myriopoden. XII: Aufsatz. Ueber Diplopoden aus Griechenland. Zoologische Jahrbücher, Abteilung für Systematik 13: 172-203.

Verhoeff K.W. 1908. Über Diplopoden 10. (30.) Aufsatz: Zur Kenntnis der Juliden und über einige Polydesmiden. Archiv für Naturgeschichte 73, I (3): 423-475. Available from http://biodiversitylibrary. org/page/15113540 [accessed 15 Jun. 2017].

Verhoeff K.W. 1913. Die süddeutschen, zoogeographischen Gaue, neue Leptoiulus-Formen und Hypsoiulus n. subg. (Über Diplopoden, 61. Aufsatz). Sitzungsberichte der Gesellschaft naturforschender Freunde zu Berlin 1913: 170-190.

Verhoeff K.W. 1929. Zur Systematik, vergleichenden Morphologie und Geographie europäischer Diplopoden, zugleich ein zoogeographischer Beitrag. 111. Diplopoden-Aufsatz. Zoologische Jahrbücher, Abteilung für Systematik 57: 555-659.

Verhoeff K.W. 1930. Über Diplopoden aus Italien, namentlich Piemont. 114. Diplopoden-Aufsatz. Zoologische Jahrbücher, Abteilung für Systematik 59: 387-446.

Verhoeff K.W. 1931. Zur Kenntnis italienischer Diplopoden. Zoologische Jahrbücher, Abteilung für Systematik 60: 281-326.

Verhoeff K.W. 1932a. Zur Geographie, Ökologie und Systematik der Diplopoden Nordwestitaliens. Archiv für Naturgeschichte, Neue Folge 1: 550-645.

Verhoeff K.W. 1932b. Diplopoden, besonders aus den östlichen Apenninen. Zoologische Jahrbücher, Abteilung für Systematik 63: 300-351, 3 pl.

Verhoeff K.W. 1935. Über Geographie und Ökologie der Diplopoden Mittelitaliens, westlich und östlich. 126. Diplopoden-Aufsatz. Archiv für Naturgeschichte, Neue Folge 4 (1): 1-71.

Verhoeff K.W. 1938. Diplopoden der Germania zoogeographica im Lichte der Eiszeit. Zoogeographica 3: 494-547.

Verhoeff K.W. 1942. Diplopoden der Insel Kapri. Zoologischer Anzeiger 139: 213-233.

Vicente M.C. 1985. Diplópodos epigeos de Cataluña, II (julidos). Eos 61: 321-350.

Voigtländer K. 1987. Untersuchungen zur Bionomie von Enantiulus nanus (Latzel, 1884) und Allajulus occultus C.L. Koch, 1847 (Diplopoda, Julidae). Abhandlungen und Berichte des Naturkundemuseums Görlitz 60: 1-116.

Voigtländer K. 1996. The life-cycle of Cylindroiulus latestriatus (Curtis, 1845). Mémoires du Muséum national d'Histoire naturelle 169: 501-508.

Voigtländer K. 2005. Mass occurrences and swarming behaviour of millipedes (Diplopoda: Julidae) in Eastern Germany. Peckiana 5: 181-187.

Voigtländer K. 2011. Preferences of common Central European millipedes for different biotope types (Myriapoda, Diplopoda) in Saxony-Anhalt (Germany). International Journal of Myriapodology 6: 6183. 
Voigtländer K. \& Hauser H. 1998. Ergebnisse der Sammelexkursion der ii. Arbeitstagung deutschsprachiger Myriapodologen. Entomologische Nachrichten und Berichte 42: 246.

Voigtländer K., Reip H.S., Decker P. \& Spelda J. 2011. Critical reflections on German red lists of endangered myriapod species (Chilopoda, Diplopoda) (with species list for Germany). International Journal of Myriapodology 6: 85-105.

Voigtländer K., Spelda J., Zulka K.-P. \& Tadler A. 1997. Diplopoden und terrestrische Isopoden aus der Umgebung von Eckberg bei Gamlitz (Weststeiermark, Österreich). Berichte des naturwissenschaftlichmathematischen Vereins Innsbruck 84: 307-314.

Wytwer J., Golovatch S.I. \& Penev L. 2009. Variation in millipede (Diplopoda) assemblages in oak woodlands of the Eastern European Plain. Soil Organisms 81: 791-813.

Zuev R.V. 2014. Preliminary data on the millipedes (Diplopoda) from the Stavropol Territory, northern Caucasus, Russia. Arthropoda Selecta 23 (4): 347-354.

Manuscript received: 19 July 2016

Manuscript accepted: 3 November 2016

Published on: 29 August 2017

Topic editor: Rudy Jocqué

Desk editor: Kristiaan Hoedemakers

Printed versions of all papers are also deposited in the libraries of the institutes that are members of the EJT consortium: Muséum national d'Histoire naturelle, Paris, France; Botanic Garden Meise, Belgium; Royal Museum for Central Africa, Tervuren, Belgium; Natural History Museum, London, United Kingdom; Royal Belgian Institute of Natural Sciences, Brussels, Belgium; Natural History Museum of Denmark, Copenhagen, Denmark; Naturalis Biodiversity Center, Leiden, the Netherlands; Museo Nacional de Ciencias Naturales-CSIC, Madrid, Spain; Real Jardín Botánico de Madrid CSIC, Spain. 


\section{Appendix 1: post 2014 papers}

The following papers, published after the cut-off date (end of 2014) for data to be included in the atlas, contain significant new data and are therefore briefly summarized:

Akkari N., Enghoff H. \& Metscher B. 2015. A new dimension in documenting new species: High-detail imaging for myriapod taxonomy and first 3D cybertype of a new millipede species (Diplopoda, Julida, Julidae). PLoS ONE 10 (8): e0135243. https://doi.org/10.1371/journal.pone.0135243; http://journals. plos.org/plosone/article?id=10.1371/journal.pone.01352. Describes Ommatoiulus avatar Akkari \& Enghoff, 2015, from ES-SPA (Andalusia).

Akkari N. \& Enghoff H. 2017. Revision of the genus Ommatoiulus Latzel (Julida, Diplopoda) in Portugal, with description of six new species. European Journal of Taxonomy 295: 1-42. https://doi.org/10.5852/ ejt.2017.295. Describes Ommatoiulus alacygni Akkari \& Enghoff, 2017, O. camurus Akkari \& Enghoff, 2017, O. denticulatus Akkari \& Enghoff, 2017, O. litoralis Akkari \& Enghoff, 2017, O. staglae Akkari \& Enghoff, 2017, O. stellaris Akkari \& Enghoff, 2017, all from PT-POR. - Synonymizes O. cervinum (Verhoeff, 1910) under O. moreleti (Lucas, 1860), O. cingulatus (Attems, 1927) under O. lusitanus (Verhoeff, 1895), and O. lienharti (Brolemann, 1921) under O. bipartitus (Verhoeff, 1910). - Gives new records of several Ommatoiulus species, including the first Portuguese records of $O$. andalusius (Attems, 1927), O. fuentei (Brolemann, 1920) and O. martensi Mauriès, 1969.

Antić D.Ž., Mock A. \& Enghoff H. 2015. Two new species of the millipede family Blaniulidae (Diplopoda, Julida) from caves in eastern and southeastern Europe. Zootaxa 3985 (4): 523-540. https://doi. org/10.11646/zootaxa.3985.4.3. Describes Cibiniulus slovacus Antić, Mock \& Enghoff, 2015, from SK, and Thassoblaniulus radjai Antić \& Enghoff, 2015, from AL.

Barber T. 2016. Centipedes and millipedes from Ventnor Botanic Gardens including a species new to Britain. Proceedings of the Isle of Wight Natural History and Archaeological Society 30: 88-93. Records Cylindroiulus apenninorum (Brölemann, 1897) and Haplopodoiulus spathifer (Brölemann, 1897) from a botanical garden, the former species as new to the British Isles.

Decker P., Voigtländer K. \& Reip H.S. 2015. On distribution patterns of very rare Chilopoda and Diplopoda in Germany. Acta Societatis Zoologicae Bohemicae 79: 169-181. Provides distribution maps for eight species of Julidae in Germany: Brachyiulus bagnalli (Brolemann, 1924), Cylindroiulus luridus (C.L. Koch, 1847), Julus terrestris Linnaeus, 1758, Leptoiulus bertkaui (Verhoeff, 1896), L. cibdellus (Chamberlin, 1921), L. trilobatus (Verhoeff, 1894), L. noricus Verhoeff, 1913 (as L. marcomannius Verhoeff, 1913) and Ommatoiulus rutilans (C.L. Koch, 1847).

Evsyukov A.P. 2016. A new species of the millipede genus Julus from the Rostov-on-Don region, southern Russia (Diplopoda: Julida: Julidae). Arthropoda Selecta 25 (3): 241-245. Describes Julus alexandrae Evsyukov, 2016, from RU-RUS, bank of Metchetka River, near Metchetinskaya, Rostov-on-Don Region.

Vagalinski B., Stoev P. \& Enghoff H. 2015. A review of the millipede genus Typhloiulus Latzel, 1884 (Diplopoda: Julida: Julidae), with a description of three new species from Bulgaria and Greece. Zootaxa 3999 (3): 334-362. https://doi.org/10.11646/zootaxa.3999.3.2. Describes Typhloiulus bulgaricus Vagalinsky, Stoev \& Enghoff, 2015 and T. orpheus Vagalinsky, Stoev \& Enghoff, 2015, both from BG, and T. rhodopinus Vagalinsky, Stoev \& Enghoff, 2015 from BG and GR-GRC (Thrace). - Synonymizes T. staregai Strasser, 1973 under T. strictus (Latzel, 1882). - Gives new records of several species of Typhloiulus. 


\section{Appendix 2: maps}

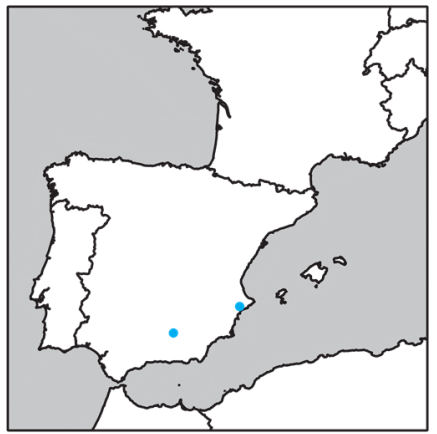

1. Acipes andalusius

Enghoff \& Mauriès, 1999

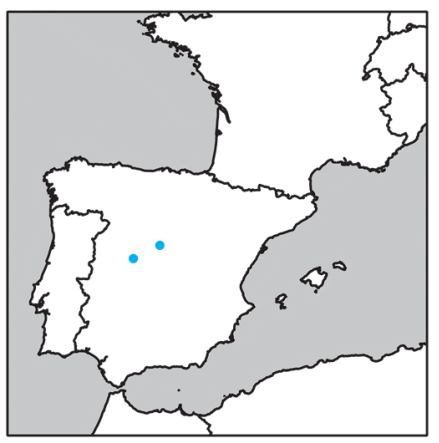

4. Acipes continentalis

Enghoff, 1986

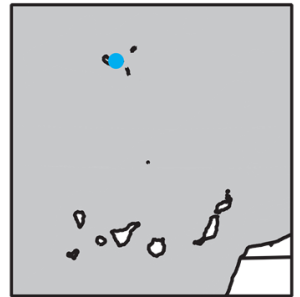

2. Acipes atlanticus Attems, 1935 10. Acipes serratus Enghoff, 1983

11. Acipes waldeni Enghoff, 1983

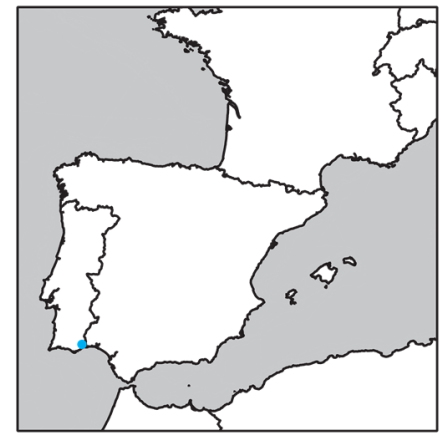

3. Acipes bifilum Enghoff \& Reboleira, 2013

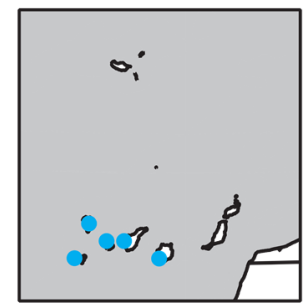

6. Acipes franzi (Loksa, 1967)
7. Acipes lateralis Enghoff, 1983

9. Acipes portosantoensis

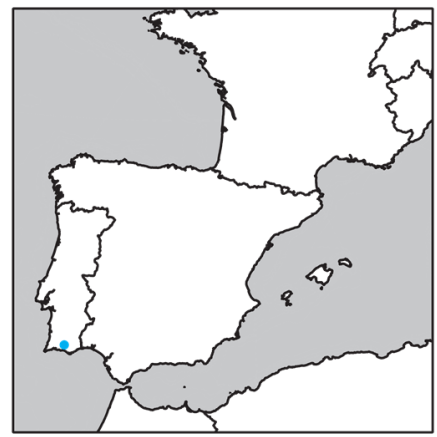

8. Acipes machadoi

Enghoff \& Reboleira, 2013

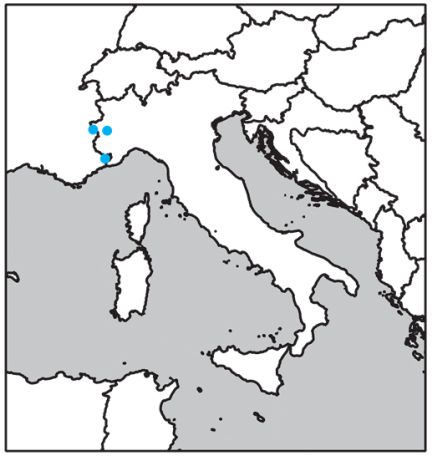

12. Alpiobates peyerimhoffi (Brölemann, 1900) 


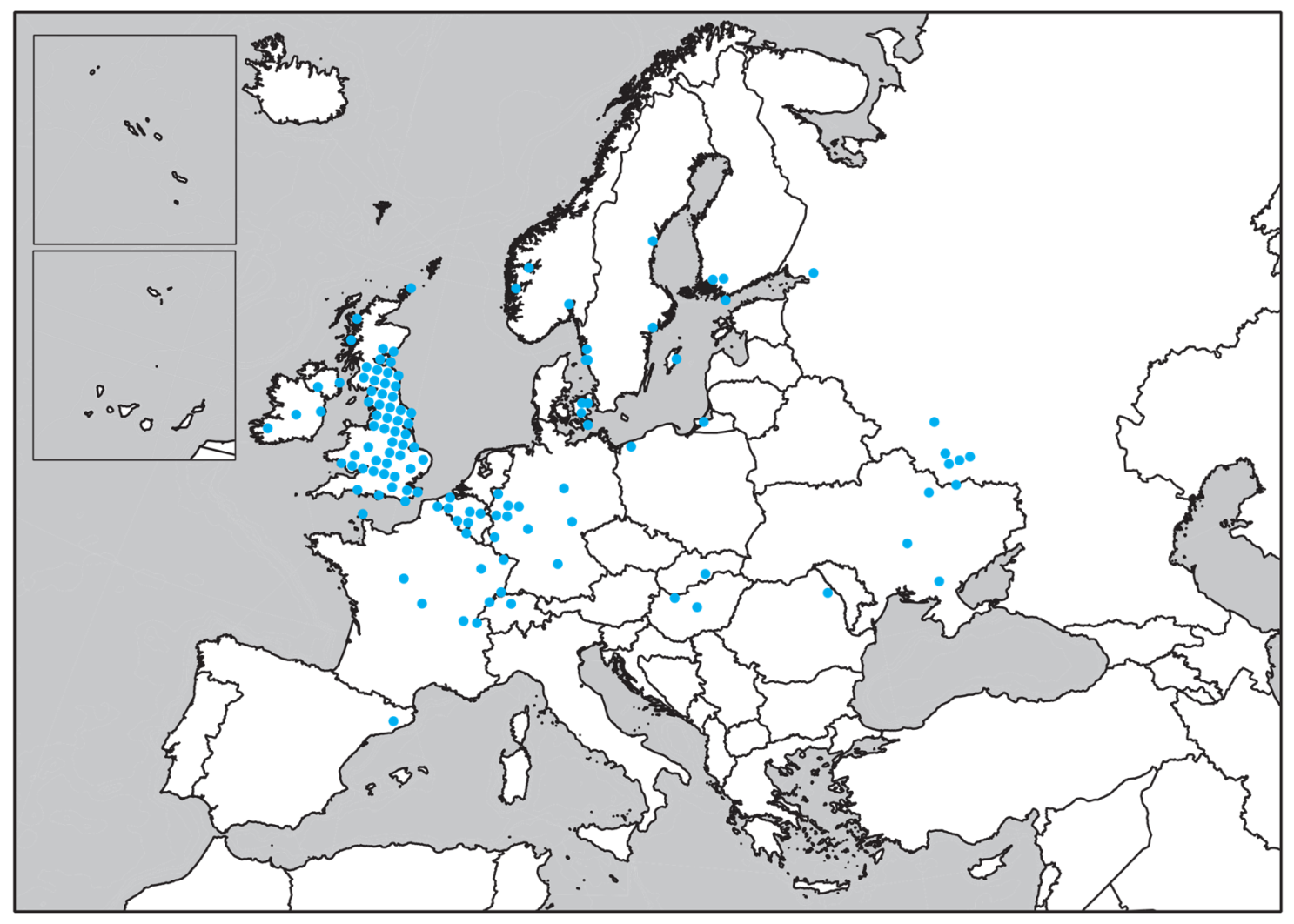

13. Archiboreoiulus pallidus (Brade-Birks, 1920)

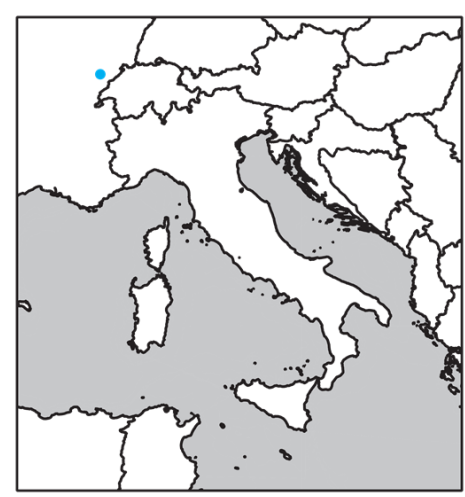

14. Archiboreoiulus sollandi 


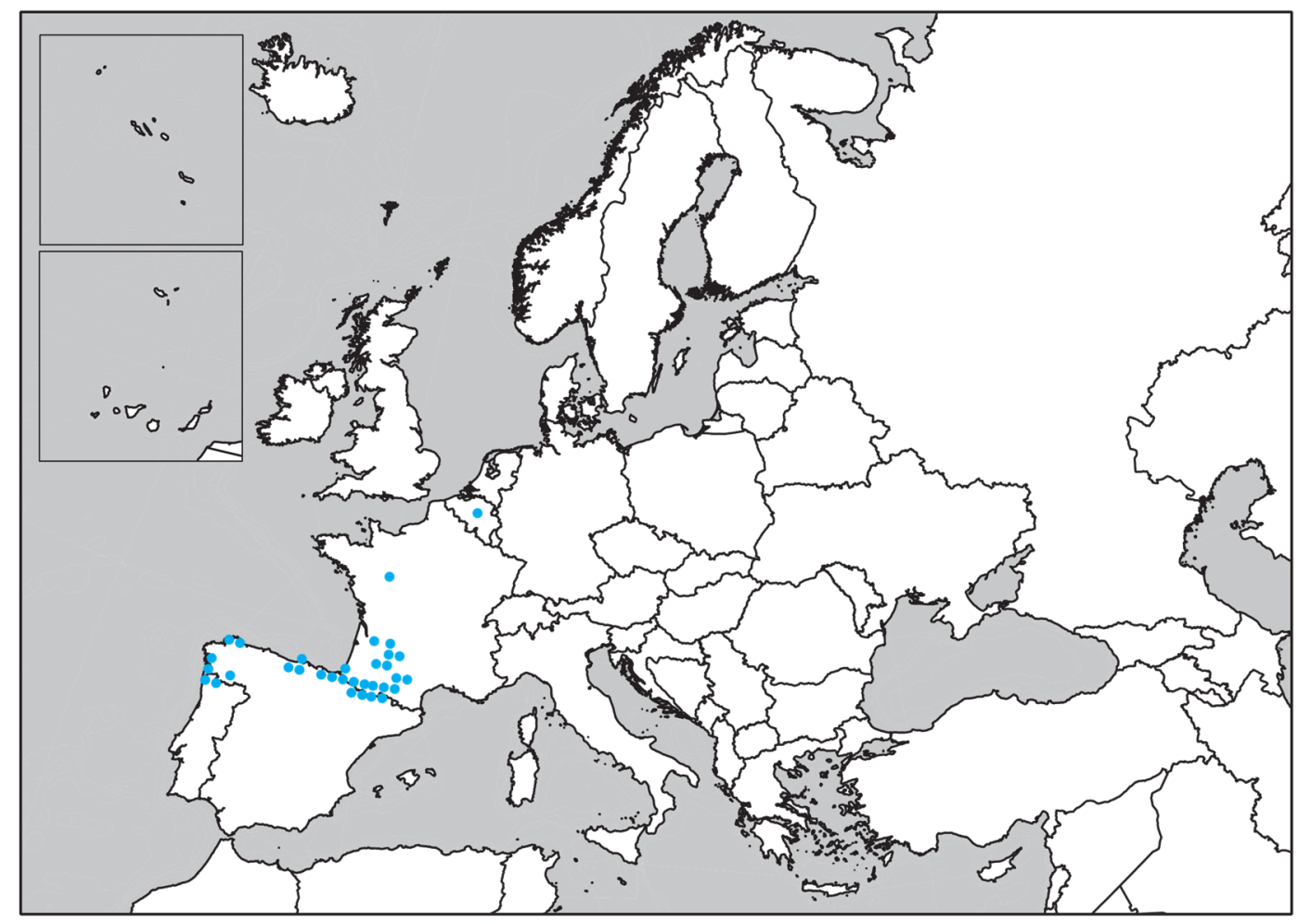

15. Blaniulus dollfusi Brölemann, 1894

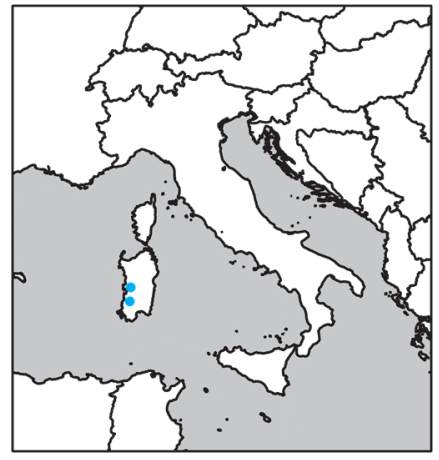

16. Blaniulus eulophus

Silvestri, 1903 


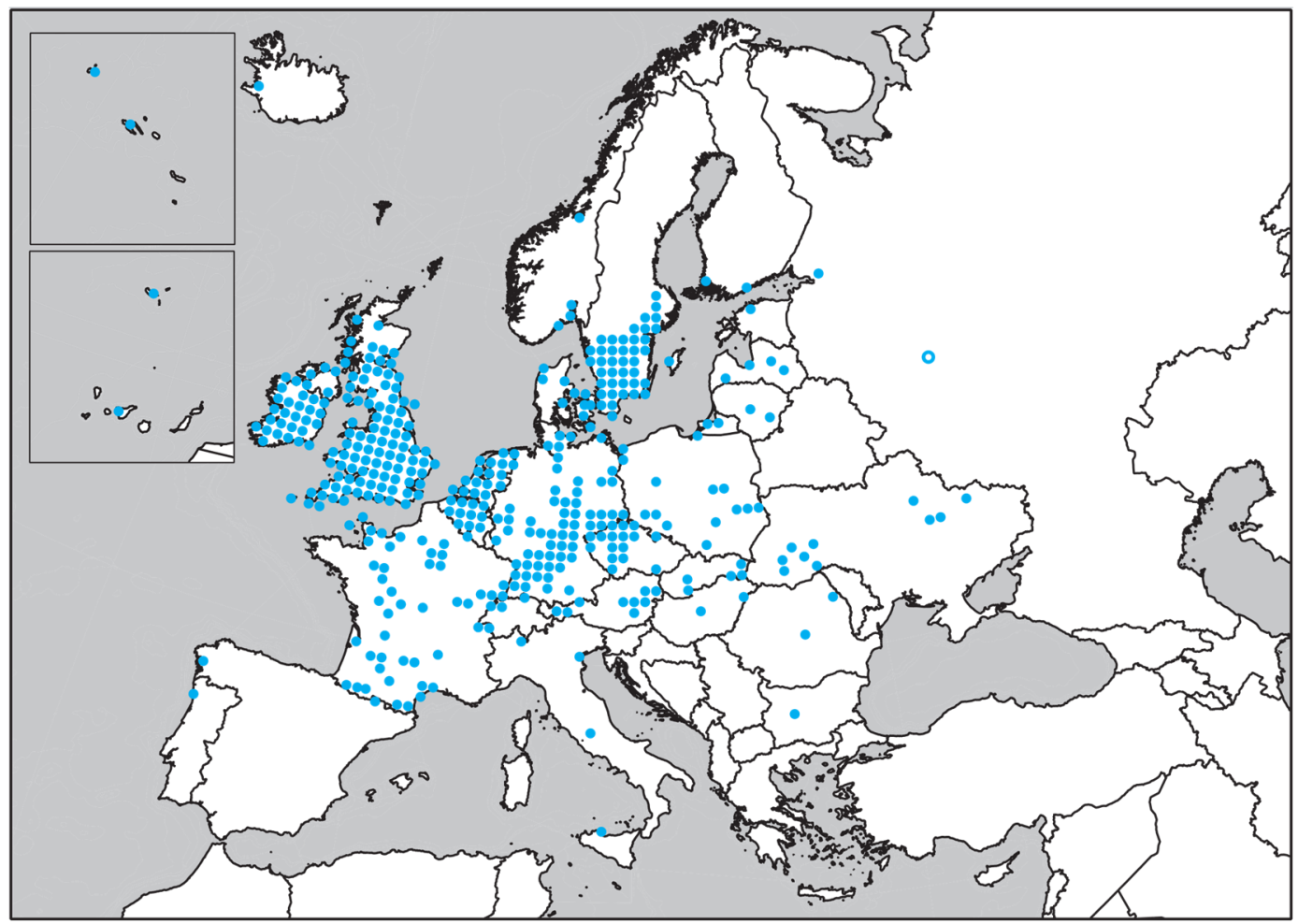

17. Blaniulus guttulatus (Fabricius, 1798)

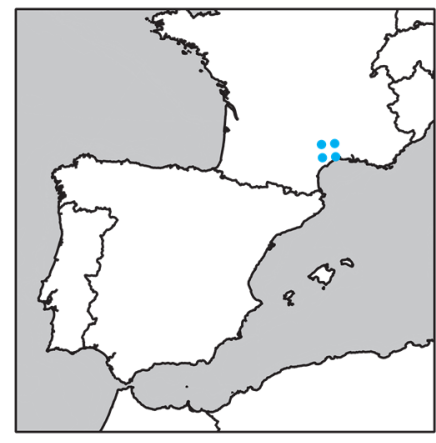

18. Blaniulus lichtensteini Brolemann, 1921

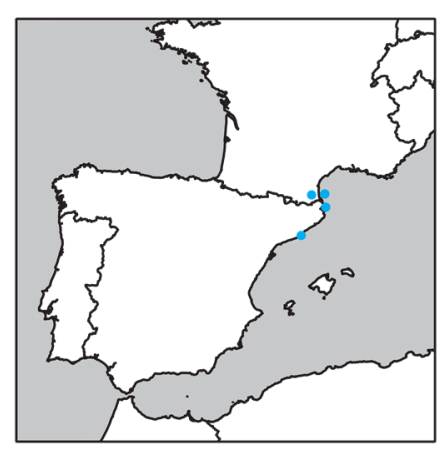

21. Blaniulus orientalis

Brolemann, 1921

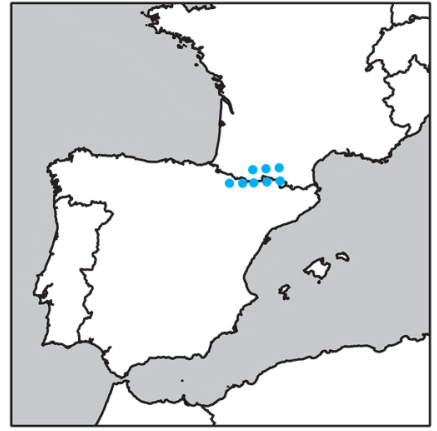

19. Blaniulus lorifer (Brolemann, 1921)

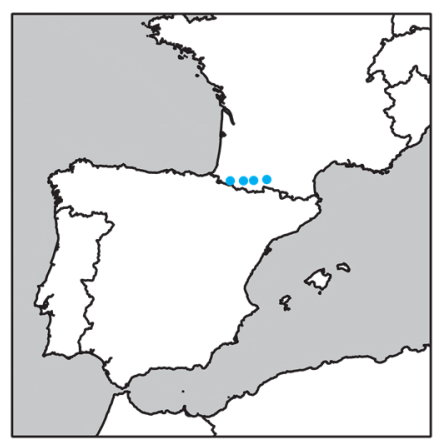

22. Blaniulus troglobius Latzel, 1886

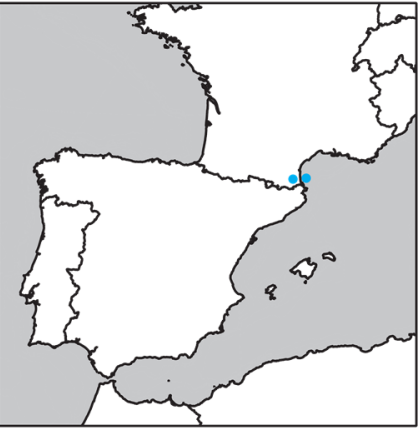

20. Blaniulus mayeti (Brölemann, 1902)

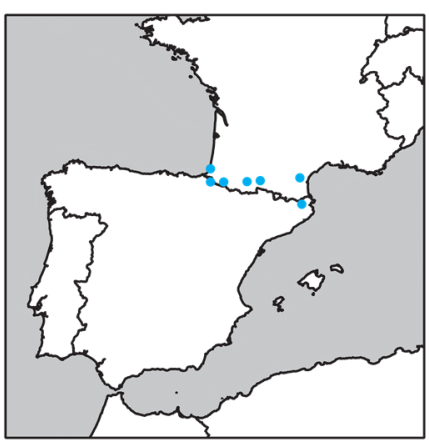

23. Blaniulus troglodites Brölemann, 1898 


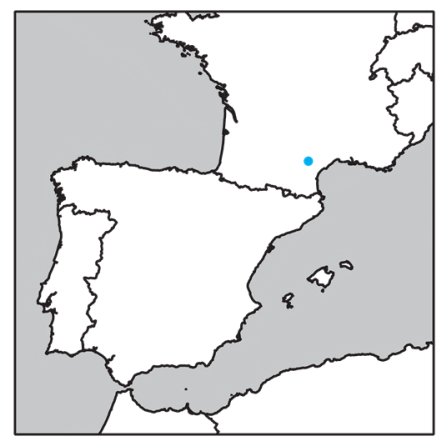

24. Blaniulus velatus Ribaut, 1954

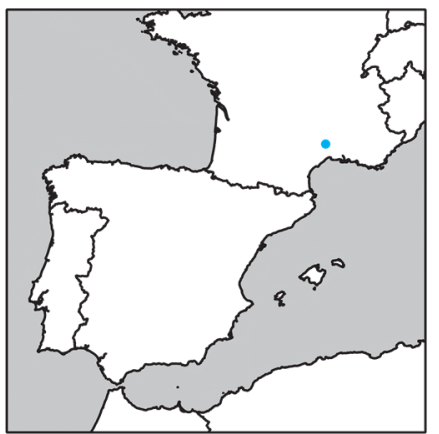

25. Blaniulus virei Brölemann, 1900

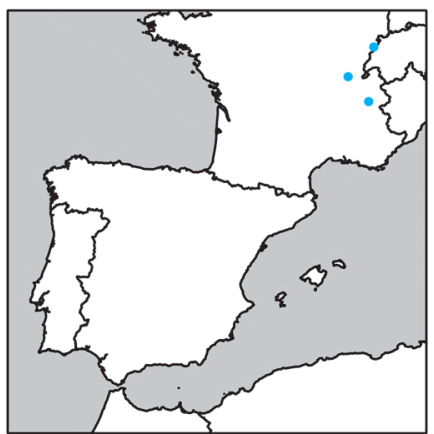

26. Boreoiulus simplex Brolemann, 1921

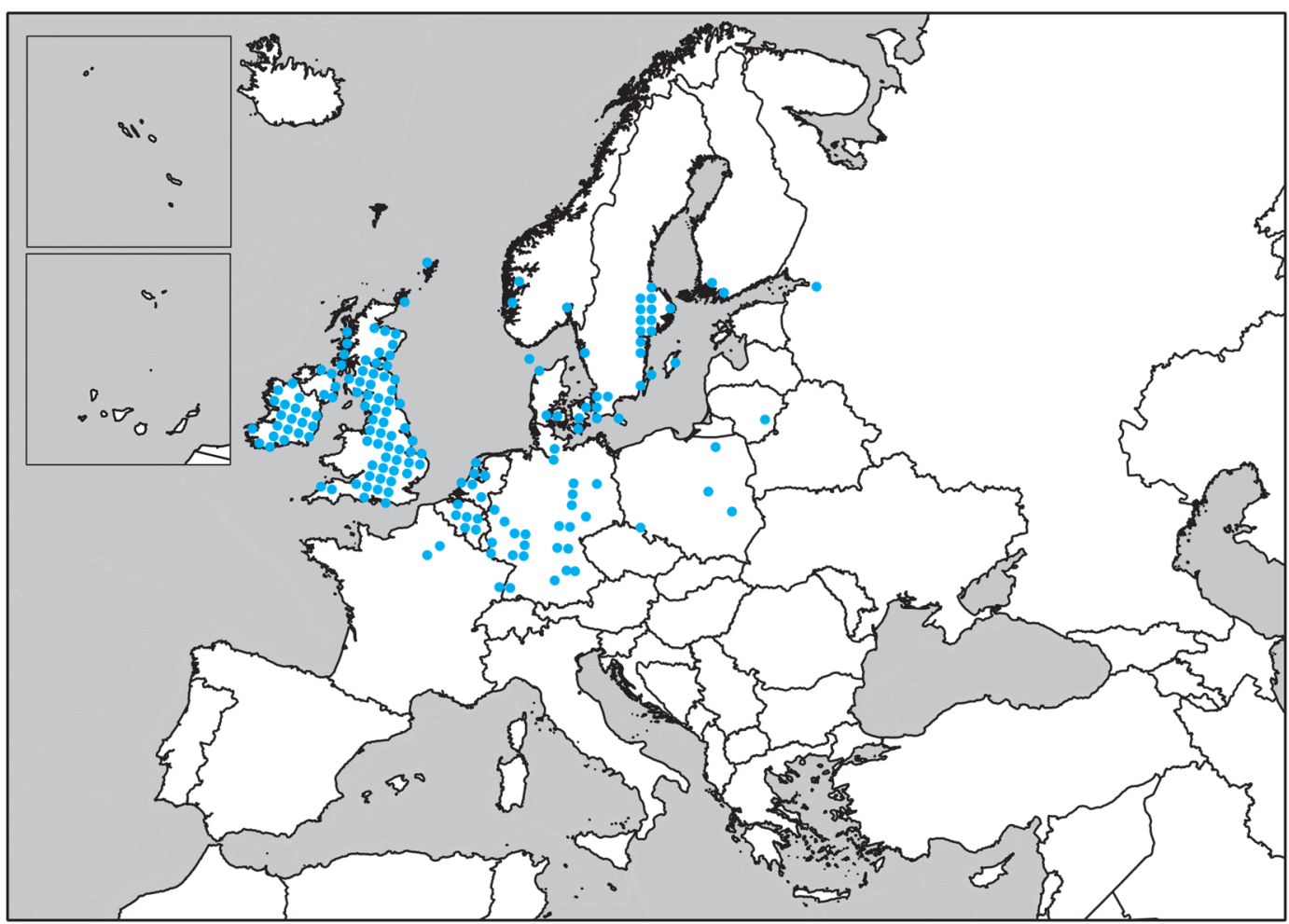

27. Boreoiulus tenuis (Bigler, 1913)

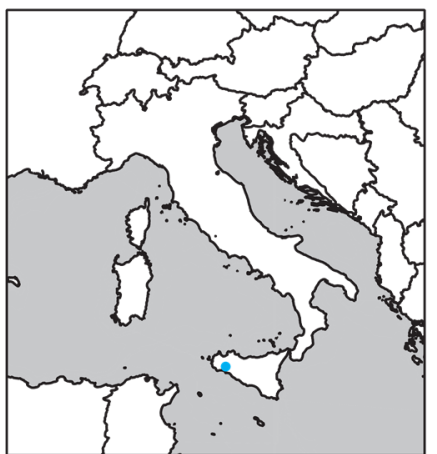

28. Choneiulus fannaeuropaeae Enghoff, 2002

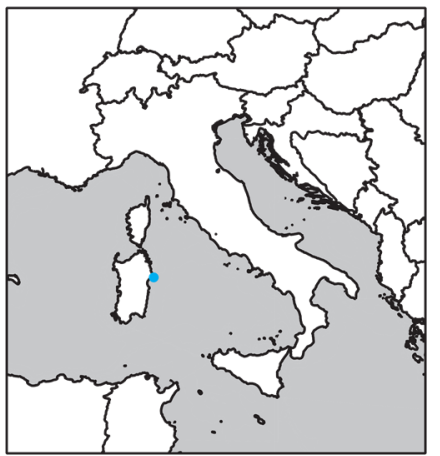

29. Choneiulus lacinifer

Strasser, 1980 


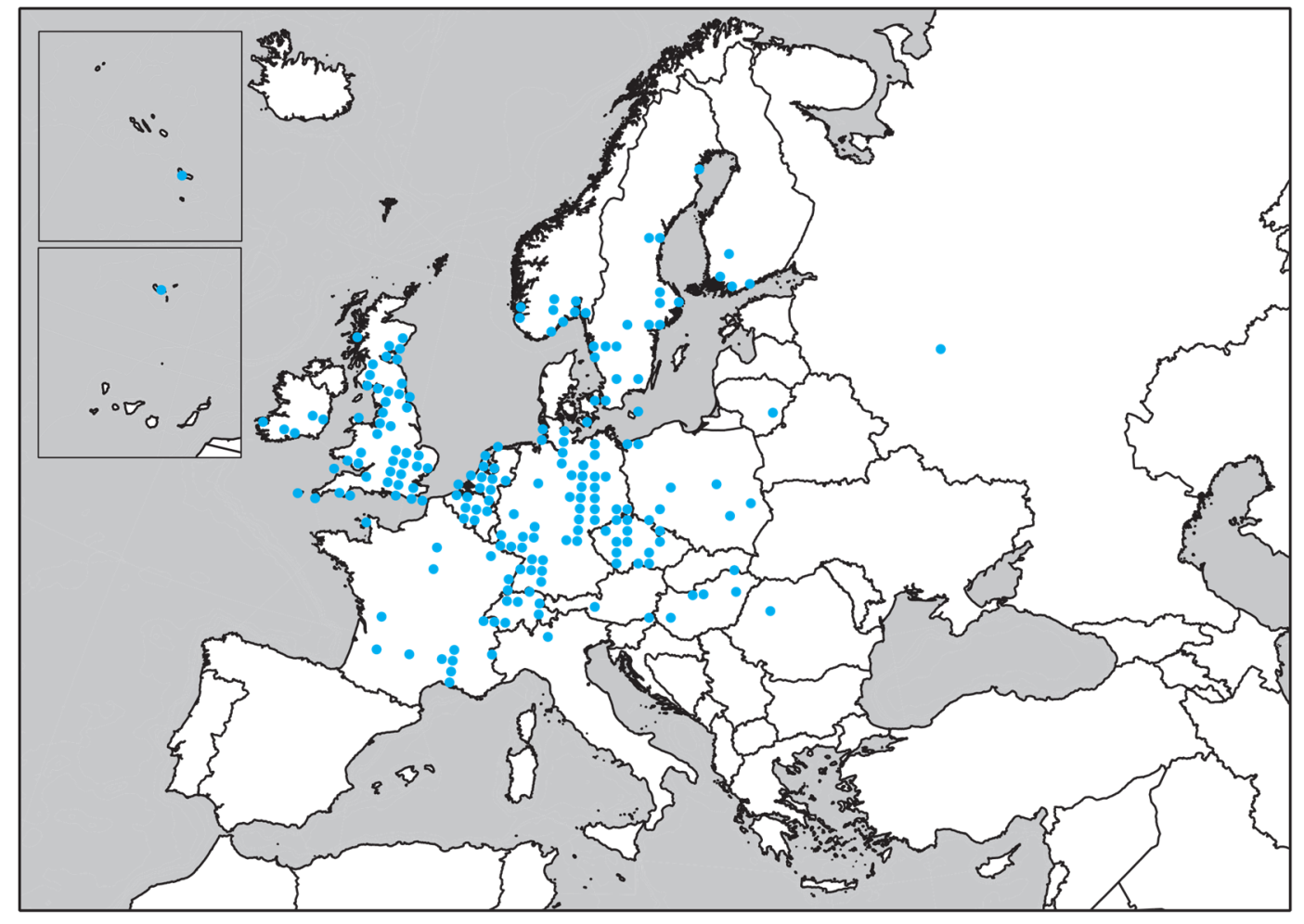

30. Choneiulus palmatus (Nĕmec, 1895)

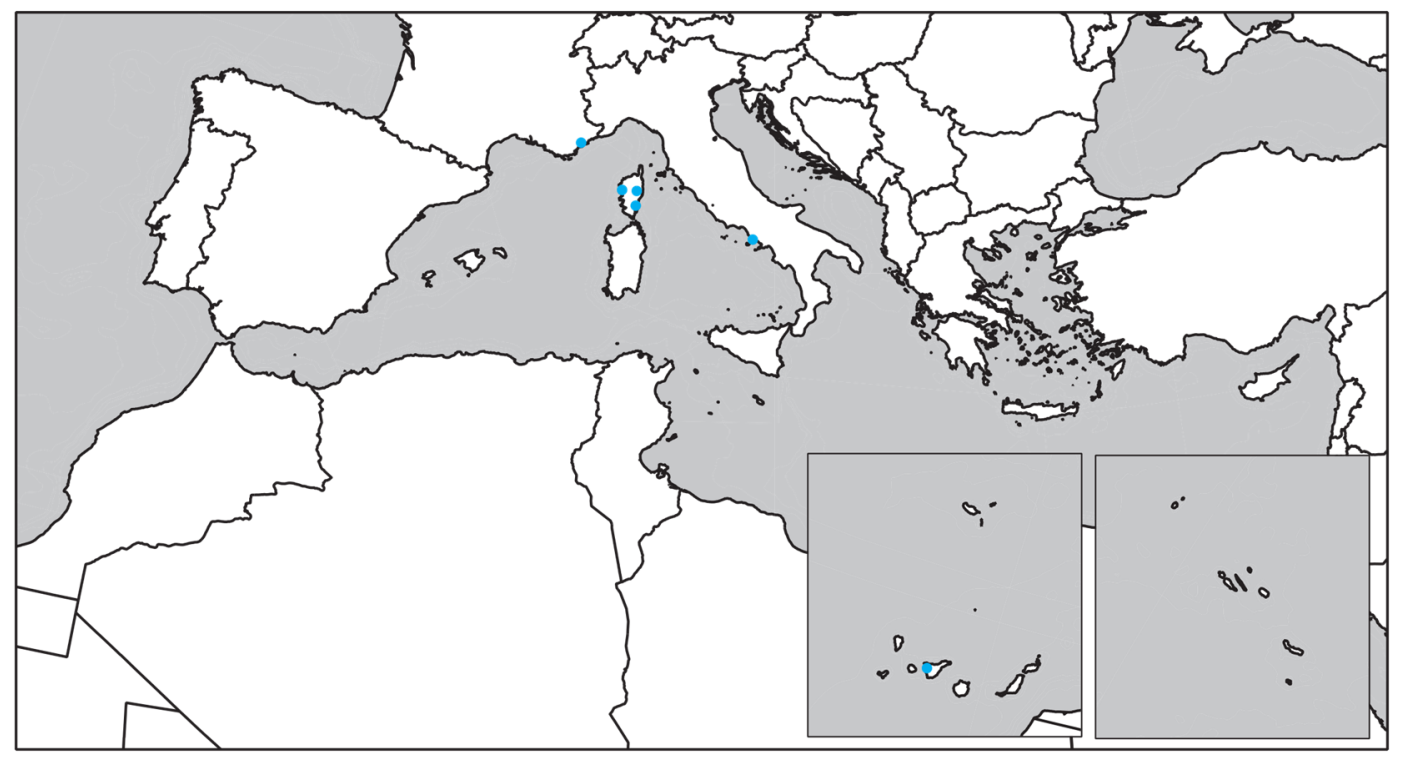

31. Choneiulus subterraneus (Silvestri, 1903) 


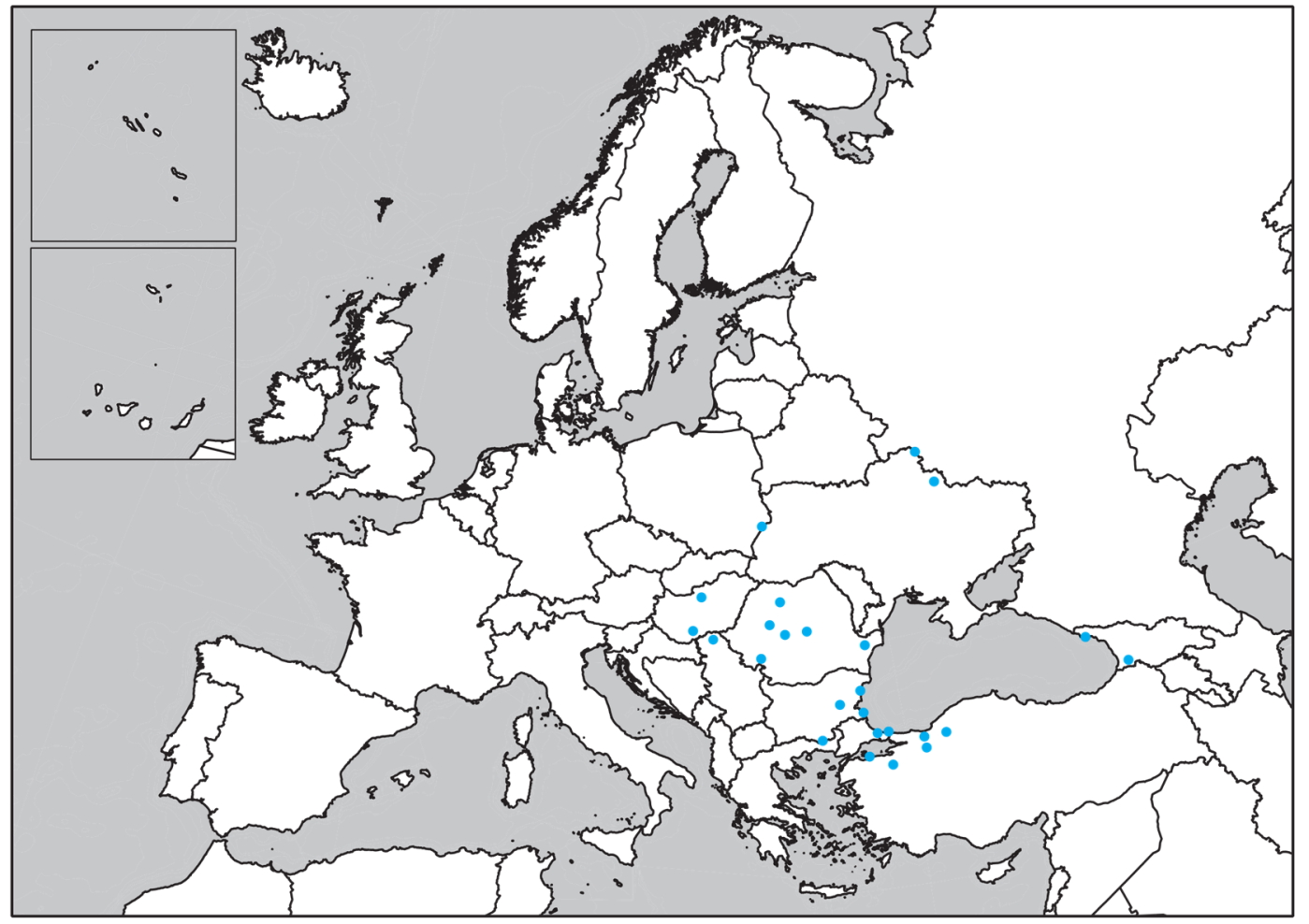

32. Cibiniulus phlepsii (Verhoeff, 1897)

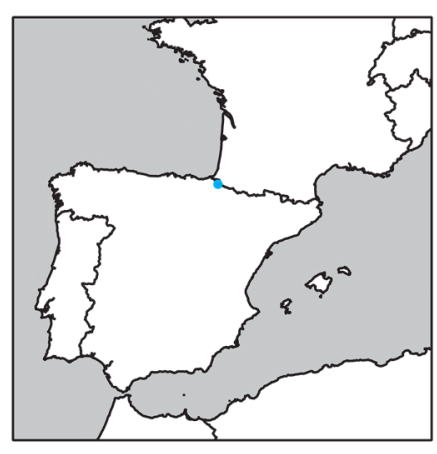

33. Euzdakiulus sarensis

Mauriès, 1970

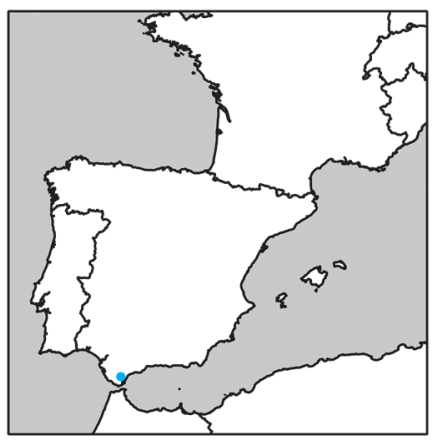

34. Iberoiulus breuili Ceuca, 1967

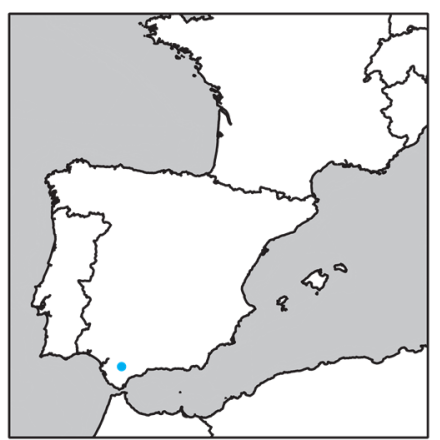

35. Iberoiulus cavernicola Ceuca, 1967

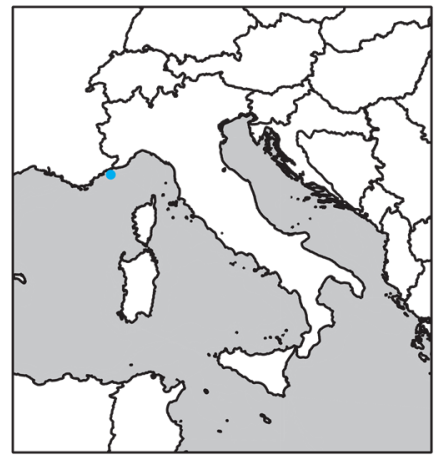

36. Mesoblaniulus serrula (Brölemann, 1905)

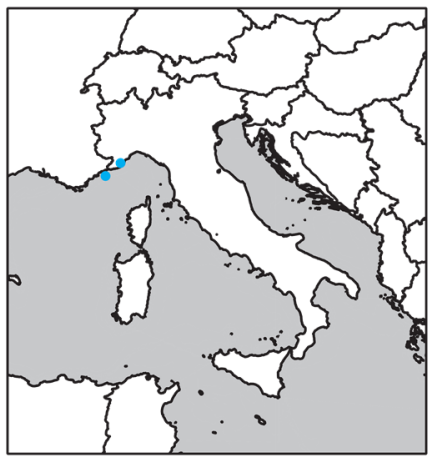

37. Monacobates monoecensis

(Brölemann, 1905) 


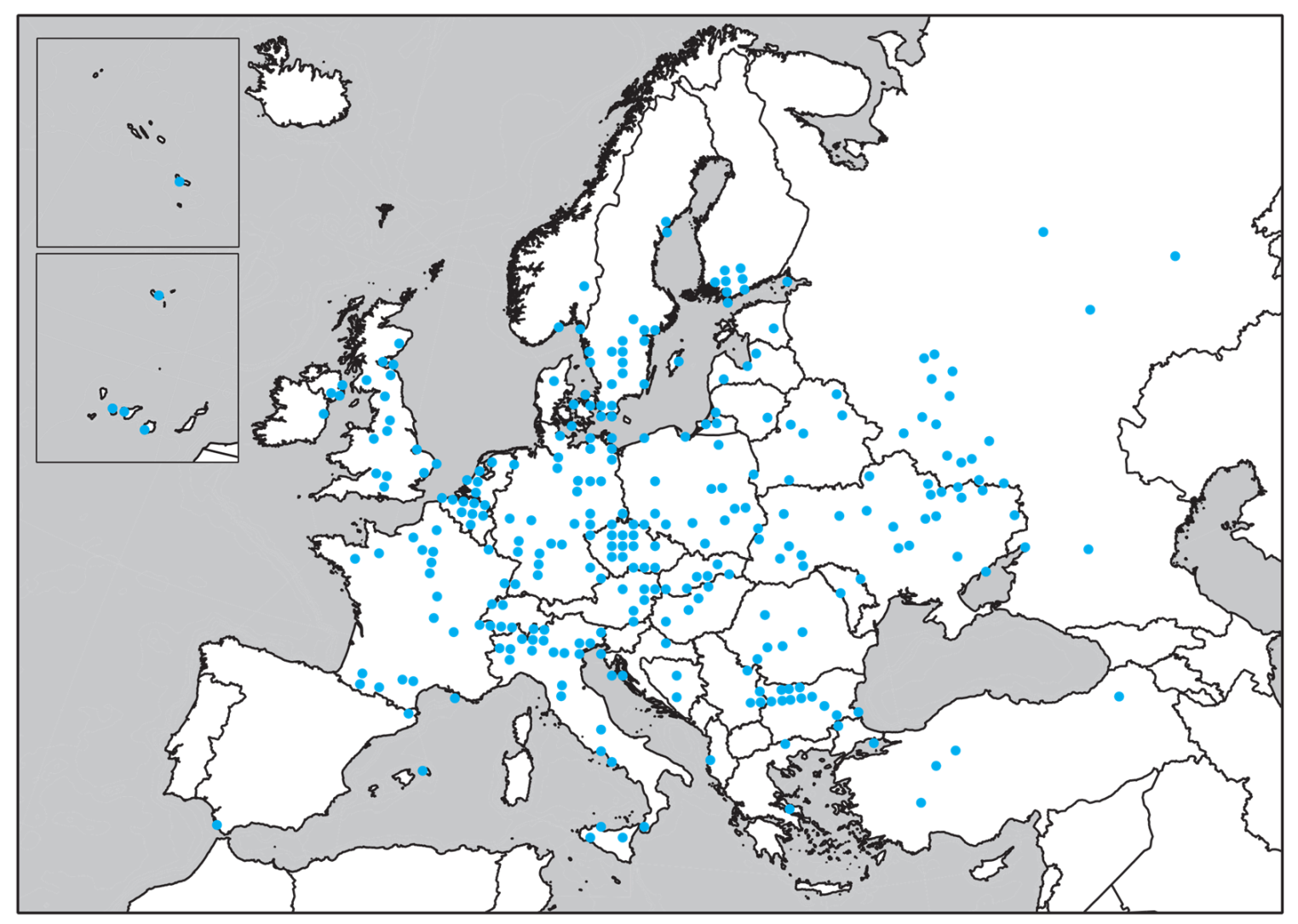

38. Nopoiulus kochii (Gervais, 1847)

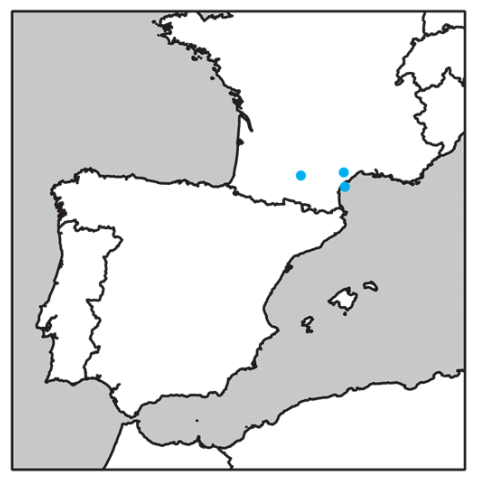

39. Occitaniulus rouchi Mauriès, 1965

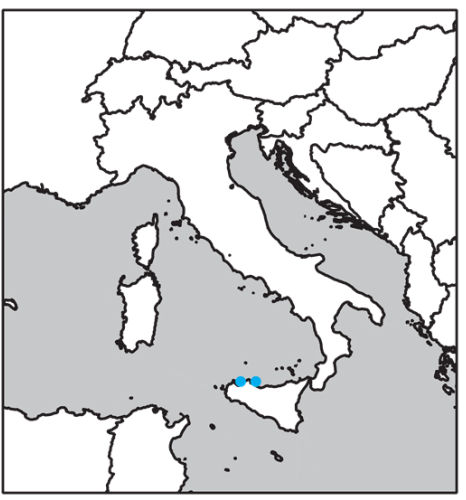

40. Orphanoiulus dinapolii Strasser, 1960 


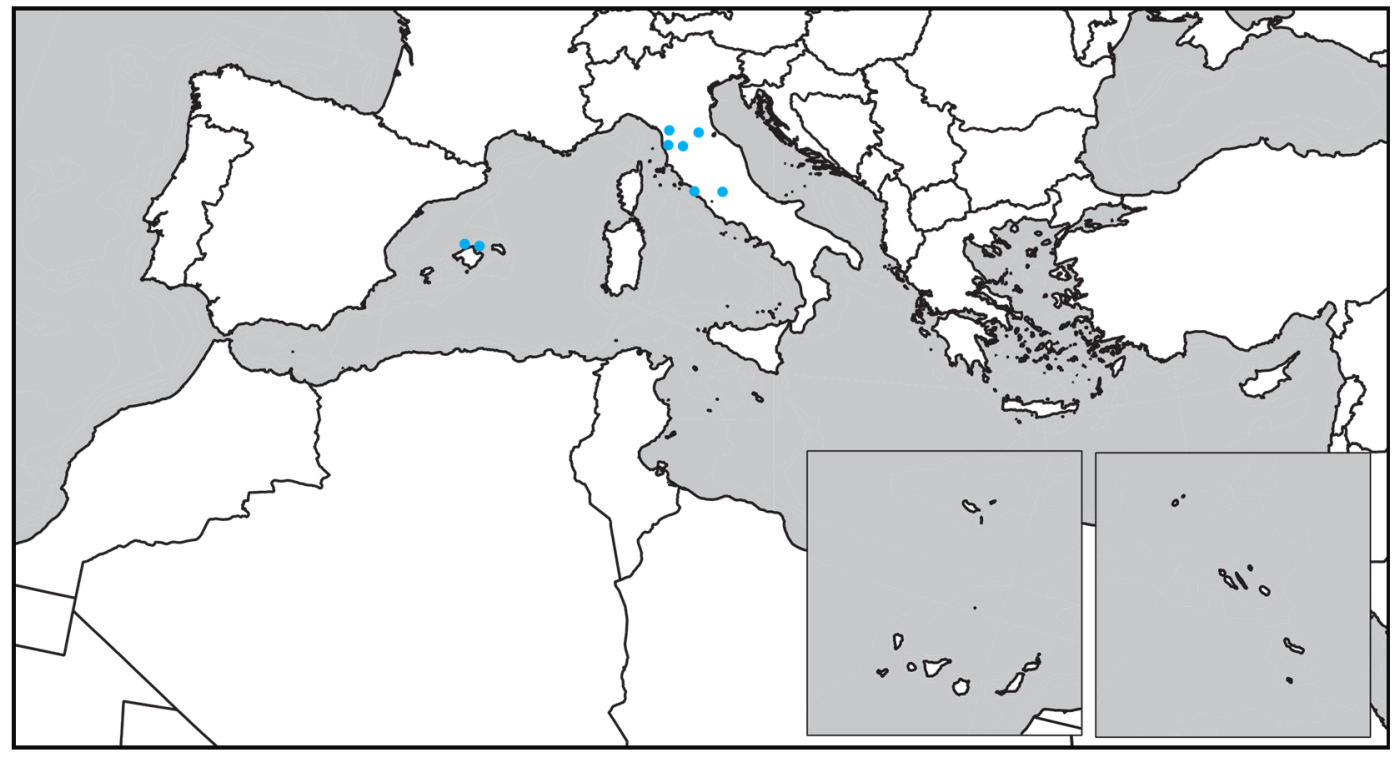

41. Orphanoiulus religiosus (Silvestri,1903)

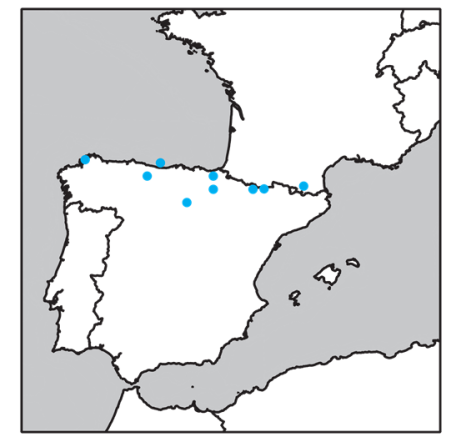

42. Proteroiulus broelemanni

Lohmander, 1925 


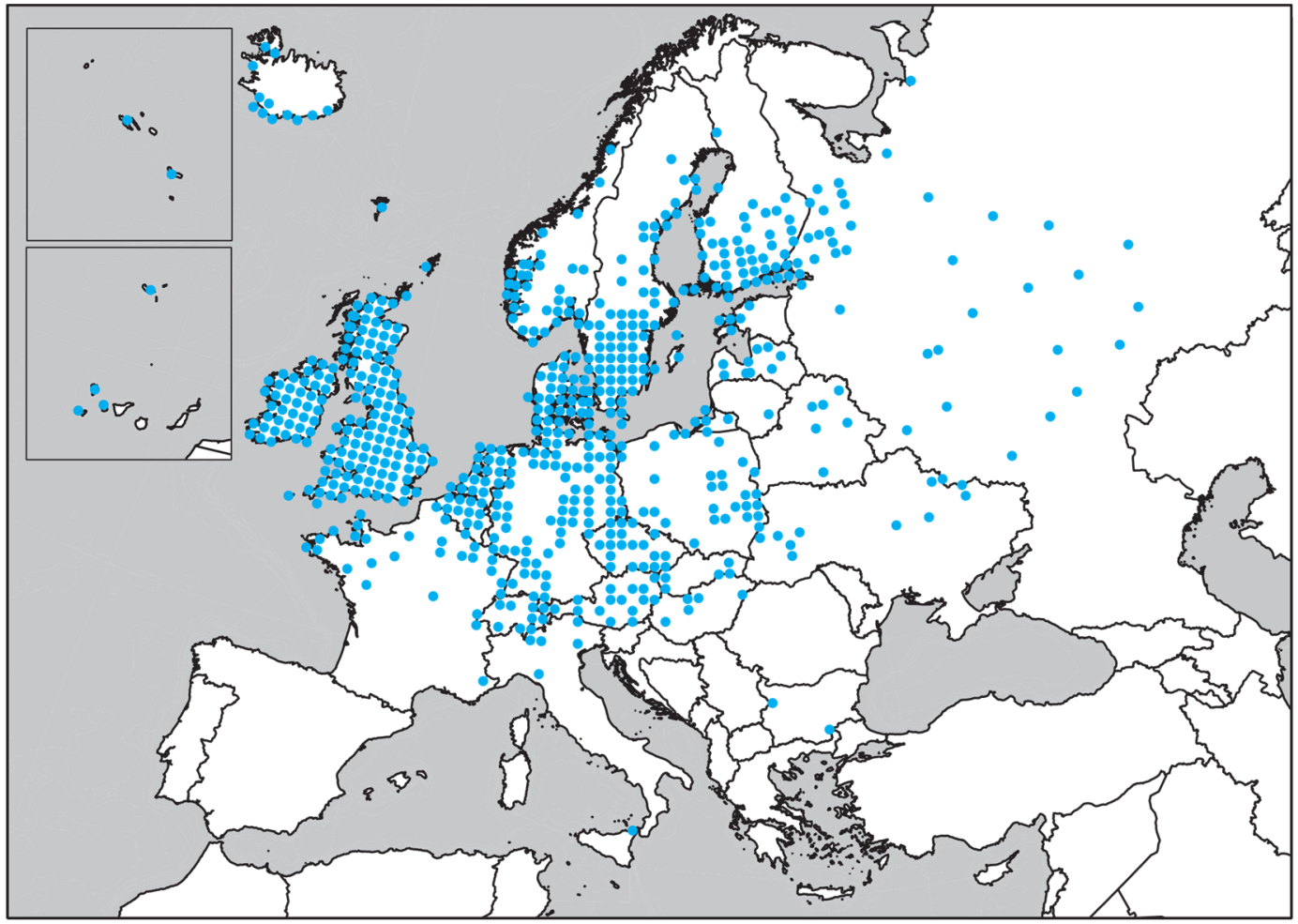

43. Proteroiulus fuscus (Am Stein, 1857)

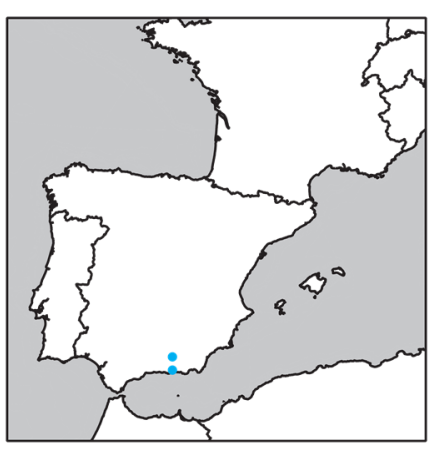

44. Proteroiulus hispanus

Schubart, 1959

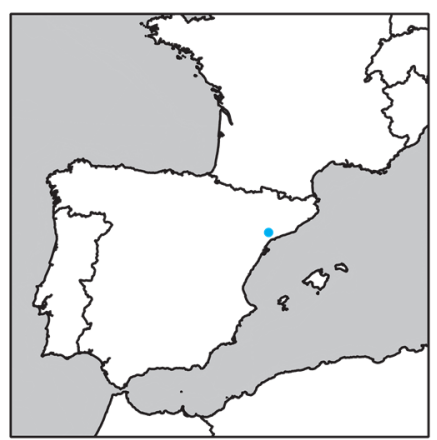

47. Tarracoblaniulus phantasmanus

Enghoff, Serra \& Martínez, 2009

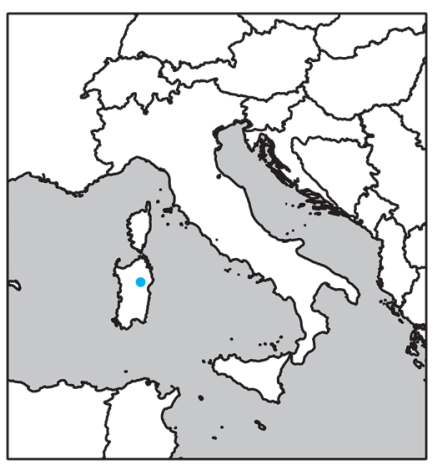

45. Sardoblaniulus annae Manfredi, 1956

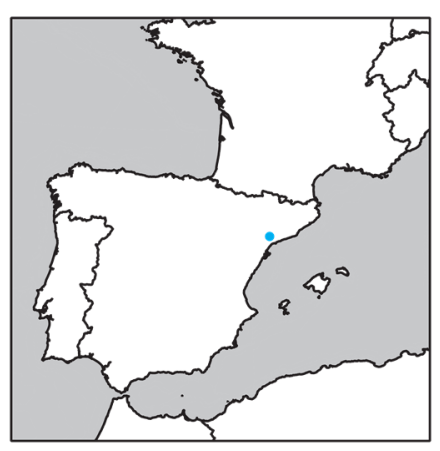

46. Tarracoblaniulus lagari Mauriès \& Vicente, 1977

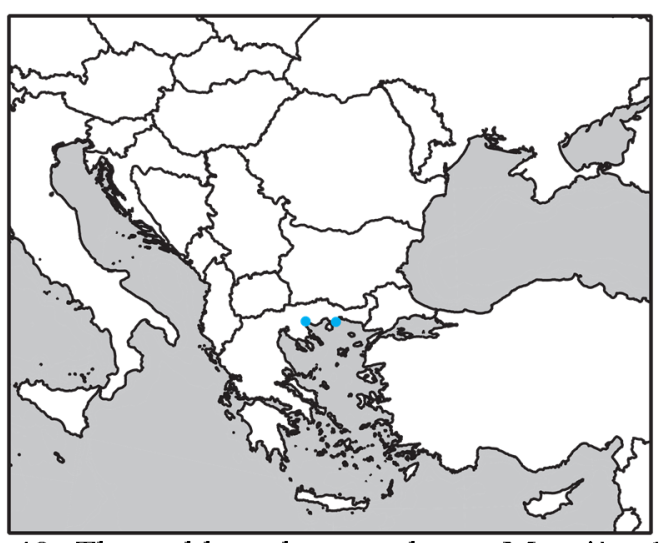

48. Thassoblaniulus simplarius Mauriès, 1985 


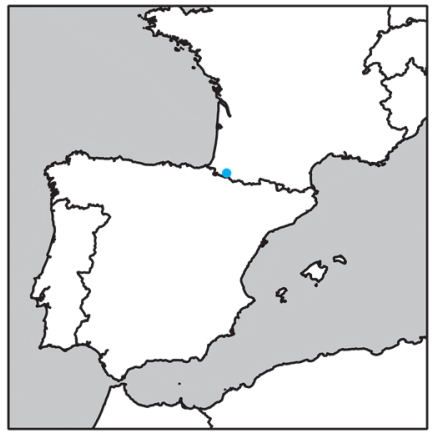

49. Vascoblaniulus cabidochei Mauriès, 1967

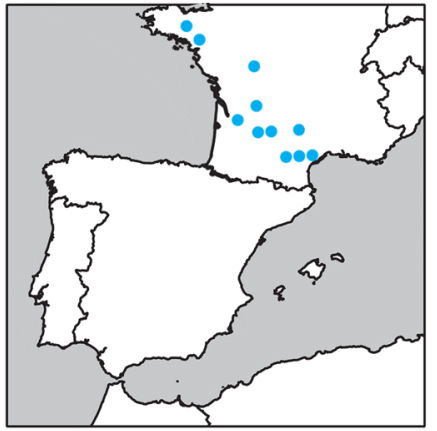

50. Galliobates gracilis (Ribaut, 1909)

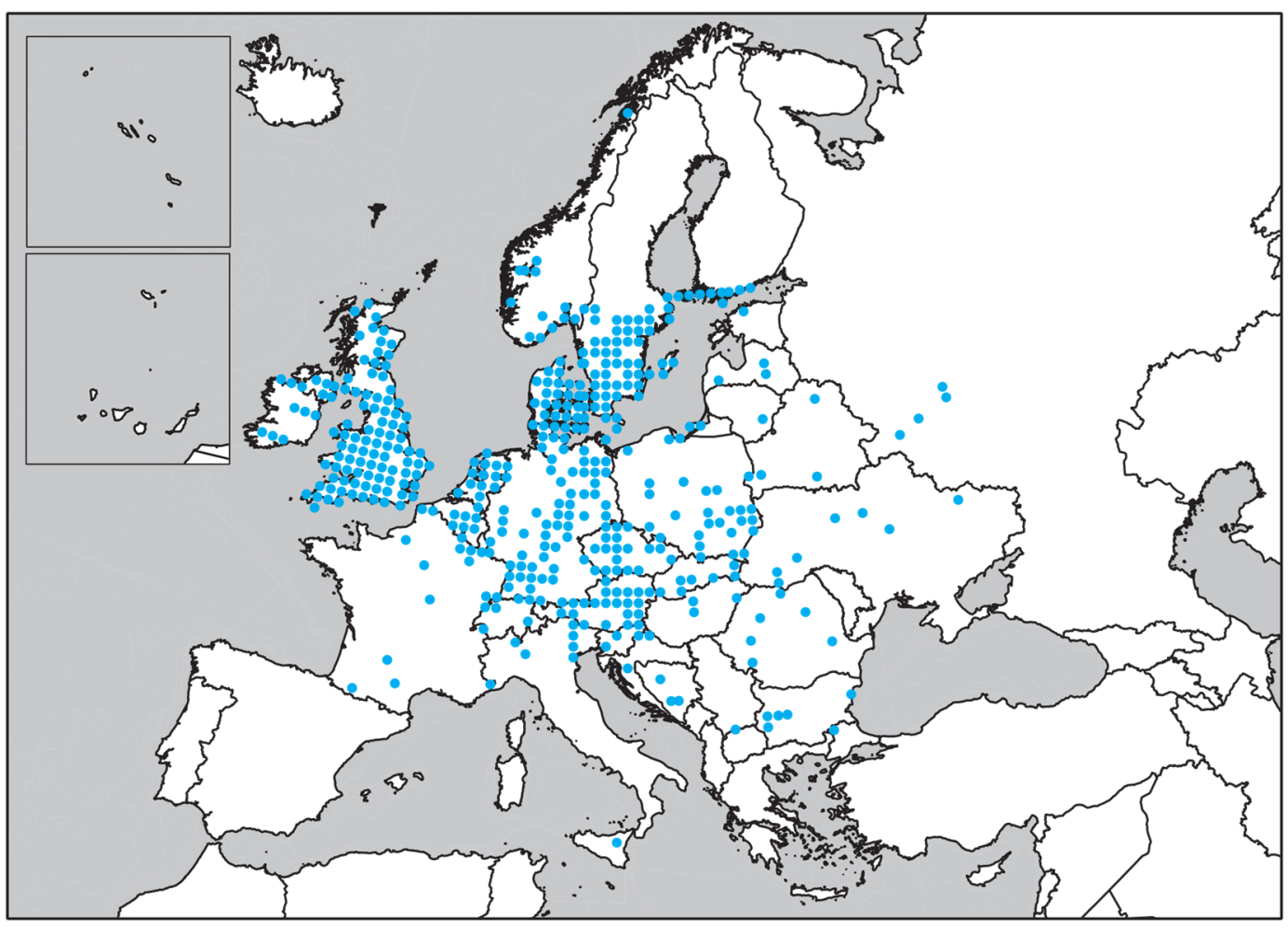

51. Nemasoma varicorne C.L. Koch, 1847

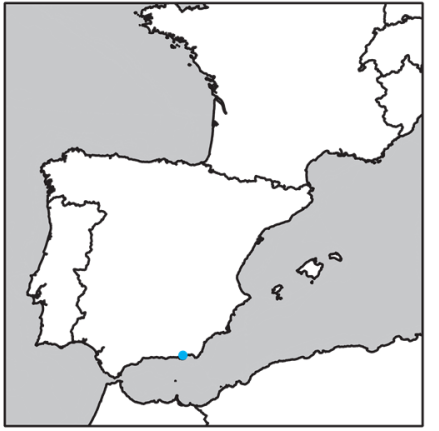

52. Thalassisobates almeriensis Enghoff, 2013

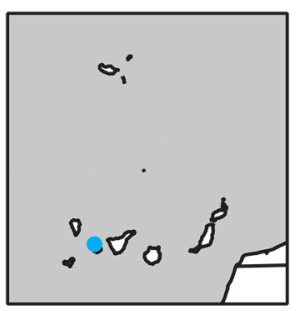

53. Thalassisobates emesesensis Enghoff, 2013 


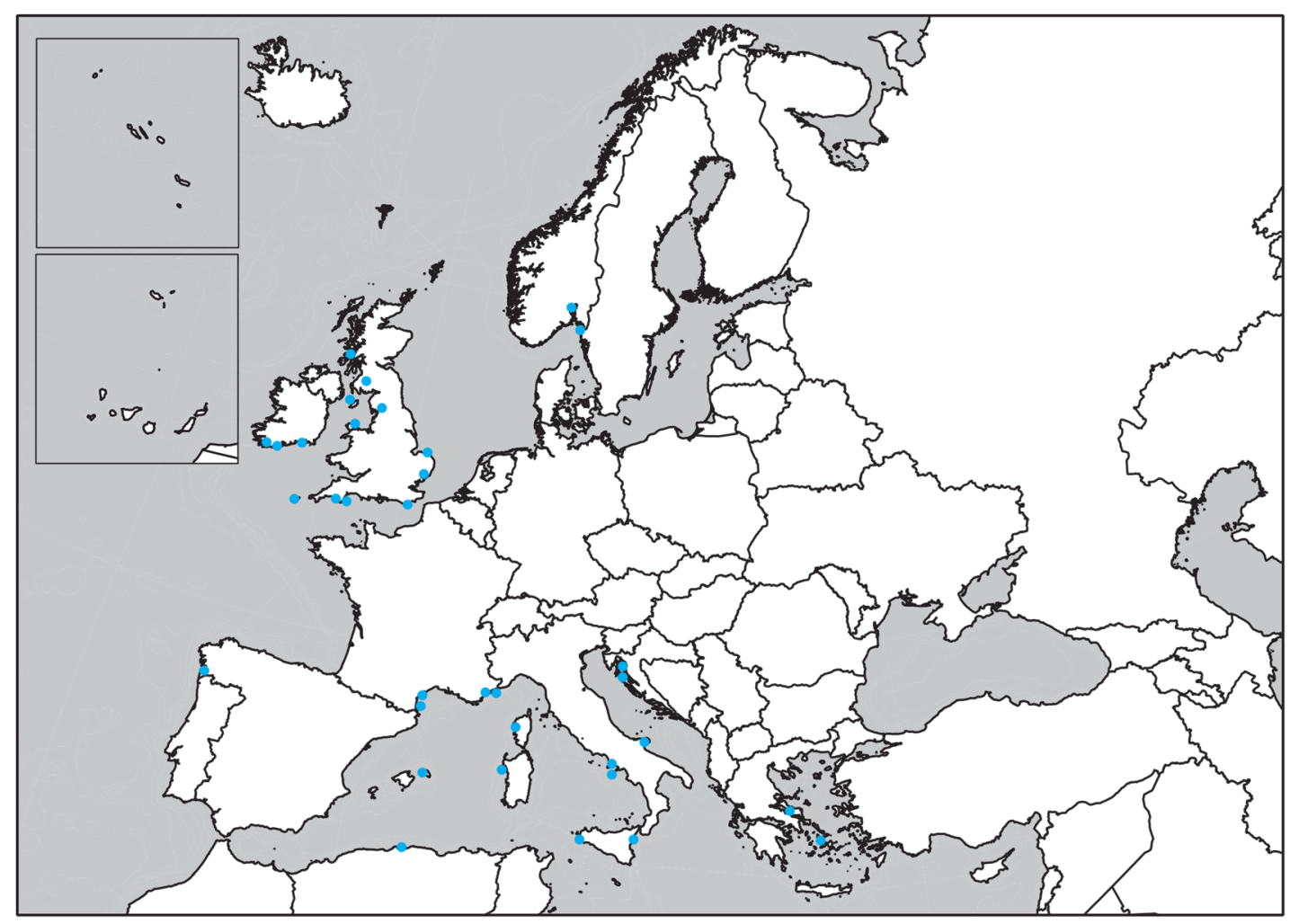

54. Thalassisobates littoralis (Silvestri, 1903)

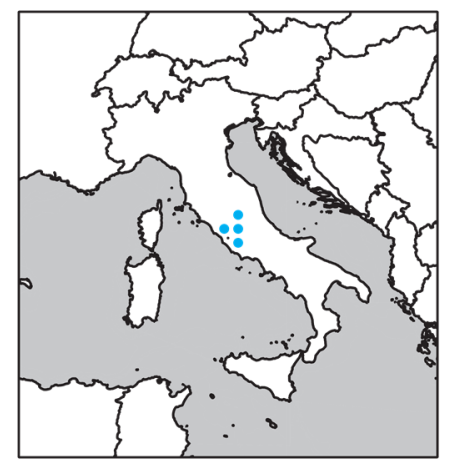

55. Rhopaloiulus cameratanus Attems, 1927

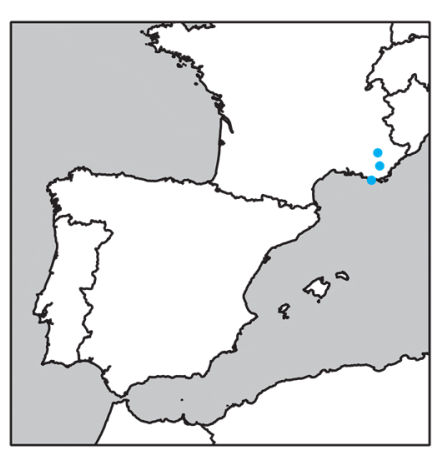

56. Trichoblaniulus cavernicola Brölemann, 1905

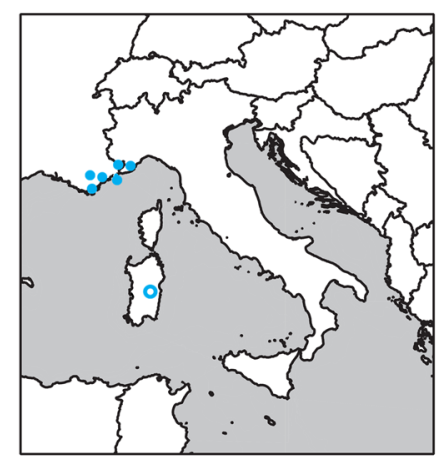

57. Trichoblaniulus hirsutus (Brölemann, 1889)

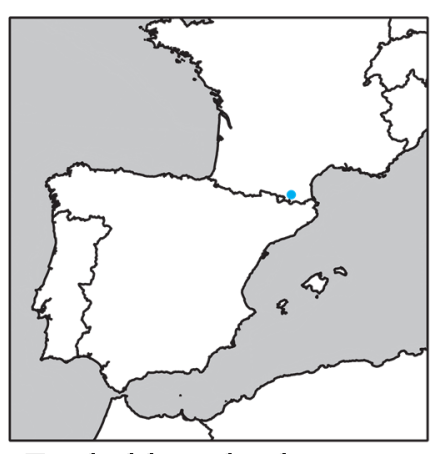

58. Trichoblaniulus lanuginosus Ribaut, 1947

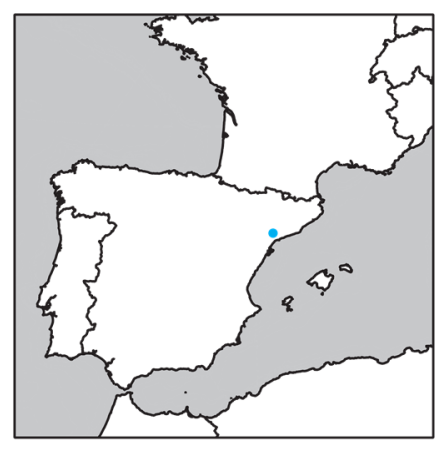

59. Trichoblaniulus tarraconensis Mauriès \& Vicente. 1977 


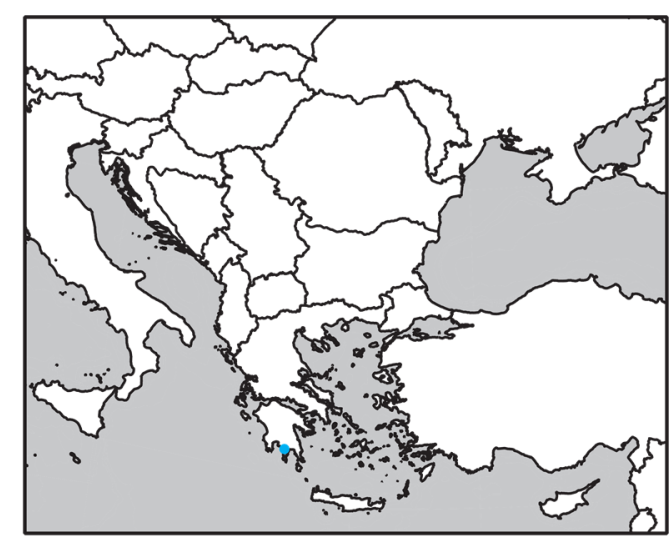

60. Trichonemasoma peloponesius

(Mauriès, 1966)

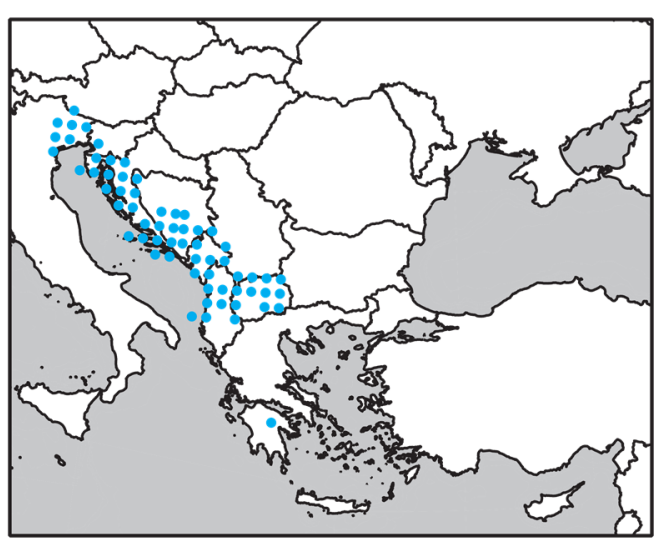

62. Acanthoiulus fuscipes

(C.L. Koch, 1847)

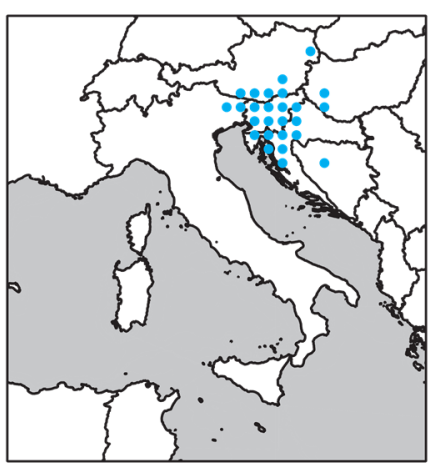

64. Allajulus dicentrus

(Latzel, 1884)

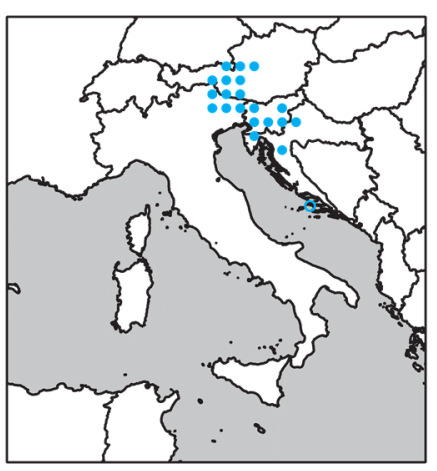

65. Allajulus groedensis

(Attems, 1899)

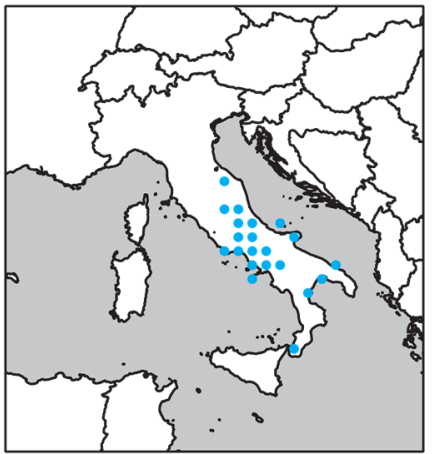

61. Acanthoiulus cassinensis

(Verhoeff, 1910)

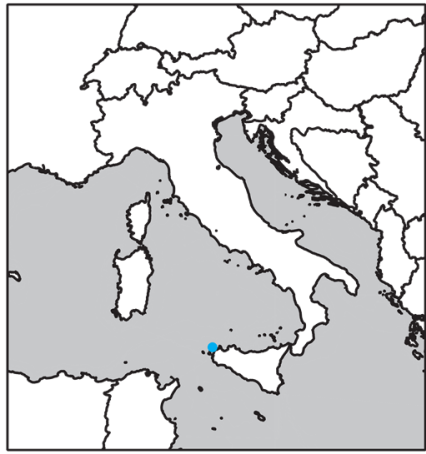

63. Afropachyiulus maritimus Strasser, 1970

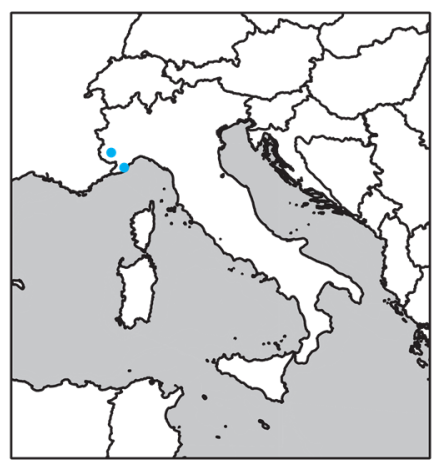

66. Allajulus infossus

(Verhoeff, 1930) 


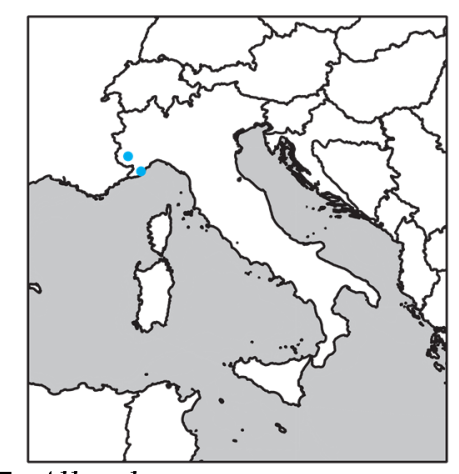

67. Allajulus marguareisi (Strasser, 1970)

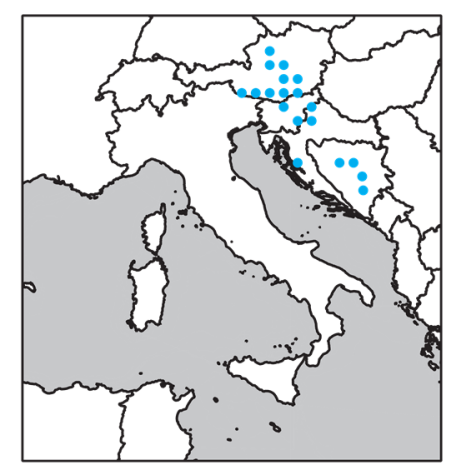

68. Allajulus molybdinus

C.L. Koch, 1847

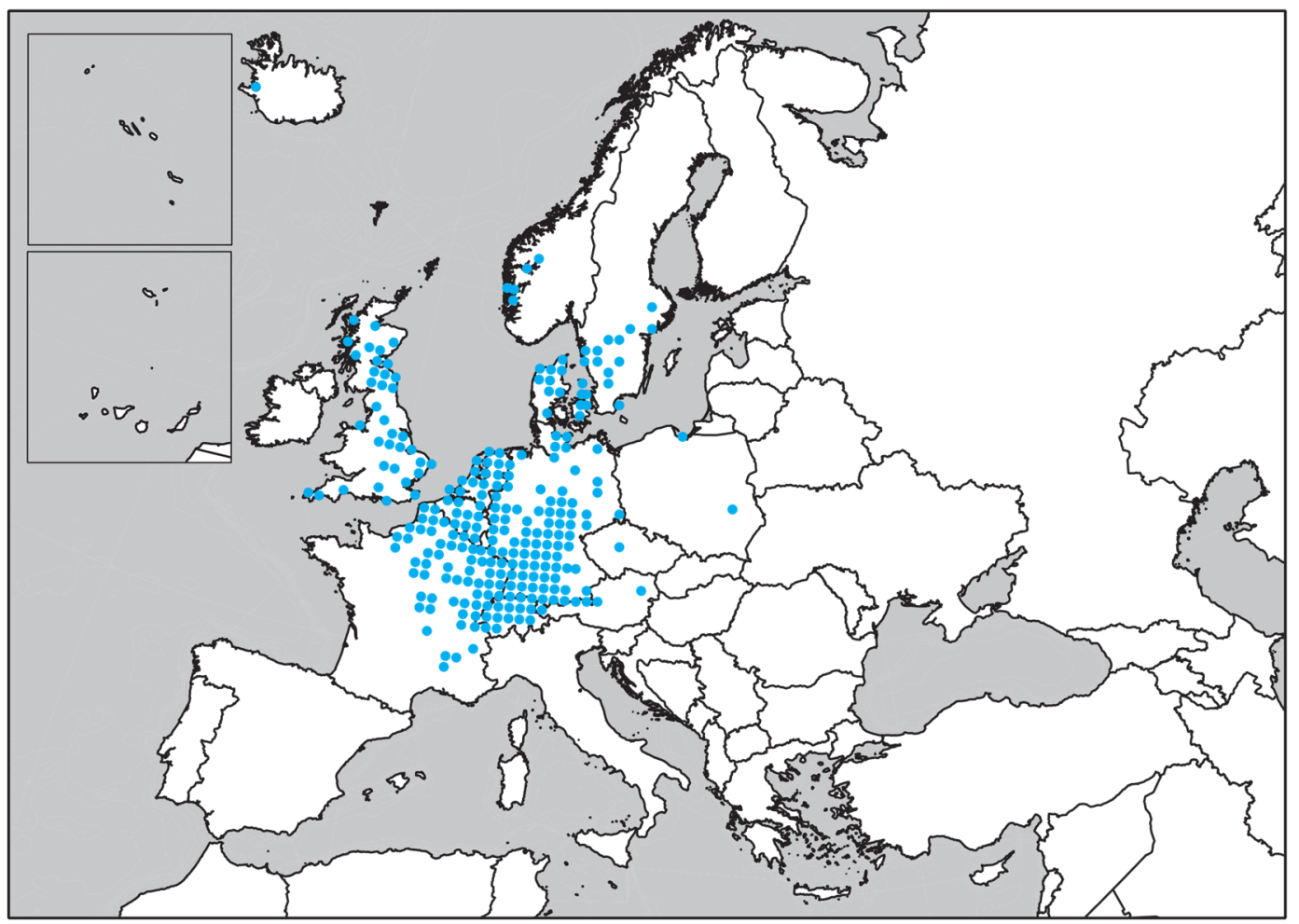

69. Allajulus nitidus (Verhoeff, 1891)

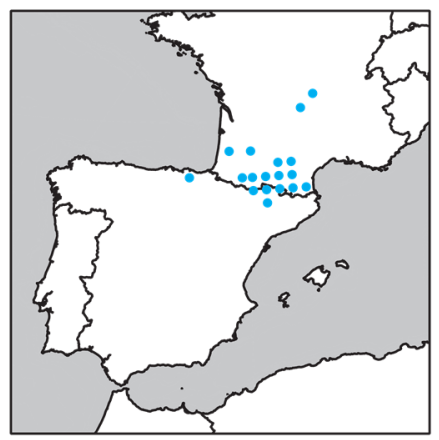

70. Allajulus spinosus

(Ribaut, 1904) 


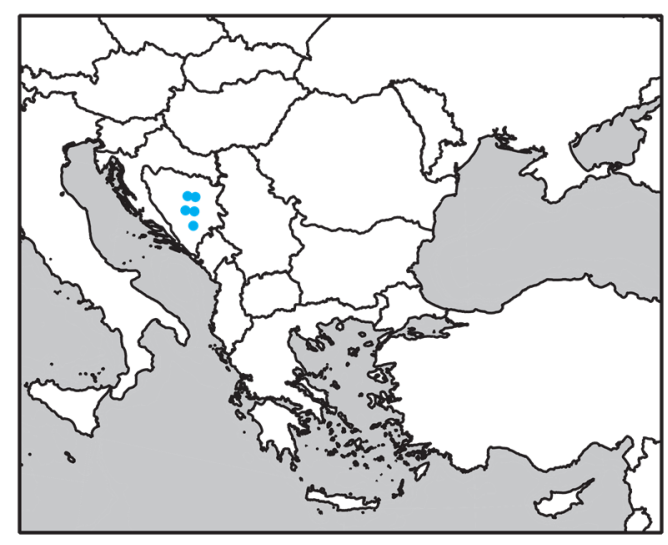

71. Allopodoiulus schiodtei (Verhoeff, 1898)

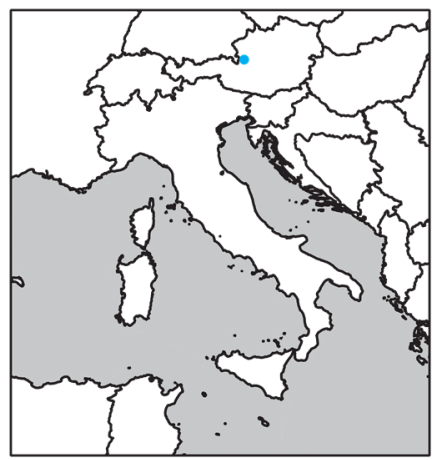

73. Alpityphlus seewaldi Strasser, 1967

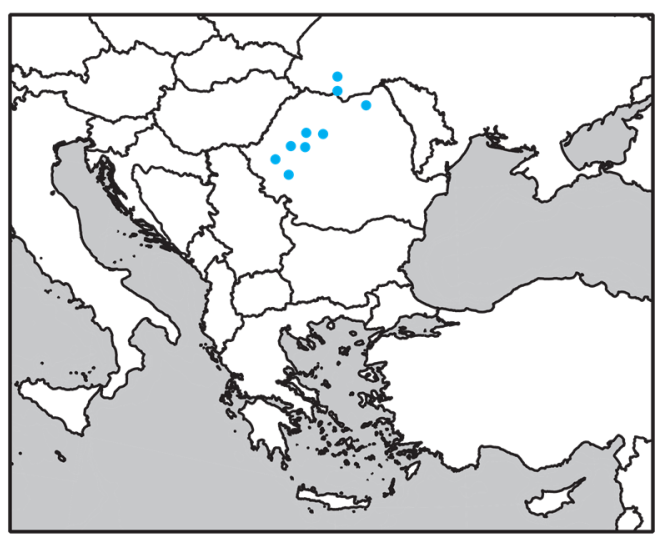

72. Allopodoiulus verhoeffi (Jawlowski, 1931)

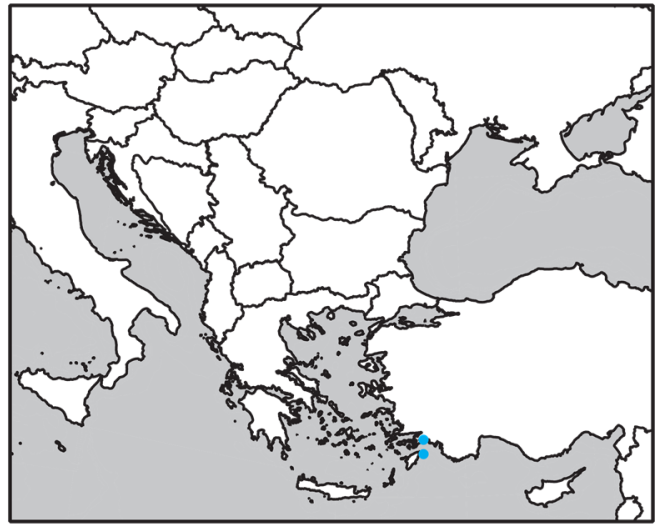

74. Amblyiulus aphroditae

(Attems, 1902)

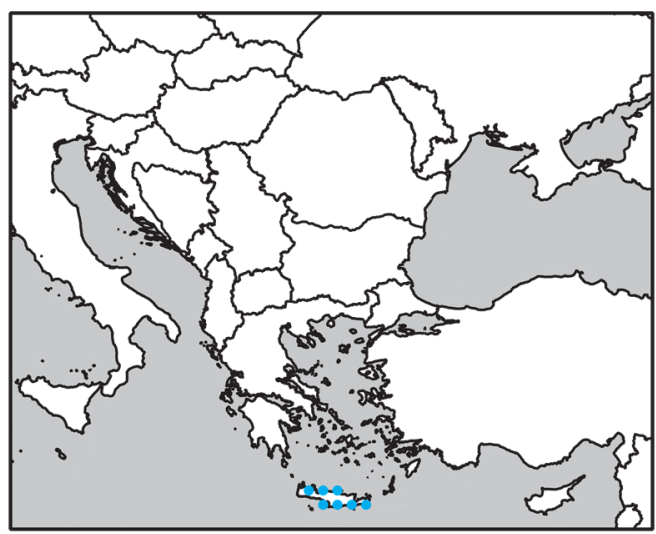

75. Amblyiulus creticus (Verhoeff, 1901) 


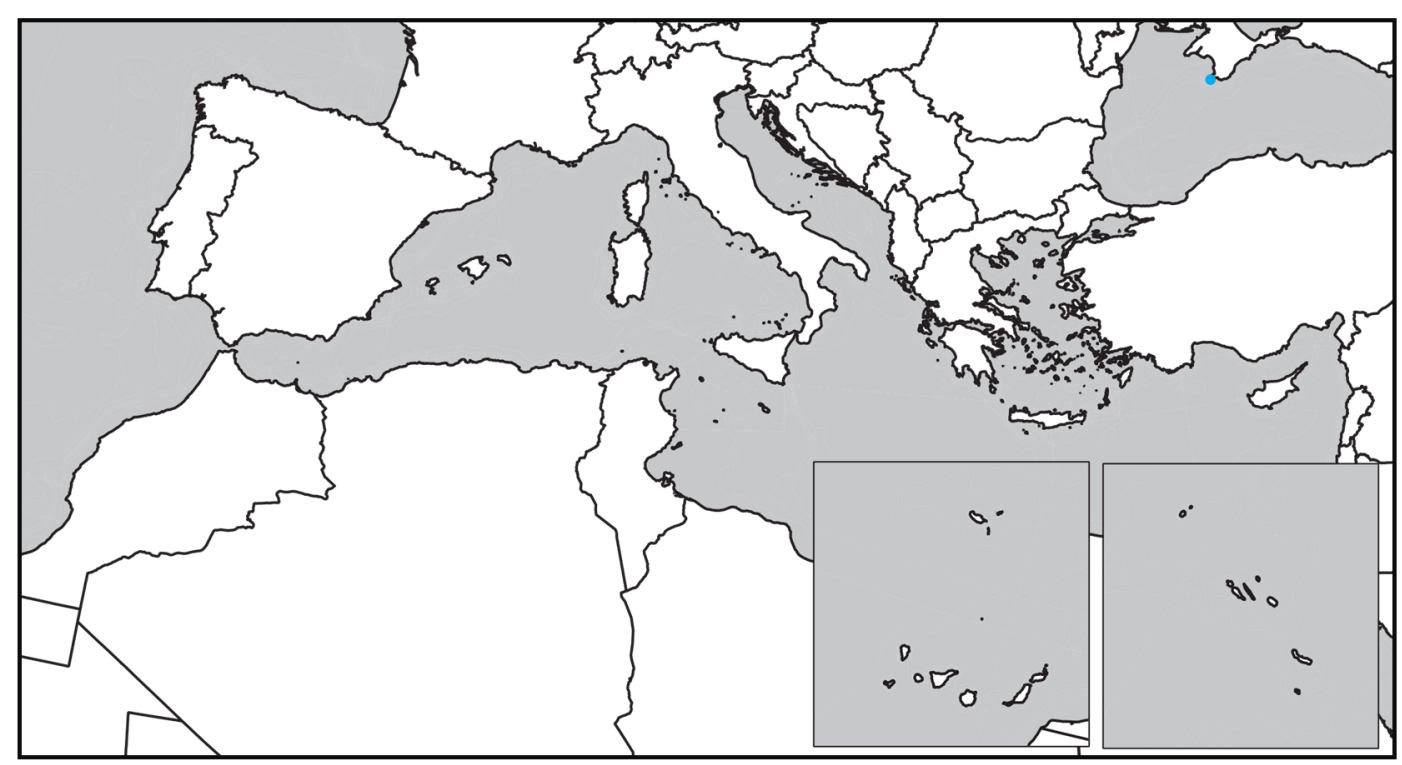

76. Amblyiulus kovali Golovatch, 2008

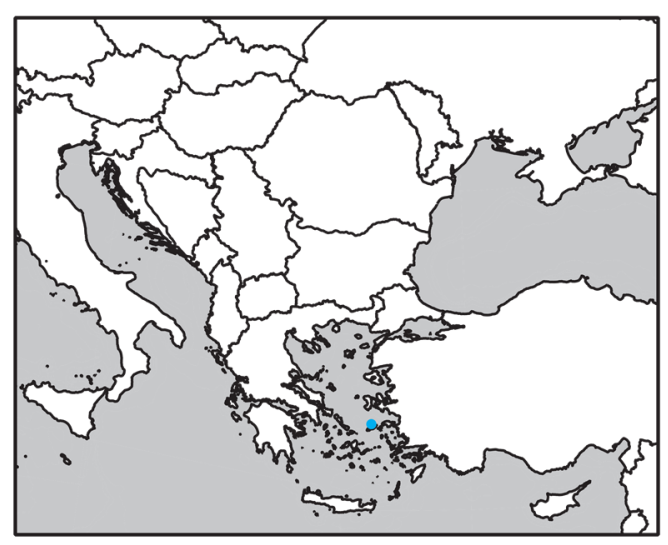

77. Amblyiulus sporadensis (Verhoeff, 1901)

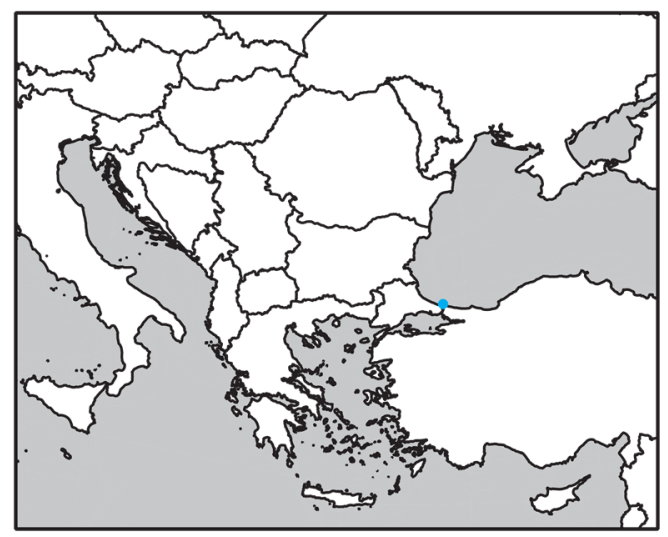

79. Apfelbeckiella byzantina Verhoeff, 1901

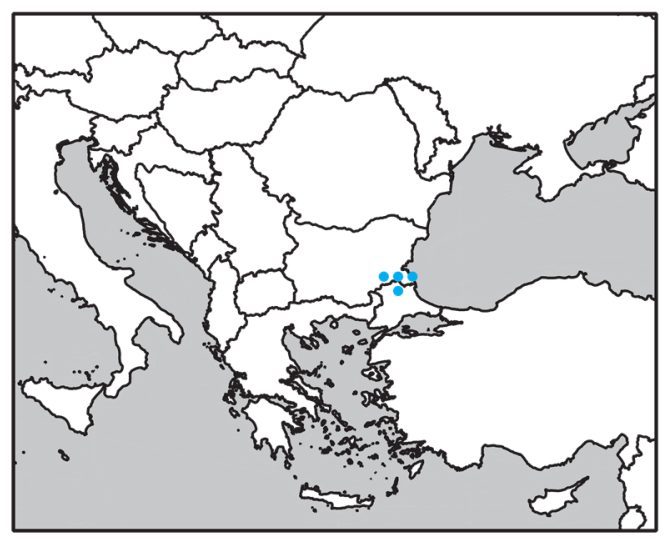

78. Apfelbeckiella bulgarica Verhoeff, 1926

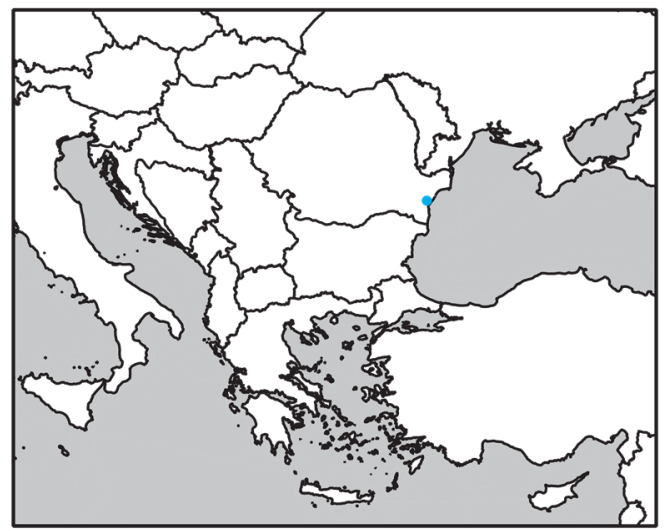

80. Apfelbeckiella dobrogica

Tabacaru, 1966 


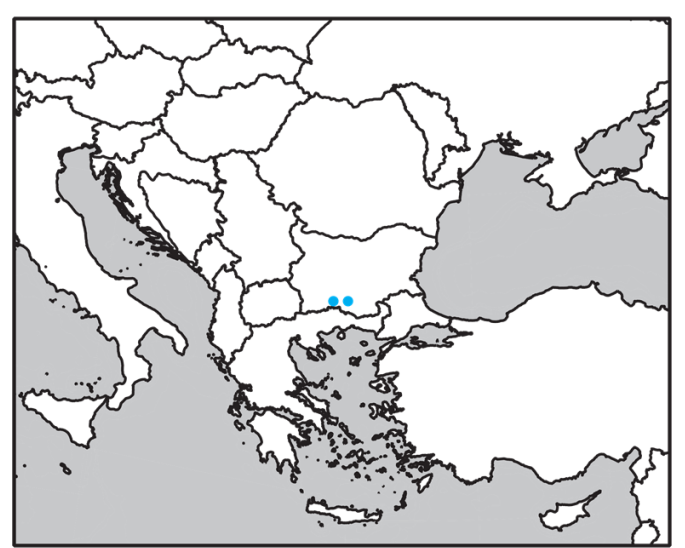

81. Apfelbeckiella golemanskyi

Ceuca, 1973

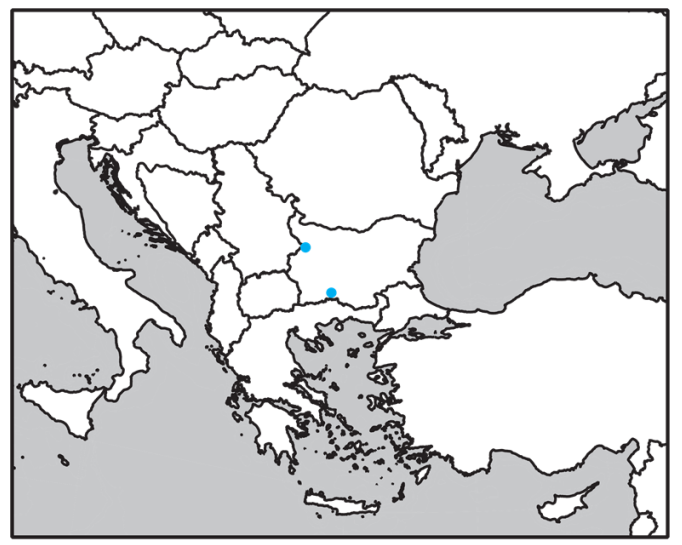

83. Balkanophoenix borisi

Verhoeff, 1937

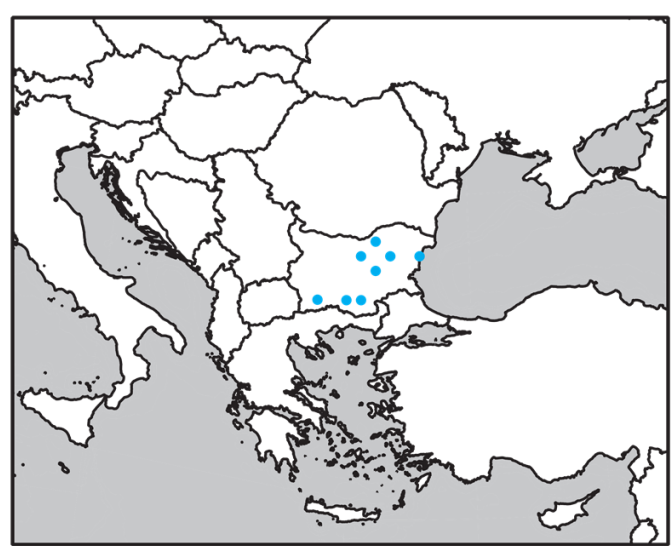

82. Apfelbeckiella trnovensis

(Verhoeff, 1928)

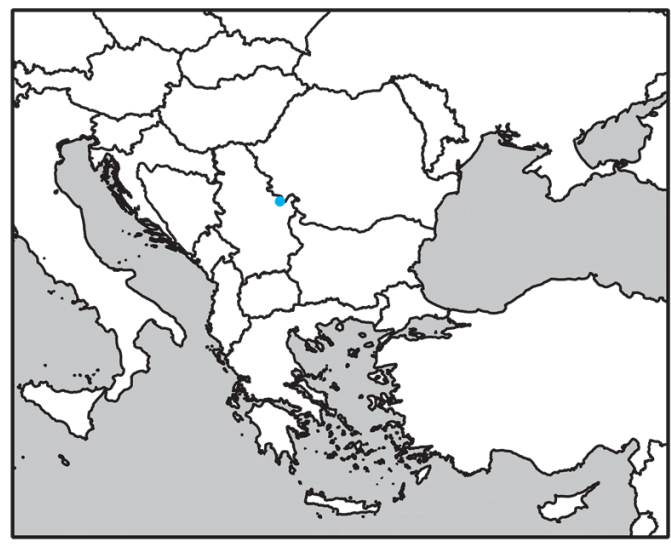

84. Banatoiulus troglobius

Tabacaru, 1985

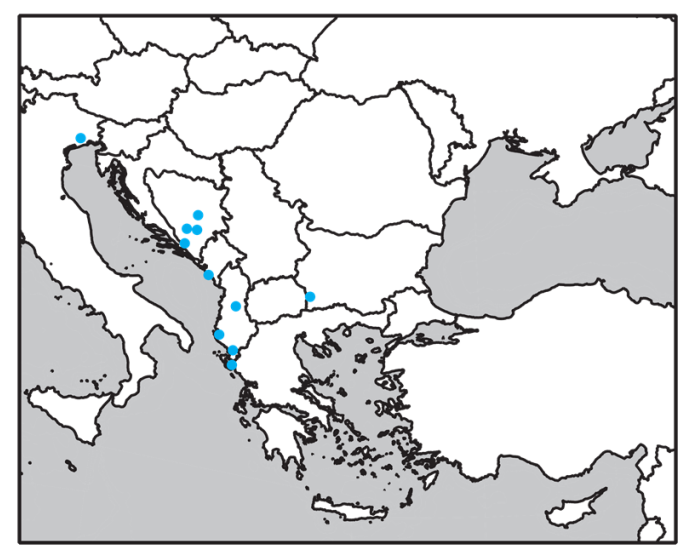

85. Brachyiulus apfelbecki

Verhoeff, 1898 


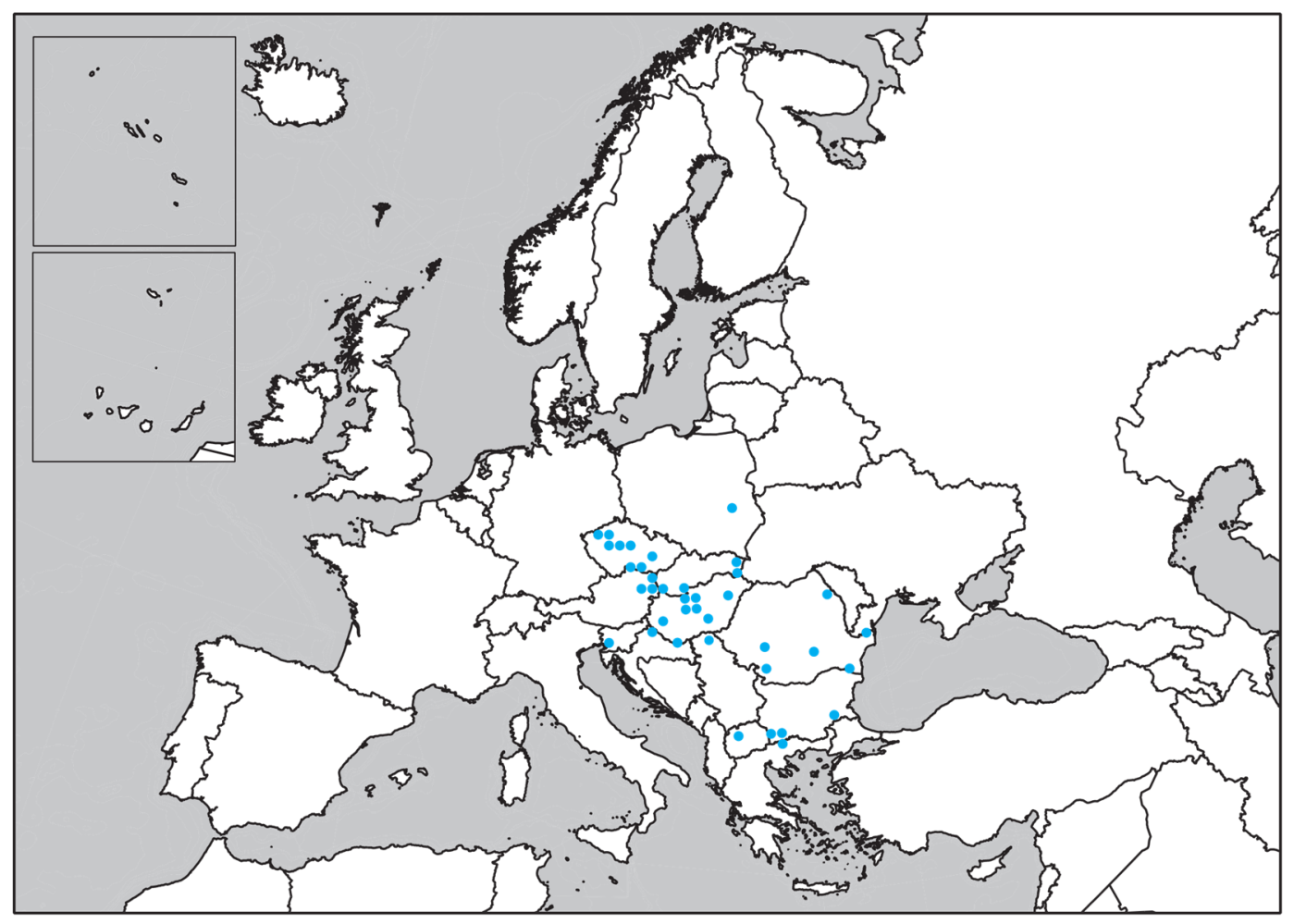

86. Brachyiulus bagnalli (Brolemann, 1924)

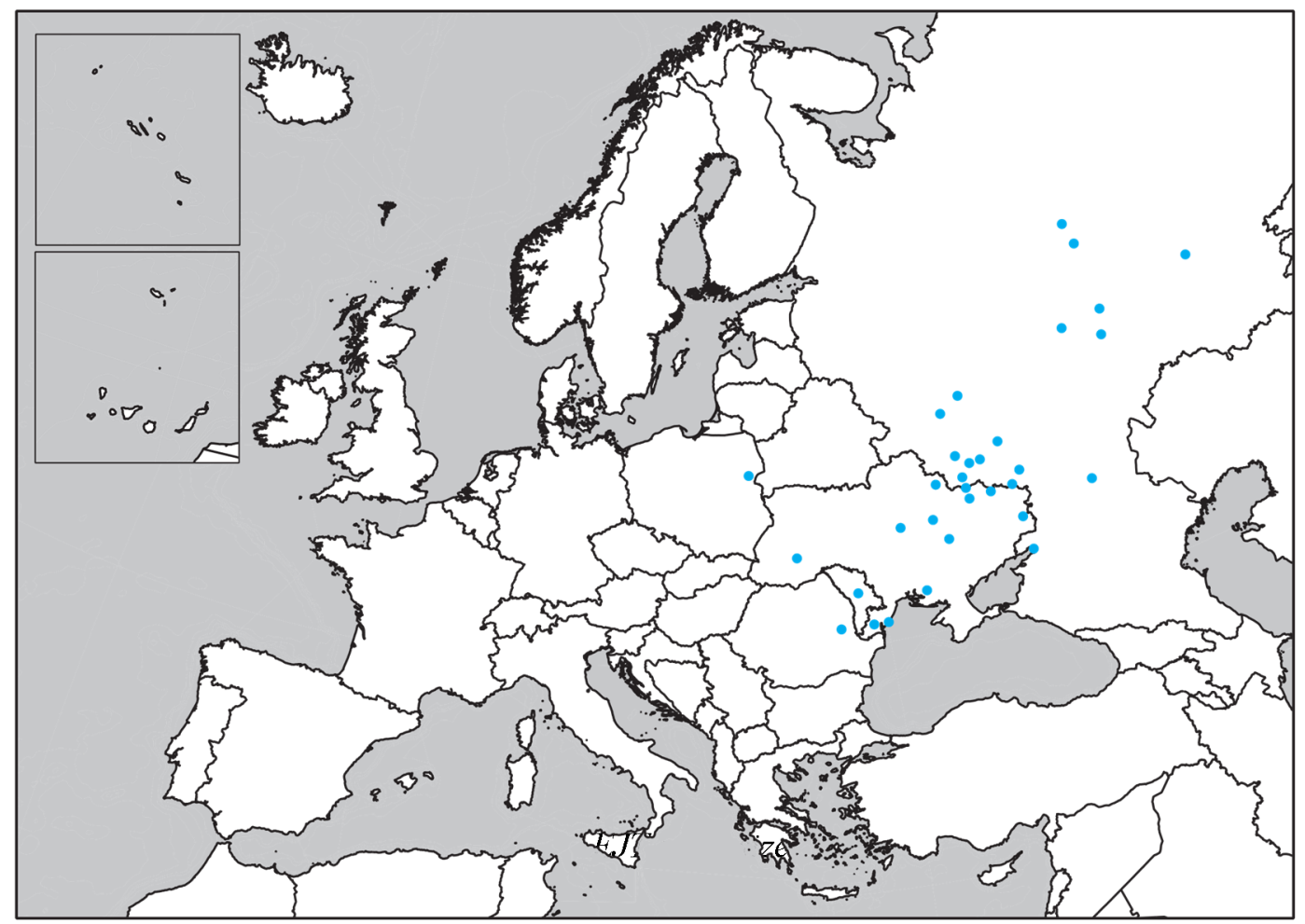

87. Brachyiulus jawlowskii Lohmander, 1928 


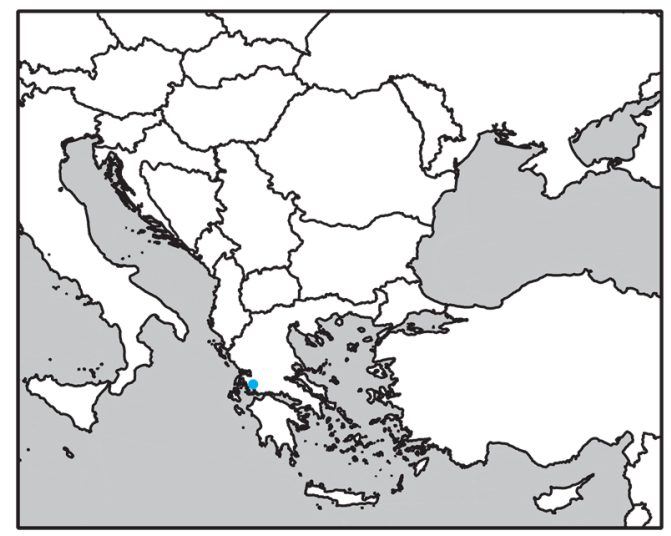

88. Brachyiulus klisurensis

Verhoeff, 1903

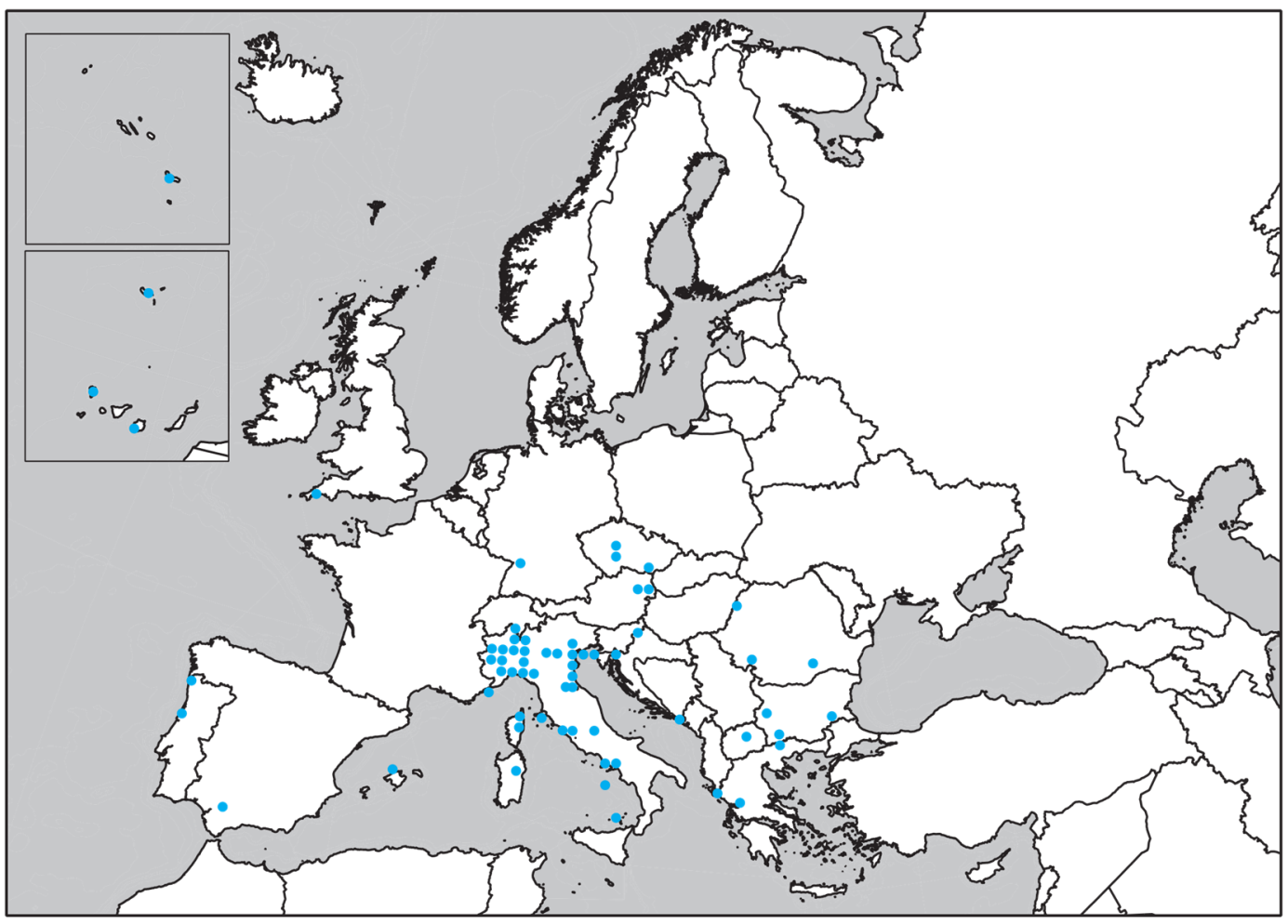

89. Brachyiulus lusitanus Verhoeff, 1898 


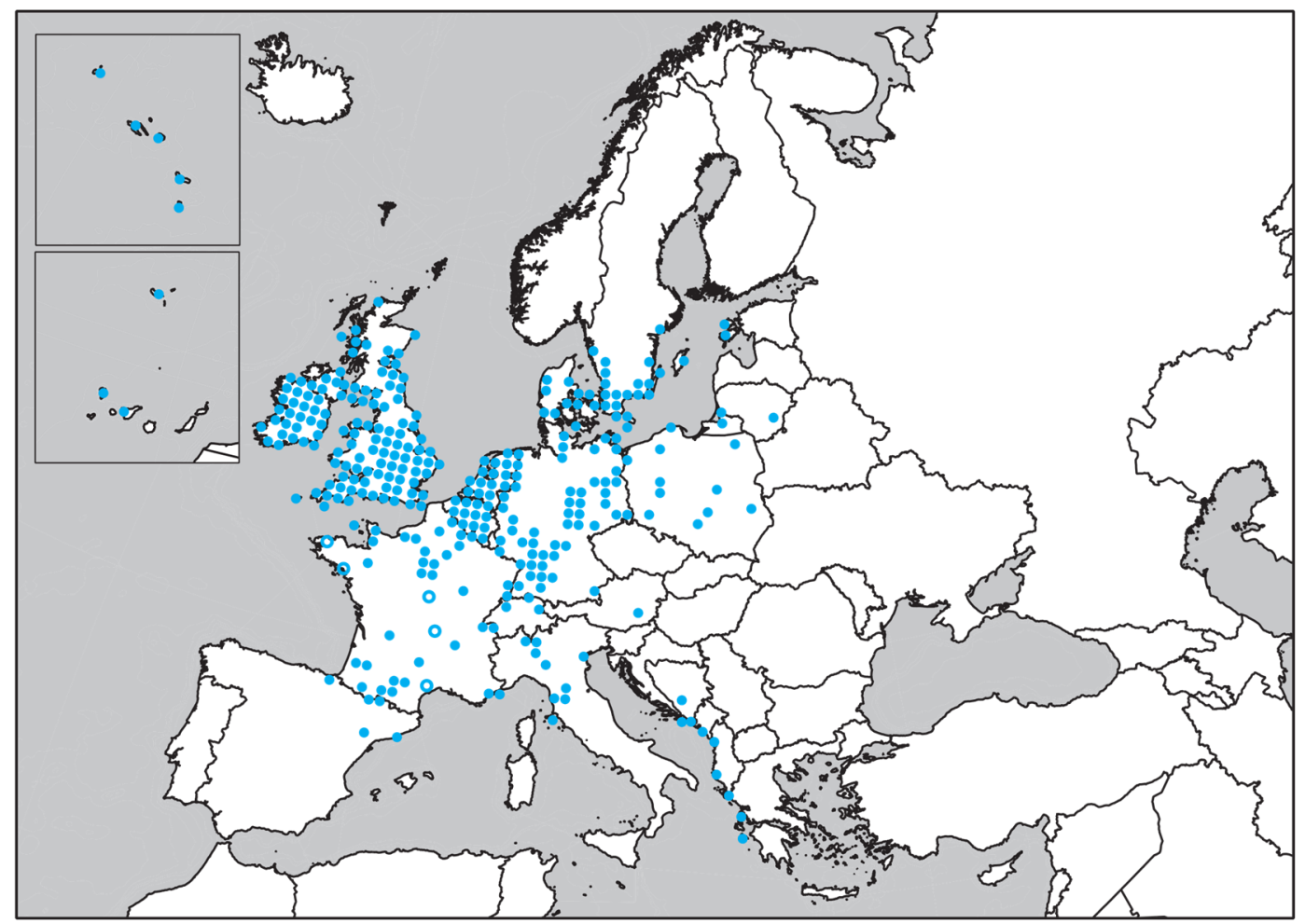

90. Brachyiulus pusillus (Leach, 1814)

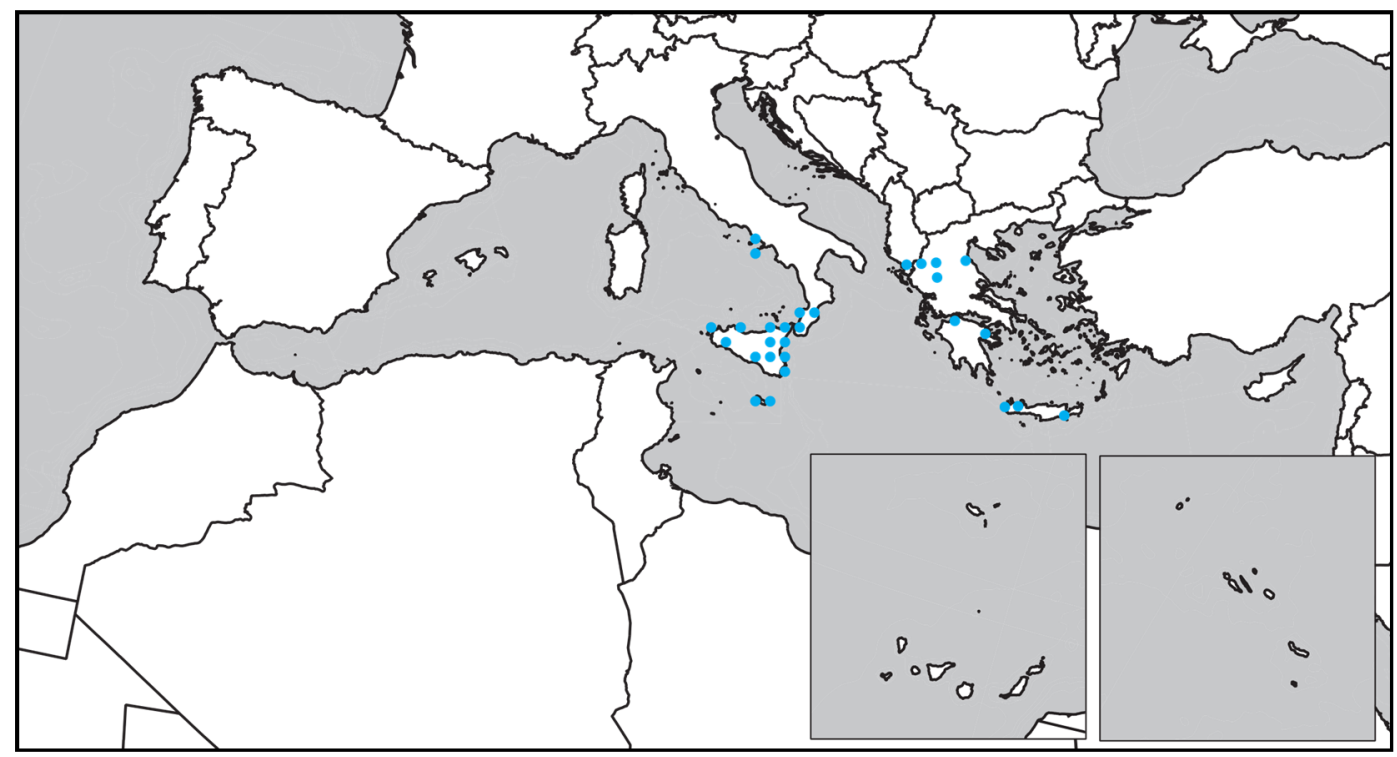

91. Brachyiulus stuxbergi (Fanzago, 1875) 


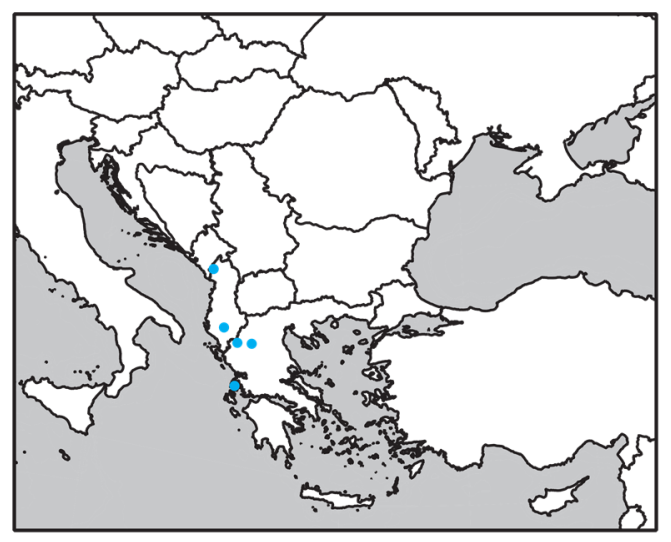

92. Brachyiulus varibolinus

Attems, 1904

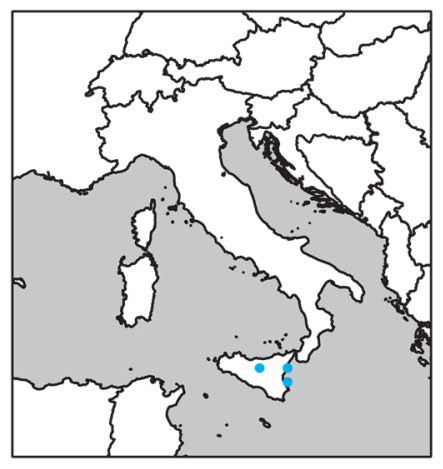

94. Buchneria sicula

Strasser, 1959

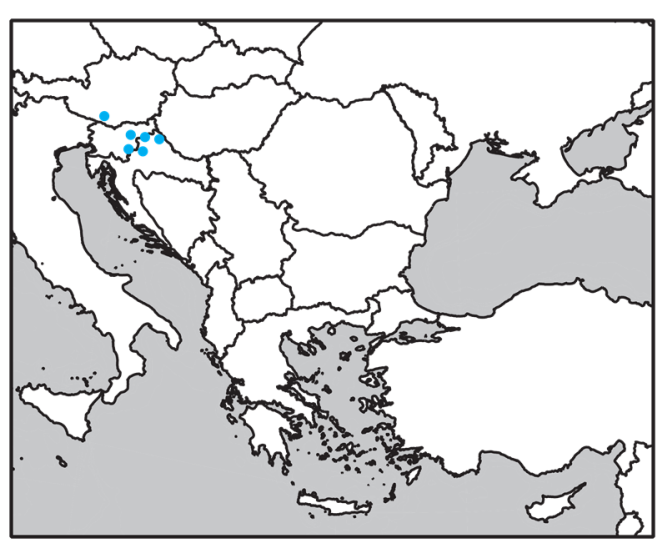

96. Chaitoiulus spinifer

(Verhoeff, 1895)

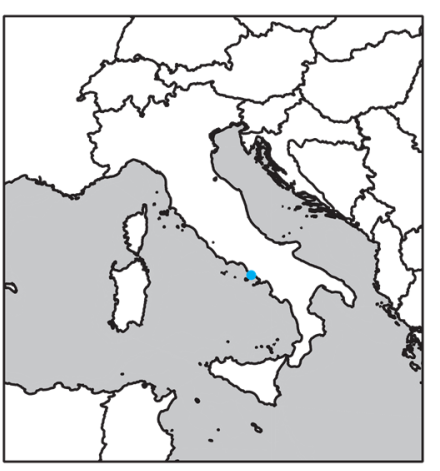

93. Buchneria cornuta

Verhoeff, 1941

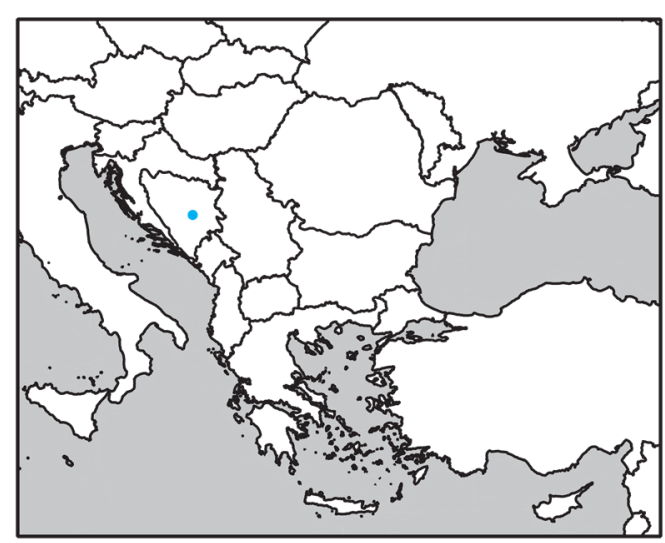

95. Chaetoleptophyllum montanum (Verhoeff, 1898)

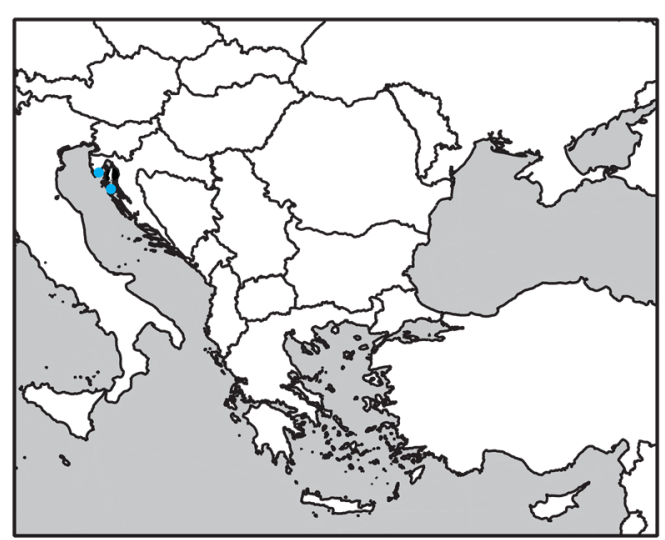

97. Chersoiulus ciliatus

Strasser, 1938 


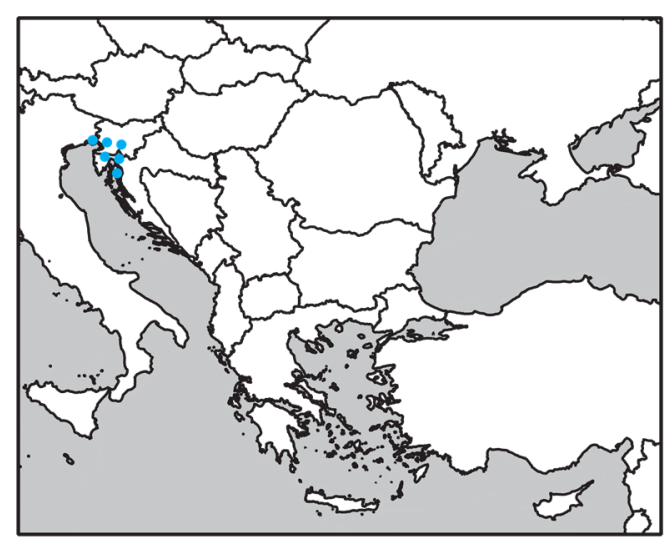

98. Chersoiulus sphinx

Strasser, 1940

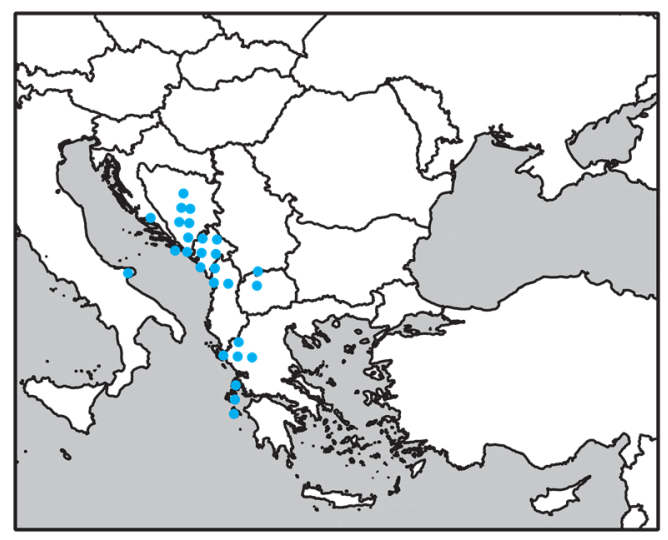

100. Chromatoiulus podabrus

(Latzel, 1884)

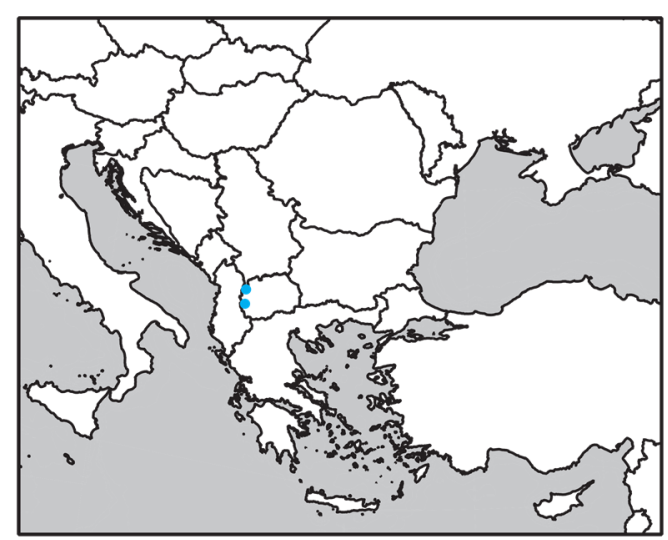

99. Chromatoiulus hamuligerus (Verhoeff, 1932)

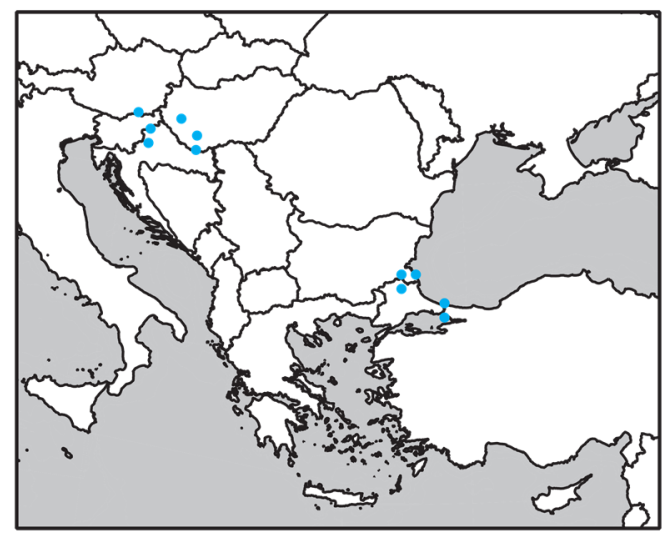

101. Cylindroiulus abaligetanus Verhoeff, 1901

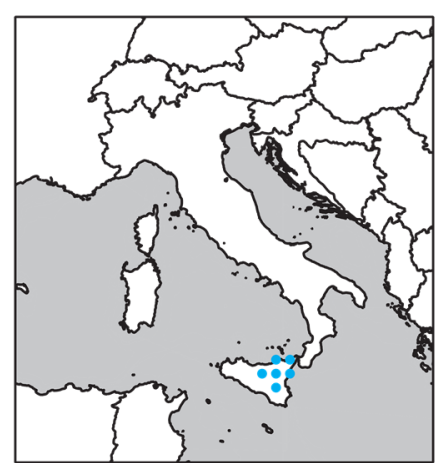

102. Cylindroiulus aetnensis Verhoeff, 1910

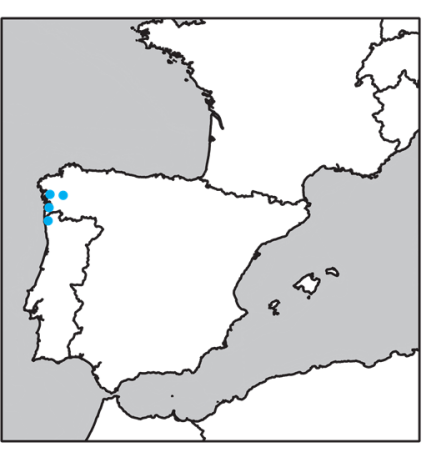

103. Cylindroiulus anglilectus Read, 2007

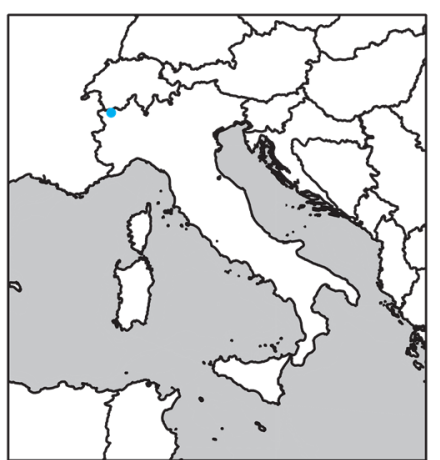

104. Cylindroiulus aostanus Verhoeff, 1932 


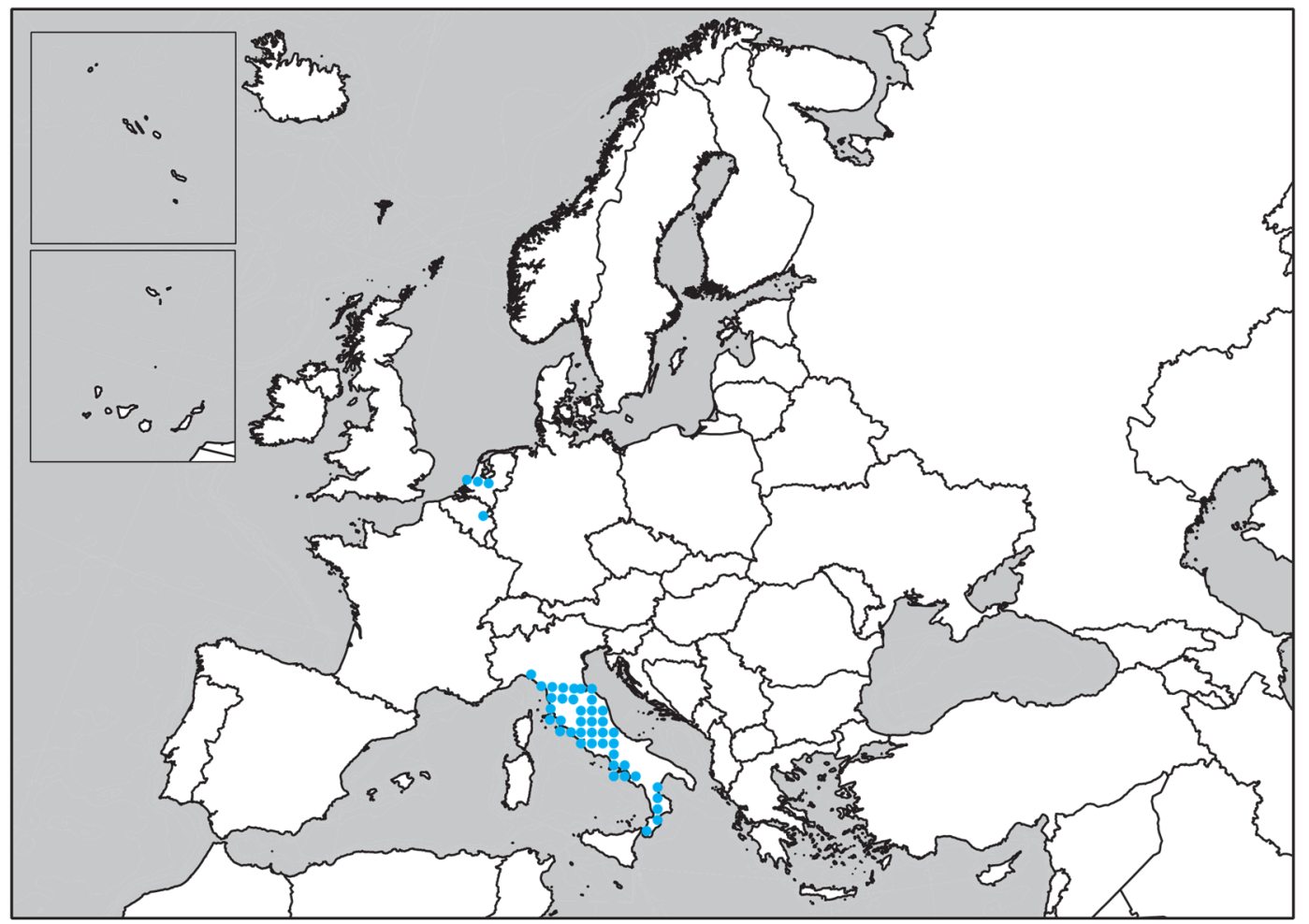

105. Cylindroiulus apenninorum (Brölemann, 1897)

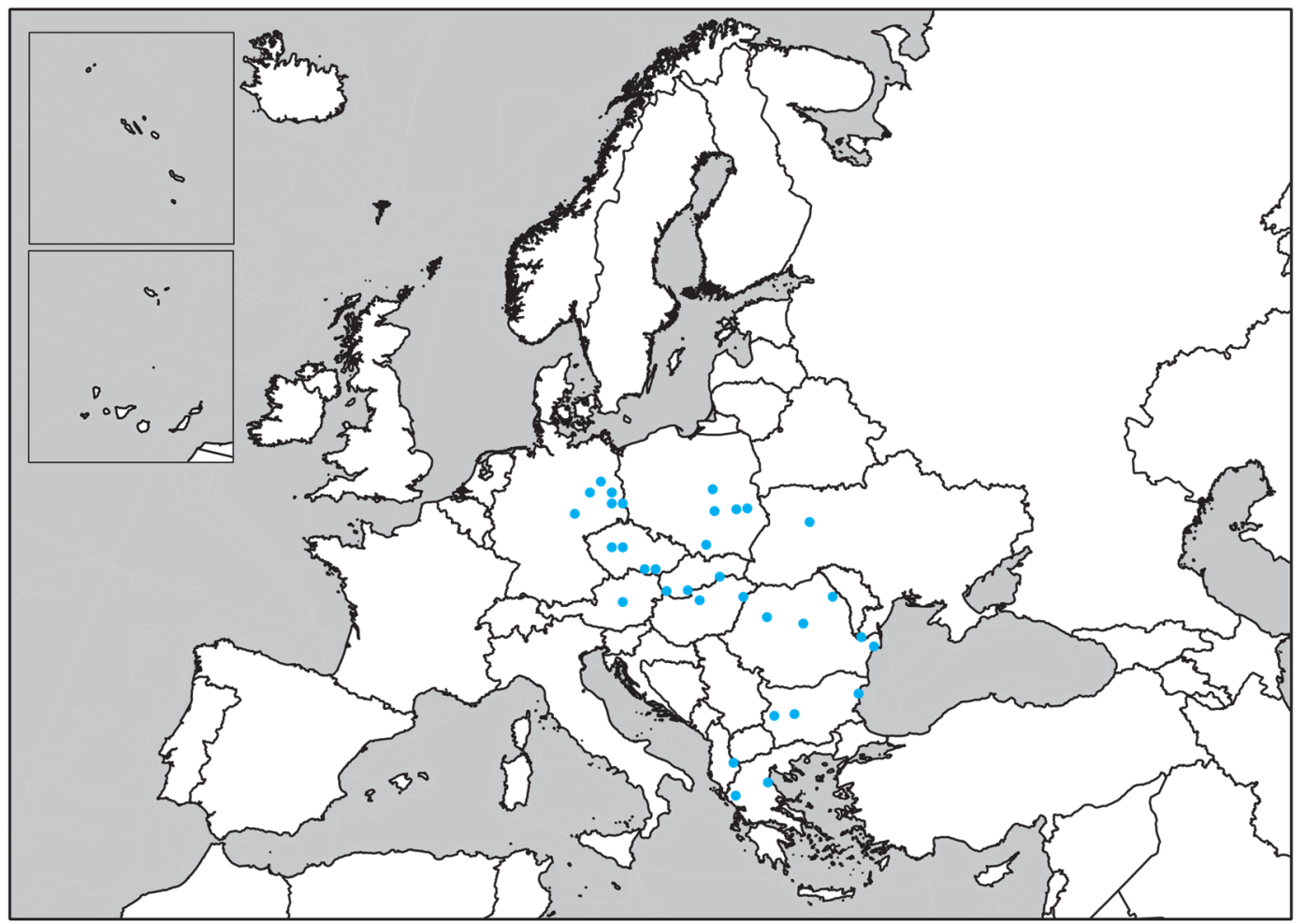

106. Cylindroiulus arborum Verhoeff, 1928 

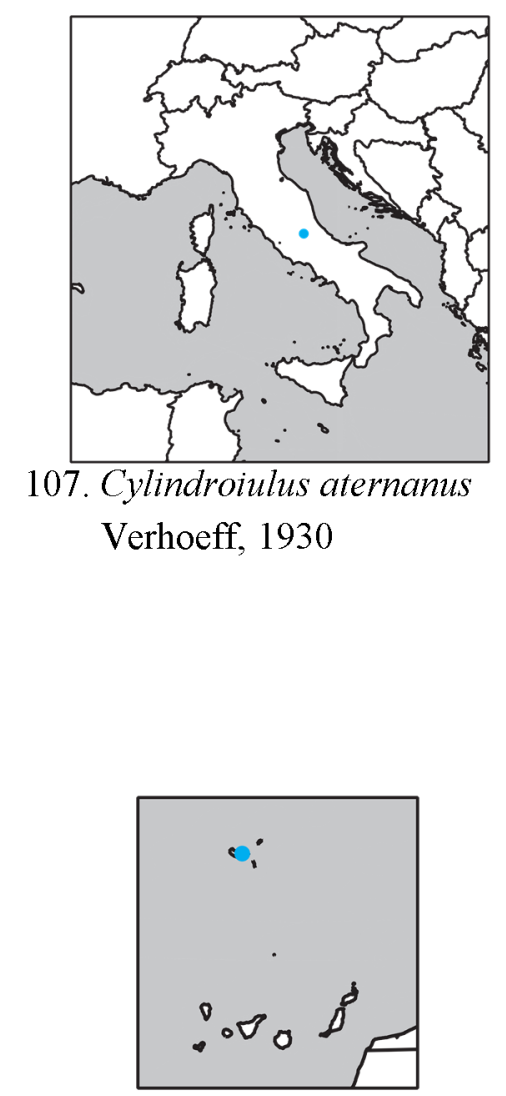

108. Cylindroiulus attenuatus Enghoff, 1982

112. C. brachyiuloides Enghoff, 1982

119. C. caramujensis Lohmander, 1955

121. C. cristagalli Enghoff, 1982

124. C. digitus Enghoff, 1982

127. C. exiguus Enghoff, 1982

130. C. fimbriatus Enghoff, 1982

134. C. gemellus Enghoff, 1982

139. C. hirticauda Enghoff, 1982

143. C. infernalis Lohmander, 1955

144. C. insolidus Lohmander, 1955

146. C. julesvernei Reboleira \& Enghoff, 2014

147. C. julipes Enghoff, 1982

148. C. kappa Enghoff, 1982
153. C. laurisilvae Enghoff, 1982

156. C. lundbladi Lohmander, 1955

162. C. obscurior Enghoff, 1982

163. C. oromii Reboleira \& Enghoff, 2014

164. C. pallidior Enghoff, 1982

171. C. quadratistipes Enghoff, 1982

172. C. rabacalensis Lohmander, 1955

186. C. speluncaris Lohmander, 1955

195. C. uroxiphos Enghoff, 1982

196. C. velatus Enghoff, 1982

200. C. waldeni $\operatorname{Read}, 1989$

201. C. xynon Read, 1989

202. C. ynnox Read, 1989

203. C. zarcoi Read, 1989 


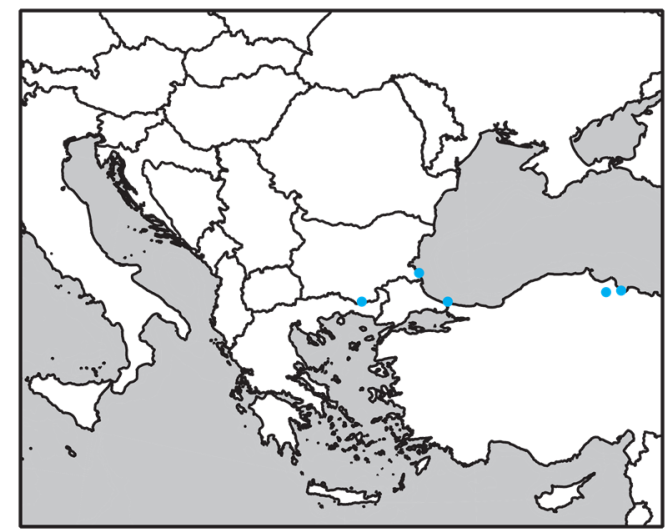

109. Cylindroiulus bellus (Lignau, 1903)

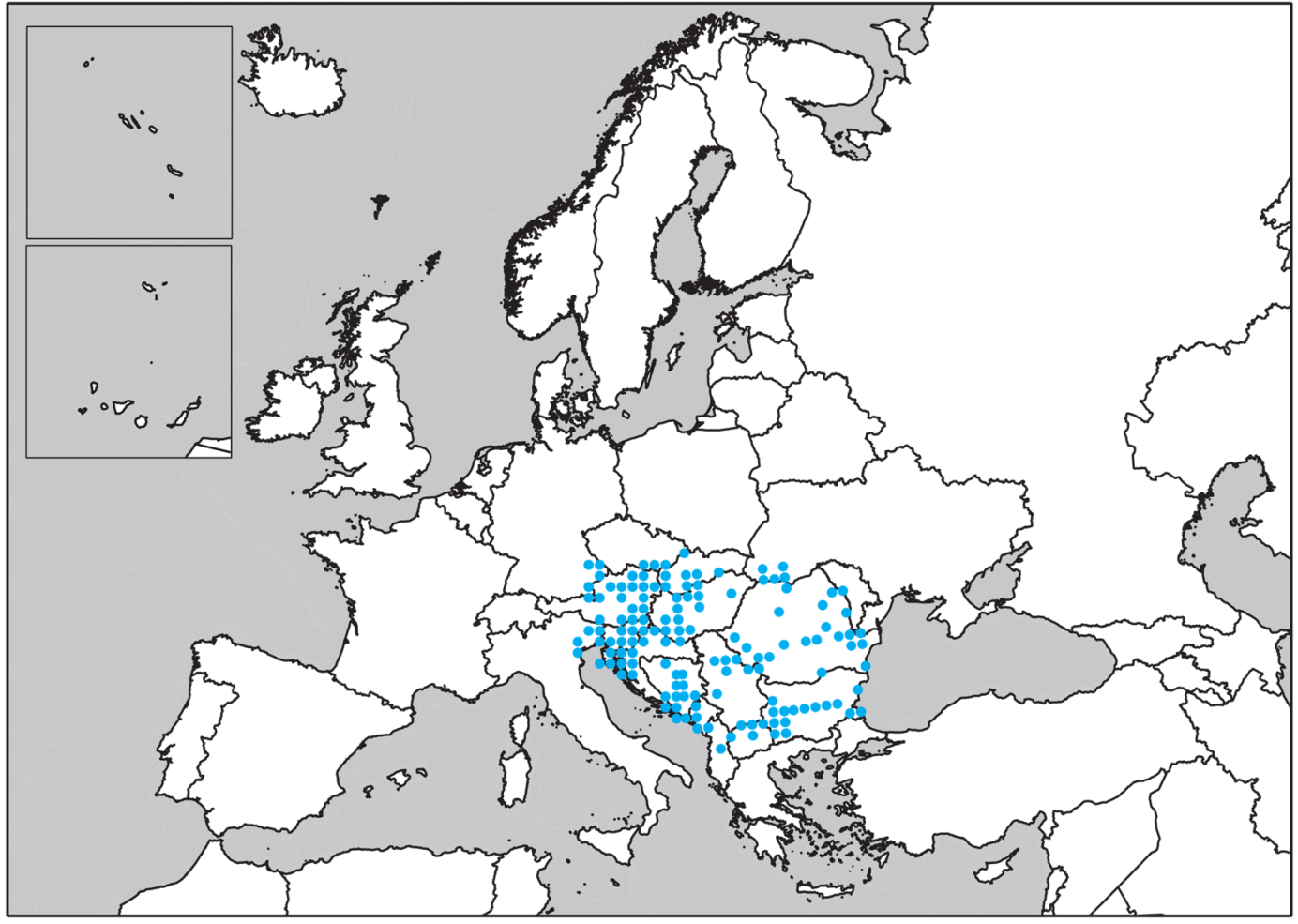

110. Cylindroiulus boleti (C.L. Koch, 1847)

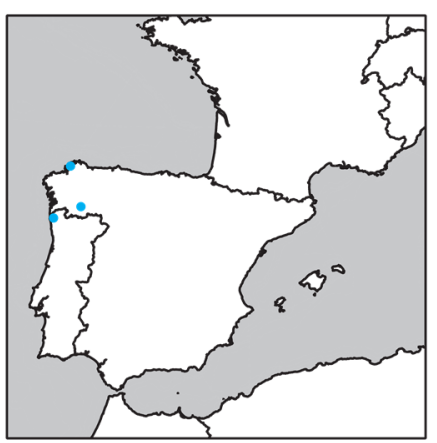

111. Cylindroiulus boreoibericus Read, 2007 
112. Cylindroiulus brachyiuloides see p. 53

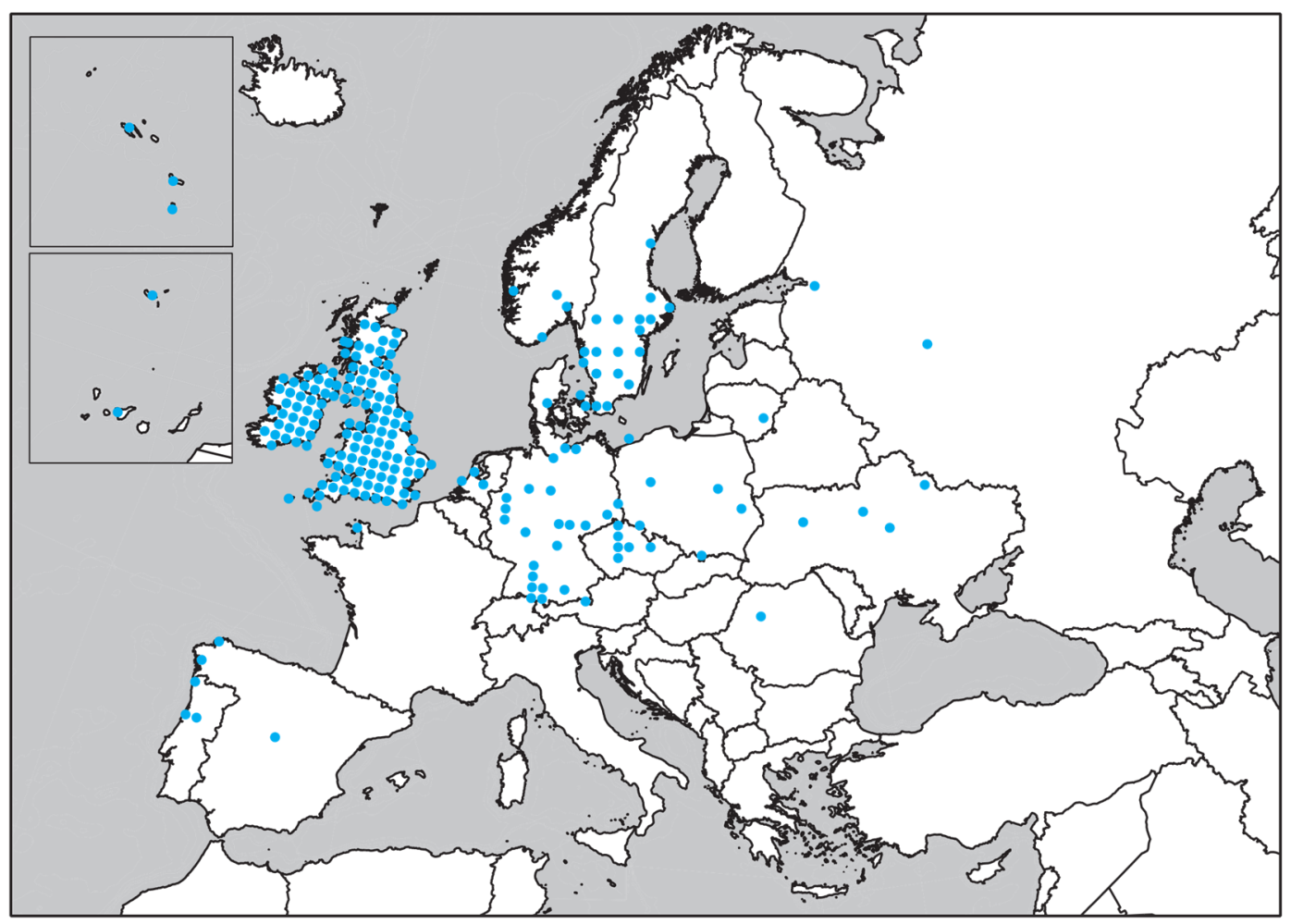

113. Cylindroiulus britannicus (Verhoeff, 1891)

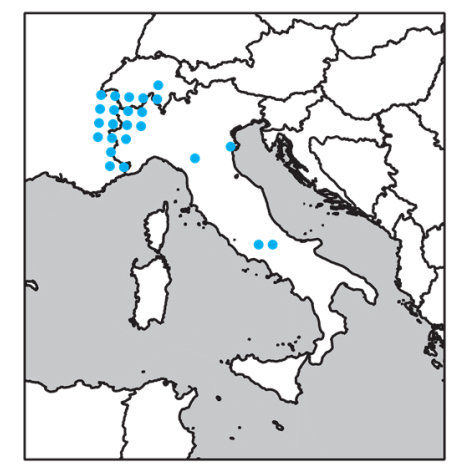

114. Cylindroiulus broti

(Humbert, 1893) 


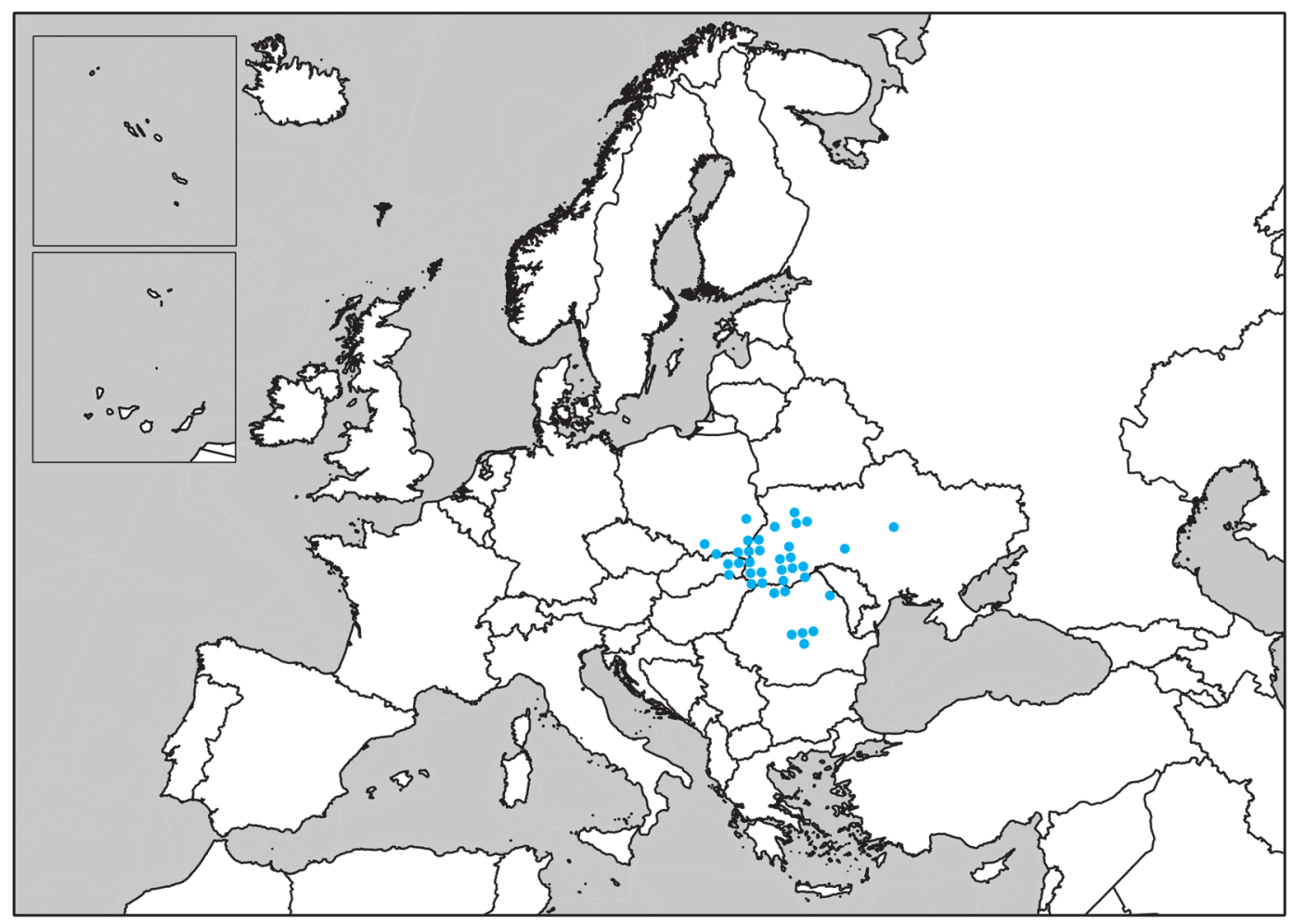

115. Cylindroiulus burzenlandicus Verhoeff, 1907

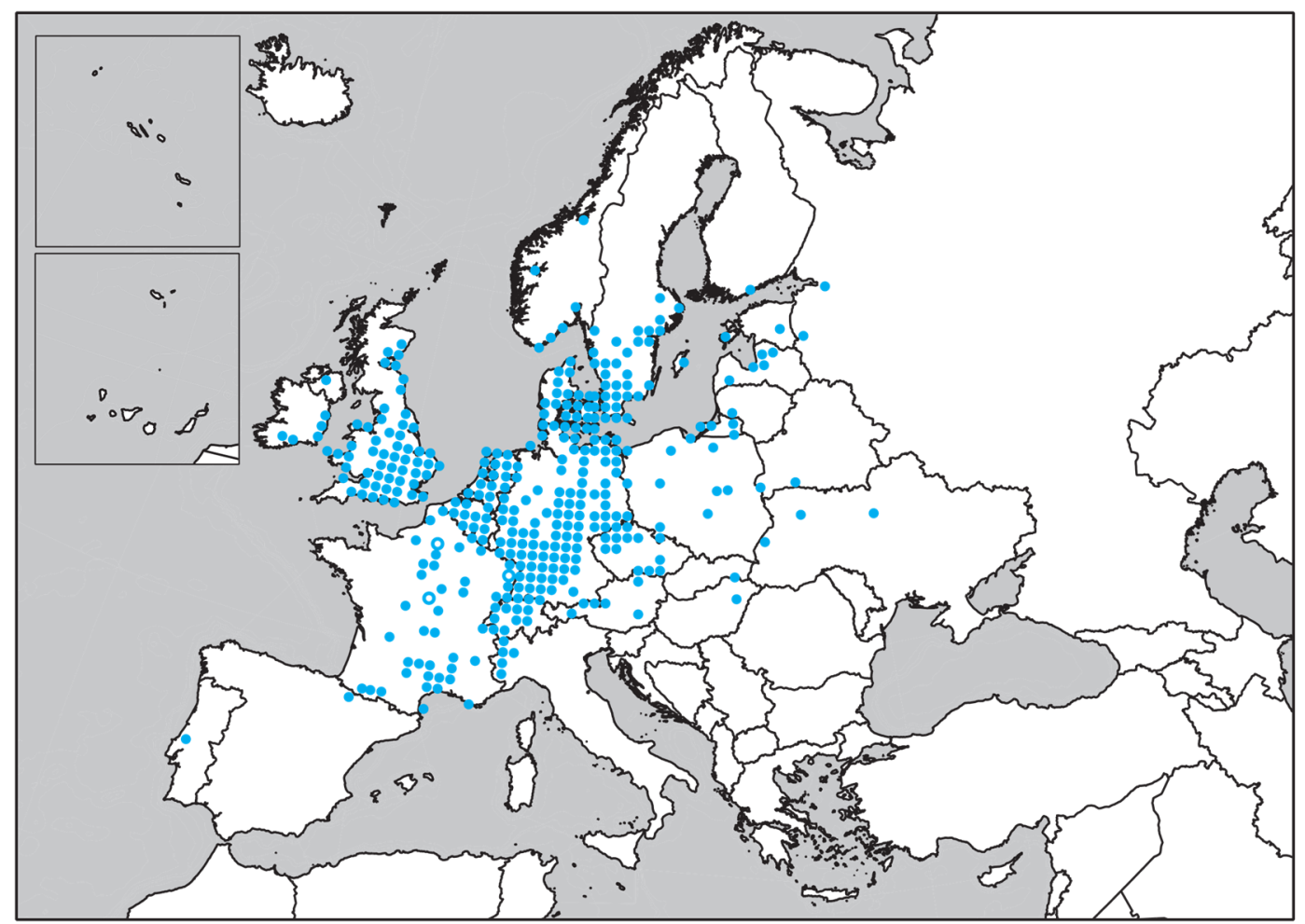

116. Cylindroiulus caeruleocinctus (Wood, 1864) 


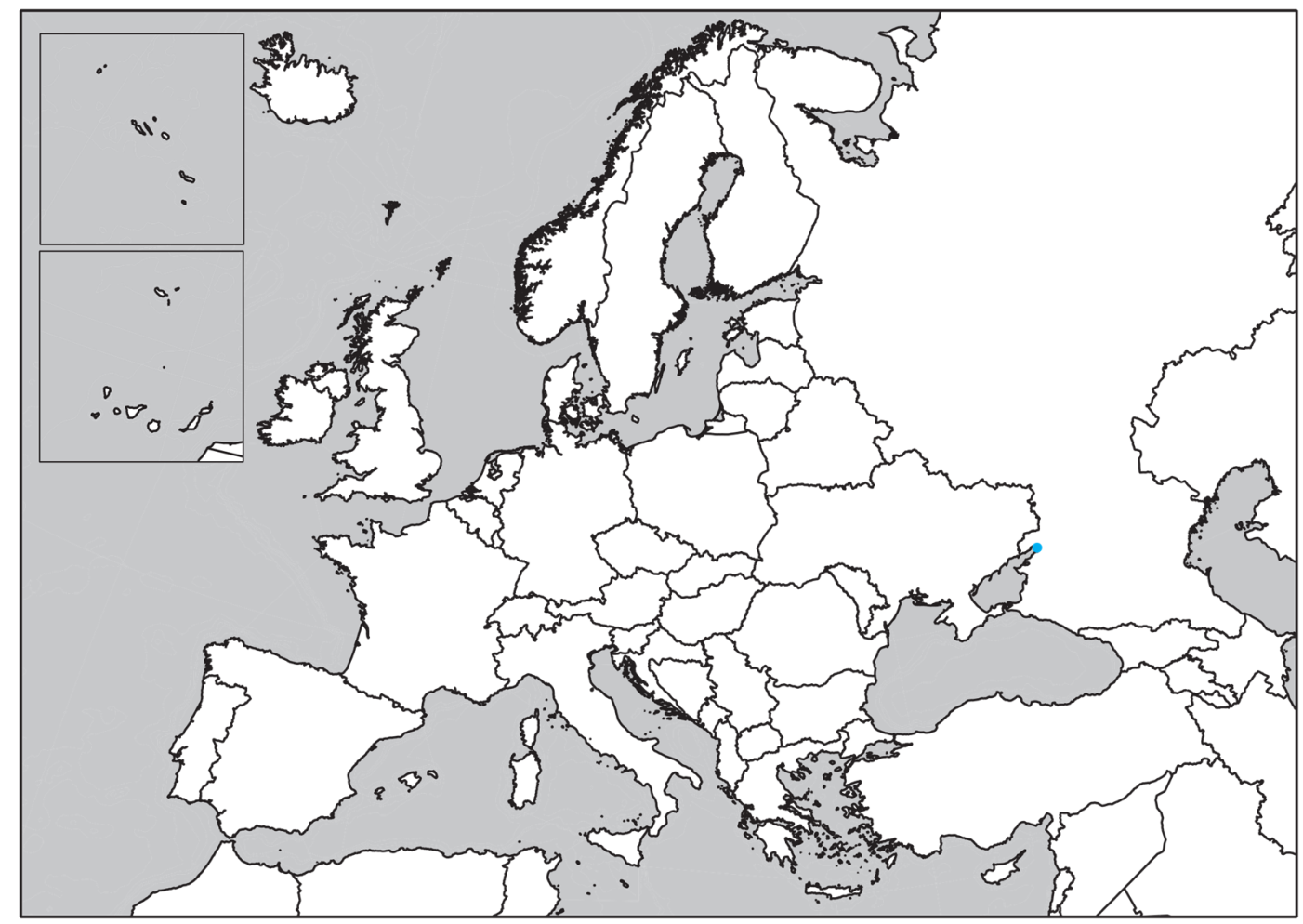

117. Cylindroiulus cambio Korsós \& Read, 1994

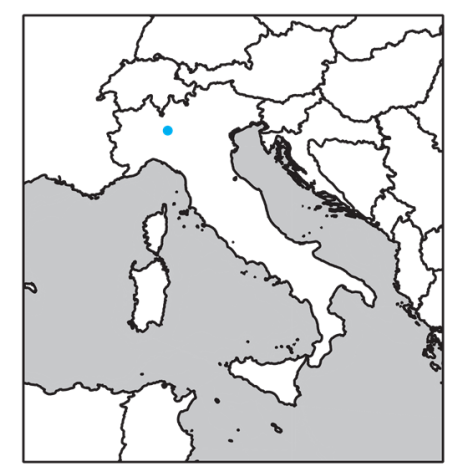

118. Cylindroiulus cantonii (Brölemann, 1892)

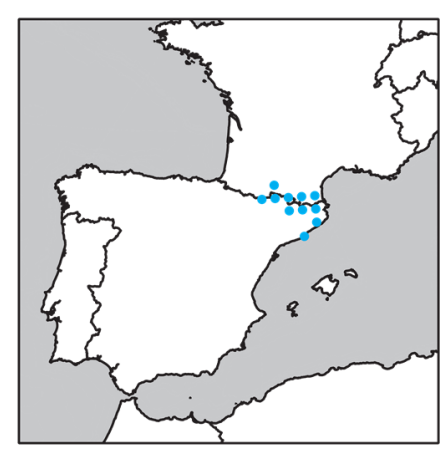

120. Cylindroiulus chalandei (Ribaut, 1904)
121. Cylindroiulus cristagalli see p. 56 


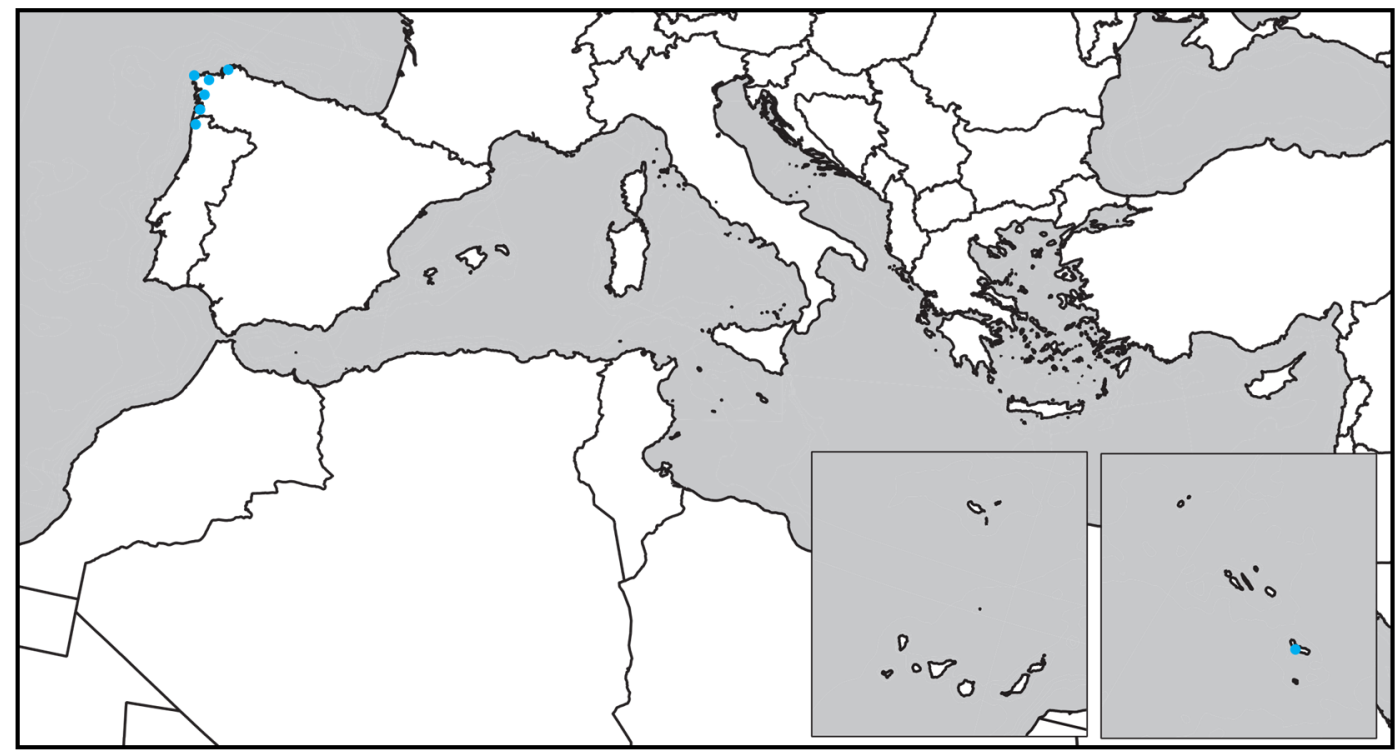

122. Cylindroiulus dahli Demange, 1970

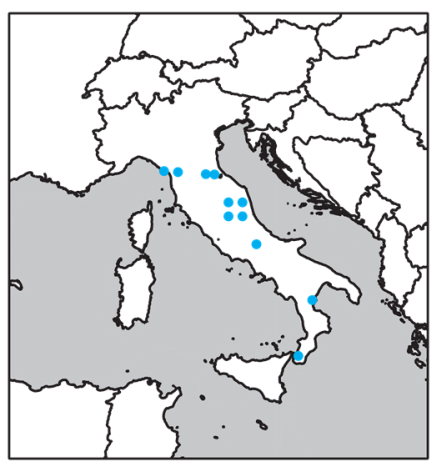

123. Cylindroiulus decipiens (Berlese, 1885)

\section{Cylindroiulus digitus} see p. 57

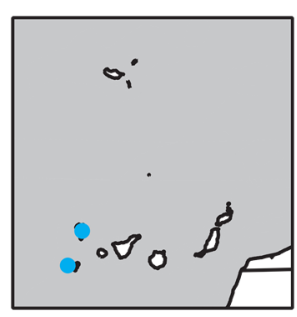

125. Cylindroiulus disjunctus Read, 1989

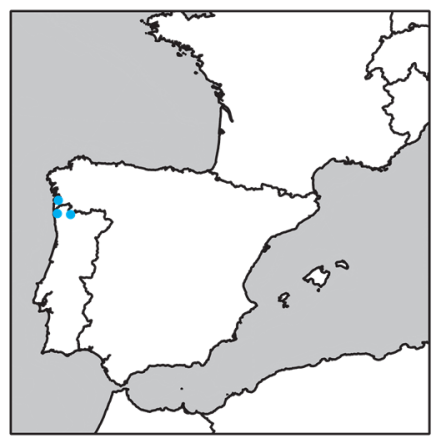

128. Cylindroiulus fenestratus Read, 1989

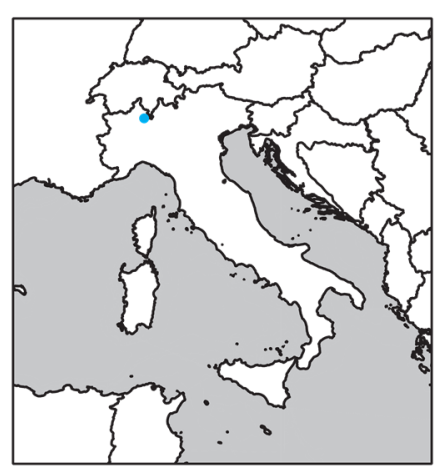

126. Cylindroiulus dubius Verhoeff, 1930

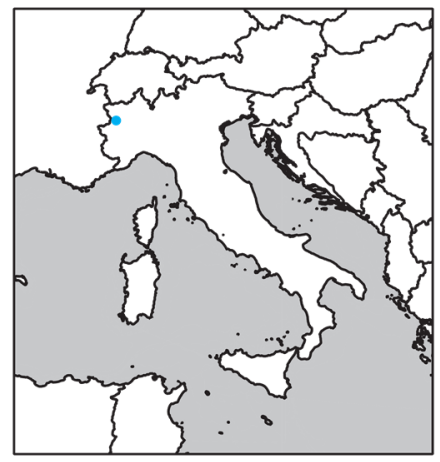

129. Cylindroiulus festai

Manfredi, 1939 


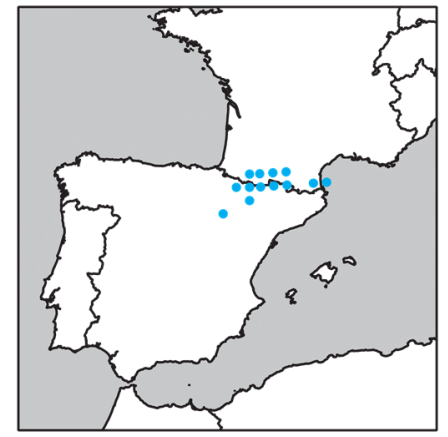

131. Cylindroiulus finitimus

(Ribaut, 1905)

134. Cylindroiulus gemellus see p. 59

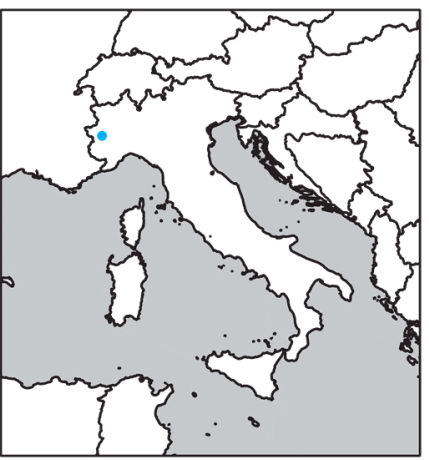

137. Cylindroiulus gigas

Verhoeff, 1932

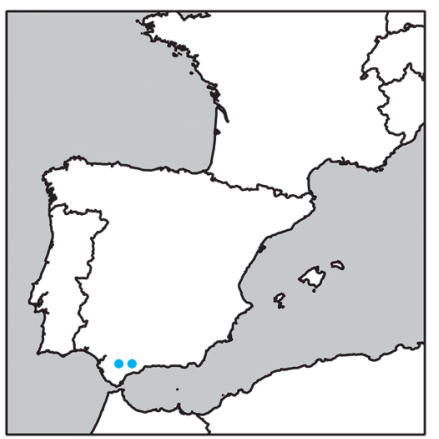

132. Cylindroiulus franzi

Attems, 1952

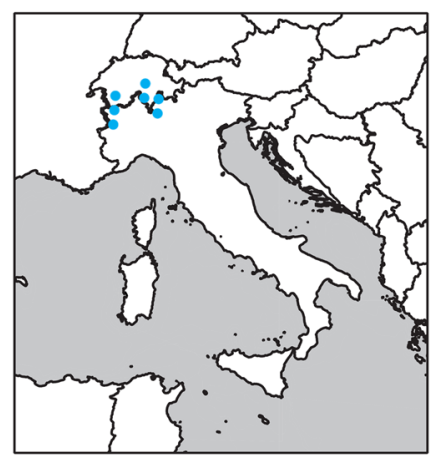

135. Cylindroiulus generosensis Verhoeff, 1900

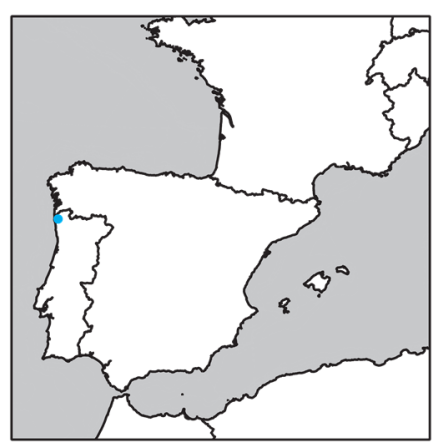

138. Cylindroiulus gregoryi

Read, 2007

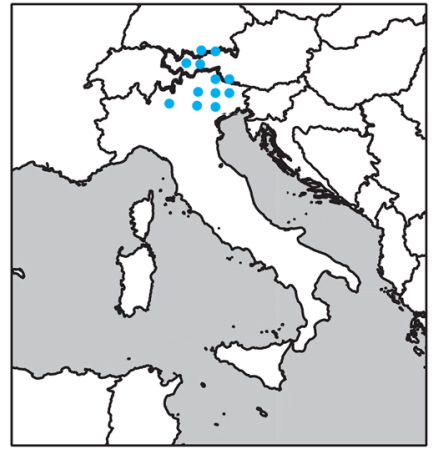

133. Cylindroiulus fulviceps (Latzel, 1884)

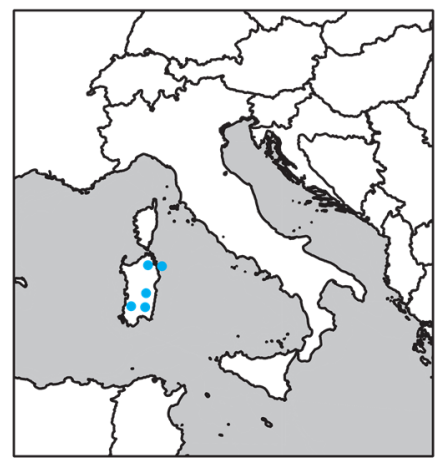

136. Cylindroiulus gestri

(Silvestri, 1898)
139. Cylindroiulus hirticauda see p. 60 


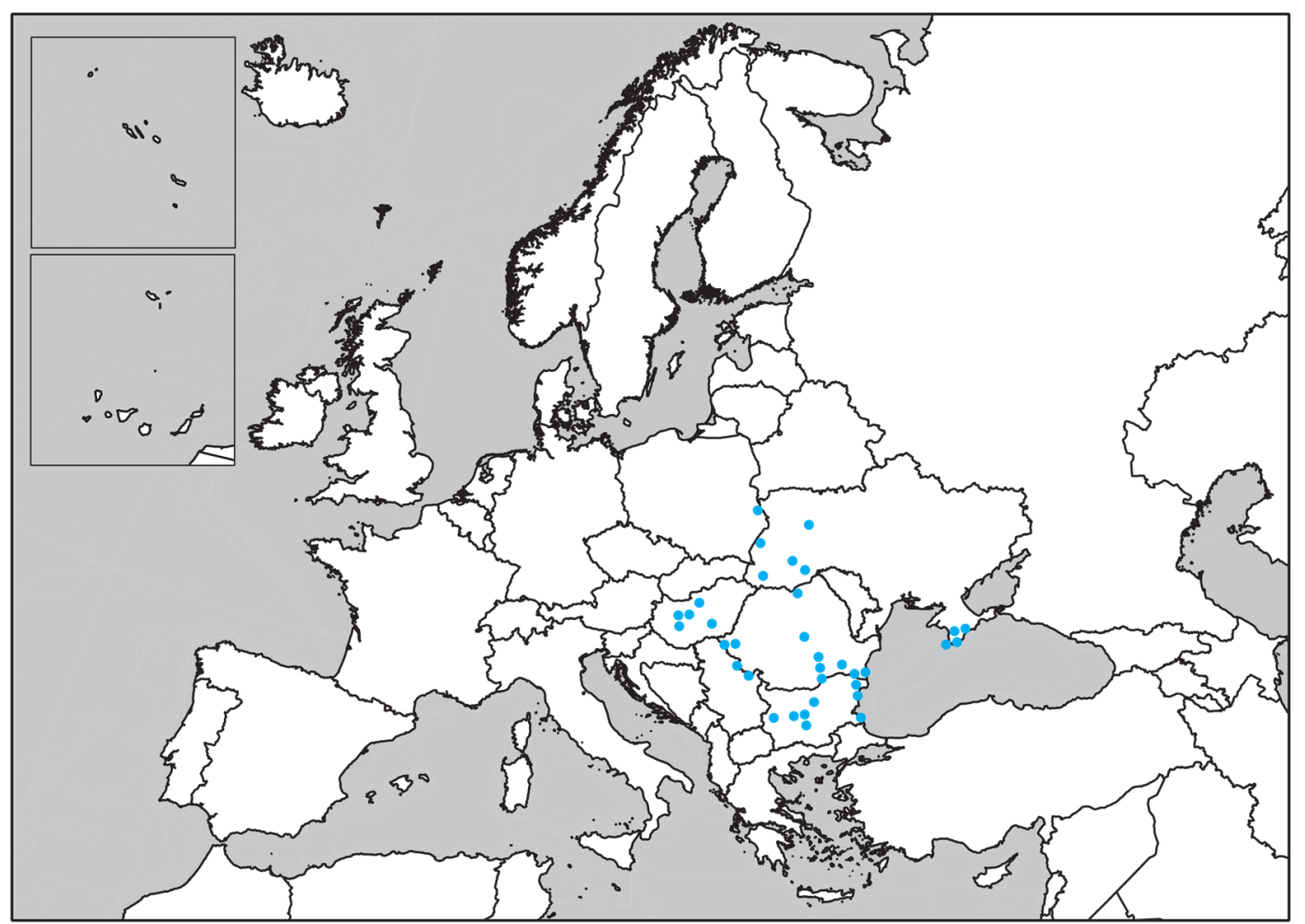

140. Cylindroiulus horvathi (Verhoeff, 1897)

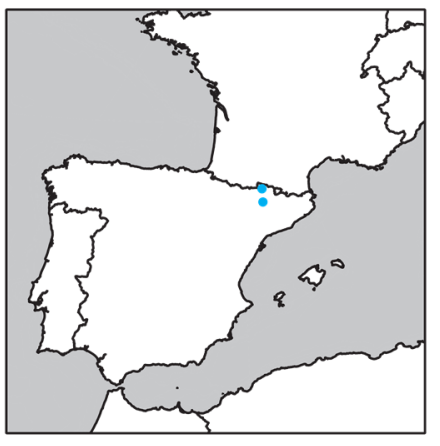

141. Cylindroiulus ibericus

Brölemann, 1913

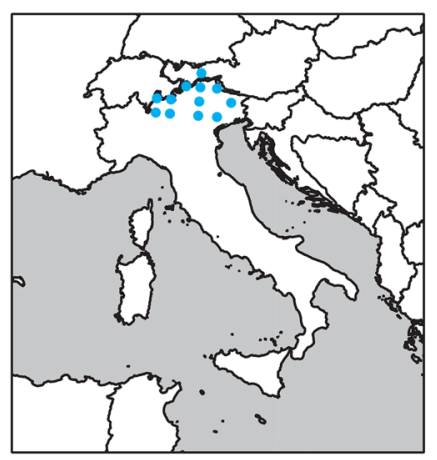

145. Cylindroiulus italicus

(Latzel, 1884)

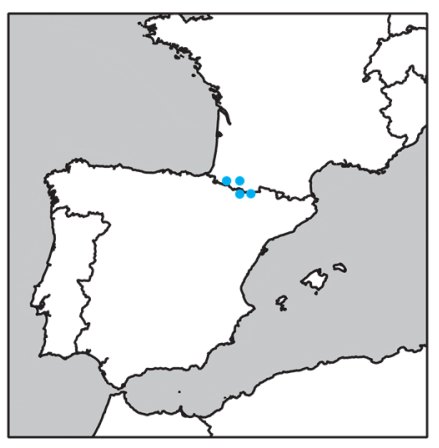

142. Cylindroiulus iluronensis Brölemann, 1912

146. Cylindroiulus julesvernei see p. 62

\section{Cylindroiulus julipes} see p. 62

148. Cylindroiulus kappa see p. 62
143. Cylindroiulus infernalis see p. 61

144. Cylindroiulus insolidus see p. 61

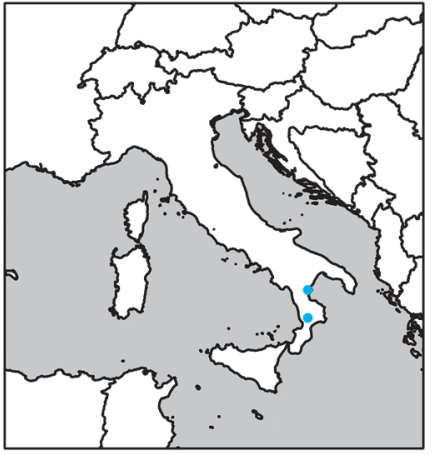

149. Cylindroiulus lagrecai Manfredi, 1957 


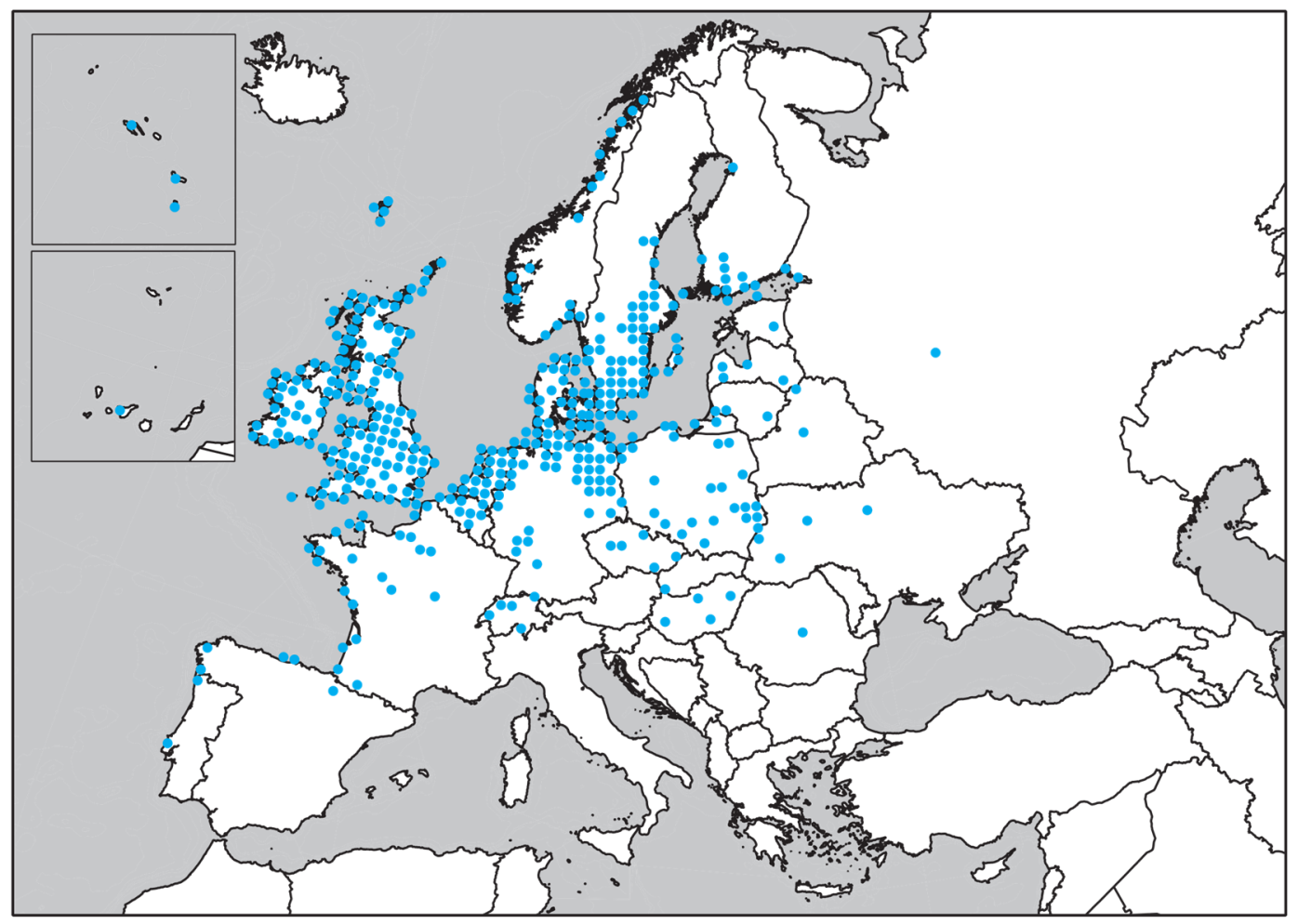

150. Cylindroiulus latestriatus (Curtis, 1845)

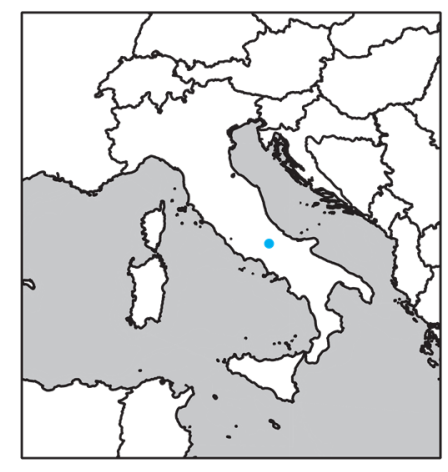

151. Cylindroiulus latro Attems, 1927

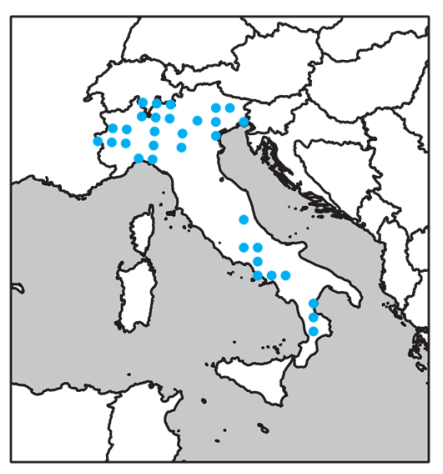

152. Cylindroiulus latzeli (Berlese, 1884)

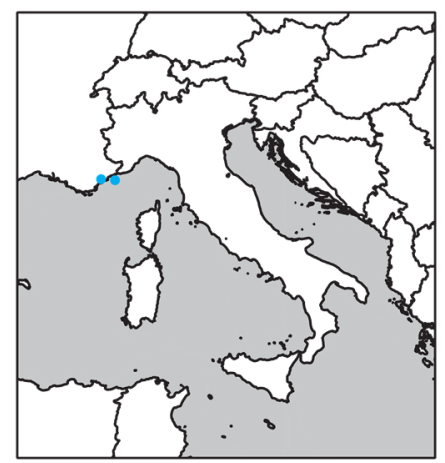

154. Cylindroiulus limitaneus (Brölemann, 1905)
153. Cylindroiulus laurisilvae see p. 63 


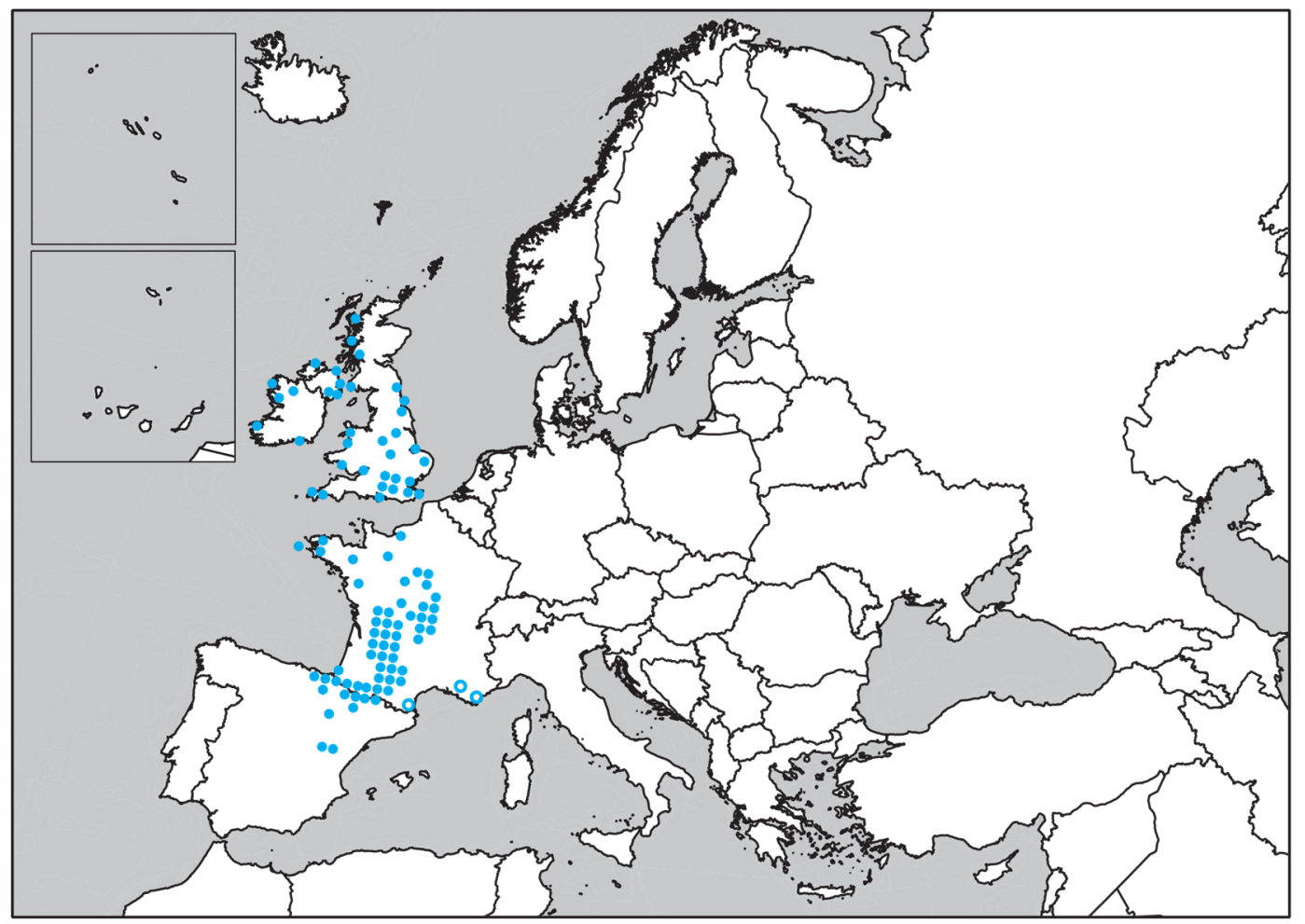

155. Cylindroiulus londinensis (Leach, 1814)

156. Cylindroiulus lundbladi, see p. 64

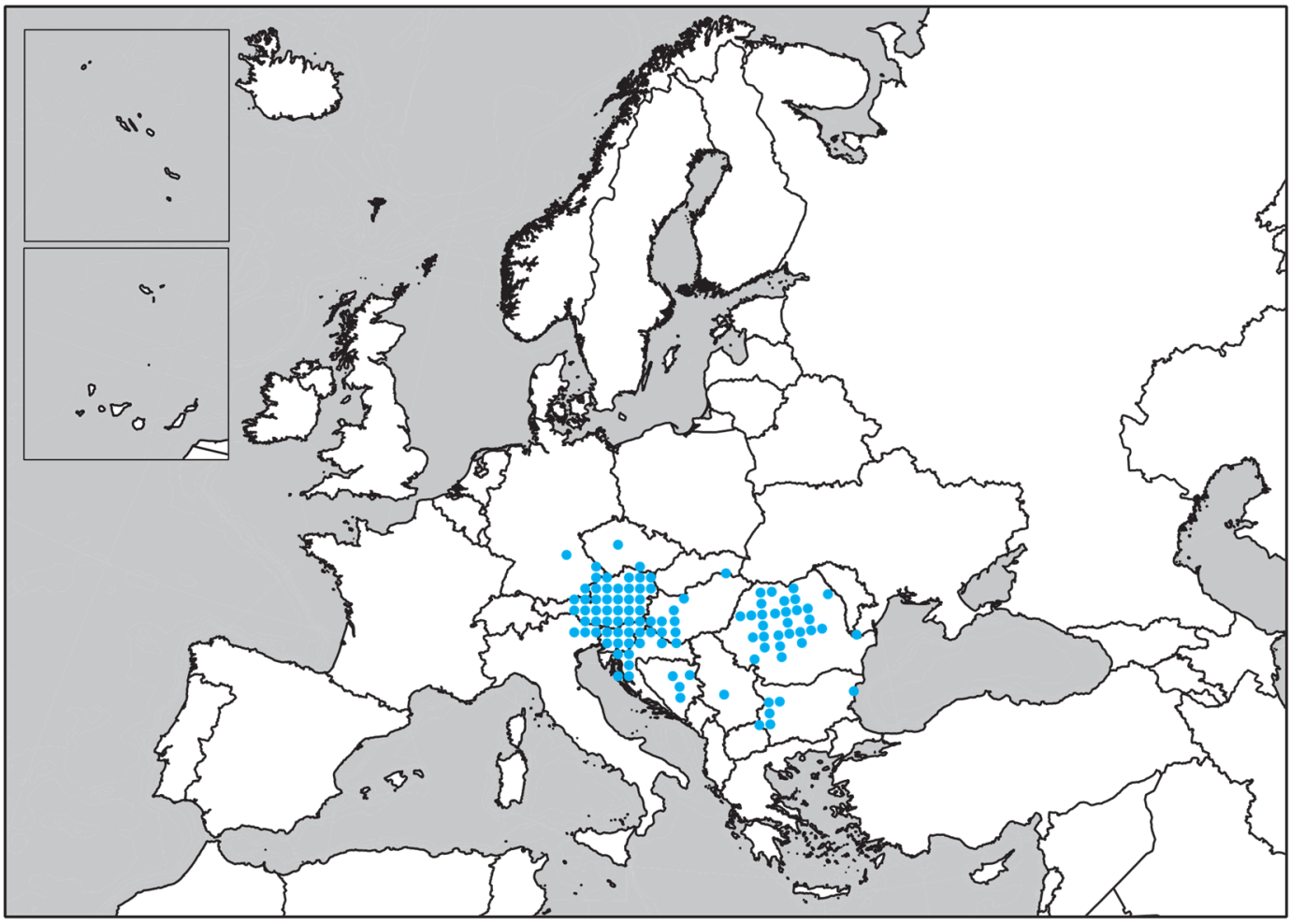

157. Cylindroiulus luridus (C.L. Koch, 1847) 


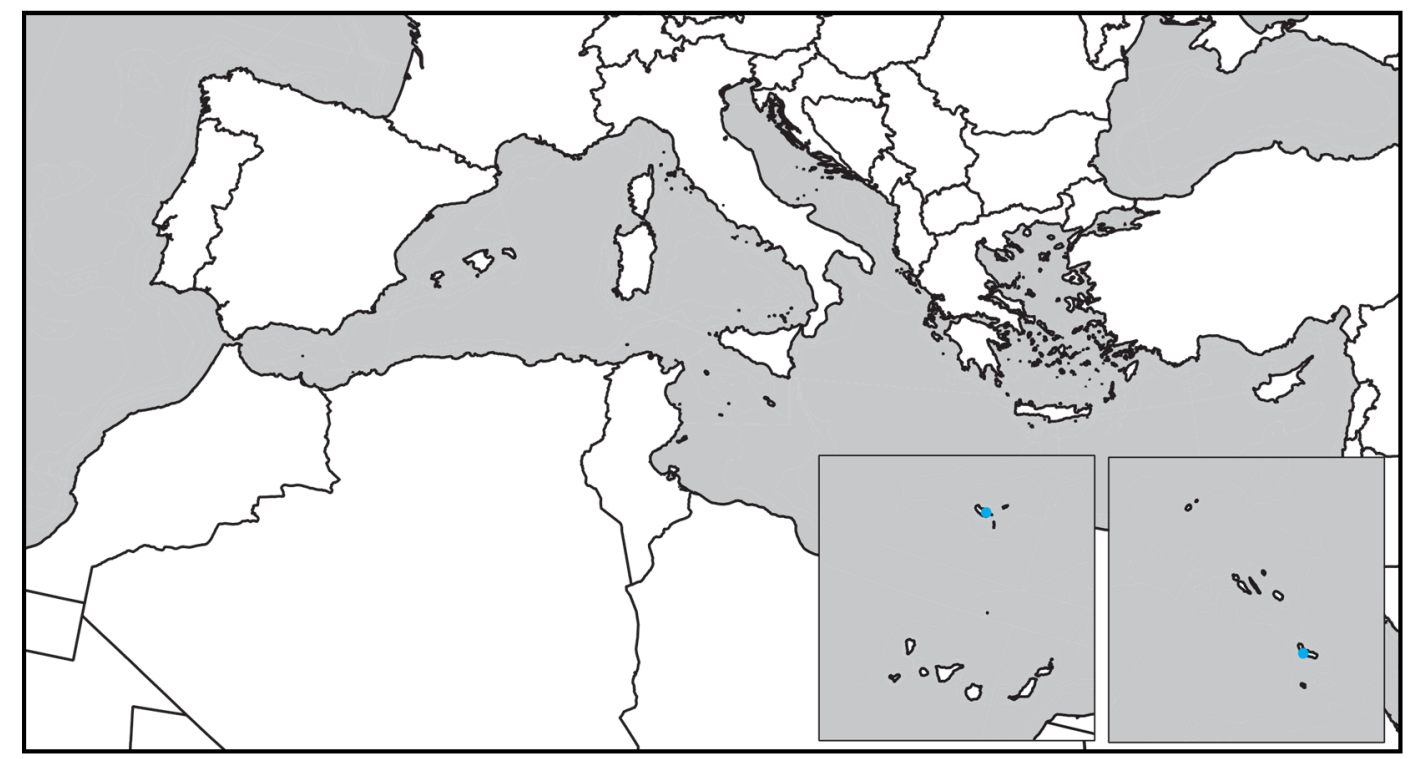

158. Cylindroiulus madeirae Attems, 1937

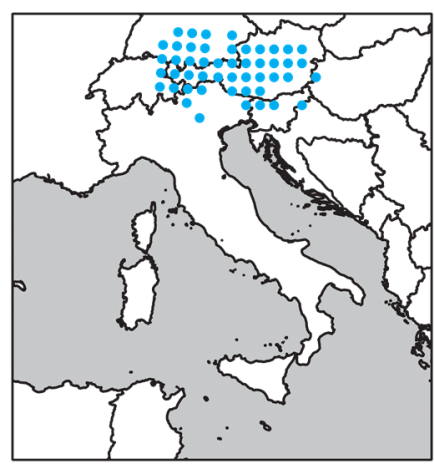

159. Cylindroiulus meinerti (Verhoeff, 1891)

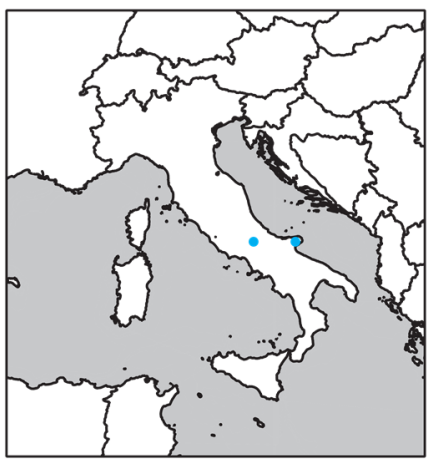

160. Cylindroiulus molisius Verhoeff, 1932

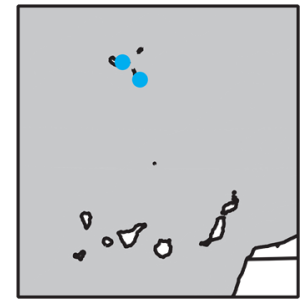

161. Cylindroiulus numerosus Enghoff, 1982
162. Cylindroiulus obscurior see p. 66
163. Cylindroiulus oromii see p. 66
164. Cylindroiulus pallidior see p. 66 


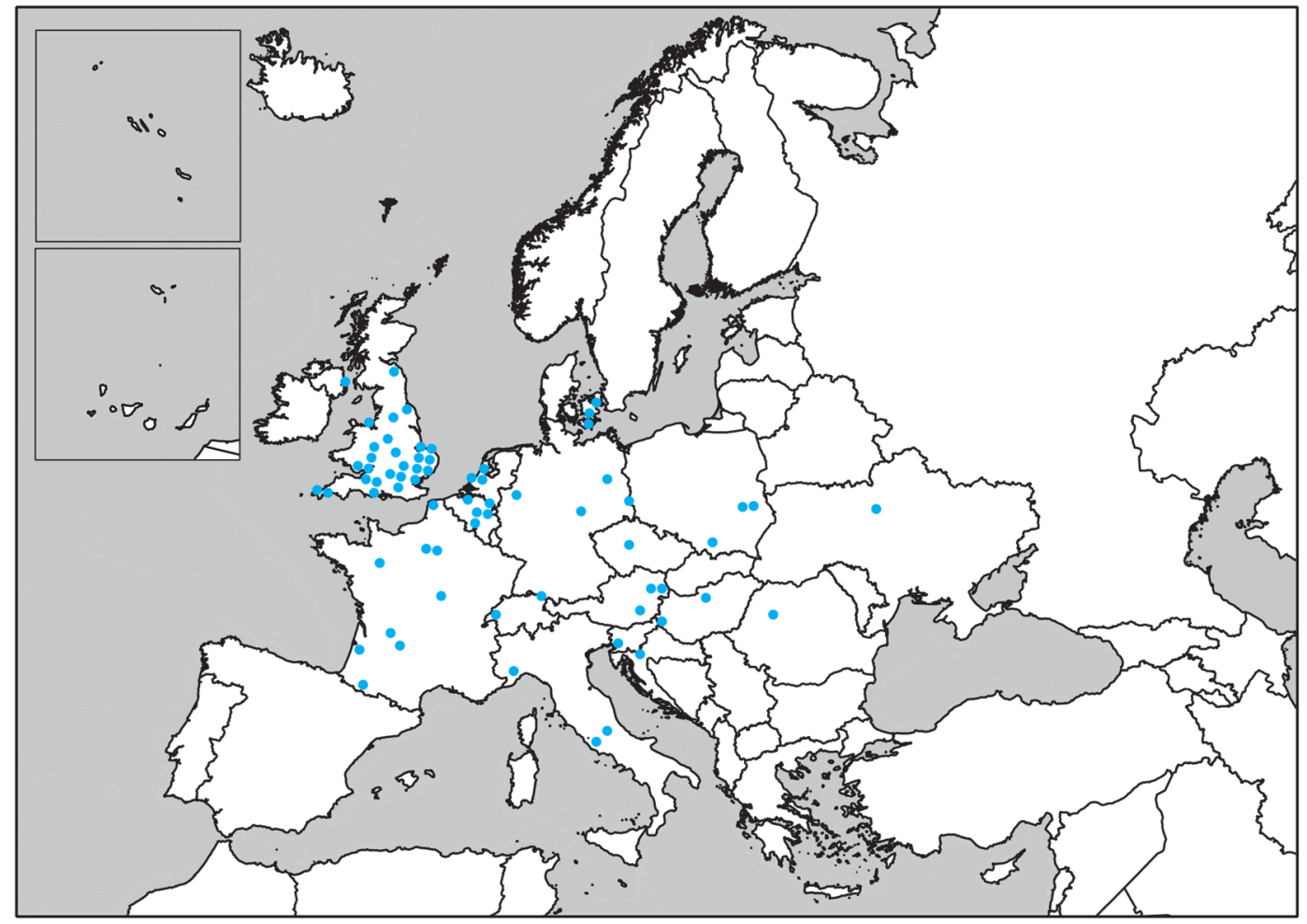

165. Cylindroiulus parisiorum (Brölemann \& Verhoeff, 1896)

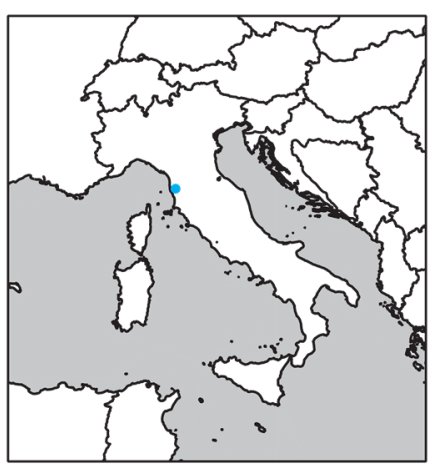

166. Cylindroiulus pelatensis Verhoeff, 1930

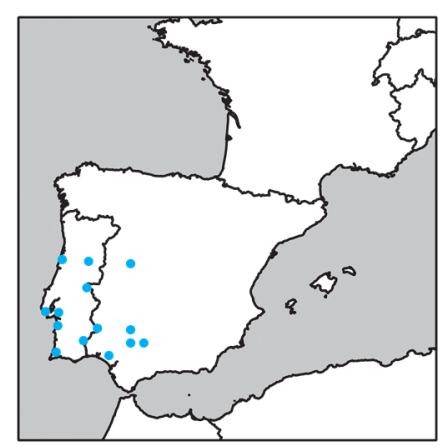

167. Cylindroiulus perforatus Verhoeff, 1905 


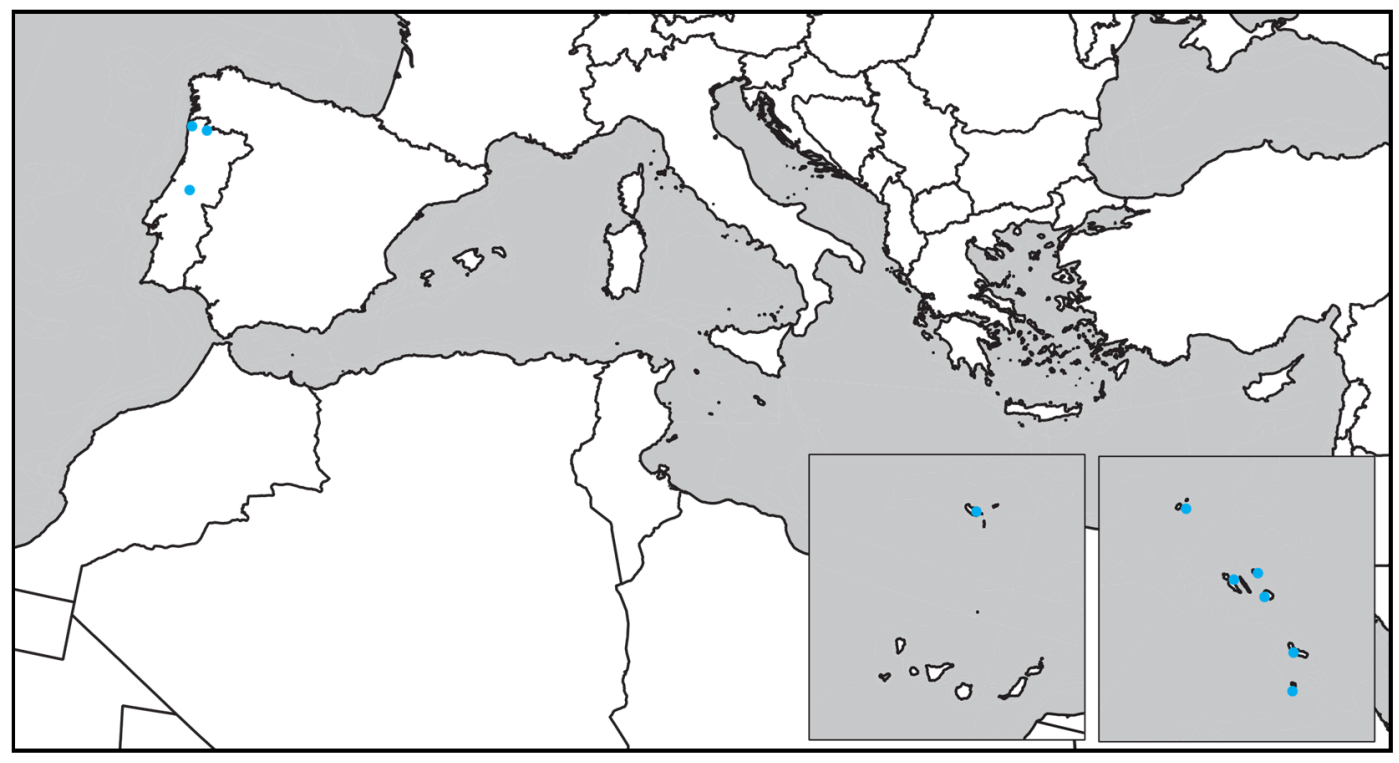

168. Cylindroiulus propinquus (Porat, 1870)

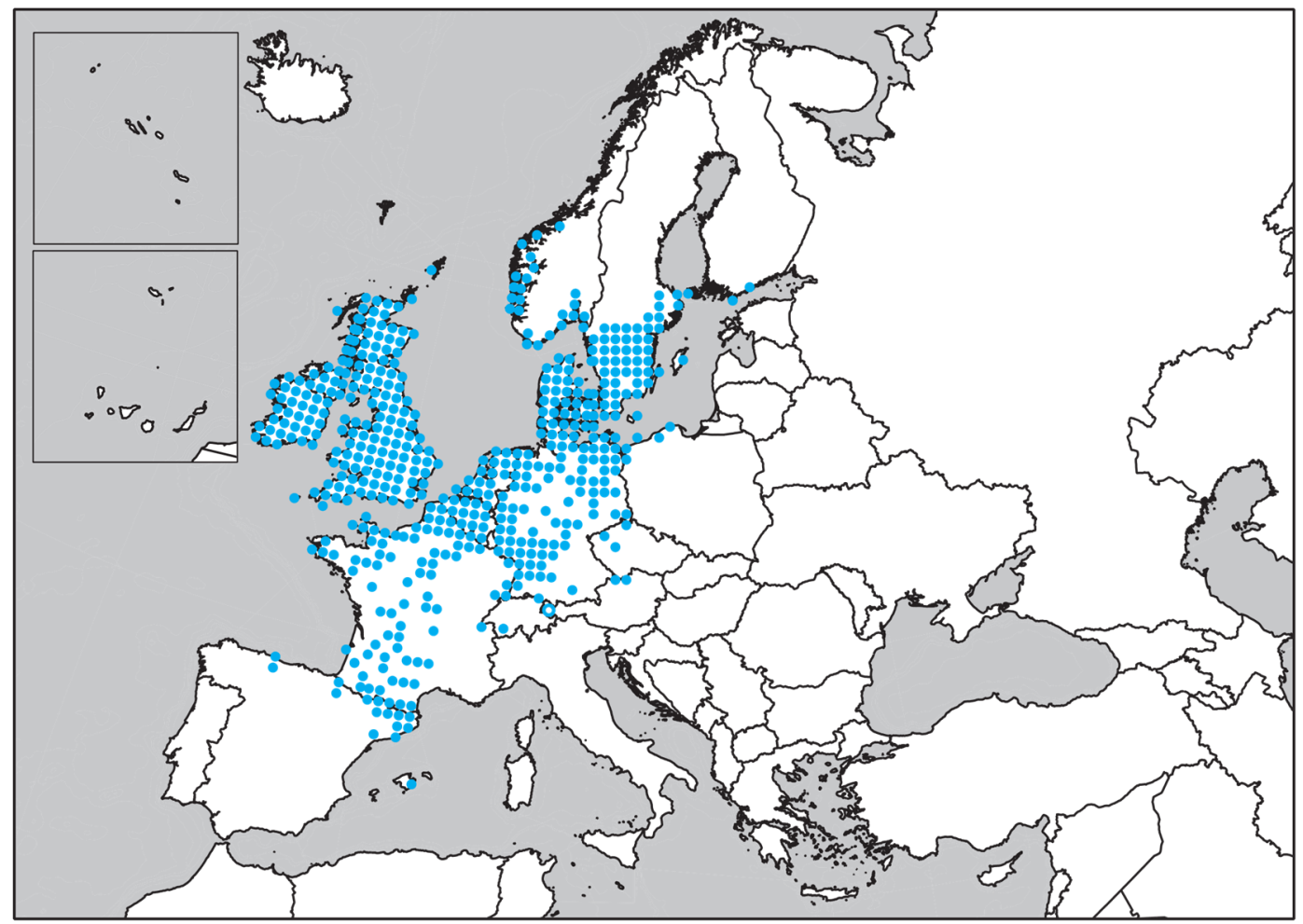

169. Cylindroiulus punctatus (Leach, 1815) 


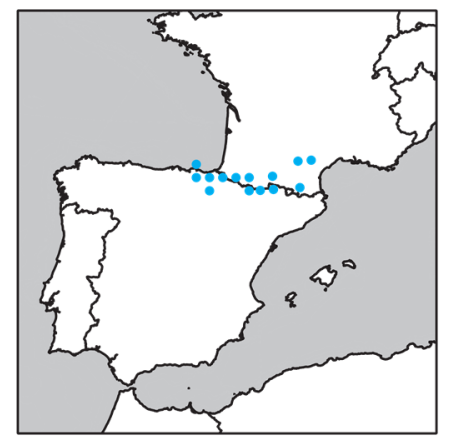

170. Cylindroiulus pyrenaicus

(Brölemann, 1897)

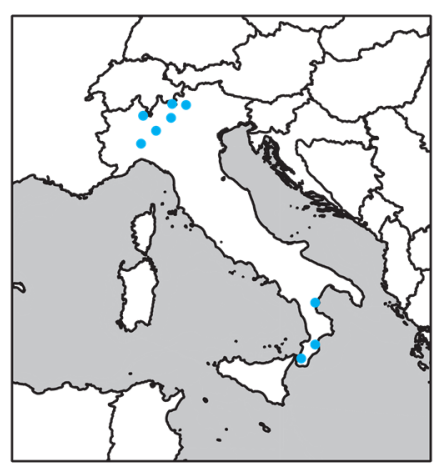

174. Cylindroiulus rufifrons (C.L. Koch, 1847)

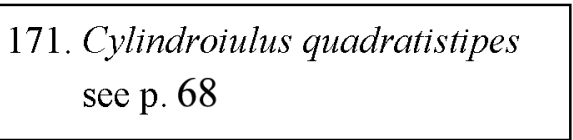

172. Cylindroiulus rabacalensis see p. 68

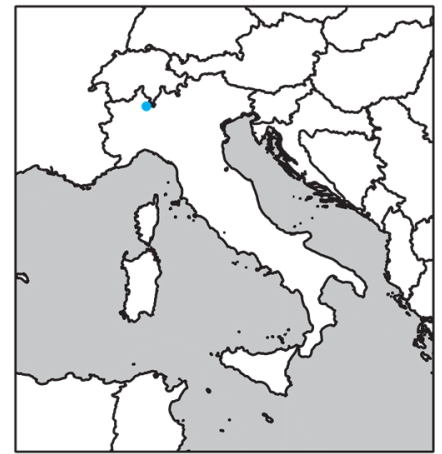

173. Cylindroiulus rubidicollis Verhoeff, 1930

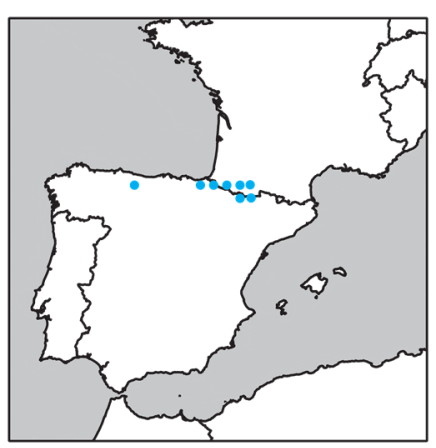

175. Cylindroiulus sagittarius

(Brölemann, 1897)

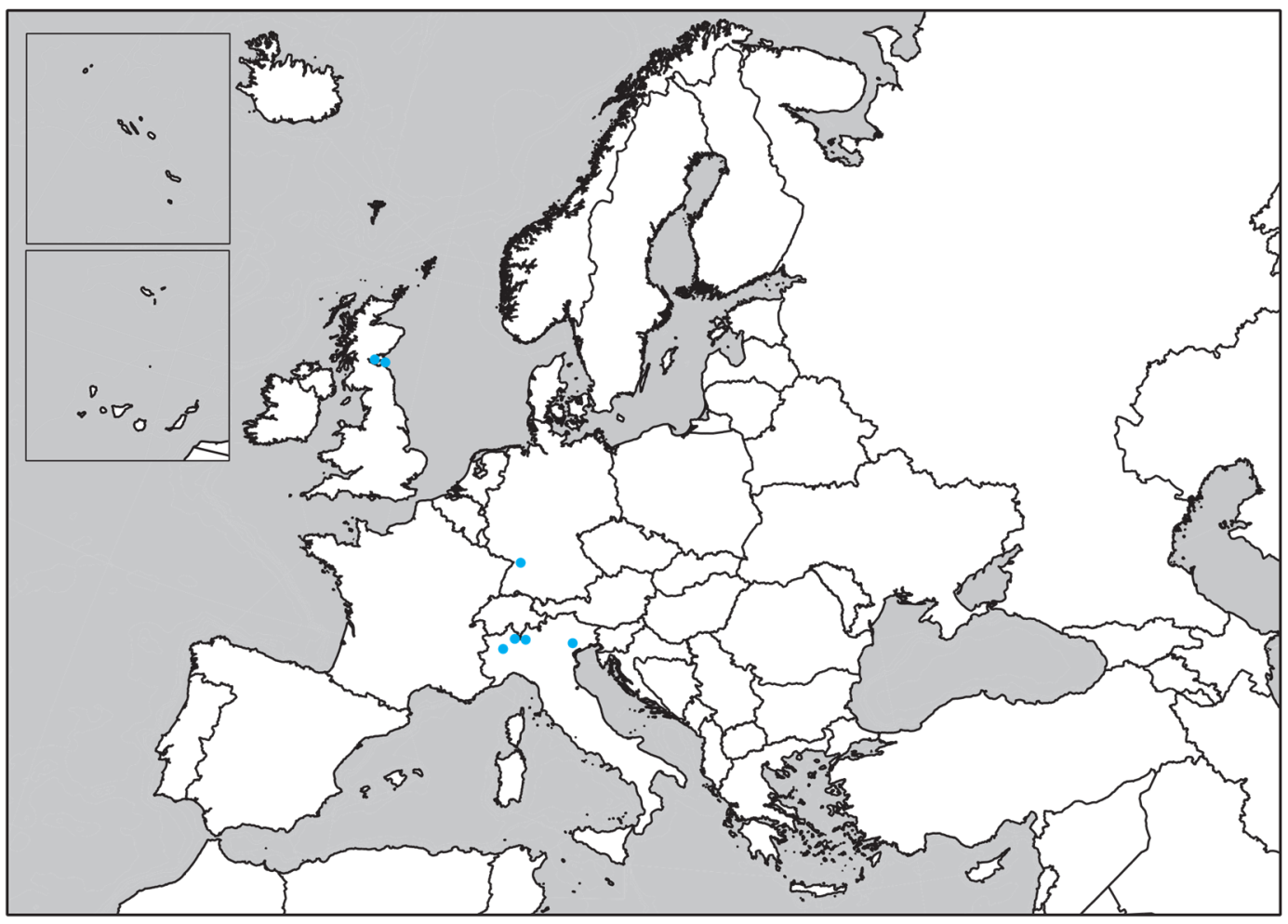

176. Cylindroiulus salicivorus Verhoeff, 1908 

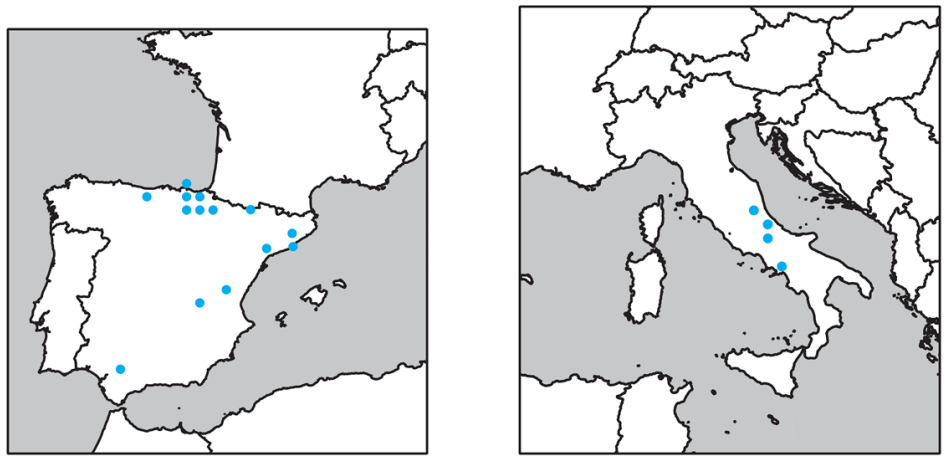

177. Cylindroiulus sanctimichaelis Attems, 1927

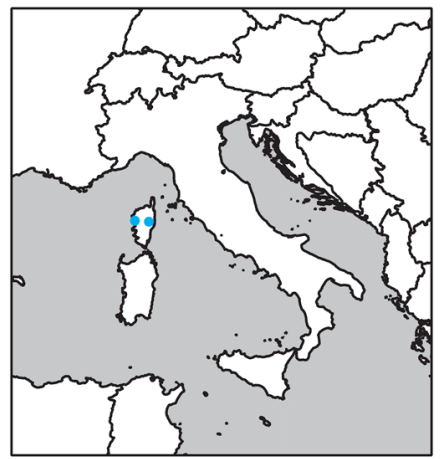

180. Cylindroiulus schubarti Verhoeff, 1943

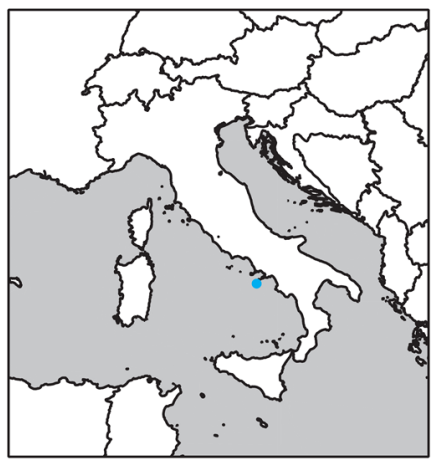

183. Cylindroiulus solarius Verhoeff, 1942

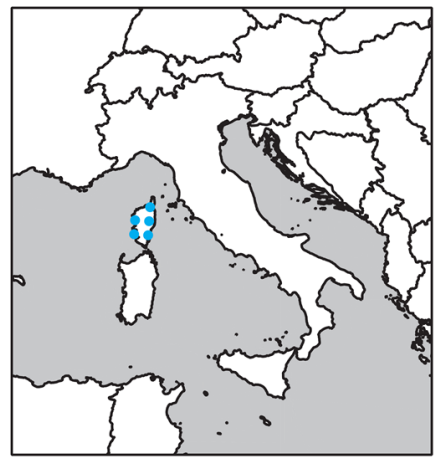

181. Cylindroiulus segregatus Brölemann, 1903

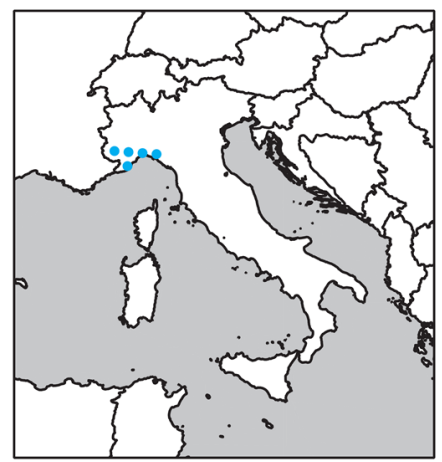

184. Cylindroiulus solis Verhoeff, 1908

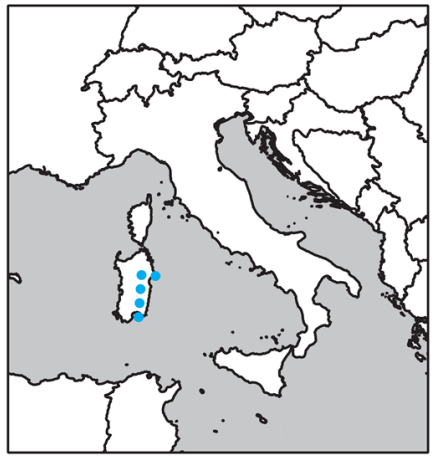

179. Cylindroiulus sardous (Silvestri, 1898)

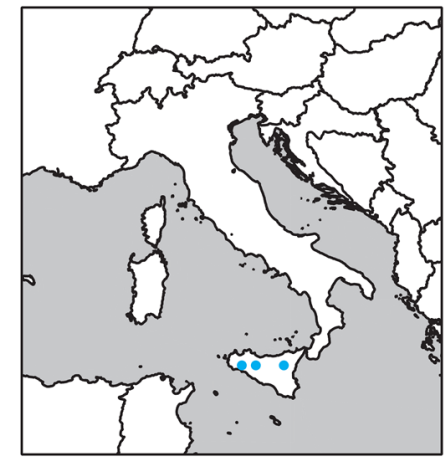

182. Cylindroiulus siculus Silvestri, 1897

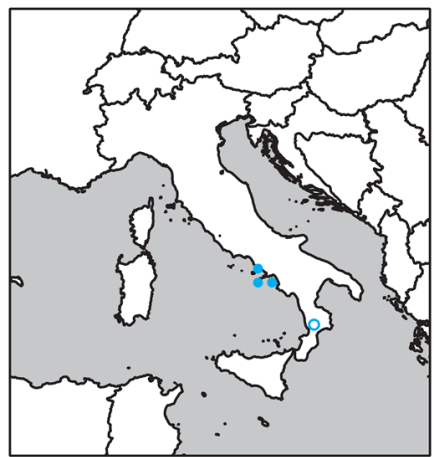

185. Cylindroiulus sorrentinus Verhoeff, 1912

186. Cylindroiulus speluncaris see p. 72 


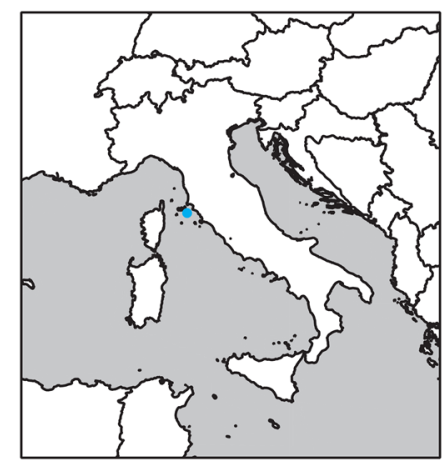

187. Cylindroiulus strasseri Verhoeff, 1930

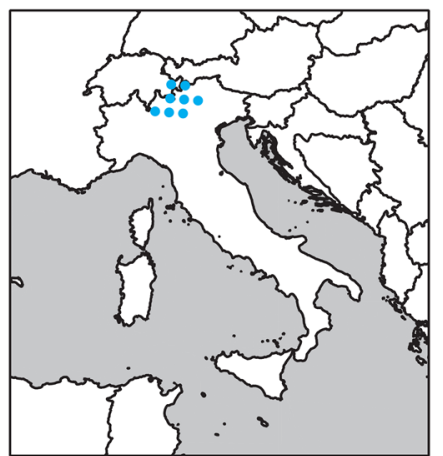

188. Cylindroiulus tirolensis Verhoeff, 1901

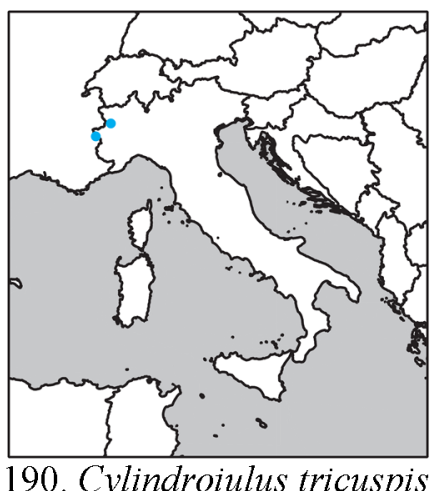

Verhoeff, 1932

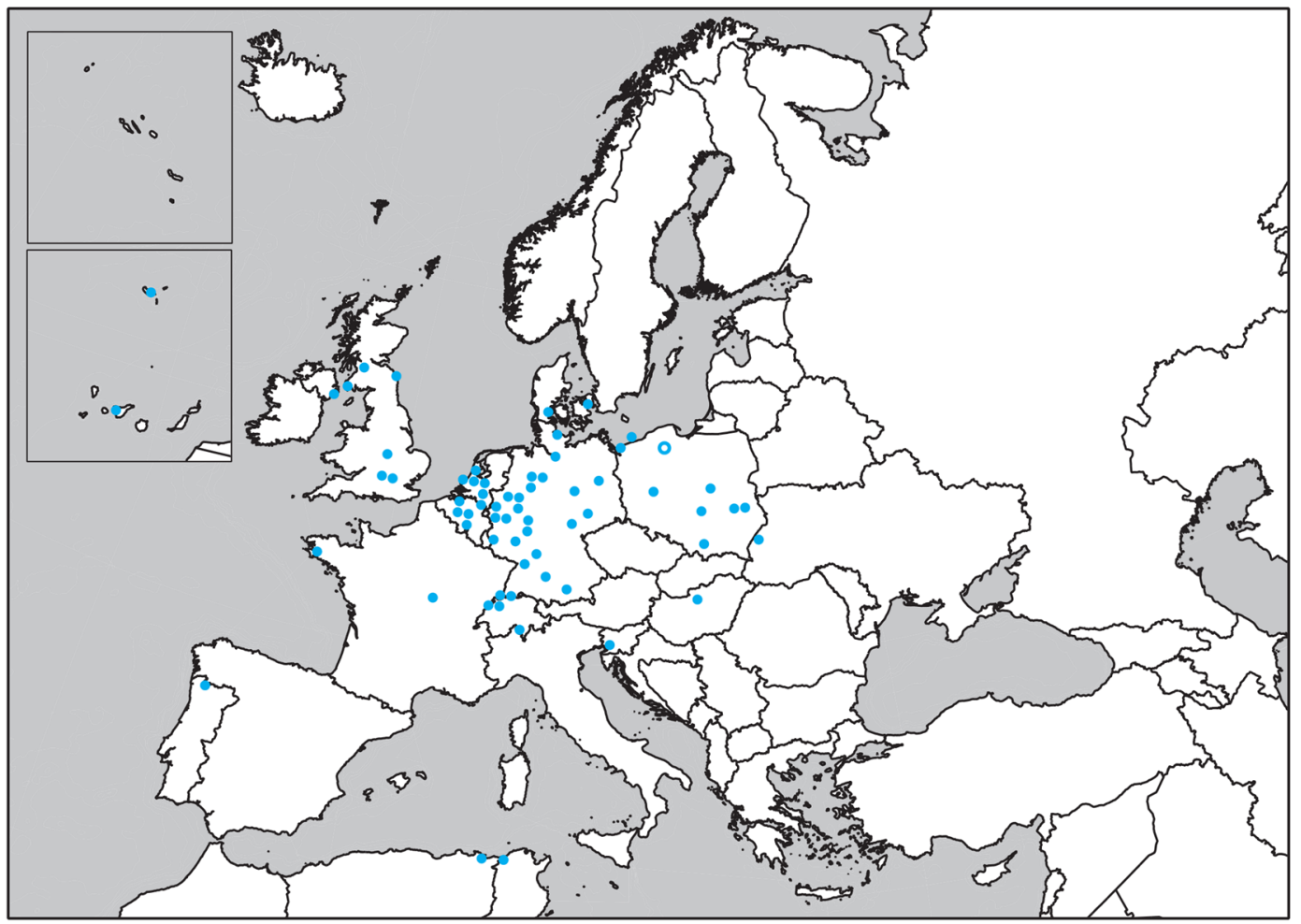

191. Cylindroiulus truncorum (Silvestri, 1896) 


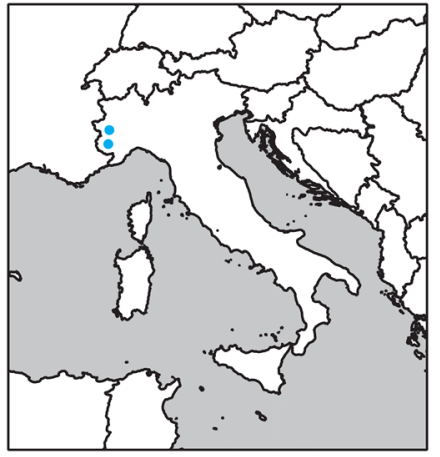

192. Cylindroiulus turinensis (Brölemann, 1897)

195. Cylindroiulus uroxiphos see p. 74

196. Cylindroiulus velatus see p. 74

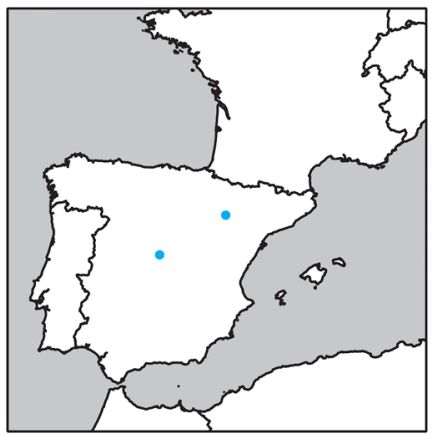

193. Cylindroiulus unciger Attems, 1952

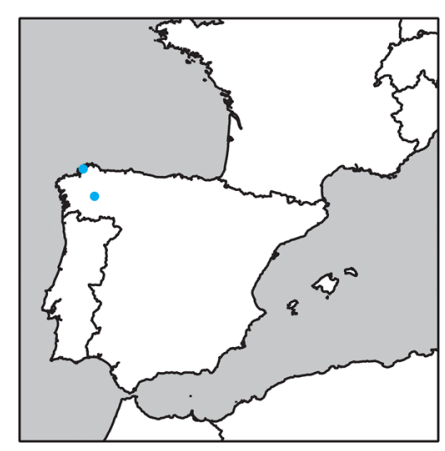

197. Cylindroiulus ventanaea Read, 2007

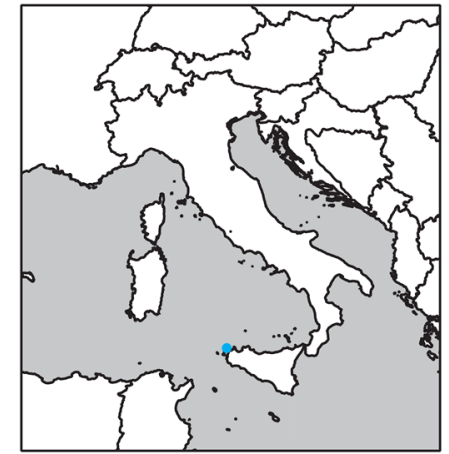

194. Cylindroiulus uncinatus Strasser, 1969

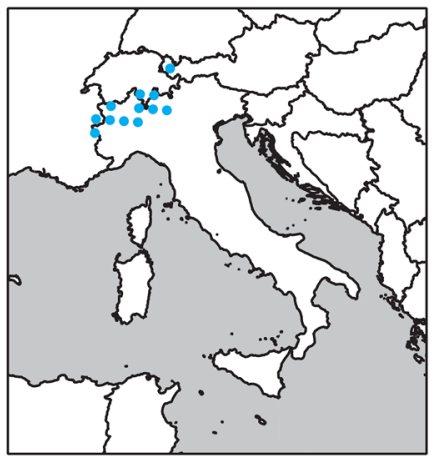

198. Cylindroiulus verhoeffi (Brölemann, 1896)

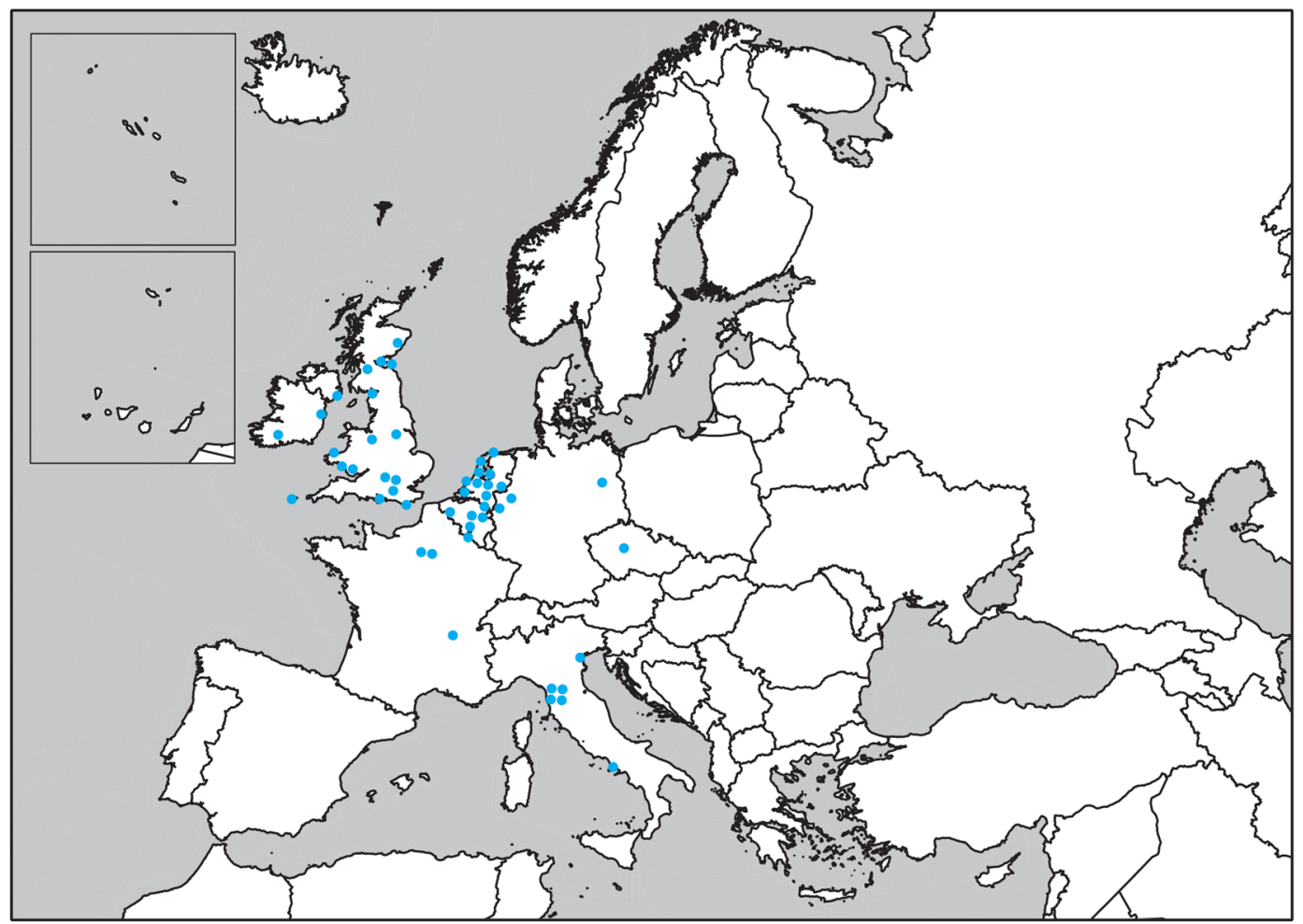

199. Cylindroiulus vulnerarius (Berlese, 1888) 


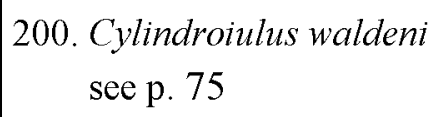

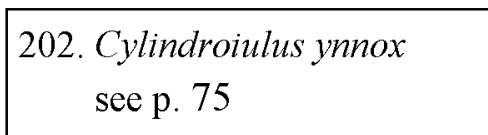

203. Cylindroiulus zarcoi see p. 76

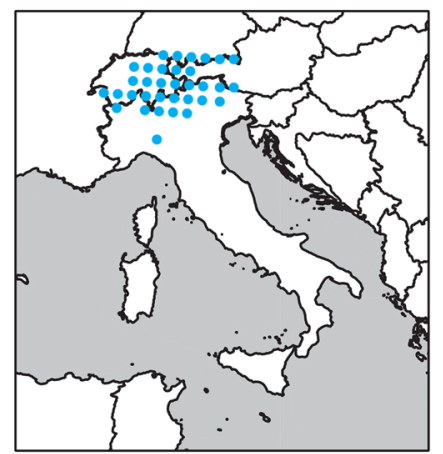

204. Cylindroiulus zinalensis (Faës, 1902)

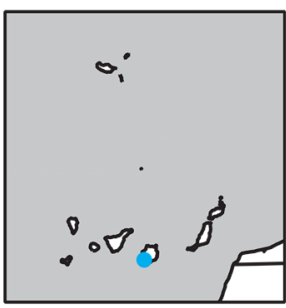

205. Dolichoiulus alluaudi (Brölemann, 1901)

208. D. architheca Enghoff, 1992

213. D. carolineae Enghoff, 1992

218. D. fjellbergi Enghoff, 1992

221. D. heliophilus Enghoff, 1992

232. D. longunguis Enghoff, 2012

234. D. martini Enghoff, 1992

237. D. oromii Enghoff, 2012

238. D. oskari Enghoff, 1992

239. D. parcestriatus (Brölemann, 1901)

251. D. typhlocanaria Enghoff, 1992

253. D. ultimus Enghoff, 2012

261. D. zygodon Enghoff, 1992

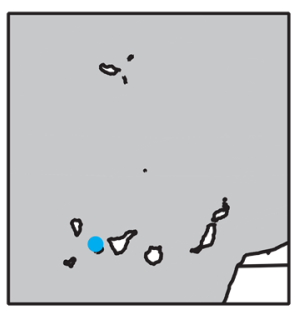

216. Dolichoiulus dubiosus Enghoff, 1992

220. D. gara Enghoff, 1992

228. D. jonay Enghoff, 1992

240. D. praesenilis Enghoff, 1992

242. D. rectangulus Enghoff, 1992

244. D. sansebastianus (Attems, 1911)

245. D. senilis (Attems, 1911)

248. D. tiendarius (Attems, 1911)

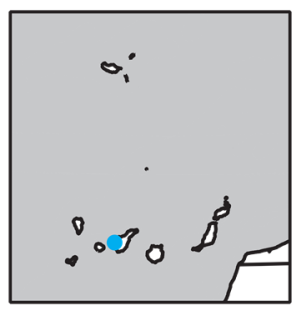

206. Dolichoiulus altitenerife Enghoff, 1992

207. D. aquasilvae Enghoff, 1992

209. D. axeli Enghoff, 1992

210. D. baezi Enghoff, 1992

211. D. blancatypa (Enghoff, 1992)

212. D.canariensis (Pocock, 1893)

214. D. chioensis Enghoff, 1992

215. D. dendromystax Enghoff, 1992

223. D. hyaena Enghoff, 1992

225. D. ingeae Enghoff, 1992

226. D. insularis (Brölemann, 1901)

229. D. kraepelinorum (Latzel, 1895)

230. D. labradae Enghoff, 1992

231. D. lasiurus Enghoff, 1992

235. D. mystax (Brölemann, 1901)

236. D. nemasoma Enghoff, 1992

241. D. quasimystax Enghoff, 1992

255. D. vosseleri (Verhoeff, 1900)

259. D. xylomystax Enghoff, 1992

260. D. ypsilon Enghoff, 1992

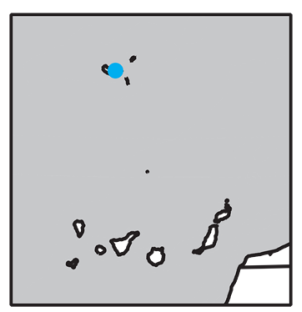

217. Dolichoiulus eumadeirae Enghoff. 1992 


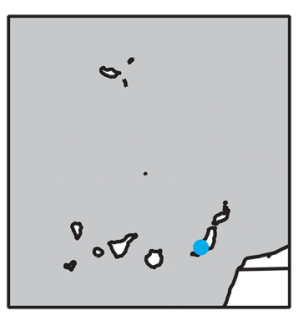

219. Dolichoiulus fuerteventurae Enghoff, 1992

227. D. jandiensis Enghoff, 1992

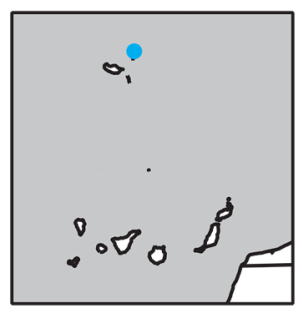

233. Dolichoiulus madeiranus

(Mauriès, 1970)

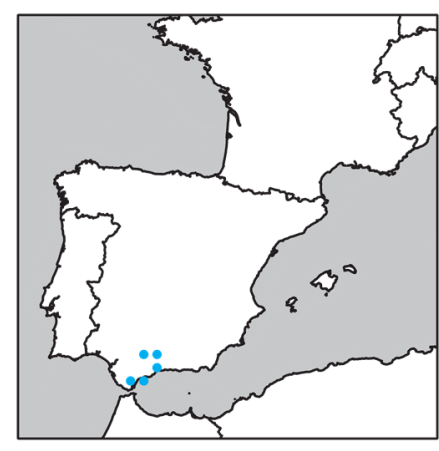

222. Dolichoiulus hercules

(Schubart, 1960)

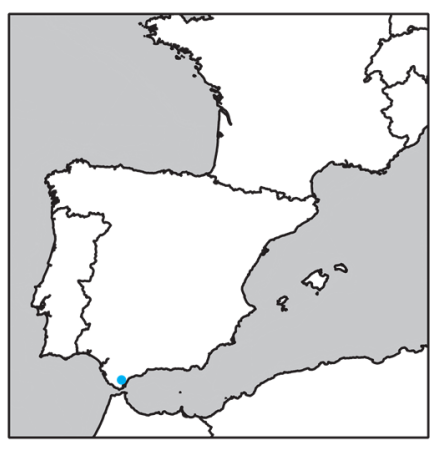

224. Dolichoiulus ibericus Ceuca, 1973

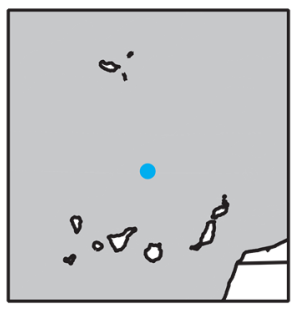

243. Dolichoiulus salvagicus (Latzel, 1895)

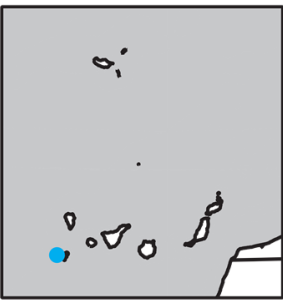

246. Dolichoiulus silvahierro Enghoff, 1992

250. D. troglohierro

Enghoff, 1992

257. D. xerohierro

Enghoff, 1992

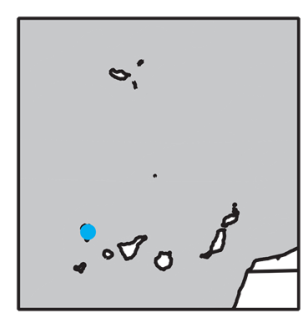

247. Dolichoiulus silvapalma

Enghoff, 1992

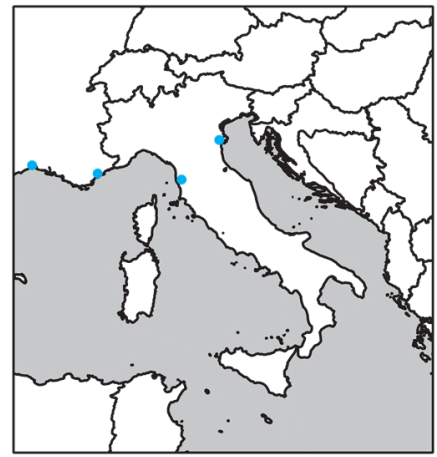

249. Dolichoiulus tongiorgii

(Strasser, 1973)

258. D. xeropalma

Enghoff, 1992 


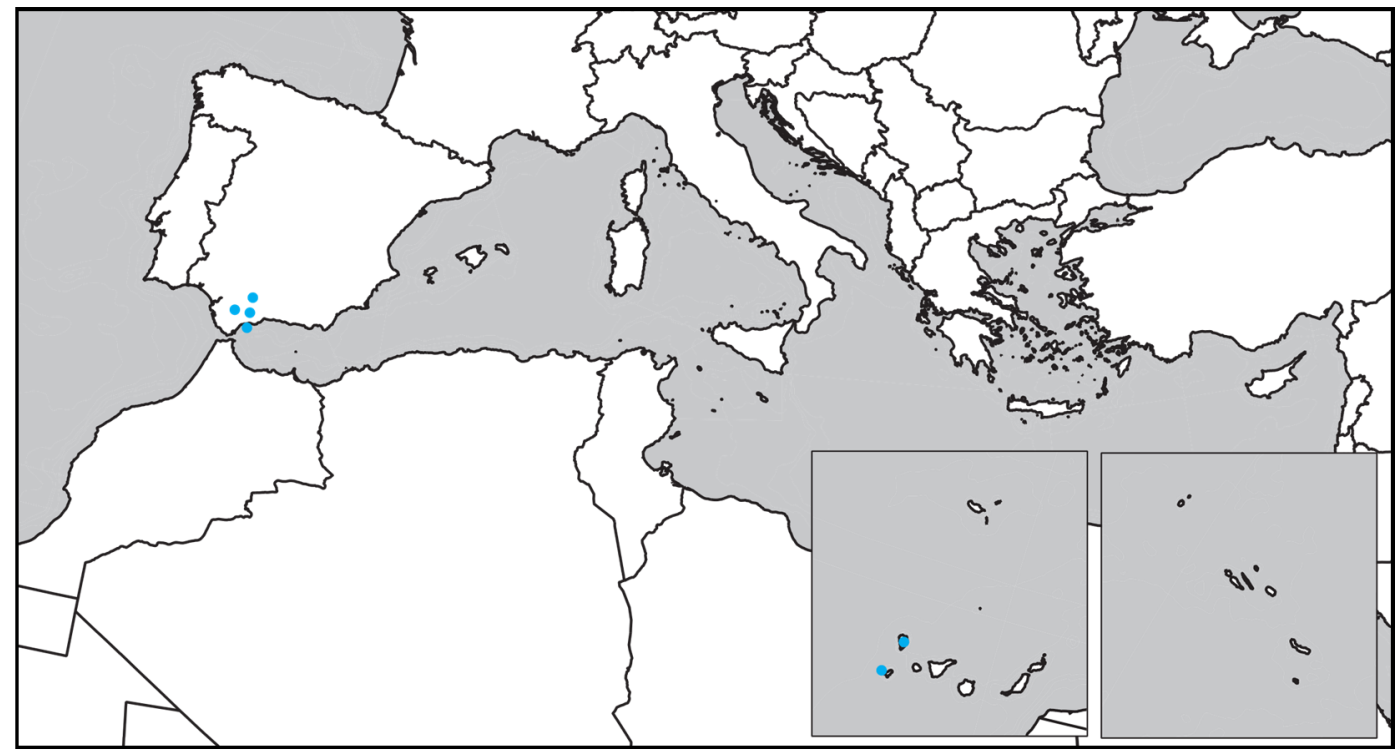

252. Dolichoiulus typhlops Ceuca, 1973

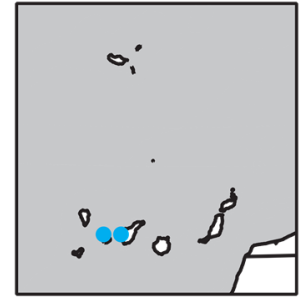

254. Dolichoiulus variabilis

Enghoff, 1992

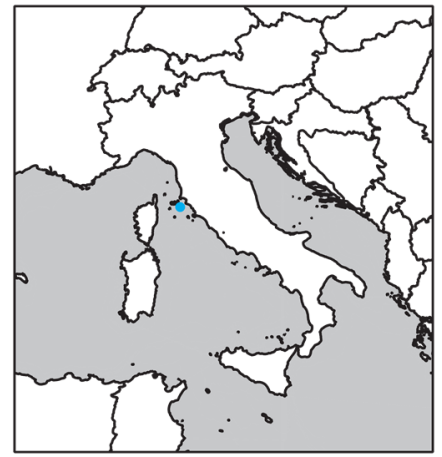

262. Elbaiulus carpinorum

Verhoeff, 1930

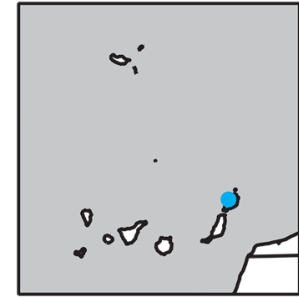

256. Dolichoiulus wunderlichi Enghoff, 1992

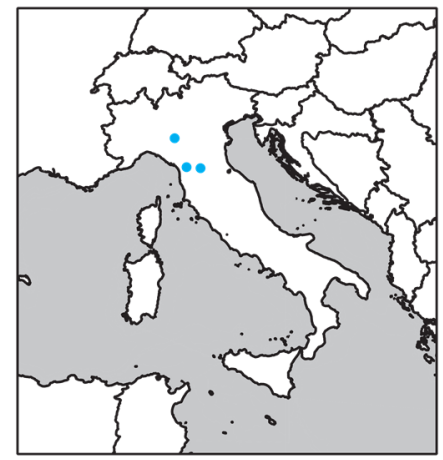

263. Elbaiulus chrysopygus

(Berlese, 1888) 


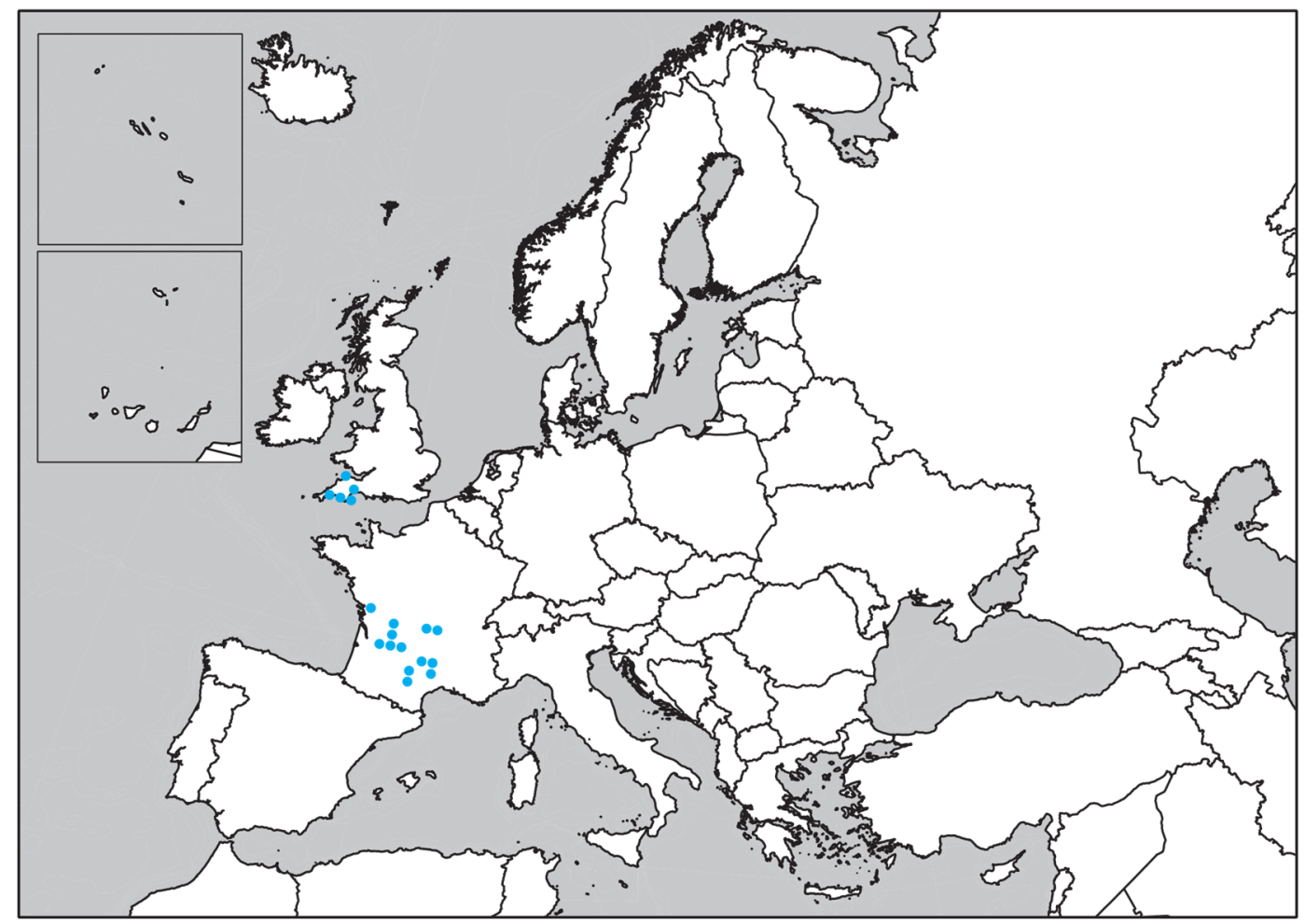

264. Enantiulus armatus (Ribaut, 1909)

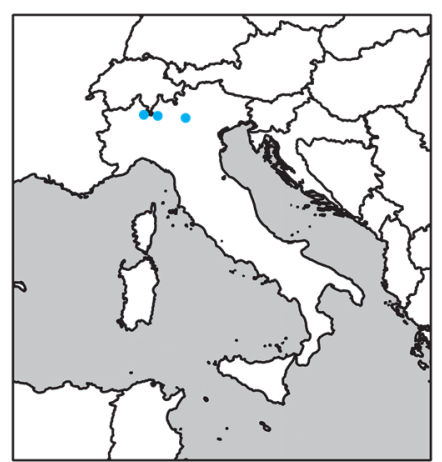

265. Enantiulus austriacus

(Verhoeff, 1896)

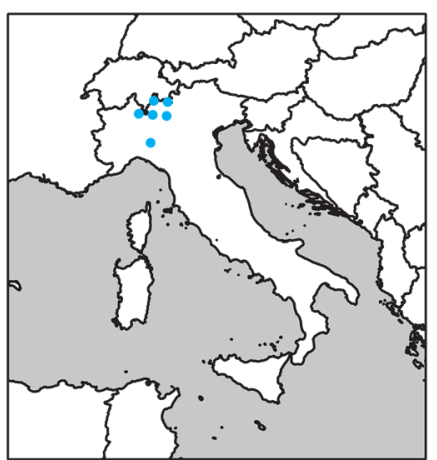

266. Enantiulus dentigerus

(Verhoeff, 1900)

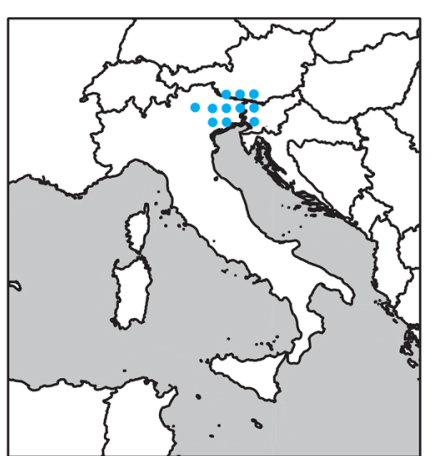

267. Enantiulus karawankianus (Verhoeff, 1908) 


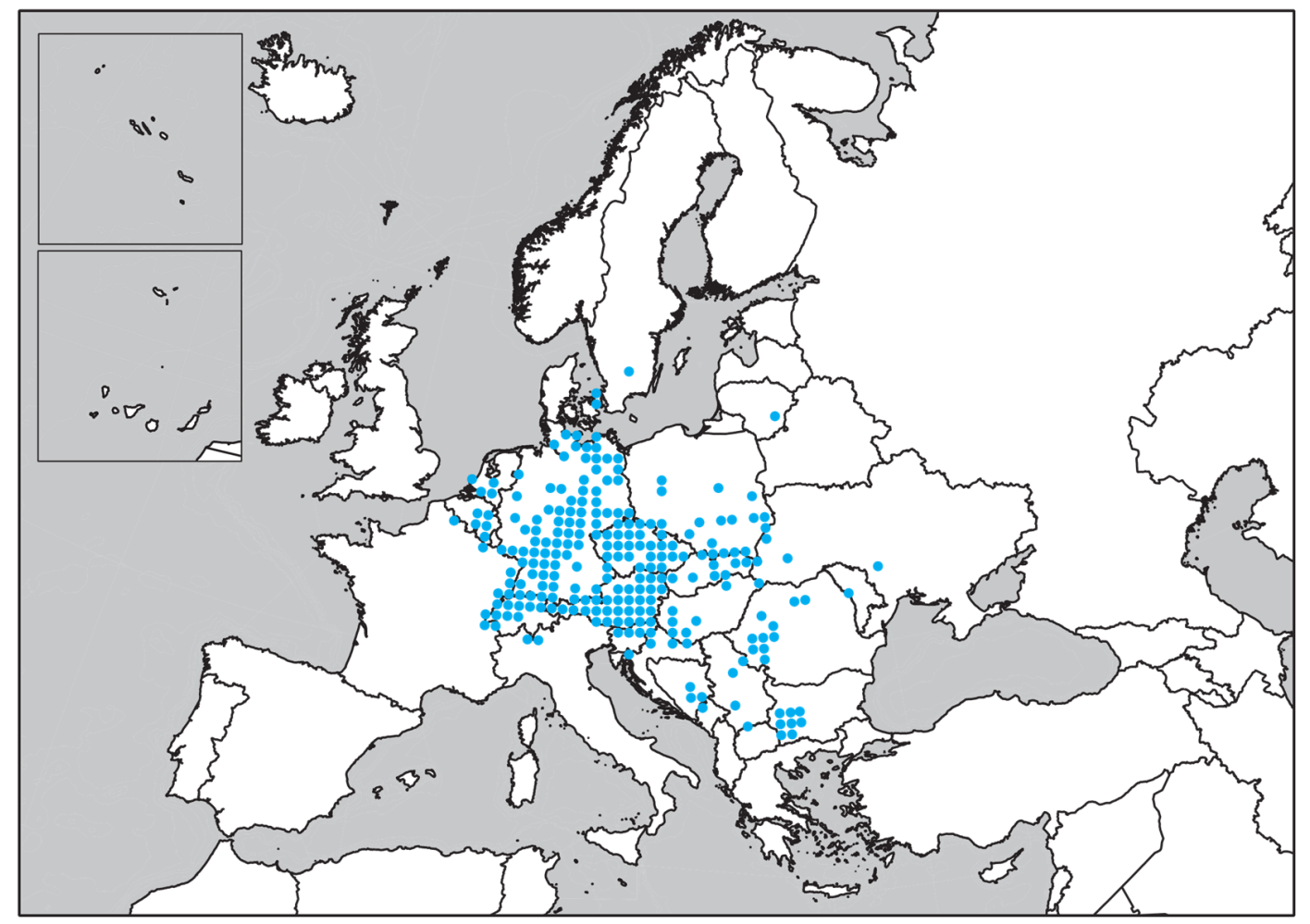

268. Enantiulus nanus (Latzel, 1884)

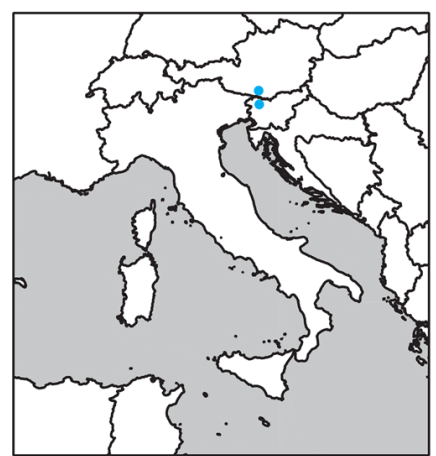

269. Enantiulus simplex (Verhoeff, 1926)

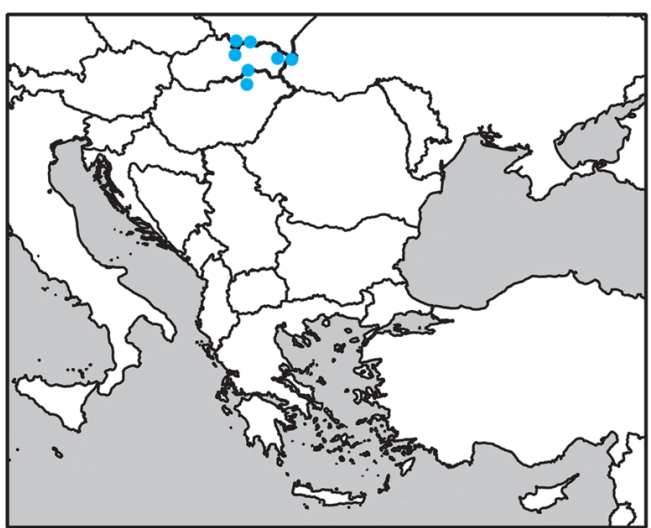

270. Enantiulus tatranus (Verhoeff, 1907) 


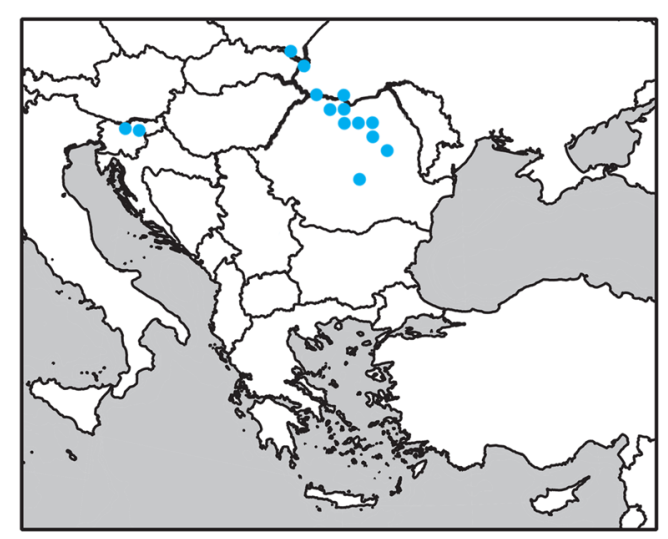

271. Enantiulus transsilvanicus

(Verhoeff, 1899)

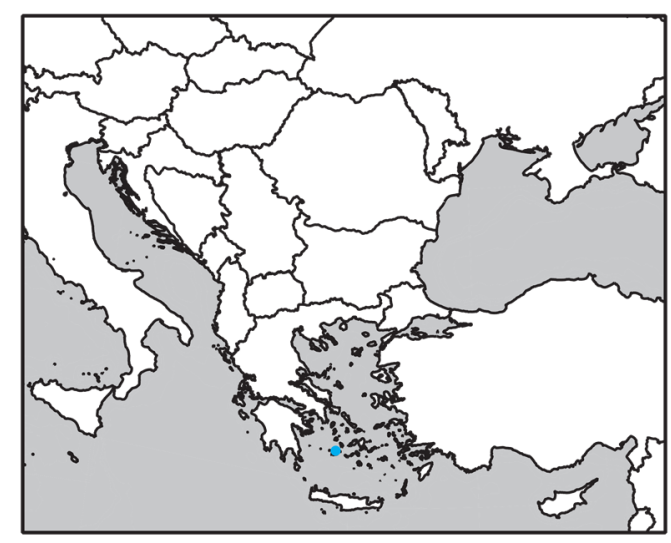

273. Enghophyllum sifnium

Lazányi \& Vagalinski, 2013

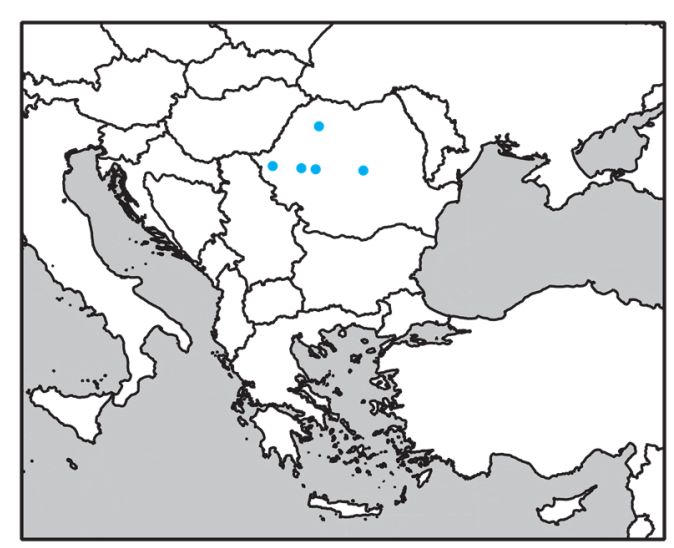

275. Geopachyiulus nematodes

(Latzel, 1884)

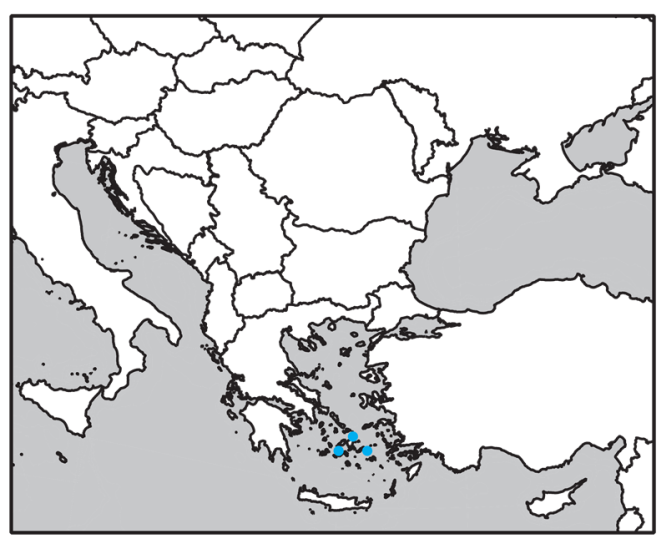

272. Enghophyllum naxium

(Verhoeff, 1901)

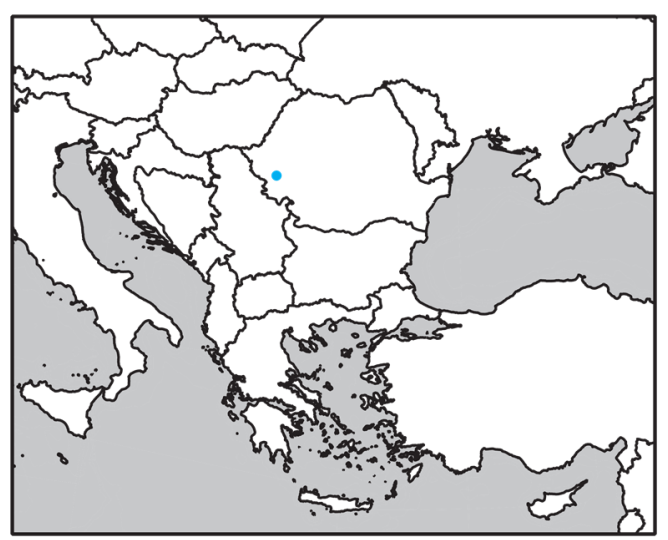

274. Geopachyiulus negreai

Tabacaru, 1978

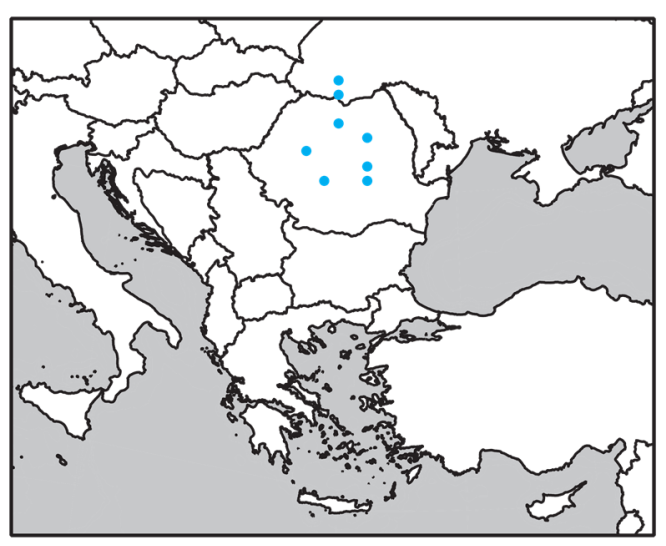

276. Haplophyllum mehelyi

(Verhoeff, 1897) 


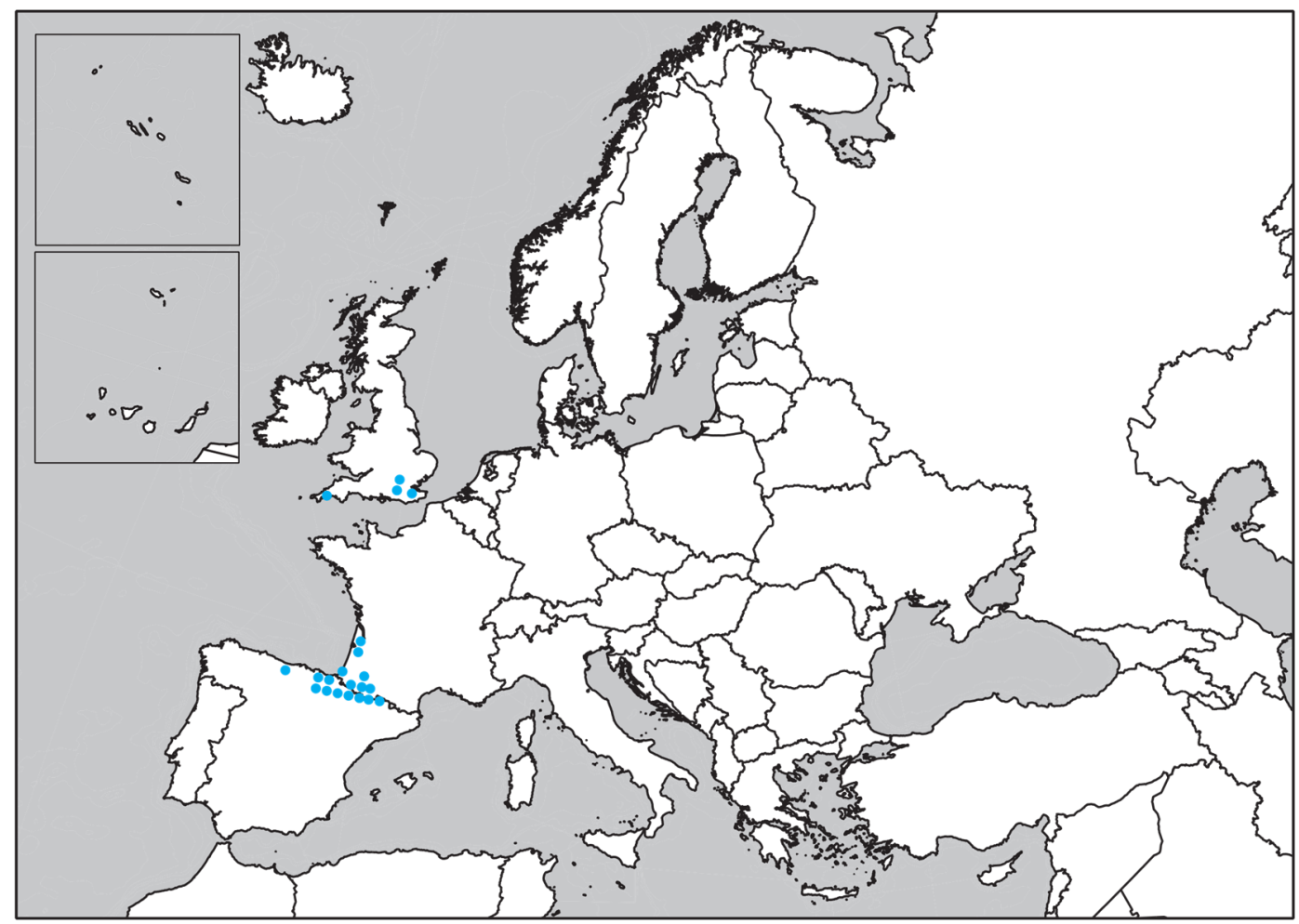

277. Haplopodoiulus spathifer (Brölemann, 1897)

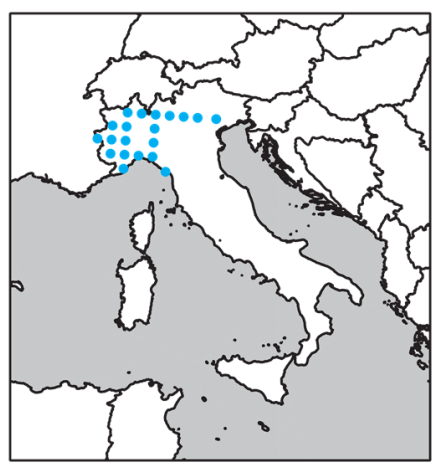

278. Heteroiulus intermedius

(Brölemann, 1892)

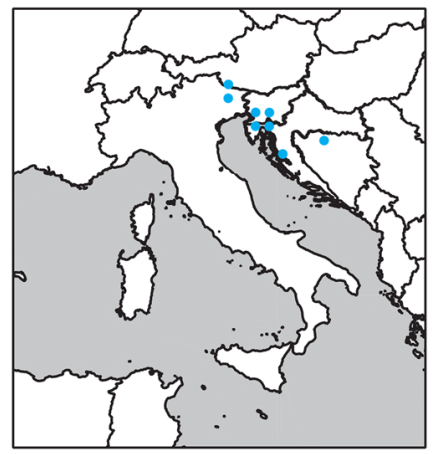

279. Hylopachyiulus pygmaeus (Attems, 1904)

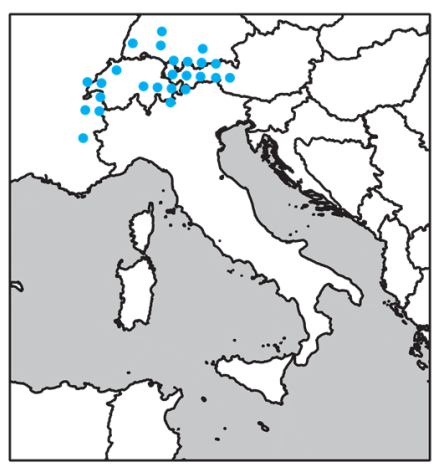

280. Hypsoiulus alpivagus (Verhoeff, 1897) 


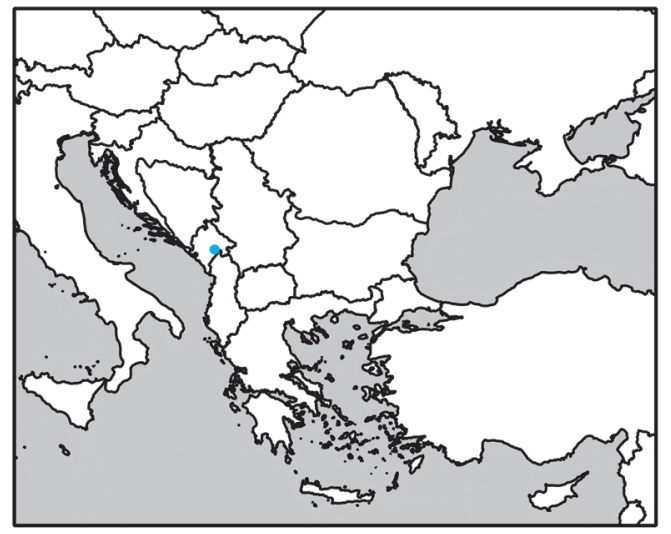

281. Interleptoiulus cernagoranus

Mršić, 1988

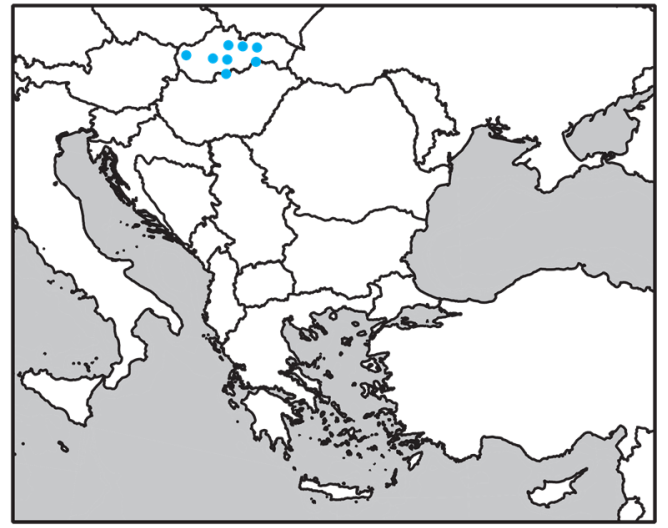

282. Julus curvicornis

Verhoeff, 1899

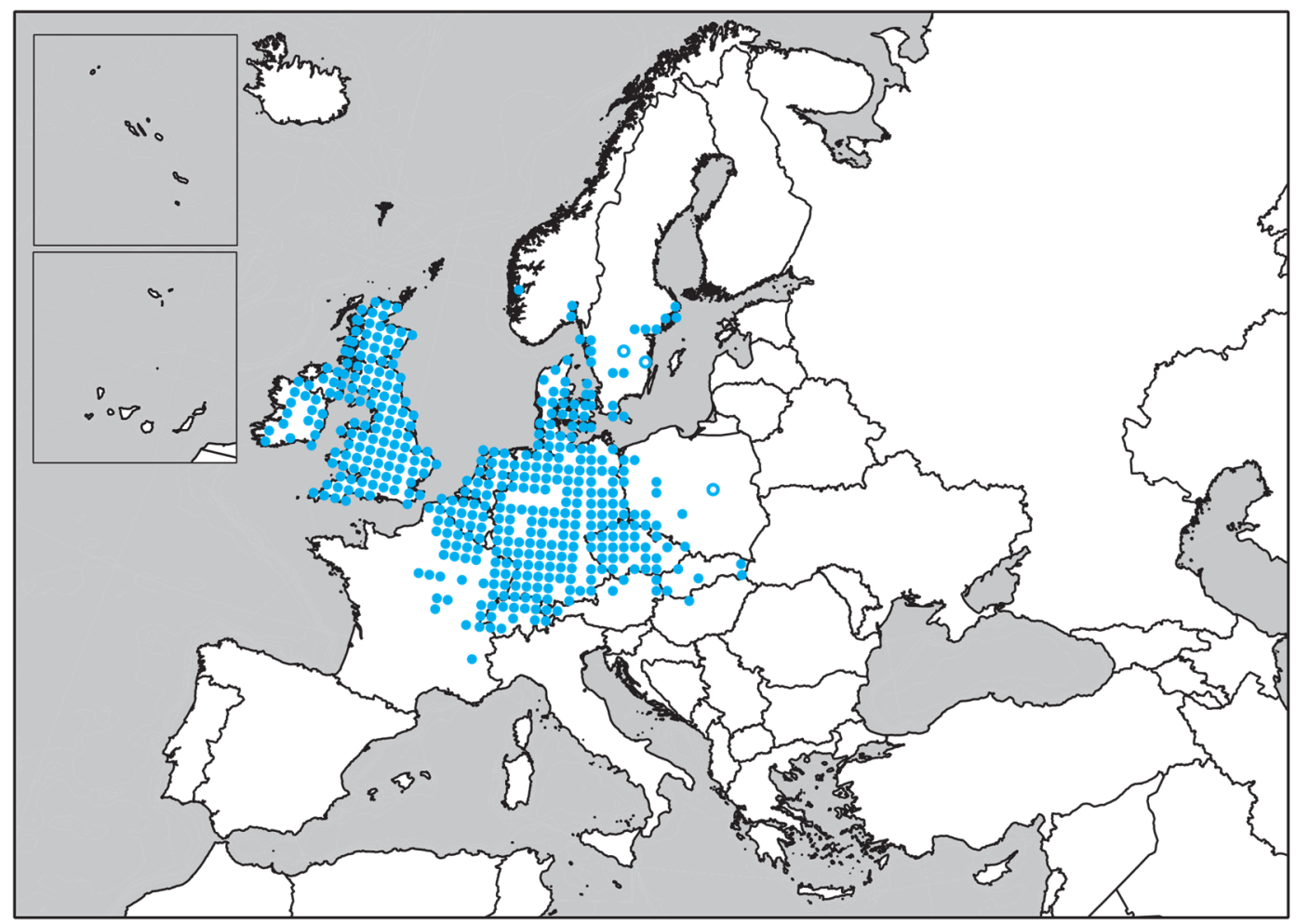

283. Julus scandinavius Latzel, 1884 


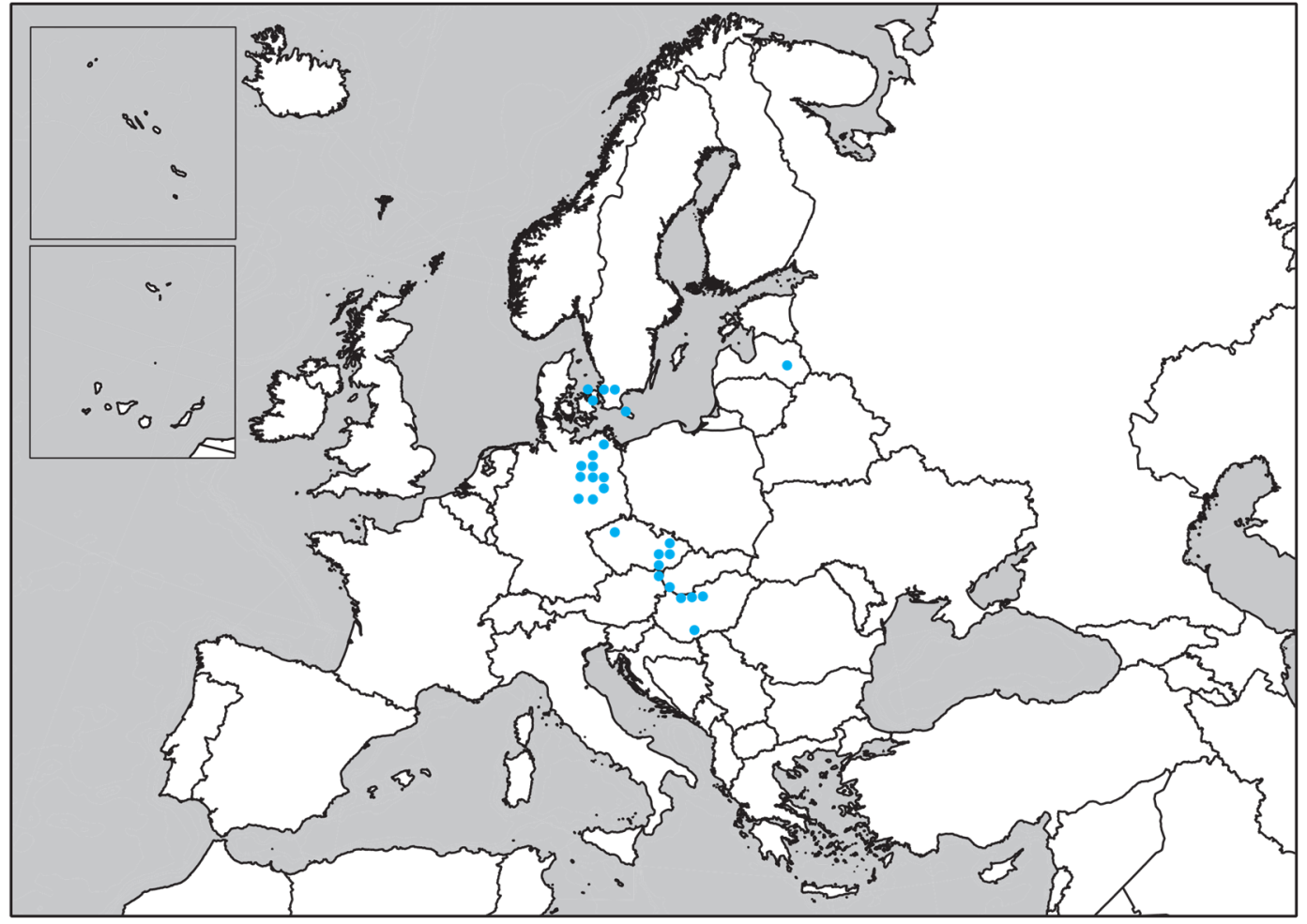

284. Julus scanicus Lohmander, 1925

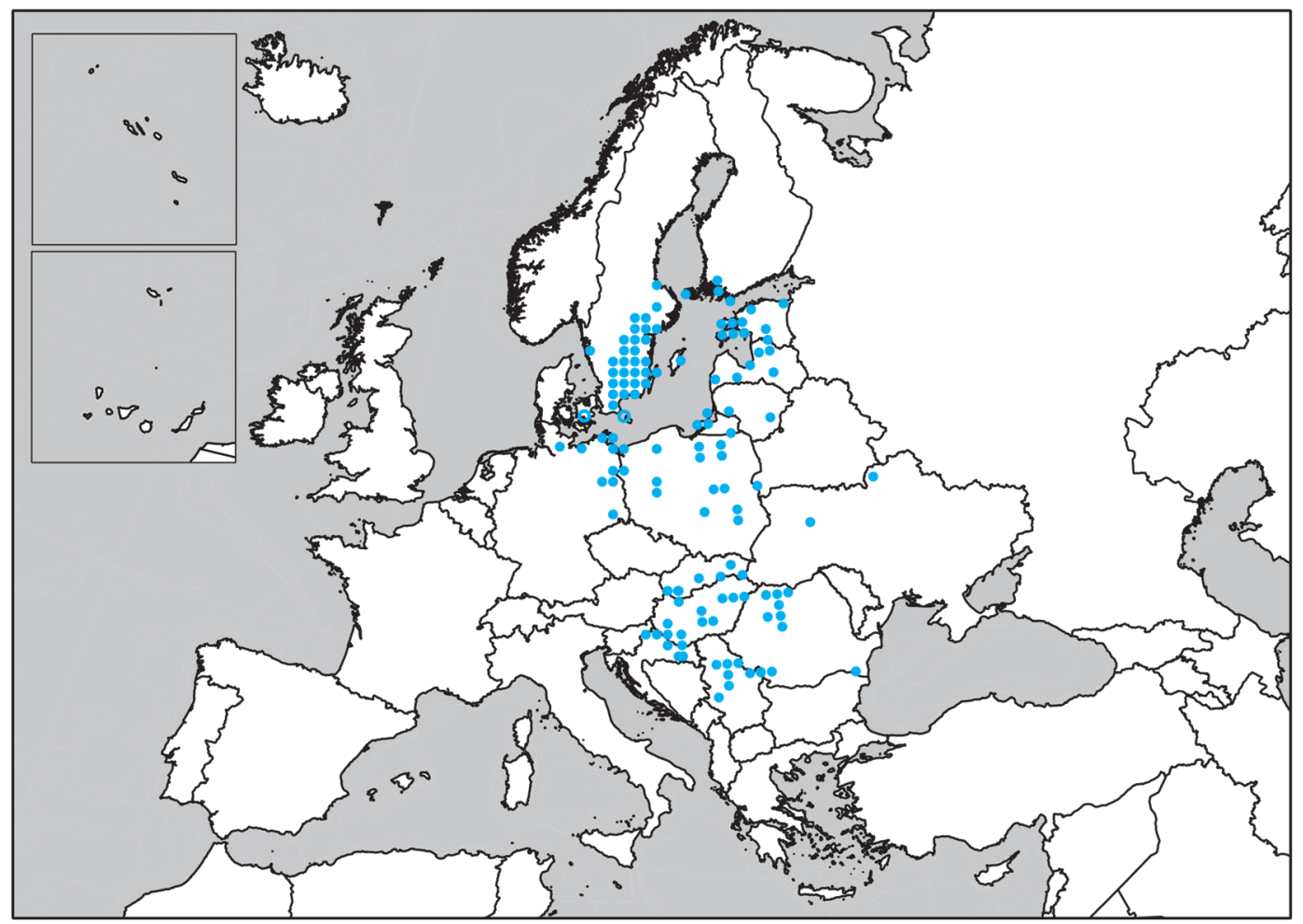

285. Julus terrestris Linnaeus, 1758 


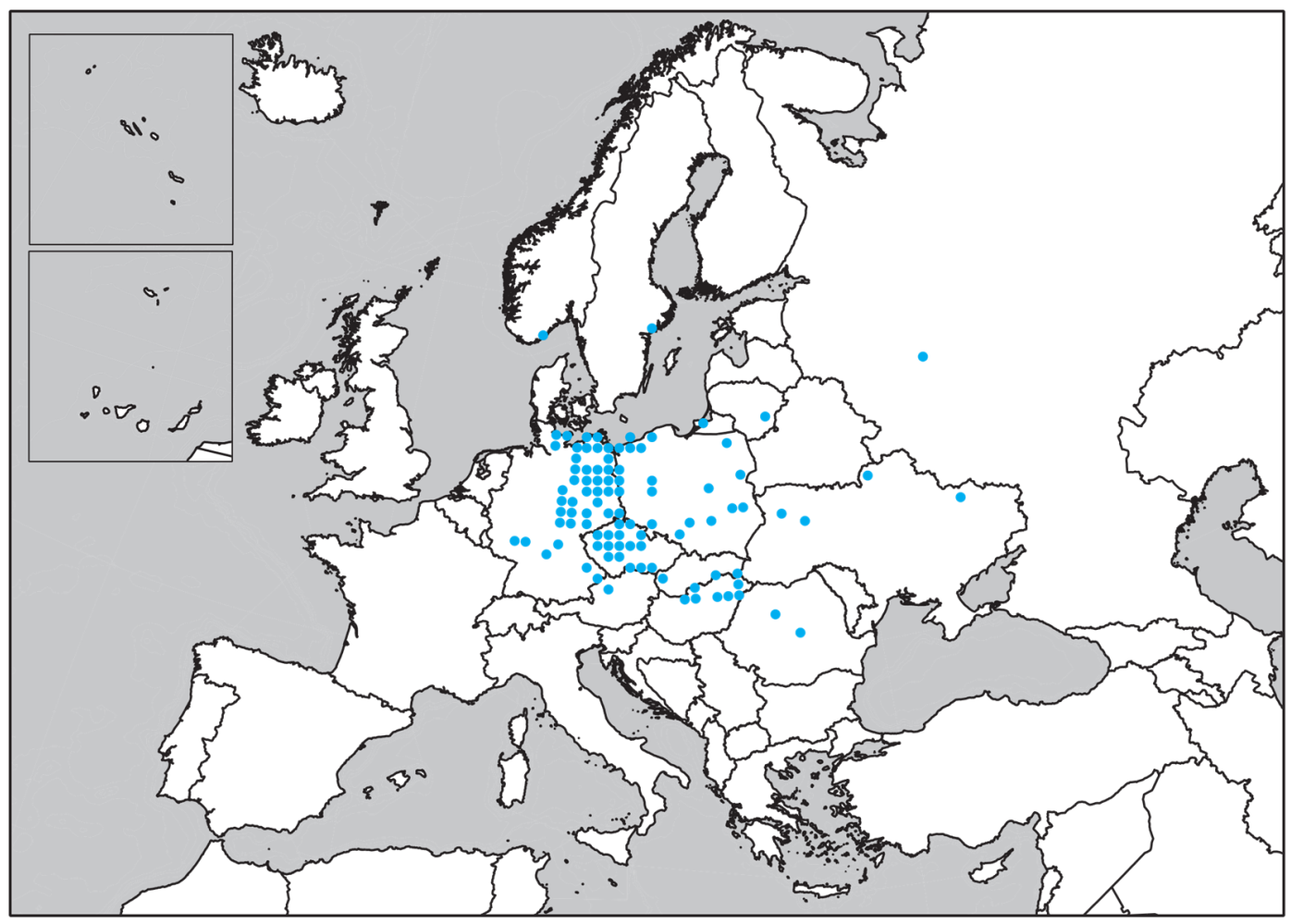

286. Kryphioiulus occultus (C.L. Koch, 1847)

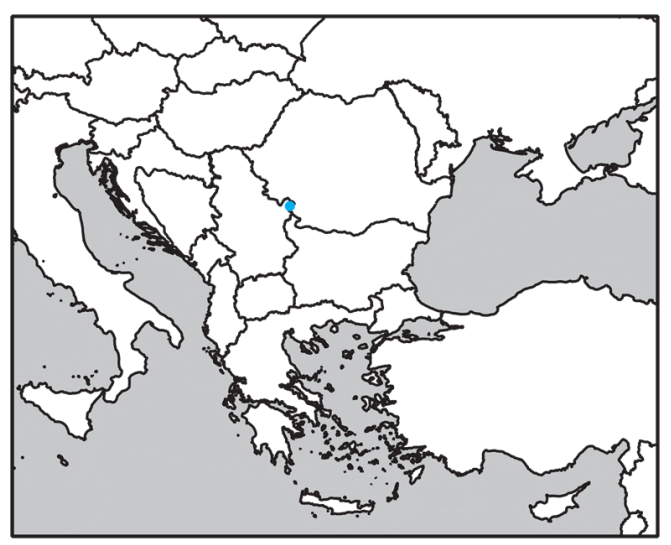

287. Lamellotyphlus belevodae

Makarov, 2008

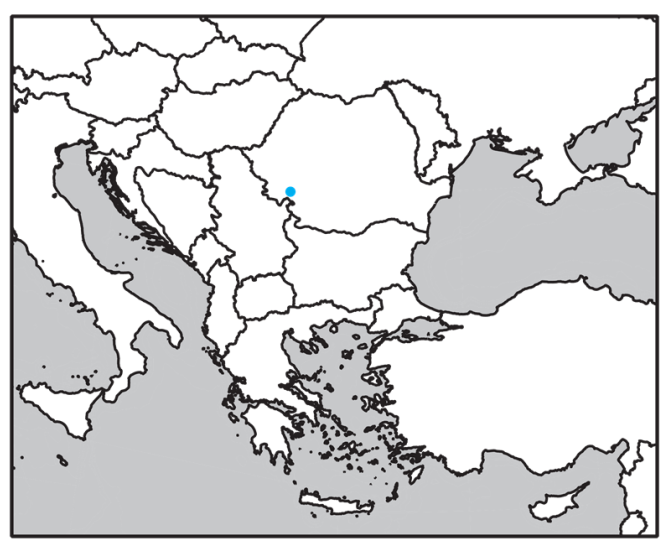

288. Lamellotyphlus mehedintzensis

(Tabacaru, 1976) 


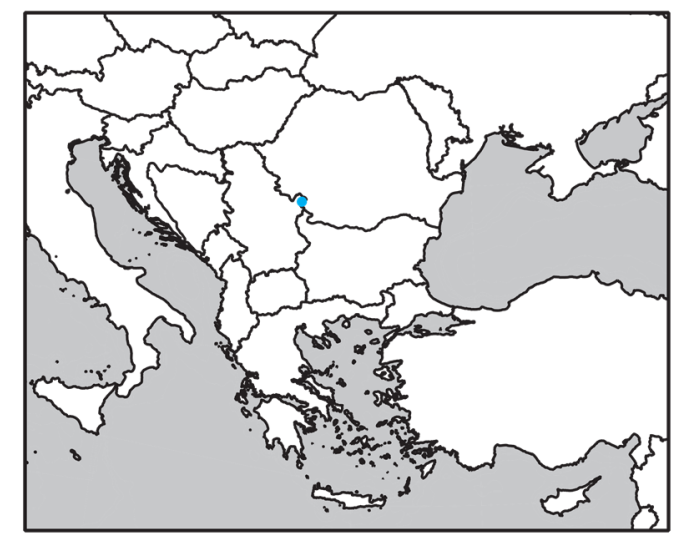

289. Lamellotyphlus sotirovi

Makarov, Mitić \& Curčić, 2002

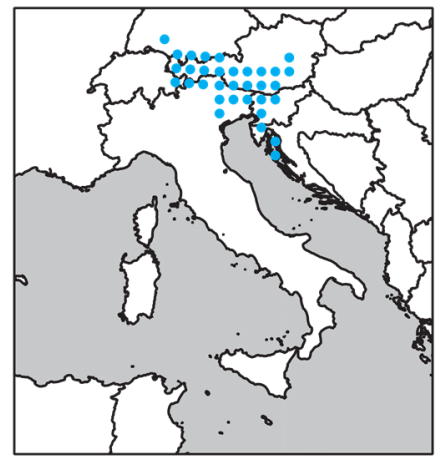

291. Leptoiulus alemannicus (Verhoeff, 1894)

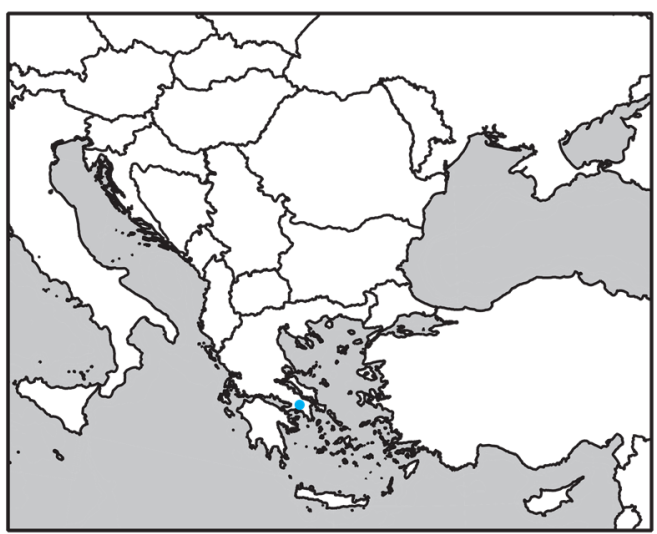

293. Leptoiulus atticus

Strasser, 1970

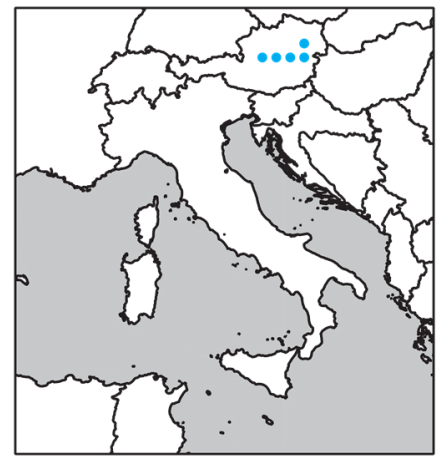

290. Leptoiulus abietum Verhoeff, 1914

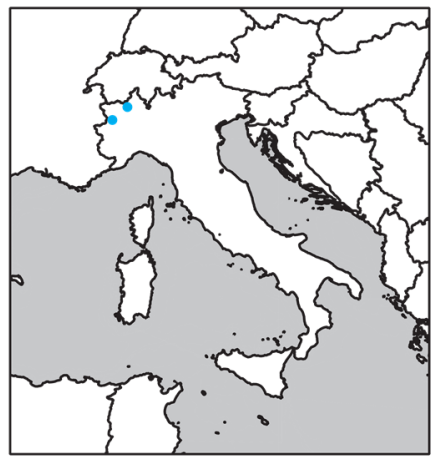

292. Leptoiulus arelatus

Bigler, 1919

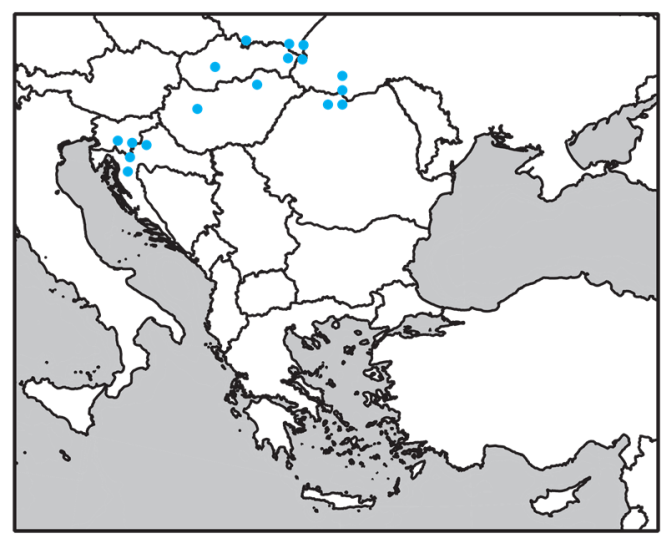

294. Leptoiulus baconyensis (Verhoeff, 1899) 


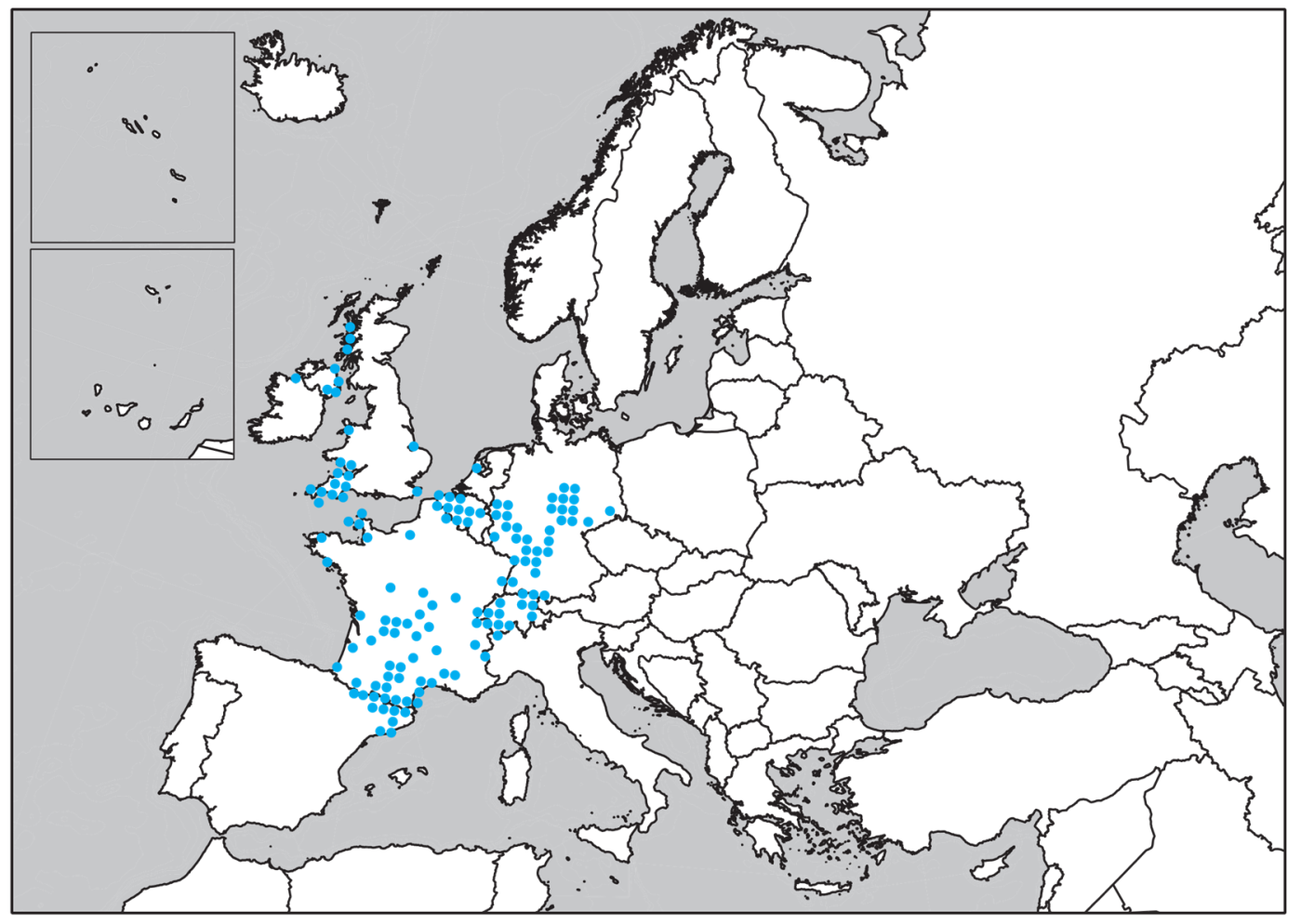

295. Leptoiulus belgicus (Latzel, 1884)

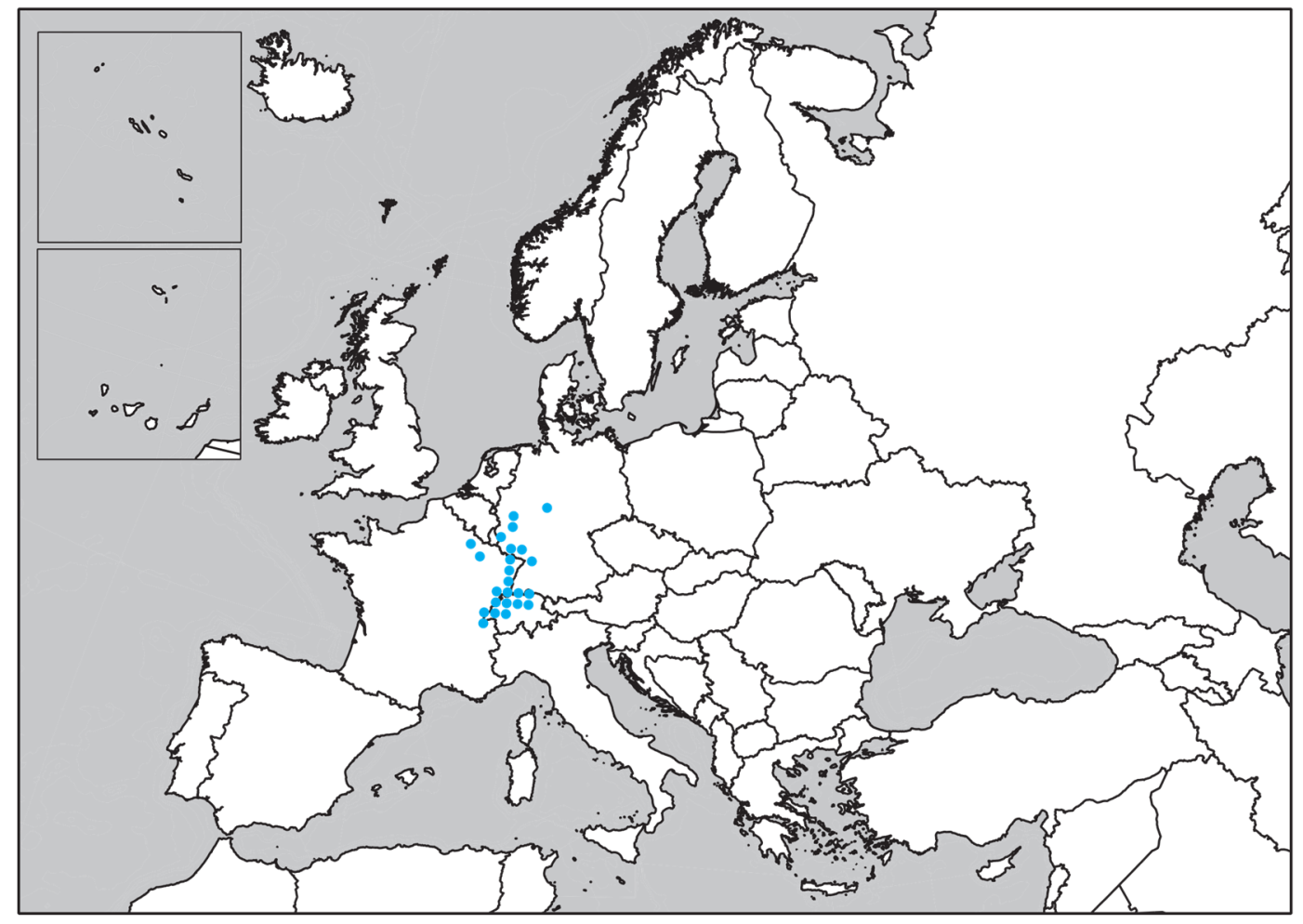

296. Leptoiulus bertkaui (Verhoeff, 1896) 


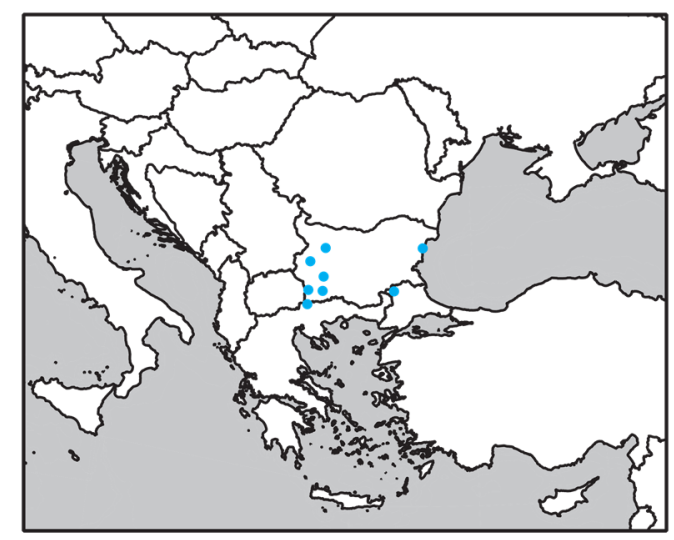

297. Leptoiulus borisi Verhoeff, 1926

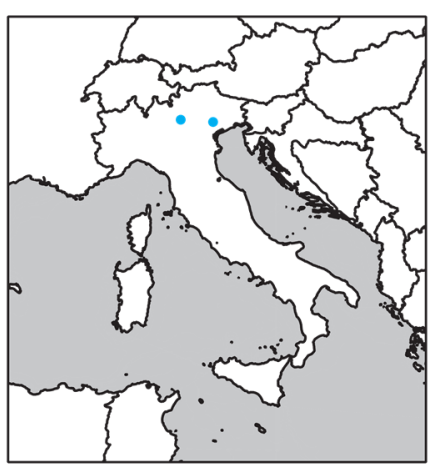

298. Leptoiulus brentanus Verhoeff, 1926

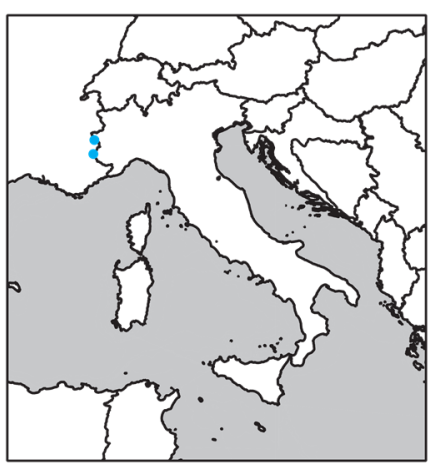

299. Leptoiulus brevivelatus Bigler, 1919

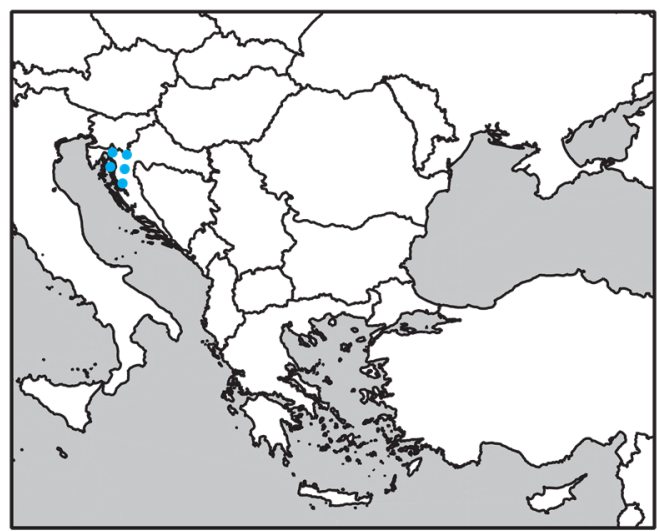

302. Leptoiulus carpinorum

Verhoeff, 1929

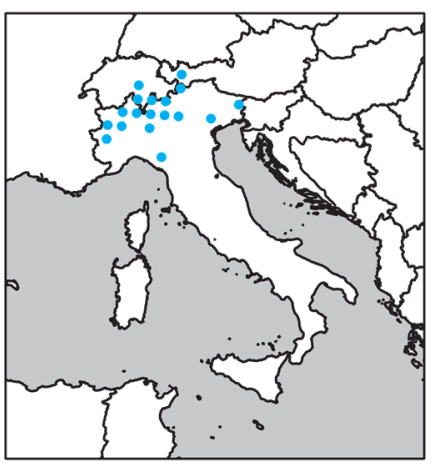

300. Leptoiulus broelemanni (Verhoeff, 1895)

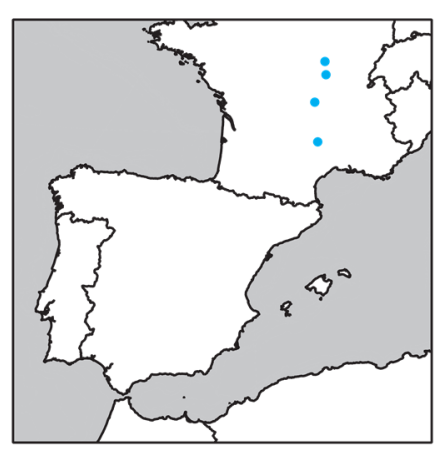

301. Leptoiulus bryanti Ribaut, 1951

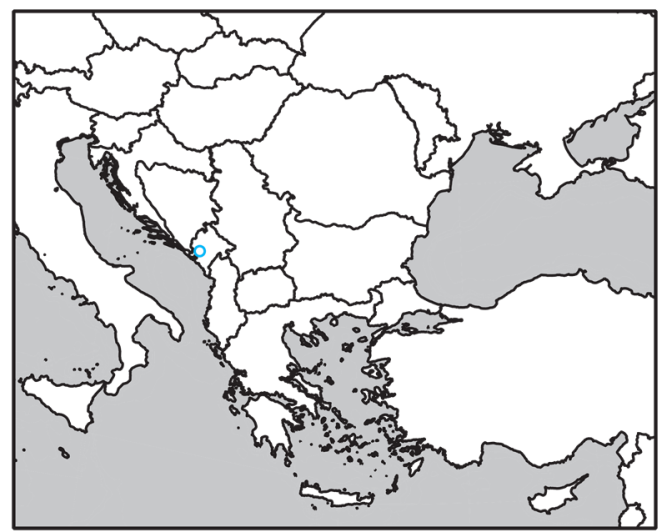

303. Leptoiulus cernagoranus (Attems, 1927) 


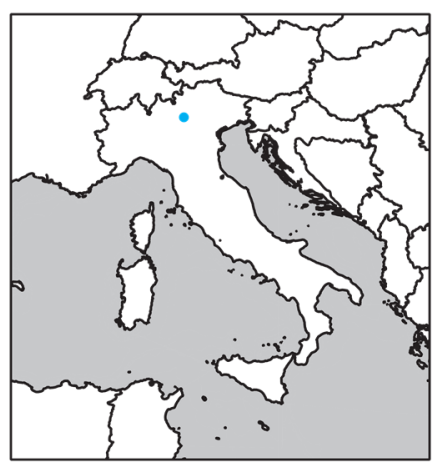

304. Leptoiulus chiesensis Verhoeff, 1934

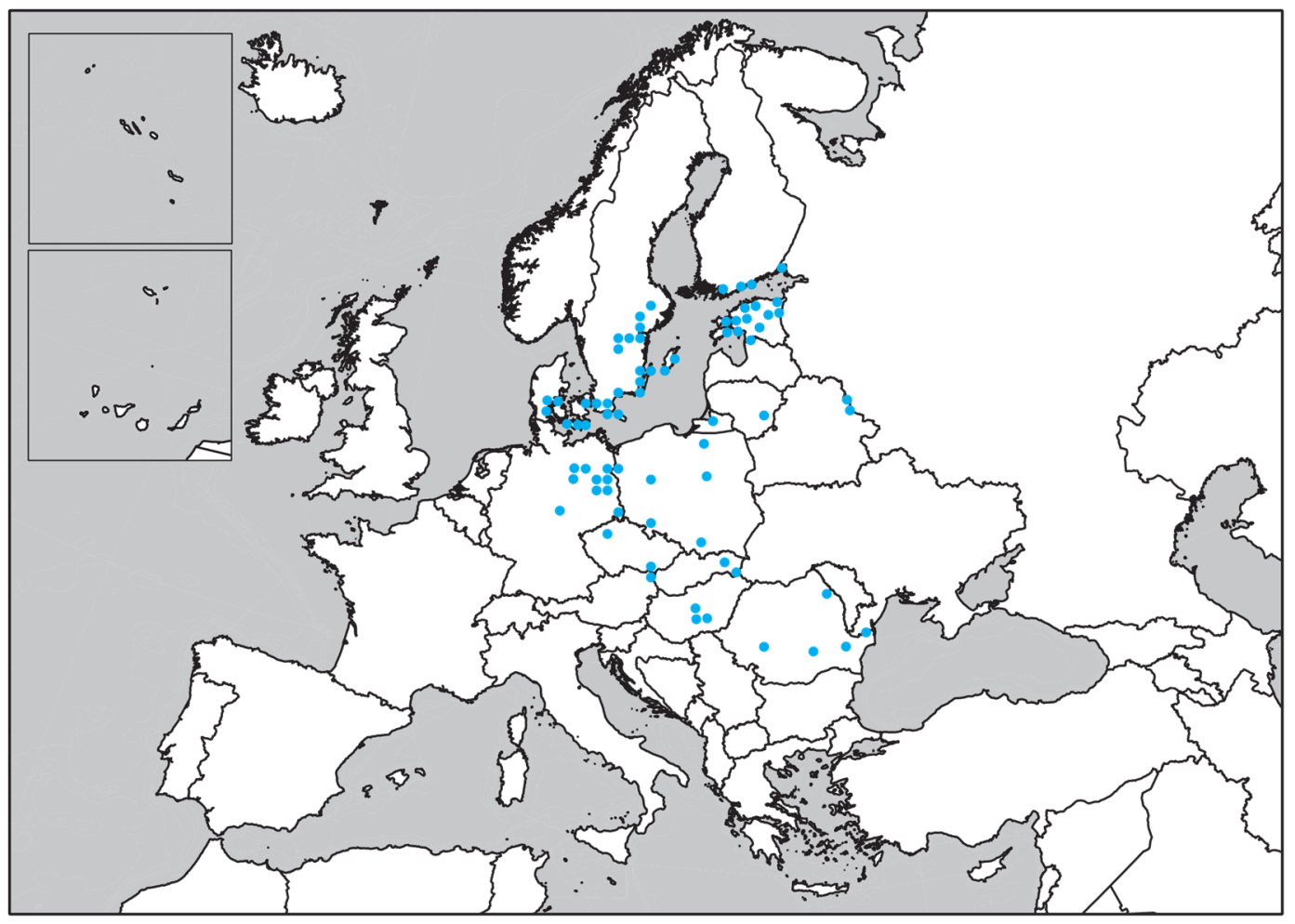

305. Leptoiulus cibdellus (Chamberlin, 1921)

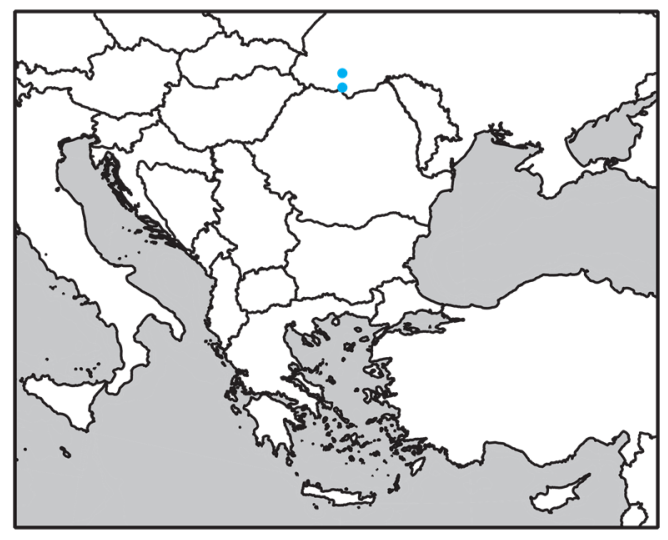

306. Leptoiulus czarnohoricus Jawlowski, 1928

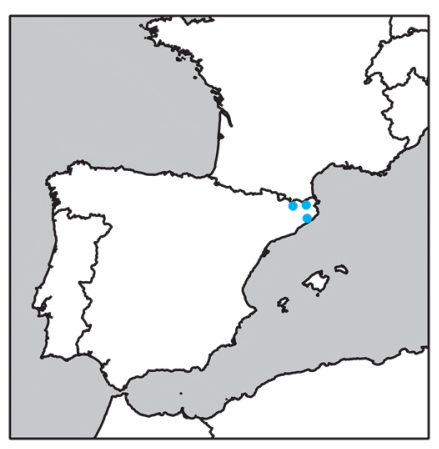

307. Leptoiulus demangei Schubart, 1962 


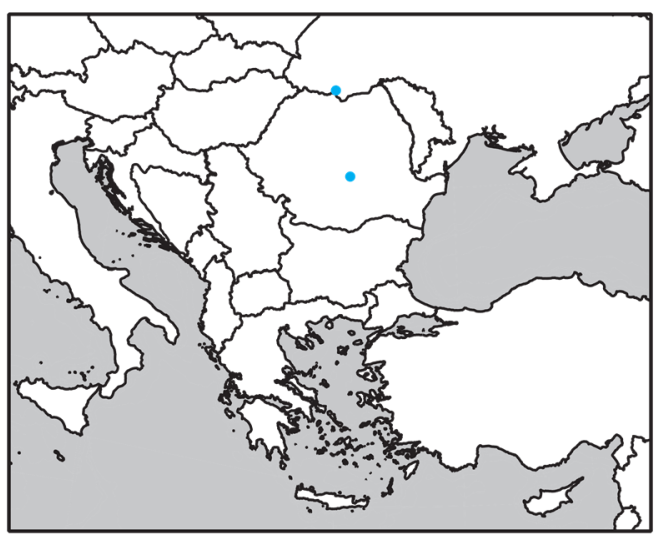

308. Leptoiulus deubeli

(Verhoeff, 1897)

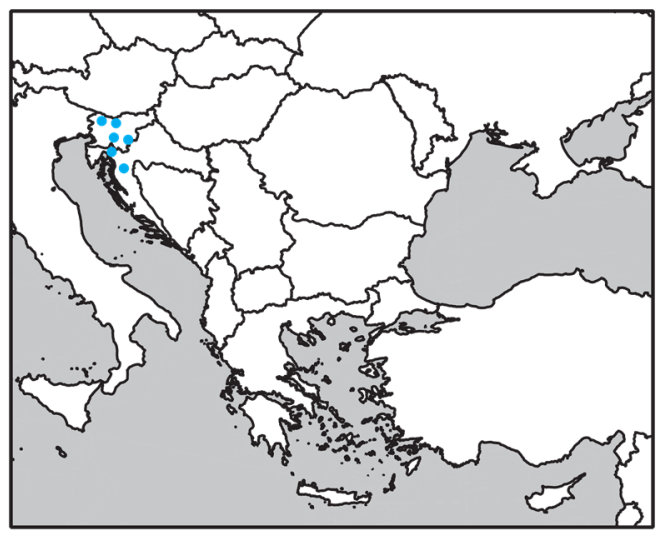

310. Leptoiulus dolinensis Verhoeff, 1928

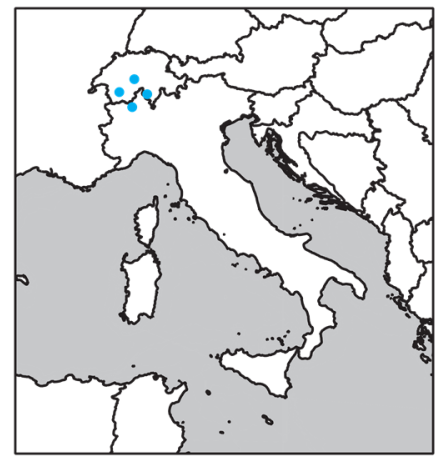

312. Leptoiulus faesi

Bigler, 1919

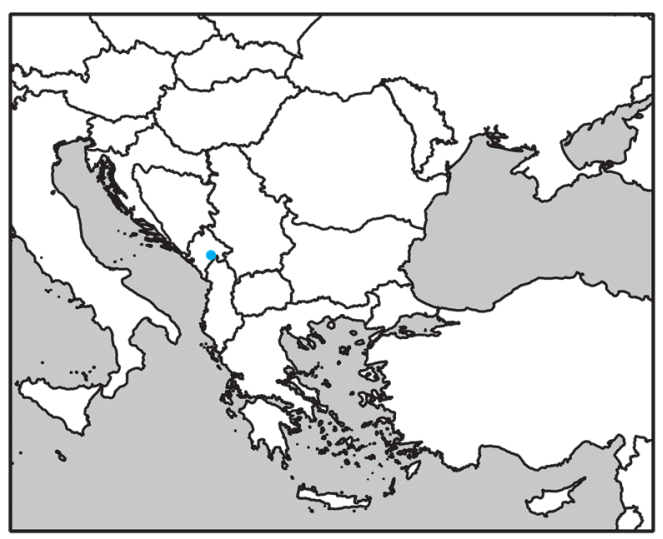

309. Leptoiulus discophorus (Attems, 1927)

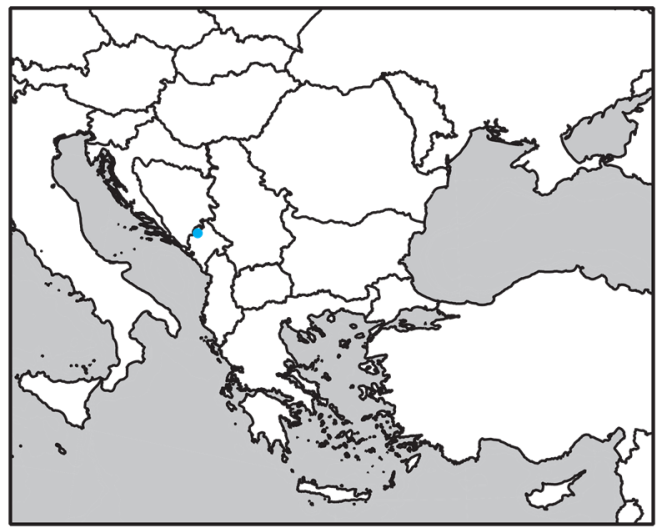

311. Leptoiulus durmitorius (Attems, 1927)

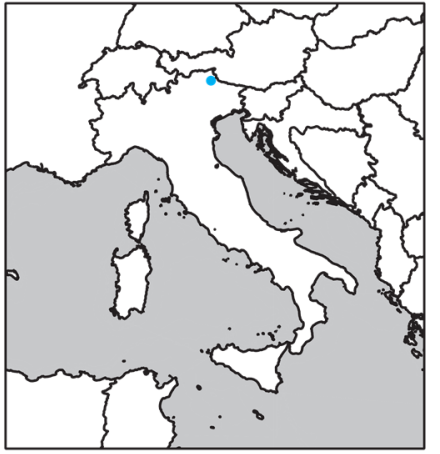

313. Leptoiulus frigidarius Verhoeff, 1913

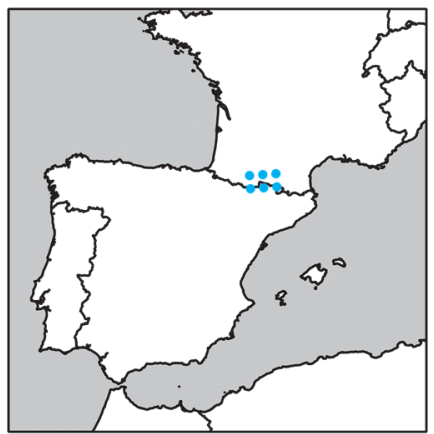

314. Leptoiulus garumnicus (Ribaut, 1904) 


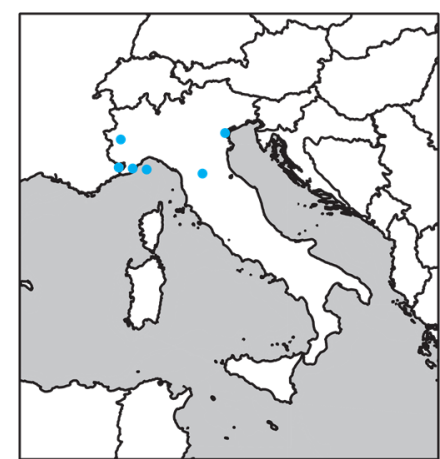

315. Leptoiulus gilvicollis Verhoeff, 1932

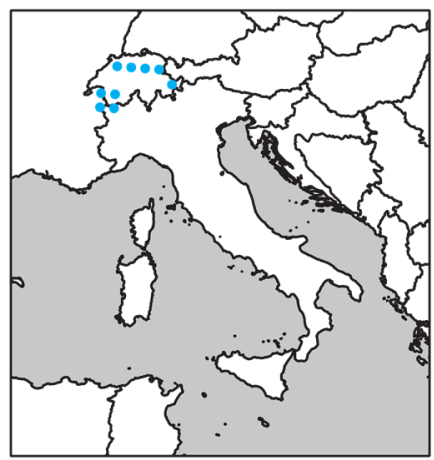

317. Leptoiulus helveticus (Verhoeff, 1894)

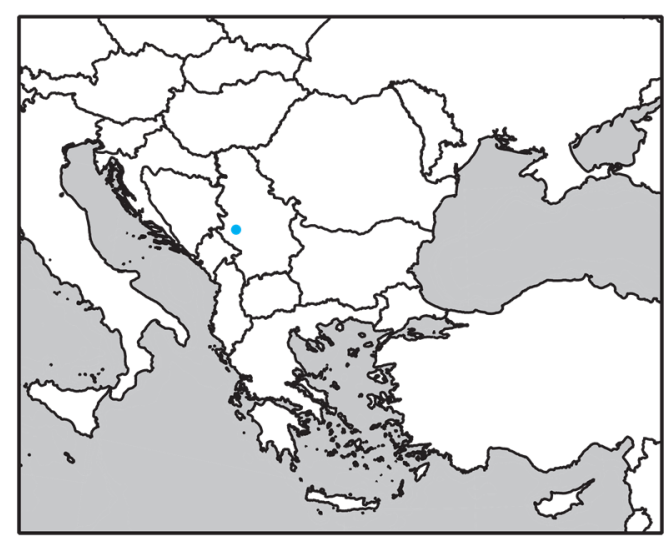

319. Leptoiulus ivanjicae Ćurčić \& Makarov, 1997

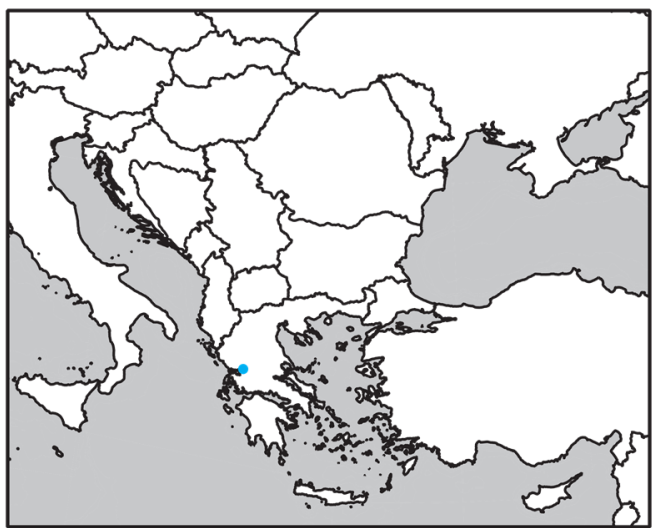

316. Leptoiulus hauseri Strasser, 1976

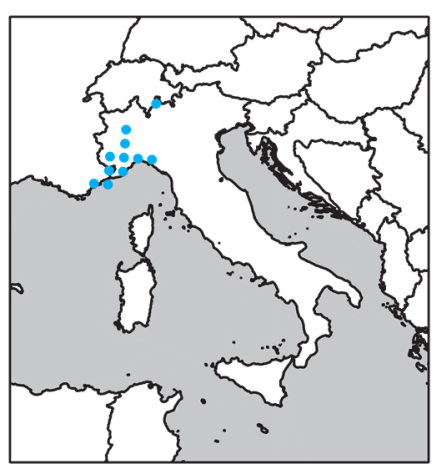

318. Leptoiulus hospitelli Brölemann, 1901

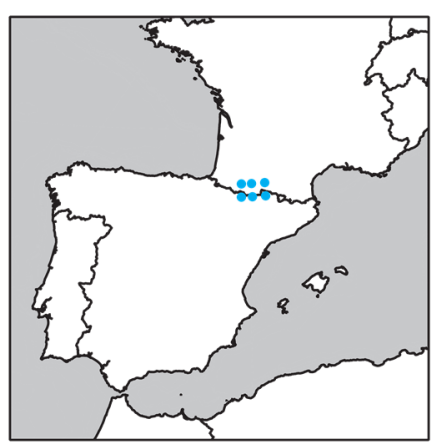

320. Leptoiulus juvenilis (Ribaut, 1908) 


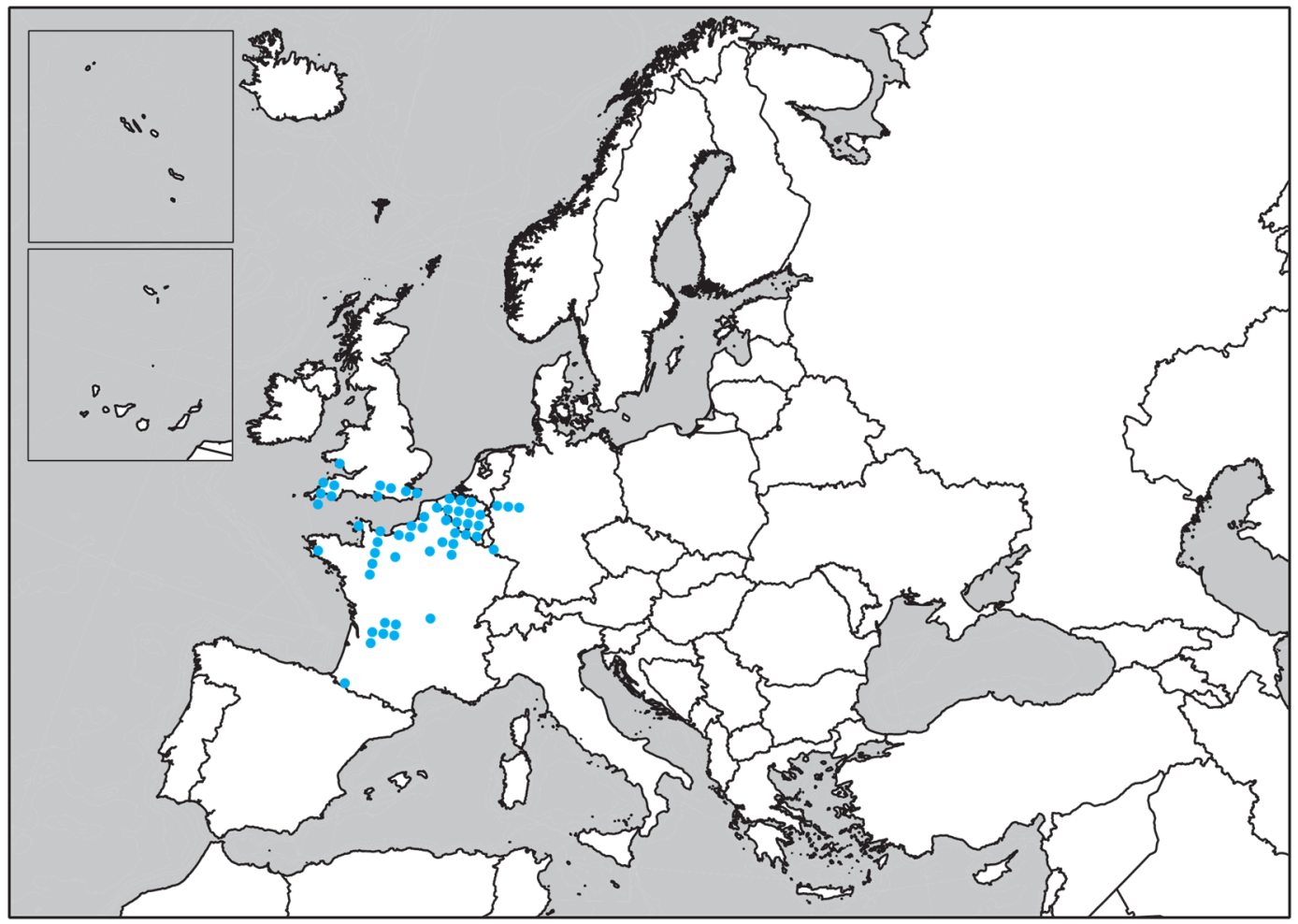

321. Leptoiulus kervillei (Brölemann, 1896)

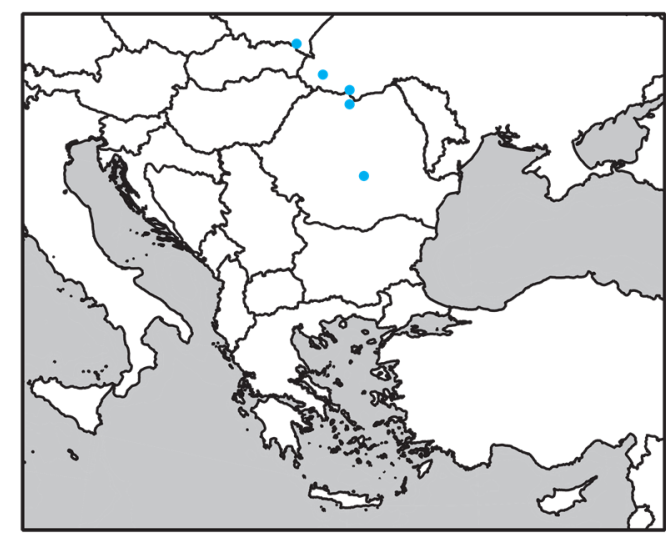

322. Leptoiulus korongsius

(Attems, 1904)

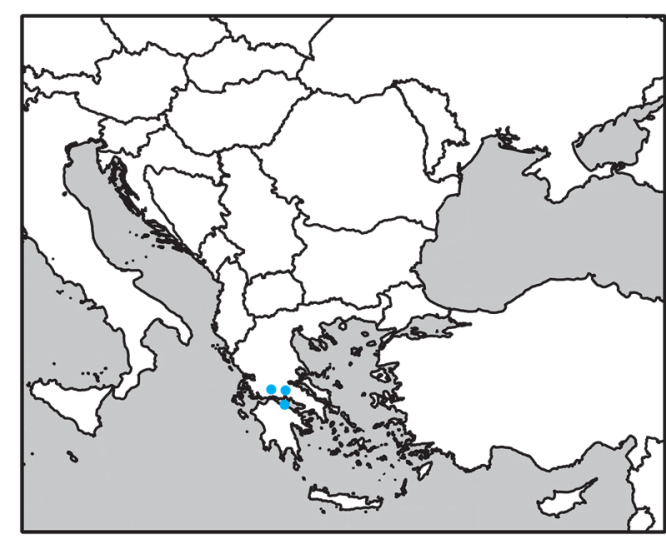

323. Leptoiulus krueperi

(Verhoeff, 1900) 


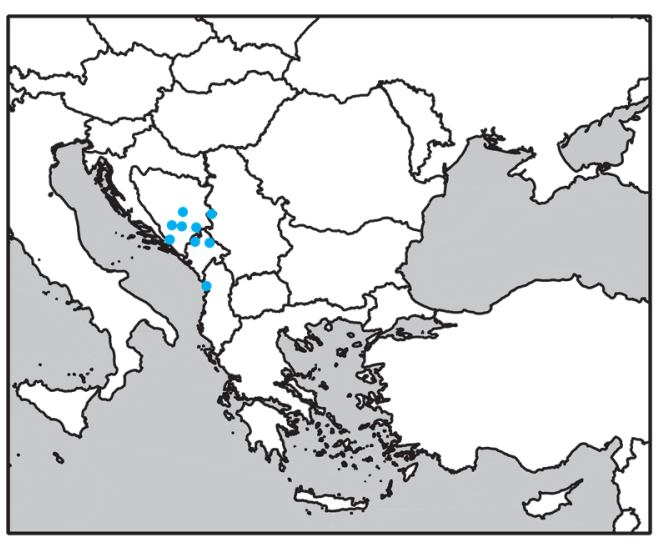

324. Leptoiulus laetedorsalis

(Verhoeff, 1898)

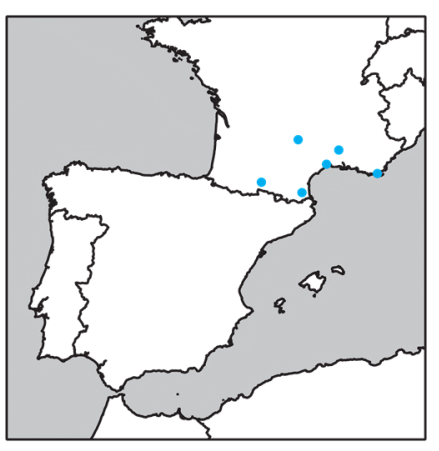

325. Leptoiulus legeri

(Brölemann, 1897)

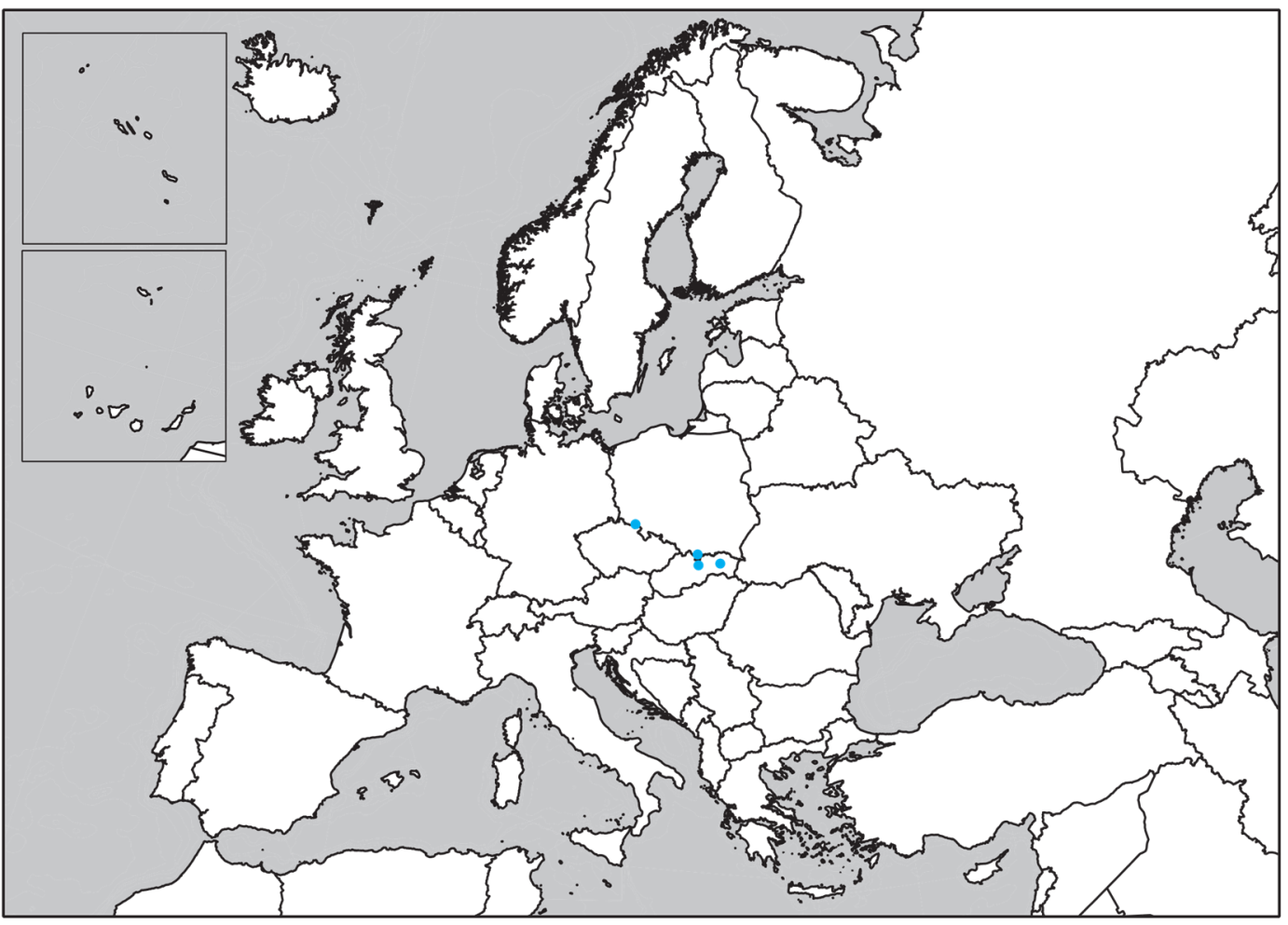

326. Leptoiulus liptauensis (Verhoeff, 1899) 


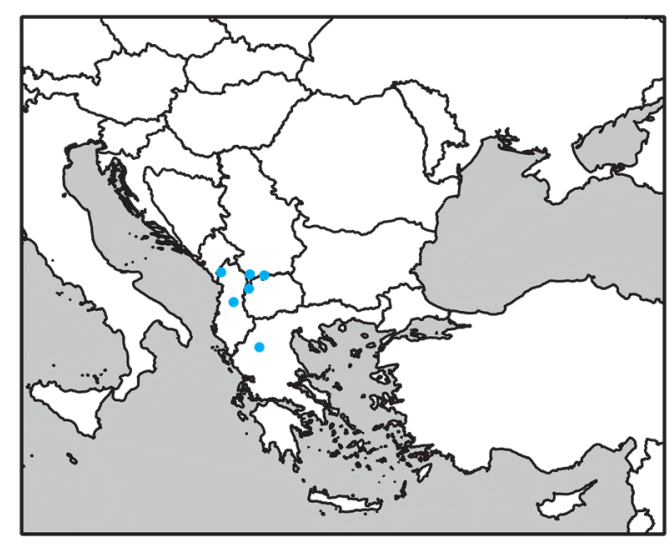

327. Leptoiulus macedonicus (Attems, 1927)

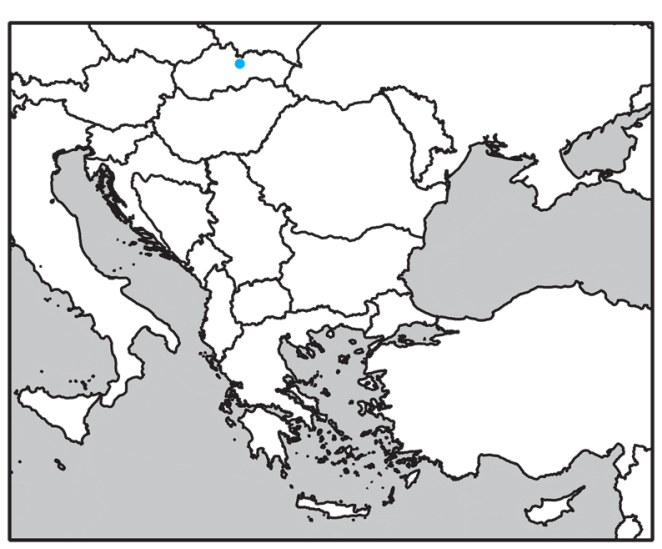

329. Leptoiulus mariae Gulička, 1952

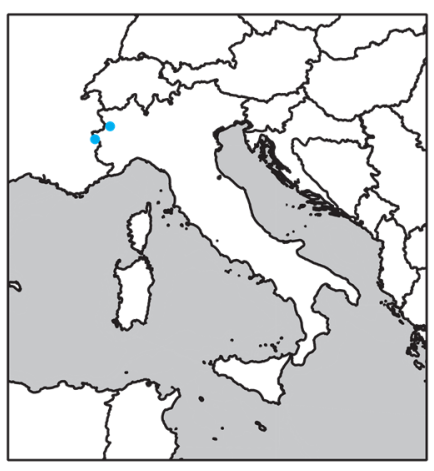

328. Leptoiulus magnus

Bigler, 1919

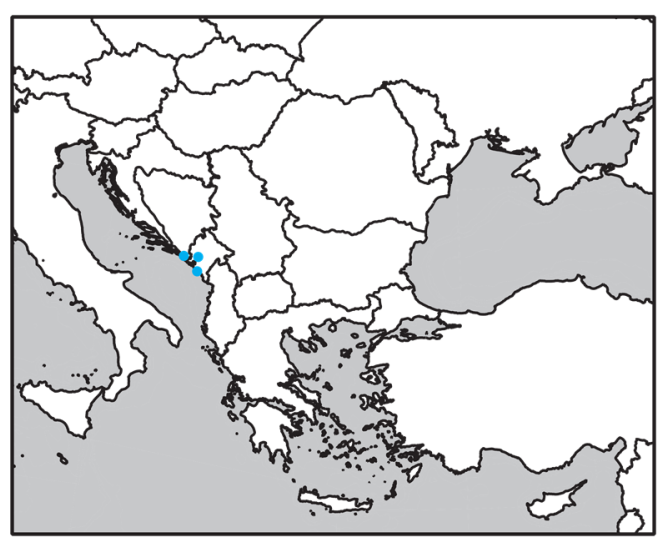

330. Leptoiulus matulicii

(Verhoeff, 1901)

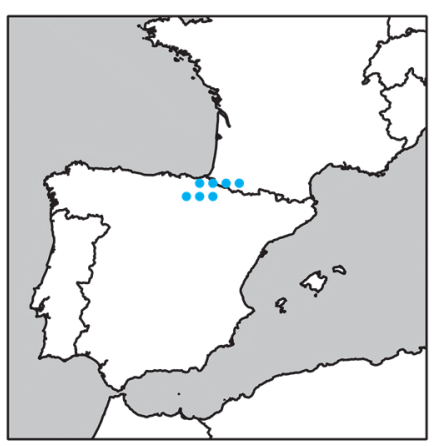

331. Leptoiulus meridionalis

(Brölemann, 1897) 


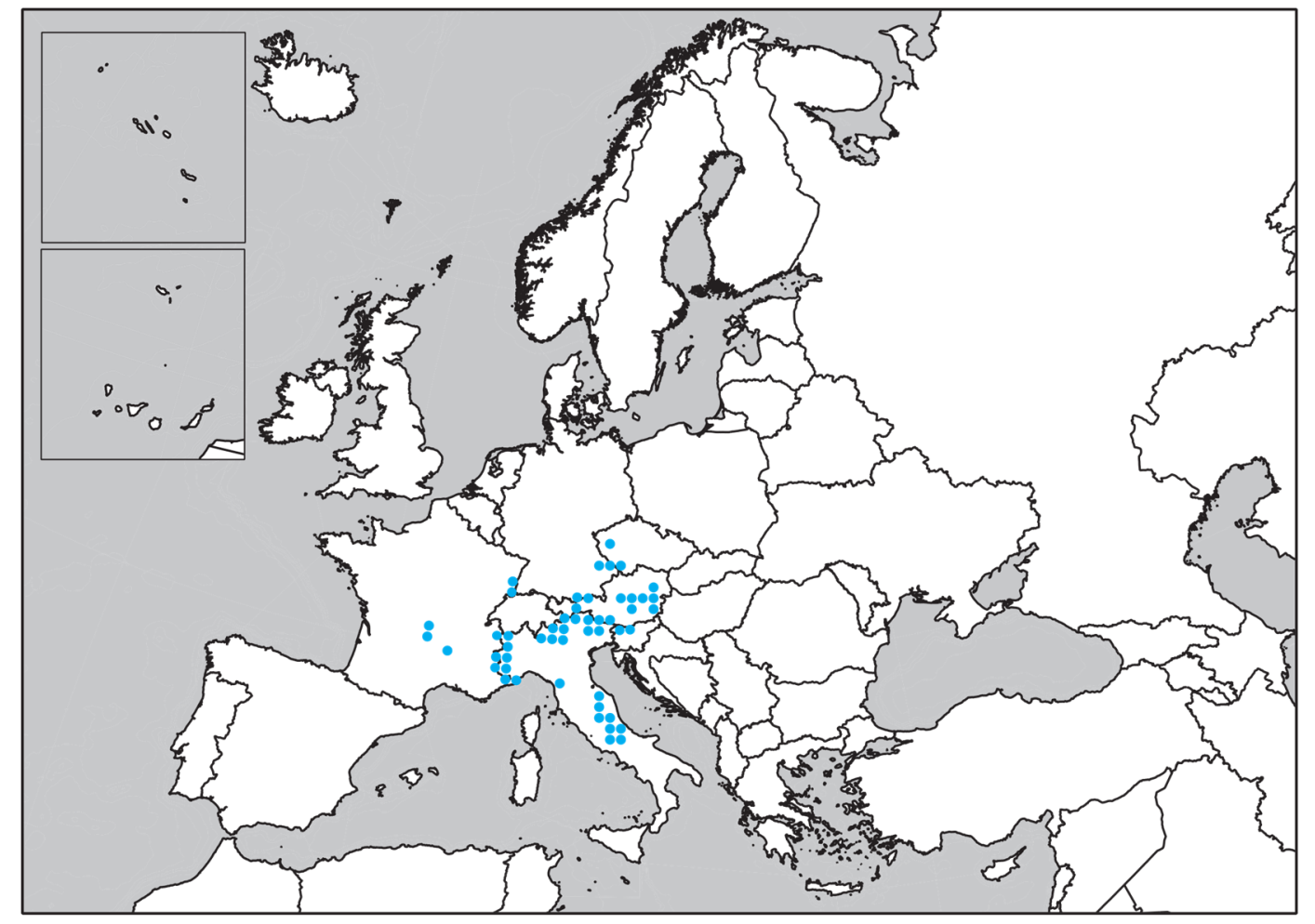

332. Leptoiulus montivagus (Latzel, 1884)

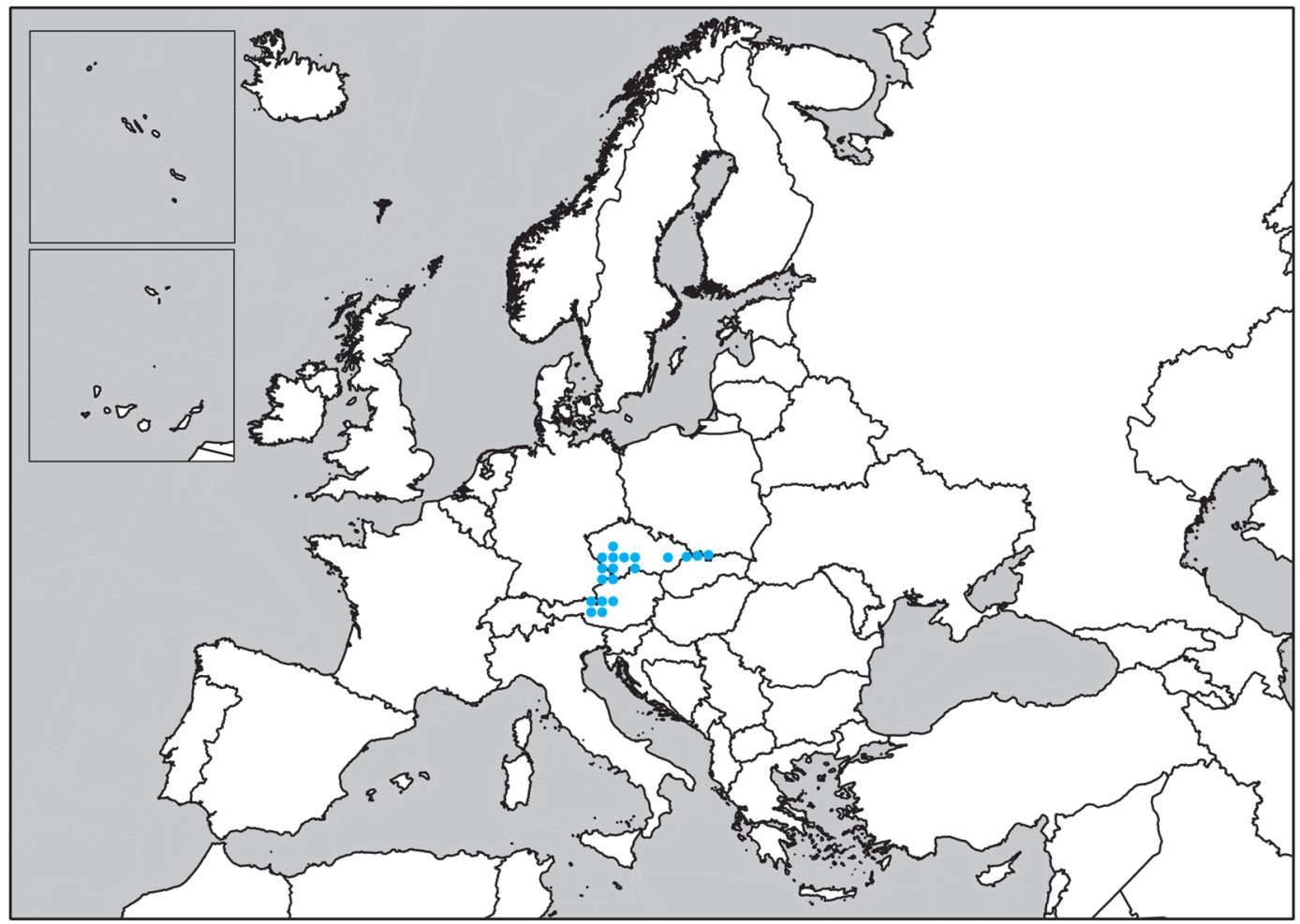

333. Leptoiulus noricus Verhoeff, 1913 


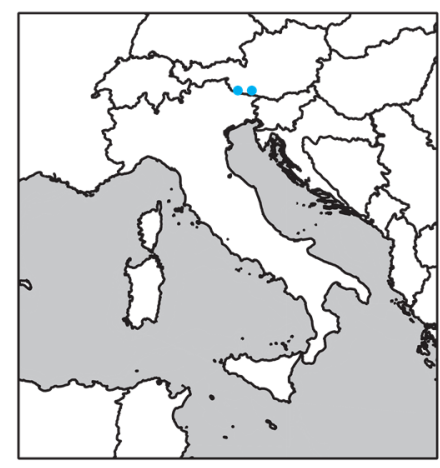

334. Leptoiulus oribates (Latzel, 1884)

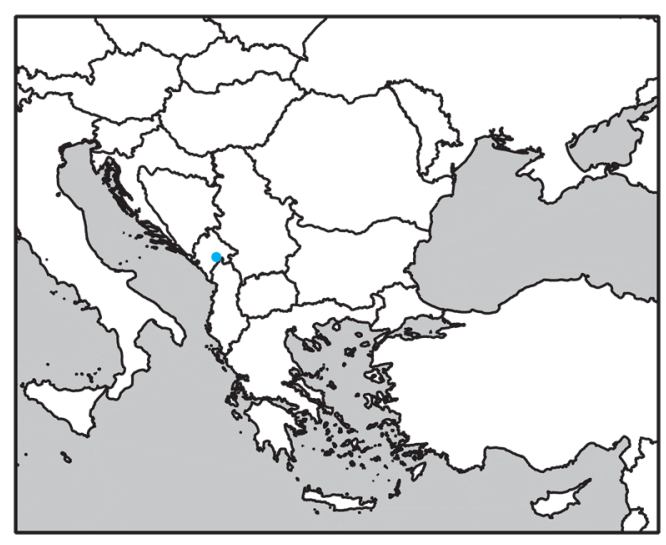

335. Leptoiulus pentheri (Attems, 1927)

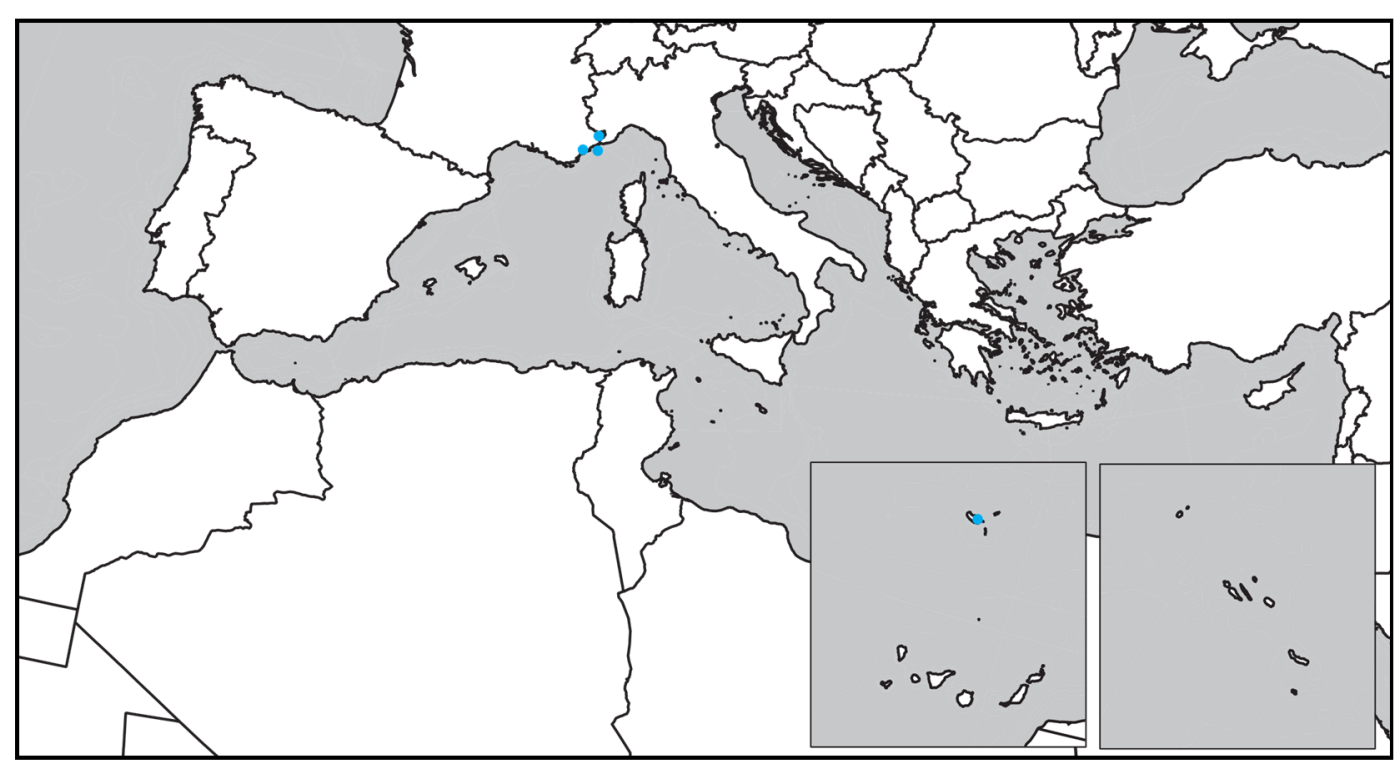

336. Leptoiulus piceus (Risso, 1826)

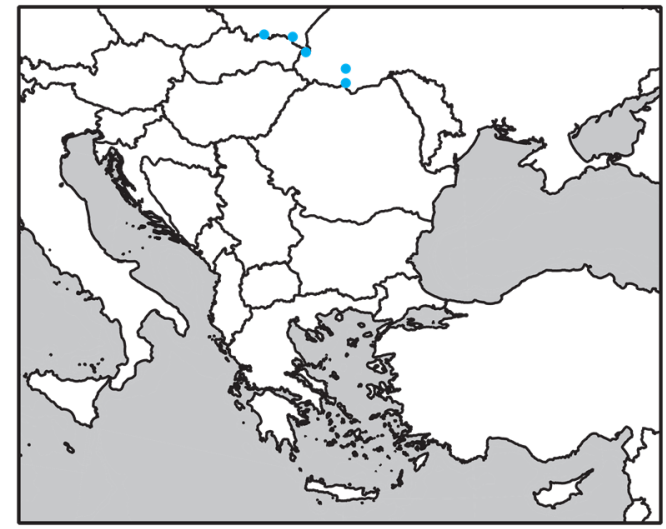

337. Leptoiulus polonicus Jawlowski, 1930

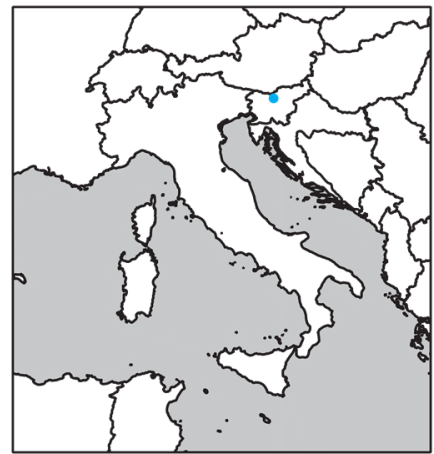

338. Leptoiulus pretneri Strasser, 1940 


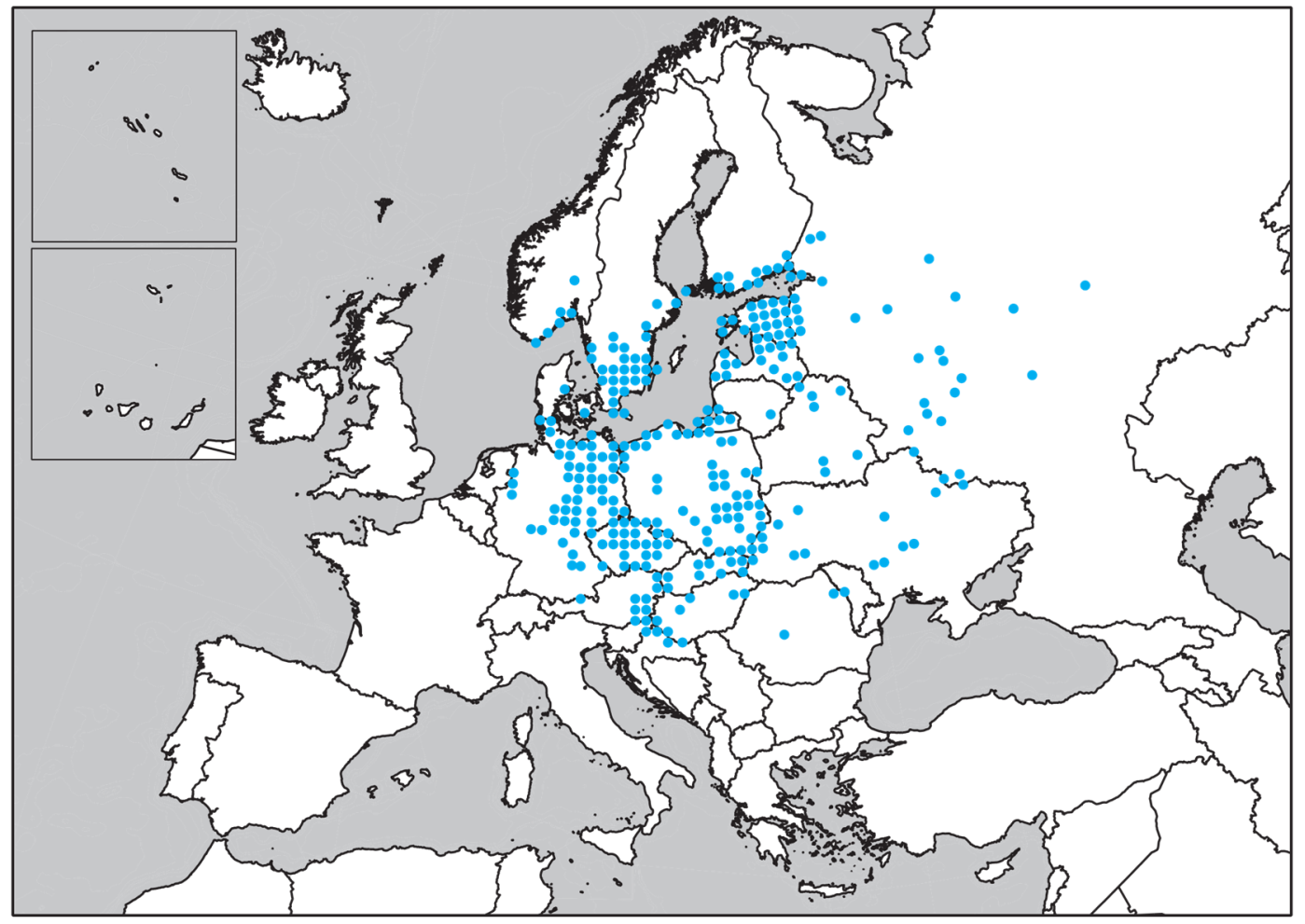

339. Leptoiulus proximus (Nĕmec, 1896)

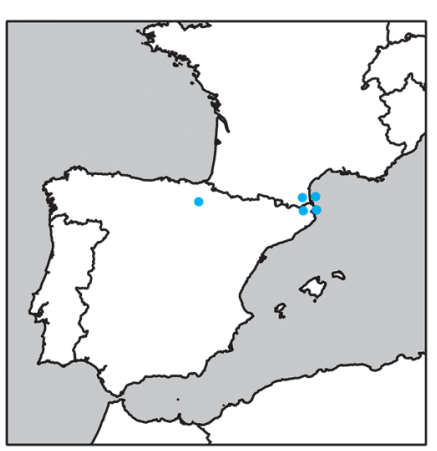

340. Leptoiulus remyi

Schubart, 1962

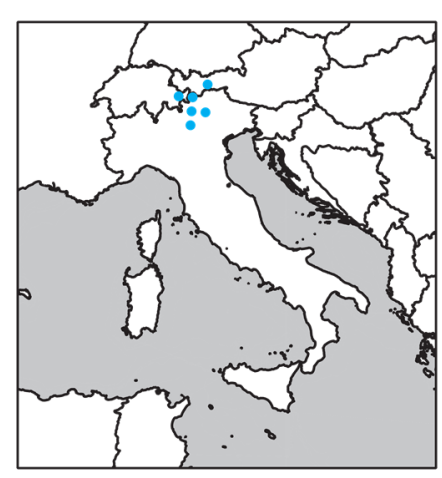

341. Leptoiulus riparius

(Verhoeff, 1894)

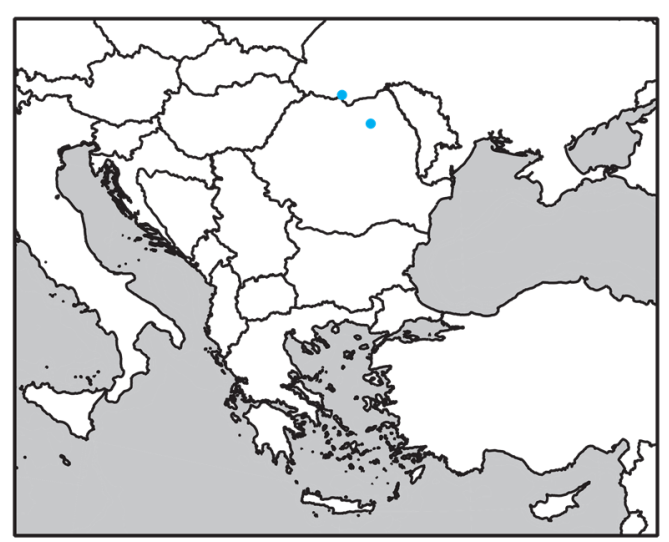

342. Leptoiulus roszkowskii Jawlowski, 1930 


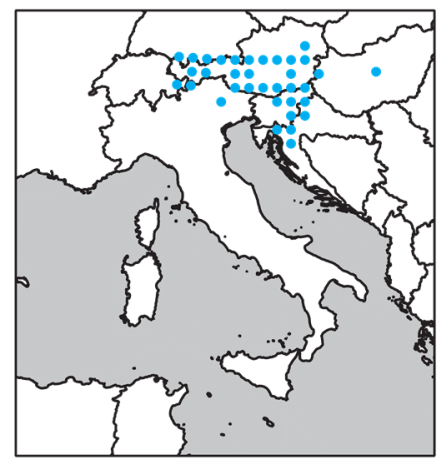

343. Leptoiulus saltuvagus (Verhoeff, 1898)

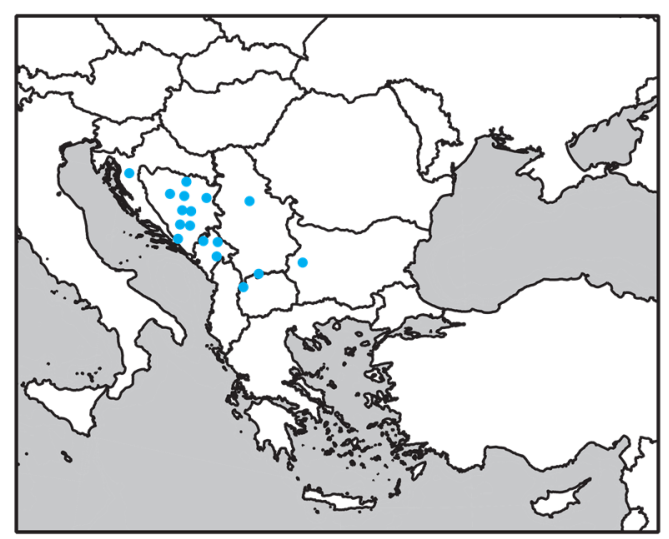

344. Leptoiulus sarajevensis (Verhoeff, 1898)

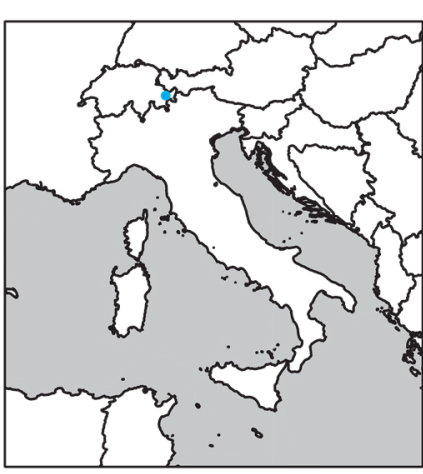

345. Leptoiulus sarasini Bigler, 1929

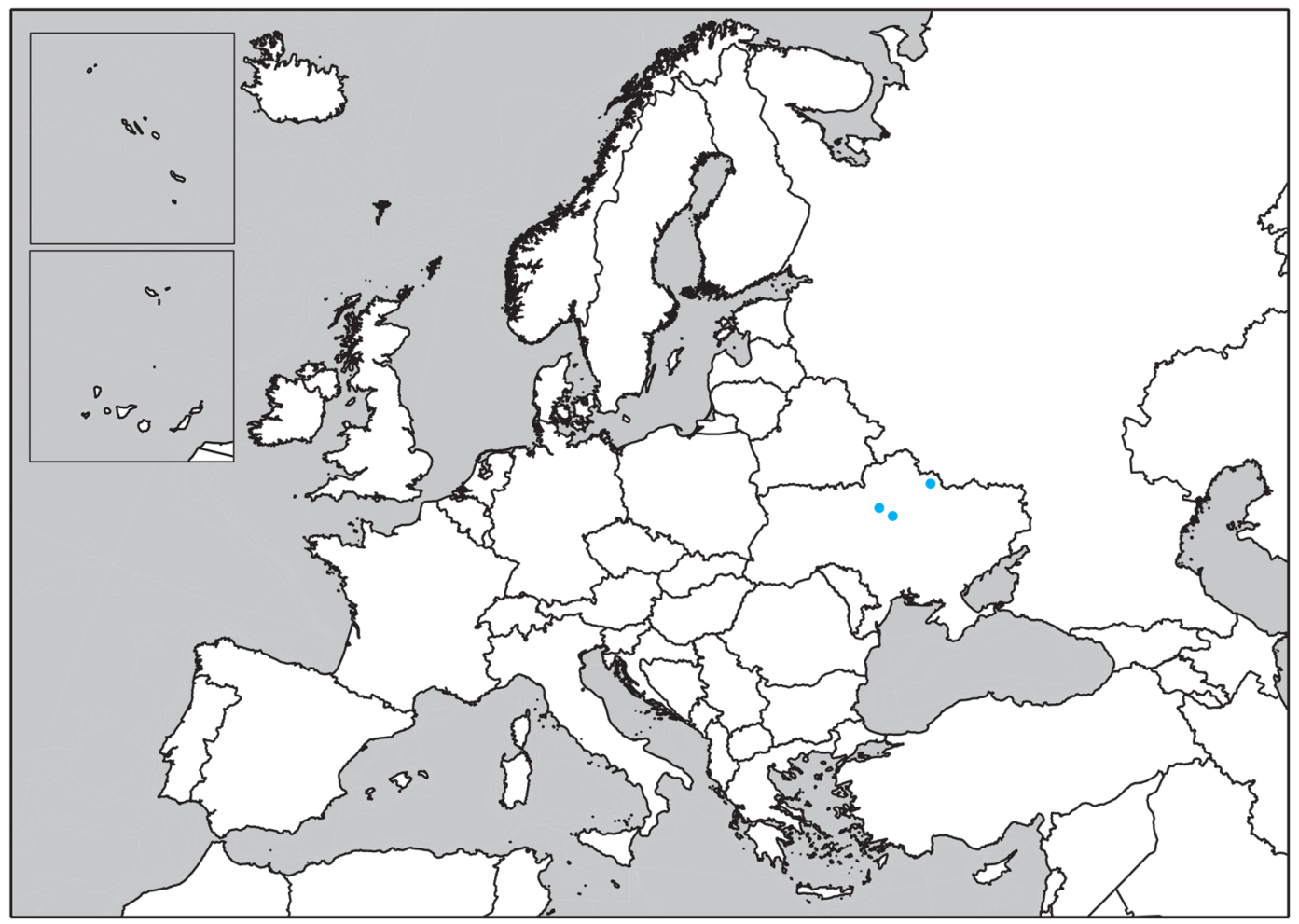

346. Leptoiulus semenkevitshi Lohmander, 1928 


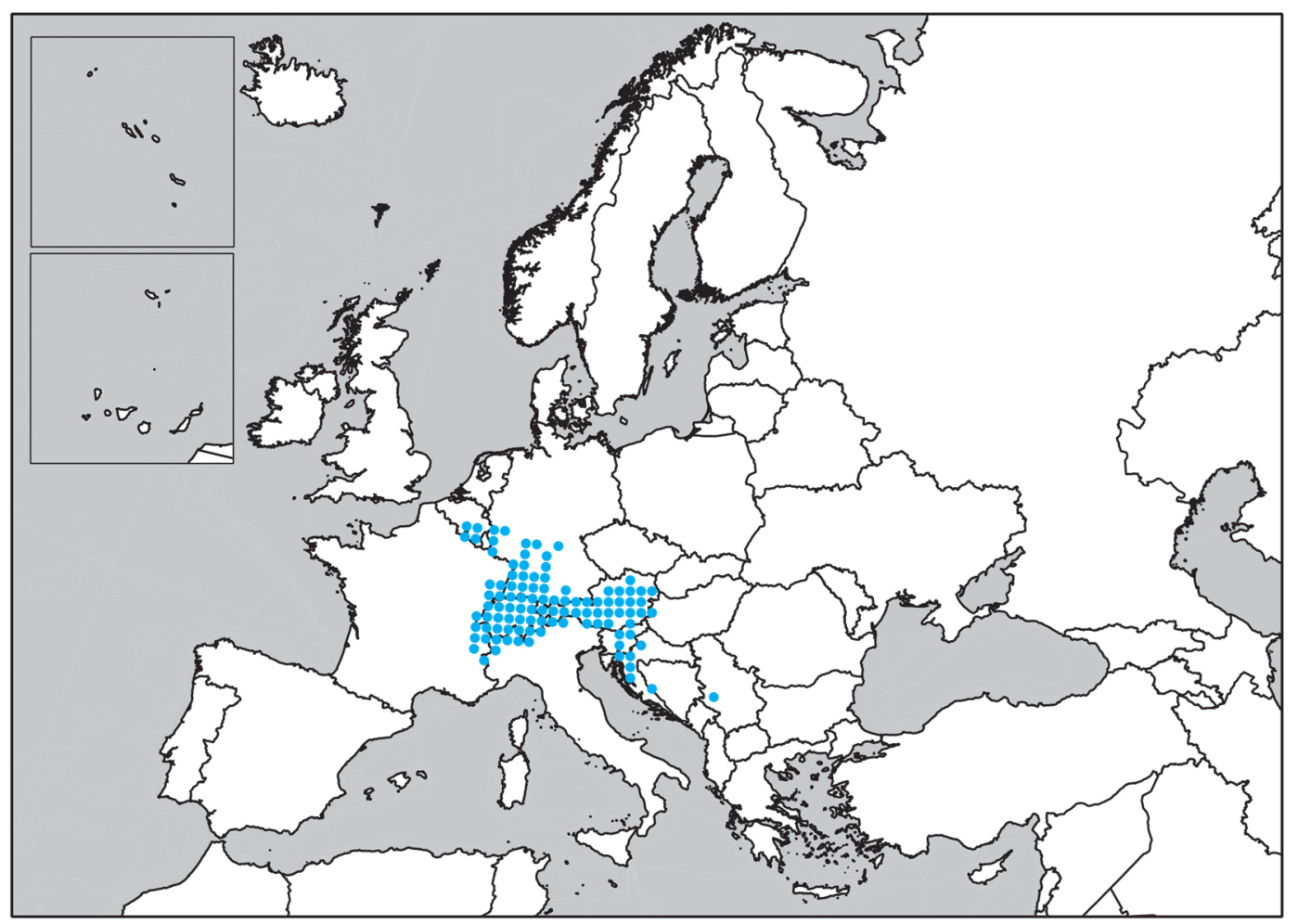

347. Leptoiulus simplex (Verhoeff, 1894)

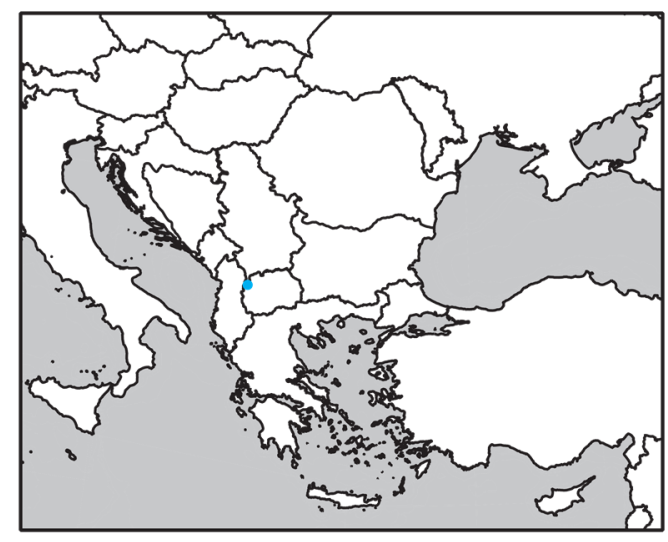

348. Leptoiulus storkani

Verhoeff, 1932

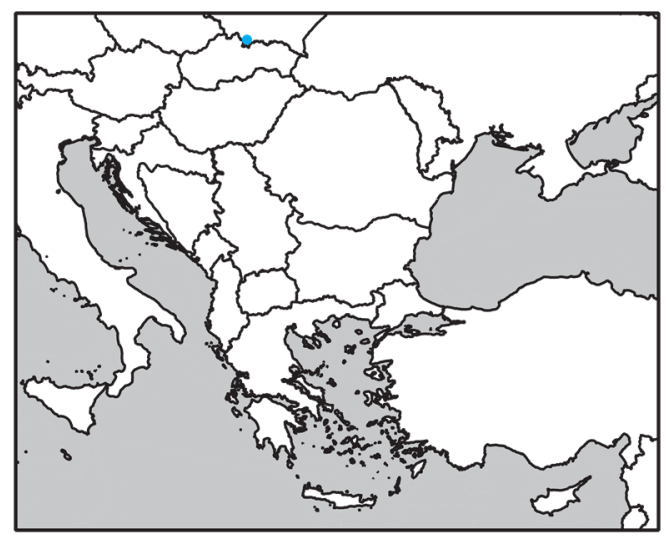

349. Leptoiulus tatricus

Gulička, 1956 


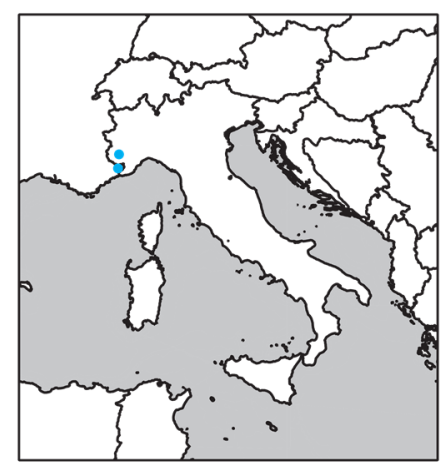

350. Leptoiulus tendanus Verhoeff, 1930

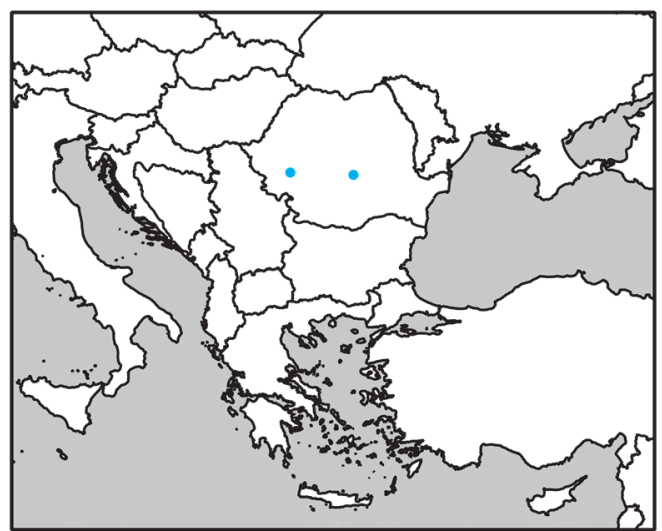

351. Leptoiulus transsylvanicus (Daday, 1889)

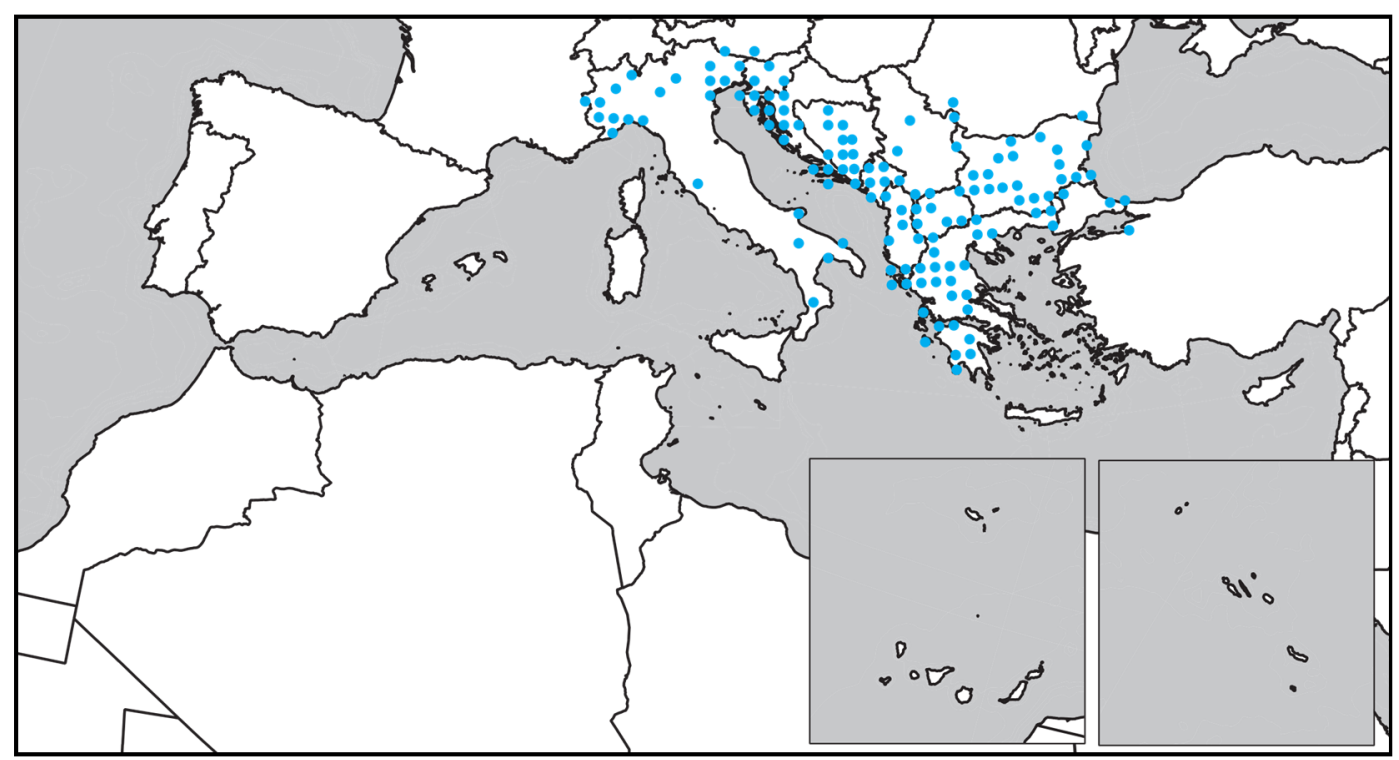

352. Leptoiulus trilineatus (C.L. Koch, 1847) 


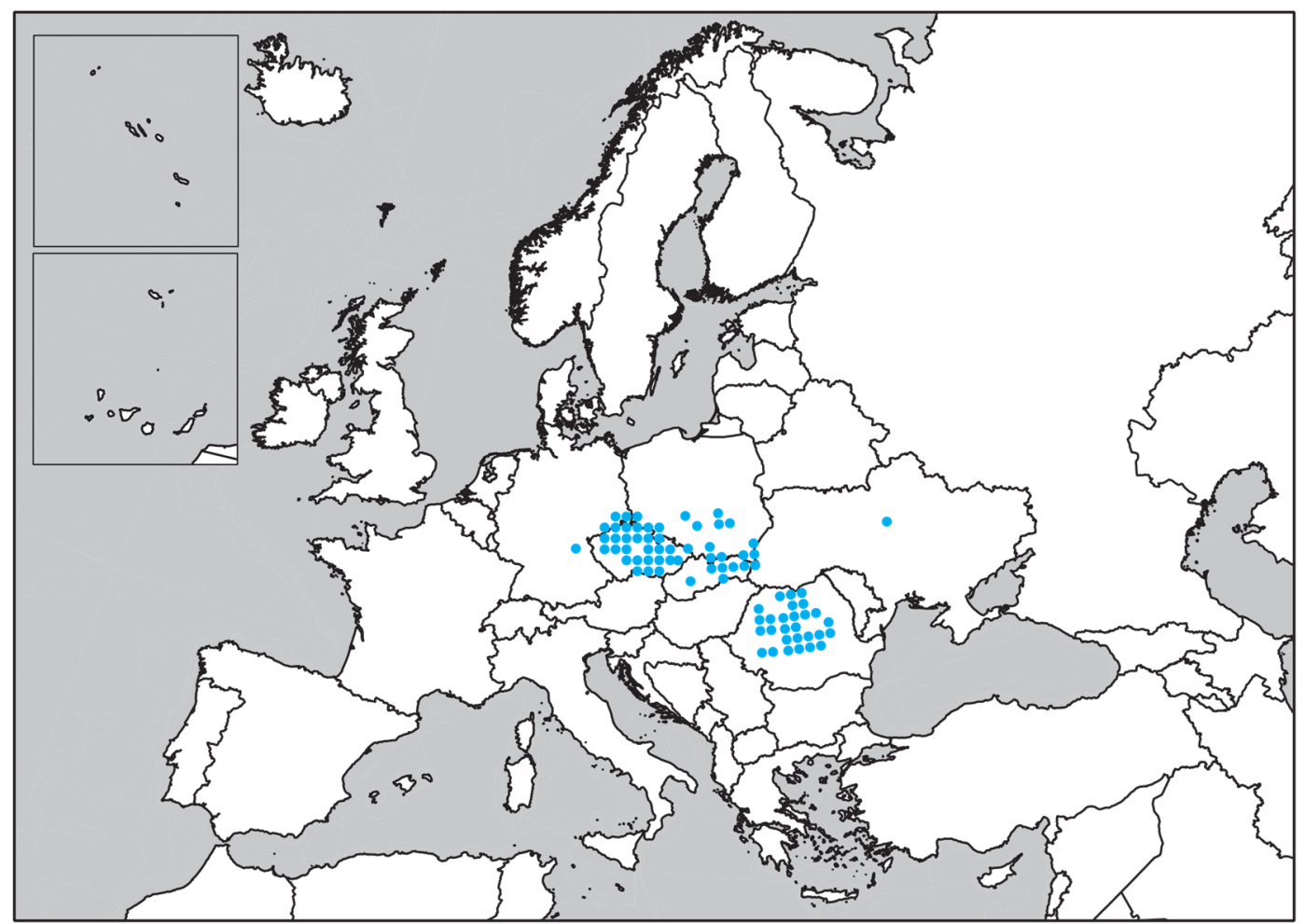

353. Leptoiulus trilobatus (Verhoeff, 1894)

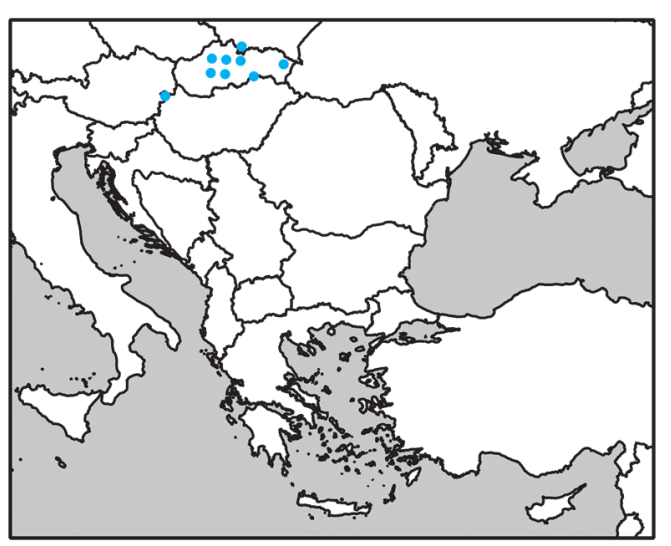

354. Leptoiulus tussilaginis (Verhoeff, 1907)

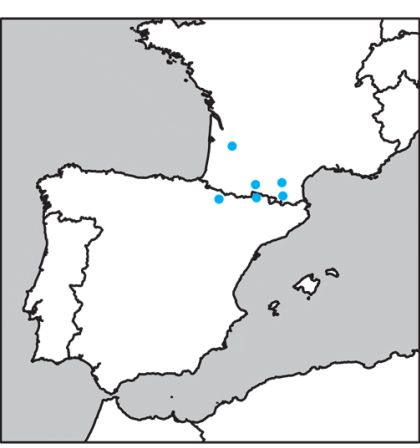

355 Leptoiulus umbratilis (Ribaut, 1905)

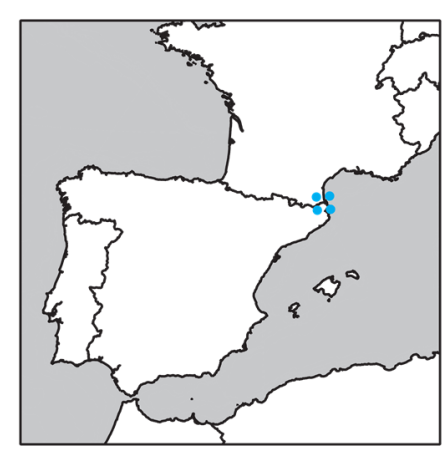

356. Leptoiulus uncinatus Ribaut, 1951 


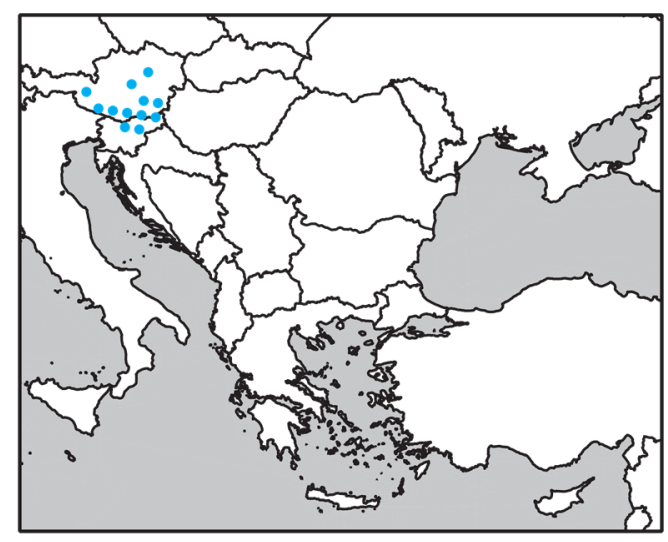

357. Leptoiulus vagabundus (Latzel, 1884)

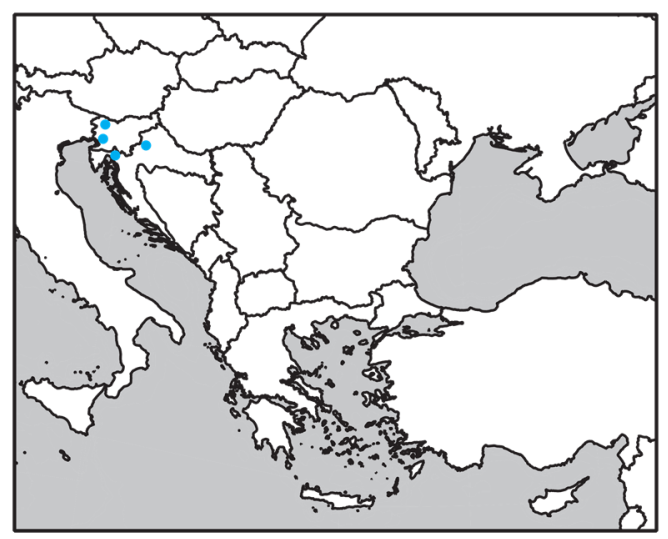

359. Leptoiulus zagrebensis

Verhoeff, 1929

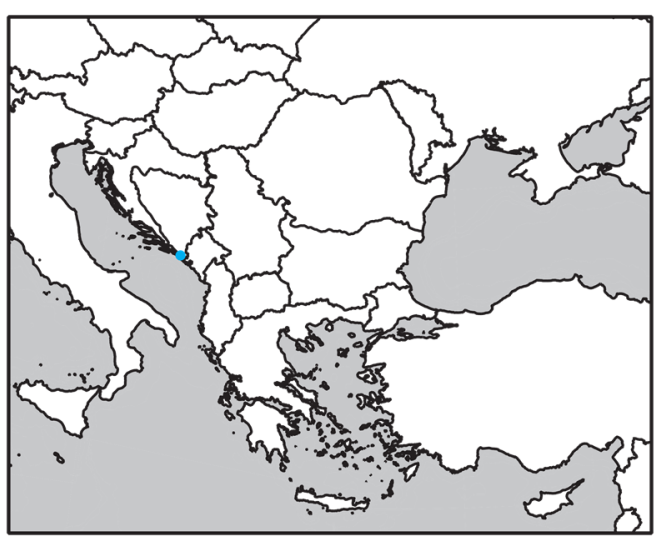

361. Leptotyphloiulus dolinensis

(Verhoeff, 1901)

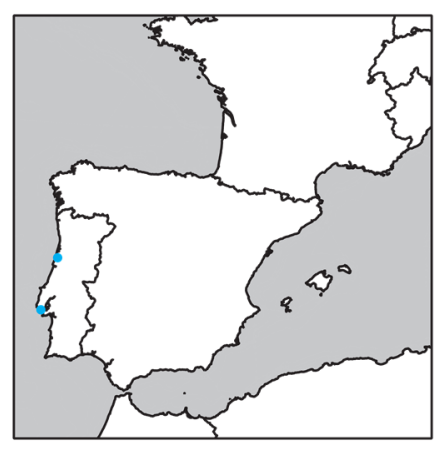

358. Leptoiulus vieirae

(Verhoeff, 1900)

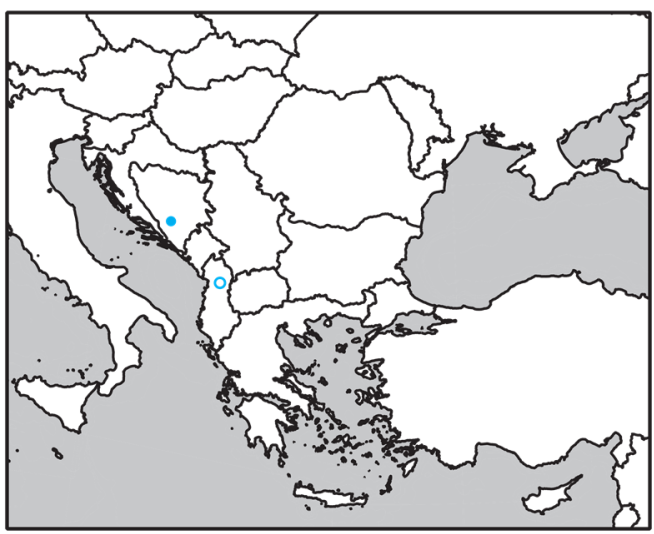

360. Leptotyphloiulus coeruleoalbus (Verhoeff, 1899)

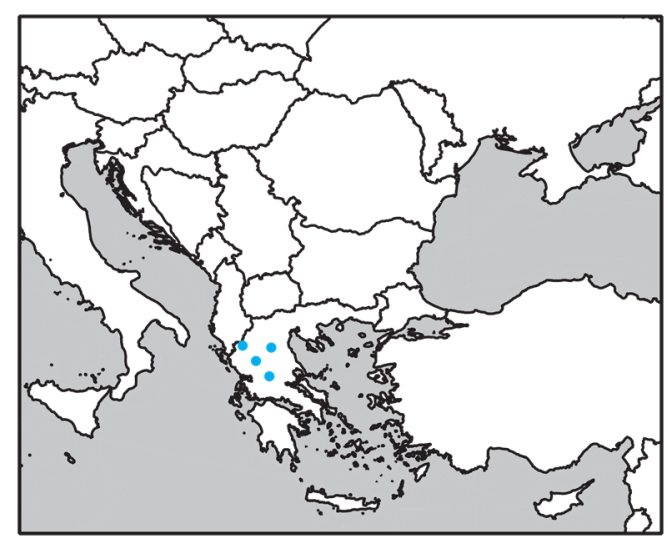

362. Macheiroiulus compressicauda Verhoeff, 1901 


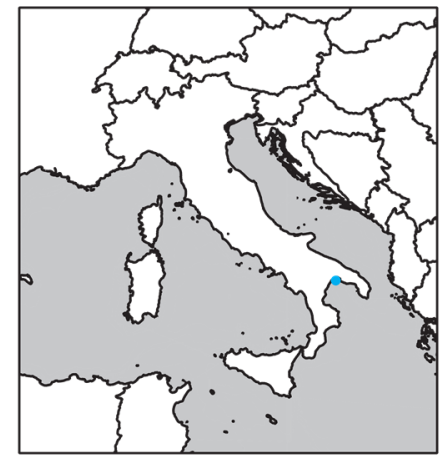

363. Mammamia profuga

Akkari, Stoev \& Enghoff, 2011

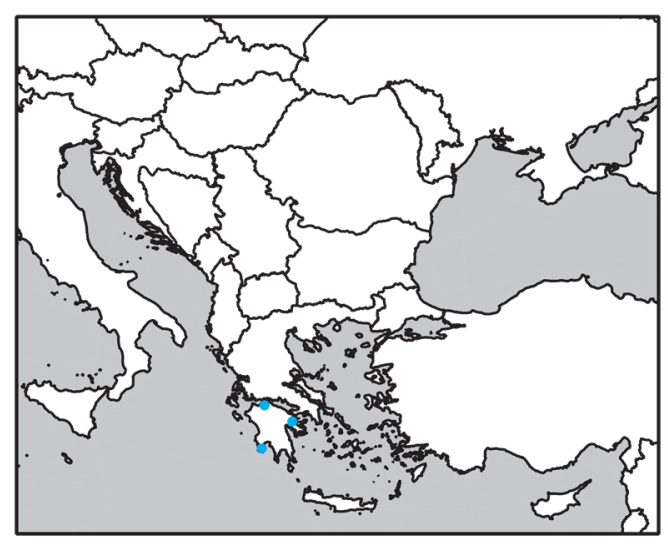

365. Megaphyllum argolicum

(Verhoeff, 1900)

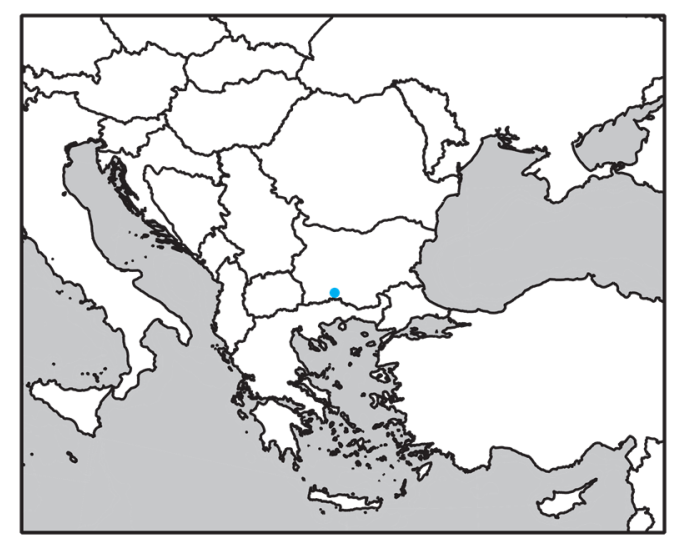

367. Megaphyllum beroni

(Strasser, 1973)

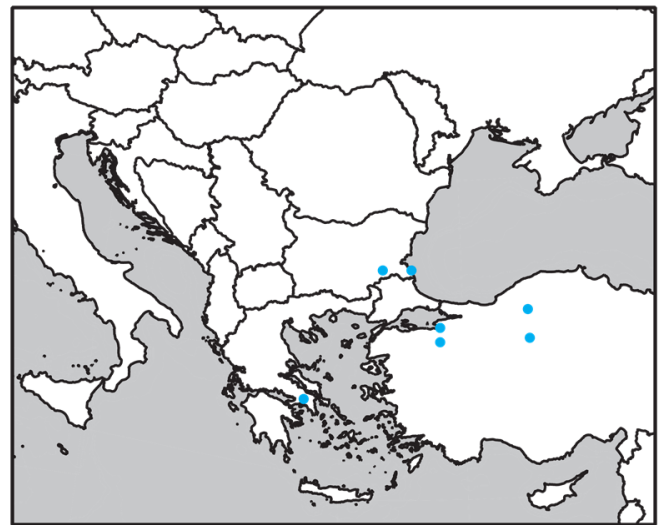

364. Megaphyllum anatolicum (Attems, 1926)

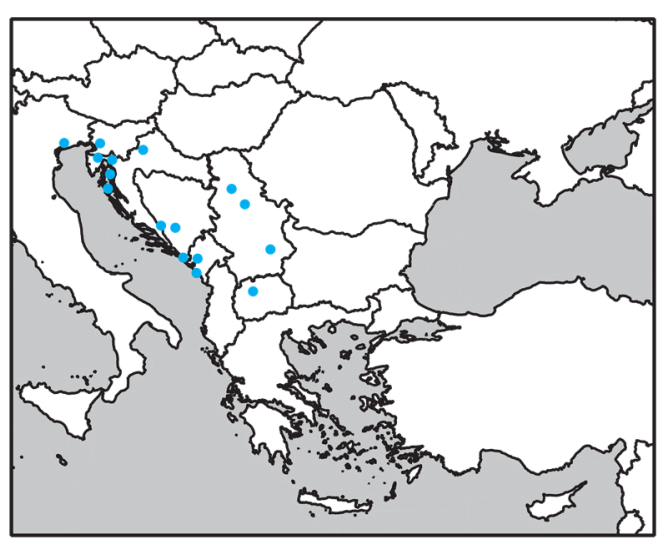

366. Megaphyllum austriacum

(Latzel, 1884)

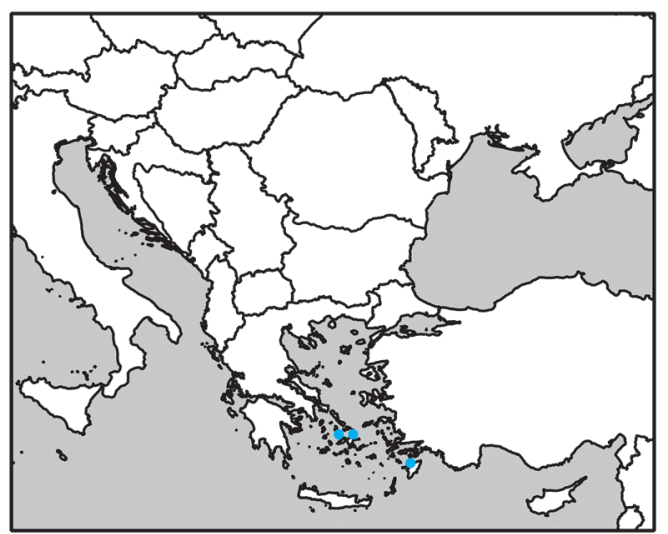

368. Megaphyllum bicolor (Loksa, 1970) 


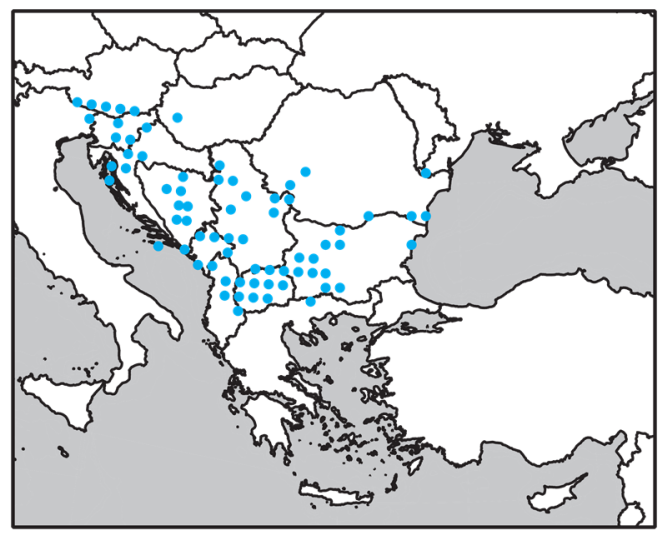

369. Megaphyllum bosniense

(Verhoeff, 1897)

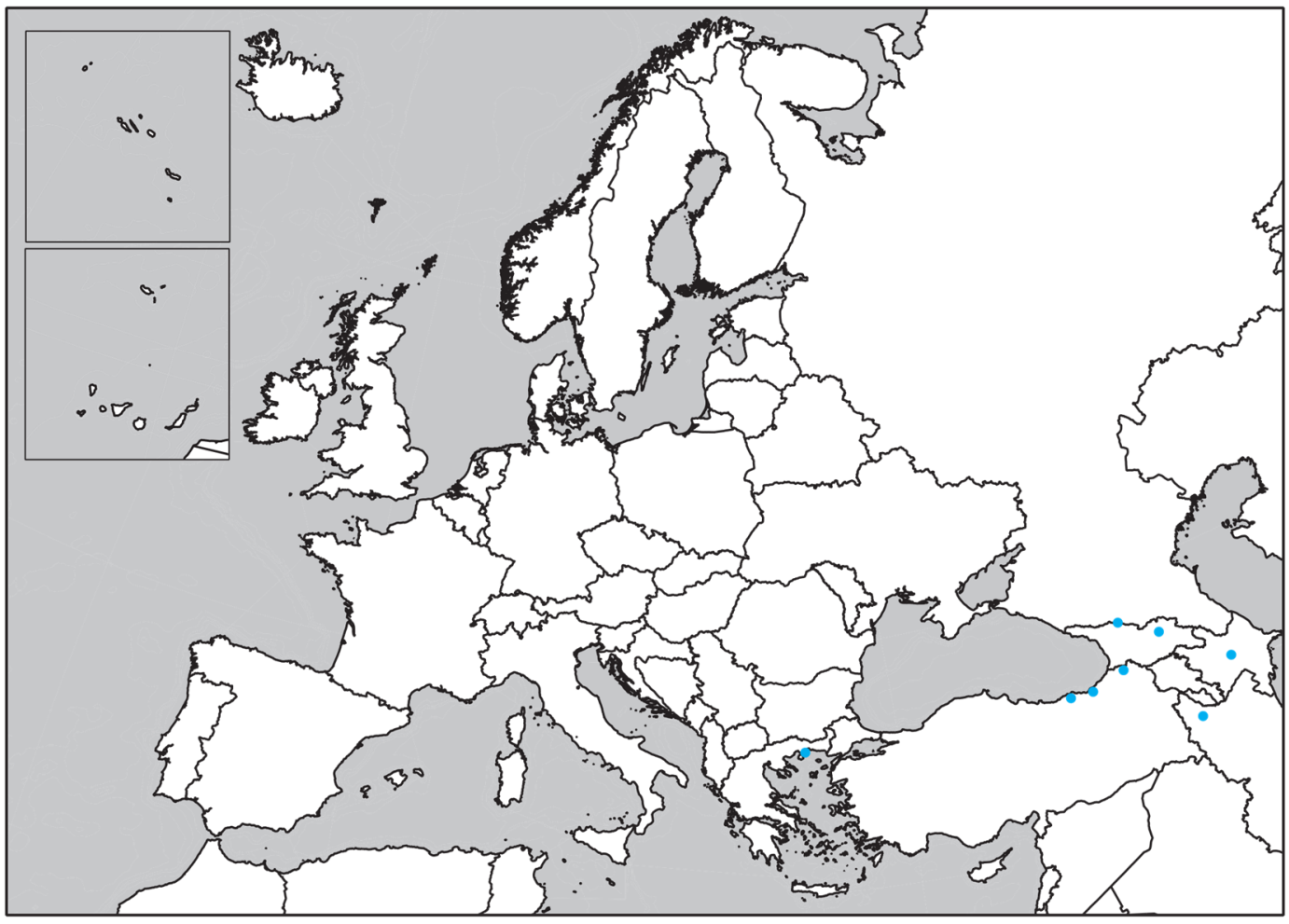

370. Megaphyllum brachyurum (Attems, 1899)

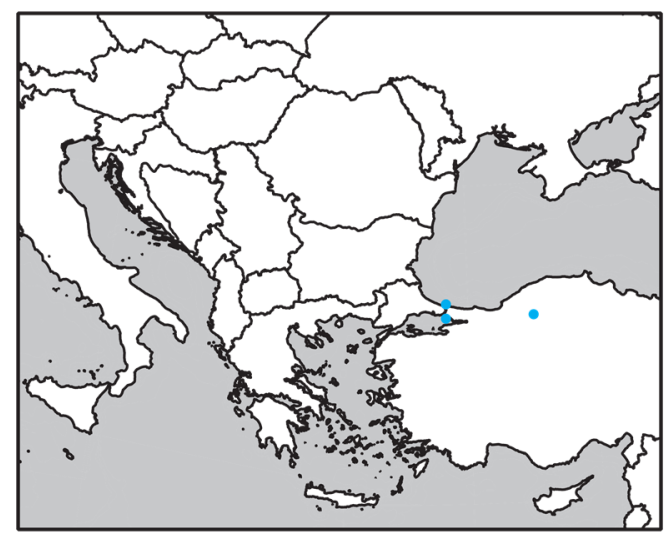

371. Megaphyllum byzantinum

(Verhoeff, 1901) 


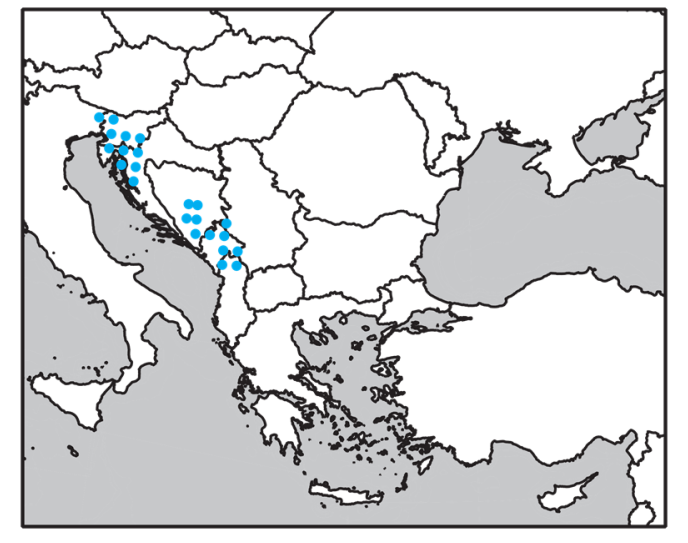

372. Megaphyllum carniolense (Verhoeff, 1897)

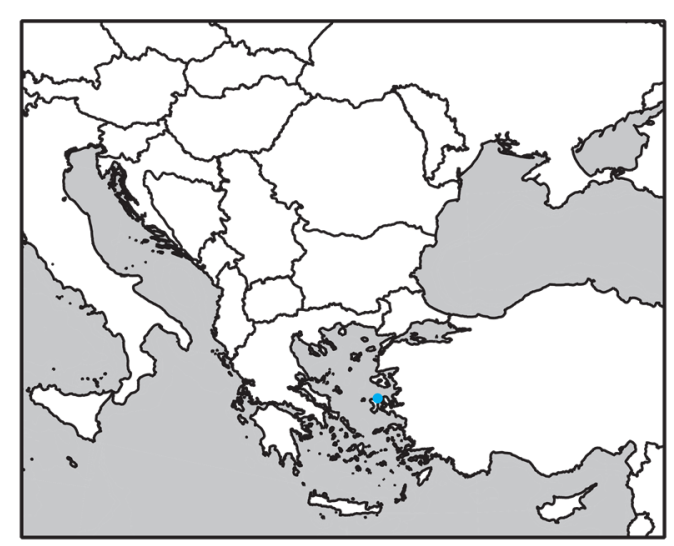

374. Megaphyllum chiosense

Lazányi \& Korsós, 2012

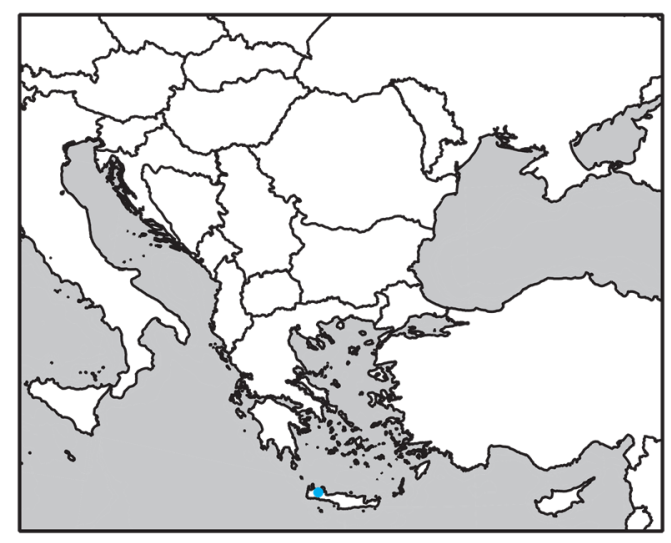

376. Megaphyllum creticum

(Strasser, 1976)

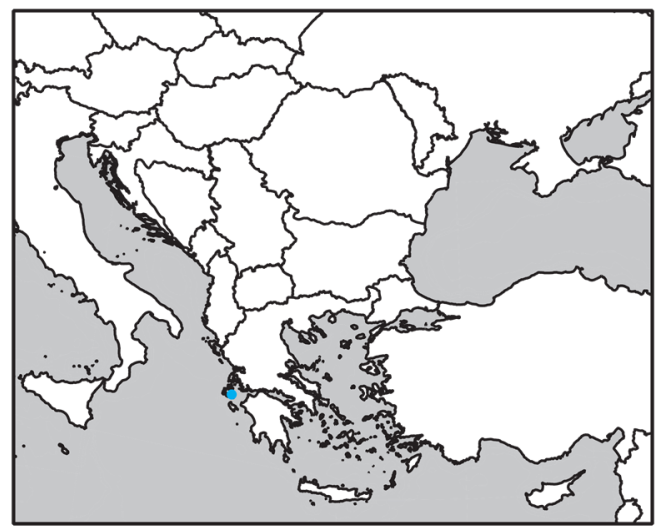

373. Megaphyllum cephalonicum (Strasser, 1974)

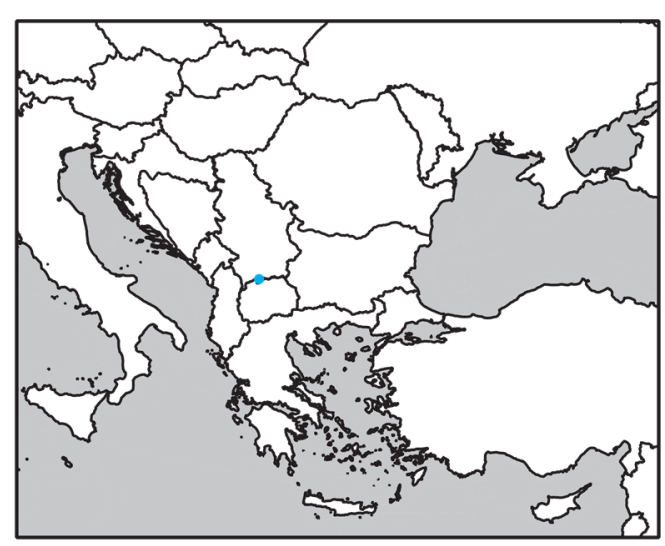

375. Megaphyllum crassum (Attems, 1929)

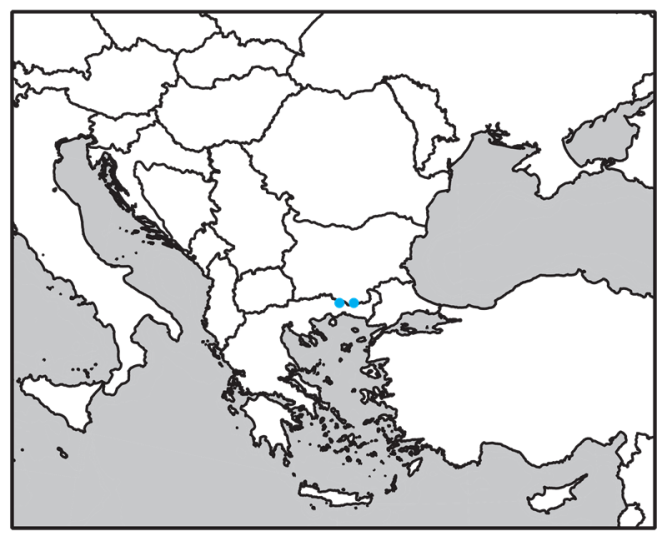

377. Megaphyllum cygniforme Lazányi \& Korsós, 2012 


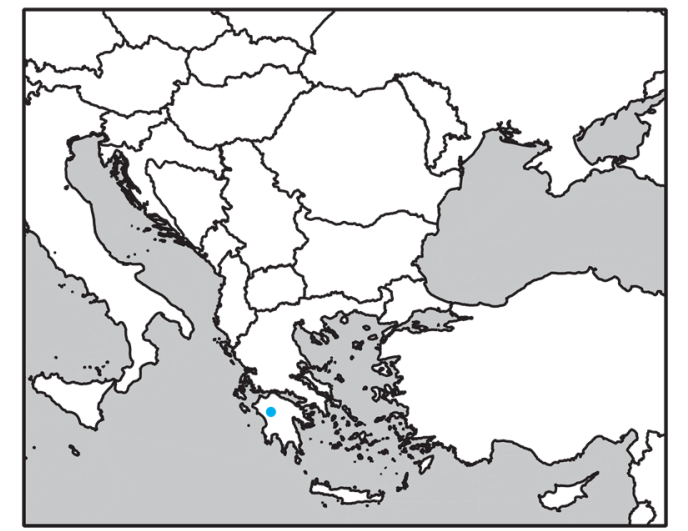

378. Megaphyllum danyi

Lazányi \& Korsós, 2012

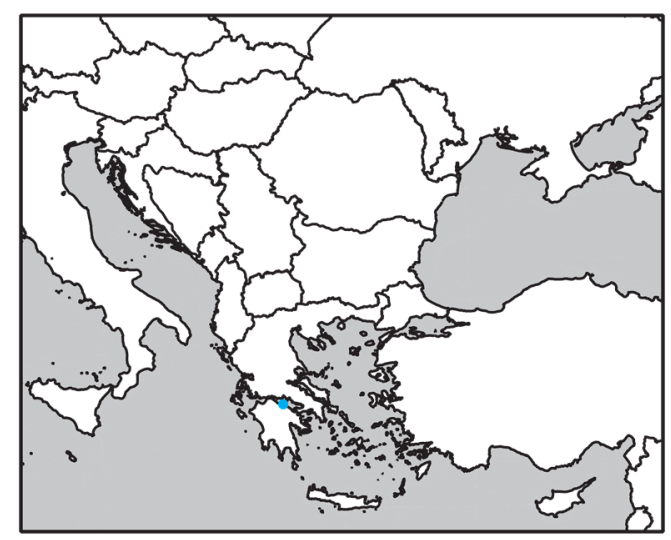

380. Megaphyllum digitatum

Lazányi \& Korsós, 2012

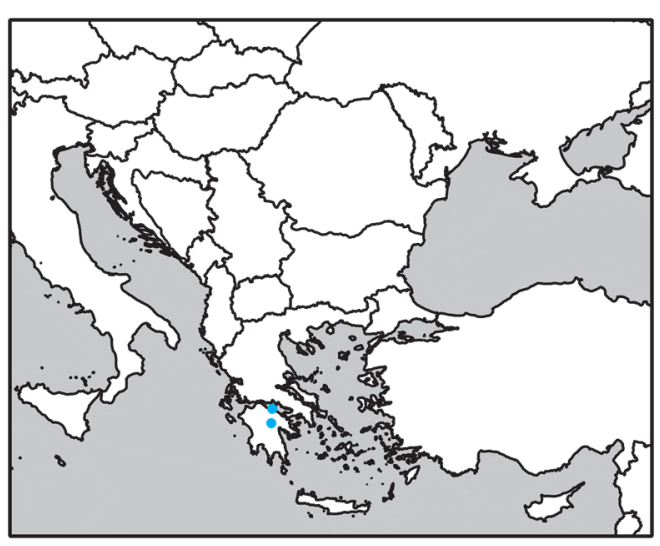

382. Megaphyllum euphorbiarum

(Verhoeff, 1900)

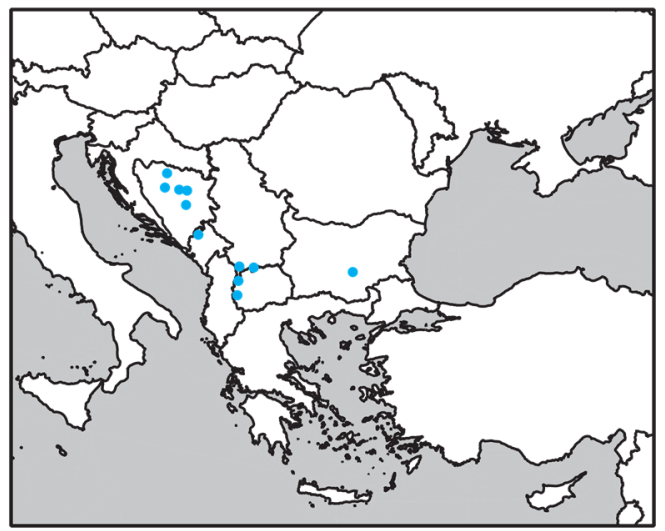

379. Megaphyllum dentatum (Verhoeff, 1898)

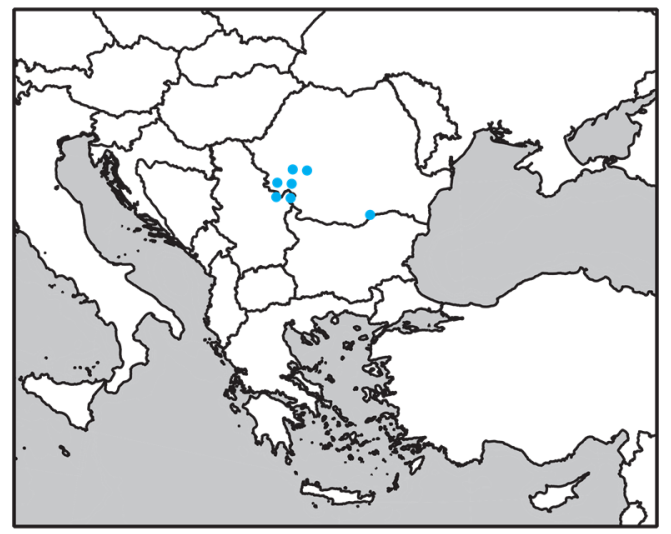

381. Megaphyllum erythronotum (Latzel, 1884)

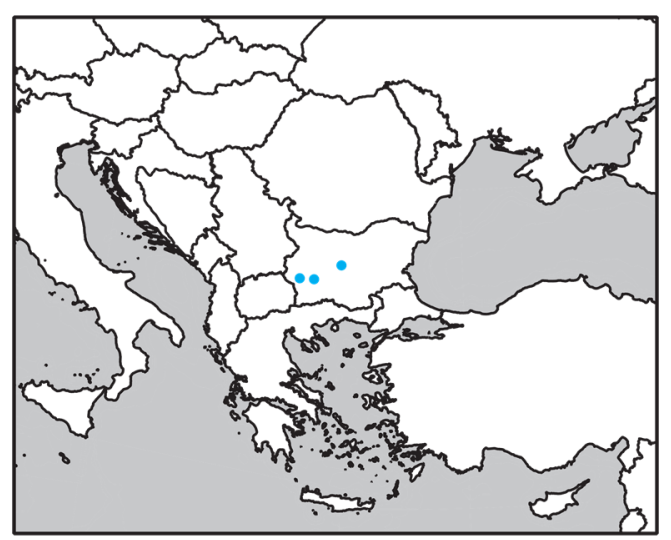

383. Megaphyllum glossuliferum (Schubart, 1934) 


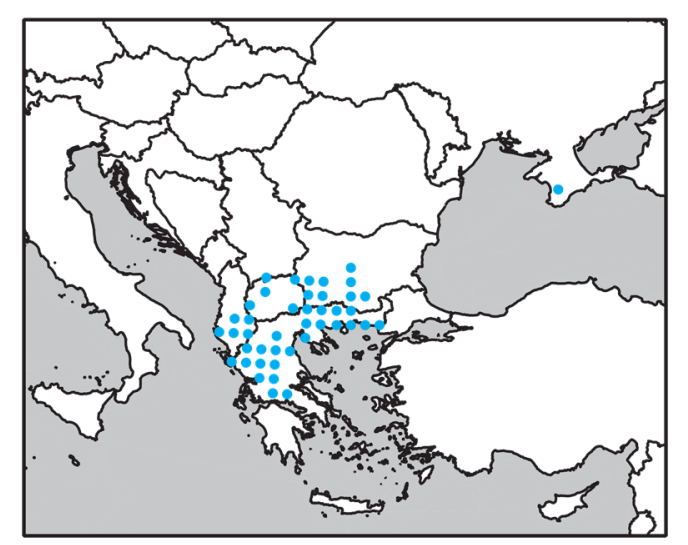

384. Megaphyllum hercules (Verhoeff, 1900)

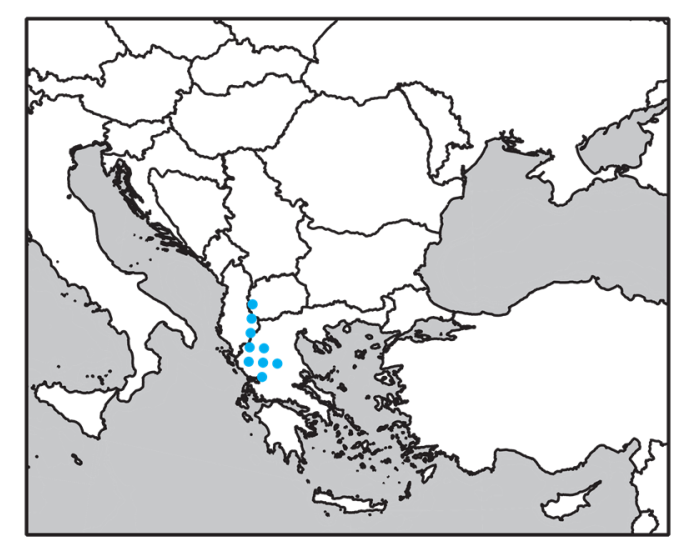

385. Megaphyllum imbecillum (Attems, 1935)

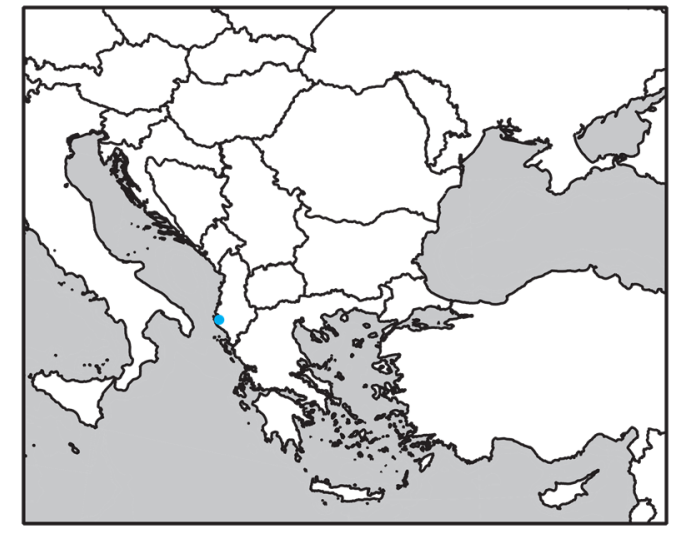

386. Megaphyllum karschi

(Verhoeff, 1901)

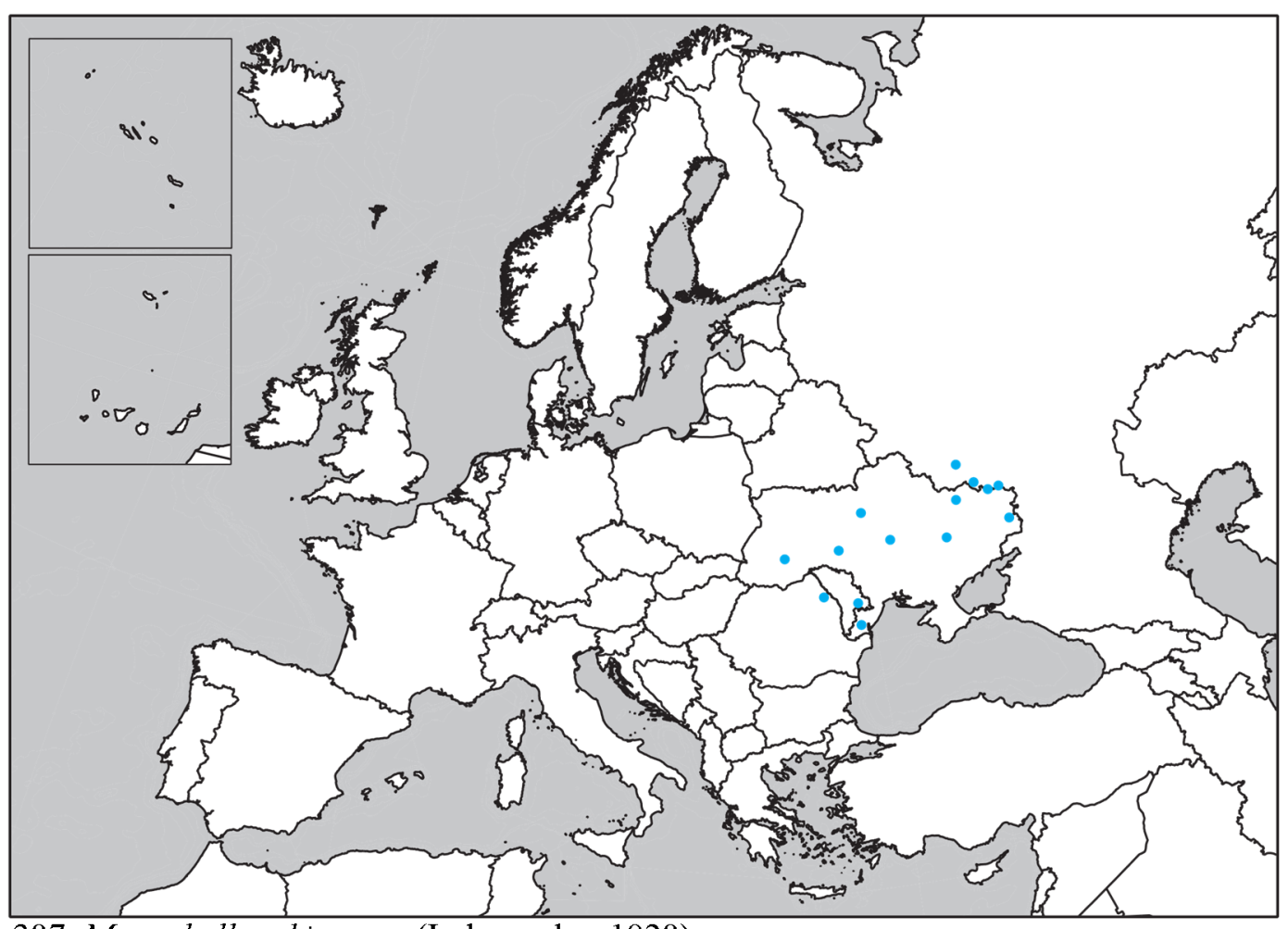

387. Megaphyllum kievense (Lohmander, 1928) 


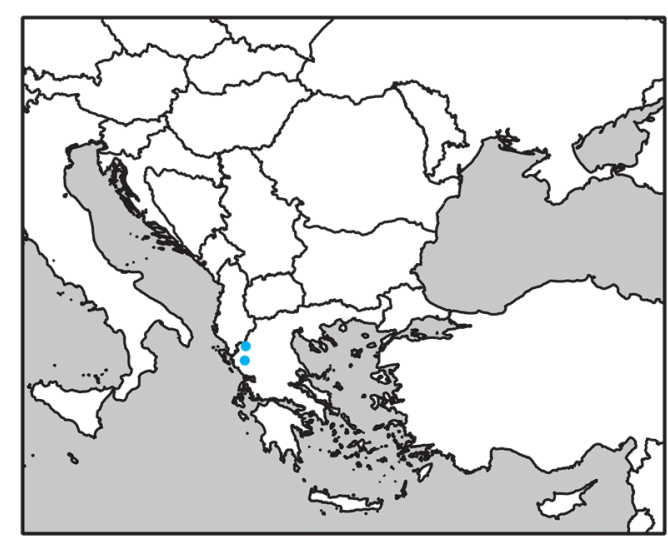

388. Megaphyllum lamelliferum (Strasser, 1974)

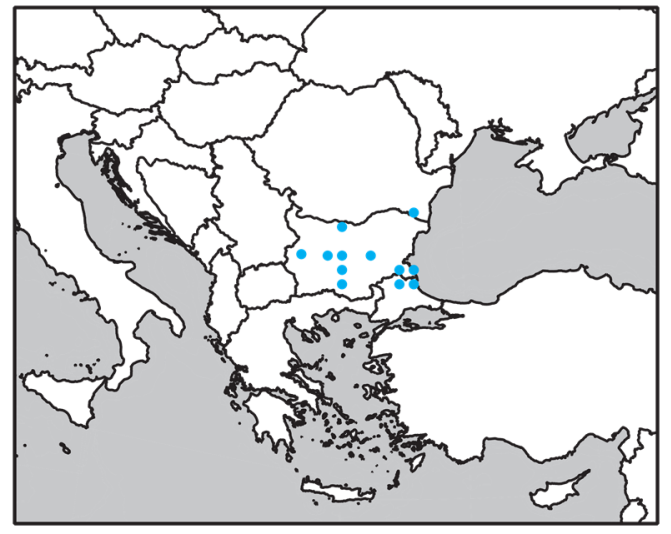

390. Megaphyllum lictor

(Attems, 1904)

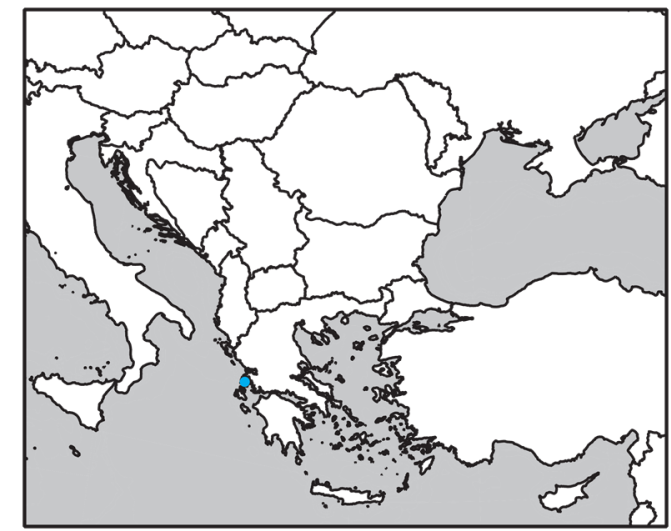

389. Megaphyllum leucadium (Attems, 1929)

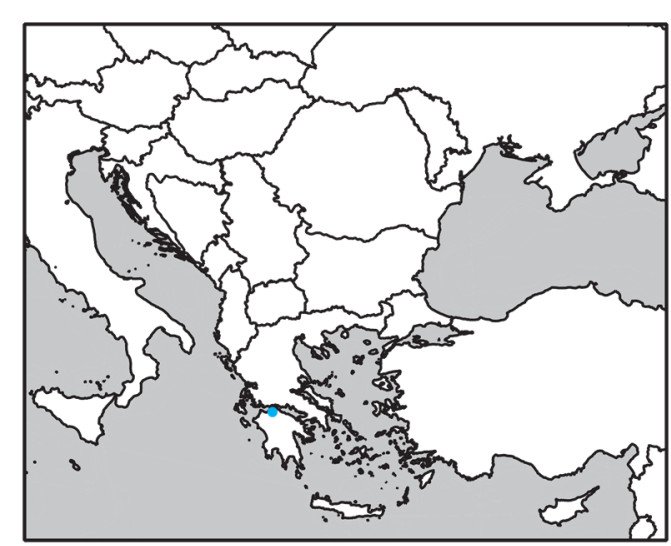

391. Megaphyllum loebli (Strasser, 1904)

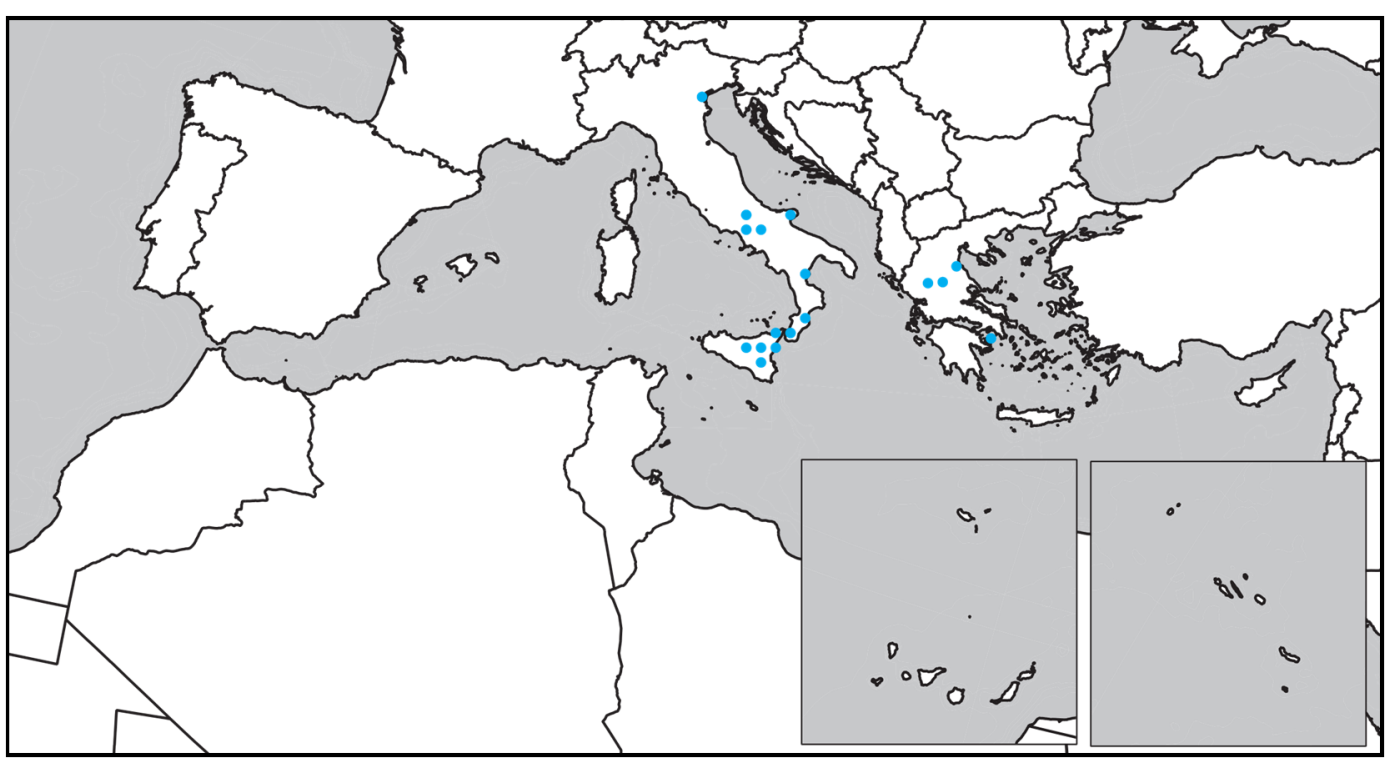

392. Megaphyllum maragaritatum (Fanzago, 1875) 


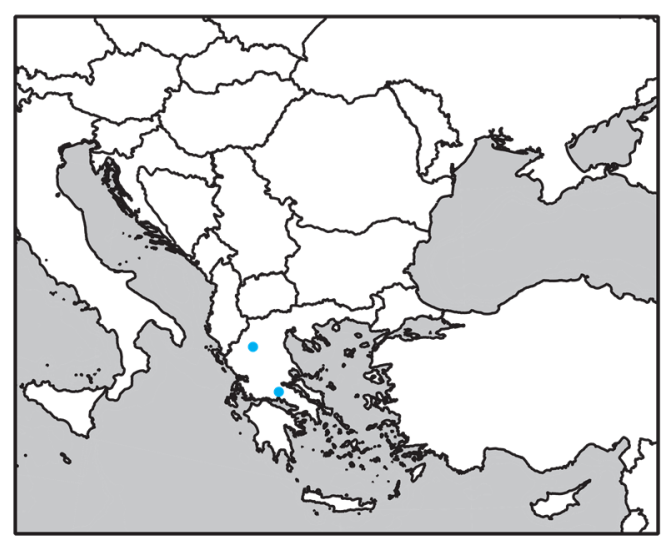

393. Megaphyllum metsovoni

(Strasser, 1976)

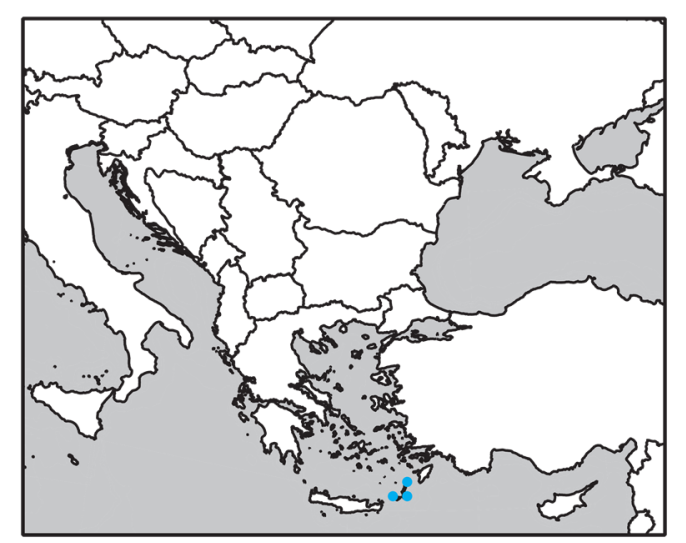

395. Megaphyllum mueggenburgi

(Verhoeff, 1901)

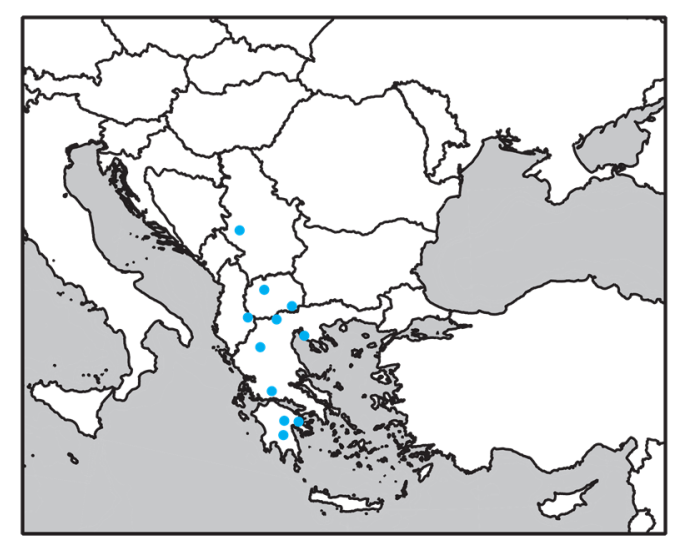

394. Megaphyllum montivagum

(Verhoeff, 1901)

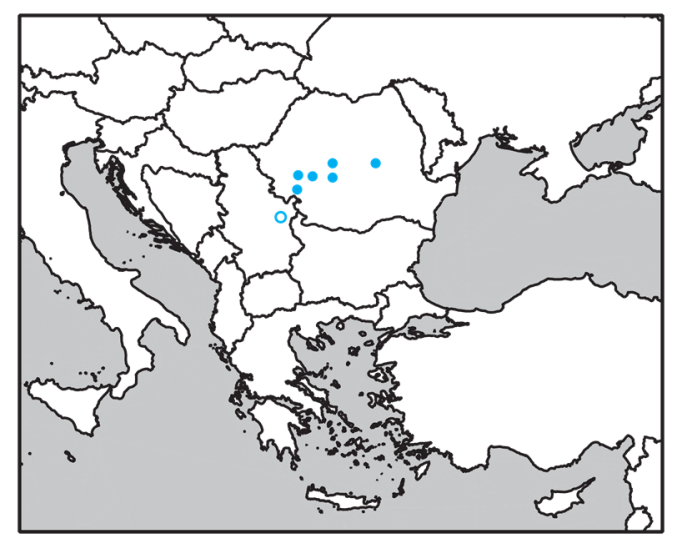

396. Megaphyllum platyurum

(Latzel, 1884) 


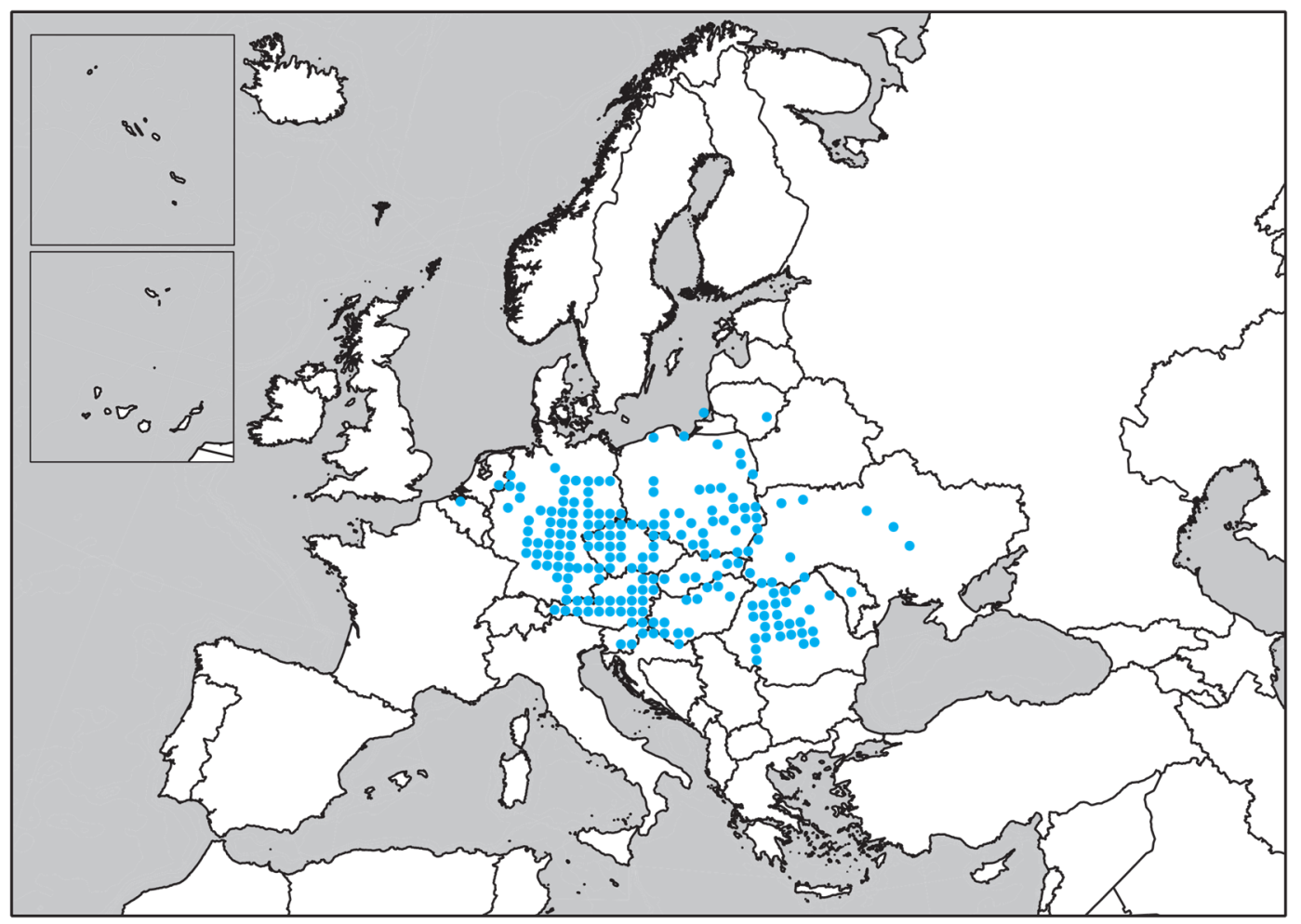

397. Megaphyllum projectum Verhoeff, 1894
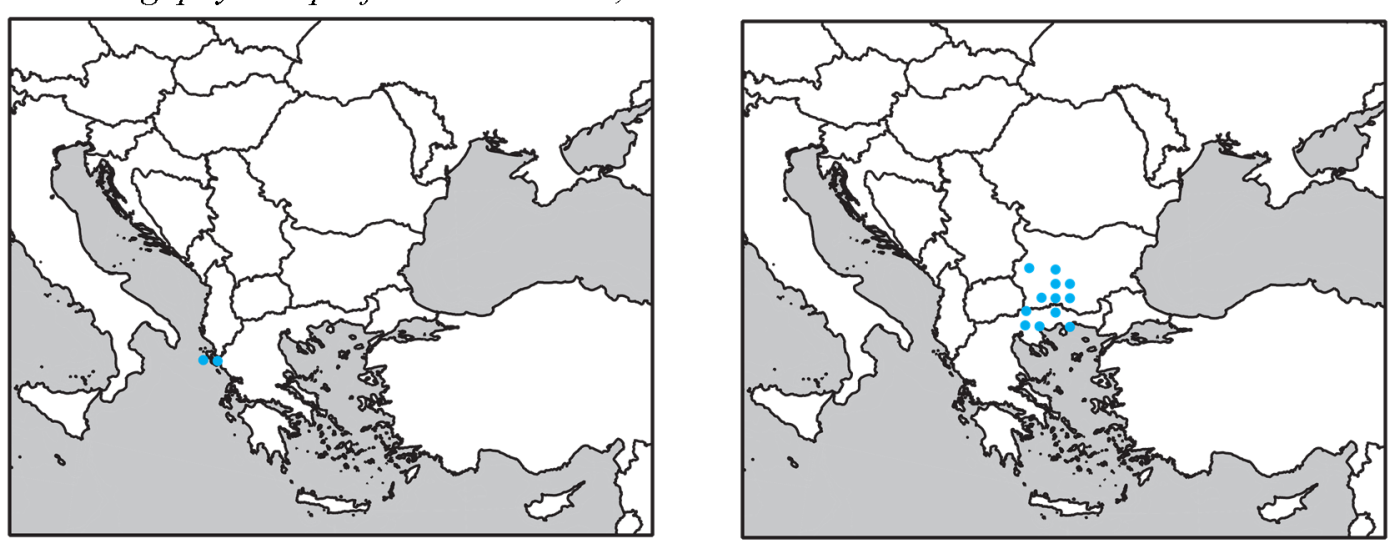

398. Megaphyllum recticauda (Attems, 1903 )

399. Megaphyllum rhodopinum (Verhoeff, 1928)

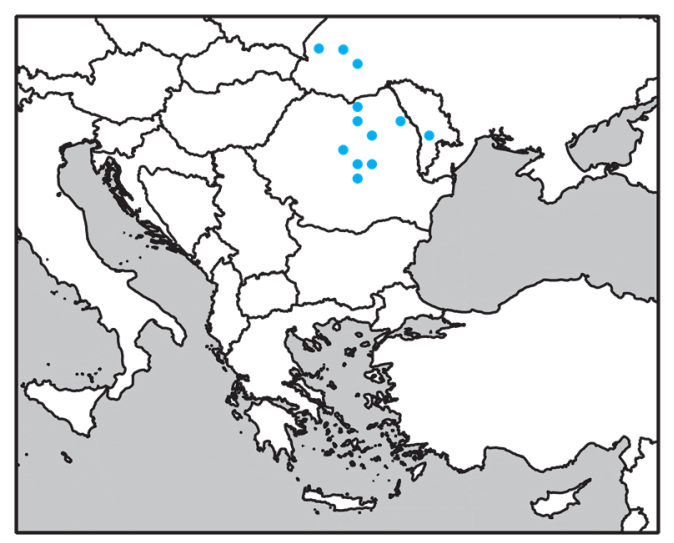

400. Megaphyllum rosenauense

(Verhoeff, 1897) 


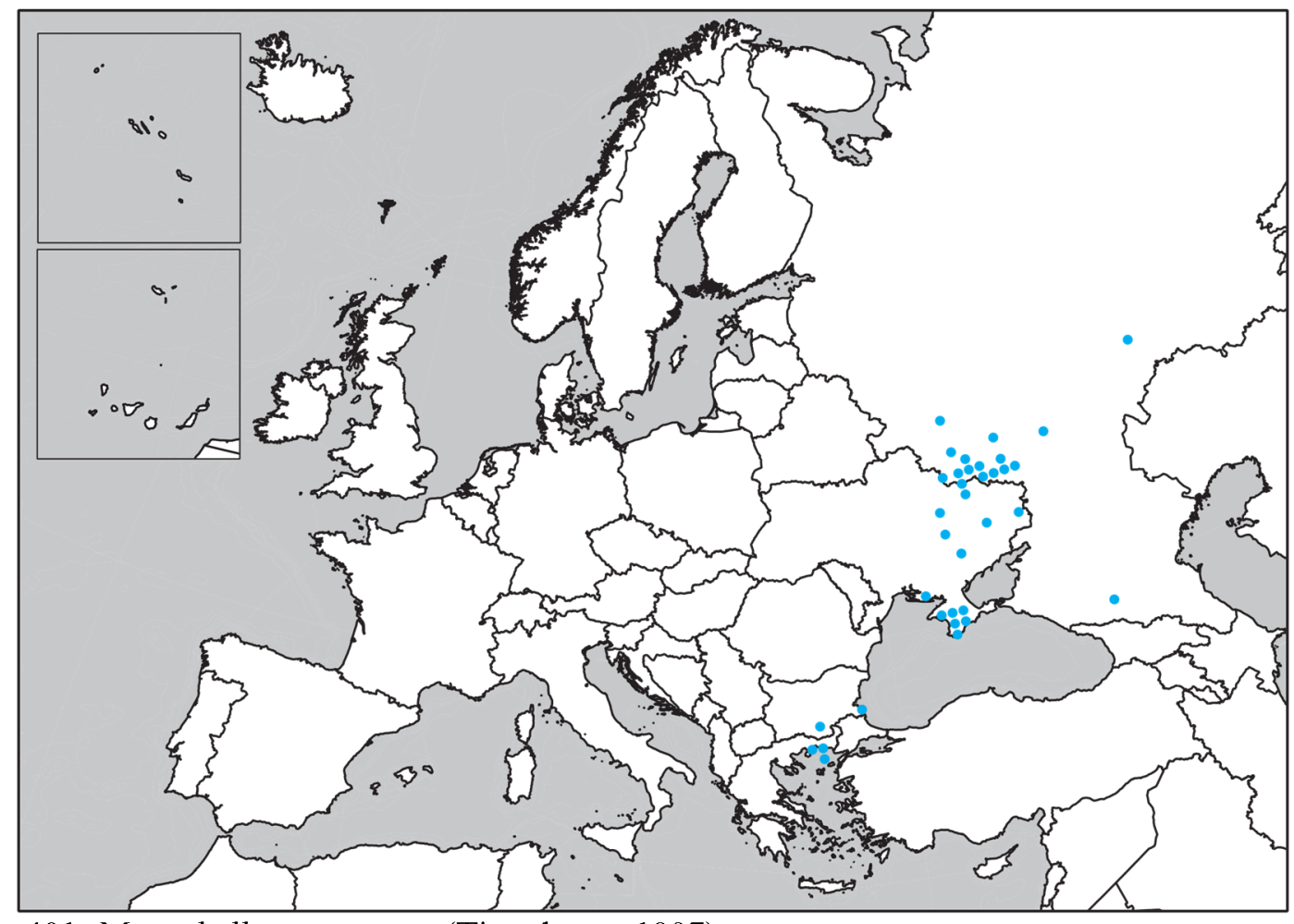

401. Megaphyllum rossicum (Timotheew, 1897)

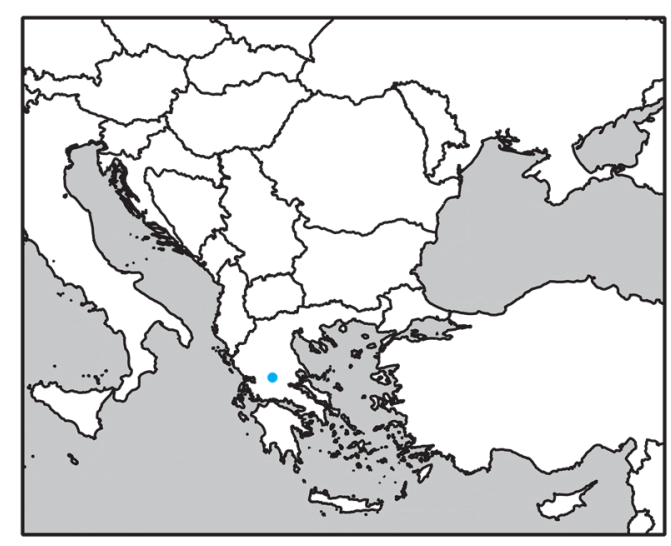

402. Megaphyllum rubidicolle (Verhoeff, 1901)

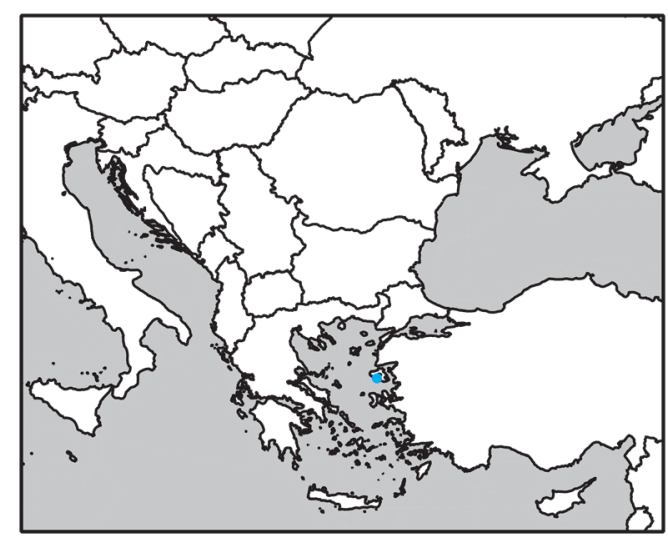

403. Megaphyllum sapphicum

(Strasser, 1976) 


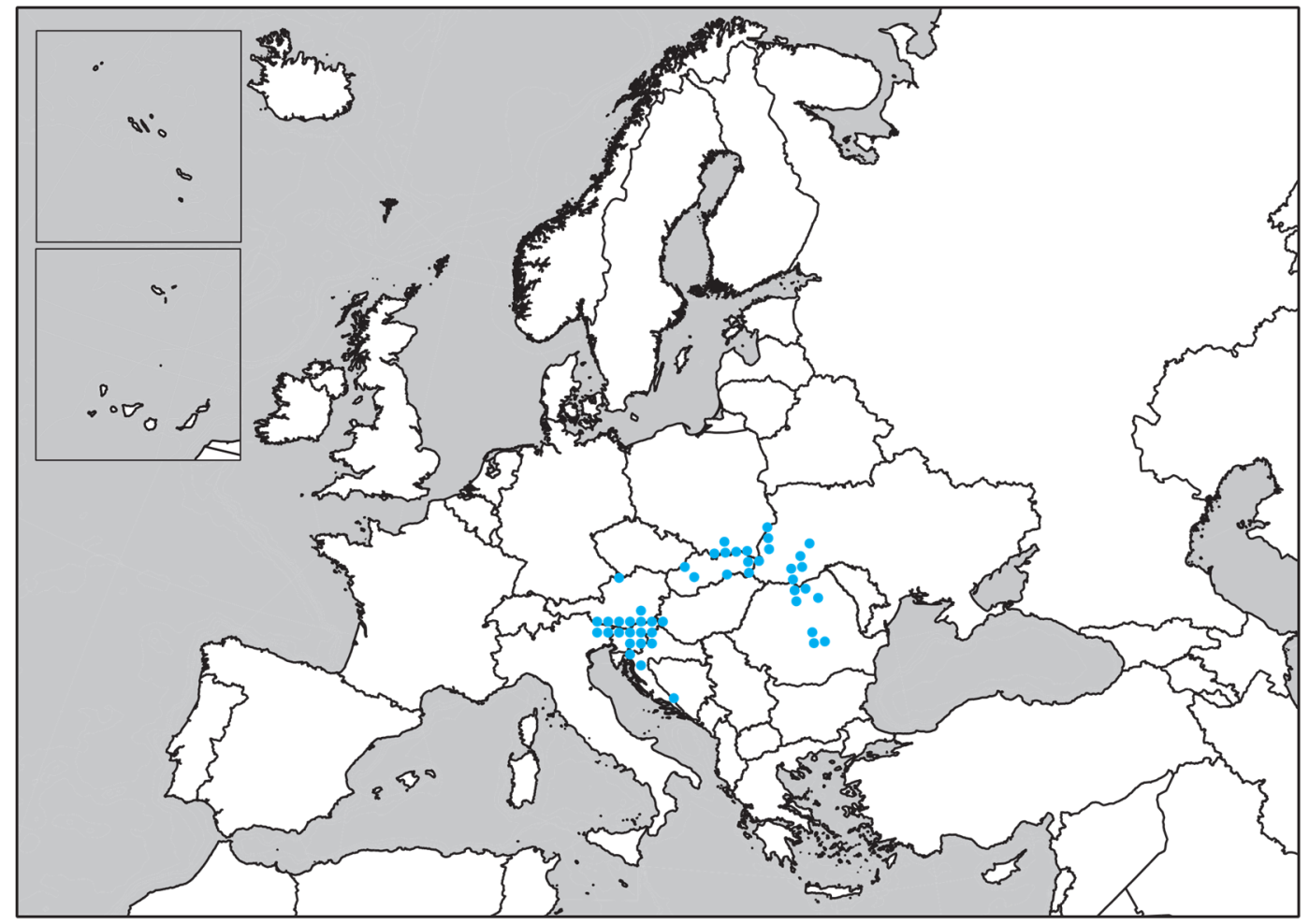

404. Megaphyllum silvaticum (Verhoeff, 1898)

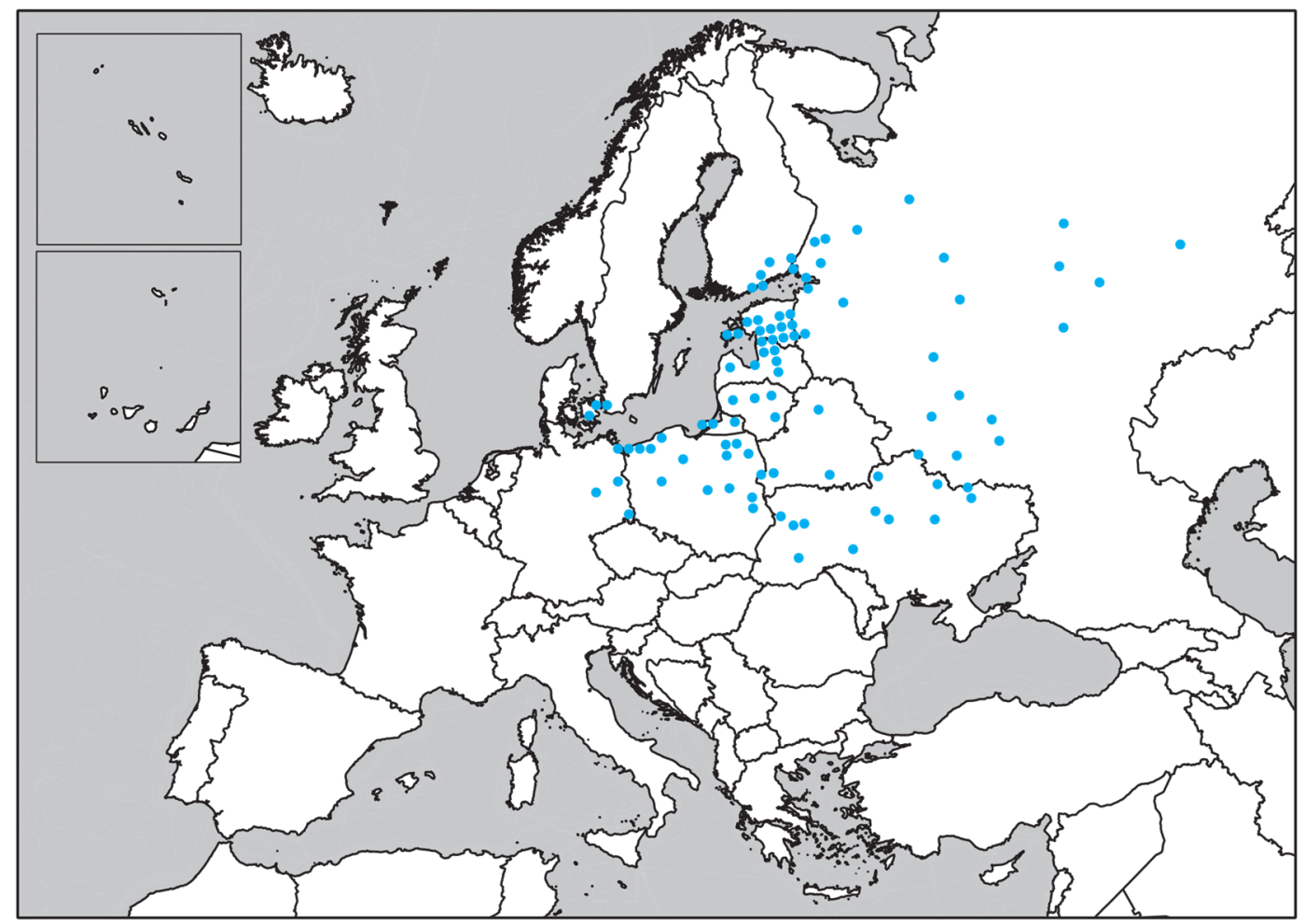

405. Megaphyllum sjaelandicum (Meinert, 1868) 


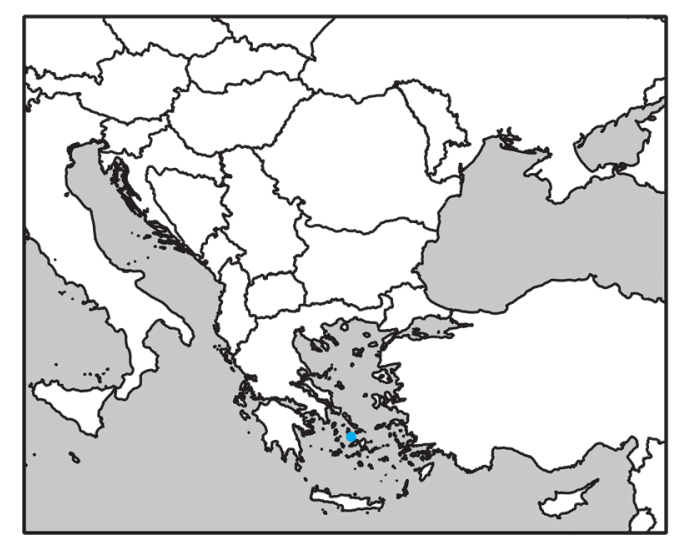

406. Megaphyllum syrense

(Verhoeff, 1903)

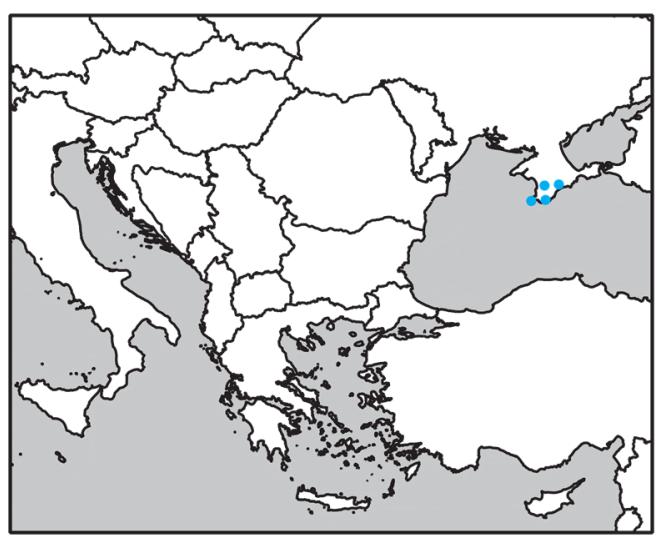

407. Megaphyllum tauricum (Attems, 1907)

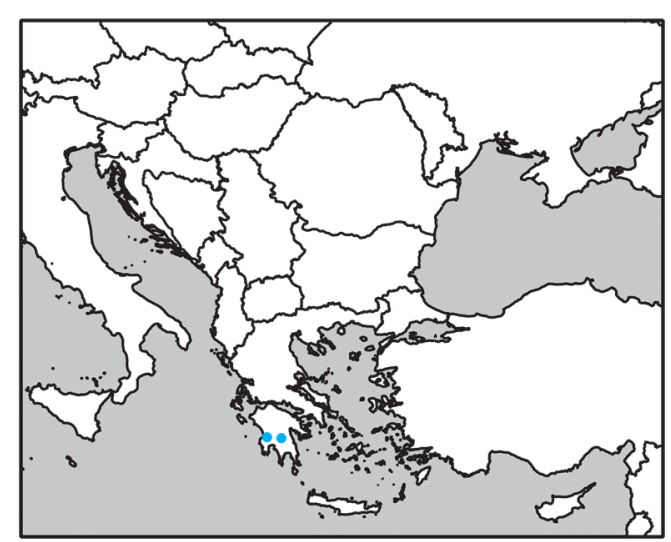

408. Megaphyllum taygetanum

(Attems, 1903)

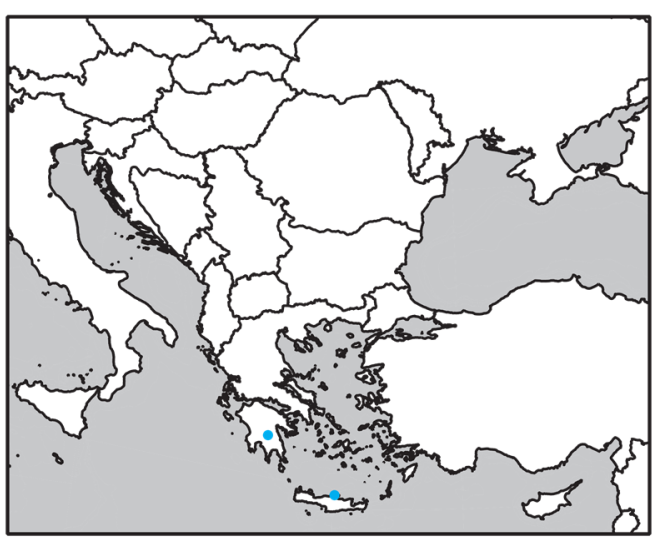

409. Megaphyllum taygeti

(Strasser, 1976) 


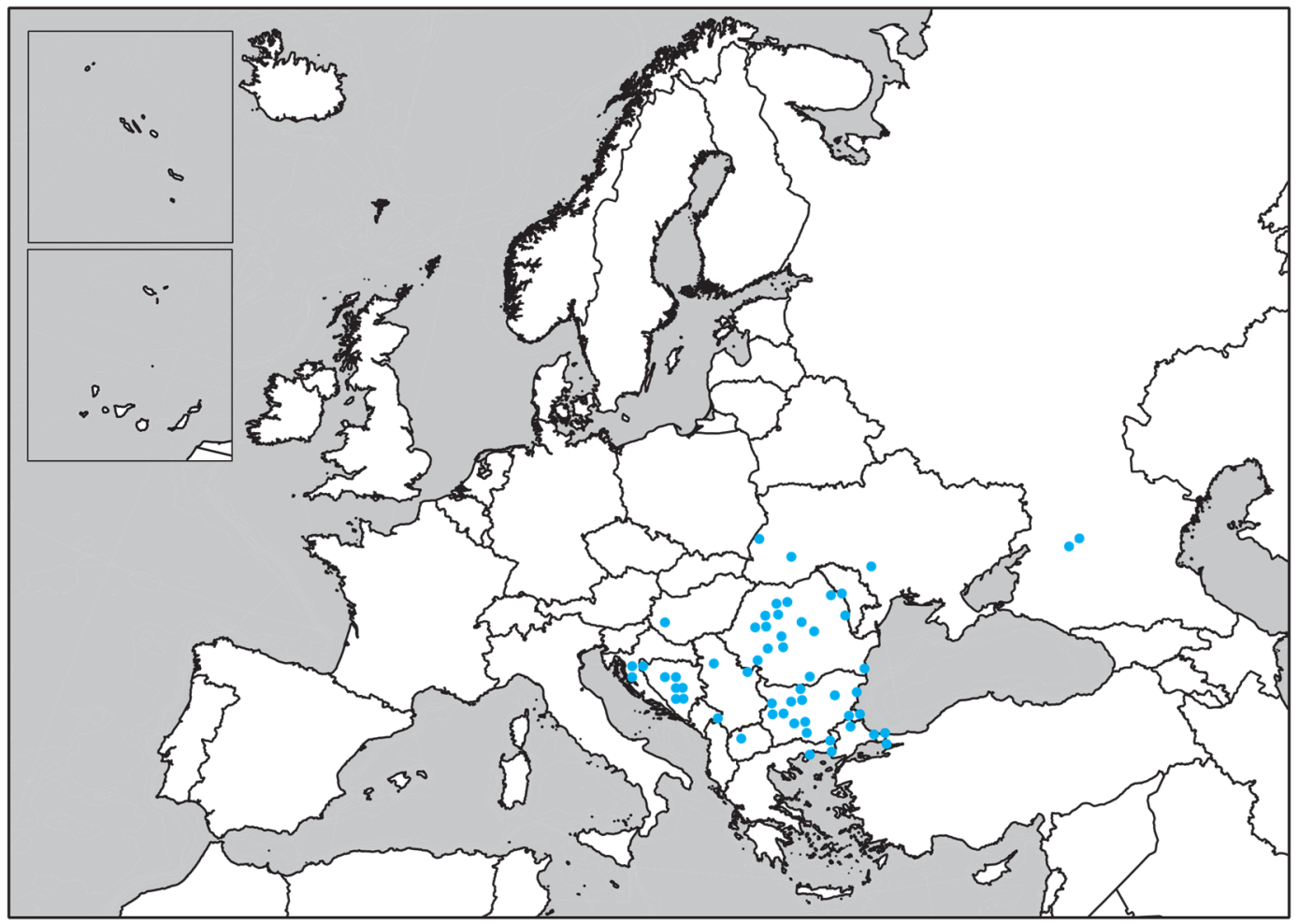

410. Megaphyllum transsylvanicum (Verhoeff, 1897)

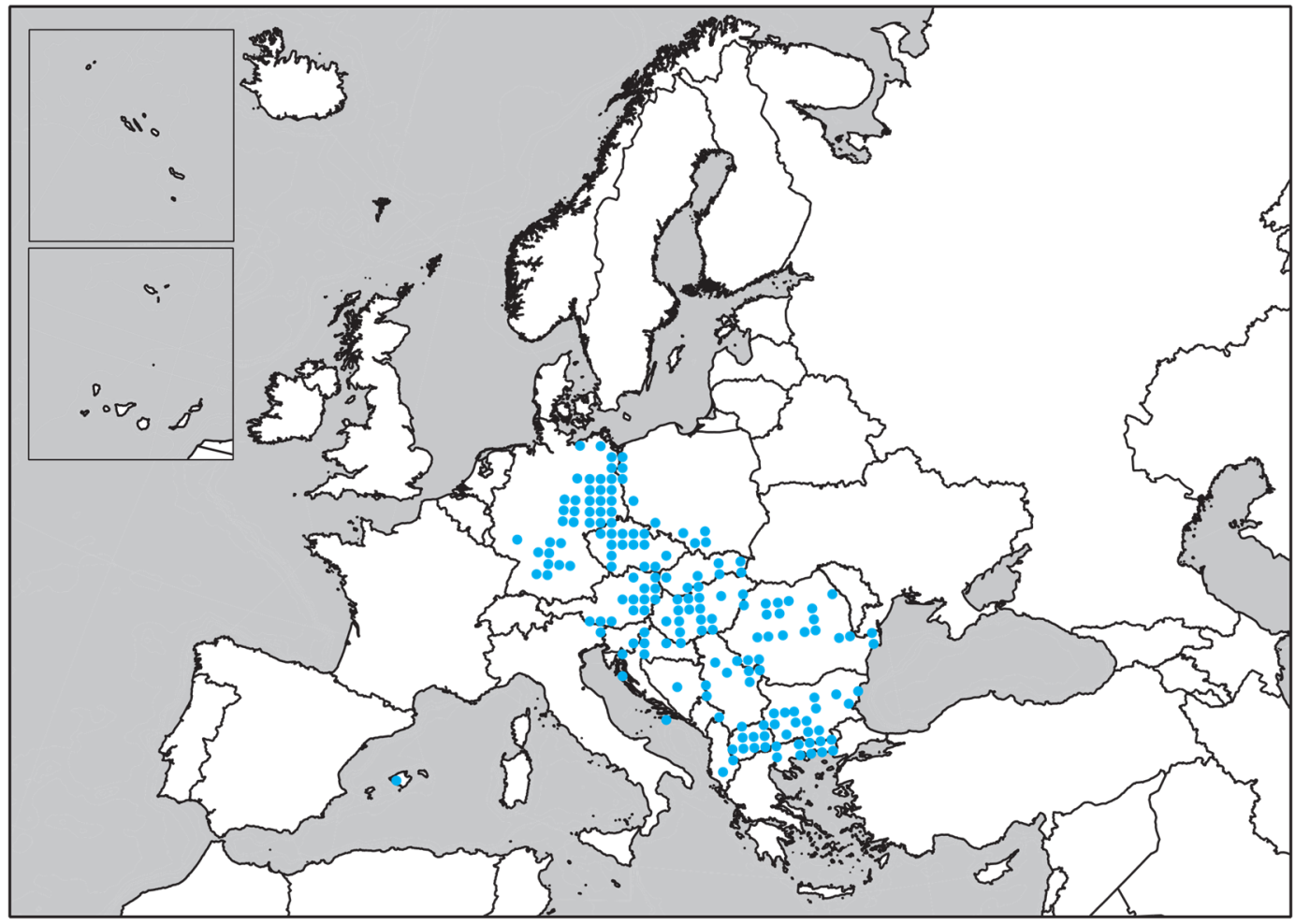

411. Megaphyllum unilineatum (C.L. Koch, 1838) 


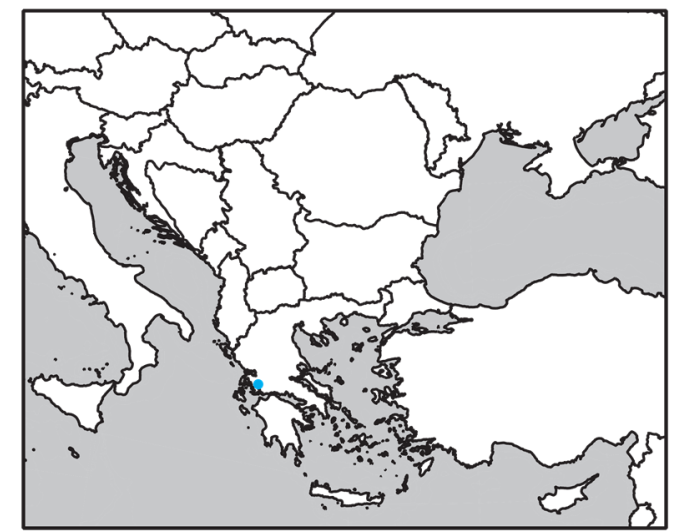

412. Megaphyllum vicinum (Verhoeff, 1903)

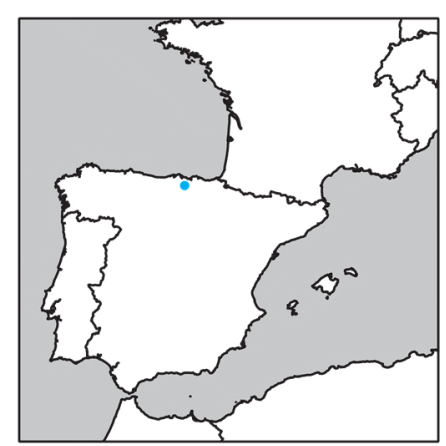

415. Mesoiulus derouteae Mauriès, 1971

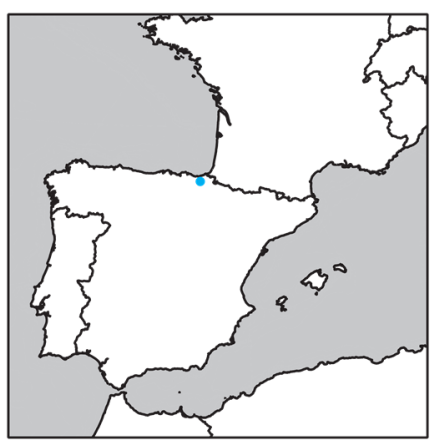

418. Mesoiulus henroti Mauriès, 1971

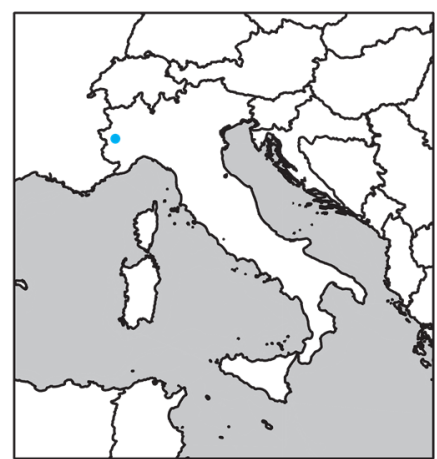

413. Mesoiulus berlesei Silvestri, 1898

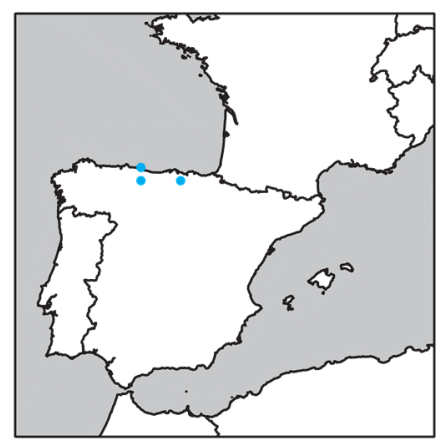

416. Mesoiulus drescoi Mauriès, 1971

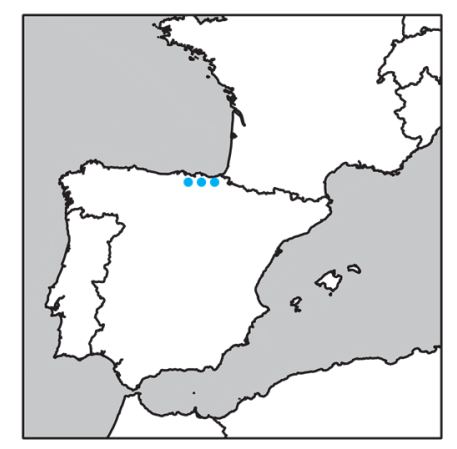

414. Mesoiulus cavernarum (Verhoeff, 1938)

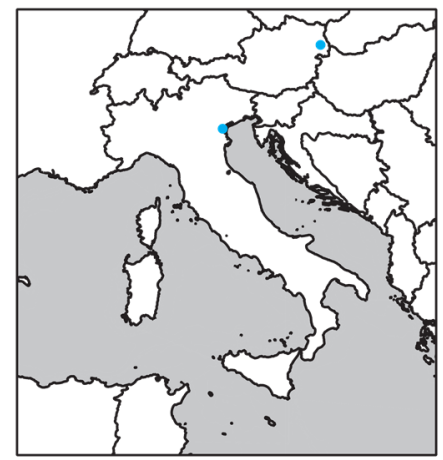

417. Mesoiulus gridellii

Strasser, 1934

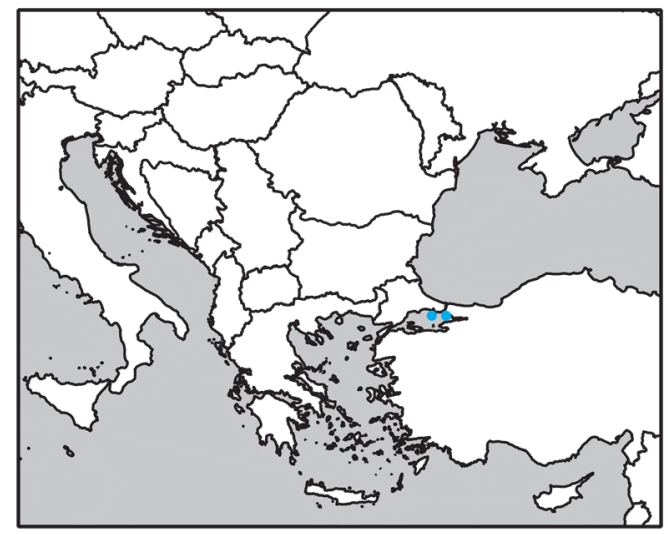

419. Mesoiulus kosswigi

Verhoeff, 1936 


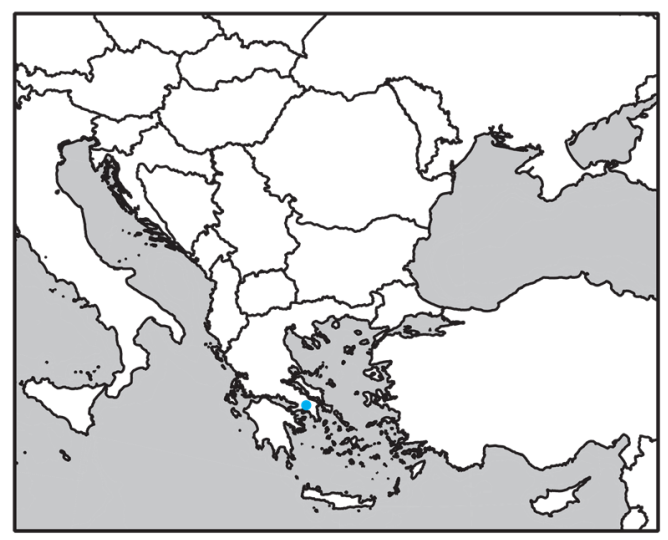

420. Mesoiulus mauriesi

Strasser, 1974

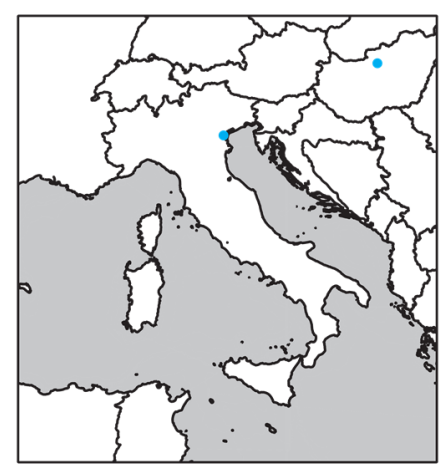

421. Mesoiulus paradoxus

Berlese, 1886

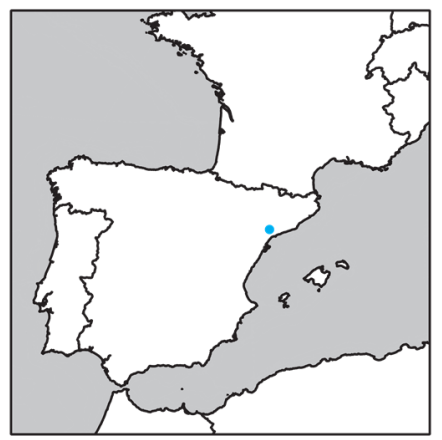

422. Mesoiulus rusticanus

Mauriès \& Vicente, 1977

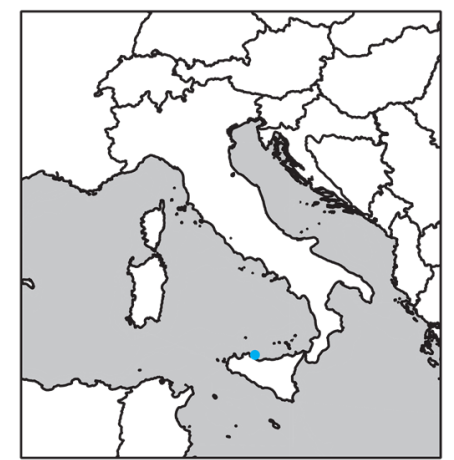

423. Mesoiulus siculus

Silvestri, 1902

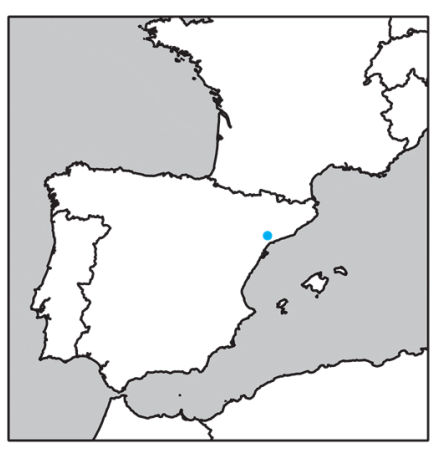

424. Mesoiulus stammeri (Verhoeff, 1936) 


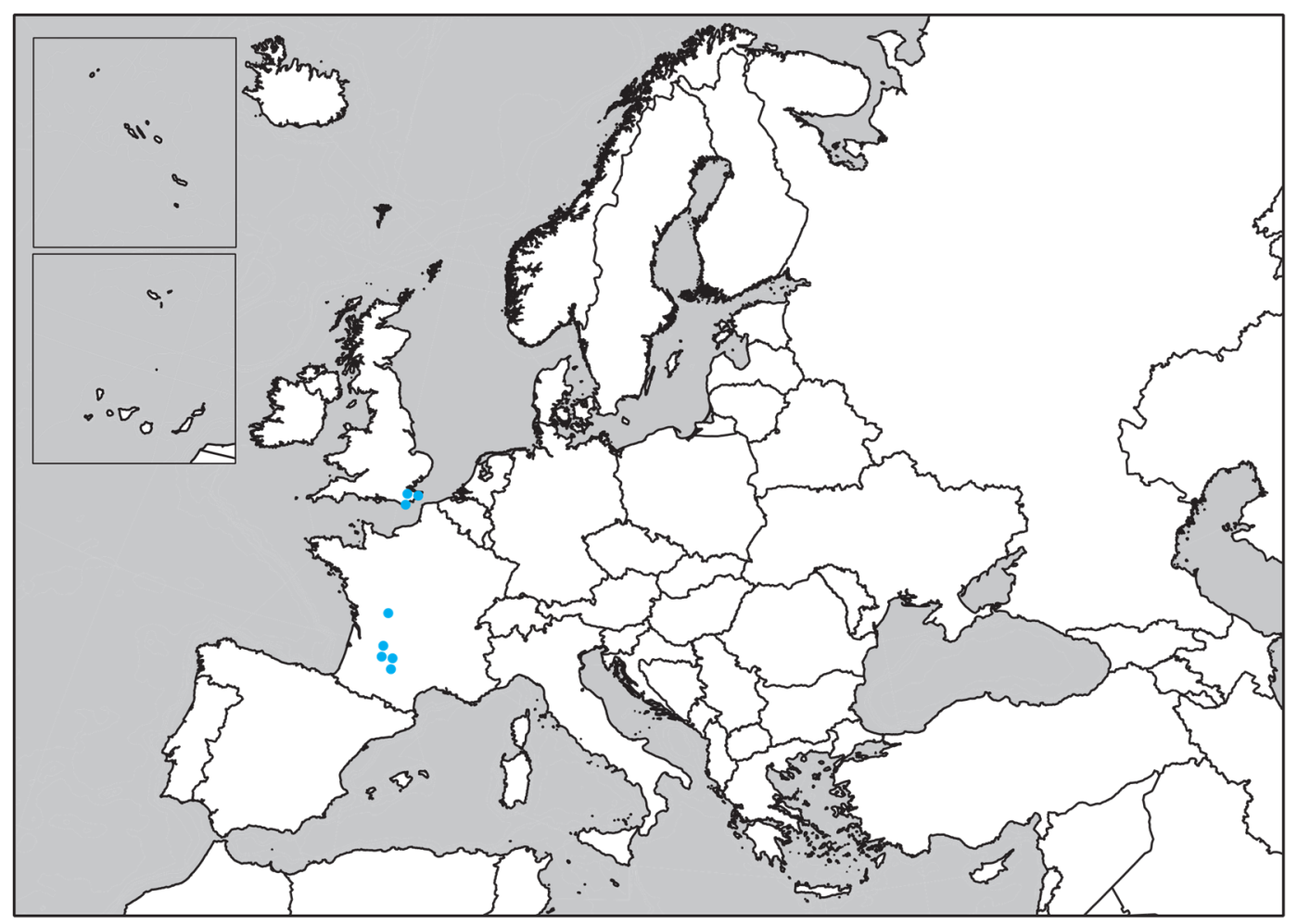

425. Metaiulus pratensis Blower \& Rolfe, 1956

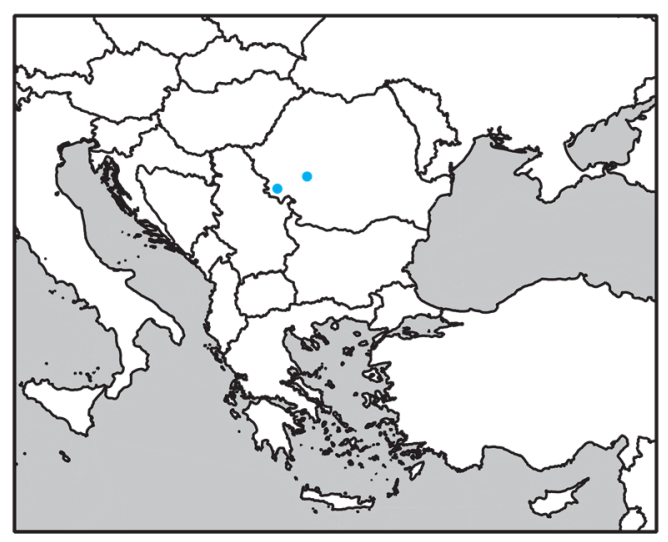

426. Micropachyiulus pauciocellatus (Verhoeff, 1899)

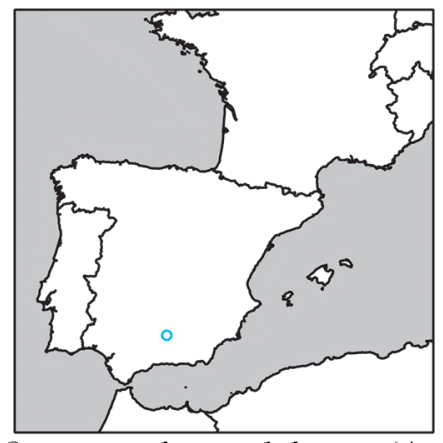

428. Ommatoiulus andalusius (Attems, 1927)

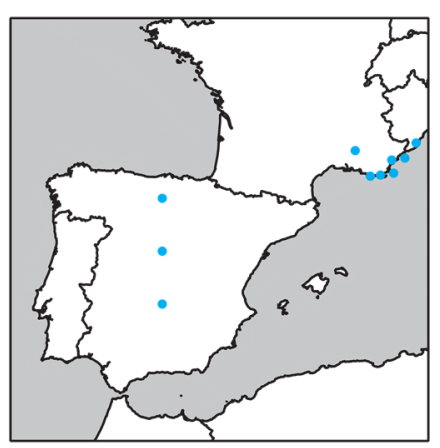

427. Ommatoiulus albolineatus (Lucas, 1845)

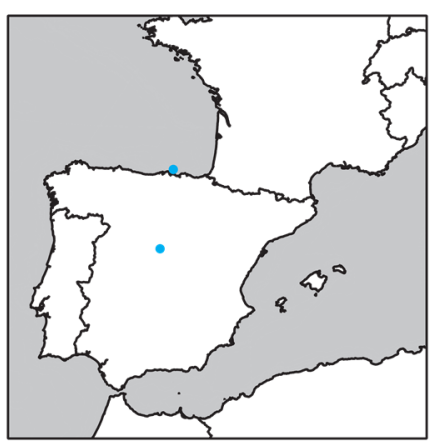

429. Ommatoiulus armatus (Verhoeff, 1910) 


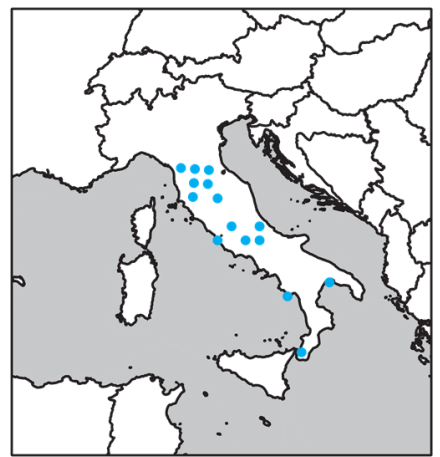

430. Ommatoiulus aurozonatus

(Berlese, 1886)

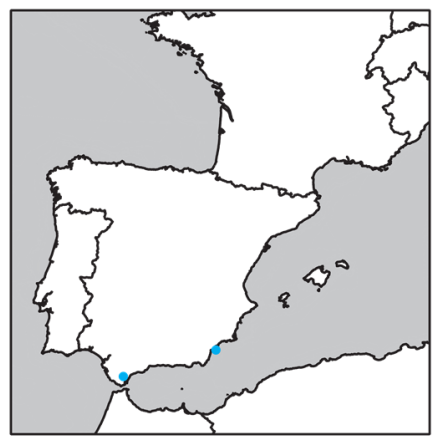

433. Ommatoiulus bavayi

(Brölemann, 1897)

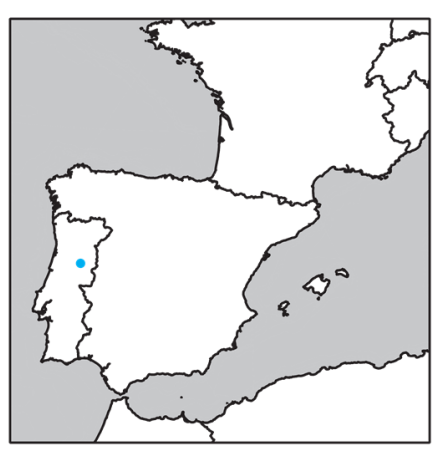

436. Ommatoiulus cervinus

(Verhoeff, 1940)

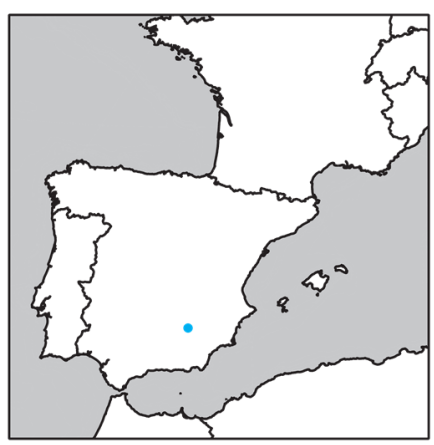

431. Ommatoiulus baenai

Akkari \& Enghoff, 2012

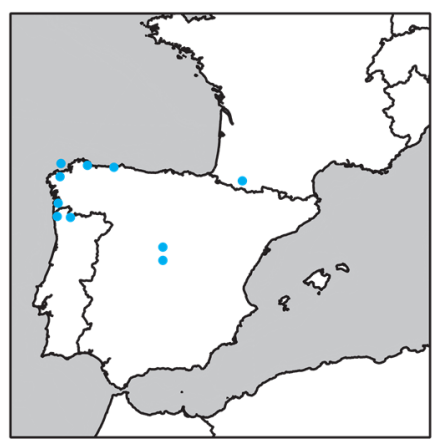

434. Ommatoiulus bipartitus

(Verhoeff, 1910)

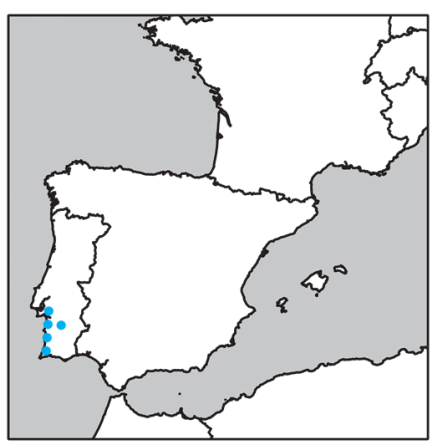

437. Ommatoiulus cingulatus (Attems, 1927)

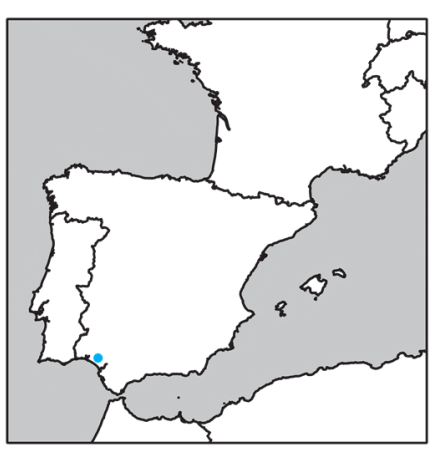

432. Ommatoiulus baileyi

Akkari \& Enghoff, 2012

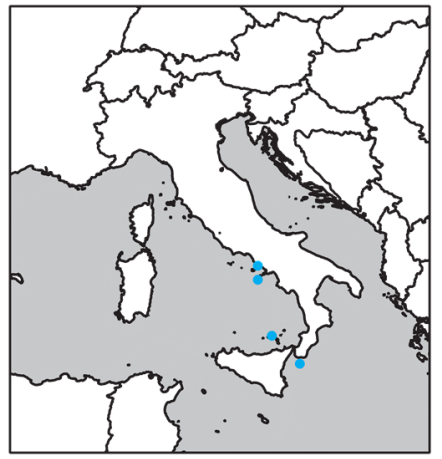

435. Ommatoiulus buchneri (Verhoeff, 1940)

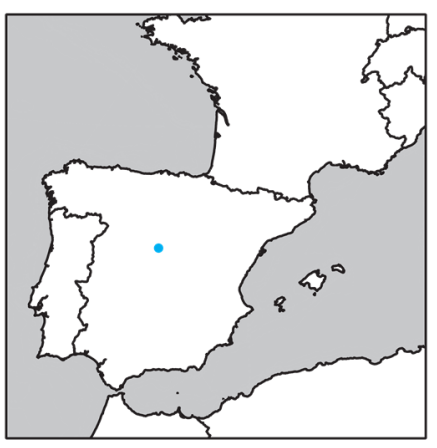

438. Ommatoiulus clavigerus (Verhoeff, 1921) 


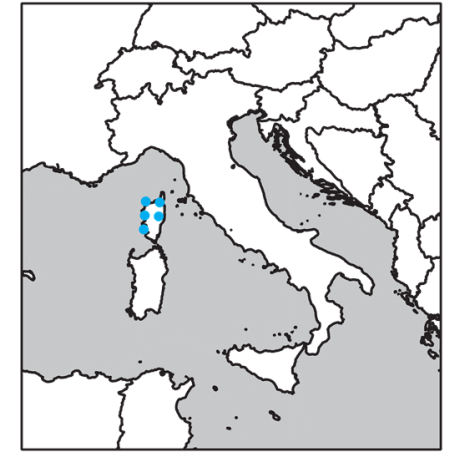

439. Ommatoiulus corsicus (Brölemann, 1903)

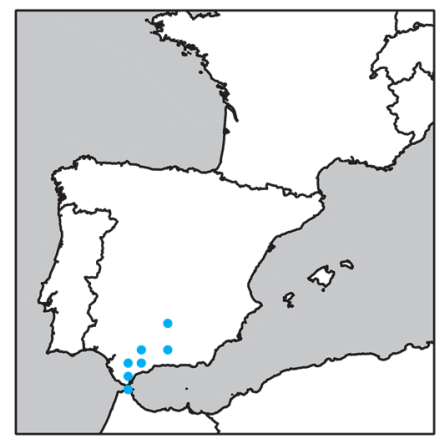

442. Ommatoiulus diplurus (Attems, 1903)

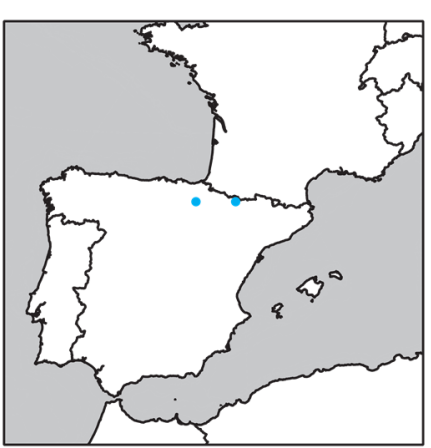

445. Ommatoiulus haackeri Mauriès, 1969

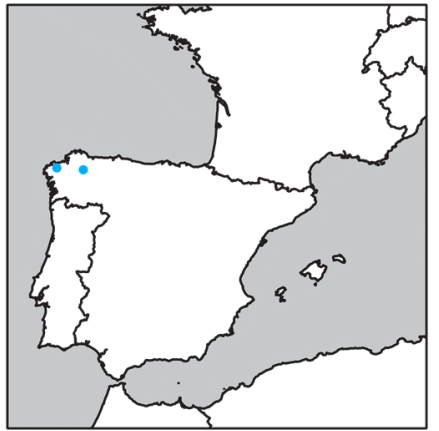

440. Ommatoiulus corunnensis (Verhoeff, 1910)

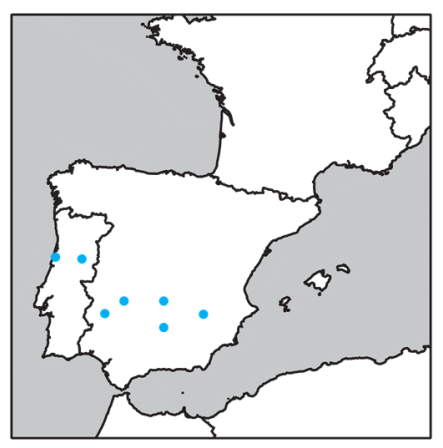

443. Ommatoiulus dorsovittatus (Verhoeff, 1893)

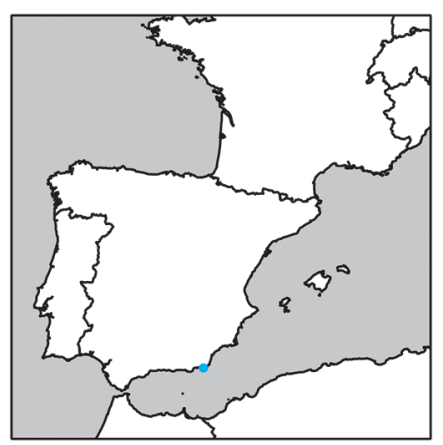

446. Ommatoiulus hoffmani

Akkari \& Enghoff, 2012

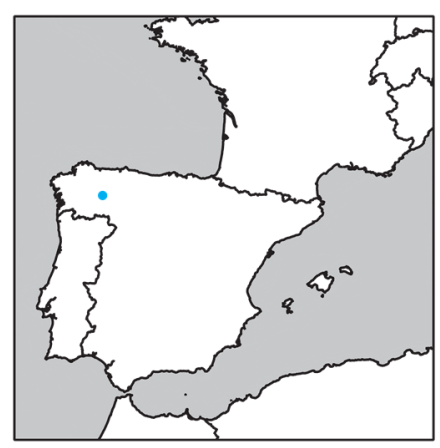

441. Ommatoiulus demangei Vicente \& Rodriguez, 1992

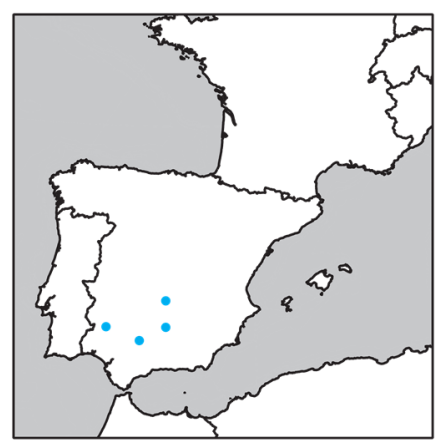

444. Ommatoiulus fuentei

(Brolemann, 1920)

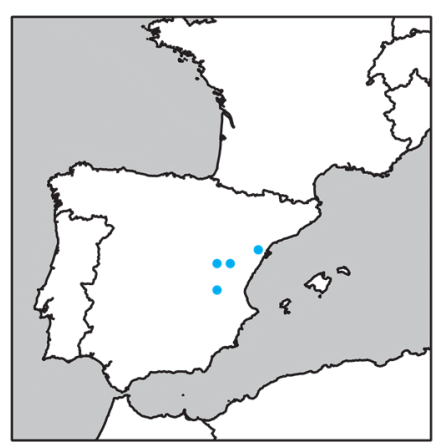

447. Ommatoiulus ibericus Ceuca, 1974 


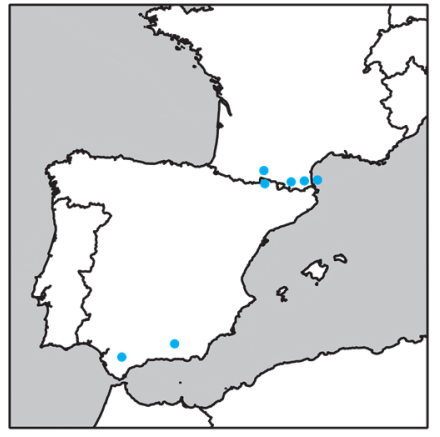

448. Ommatoiulus ilicis

(Brölemann, 1897)

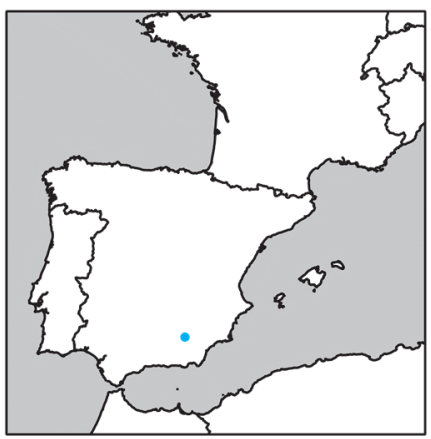

451. Ommatoiulus jaenensis

Akkari \& Enghoff, 2012

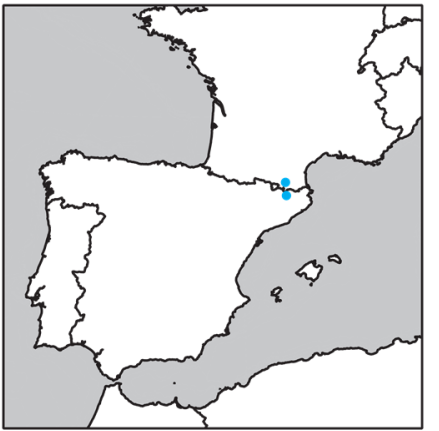

449. Ommatoiulus imminutus

(Brolemann, 1926)

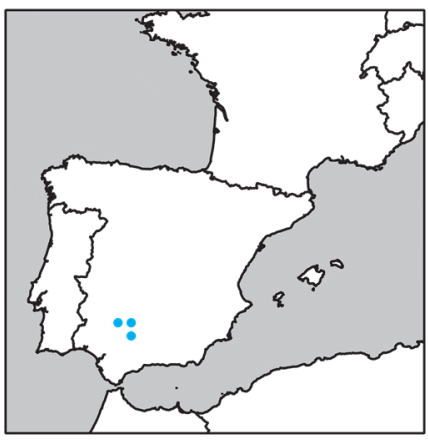

452. Ommatoiulus kimei

Akkari \& Enghoff, 2012

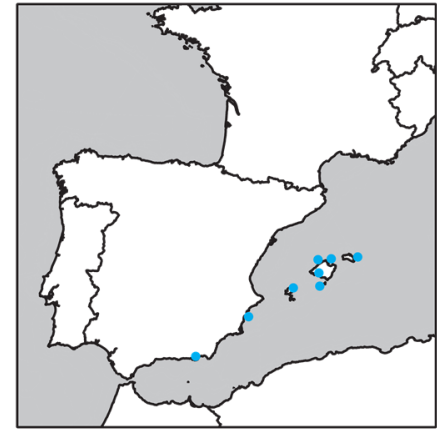

450. Ommatoiulus inconspicuus (L. Koch, 1881)

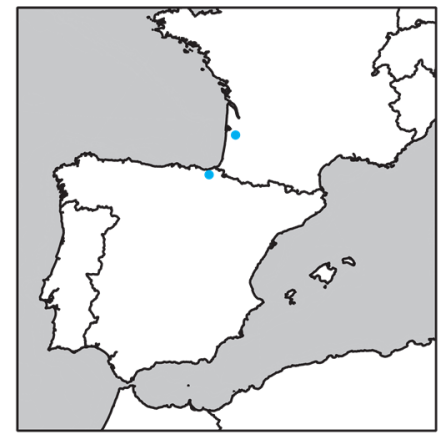

453. Ommatoiulus lienharti

(Brolemann, 1921)

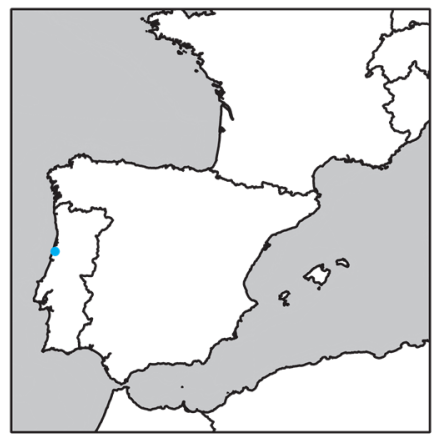

454. Ommatoiulus lusitanus (Verhoeff, 1895)

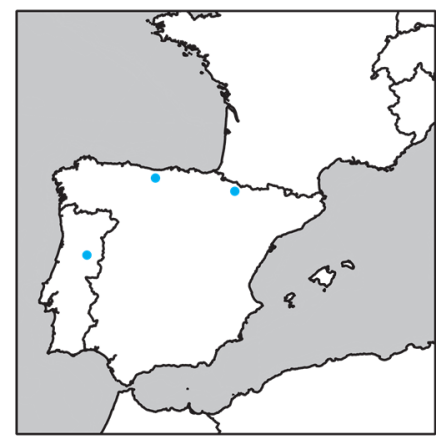

455. Ommatoiulus martensi Mauriès, 1969 


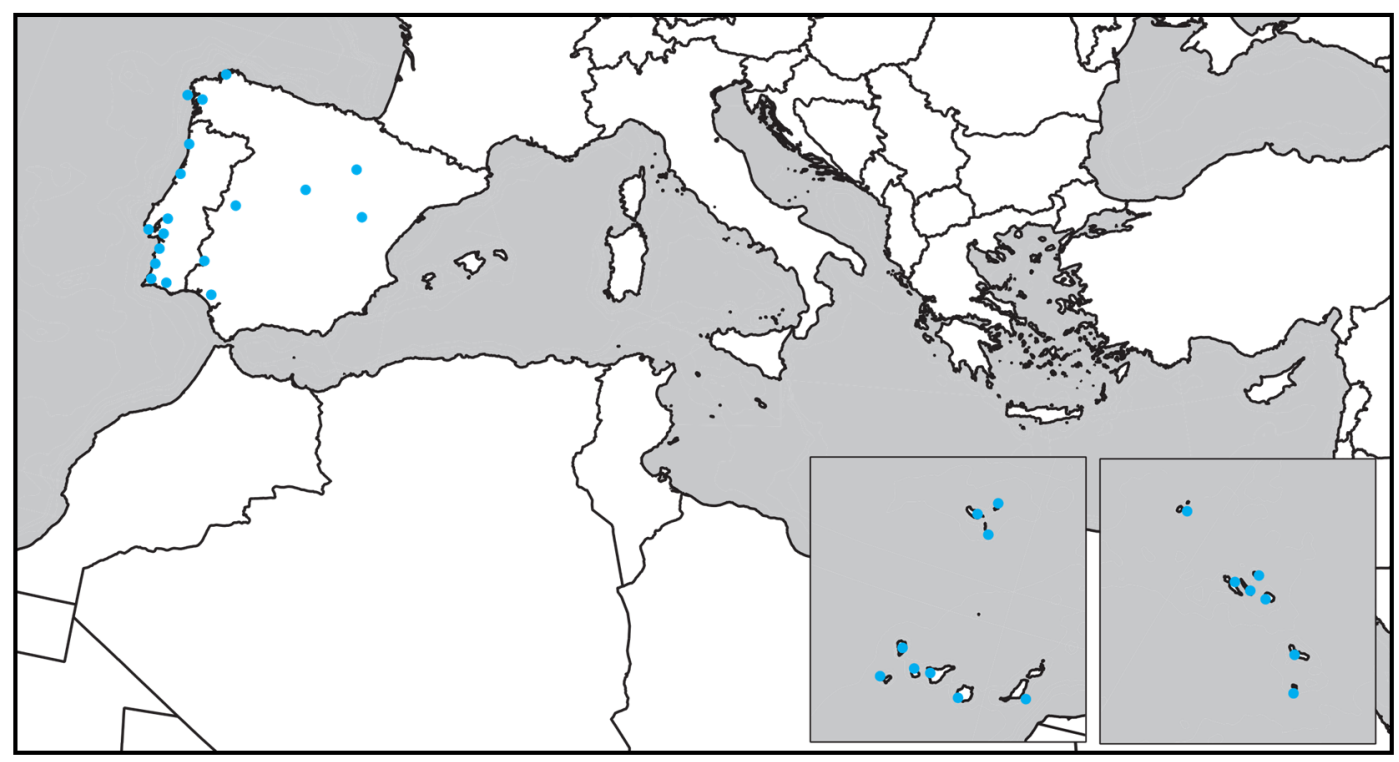

456. Ommatoiulus moreleti (Lucas, 1860)

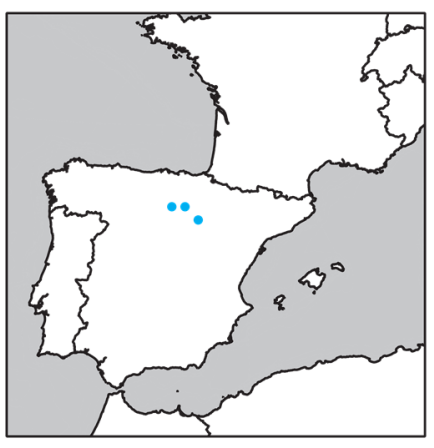

457. Ommatoiulus navasi

(Brölemann, 1918)

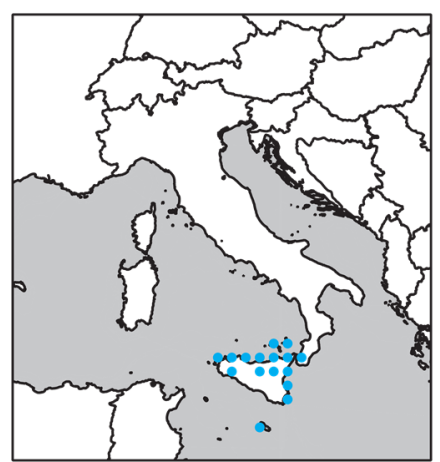

460. Ommatoiulus oxypygus

(Brandt, 1841)

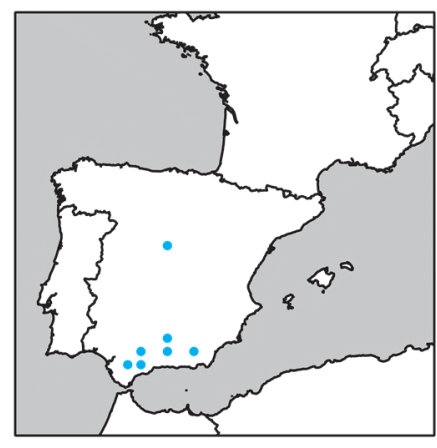

458. Ommatoiulus niger

(Attems, 1952)

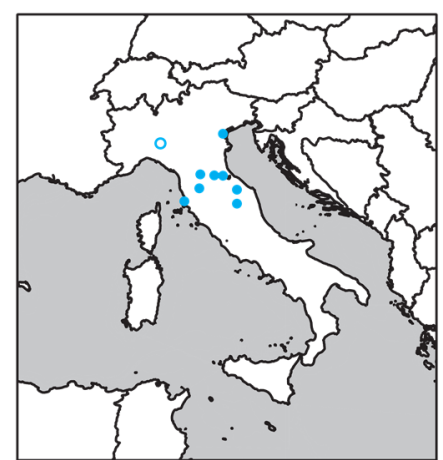

461. Ommatoiulus parallelus (C.L. Koch 1847)

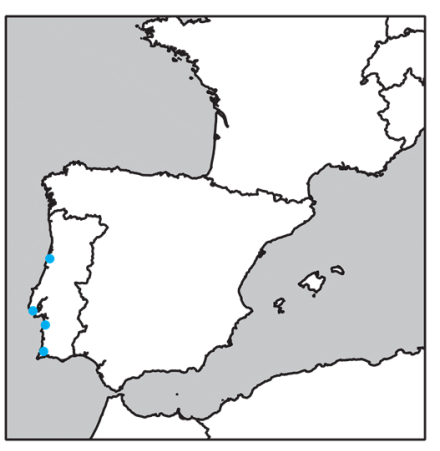

459. Ommatoiulus oliveirae (Verhoeff, 1893)

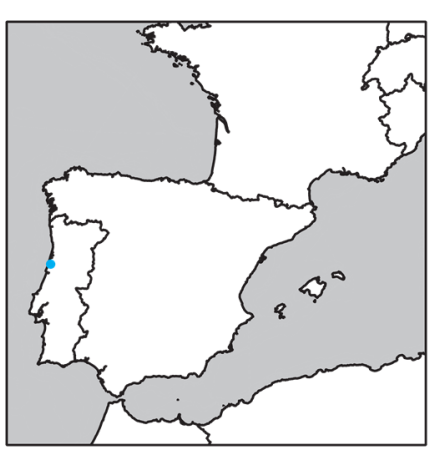

462. Ommatoiulus porathi (Verhoeff, 1893) 


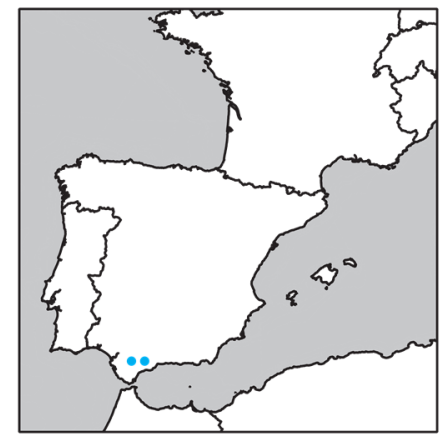

463. Ommatoiulus pseudoflagellatus Akkari \& Enghoff, 2012

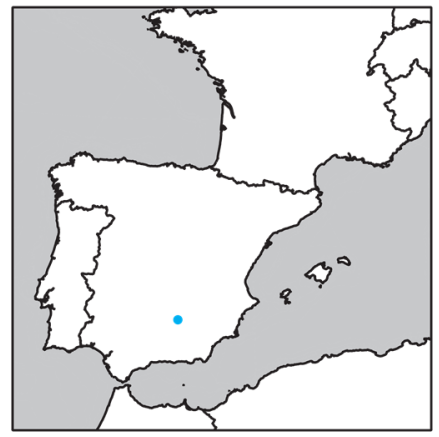

464. Ommatoiulus recueroi Akkari \& Enghoff, 2012

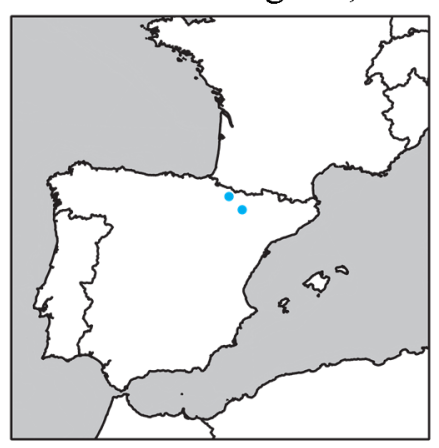

466. Ommatoiulus robustus

Ceuca, 1972

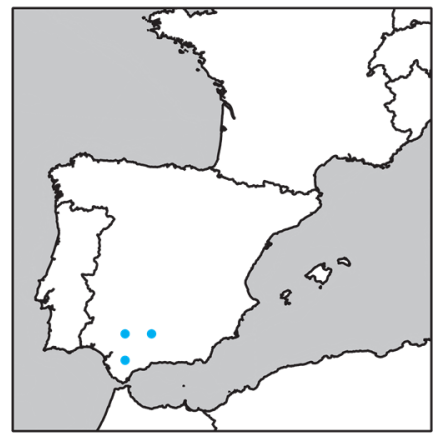

465. Ommatoiulus reipi

Akkari \& Enghoff, 2012

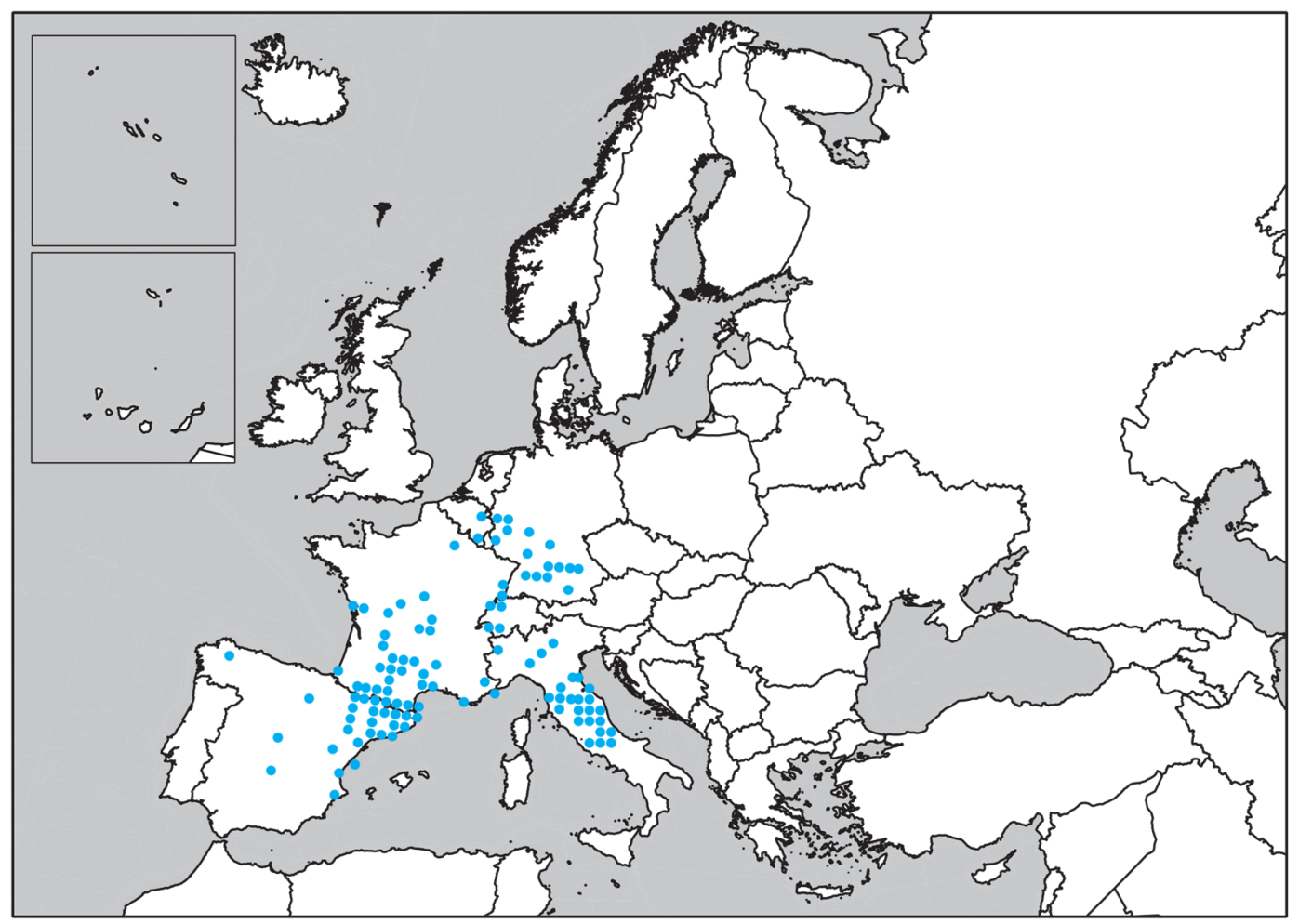

467. Ommatoiulus rutilans (C.L. Koch, 1847) 


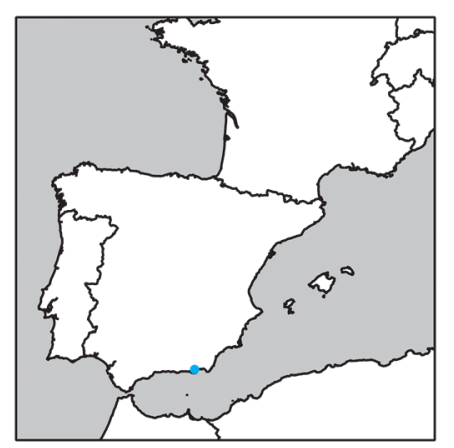

468. Ommatoiulus sabinarensis Akkari, Mauriès \& Enghoff 2012

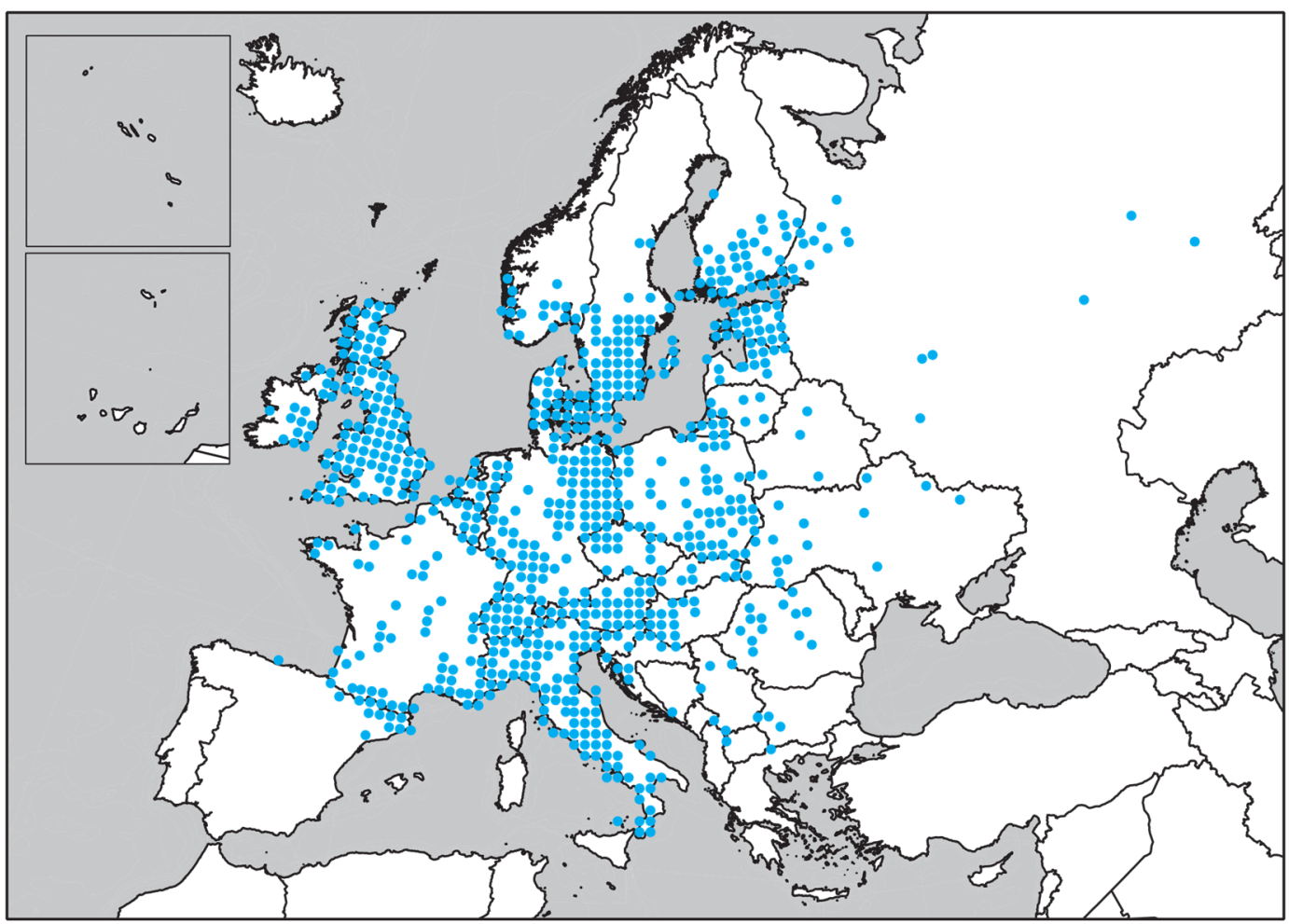

469. Ommatoiulus sabulosus (Linnaeus, 1758)

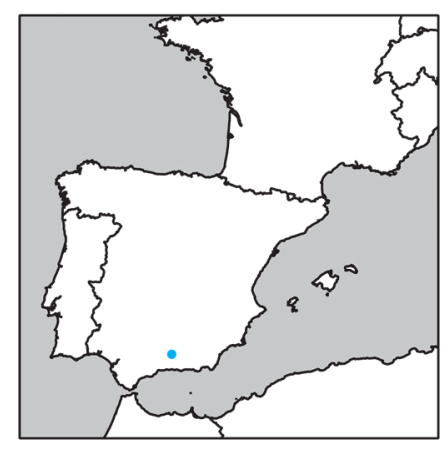

470. Ommatoiulus schubarti

Akkari \& Enghoff, 2012

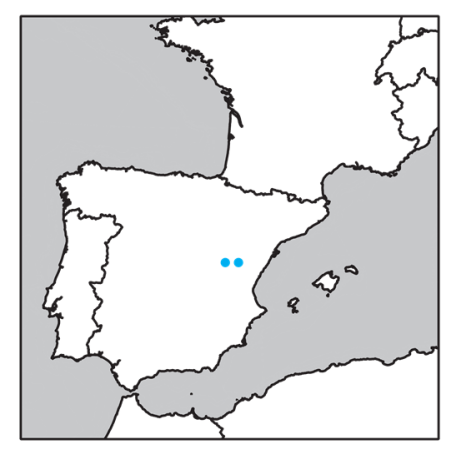

471. Ommatoiulus teruelensis

Ceuca, 1974

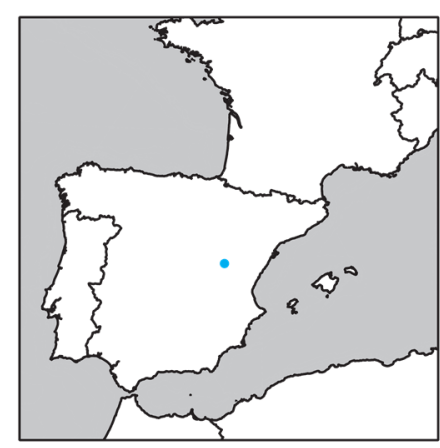

472. Ommatoiulus tridentifer

Ceuca, 1974 


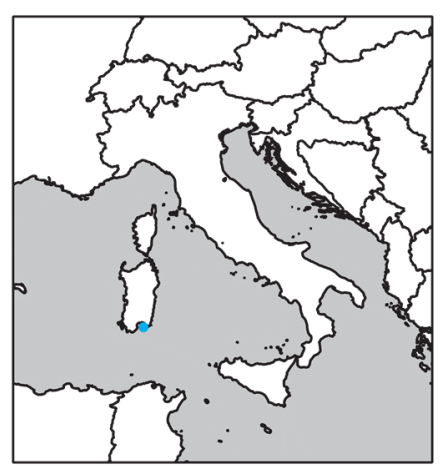

473. Ommatoiulus variolosus (Silvestri, 1898)

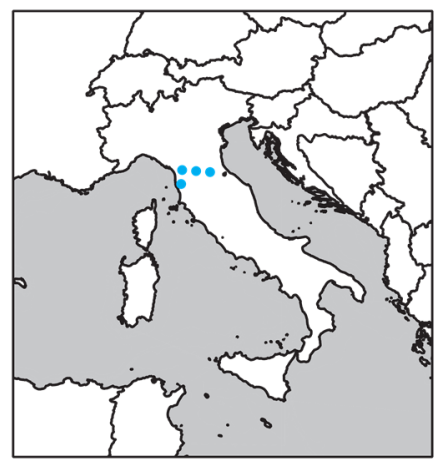

476. Ophyiulus castanearum Verhoeff, 1930

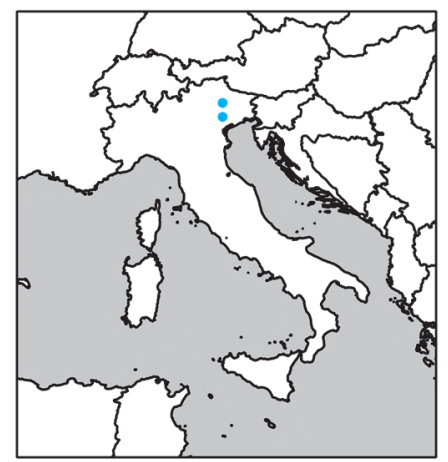

479. Ophyiulus collaris Verhoeff, 1930

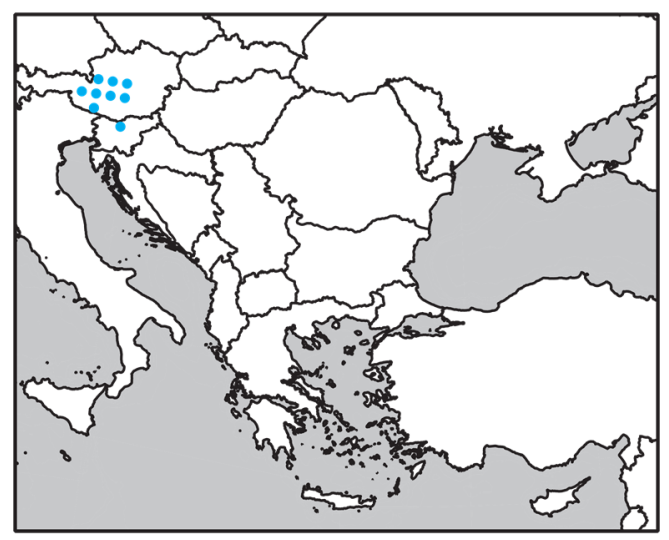

474. Ophyiulus aspidiorum (Verhoeff, 1913)

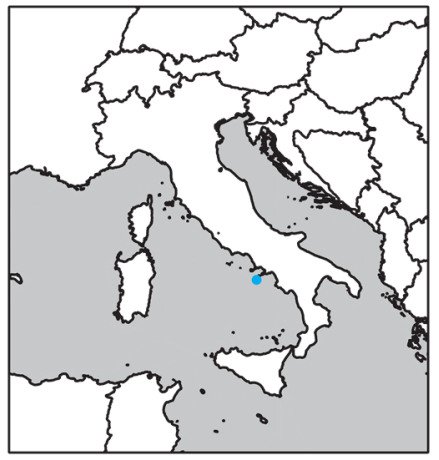

477. Ophyiulus cerii Verhoeff, 1942

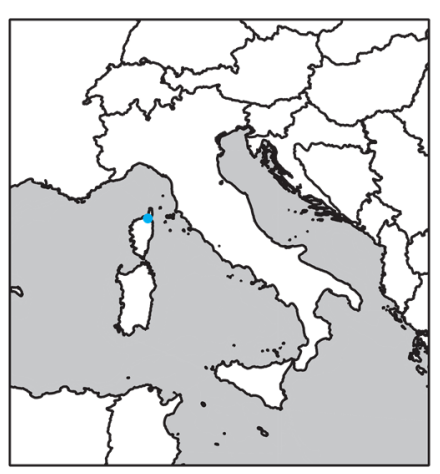

475. Ophyiulus bastiensis Verhoeff, 1943

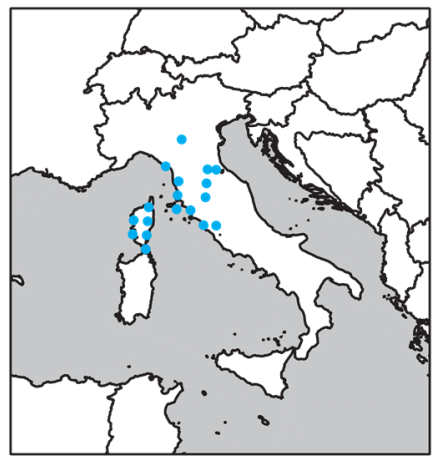

478. Ophyiulus chilopogon (Latzel, 1884)

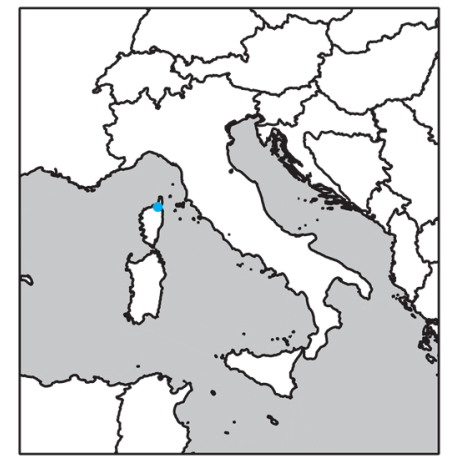

480. Ophyiulus corsicus Verhoeff, 1943

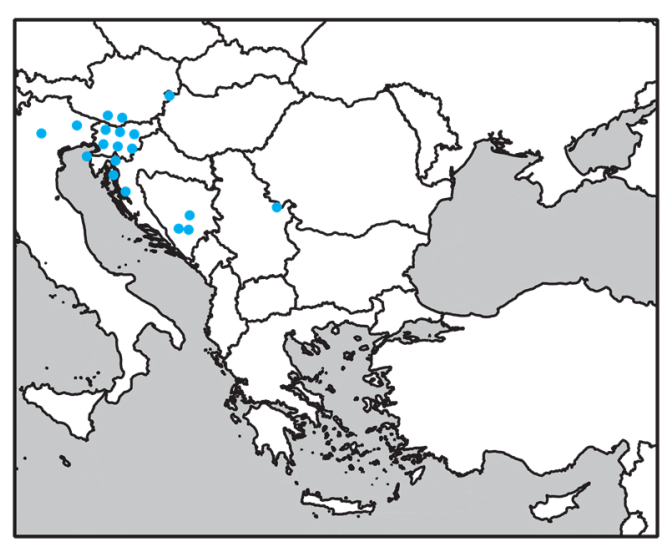

481. Ophyiulus curvipes

(Verhoeff, 1898) 


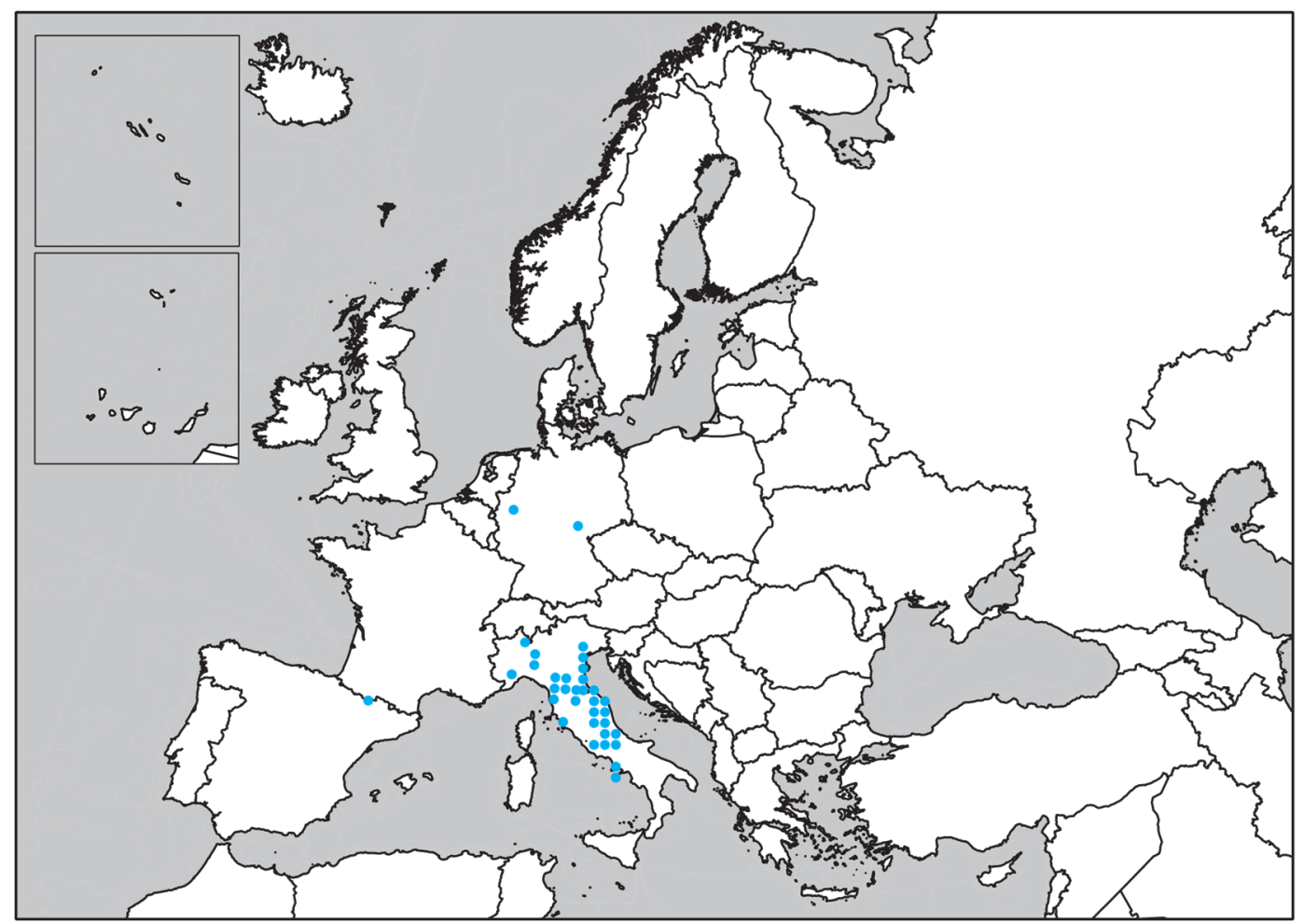

482. Ophyiulus germanicus (Verhoeff, 1896)

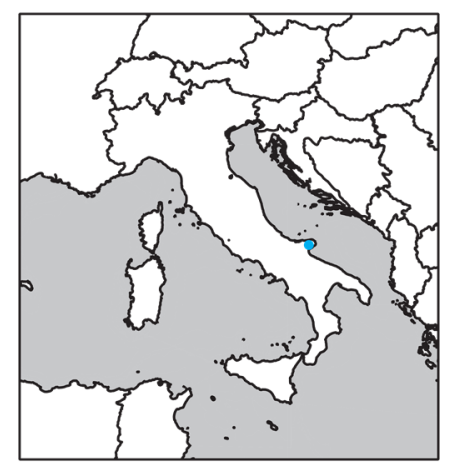

483. Ophyiulus italianus Attems, 1927

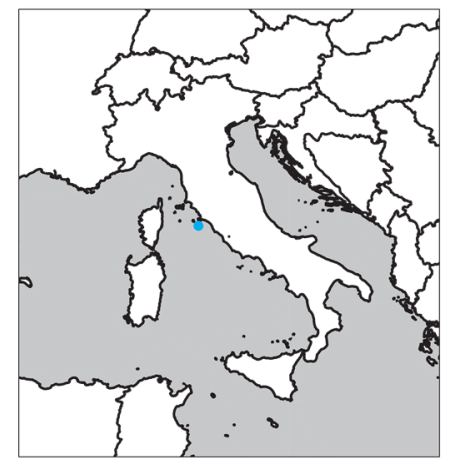

486. Ophyiulus macchiae

Verhoeff, 1930

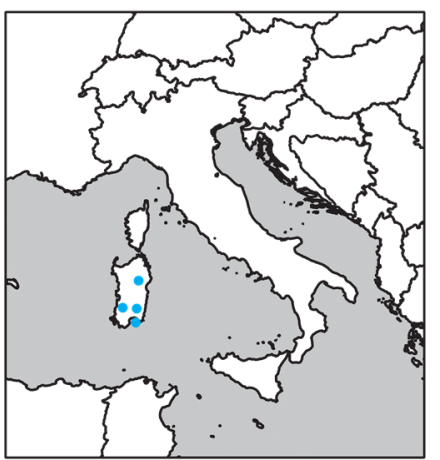

484. Ophyiulus jeekeli Strasser, 1974

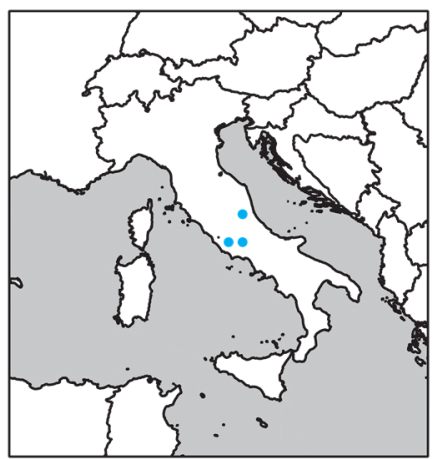

487. Ophyiulus minimus

Strasser, 1958

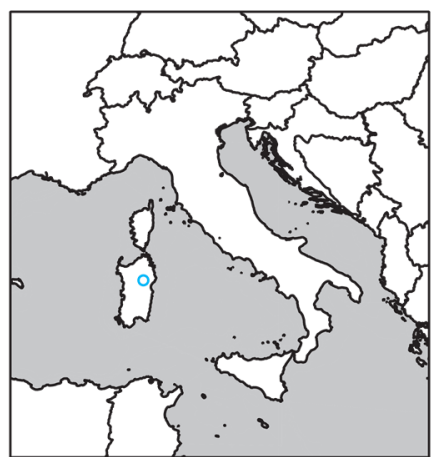

485. Ophyiulus lostiae Silvestri, 1898

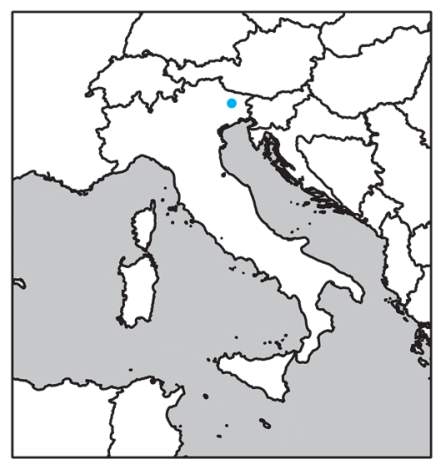

488. Ophyiulus muelleri Strasser, 1937 


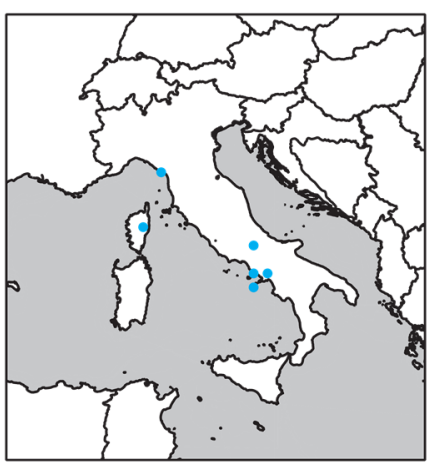

489. Ophyiulus napolitanus (Attems, 1903)

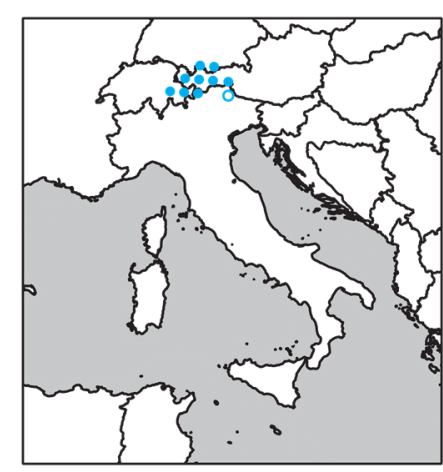

490. Ophyiulus nigrofuscus

(Verhoeff, 1894)

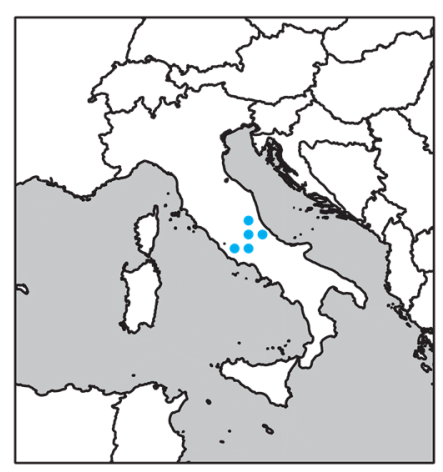

491. Ophyiulus osellai

Strasser, 1970

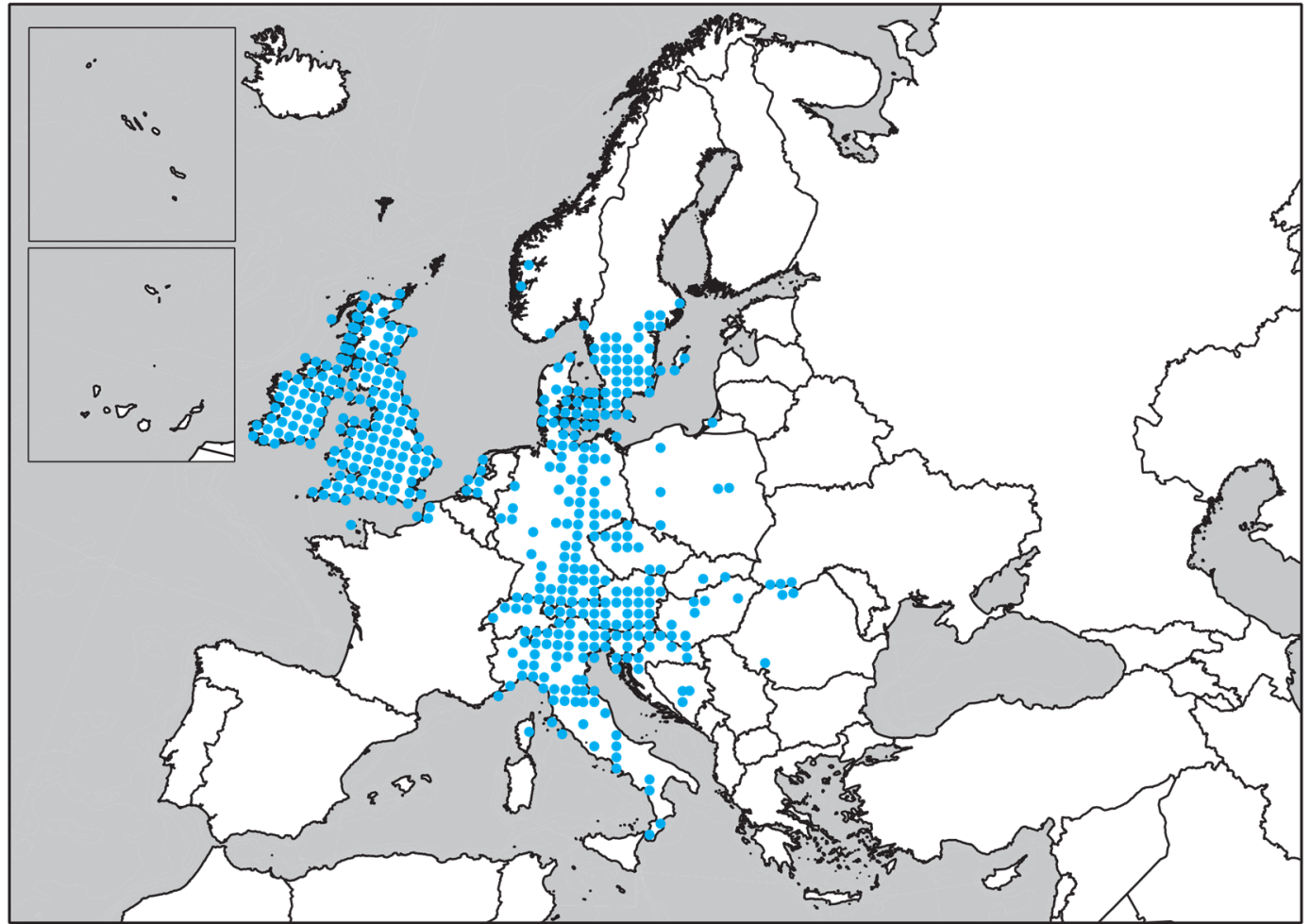

492. Ophyiulus pilosus (Newport, 1842)

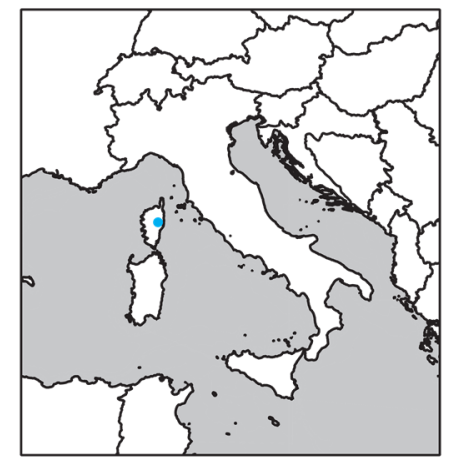

493. Ophyiulus renosensis

Mauriès, 1969

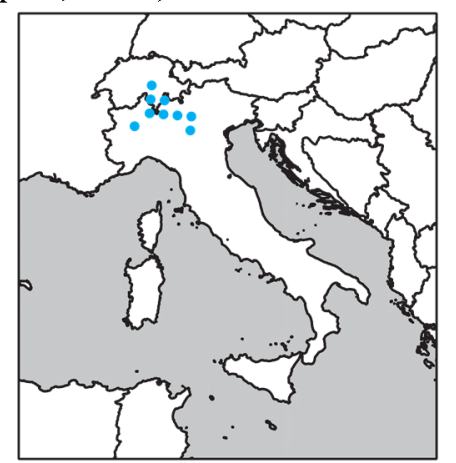

494. Ophyiulus rubrodorsalis

(Verhoeff, 1900)

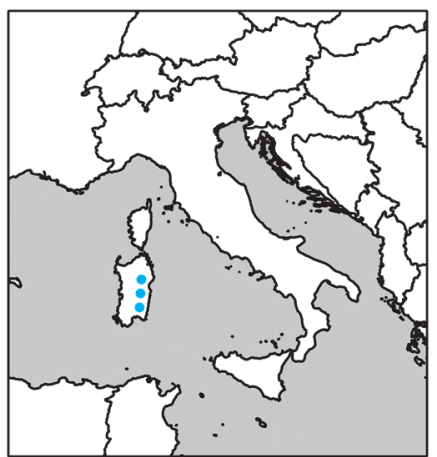

495. Ophyiulus sardus

Attems, 1927 


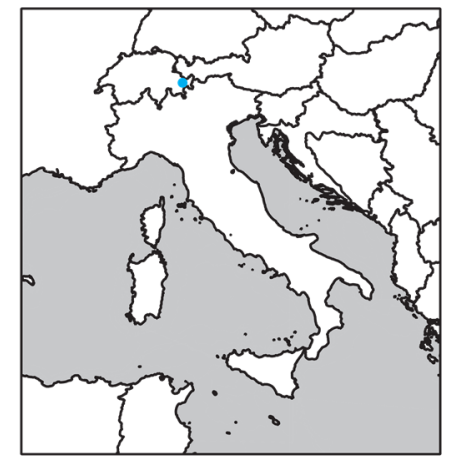

496. Ophyiulus solitarius

Bigler, 1929

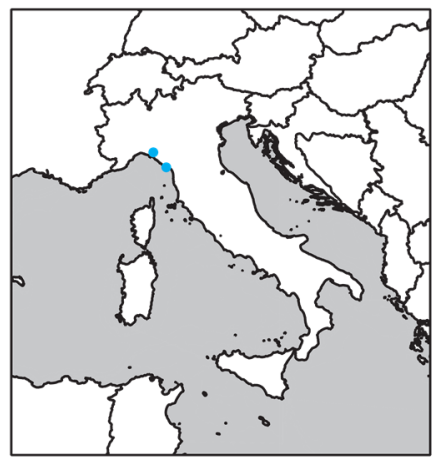

497. Ophyiulus spezianus Verhoeff, 1936

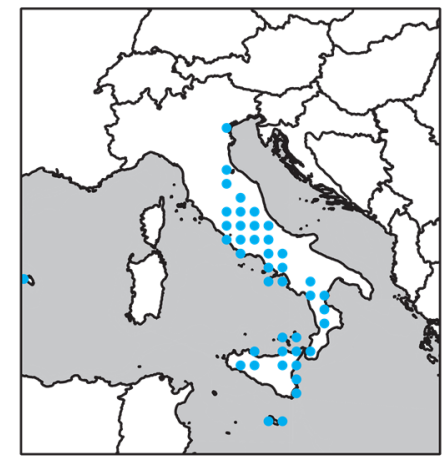

498. Ophyiulus targionii Silvestri, 1898

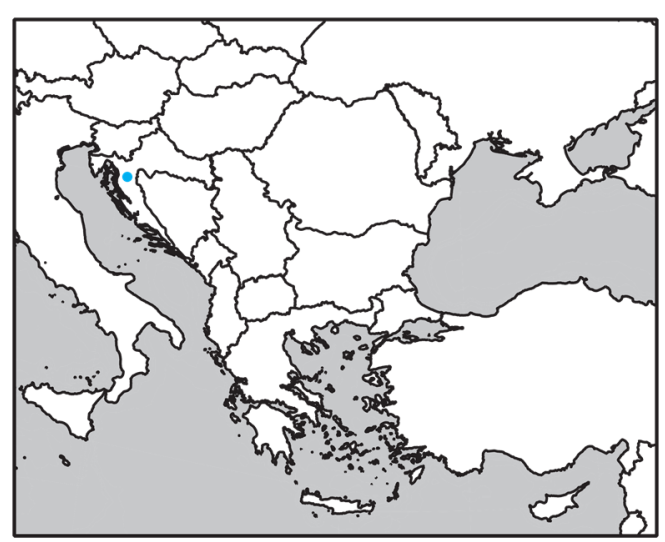

499. Ophyiulus velebiticus Attems, 1927

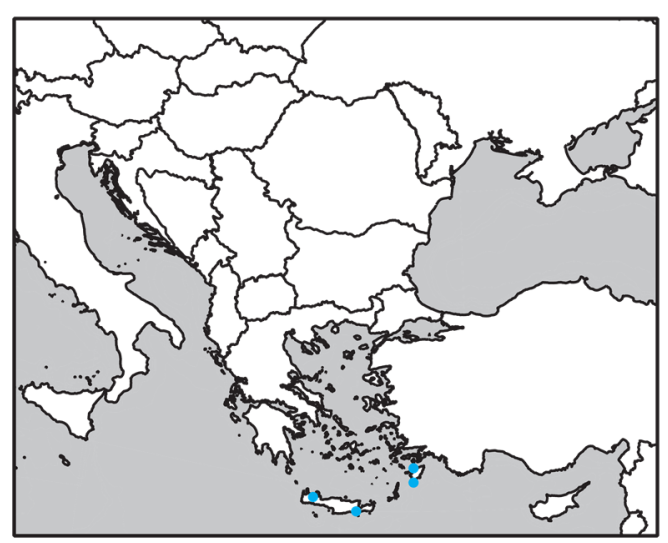

501. Pachyiulus asiaeminoris

Verhoeff, 1898

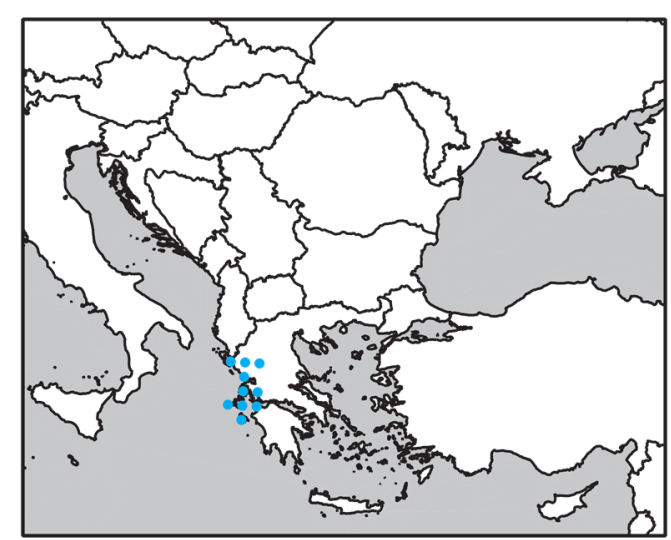

500. Pachyiulus apfelbecki Verhoeff, 1901

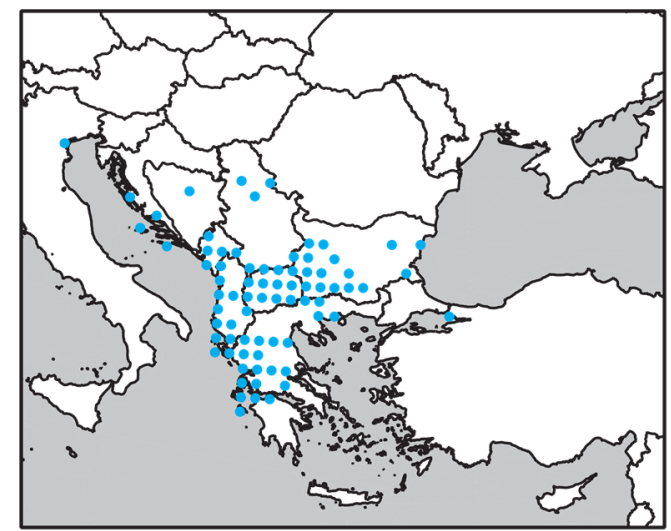

502. Pachyiulus cattarensis (Latzel, 1884) 


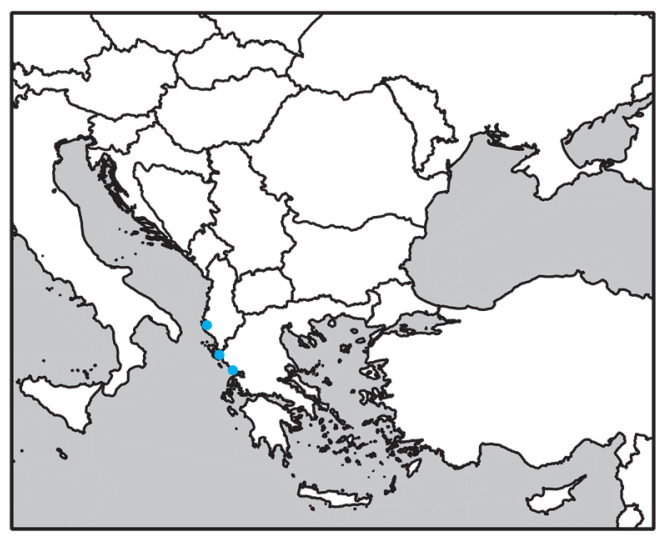

503. Pachyiulus dentiger

Verhoeff, 1901

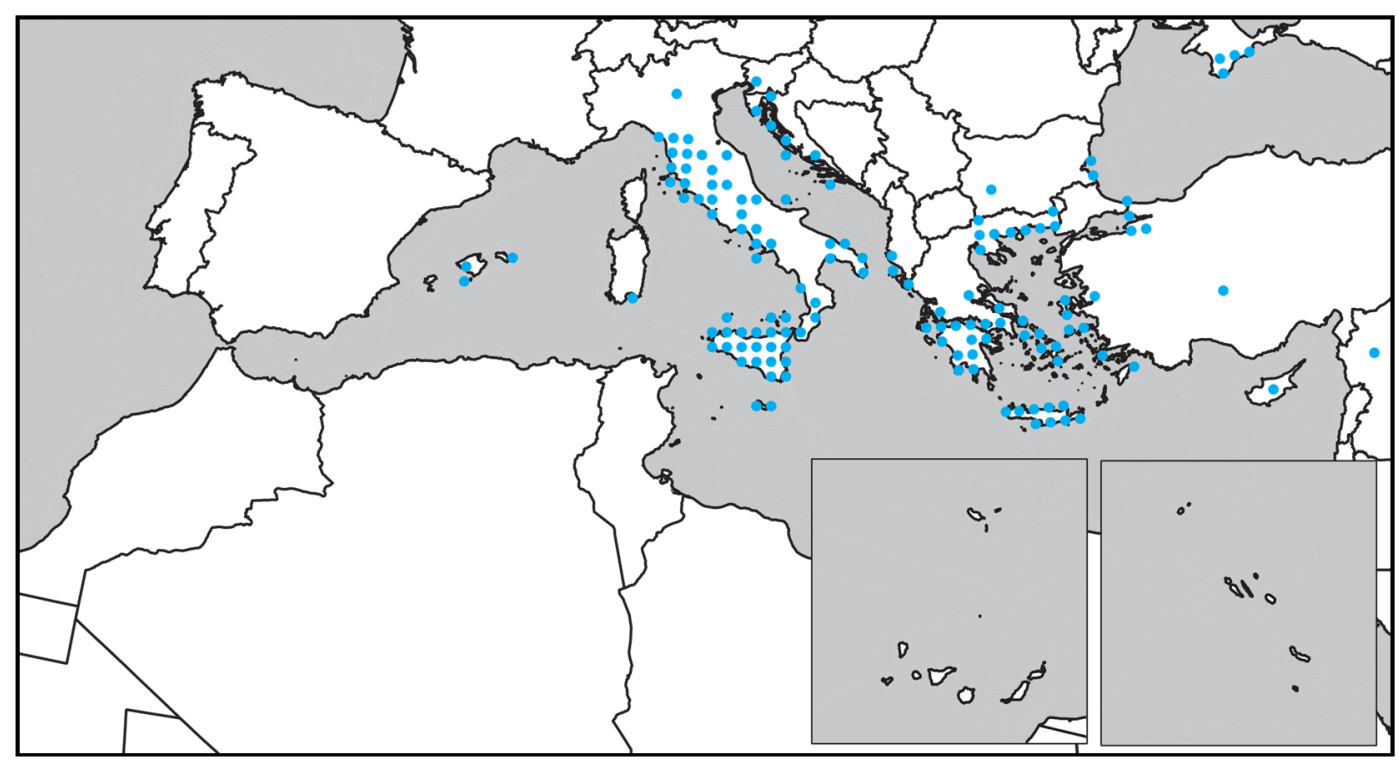

504. Pachyiulus flavipes (C.L. Koch, 1847)

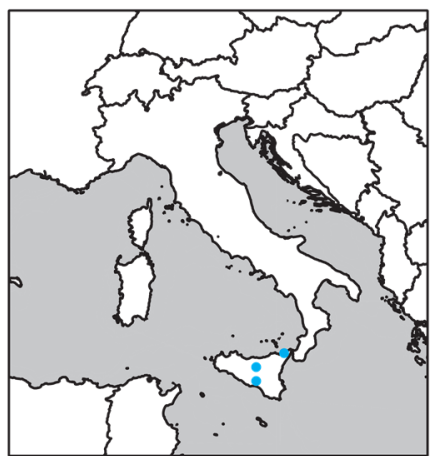

505. Pachyiulus humicola Verhoeff, 1910

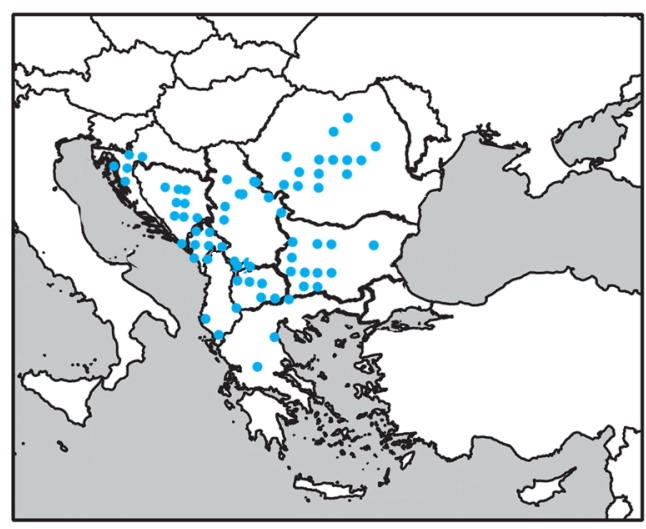

506. Pachyiulus hungaricus Verhoeff, 1910 


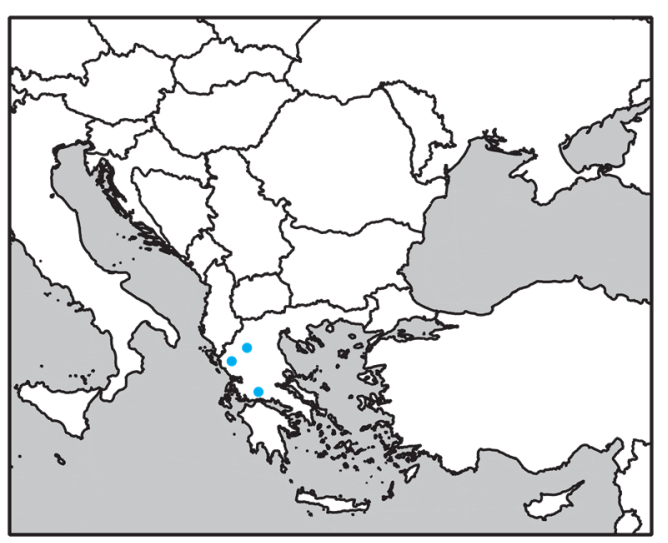

507. Pachyiulus marmoratus Verhoeff, 1901

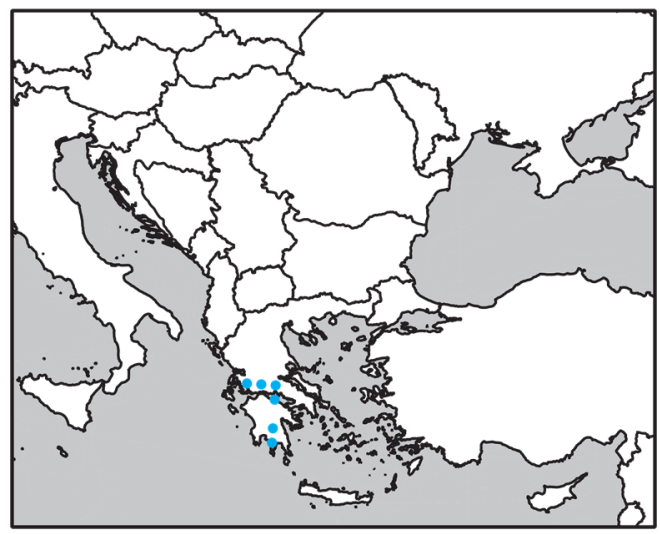

510. Pachyiulus speciosus

Verhoeff, 1900

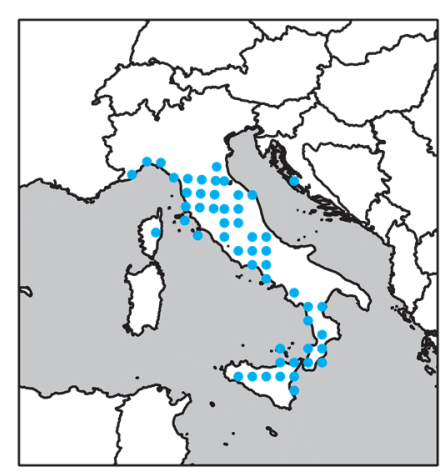

508. Pachyiulus oenologus (Berlese, 1885)

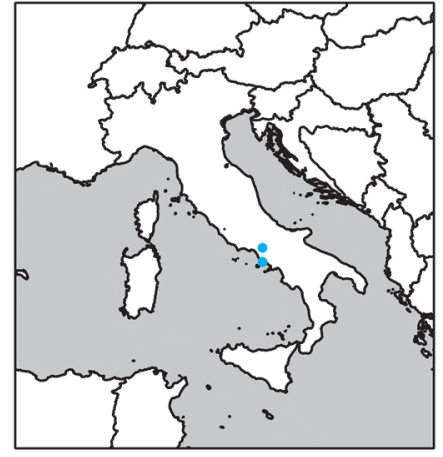

509. Pachyiulus silvestrii Verhoeff, 1923

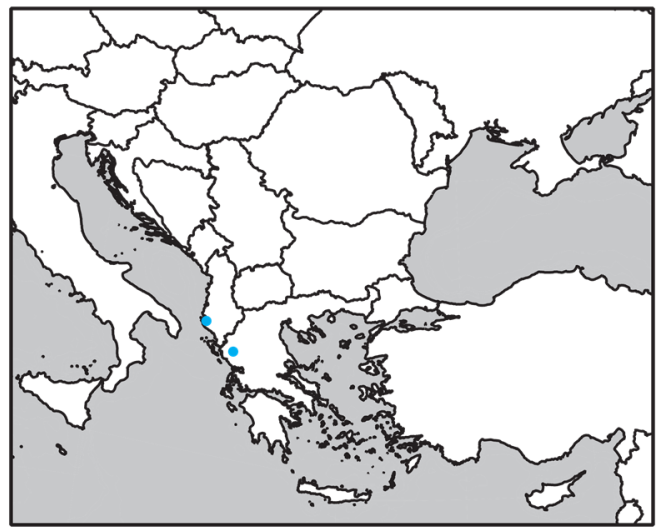

511. Pachyiulus valonensis Verhoeff, 1901

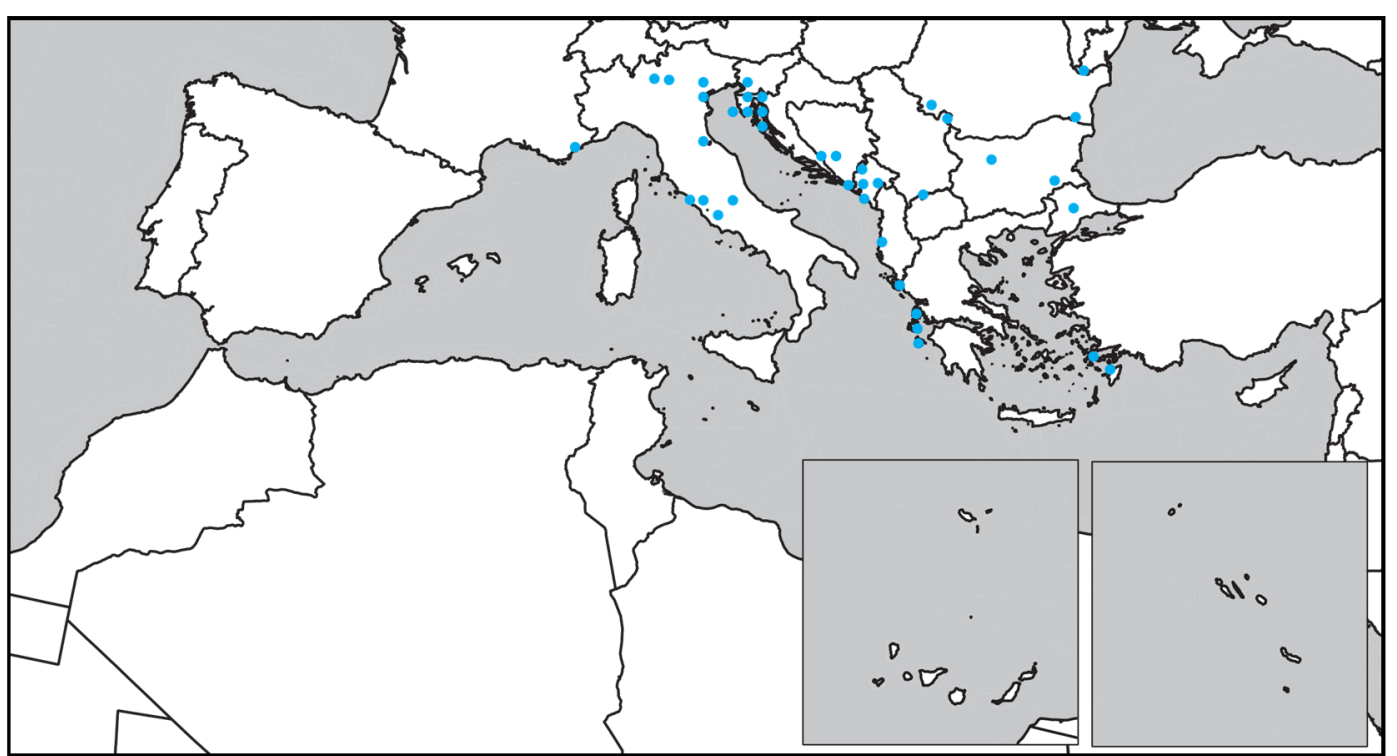

512. Pachyiulus varius (Fabricius, 1781) 


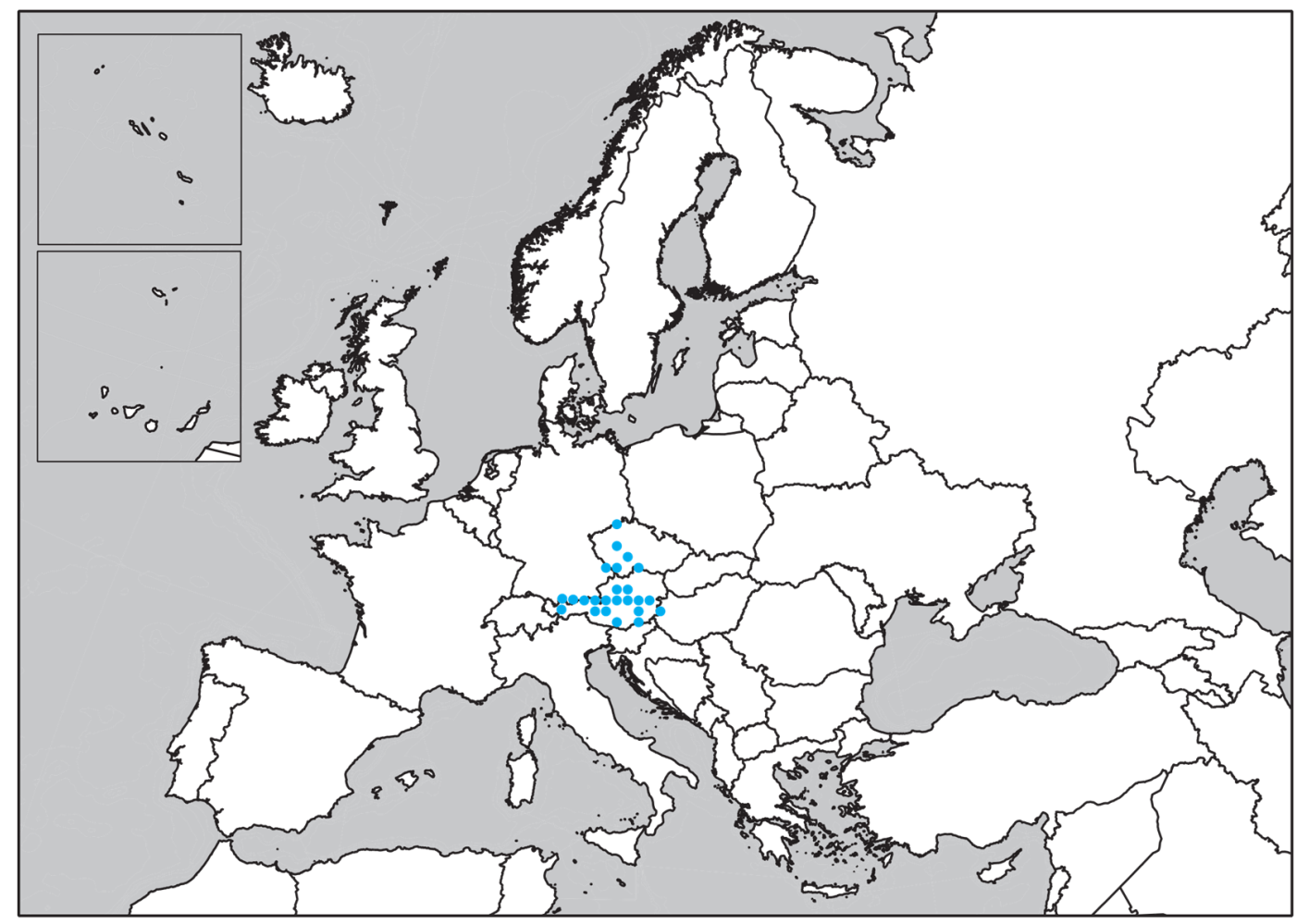

513. Pachypodoiulus eurypus (Attems, 1895)

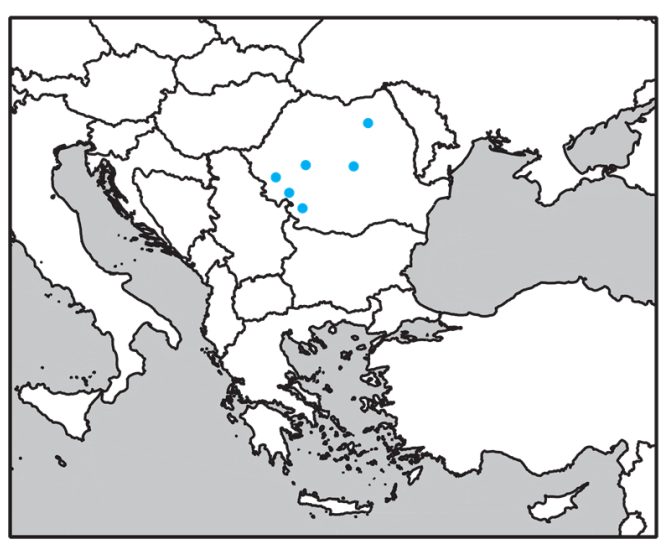

514. Parastenophyllum frondicola

(Verhoeff, 1899)

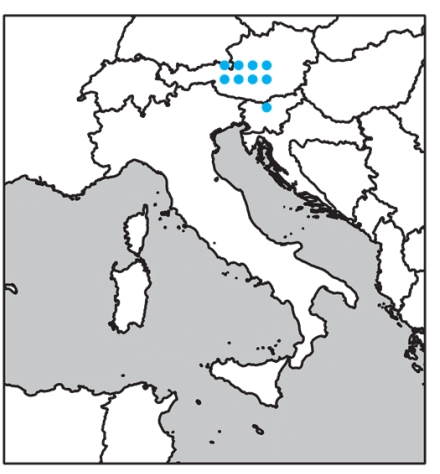

515. Pteridoiulus aspidiorum Verhoeff, 1913 


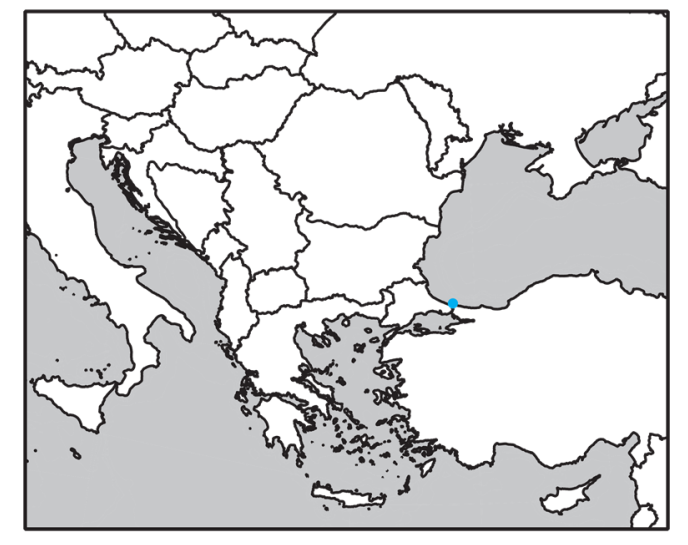

516. Rhamphidoiulus bujukdurensis Attems, 1905

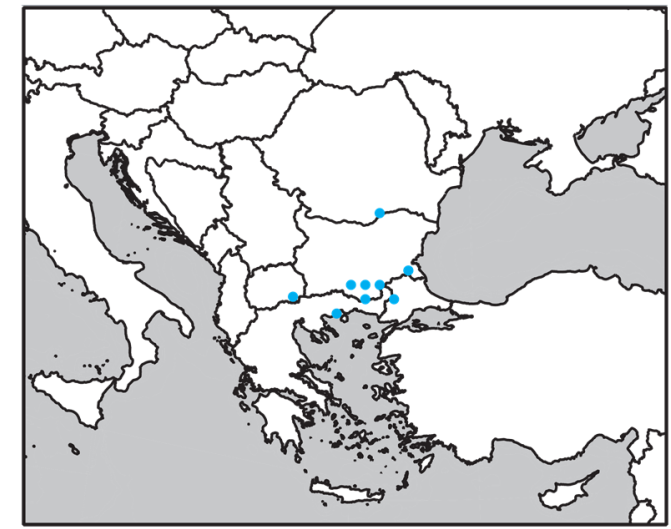

517. Rhodopiella beroni (Strasser, 1966)

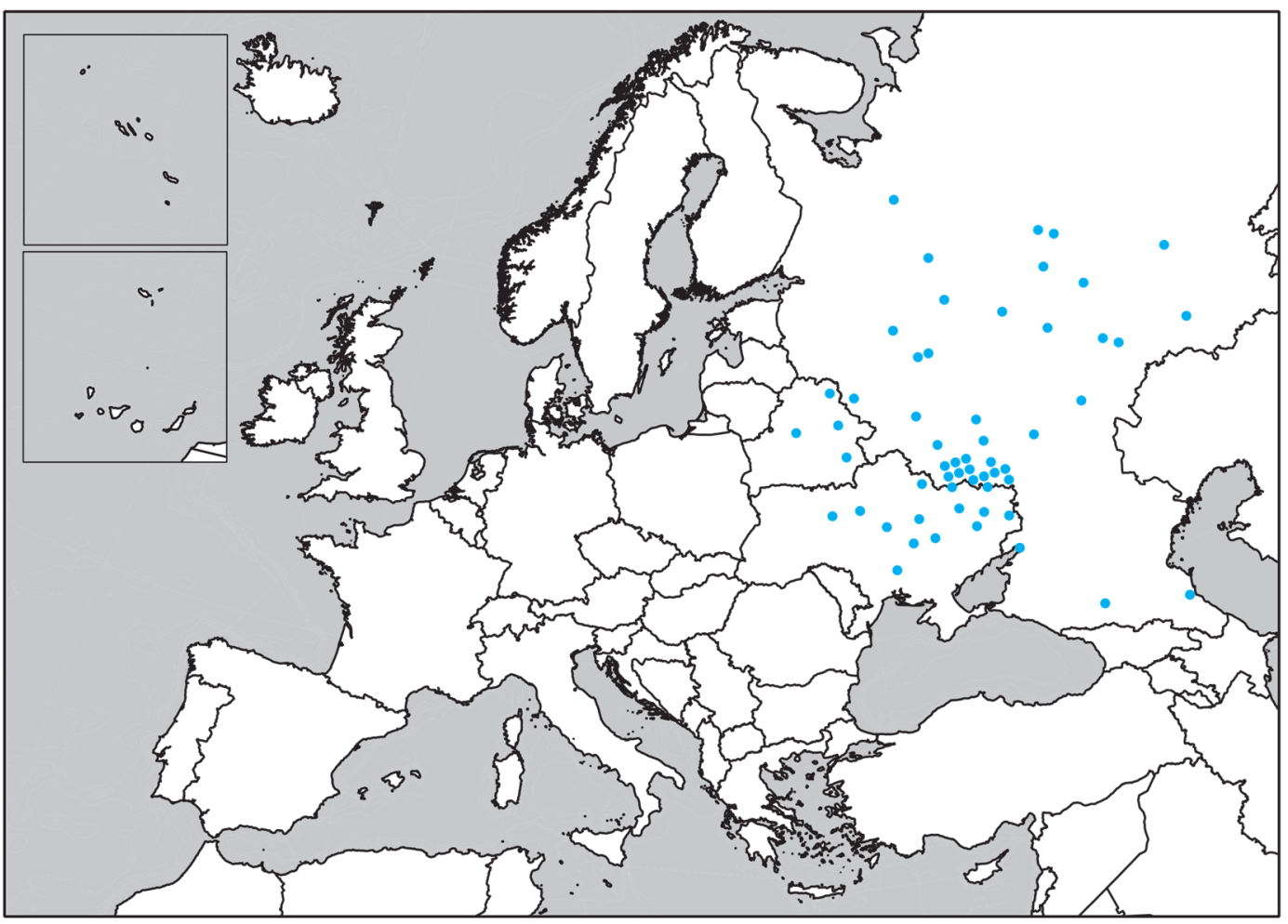

518. Rossiulus kessleri (Lohmander, 1927) 


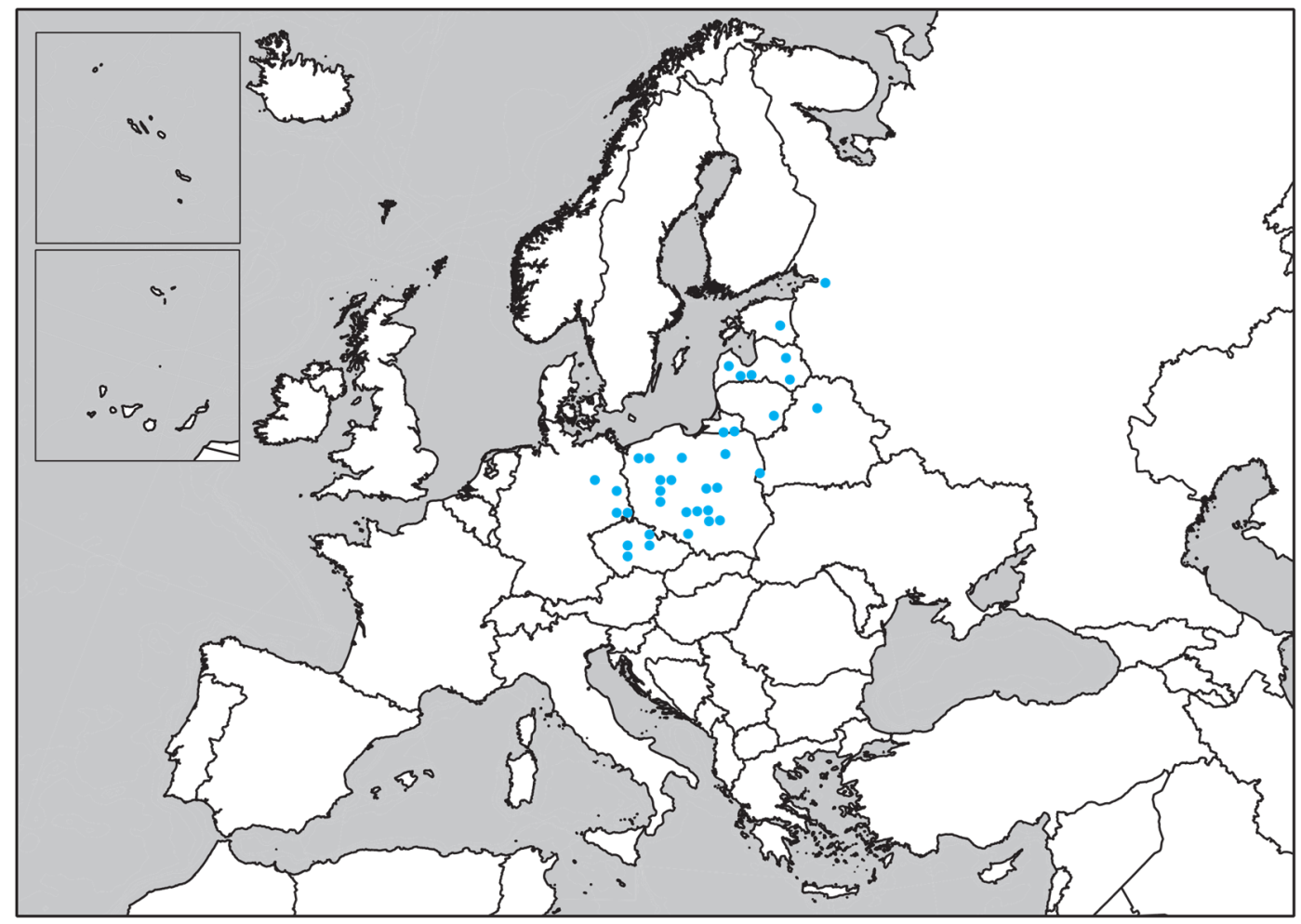

519. Rossiulus vilnensis (Jawłowski, 1925)

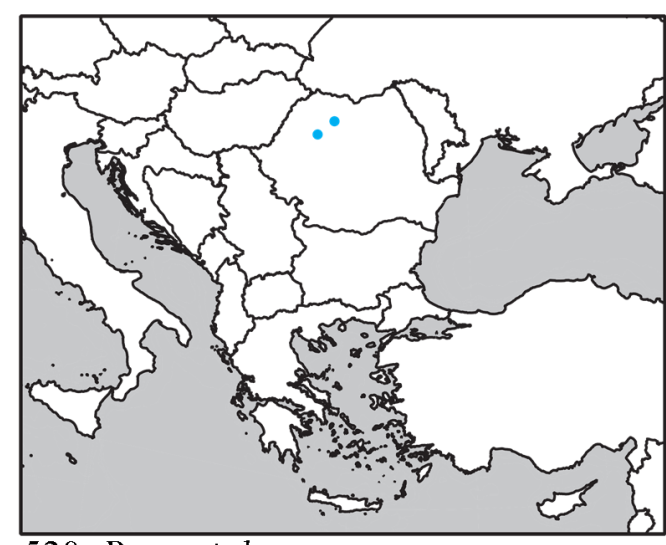

520. Rumaniulus mammosus

Attems, 1927

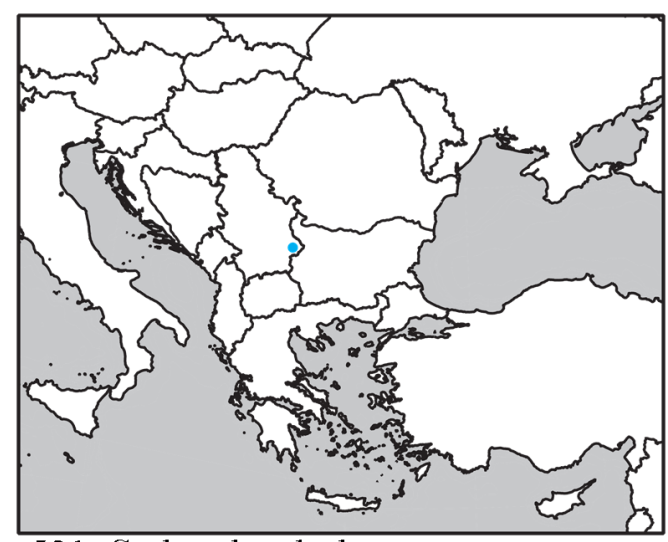

521. Serboiulus deelemani

Strasser, 1971 


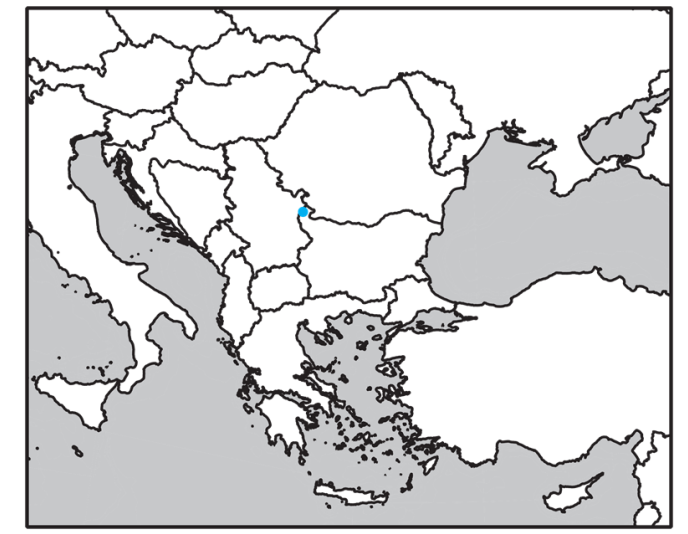

522. Serboiulus kresnik

Makarov, 2013

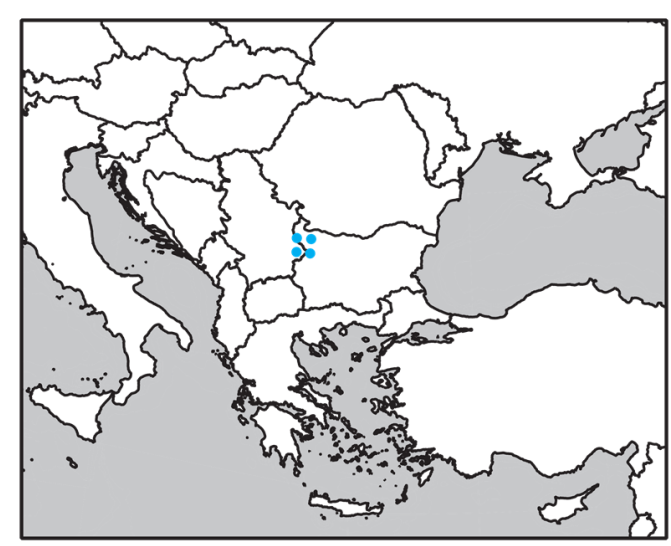

524. Serboiulus spelaeophilus

Gulička, 1967

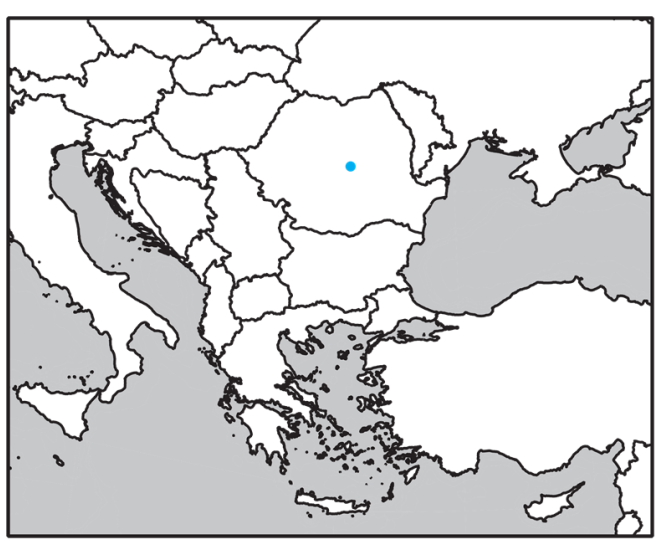

526. Stenophyllum primitivum

Verhoeff, 1897

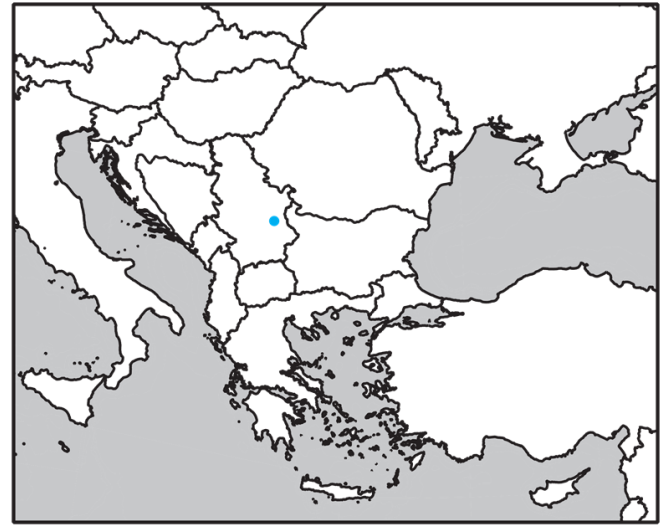

523. Serboiulus lucifugus

Strasser, 1962

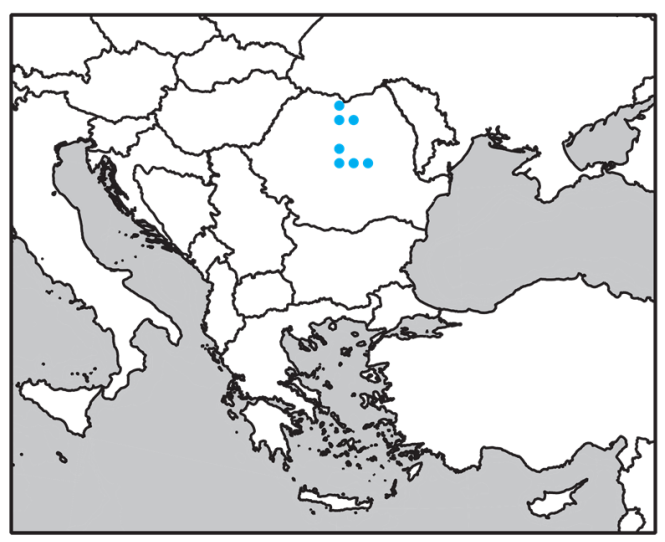

525. Stenophyllum hermannimuelleri Verhoeff, 1897

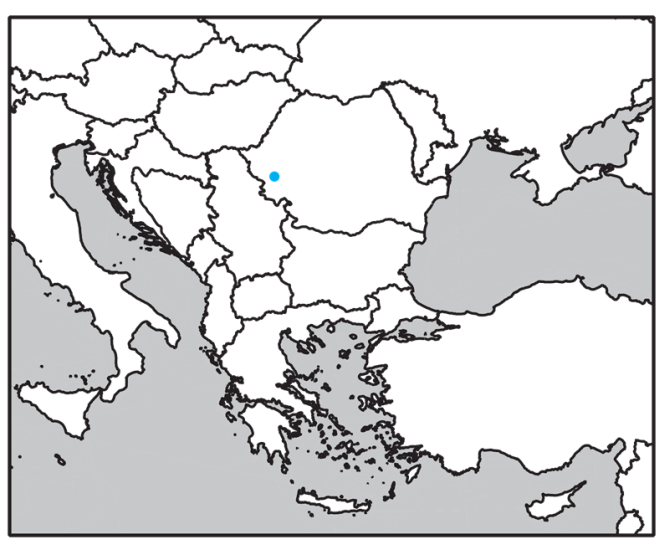

527. Stenophyllum semenicense

Ceuca, 1989 


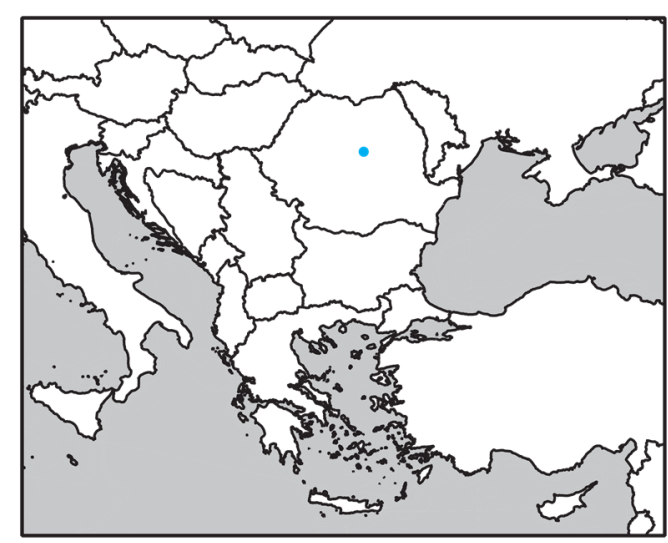

528. Stenophyllum tabacarui Vanoaica, 2003

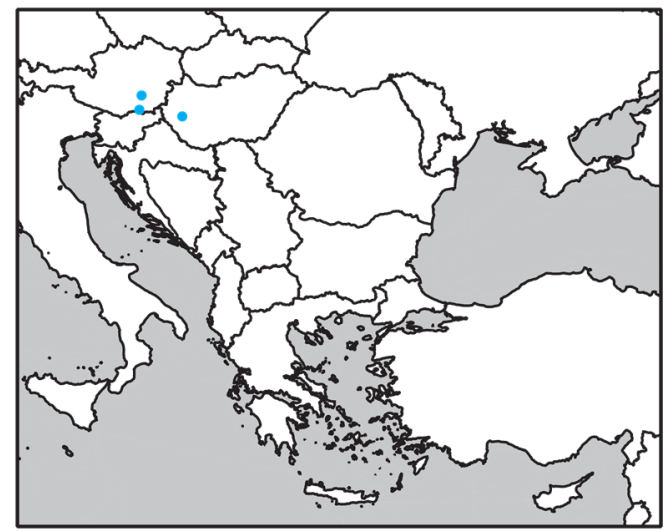

530. Styrioiulus styricus (Verhoeff, 1896)

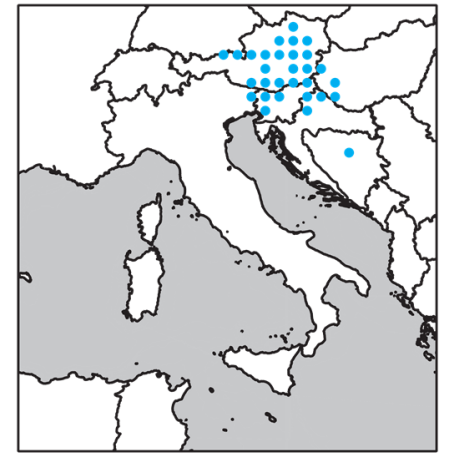

529. Styrioiulus pelidnus (Latzel, 1884)

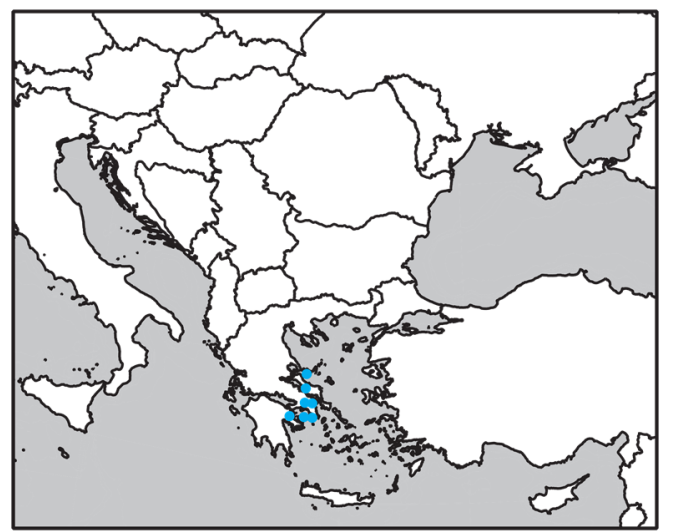

531. Symphyoiulus impartitus (Karsch, 1888)

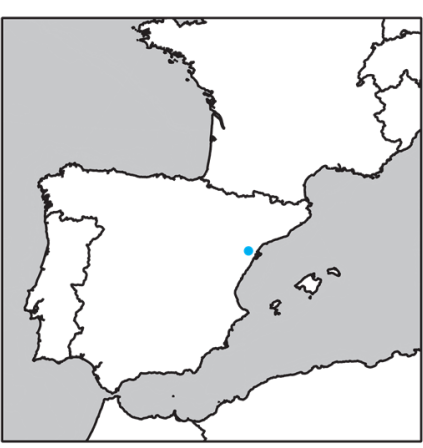

532. Syniulus bolivari

(Ceuca, 1971)

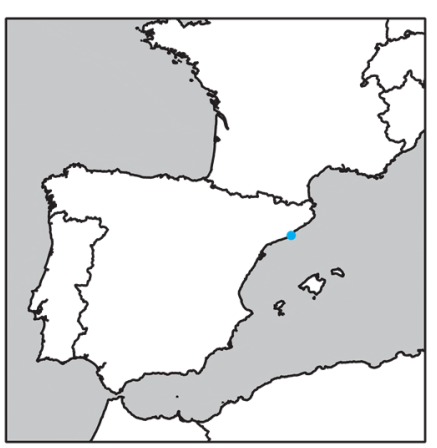

533. Syniulus lagari

(Ceuca, 1971)

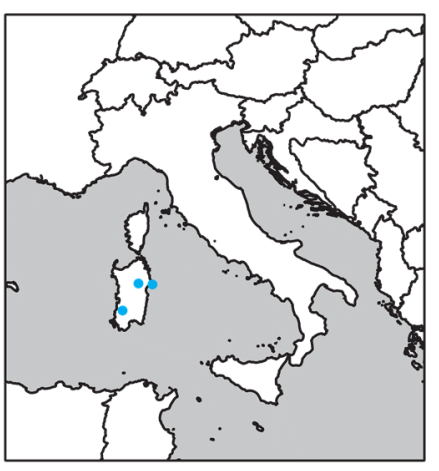

534. Syniulus puddui

Strasser, 1974 
535. Syrioiulus andreevi

Mauriès, 1984
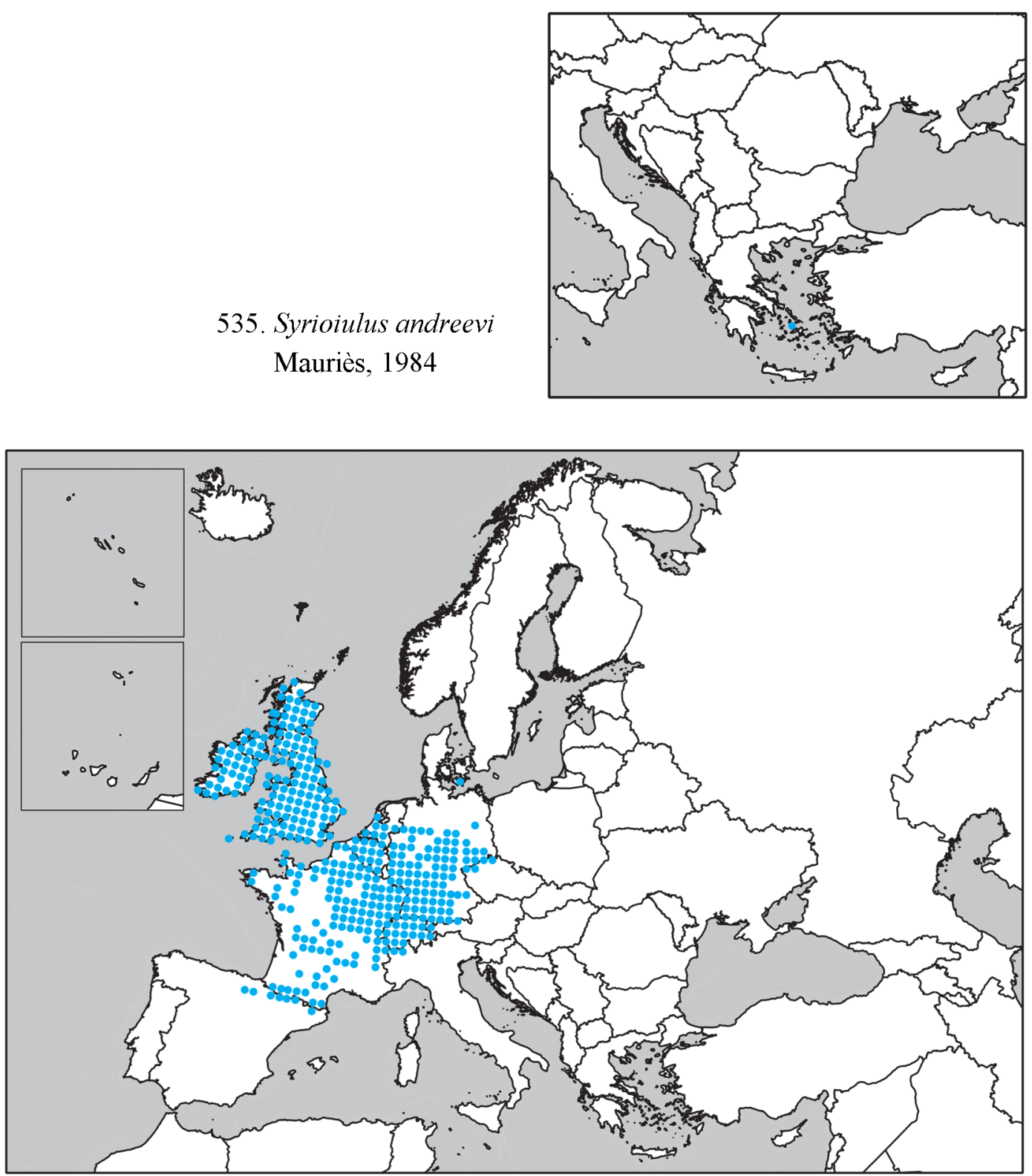

536. Tachypodoiulus niger (Leach, 1814)

537. Telsonius nycteridonis Strasser, 1976

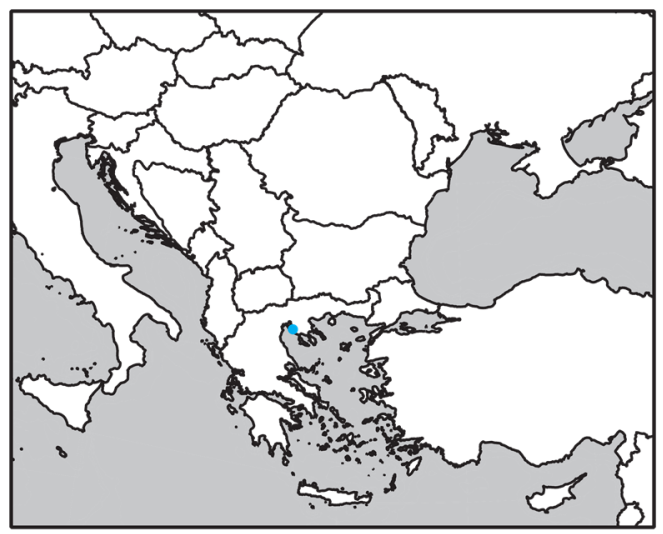




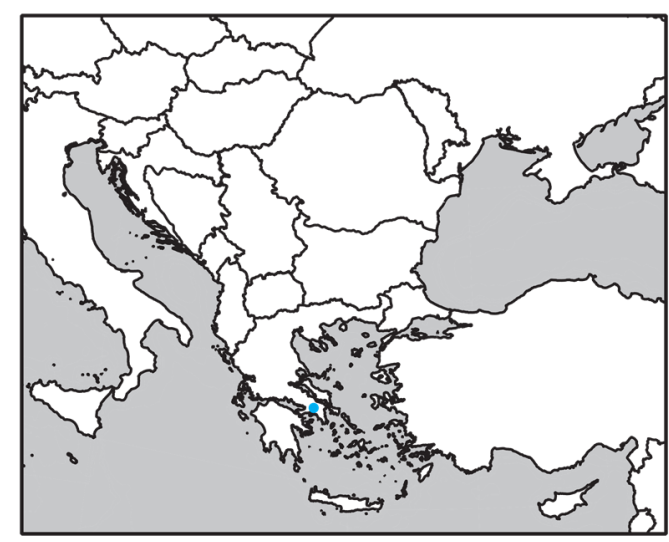

538. Titanophyllum spiliarum

Akkari, Stoev \& Enghoff, 2011

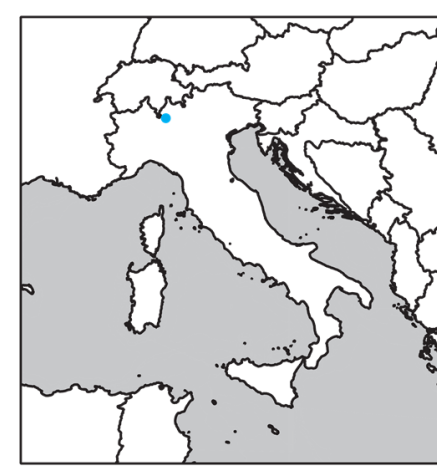

539. Trogloiulus binii Enghoff, 1985

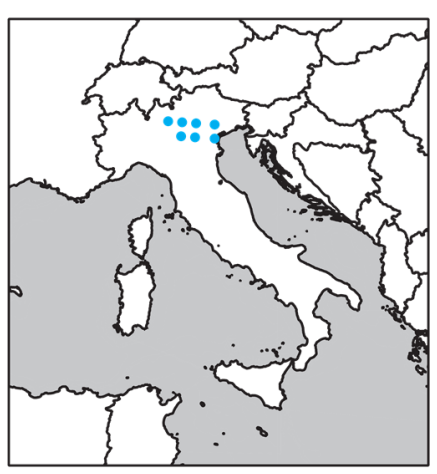

540. Trogloiulus boldorii Manfredi, 1940

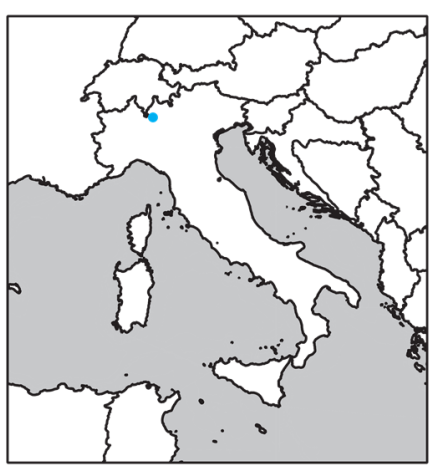

541. Trogloiulus comensis Strasser, 1977

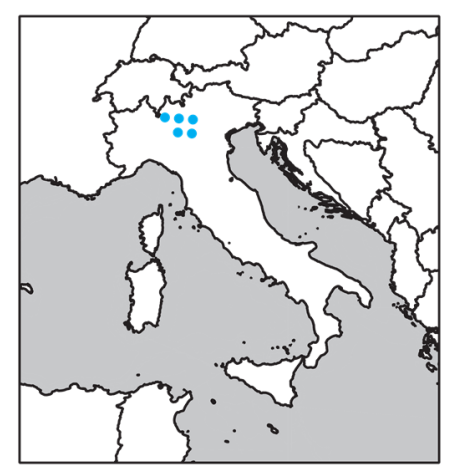

544. Trogloiulus mirus

Manfredi, 1931

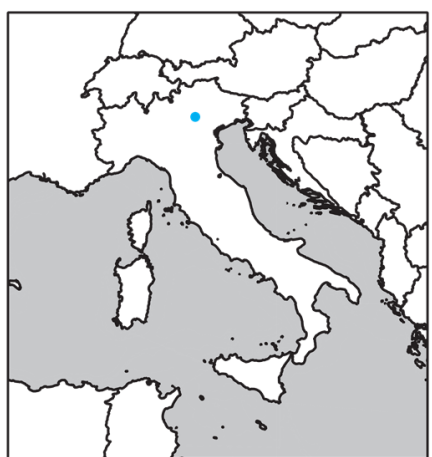

542. Trogloiulus concii

Manfredi, 1948

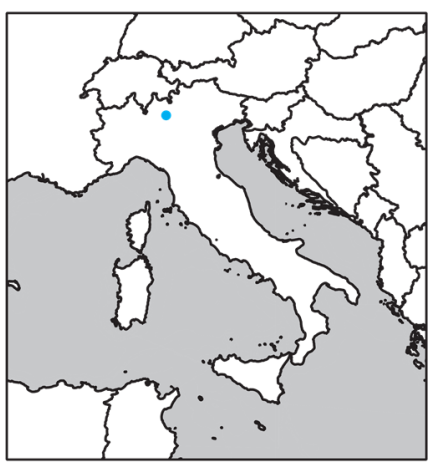

545. Trogloiulus osellai

Strasser, 1977

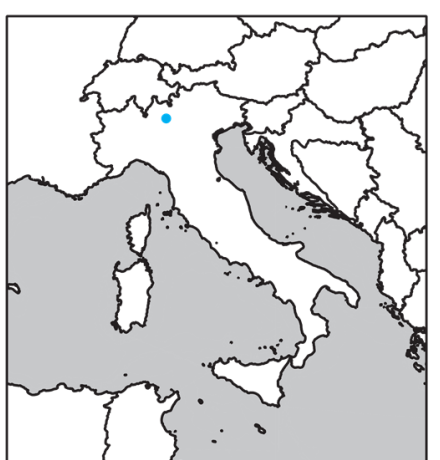

543. Trogloiulus minimus Manfredi, 1935

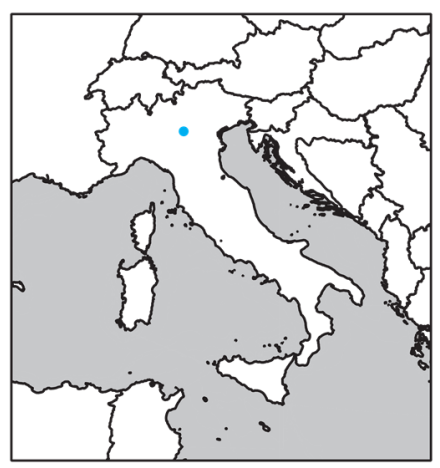

546. Trogloiulus vailatii Strasser, 1978 


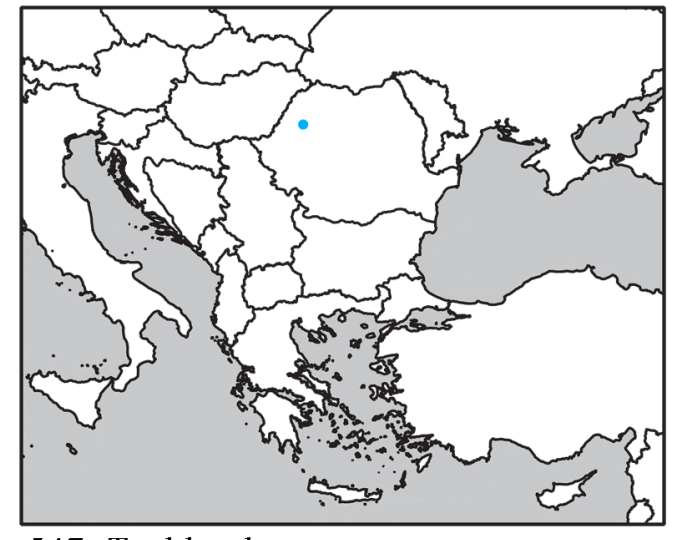

547. Typhloiulus acutunguis

Ceuca, 1979

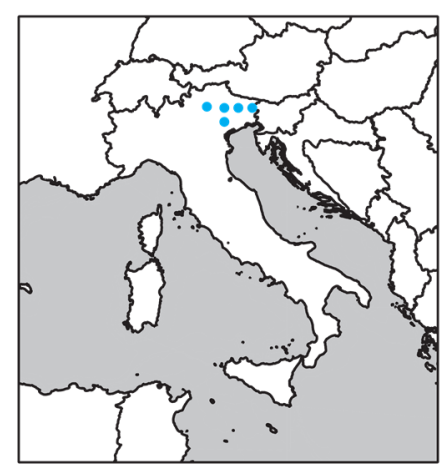

549. Typhloiulus ausugi

Manfredi, 1953

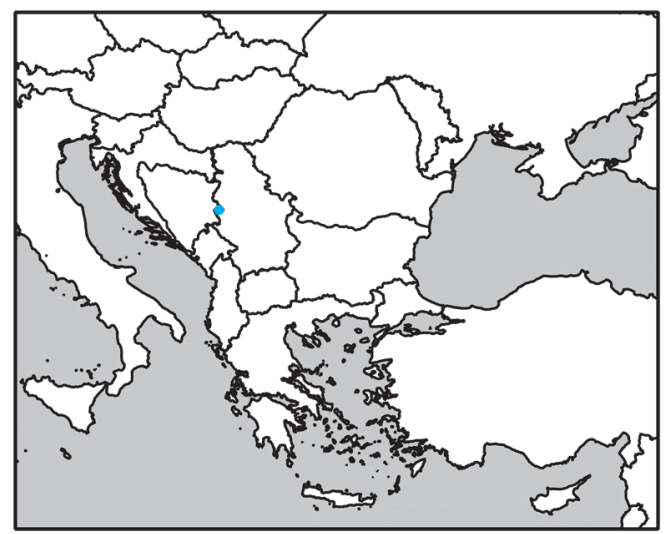

551. Typhloiulus bosniensis

Strasser, 1966

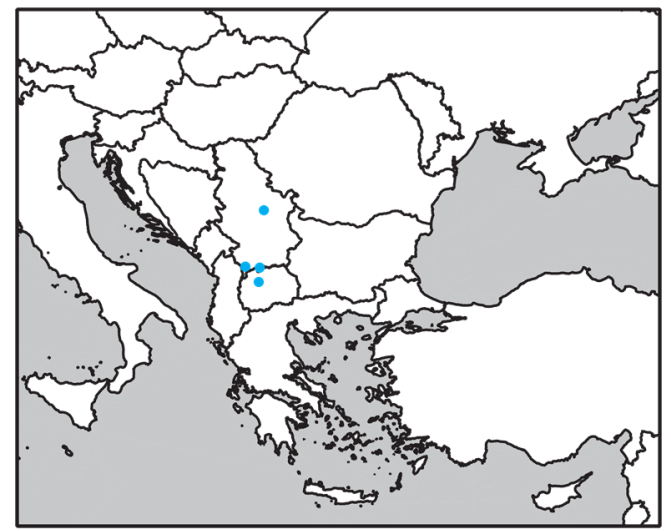

548. Typhloiulus albanicus Attems, 1929

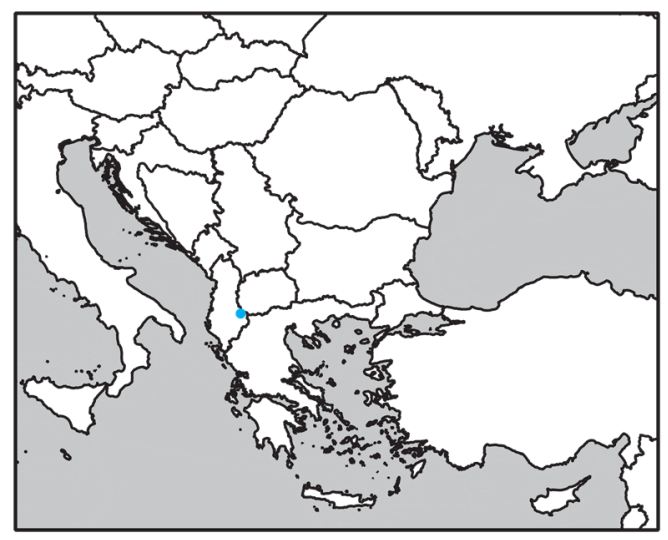

550. Typhloiulus beroni

Mauriès, Golovatch \& Stoev, 1997

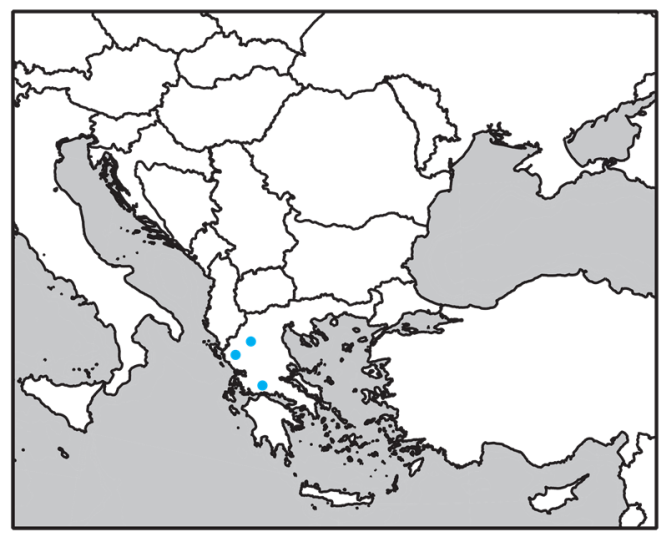

552. Typhloiulus bureschi

Verhoeff, 1926 


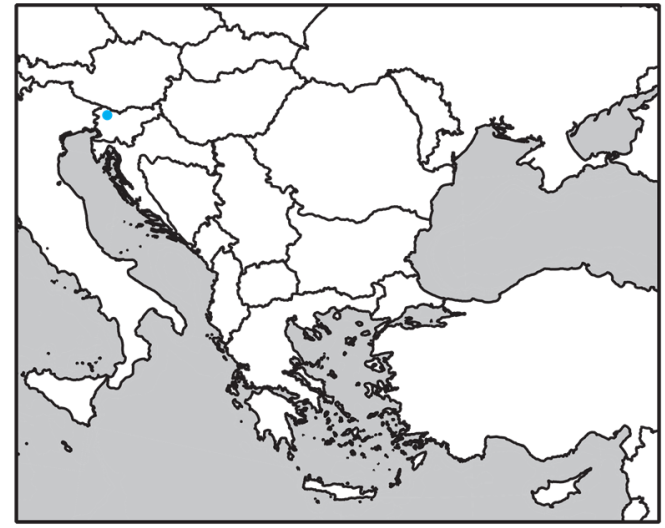

553. Typhloiulus carniolensis

Strasser, 1940

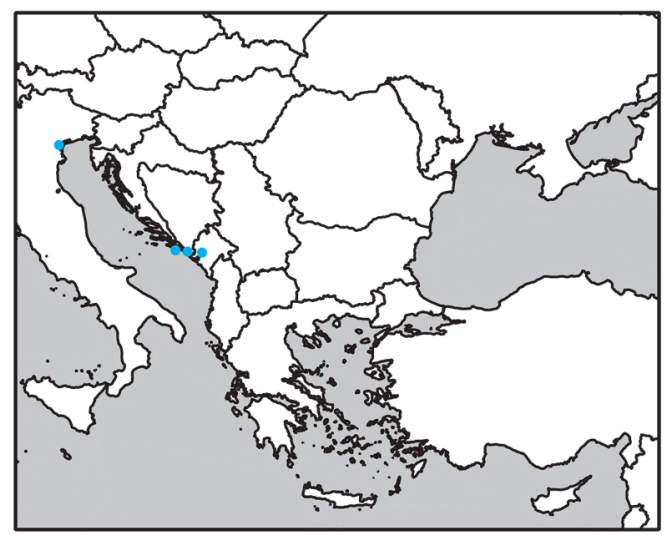

555. Typhloiulus ganglbaueri

(Verhoeff, 1898)

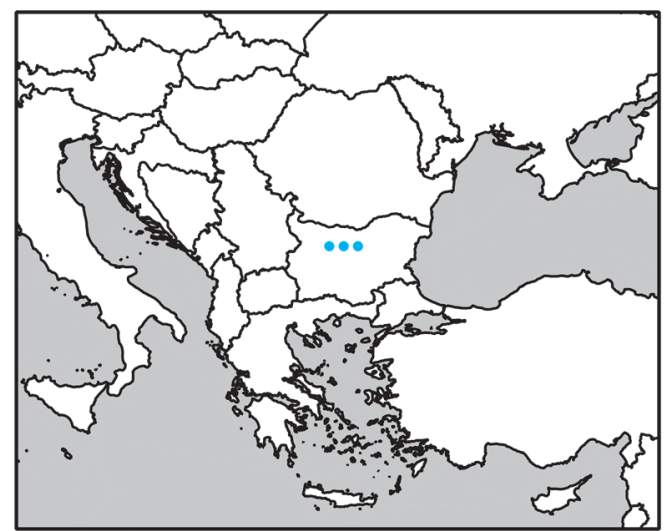

557. Typhloiulus georgievi

Strasser, 1962

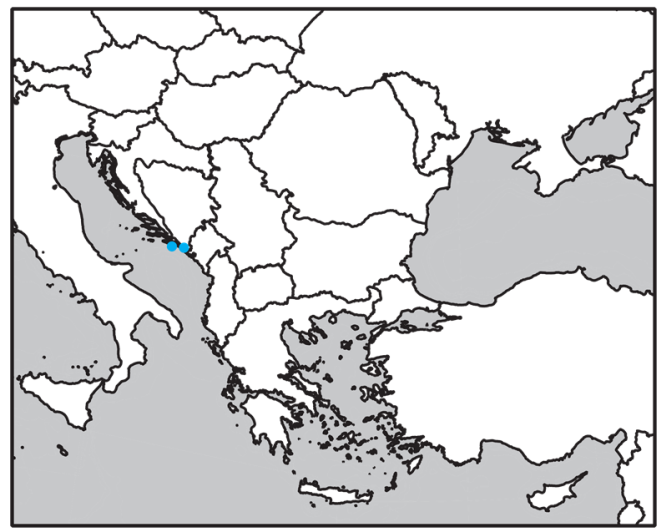

554. Typhloiulus edentulus

Attems, 1951

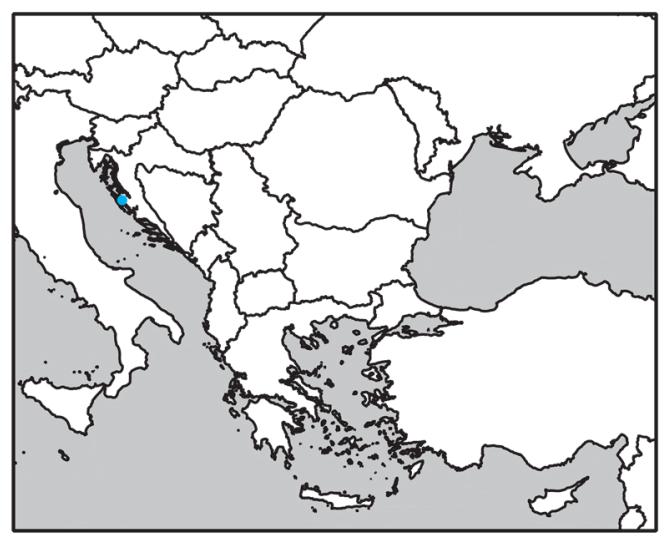

556. Typhloiulus gellianae

Makarov \& Rađa, 2008

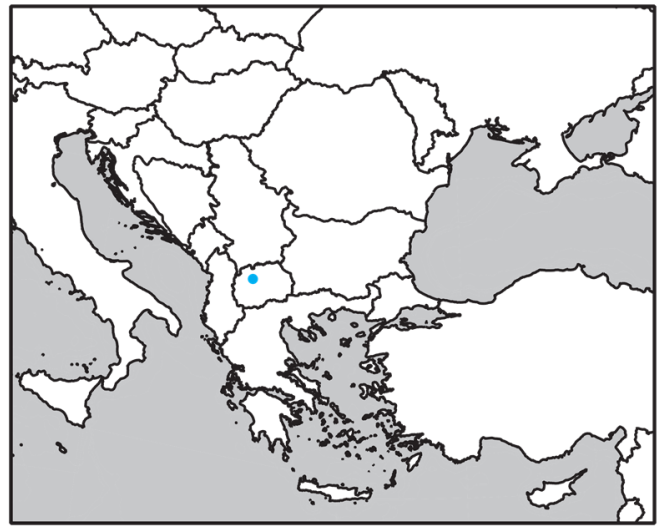

558. Typhloiulus giganteus

Curčić \& Makarov, 2002 


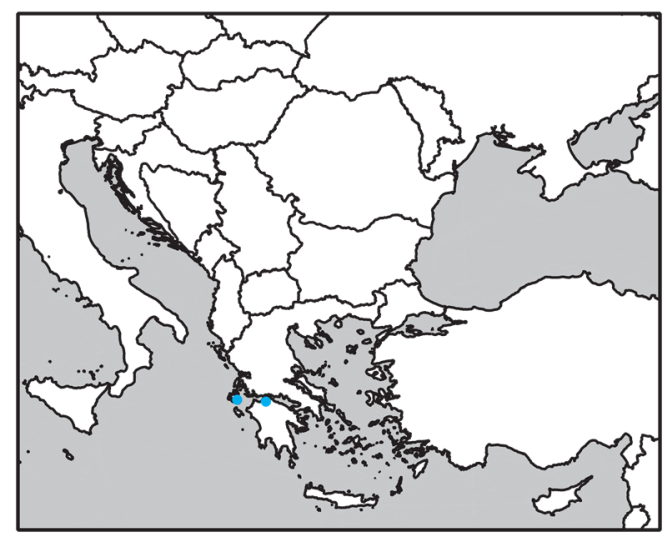

559. Typhloiulus hauseri Strasser, 1974

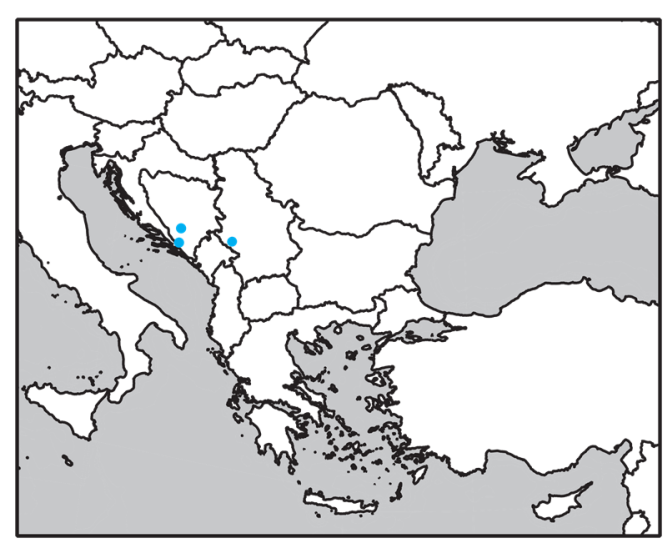

561. Typhloiulus incurvatus

Verhoeff, 1899

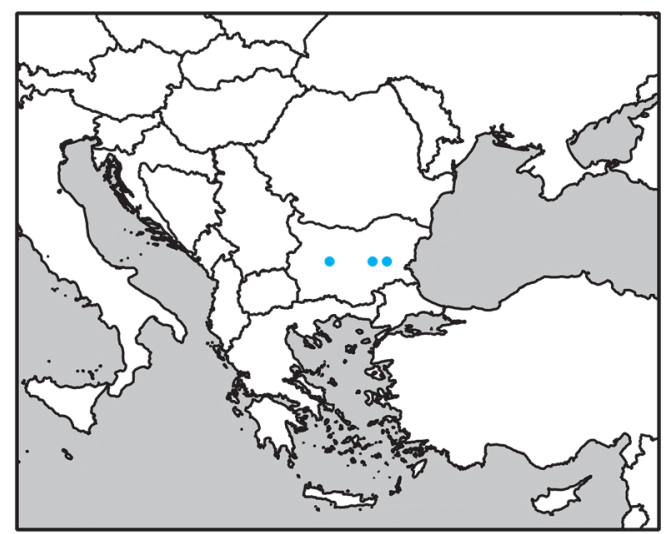

563. Typhloiulus kotelensis Jawlowski, 1938

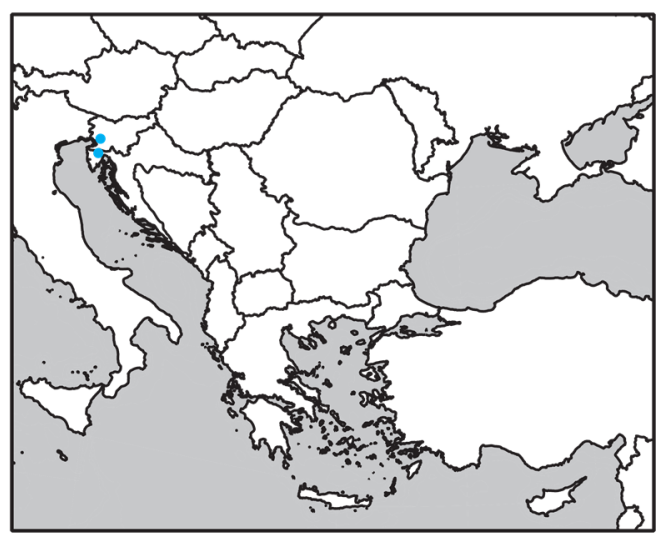

560. Typhloiulus illyricus

Verhoeff, 1929

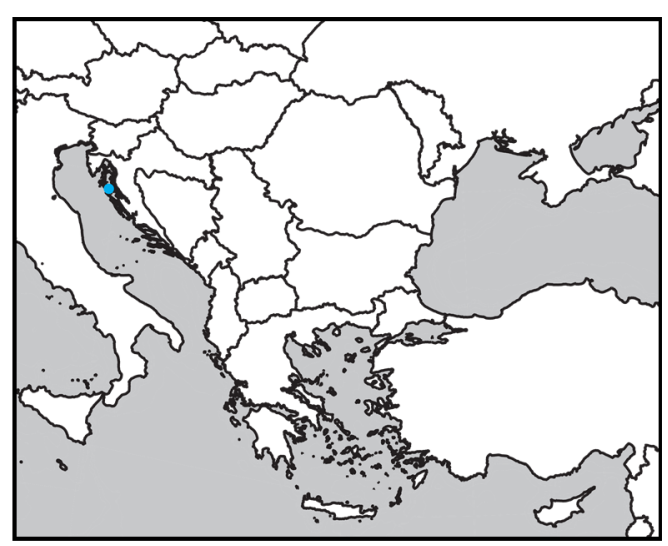

562. Typhloiulus insularis

Strasser, 1938

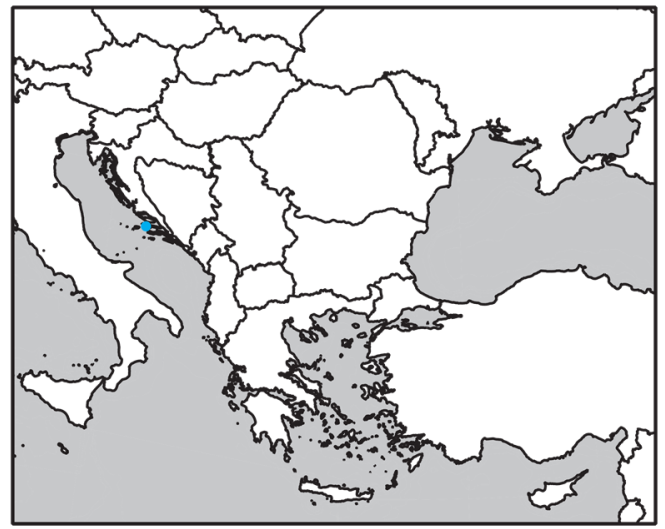

564. Typhloiulus lobifer

Attems, 1951 


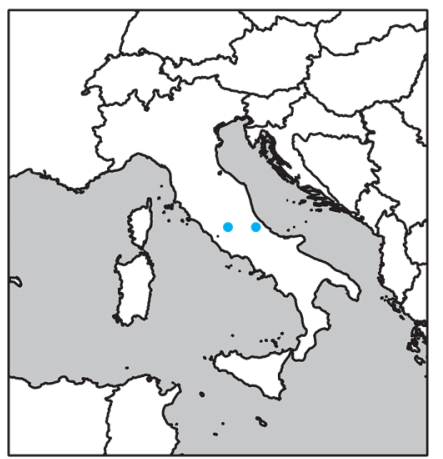

565. Typhloiulus longinquus Strasser, 1966

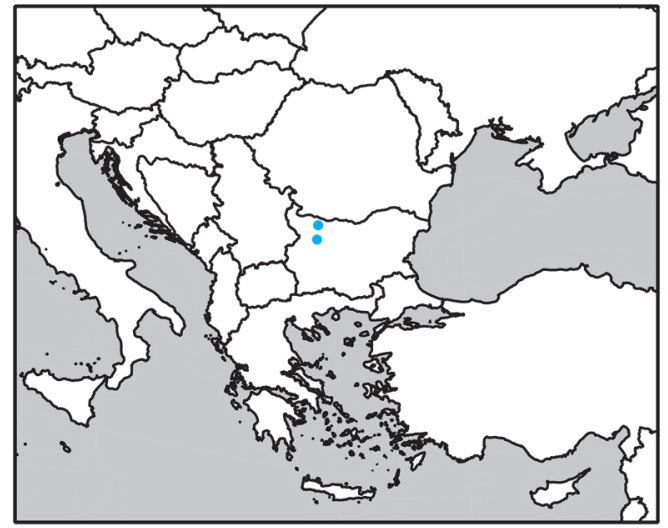

566. Typhloiulus longipes

Strasser, 1973

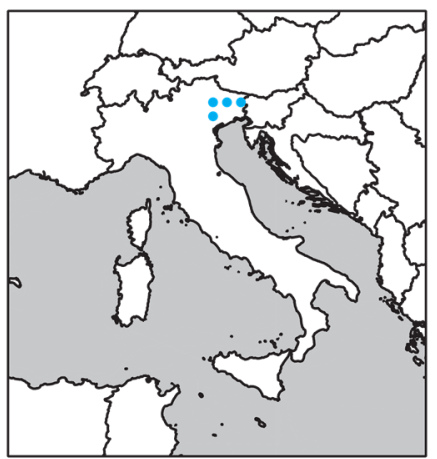

567. Typhloiulus maximus Verhoeff, 1929

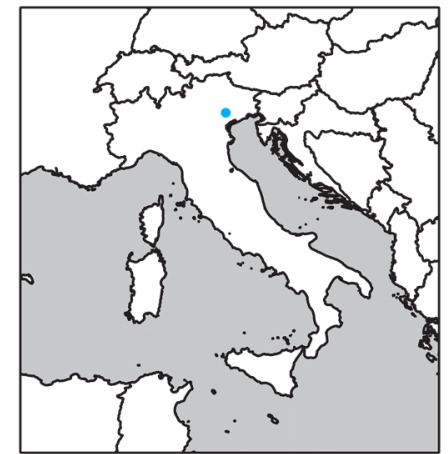

568. Typhloiulus montellensis Verhoeff, 1930

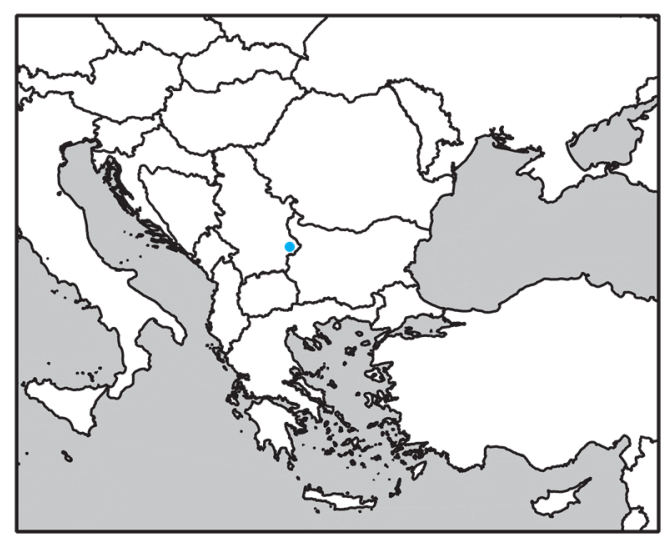

570. Typhloiulus nevoi

Makarov, Mitić \& Ćurčić, 2002

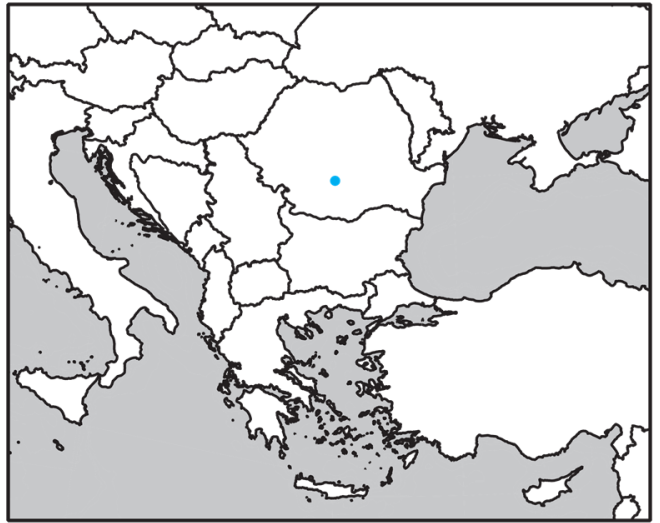

569. Typhloiulus motasi

Tabacaru \& Gava, 1992

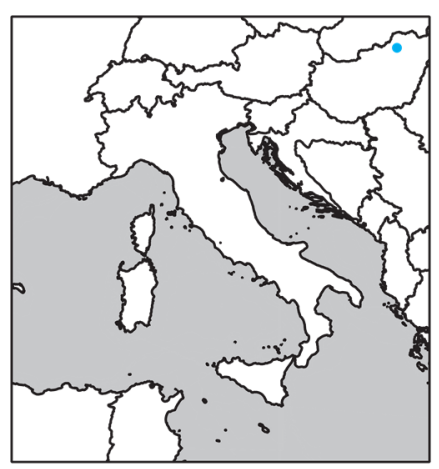

571. Typhloiulus polypodus (Loksa, 1960) 


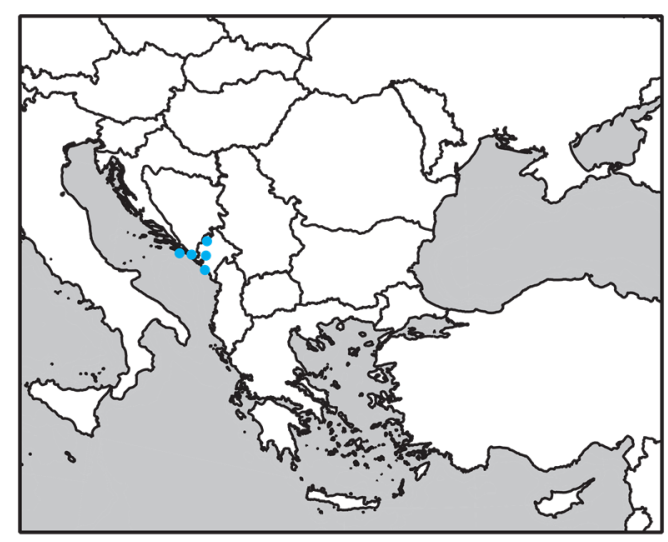

572. Typhloiulus psilonotus (Latzel, 1884)

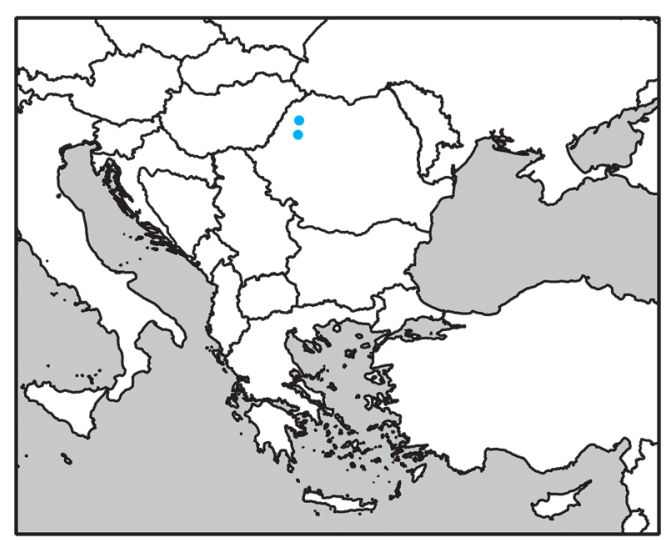

574. Typhloiulus serbani (Ceuca, 1956)

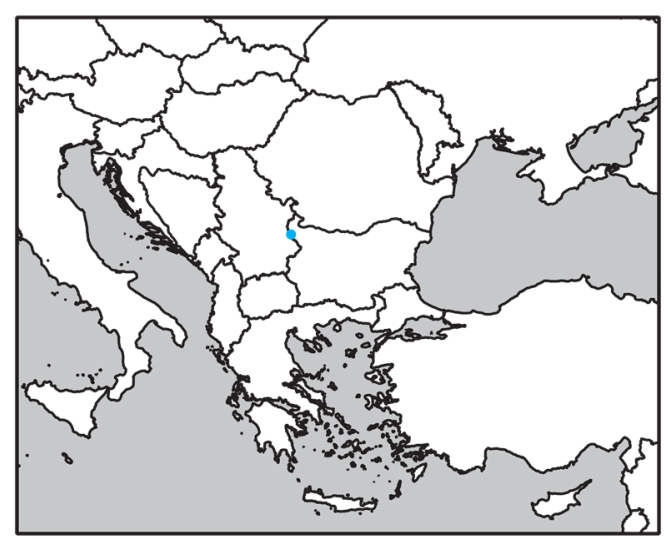

576. Typhloiulus staregai

Strasser, 1973

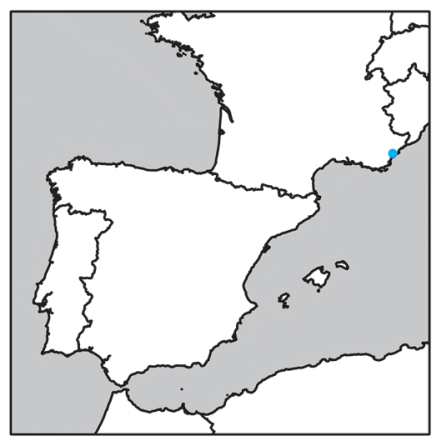

573. Typhloiulus sculterorum Brölemann, 1905

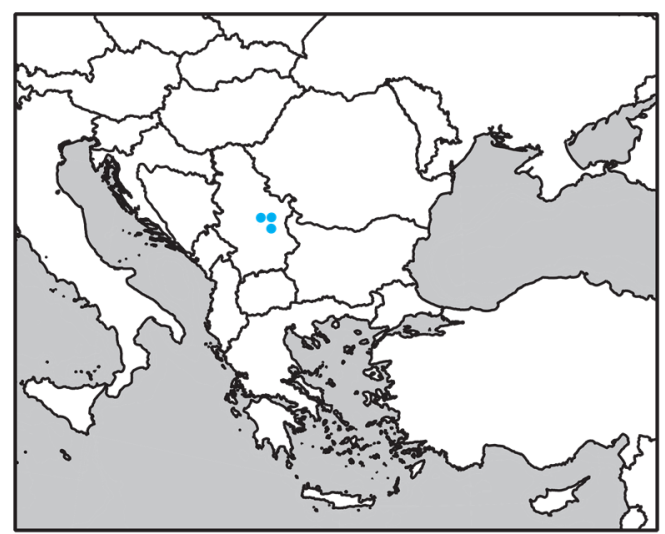

575. Typhloiulus serborum

Ćurčić \& Makarov, 2005

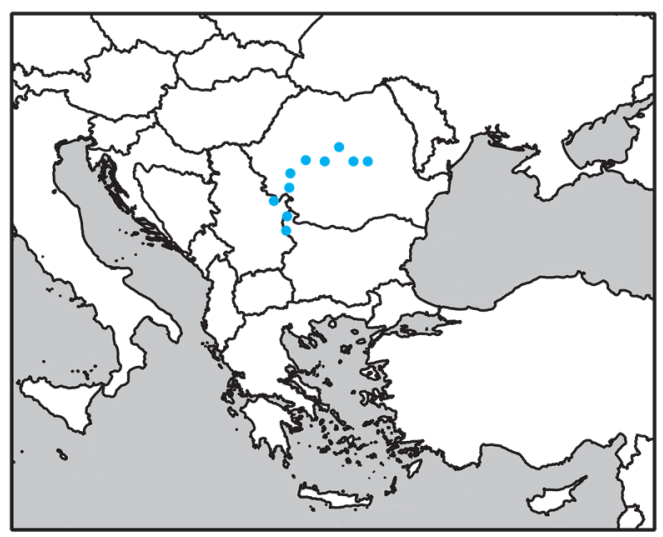

577. Typhloiulus strictus

(Latzel, 1882) 


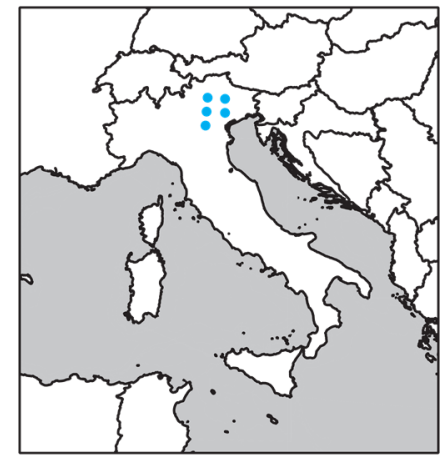

578. Typhloiulus tobias (Berlese, 1886)

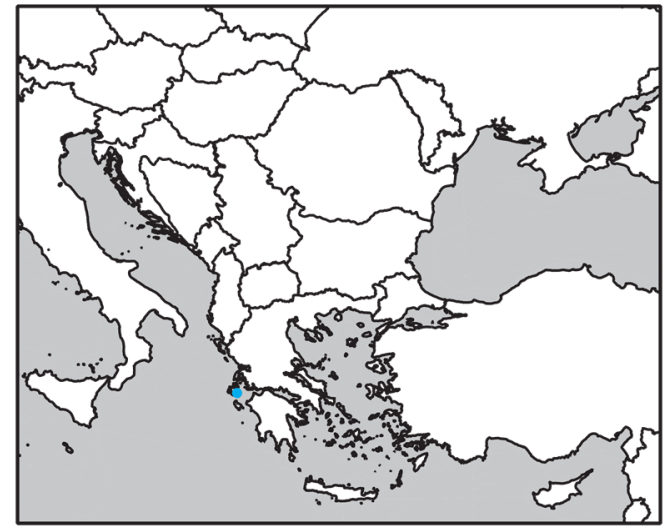

579. Typhloiulus uncinifer Strasser, 1974

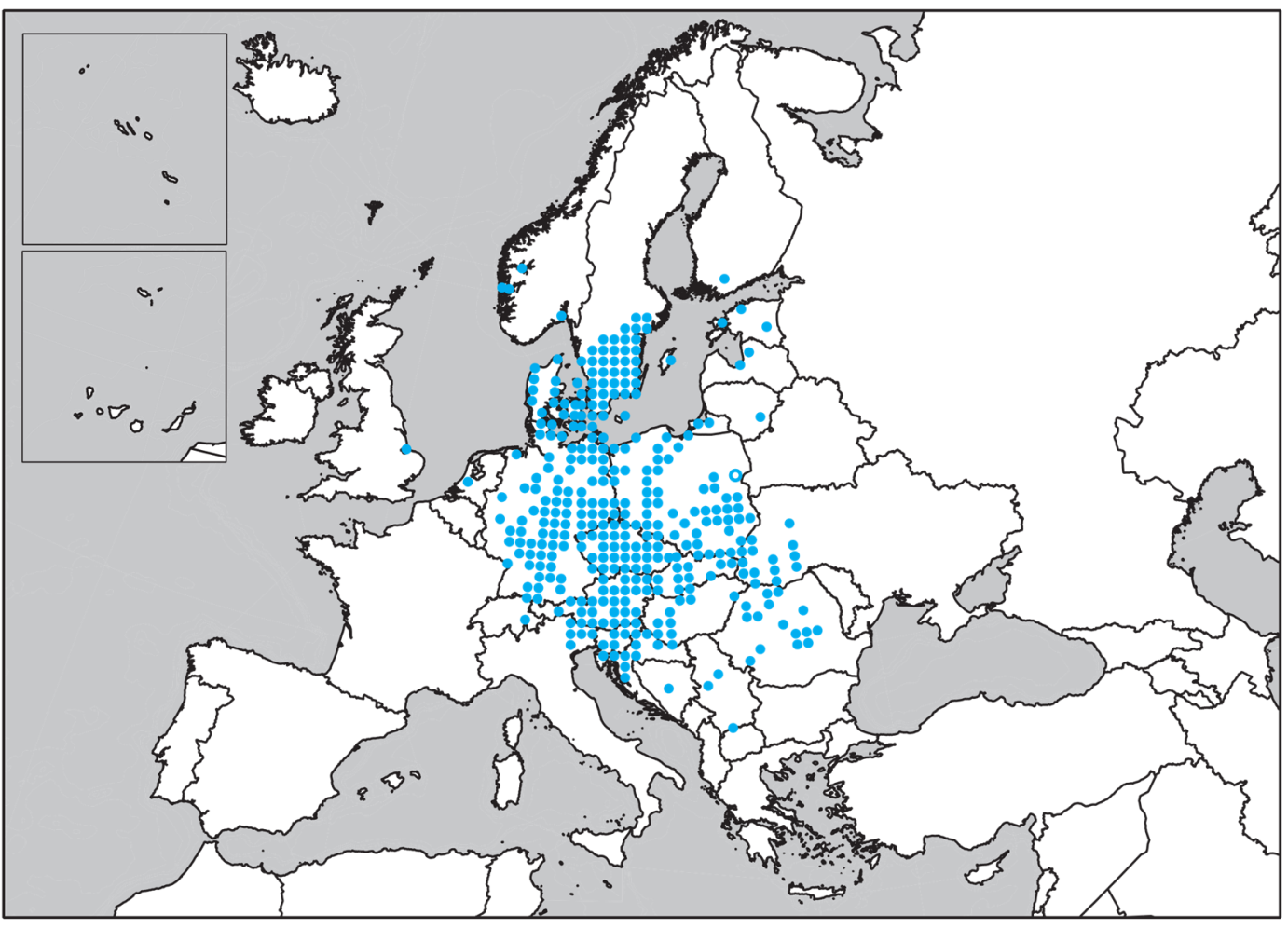

580. Unciger foetidus (C.L. Koch, 1938) 


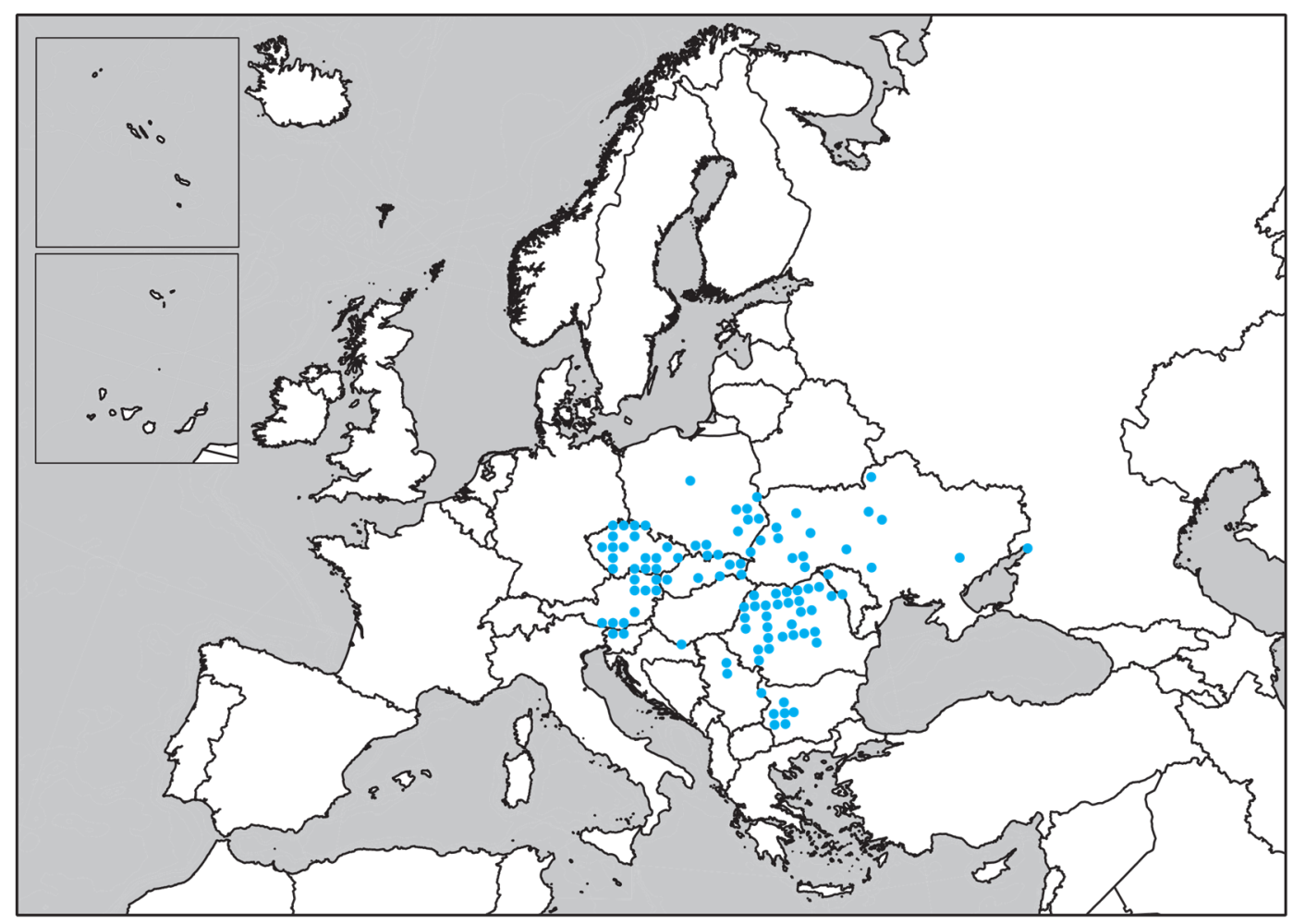

581. Unciger transsilvanicus (Verhoeff, 1899)

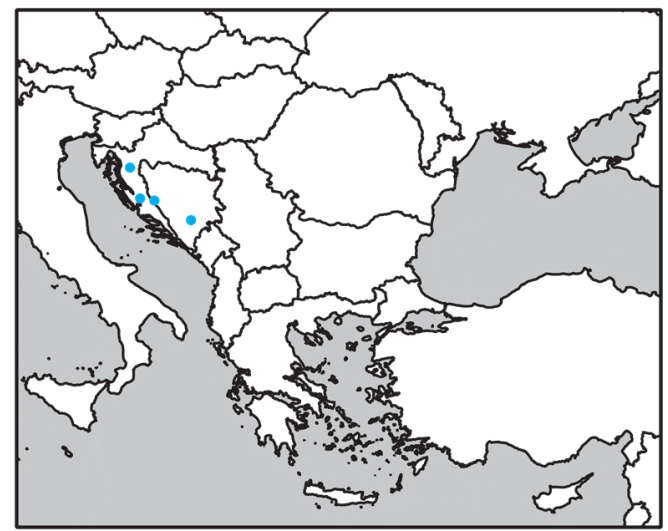

582. Xestoiulus bjelasnicensis

(Verhoeff, 1898)

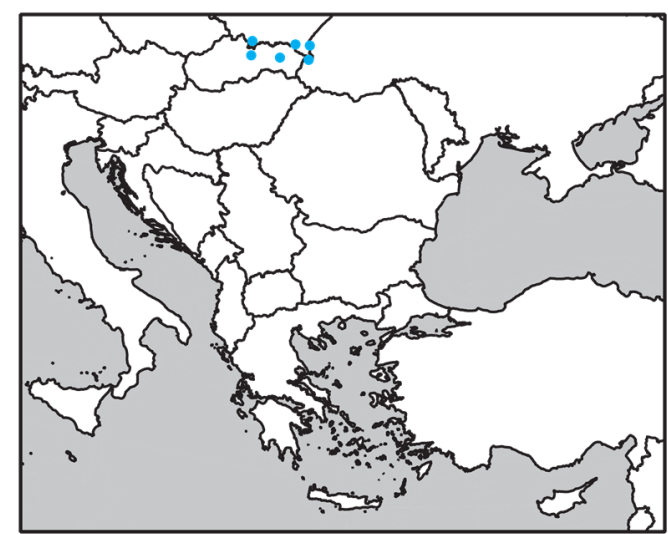

583. Xestoiulus carpathicus

(Verhoeff, 1907) 


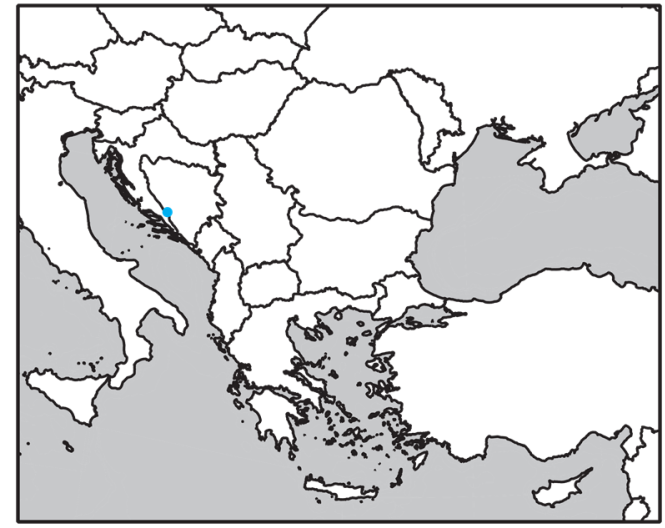

584. Xestoiulus dalmaticus

Mršić, 1987

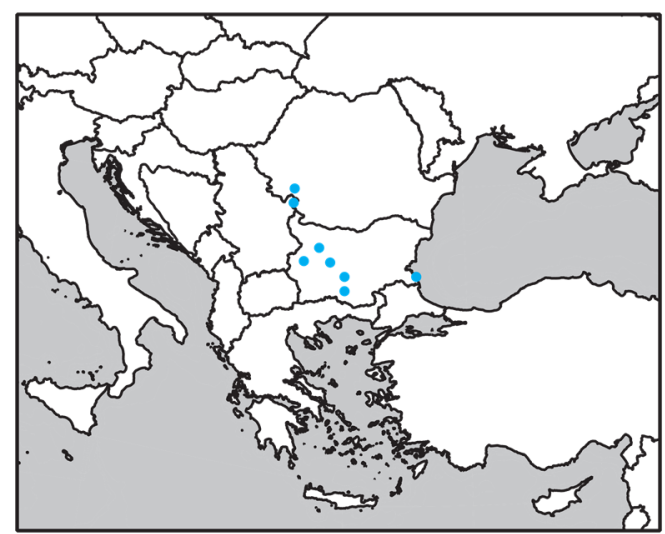

586. Xestoiulus fontisherculis

(Verhoeff, 1899)

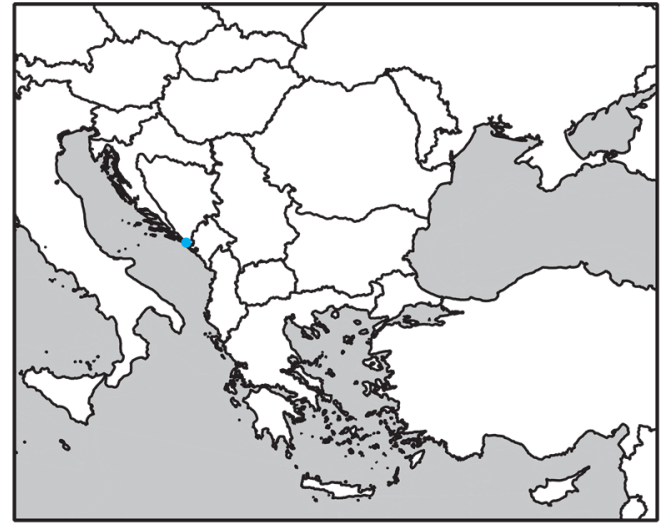

585. Xestoiulus fimbriatus

(Attems, 1904)

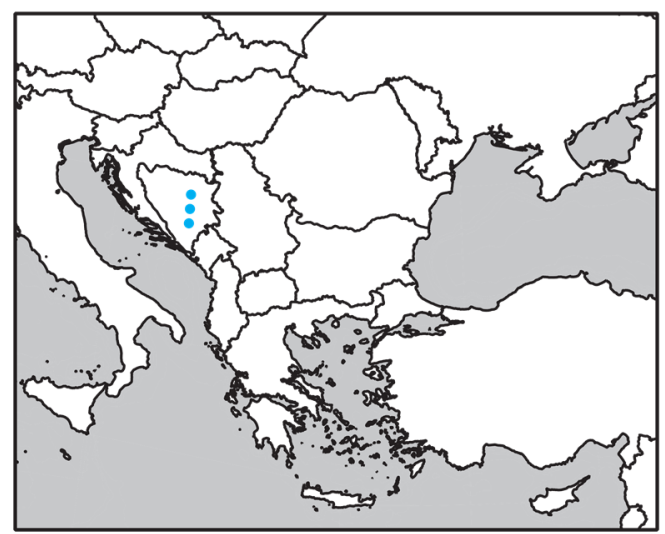

587. Xestoiulus graciliventris (Verhoeff, 1898)

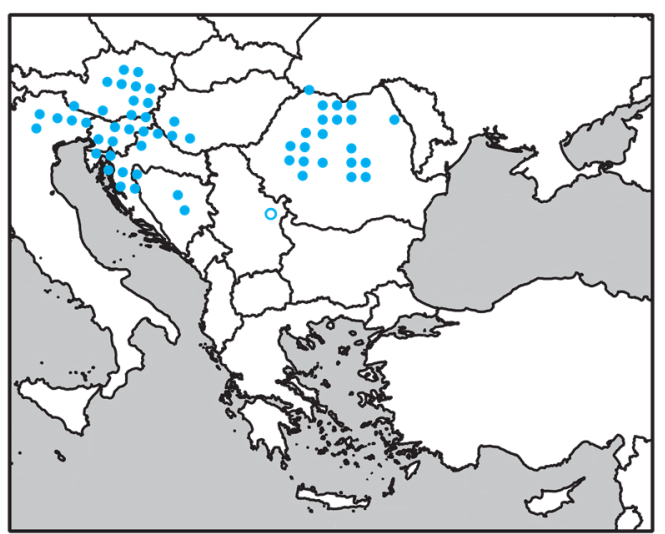

588. Xestoiulus imbecillus

(Latzel, 1884) 


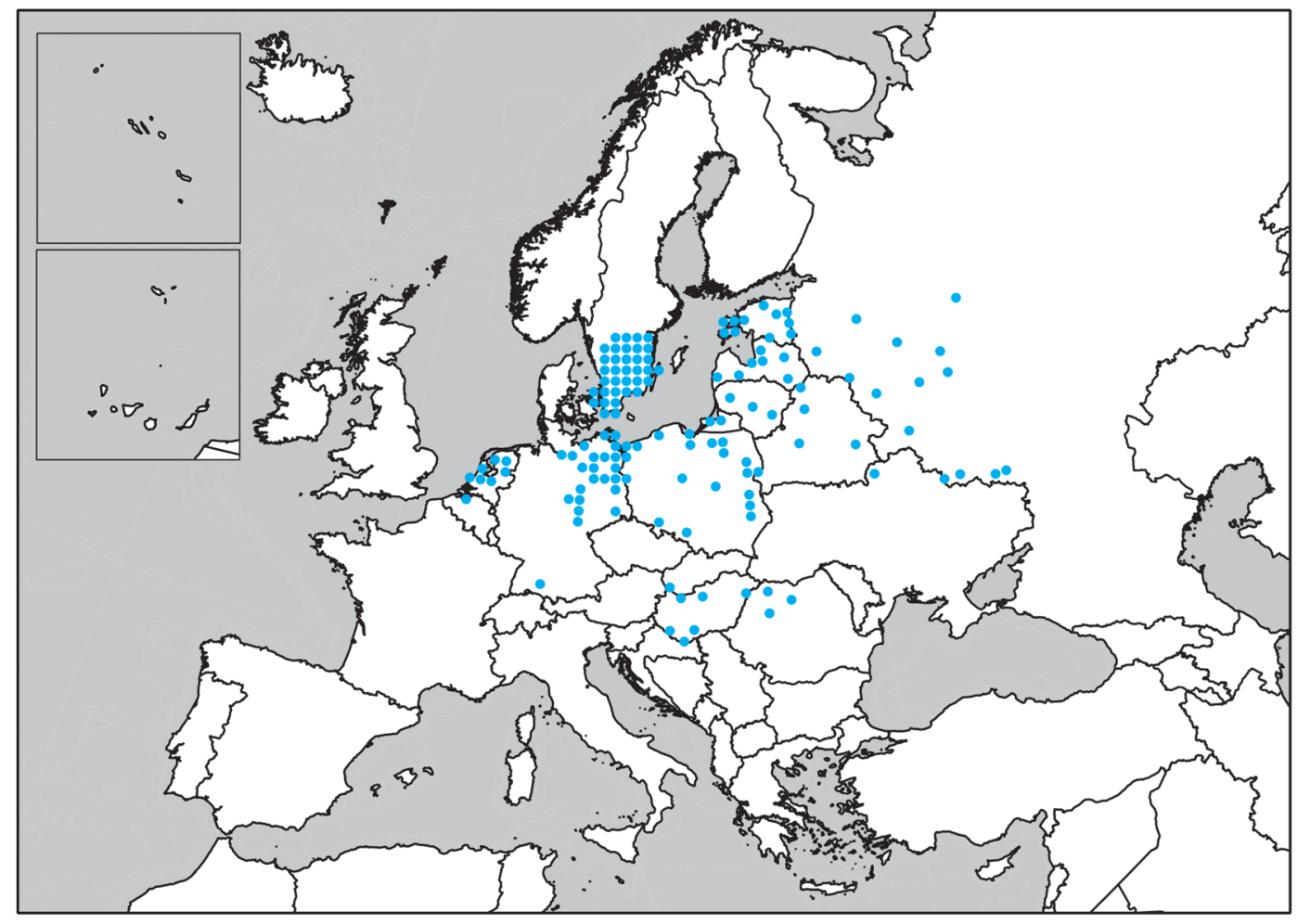

589. Xestoiulus laeticollis (Porat, 1889)

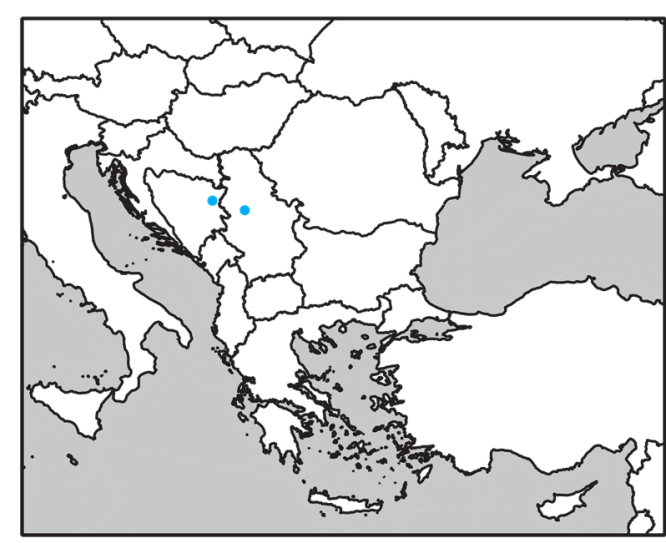

590. Xestoiulus luteus

(Attems, 1951)

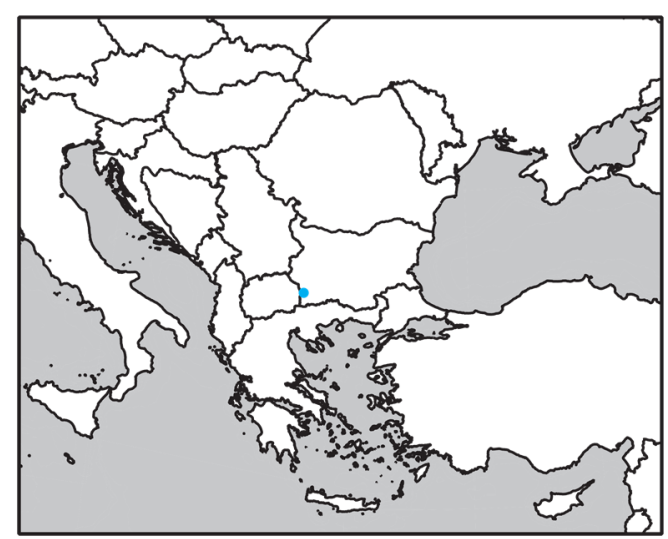

591. Xestoiulus pirinicus

(Gulička, 1967) 


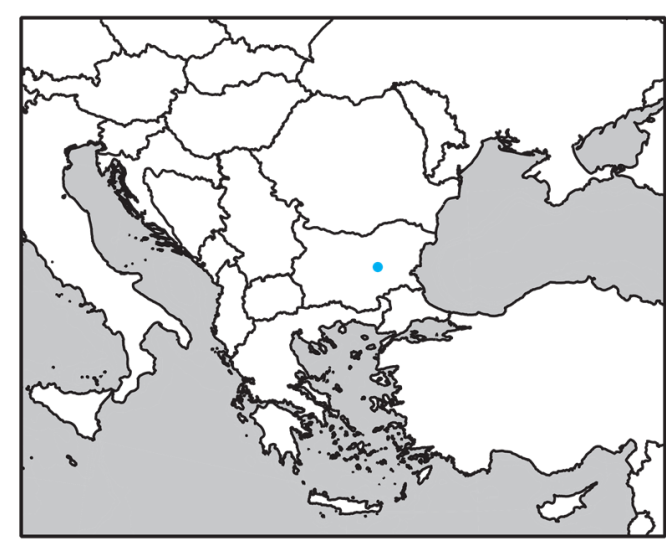

592. Xestoiulus rebeli (Attems, 1904)

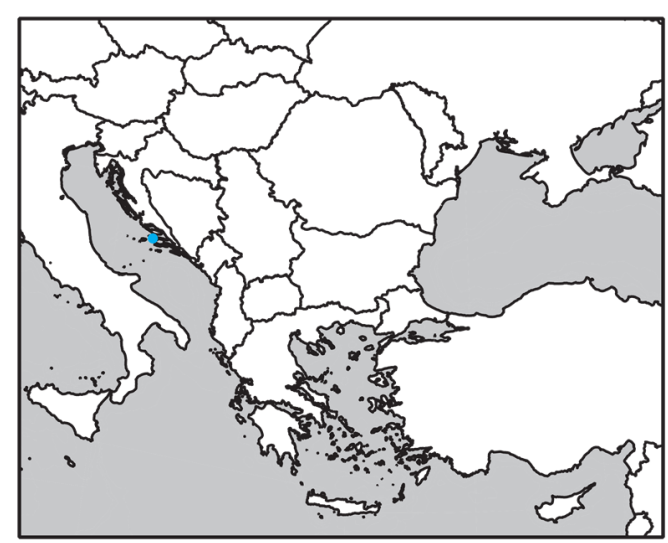

593. Xestoiulus rucneri

(Ceuca, 1990) 